\title{
MANNING'S BOOK.
}


From the Personal

Reference Library of

PAUL IVES

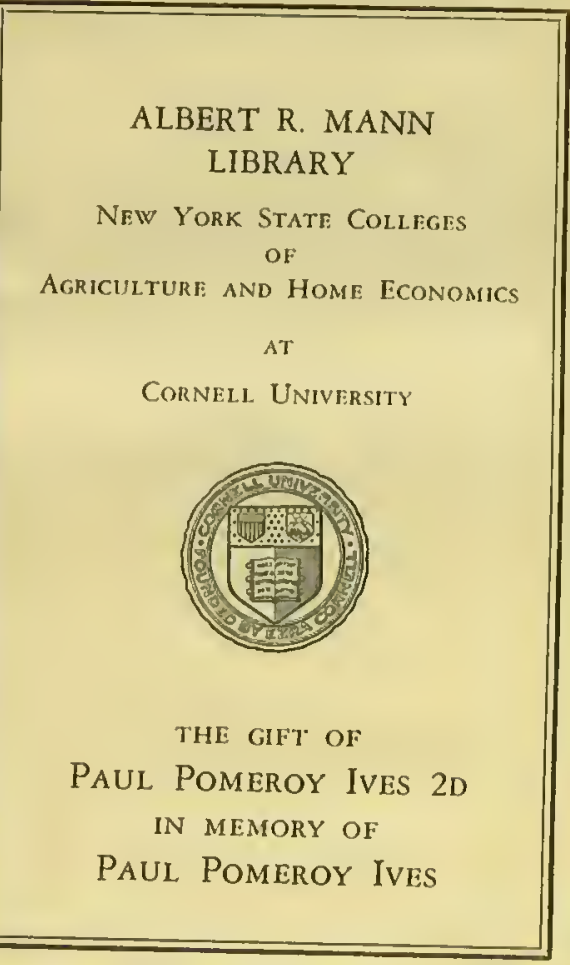




\section{Date Due}

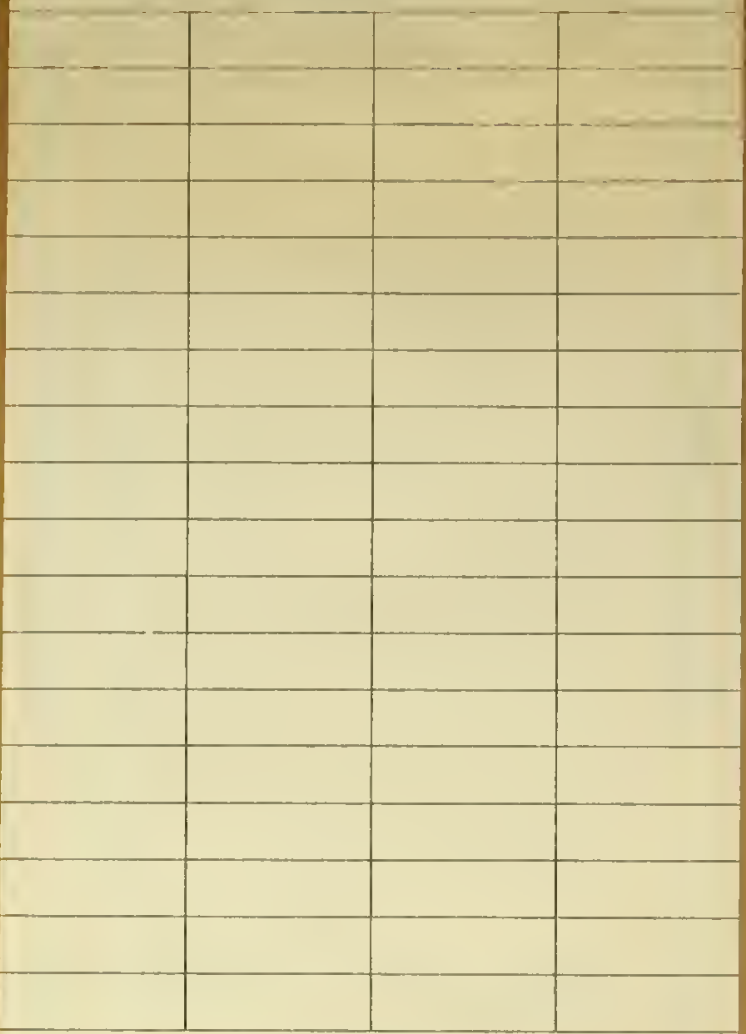

Lilrary Bureau Cat. No. 1137 


\section{MANNING'S BOOK.}

\section{Cattle, Sheep, Swine, Poultry, Bees, Dogs,}

\section{Pigeons and Pets.}

GIVING ALL TIE

SACTS CONOERNING THE VARIOUS BREEDS AND THEIR CHARACTERISTICB, BREAKang, Training, Sheltering, Buying, Seiting, Profitable Use, and GrinERAL CARE, AND ALL DISEASES TO WHICH THEY ARE SUIJECT-THE CAUSES, HOW TO KNOW, AND WHAT TO DO IN SICKNESS.

PREFARED, AFTER A RIPE EXPERIENCE OF TWENTY-FIVE YEARS

By J. RUSSELL MANNING, M. D, V. S,

TO WHICH HAS BEEN ADDFD

A CंOMPLETE HISTORY OF BEES, GIVING THE LATEST AND MOST APPROVED METHODS AND SYSTEM OF BET CULTURE

By D. A. JONES, OF BEETON, ONTARIO.

A VALUABLE TREATISE ON DOQS.

CONTAINING THEIR HISTORY, BREEDS, TRAINING, DISEASES, AND ESPECIALLY GIVING A SURE PREVENTIVE OF IYYDROPIOBIA.

A COMPLETE TREATISE UPON THE RAISING OF PIGEONS, WTTE A HISTORY AND DESCRIPTION OF EACH VARIETY, AS WELL AS A CHAPTER ON CANARIES AND O'THER PETS.

BY GEORGE E. HOWARD, A PRACTICAL EXPERT.

PROFUSELY ILLUSTRATED.

NEW IEDITION.

THE NATIONAL TRIBUNE, WASHINGTON, D, C.: 1899. 


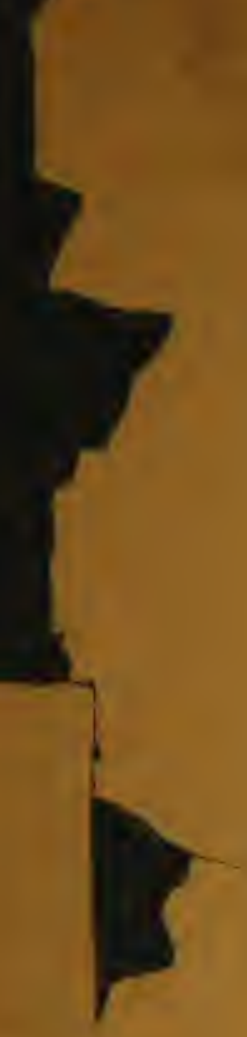

\section{3,5 \\ 85

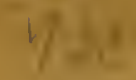

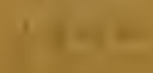

\section{E 72.25}

COPXRIGIT 1800 BY MCEWROT, GHOPPET A ANDREWL

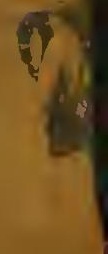




\section{PUBLISHERS' PREFACE。}

It is with especial pleasure and pride that the publishers present to the public this volunc. They believe that in design, cxtent, variety of matter and illustration, especial adaptability to the wants of the farmer and stock owner, and in its explicit and practical teachings, it has not been equalled in the history of American agricultural publications. No authors have to the same extent carried into effect in this departunent of literature the modern and popular idea of "object teaching." And in no department of literature is such teaching so useful and practical in character. With our authors it has not been enough to describe, but they illustrate, teaching through the eye, as well by word, and with a definiteness in both resprects that will enable any one, by proper study, howerer unfamiliar with the subjects of which it treats, to become well versed in all the essentials of a practical knowledge of the use, care, discases, and treatment of doniestic anmals. Though the book is large, the system of the arrangement is so perfect that any fact in its contents can be readily found, and this constitutes it a most convenient work for ready reference as well as for general study. The illustrations, covering the subjects of breeds, characteristics, points, character, and the various stages of disease, etc., are decided features and most useful.

Dr. Manning's careful education in the profession of Veterinary Medicine, his large practice, and his experience in the general care and management of live stock, have eminently qualified him for the task he has undertaken, and we place the result of his labor before the public, believing that he has done his work well-that he has produced a book that will be of most practical and pecuniary value to every stock-owner. Believing this, the book is launched upon the sea of agricultural literature with the confident belief that it is demanded, and that it will accomplish its mission of uscfulness.

In what we have said concerning the characteristics, excellences, and defects of the various breeds of live stock (and in this we have tried to be full, explicit, and exact), we have not been biased by partiality for any, and have studiously avoided cxpressing any preference, when the facts obtained by long familiarity with th: subjects, and much reading and observation, did not clearly sustain tic position taken.

iii 
The book is not in any sense in the interest of any breed or breeds, and even less is it in the interest of any class of breelers or iniporters. In these things the interests of truth and the reader ire been the influences that controlled.

If in the directions given throughout the work we have subjected ourselves to the charge of inaking a hobby of careful and tender treatment of aniunals, we reply that a long experience, and the observations of a lifetime, have very strongly impressed us that, not only humanity, but economy is best served by lkindness, and if the influence of this book shall lead to a inore general study of the comfort of domestic animals, we will feel that we have served the financial interest of the breeder in an equal proportion to the welfare of the animals.

Hard names and technical terms have been avoided as much as possible, but when terms of anatomical and medical science have been necessarily employed, they are explained and applied with a degree of plainness and precision that brings them within the ready comprehension of every reader.

To aid the non-professional owner in deciding the nature of disease, engravings are given which show the positions in the different stages of various discases, and which cannot fail to be of great value in determining the character of the disorder.

Special attention is called to the new illustrations which have been specially made for this edition and which appear in no other.

The new chapters specially written by Mr. George E. Howard, upon the subject of pigcons and pets, is also to be found in no other edition, being written by this well-known expert exclusively for us.

WASHINGTON, D. C., I8gg. 


\title{
TABLE OF CONTENTS.
}

\author{
CATTLE.

\section{THEIR HISTORY, ORIGIN, BREEDS AND CHARACTERISTICS, MANAGEMENT AND CARE.}

\section{CHAPTER I.}

NATURAL HISTORY OF CATTLE.

Their Origin.-Early Domestiention.-The Different Kiuds and Their Peeuliarities.Improved Breeds.-Devons.-Herefords-Sussex.-Short Horns.-Alderneys-Ayrshires.-Holsteins.-Kerry Cows-Polled Cattle.-Galloways.-The Cherokee or Texas Cattle, ete., elc.

CHAPTER II.

BREEDING AND FEEDING.

Grasses.-Best Breeds.-How to Breed.-General Utility.-Breeding in Line.-Form and Quality.-Practieal Suggestions.-Breeding Grides.-Start the IJerd.-Tens Years' Produce.-Seleetion.-Common-Sense.-Gestation of Cowr.-Feeding Standards.Ration for Mileh Cows.-Raising Young Cattle.-Custratiou.

CHAPTER IIL.

TRAINING AND FORKING.

Training * Brenking.-Training the Calf--IIaltering.-Training to Milk.-Feeding at Milking Time.-Vieiousness in Cors.-IIooking Cows.-Training Oxen.-Train Stock Young.-Summing Up.-Managing a Kieking Cuw.

\section{CHA PTER IV.}

HOW TO SEELTER.

Wecessity of Shelter.-Artifieial Protection.-A Frnmed Stable.-A Cheap Stable.-A bout Barns.-A CommonaSense Barn.-A Square Cross Barn.-Basements for Cattle.Arranging the Basement.-Adapting Merns to the End.-What to Plant. 
ROW TO FASTURE, FEED AND TATRR,

About Puaturage.-Clovers that do Well.-Undesirable Clovers.-Alfalfa.-The Irue Grasses-Timothy, or Cat's Tail Grass.-Blue Grass.-Red Top.-Orehard Grass.Fowl Meadow Qrass.-Time for Pasturing.-Watering._Feeding Stock Cattle.-How to Feed.-Feeding Mileh Cows.

\section{CHAPTER VI.}

BENEFITS OF KIND AND CAREFUL TREATMENT.

Fecding for Profit.-As Between Well and Ill-Kept Stock.-Heavy Weights.-Profit in Early Maturity.-Maks Beef Young.-Baby Beef-Feeding: Cost in England.Summer Feeding.-Animal Waste.-Animal Heat.-Advantages of Summer and Winter Feeding.....

\section{CHAPTER VII.}

LOW TO BUY AND HOW TO SELI.

The Value of Good Caro.-Estimating Weight.-Estimating by Measurement.-Buring to Feed.-How to Buy Breeders. - Where Good Becf Lies.-Buying Feeding Stoels.Aaalyzing the Careass.-Proper Shape of Well-Bred Fattening Stock.-HIow to Buy. -Buying Milch Cors.-Buying Dairy Milkers.-Milk Mirrors.-The True Value of Mrilk Mirrors.-Value of Escutcheon Mark8.-Milkers in all Breeds.-Hercdity.Digestion.-Respiration.-Milk Veins.-Veins of the Udder.-Judging Age by the Teeth

\section{SHAPTER VII.}

TIIE DAIRY.

Rushing into New Industries.-The Importance of Dairring.-Eetimated Production of Butter and Cheese.-Conditions Neeesary to Dairying.-How to Build.-Sub-earth Ventilation.-Care of Milk.-Modern Home Dairies.-Aninal Odor.-Temperature. -Various Methods of Raising Cream.-Making Dairy Butter.-Salting Butter.Washing or Working Butter.-Packing Butter.-Preparing Paclages.-Kind of Salt to Use.-Chcese-Making.-Cheddar Cheese.-Cheshire Cheese.-How to Sell Butter. -Utilizing Waste Produets.

PART IV

\section{DISEASES OF CATTLE}

\section{THEIR CAUSES; HOW TO INNOW THEM; WHAT TO DO.}

\section{CHAPTER I.}

DISTASEg IN GENERAL-RECOANIZING AND DISTINGUISHING THEA.

Farmers Should Understand Symptoms.-Of Diseases in General.-Use Common Sense.Graduation of Doses.- Frequency of Administering.-Forms of Doses.-How to Give Medicine.-Injections.-Vapors, Spraying and Fumigation.-Anxsthetics.-To Doprive of Sonsation.-Blistering.-Firing.-Setons.-Borrels.-Sewing up Wounds.Fomentations.-Operation of Bleeding.-Reeognizing and Distinguishing Diseases. -Tlie Pulse.-The Breathing.-2he Animal Heat.-The Skin and Hair.-The Posture.-Indications of Pain.-Specend Signs in Cattle.n......................................... 
CHAPTER II.

DESTATION, DISEASES AND ACCIDEATB THEREOF.

Plural and Multiple Gestatiou.-Treatment During Gestation.-Birth.-Prolonged Labor. - Large Presentation.-Unnatural Positions of the Calf.-Elooding.-Presentation of After-birth.-Inversion of the Womb.-Languid Labor.-Irritability and Straining. -Terporary Paralysis.-Abortion.-Isolation.-Milk Fever.-Mammitis.-Treatmacut of Calves.-Drsenter.v.

\section{CHAPTER III.}

\section{INFECTIOUS, CONTAGIOUS AND EPIDEMIC DISEASES.}

Pnenmonia.-Mistory.-Its Malignant Contagiousness.-Definition.-Hor the Infection enters the System.-How Long is a Diseased Animal Infectious.- How to Know it. -What to do.-Texas Fever.-Irow to Know it.-Bloody Mlurrain.-Its Malignant Character.-Preventives.-What to do.-Foot and Moutl 1 Diseases.-Malignant Catarrh.-Lice.-Fouls.-Horn Ail.-Cholsing ....................................... 261

\section{CHAPTER IV.}

MEDICINES AND INSTRCMENTS: WHAT TO KEEP.

I. Distection.-II. Action of Medieines.-III. Medicines to be IKept, and Doses.-IV. Simple and Valuable Recipes.-V. Forms of Clysters.-VI. Infusions.-VII. AntiSpasmodics.-VIII. Mueilages.-IX. Washes,-X. Poultices.-XI. Fumigations,XII. 'Tiucture for ounds.

\section{PART V.}

\section{SHEEP}

\section{THEIR HISTORY, BREEDS, CHARACTERISTICS, BREEDING, AND MANAGEMENT.}

CHAPTER I.

ORIGIN, PRINCIPAL BREEDS AND CHARACTERTSTICS,

Cosmopolitan Nature of Sheep.-Long.Wooled Sheep.-I. Leicestcr.-II. Border Leicester.-III. Cotswold.-Good Qunlities of Cotswolds.-Cotswolds in the West.-IV. Lincoln Sheep.-V. Now Oxfordshire Sheep.-VI. Middle-Wooled Sheep.-VII. Cheviot Sheep.-VIII. White-Faced Highland Sheep.-IX. Iorset Sheep.-X. Soutlidowns. -XI. Harpphire Downs.-XII. Shropshire Downs.-XIIT. Oxford Downs.-FineWooled Sheep.-XIV. American Merinos.-The Fleece.-The Ilead.-The Body.Tho Most Profitable Sheep.-Divisions of Wool...

\section{CHAPTER II.}

BREEDING AND MANAGEMENT OF GMEEP.

Watchfulness Necessary.-How to Breed.-Time for Breeding.-Conpling.-Keeping the Record.-The Management of Rams.-Training Rams.-Pasturing Sheep.-Slaade in Pastures.-Water.-Dosing Sheep.-Fall Pasturage and Feeding.-Sheep Barns.Special Winter Food.-Management of Lambs.-Docking Lambs.-Castration.Wenting.-The Nursery ..................................................................... 313 


\section{PART VI. DISEASES OF SHEEP. \\ HOW TO KNOW AND HOW TO CURE.}

\section{CHAPTER L}

\section{ANATOMY AND DISEABSY OF BUEEP.}

The Head.-The Trunk.-The Fore-Leg.-The Ilind-Leg.-Importance of the Head to Breeders.-Diseases of the Head and Brain. - The Teeth. - Swelled Head. - Vegetable Poisoning.-Inttammation of the Eye.- Sheep Distemper.-How to Kuow it.-W hat to do.-Grubs in the Head.-How to Sare the Sheep.-Apoplexy.-Prevention.Inflammation of the Brain.-Tetanus, or Loek-Jaw.-Palsy.-Rabies.-Hydatids on the Brain.-Parasites of the Body and Skin.-The Scab.-How to Know it.-Diseases of the Generative and Urinsry Organs.-Diseases of the Limbs and Iloofs.-Foot Rot.-How to Cure it.-Fouls, and Travel-Soro Feet.-Gravel.-The Biflex Canal.-Maggoty Sheep.-Lung Worms.-Intestinal Worms.-Rotten Liver.-Colie.....

\section{PART VII.}

\section{SWINE}

HISTORY, BREEDS, CHARACI'ERISTICS, AND MANAGEMENT.

CHAPTER I.

MISTORY AND BREEDS

Origin of the Hog.-Teeth of the Hog.-Importance of Swine to Man.-I. Improped Breeds of Swine.-English Breeds.-II. The Berkshires.-Establishing the Improved Berkshire.-Standard Claraeteristics of Berkshires.-III. Neapolitan IIogs.-IV. Essex Breed.-V. Yorkshiro Flog.-VI. Suffolks.-VII. Lancashire Hogs.-VIII. Lancashire Middle-Breed.-IX. Large Lancashire-Anerican Breeds.-X. I'oland Clina.-XI. Chester Whites.-XII. Jersey Reds.-Cheshires.-XIII. Charaeteristics.

- Reeapitulation of Breeds

\section{CTAPTER II.}

BREEDTNO AND MANAOEMENT.

Importance of Swino.-A Back-Woods Mog.-Fixing and Iolding the Characteristics.Selection Always Important. = Breeding Ago of Swine.-Care of Breeding Sors.Weaning.-Management of Swine.-Absolute Cleanliness Necessary. Summary.....

\section{CHAPTER IIT.}

\section{FEEDINO $\triangle$ ND BTELTER.}

Good v. Bad Food.-Summer Feeding.-Other Summer Foods.-Roots-The GrainsFeeding South.--Mast.-Feeding in Confinement.-Hog Barns.-A Cross Barn.-A Simple Pen.-Surnmary.-Light थs. Heary Hoga... 
TARIE OF CONTENTS.

\section{PART VIII. \\ DISEASES OF SWINE. HOW TO KNOW AND HOW TO CURE THEM. \\ CHAPTER I. \\ DISEASES OF SWINE.}

Explanation of Cut.-Diffeulty of Administering Medicine.-Good Nursing the Eisential.-Malignant and Contagious Diseares.-Malignant Epizootic Catarrh.-How to Know it.-What to Do.-Intestinal "Hog Cholera."-How to Know it.-CausesTreatment.-Prevention.-Contagious Pneumo-enteritis.-Its Origin.-The Erysipelatous Form.-The Form mith Malignant Throat.-What to Do.-Malignant Anthrax, Splenic Fcrer.-True Charbon.-Inflammatory Diseases.-Quinsy, or StranglesRising of the Liglits-Pneumonia.-Catarrh in the Hcad.-Diseases of the Skin.Measles.-How to Know it.-The Lard Worm.-What to Do.-Trichina SpiralisIlory to Cure,-Lice,-Diarshoea.-Summary ................................................... 391

\section{PART IX.}

POULTRY.

HISTORY; BREEDS, THEIR CHARACTERISTICS; BREEDING AND GENERAL MANAGEMENT.

CIIAPTER I.

History and Wild Types.

\section{CIIAPTER II.}

VARIETIES OF BARN-YARD FOWL.

I. Dorking Fowls.-II. Silver Grey Dorkings.-III. Black Dorkings,-IV. Fawn-Colored Dorkings.-V. Bolton Greys.-VI. Dominiquo Fowls.-VII. Plymouth Rocks.VIII. The Ostrich Fowls.-IX. Hamburg Fowls.-X. Black Hamburgs.-XI. Leghorn8.-XII. White Leghoras.-XIII. Spanish Fowls.-XIV. French Fowls.-XV. The Foudans.-XVI. La Fleche Fowls.-XVII. The Crevc Cours.-XVIII. Large Asiatlc Breeds. - XIX. The Chittagongs. - XX. Buff Cochins. - XXI. Partridge Cochins-XXII. Whits Cochins,-XXIII. Brahma Fowls.-XXIV. Light Brahmas.-XXV. Frizzled Fowls.-XXVI. Silkies.-XXVII. Breda or Guelder Fowls.XXVIII. Game Fowls.-1. Brown-breasted Reds.-2. Earl Derby Gamc.-3. Duckwinged Game.-4. White Georgian Game.-5. Game Bantans.-6. Other Bantams. -7. Beabright Bantams -8. Japanese Bantams...

\section{CHAPTER IIL} BREEDING.

The Plumage.-Ideal Shape.-Breeding to Type.-Dieparity of Sexes,-Mating.-Breeding Grades.

\section{CHAPTER IV.}

MAYACEMENT OF FOWLS.

Boing into Business.-Village Yards.-The Ponltry House.-Proper Food for Forls.Best Breeds for Market.-Fgg Producers.-How to Fatten.-How to Kill and Dress Fowls.-Packing for Martet.......................................................1.............. 445 
CHAPTER V.

TIE TOME OF TUE TUREET.

Verieties of the Domestic Turkey.-I. The Common Turkey.-II. English Turkcy.-

III. The Honduras Turkey.-IV. Bronzed-black Turkey,-V. Gulnea Fowl.-VI.

The Peacock

CHAPTER VI.

DUCKS.

I. Rouen Ducks.-II, Aylesbury Ducks.-III. Call Ducks.-IV. Cayuga Black Ducks.-

Y. Fancy Ducks,-VI. Black East India Ducks.--Sumnury....

CHAPTER VII.

GEESE.

2. Embden or Bremen Geese.-II. Toulouse Gcese.-III. Hong Kong Geese.-TV. White

Chinese Geese.-V. Alricun Geese.-VI. Canada Wild Geese.-Management of Guese.. 465

PART X.

DISEASES OF POULTRY, AND THEIR REMEDIES.

CHA PTER I.

Anatomy of the Hen.-A poplexy.-Its Cause.-Roup.-To Cure,-Egg Bound.-Infiam. mation of the Egg Pasuage.-Cholera.-Gnpes.-Cause.-How to Cure.-Crop Bound. -Diphtheria, or Croup.-Lice.

PART XI.

BEES: THEIR HISTORY, CHARACTERISTICS, AND MANAGEMEN'T.

CHAPTER I.

Classification of Bees and Fistory.-Queens, Droncs, and Workers.-Stages of Bce-Life.The Queen.- Products of Bees. - Management. - Old and New Stylcs. - Honey Extractor.-Wax Extractor. - New Races of Bees. - Prospects of Bee-Culture.Starting an Apiary.-Hives.-Transferring Bees.-The Bee-Smoker.-Location of the A piary.-Bee.Veils.-Example of Successful Bee-Keeping.-The Way to DQ it.Setting Out Hives.-Artificial Swarming.-Introducing Queens.-Extracting CombUoney.-Treatnent of Cowb-Honey.-Wintering

PART XII.

THE DOG : HISTORY, BREEDS, AND CHARACTERISTICS. CHAPTER I.

Origin of the Dog.-Usefulness of the Dog to Man.-Tho English Setter.-The Irish Setter.-The Gordon Setter. -The Native Setter,-The Dropper.-Tho Pointer.-Tho Spaniel. - The Newfoundland Dog. - The Mastiff. - Tho Bull-Dog. - The BloodHound.-The Fox-Hound.-The Beagle. -The Shcep-Dog.-The Grcyliound. - The Dalmatian or Coach-Dog.-The Scotch Terrier.-Tho English Tcrrier.-The \$kye Terrier.-The Poodle..............................................., 
CHAPTER II.

Choice of Sire and Dam in Breeding.-Age to Brced.-Time of Year to Breed.-Manage ment of Bitch in Season.-Duratiou of Heat.-Munagement of Biteh in Whelp.Whelping. - Care of Wlielps. - Weaning. - Feeding. - T'raining of Pointers and Setters.-Training of Spaniels. - Training of IJounds.-Training of Vermin Dogs.To Prevent and to Break from Gun Shyness.-Hunting a Bitch While in Whelp.....

\section{CHAPTER III.}

DISEASF OF DOGS AND THEUR TREATMENT.

Treatment of Asthma.-Bronchitis.-Common Cold,-Influenza.-Pleurisy.-Pneumonia. -Consumption.-Rheumatic Fever.-Distemper.-Inflammation of the Stomach.Inflamination of the Liver.-Inflammation of the Bowels.-Mange.-Canker of tho Ear.-Fleas and Lice._Cliorea, or Jerks.-Fits.-Worms.-Rickets, or Large Joints.Tumor and Caneer.-Puerperal Fits.-Protraeted I abor.-Sprains,-I'o Harden Tender Ihect.-Rabies, or IJdrophobia......

\section{PART XIII.}

GENERAL MANAGEMENT OF PIGEONS, BIRDS, AND PET STOCK.

\section{CHAP'TER I.}

PIGEONS, BREEDING AND MANAGEMENT.

Building the Loft.-Perches for Pigeons.-Food for Pigeons.-Popular Vari-

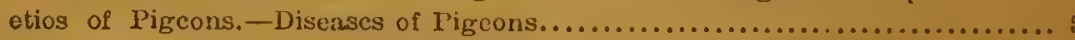

\section{CHAPTER II.}

CAGE BIRDS.

Canaries.-Breeding Canarics.-The Moeking Bird.-Tho Bullfnch.-The Cardinal Grosbeak, or Red Bird.-The Linnet.-The Blue Bird.-The Nightingale.-The Starling.-Tho Thrush.-The Black Bird.-ling Doves.

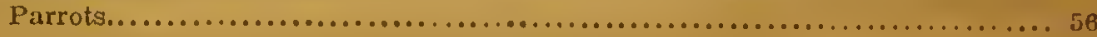

\section{CHAPTER 111 .}

RABBITS AND PET STOCK.

The Belgrian Hare.-Lop-Eared Rabbits,-Angora Rabbits.-Himalayn Rut bits. -English Rabbits.-Guinea l'igs.-Ferrets. - The Angrorn Cat ......... 


\section{CATTLE.}

\section{CHAPTER I.]/}

\section{ITATURAT FISTORY OF CATHLE.}

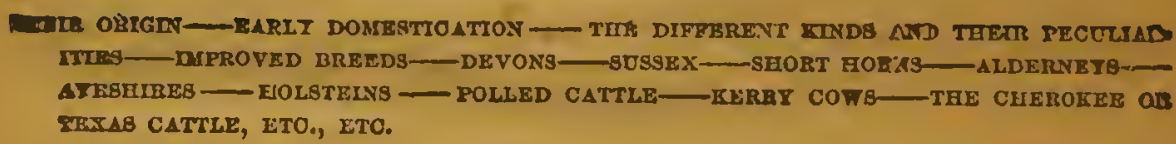

Tho native country of the genus Bos is not known, and the wild typo das long since passed away.

The Urus is regarded as the parent of domesticated cattle, and is described in its wild statc, as an animal of enormous size, of great ficreo ness, and fable has thrown around it an air of mystery, as is common in all legends that have come down to us from the far past.

\section{Domestication of Oattle.}

The domestication of cattle is also a matter of conjecture.

Our earliest record comes from scripture. Jubal, tho son of Lamech, who lived in the lifetime of Adam, is recorded as being "the father of "uch as have cattle."

Noah certainly had cattle, and whcrever the sons of Noah migrated, they carried cattle with them.

Cattle were worshipped by the earliest Fgyptians, and among the ancient nations of Judea, they were, and still are, held in great veneration.

In the days of Abraham, cattle certainly were regularly bred, and in the days of Jacob we have an account of systematic brceding to color, and probably to type. 
In every civilized nation, tho keeping of cattle forms among tho earliest productivo industries recorded, and every Celtic nation has at ono time or another represented them as divinely given, or else, like the Hindoos, beld them in the greatest veneration.

\section{Scientiflc Nomenclature:}

According to naturalists cattle bclong to the cuss Mammatia ; that is, ? having mammæ or teats; their natural order is called ruminantia, from their habit of ruminating, or chewing the cud.

Their TrIBE is termed bovida, meaning the ox kind. The Genus is bos, tho $\mathrm{ox}$; the horns growing, from tho erest, projecting at first sideways, and porous or cellular inside, with a film of true horn encasing tho ccllular bony structuro inside; tho sub-Gevos, which will form tho subject of what we havo to say, is termed bos taurus, or the domesticated ox.

Of these there aro many families, or sub-families; each distinctivo breed bcing a family. Mixed breeds, grades, and crosses, may, bo tcrmed sub-familics

\section{Tho Toeth.}

Cattle are distinguished as to their teeth by having eight lower ineisors; and none upper; these are the cutting teeth. They have no canino teeth or tusks, but have twenty-four molars or grinding tecth; six on each side of the lower jaw, and six on each side of the upper jaw. The upper jaw has no incisors; but tho skin upon which the lower incisors meet in the upper jaw is thickened, ha:d, and in aged auimals almost horny. The teeth may be represented as follow's; the figures above the line represcnting the upper, and the figures below the line representing the lower jaw:

$$
\begin{aligned}
& \text { Cattle, incisors, } \frac{0}{8} \text {, canines, } \frac{0}{0} \text {, molars } \frac{6}{6} \frac{6}{6} \text {. } \\
& \text { Total, } 32 \text { teeth. }
\end{aligned}
$$

We annex a cut of a scction of the lewer jaw sloowing the eight inclsors, of a mature $0 x$, or at the agc of five years. Before apul after this age the tceth vary very materially, az other portions of this sectiou

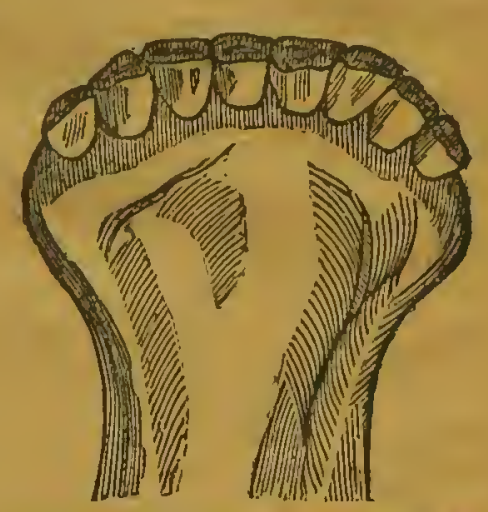

TEETE OY OX AT AGE OR FIVI YrARS now. 
The annexed cut of section of the head of an ox will show the molars, or grinding teeth, and also the terminal boure of the upper jaw, corresponding to the lower face jaw, and destitute of tecth.

Explanation. - $a$-Molars or grinders. b-Superior maxillary bone-its palatiue process. c-Cells of the palatine bone. $d$-Anterior maxillary bone: destitute of incisor tceth.

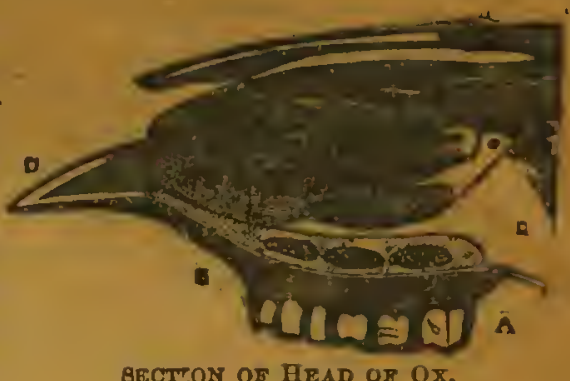

BECT.ON OF HEAD OT OX.

\section{Breeds of Cattle.'}

The breeds of eattle which have aequired favor in the United States are confined to but few.

The Devons are the typical race of England, as among those that have retained their purity, through long generations, breeding with entire uniformity as to color, synmetry, horns, and other general characteristics, fully as much so as the Chillingham white cattle, which are regarded as descendauts of the original or aboriginal cattle of the British Islands.

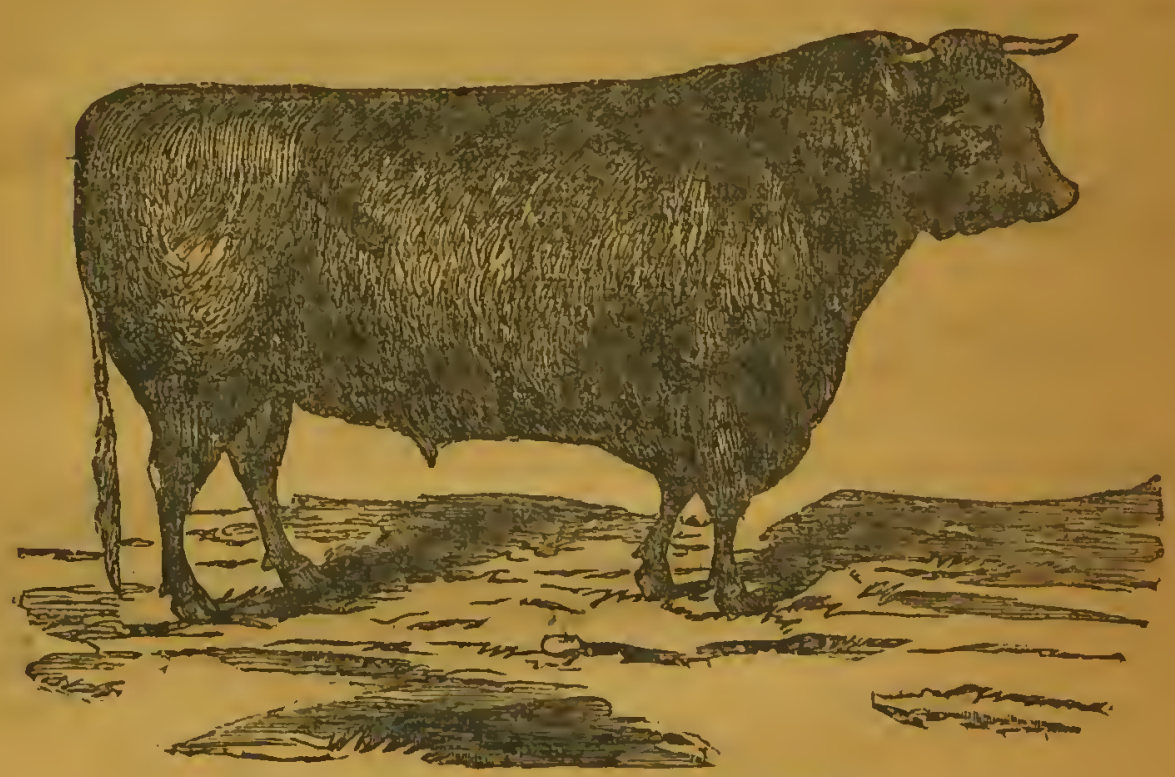

First Prize Defon Buld, "Wrumor."

Tro Years Old.

The Property of Mr. Gcorge Rudd, Guelph, Dat 
The foregoing eut is a good illustration of a Devon bull as he appearcd when but two years old. Such an animal may be regarded as a most admirabls opecimeu.

\section{Classiflcation of Races.}

In England eattle are divided into bcef and dairy cattle. Beef cattlo ngain are divided into long-horns, middle-norns, short-horns, and pollod or hornless cattle.

\section{Long-Horns.}

Of the iong-horns; the old Irish long-horns showed a striking peculiarity, which was, that their horus turned directly downward.

In Craven, England, has long existed a breed of cattle peculiar in themselves, broad in the chime, quick and casy to fatten, and noted for making excellent beef.

Under the scientific breeding of Bakewcll, a hundred years ago, and his immediate successor, Leicester, long-homs acquired a wide celebrity. This was undoubtedly attained by breeding in-and-in. He was known to have done so to a remurkable degree.

With the death of Bakewall and his immediate successors, cxcessivo delicacy of constitution began to tell, and they began to lose caste years ago, as a race.

They have left their impress, however, and, most decidedly, upon the whole family of long-horns. They became better feeders, better handler's, and made better beef than before the infusion of this blood.

They have long been superseded by the short-horn and the Herefords, and are only noticed here, as forming a part of the mixed blood of cattle, of the United States and Canada.

We occasionally sce by reversion, animals among our so called nativo cattle, showing strong characteristics of Leicester, Hercford, Devou. tho cld Teeswater, the Dutch and polled cattle

\section{Iridale-Horns.}

Of the Middle-Horns the only cattlc valuable in the United States, cro the Devons and the Herefords, both wonderful fanilies, in their unake up, and valuable whether for beef or working oxen.

In fact the Devon is the hest working ox in the world, and as beef makers their fiesh is superior to that of any other breed, except the Scotch, or West Highland cattle.

Besides the Devous the other families of the Middle-Horns, are the 
Sussex, Pembroke, Glamorgan, Angelsea, and, in Scotland, the Wost Highland eattle, noted for the superiority of their flesh, and which have, for many generations, remained unchanged, or improved except by seleotion.

Their prineipal valuc, after all, is their extremo hardincss, and aptitude to fatten where other animals would starvo.

Above, as showing the characteristics of this breed, we give an illustran tion of a WVest Highland ox, in good feoding flesh,

\section{The Derons.}

The eelebrity that the Devons long ago attained for their superior beef and working qualities, is wholly due to the fact that they havo long been bred, in North Devon, pure. Hence, they are often called North Devon, to distinguish them from the South Devons and the Sussex, both inferior cattle, oithel from a feeding or working standpoint.

The Devons are undoubtedly an original and pure race, and havo been noted for their high excellenee for many generatious.

It is only within the last two hundred years that systematic efforts have been made to increase the excellenee of Euglish eattle, and it is not moro ihan one hundred and fifty year's ago that Devon farmers were wakod up to the improvement, that might be made in theso high strung, generous feeders. They have within the last seventy-five years been brought to such high perfection, that they do not suffer in comparison witl other bigh easte cattle, and they would ecrtainly suffer by intormisture with any other breed.

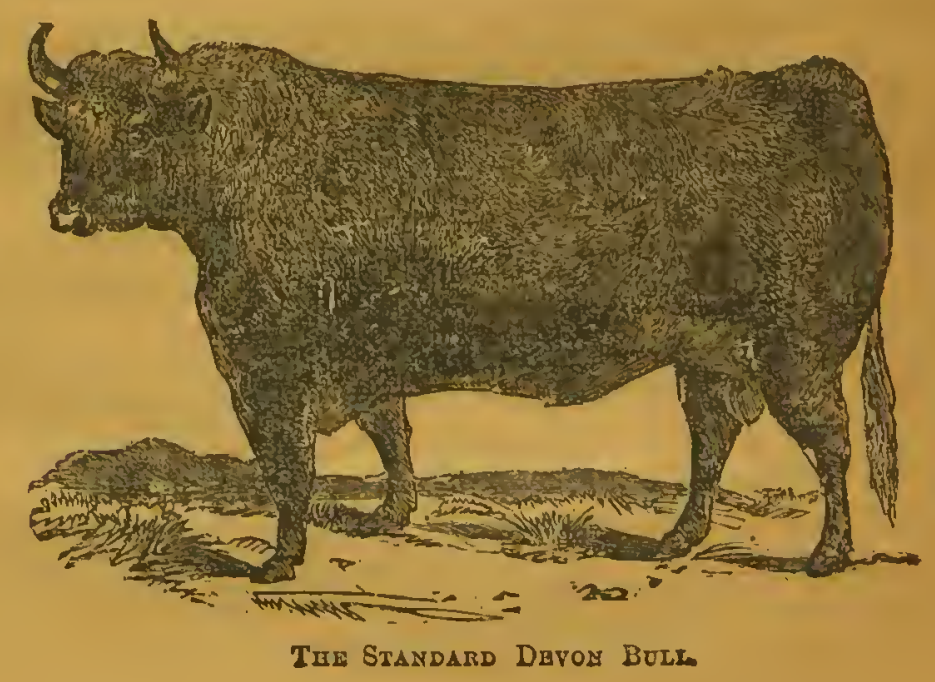




\section{ILLUSTRATFD STOCK DOCTOR}

\section{Where Devons Thrive.}

They cannot compete with the Short-Horns and Herefords, on flush restern pastures.

They lack size, and early maturity, but on hill, or broken pastures, and in elimates too cold for these breeds, and cepccially in climutes unsuitablo to Short-Horns, they ure the best cattle over known.

On the previous page, as showing the extraordinary symmetry and stylo of this remarkable breed, we present a likeness of a Devon bull, remarkable for cwinent churacteristics of the brecd.

\section{Dovon Cows.}

The bulls of this breed aro inelined to be vicious as they get old. The cows aro gentle, and if gently used, kind in the cxtreme. Both males and females, however, are so high strung that they will not bear abuse. A brutal master they will fight, but if managed with a firm, yet gentle hand, they are the most familiur, as they are the most intelligent, of horned cattle.

The eows grive exceedingly rich milk, and many of them fair quantitieg.

The males are said to cross lindly with the Guernseys, and these make valuable duiry eattle.

There are however now so many execllent purc breeds of milkers that it would be futile to experiment with the cross, since it will surely reduce the value of the animal either for work or beef.

As workers, milkers and beef mikers combined, for the amount of food taken, they have no superior, if they have their equal. Is beef makers alone, iu the West, the Short Horns and Hereford are superior. As milkers the Jersey, tho Holstein and Ayrshire tako the palm. Is working eattle the Devons are superior to all known breeds.

The cut on tho following page is a good illustration of a high casto Devou cow.

\section{Cheracteristic 3 of tho Devon Corr.}

\section{I'his we give as follows:}

There are few things inore remarikable about the Deron cattle than the comparative smallness of the cow. The bull is a great deal less than the ox and the cow smaller thum the bull.

This is some disadvintage, and the breeders are aware of it; for, although it may not be necessary to lave a large bull, and especially as those of an extraordinary size are seldom landsome in all their points, bur sumewlere or other present coarseness or deformity, it is almost 
impossible to procure large and scrviccable oxen except from a somewhat roomy cow

These cows, however, although small, possess that roundness anä projection of the two or threc last ribs, which make them actually moro roomy than a careless examination of them would indicate.

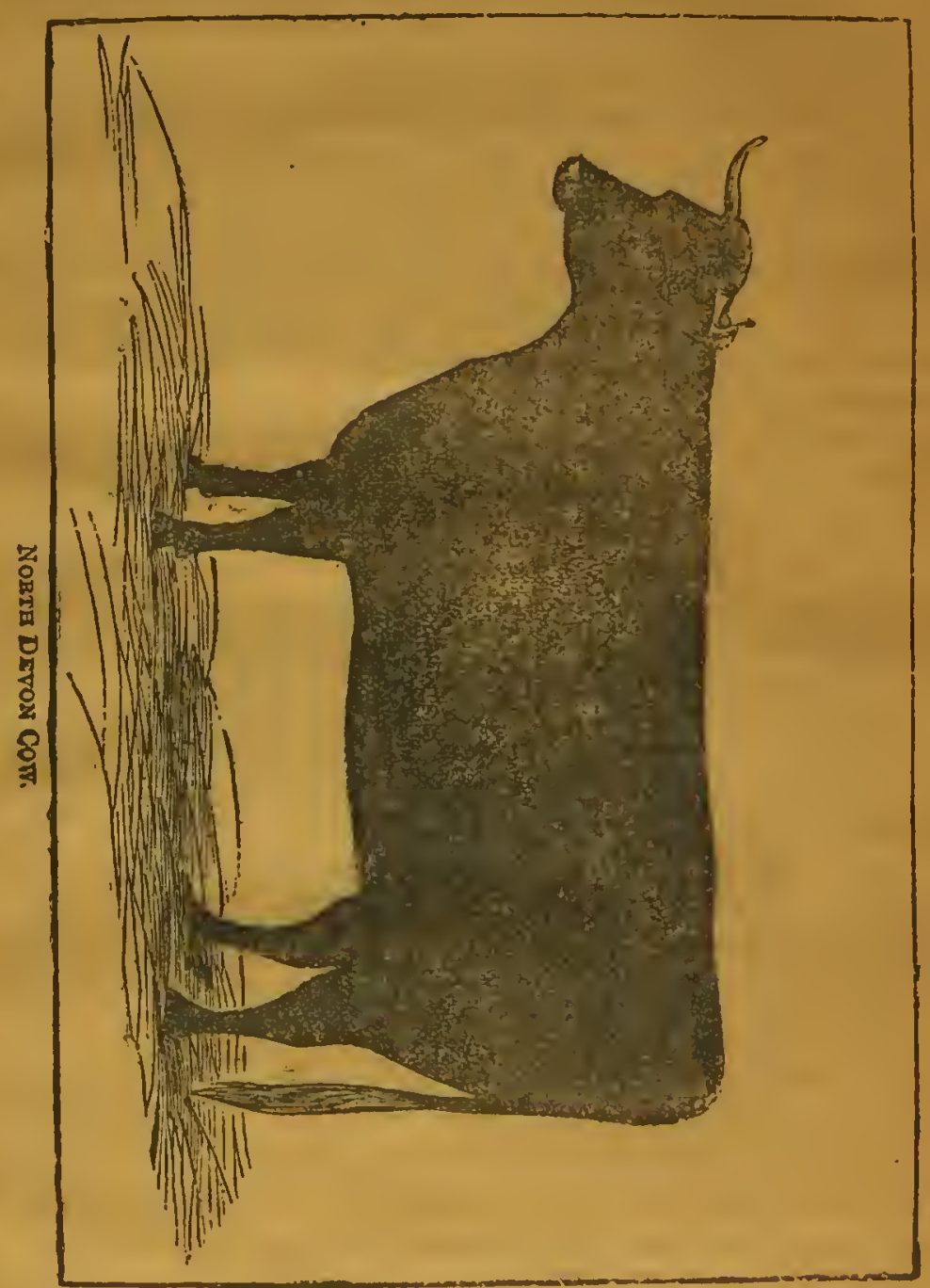

The cow is particularly distinguished for her full, round, clear eye the gold-colored eircle around the cye, and the same solor on the inside blie of the ear.

The countenance is cheerful and the muzzle orange or yellow. 
Tho jaws aro freo from thicknoss, and the throat from dewlap.

The back, tho barrel, and the hind quarters differ from thosc of othcr breeds, having more of roundness and beauty, and bcing frce from angles.

\section{Points of the Derons.}

Youatt, than whom none have written morc intelligently on domestio enimals, describes the charactcristies of the breed as follows:

The more perfect specimens of the Dcron brced are thus distinguisied:

The horn of the bull ought to be neither too low nor too high, tupering at the points, not too thick at the tip.

Tho eyo should be clcar, bright, and prominent, showing much of tho white, and have around it a eirele of dark orange color.

Tho forchcad should be fiat, indented, and small, for, by the smallness of the forehead, the purity of the breed is very much cstimatcd.

The chcek should be small, and tho muzzle fine; the nosc must be of a clear yellow.

The nostril should be high and open; tho hair eurled about the head.

Tho neck should be thick, and"that sometimes almost to a fault.

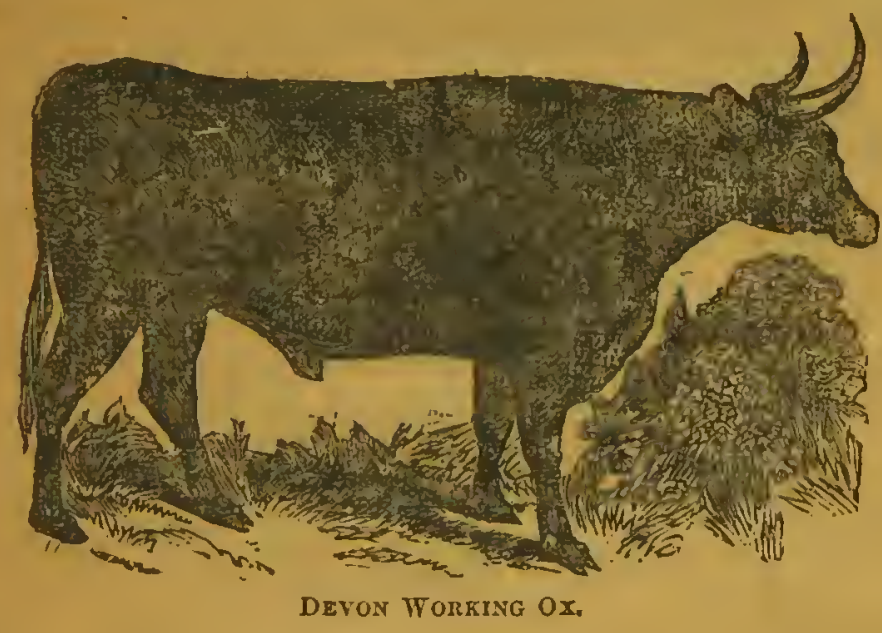

Excepting in the head and neck, the form of the bull does not mata rially differ from that of the ox, but he is considerably smallcr. Thero arc exceptions, however, to this rulo.

The head of the ox is small, very singularly so, relatively to his bulk; yct it has a striking brcadth of forehcad; it is elean and frco from flesb about the jaws.

The oye is very prominent, acd the animal has a pleasing vivacity of 
countenarce, distinguishing it from the heavy aspect of many other breeds.

Its nock is long and thin, admirably adapting it for the eollar, or the mole common and ruder yolke.

It is accounted one of the characteristics of good enttle, that the line of the neck from the horns, to the withers, should searcely doviato from that of the buck.

In the Devon ox, however, there is a peculiar rising at the shoulder, reninding us of the blood-horse, and sssentially connected with the free and quick action by which this breed has ever been distingr:shed.

It has little or no dewlap depending from the throat.

The horns are longer than those of the bull, smaller, and fine even to the bise, and of a lighter color, and tipped with yellow.

The animal is light in the withers; the shoulder's a little ohlique; the breast deep, and the bosom open and wide, particularly as contrasted witl the fineness of the withers.

The fore legs are wide apart, looking like pillars that have to șupport a great weight.

The point of the shoulder is raroly or never seen. There is no projec tion of bone, but there is a kind of level line running on to the neck.

\section{Characteristics and Important Points.}

Angular bony projections aro never found in a beast that carries much lesh and fat.

The fineness of the withers, the slanting direction of the shoulder, and Uhe broad and open breast, inply strength, speed, and aptitude to fatten.

A narrow-chested animal an never be useful either for working or glazing.

With a!l the lightness of the Devon ox, there is a point about him, disliked in the blood or riding horse, and not approved in the horse of light draught-the legs are fur under the chest, or rather the breast projects fur and wido before the legs. We see the advantage of this in the beast of slow drunght, who rarely breaks into a trot, exeept when he is goaded on in catching tims, and the division of whose foot prevents him from stumbling.

The lightness of the other parts of lis form, lowever, counterbalances heaviness there.

The legs are straight, at least in the best herds. If they are in-kneed or crooked in the forc-legs, it argues a deficiency in blood, and eomparative incapreity for work; and for grazing, too, for they will be hollow behind the withers, a point for which nothing ean compensate, beenuse it takes away so much from the place where good tlesh and fat should bo 
thiekly laid nn, and diminishes the eapacity of the chest ana two power of creating arterial and nutritious blood.

\section{The Limbs of tho Derons.}

Tho fore-arm is particulariy largo and powerrul. ' It stells out sud.' denly above the knee, but is soon lost in the substance of the shoulder, which is specially full and round.

Below the kneo the bone is small to a very extraordinary degree, indisating a soeming want of strength; but this impression immediately ceases, for the sinallness is only in front-it is only in the bone; the leg is deep, and the sinews are far removed from tho bone, promising both strength and speed.

It may be objected that the leg is a little too long. It would ve so in an animal destined only to grazo; but this is a working animal, and some length of $\operatorname{leg}$ is necessury to get him actively over the ground.

Tho Body of the Derons.

Thrre is somo trifling fall behind the withers, but no hollowness, and the line of tho back is straight from thence to the setting on of the tail. If there is any seeming fault in the beast, it is that the sides are a little too flat. It will appear, however, that this does not interfere with feeding, while a deep, although somewhat flat ehest is best adapted for speed.

The two last ribs are particularly bold and prominent, leaving room for the stomach and other parts conecrued in digcstion to be fully developed.

'Tlıe hips, or huekles, are high up, and on a level vith the back, whethe the beast is fat or lean.

The hind quarters, or the space from the hip to the point of the rump, are particularly long and well filled up-a point of importance both for grazing and working. It leaves room for flesh in the most valuable part, and indicates much power behind, equally connected with strength and speed. This is an improvement quite of modern date. The fullness here, and the swelling of the thigh below, are of much more consequence than the prominence of fat which is so much admired on tho rump of many prize cattle.

The setting on of the tail is high, on a level with the back, rarely much elevated or depressed. This is another great point, as connected with tho perfection of tho hind quarters.

The tail is long and swall, and taper, with a round bunch of bair at tho bottom. 


\section{Of the Skin and Hair.}

The okjin of the Devon, with his curly hair, is cxcecdingly moliow and elastic. Graziers well know that there is not a more important point than this. When tho skin can be easily raised from the hips it shows that thero is room to set on fat below.

Tho skin is thin rather than thick. Its appearance of thickncss arises from the curly hair with which it is covered, and curly in proportion to the condition and health of the animal. Theso curls run like littlo ripples on water. Some of these cnttle havo the hair smooth, but then it shonld bo fine and soft. Those with curled hair uro moro hardy, and fatten moro kindly.

The favorite color is blood red. This is supposed to indicate purity of breed; but there are many good cattle approaching alouost to bay, aud others of intermediate hues.

If the eye is clear and good, and tho skin mellow, the paler color wi, bear hard work, and fatten as well as other's, but a beast with palo hair, and hard under the hand, and the cyo dark and dead, will bo a slugoisia worker, and an unprofitablo feeder.

Thoso of a ycllow color are said to bo subject to diarrlica, or scouring

These are the principal points of a good Devon ox; but he used to bo; perhaps as many aro yet, a littlo too flat-sided, and the rump narrowed too rapidly behind tho hip bones; there was too much space between tho hip boncs and tho last rib, and he was too light for plowing in tenacions and strong soils.

A sclection from tho nost perfect animals of tho truo breed-the bone small and tho neck fine, but the brisket decp and wide, and down to tho knees, and not an atom of flntness all over tho side-these huvo improved the strength and bulk of the Devon ox, without imparing, in the slightwot degreo bis activity, his beauty, or his propeusity to fatten

\section{The Herefords.}

The Herefords, named from the county of Hercford, England, wero originally red or brown, with no white abont them. From that they wero bred to browuish or yellowish red, somo few even being brindle. Only within the last hundred years have thoy been bred to whito faces.

It was finally made to extend along tho top of tho neck, along the throat, dewlap, briskot and fore legs, belly and flanks; and whito hind fect and tail are now fnshionable.

They are a very ancient breed, and undoubtedly allied to the Devons, which they very much resemble, 


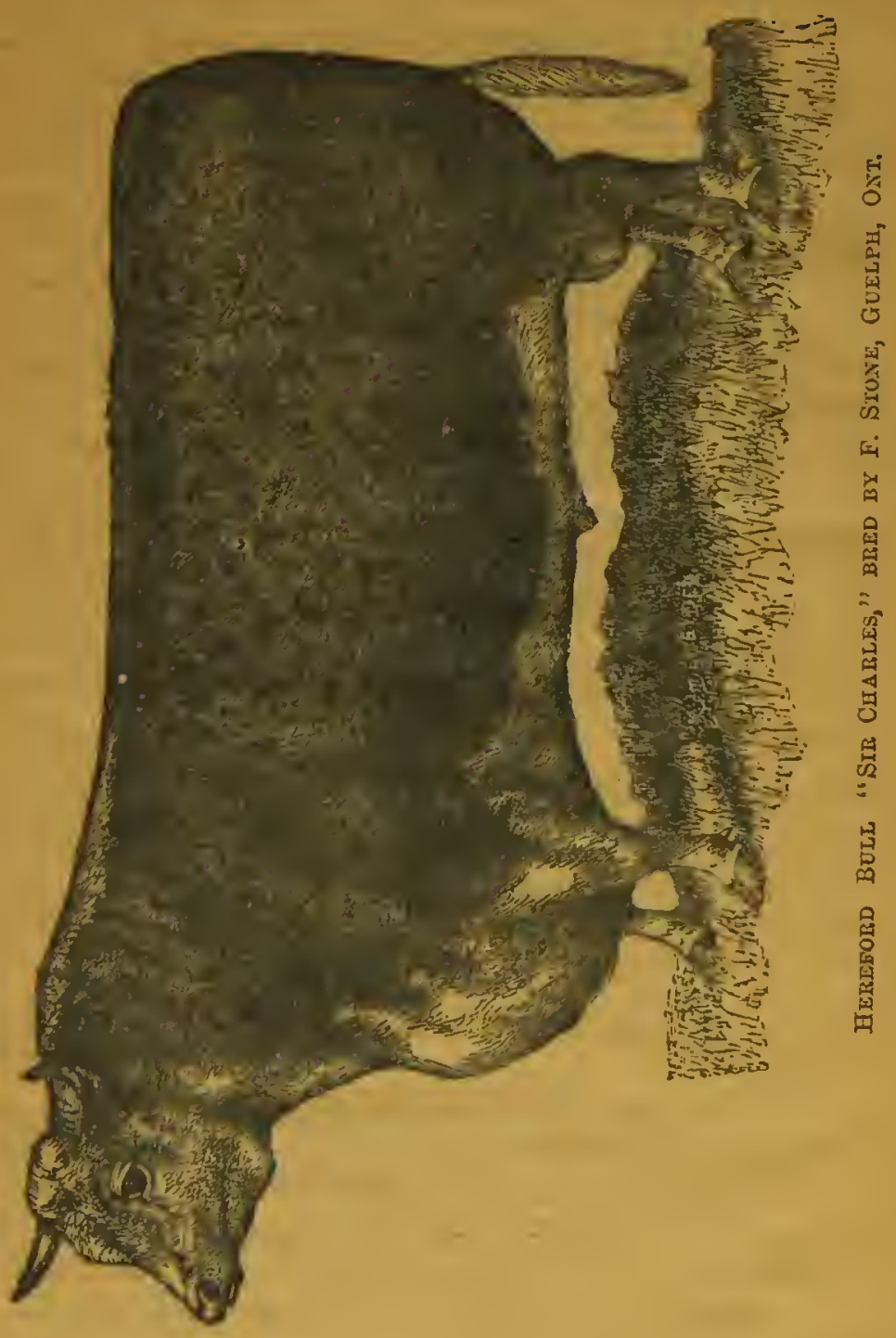




\section{Ferefords Fifty Years Ago.}

Mr. Marstal, a most competent authority, gives the following account of tho improved Hereford as it was lnown tifty yeurs ago:

"The countenance plcasant, checrful, open; the forehead broad; cyo full and lively; horns bright, talpcr, and spreadiug; head small; chop lean ; neck long and tapering; chest dcep ; bosom broad, and projeeting, forward; shoulder-bone thin, flat, no way protuberant in bone, but full and mellow in flesh; chest full ; loiu broad; hips standiug wide, aud lcvel with the ehinc; quarters long, and wide, at the neck; rump even with the level of the back, and sharp above-tho quarter's; tail slender and neatly haired; barrel round and l'oony; the carcass throughout deep and well spread; ribs broad, standing flat and close on the outer surfaee, forming a smooth, cveu barrcl; the hind parts large and full of strcngth; ncels bones snug, not promiuent; thigh elean, and regularly tapering; legs up. right and short; bone below the knce and hoek small ; feet of middle sizo: llank large; flesh cvery where nellow, soft, and yieldiug pleasantly to the toucl, especially on the chine, the shoulder and the ribs; hide mellow, supple, of a middle thiekncss, and loose on the neck and huckle; coat ncatly haired, bright, and silky; color, a middle red; this, with a bald face, is charicteristie of the true Hereford breed."

\section{The Hlereford Cow.}

The Hereford corv compared with the ox is small and delieate, and not always handsomcly made, to the suporficial obscrver.

Hero again this breed would secm to show their relationship to tho Devon. She carries but little flesh, in brecding condition, and when brecding, should not be fed suffieiently to aecumulate much fat; for, in order that the young be superior, the dam should have plenty of room inside.

With the Herefords, experience has shown that the dam may not be too large or coarse but she should be roomy. Then the breeder will get, even from apparcutly inferior eows, large, handsomo stcers, that will fatten early, and kindly, aud to great weights.

When the eow is done brceding, and ready for fatting, it will pleaso the owner to see how she will spread out, and accumulate flesh and fat and this to a greater degrec, than if not allowed to breed.

The Hcrefords are a hardy, gentle race, maturing carly, and are long lived. The flesh is superior, handsomely marbled, heavy in the prine parts, and they fatten to weights fully as heavy as any known breed.

Their massive strength, honesty and gentleness make them the best working osen lnown, and the potency of the bulls, when crossed upou 
red or ncarly red eows of the eountry, renders the steers easily matched in color, as they will be easily matehed in general characteristics of tho progeny.

\section{Herefords in America.}

Herefords were first brought to Ameriea for systematic breeding in 1816 or 1817 , by the great Kentueky statesman, Henry Clay. They were soon, however, allowed to run down and were at length entirely lost eight of there. Admiral Sir Isaae Coffin, a few years after, sent out from England a Hereford bull to his friends in Massachusetts, which was used in erossing upon the mative eattle of the State. He made a very marked impress there, and for many years the good result was seen in the eattlo of the Statc.

Abuut the year 1840 there was a large importation made into the State of New York, from Lingland. They went prineipally to Jefferson county and some to Vermont.

About the year 1852 there was another eonsiderable importation of Herefords into Ohio-very fine animals, where they, in connection with later importations, hare been suceessfully bred.

In 1860 and 1861 two importations were made into Canada, eonsisting of two bulls and eleven eows and heifers, From these there have como down many most exeellent animals, which have left their inpress far and wide. Since that time there have been various importations, prineipally in Illinois and Maryland, the produce of which have fought their way against the opposition of the Short-Horns, until now they may be said to fairly divide honors with this famous breed in Ameriea as they are well known to do in Eingland.

\section{As Milkers.}

The eows are not very deep mullers, in faet they give but little milk. They were uever large milkers, and a course of breeding for many generations as beef makers, while it has brought up the animals to great weights and such wonderful symmetry that they fairly dispute the palm in the showrings with the hest Slort Horns, the wilking qualities have gradually beeome less and less. It is but another exemplifieation of the fact, that all goodness eannot be combined in ono animal.

It is enough that the seicnee of breeding within the last fifty years has brouglit all our domestie animals far toward perfection, in the two great elasses needed in eattle: that is, superior execllenee as beef makers, or else superior execllence as deep and rieh milkers. It is obvious that it must be so, for the animal superior as a milker must necessarily be altogether different in her eonformation from one destined to produce a maximum weright of primo beef at tho earliest age. 
CATTLE, HEREFORDB.।

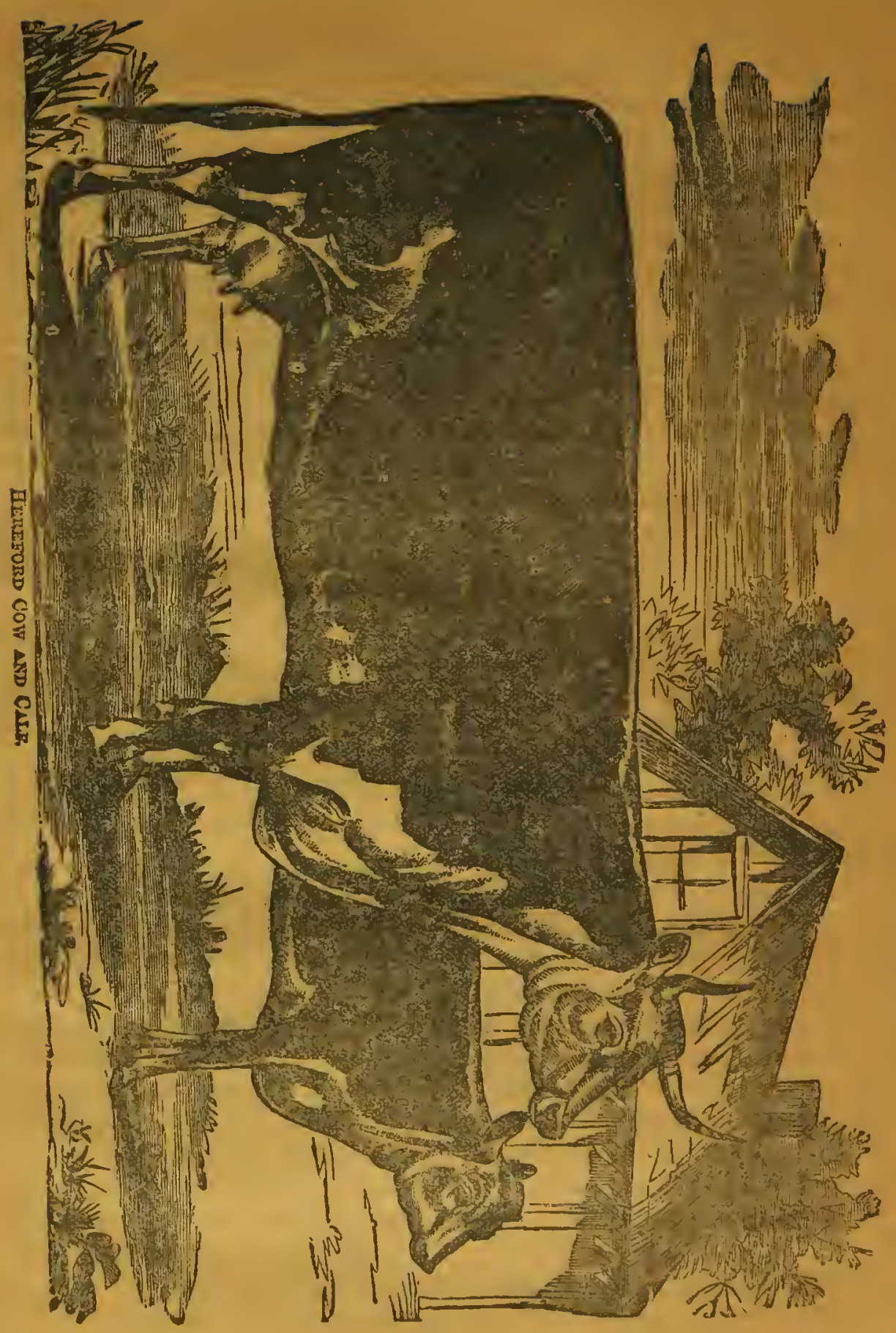




\section{Tho Hereford $O x$.}

Whether we consider this remarkable breed either in their adaptability to heavy draft, or in their wonderful fattening qualities, it is tho stoers that make the money for the feeder.

Their capability of standing fatiguo and constitutional adaptability in resisting winter weather, has of late mado them great favorites with the ranchmen on the plains.

So, while we sce them winning honors in the show rings at home, the young bulls aro eagerly picked up for transportation to Colorado, New Mexico, Montana and Wyoming, to put with the herds there, for the purpose of breeding grades.

Thus two valuable ends will be conserved: That country will send East most superior cattle for feoding fat, in the great corn region of the West, while at the same time they will bo raising up steers admirably adapted to the heavy freighting business in the mountains and mining districts.

\section{The Hereford of To-das.}

As showing the extreme care that has been exercised of late years it improving this comparatively rare breed in England, to such great perfoction as to fairly claim hours with the very best Short-Horns, the following extracts from leading agricultural journals, relating to one of the great show rings there in 1878, the Bath and West of England, the Mark Lane Express speaking of the Hereford exhibit says:

"They are not so numerous as tho more fashionable breed, but the quality throughout is exeellent. In the aged bull class there are five animals of which the Icreford men need not bo ashamed.

"The heifers in milk or in calf numbered only three, but two of them were sueh animals as it was worth while coining to Oxford on purpose to see. Mrs. Sarah Edwards, of Wintercott, took first and second, leaving Mr. Lutley the reserve; but Mr.3. Edwards' Leonora is one of the most perfect auimals that has been shown for years. It was first last year as a yearling at Liverpool, and will likely be first wherever it goes. The champion prize given by the Oxfordshire Agricultural Soeiety was also awarded to this heifer as the best female horned animal in the yard. The companion heifer, Beatriee, is also very handsome, and took second to Leonora's first at the Royal last year, as it did last weck at Oxford. Mrs. Edwards may well be proud of sueh stoek as that; if Leonora had been a Grand Duchess Short-Horn a poem would have been composed in her honor, and translated into seroral languages by this time. But no Short-Horn that we have ever soen was east in such a mould. 
In the Agricultural Gazelte (London) we find the following:

"This breed enjoyed the remarkible distinction of producing both the champior animals at Oxford. Mr. Aaron Rogers' Grateful being dcclared to be the best bull, and Mrs. Sarah Edwards' Beatrice (a two year old heifer) being declared to be the best cow or heifer in the yard. Both, as may be supposed, were very good, the heifcr pre-eminently so. She is a daughter of the famous bull, Wiuter de Cote, and another instance of hereditary mcrit.

"The yearling heifers and calves indicate that this breed is, as beef malsers at an carly age, quite up to the lighest Short-Horn standard. The Tecswater may milk better, and be more ready in adapting itself to local circumstances; but where the pasture is good, it is hard to beat tho white-faces for grazing."

The Chamber of Agriculture Journal (London) also says:

"'The old bull Hercford class produced an extraordinary animal in Mr. Aaron Rogers' Grateful, who secured the reserve at the Hereford Show in 1876, but did not make his appearance at Bath or Liverpool last year. He has made wonderful development since, appearing as a two-year-old, as is proved by the fact that Thoughtful, who was then placed above hin, and has since taken firsts at Birmingham, Liverpool and Bath, has now bcen put second to him; and that not only was he selected by the judges as the best Hereford bull on the ground, but in the contest for the championship succeeded in carrying it off against such a Short-Horn competitor as Sir Arthur Ingram. This is no slight honor to the IIereford brecd, and of course any animal counted worthy of such a distinction must be a first-class one. Gratcful, at four years old, has capital loins and chines, with grent thickness and depth of frame, and is very level all over; hut his grand feature is the astounding mass of flesly with which his frame is covered. His girtl is cight feet ten and one-lialf inches. Thoughtful has frequently been described in these columns, and it is sufficient to state that he is a massive, grand bull, who well supports his merit. The next class was a very reak oss, only consisting of two, and those not so good as the herds of Mr. H. N. Edwards and Mr. Philip Turner are accustomed to supply.

"In the cow class the late Mr. Warreu Evans' Lady Blanche, which took second prize at Bath, now cane to the front position. She is marvelous at her fore flank, and displays a grent mass of flesh on a wcll-shaped, grand franc, which, however, fell off slightly at the rump. The second prize cow, Mr. E. J. Lewis' Little Beauty, had a highly commended at Batll, and wonderfully retains her show-yard merit at eleven years old. The two-year-old lieifers of Mrs. Surah Edwards, Leonora and Beatrice, were, of course, sure to win. Beatrice has recently reared a calf, wanch 
is slightly against her for showing; but Leonora is in full bloom with her beautiful head, symmetrical form, and all that loveliness which is so talcing to the oye. After being selected as the best Hereford female on the ground, she carriod off the champion prize against a remarkably

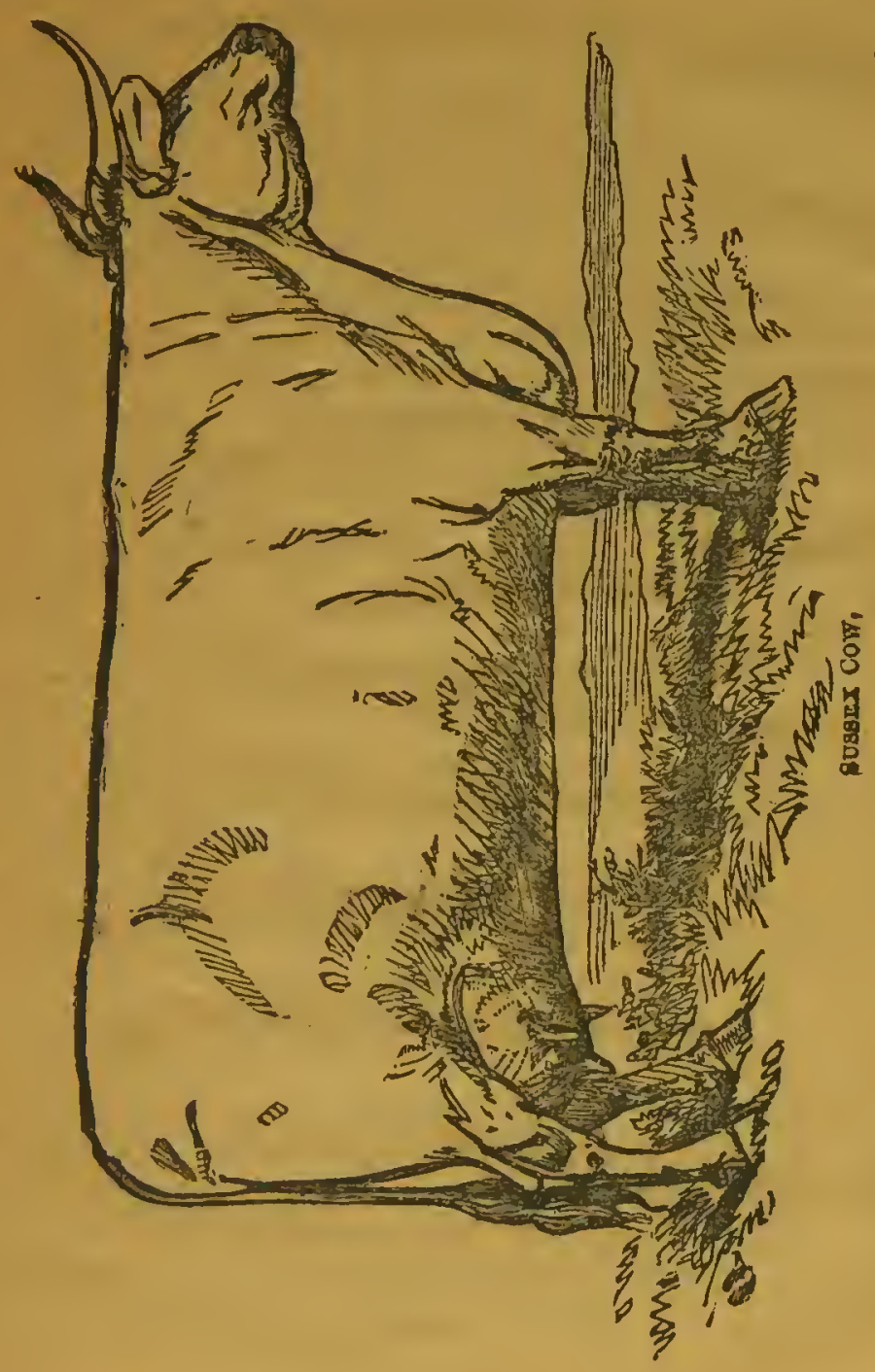

shapely Short-horn heifer, and one of tho best Devons that has appearea for years, so that both cups wero awarded to Herefords." 


\section{Cuscex Cattlo.-Distinguishing Trarles.}

This hreed is closely allied to the Devons, but coarser. Their distinEuisting marks are:

Tho horns are more :apering, pushing farther forward, and turning tp more. The head is small and well formed, the eye full, largo and mild in the ox, but rather wild and unquiet in the cow. The throat is clean and the neck long and thin, but coarser than in the Deron. Tho ghoulder is wider and rounder on the wither's; straighter from tho top of the wither's towards the back, and curries much flesl, griving too much reight to umprofitable parts. On the other hand, the barrel is round and deep, the back straight, and the back-bone entirely hidden by the museles on each side. 'The licart and lungs are full and lirge, and tho belly and flank capacious. The barel is well-riblod home. The loins are wide, tho hip-lone low, free from ragredness, large, and well spread, and the space between the hips well fillec up. The tail, which is fino und thin, is set on lower \{lism in the Devon, yet the Jump is nearly as straight, for the deficiciey is supplied by a mass of flesh and fat swelling above. The hind qumter's are cloanly made, ind if the thighs appear to be straight without, there is plenty of fullness within.

In color the Suasex is a deep chestnut red, or blood bay. They aro ail lisbter in color than the Devon, but in color they are fully as uniform.

\section{Tho Eussex Cow.}

The cows have fine hair, a mellow, ratlie: than thin sisin; a small teat; horns fine, clean, and trausparent, which reach forward from the head and turn up at the tips; the neck is thin and clean; back and belly struight; ribs ronud and springing out well ; shoulder flat. but projecting .. at the point.

Ilips and rump wide; the tail set on level with the ruspip, and tho car. cass large; the legs are rather short and finc.

The cows are not good milkers; they are often uneasy in the pasture. and as before stated, unquiet in temper.

They have been, some of them, imported to tho United States and cren exhibited and sold as Devons.

This description of the Sussex is given for this reason: Those who buy Derons should be careful that they lave no stain of this blood; in other words, their pedigreo should be perfect.

\section{Short-IIorned Breeds.}

The Short-Horn breeds of England are represented lyy the Durham, tho Zorkshire, the Lineolnshine, the I'ceswater and the Holderners breeds. 2 II 


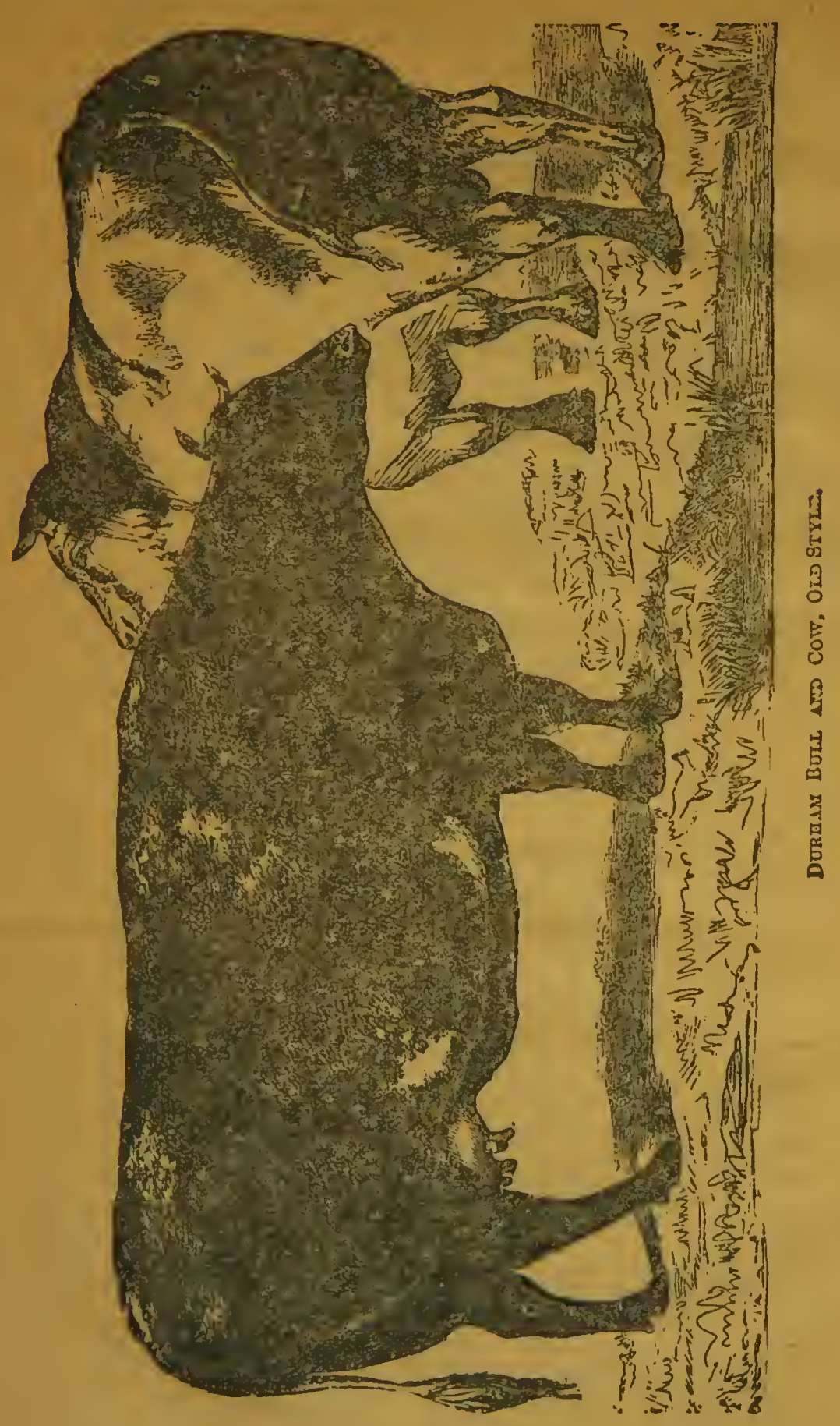

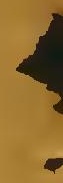


The Yorkslures and Lincolnshires are now but little linown, being superseded by the improved breed now generally known and recognized by the name of Short-Horn, or the crosses thercof.

Their characteristics were those in in mudified degreo of the old Durham and Tceswater cattle.

\section{Short-Horns Proper.}

The only represcntation of this class worthy of notice here, are the desecndants of the old Durham or Tecswater cattle, which have existed in the counties of Durham and York, from the earliest historical periods. These unifornily had short horns, were of large sizc, and were extruordinary milkers.

As to their eharacteristics, they were thin-skinned; slcek-haired; rather delicate in constitution; not mellow to tho touch ; conrse in offal; defective in girth forward; slow to fatten; the meat inferior, and often of a dark hue.

Excellence in the aptitude of the Short-Horns of latter years to fatten, early maturity, and mellowness of hide, go back almost one hundred and fifty years, when the Short-Ilorus, on the banks of the river Tees, (and henco called the Tceswater breed), began to assume the distinctivo characteristies of the Short-Horns of a later period.

\section{Short-Horn History.}

Whatever may have been the origin of the cattle irom which haro descended the present race of Short-Horns, it is not of moment hrre. It is cnough to know that they had been for many generations bred sufficiently pure to establish ecrtain cliaracteristics that attraeted the inost eminent breeders of the day.

Among the brecders of the latter part of the last century, and the early part of the present century, were the Collings, (Charles and Robert), Sir Henry Vime, Col. Johu Trotter, and Mr. Mason.

In the carly years of the present century, Mr. John Sterenson, Mr. Bates, and Mr. Booth, each became celebrated for the eninence of their animals. Earl Spencer aiso acquired a great reputation, as the possessor of extraordinary animals, and for prices received by himself and Mr. Bates.

Sinee the death of the latter gentleman in 1849, Short-ilorns lave stcalily inereased in price for fashionably bred animuls, running far into thousands of dollars, of late years, for a single animal, while those not so fashionably bred were equilly sought at prices that wet:ld have secmed lurge fifty or sixty years ago. 
Belnw nuy be foumd an outline representation of a fat Sloort-ITorn $\mathrm{cnw}$.

It will he observad that this animal camies freat size, a square body of Treat substance, while the legs are sufliciont for locomotion, although from the fullness of the carcass they seem short, and that there is abundance of weat in the prime parts, including tho thighs, which curry thoir

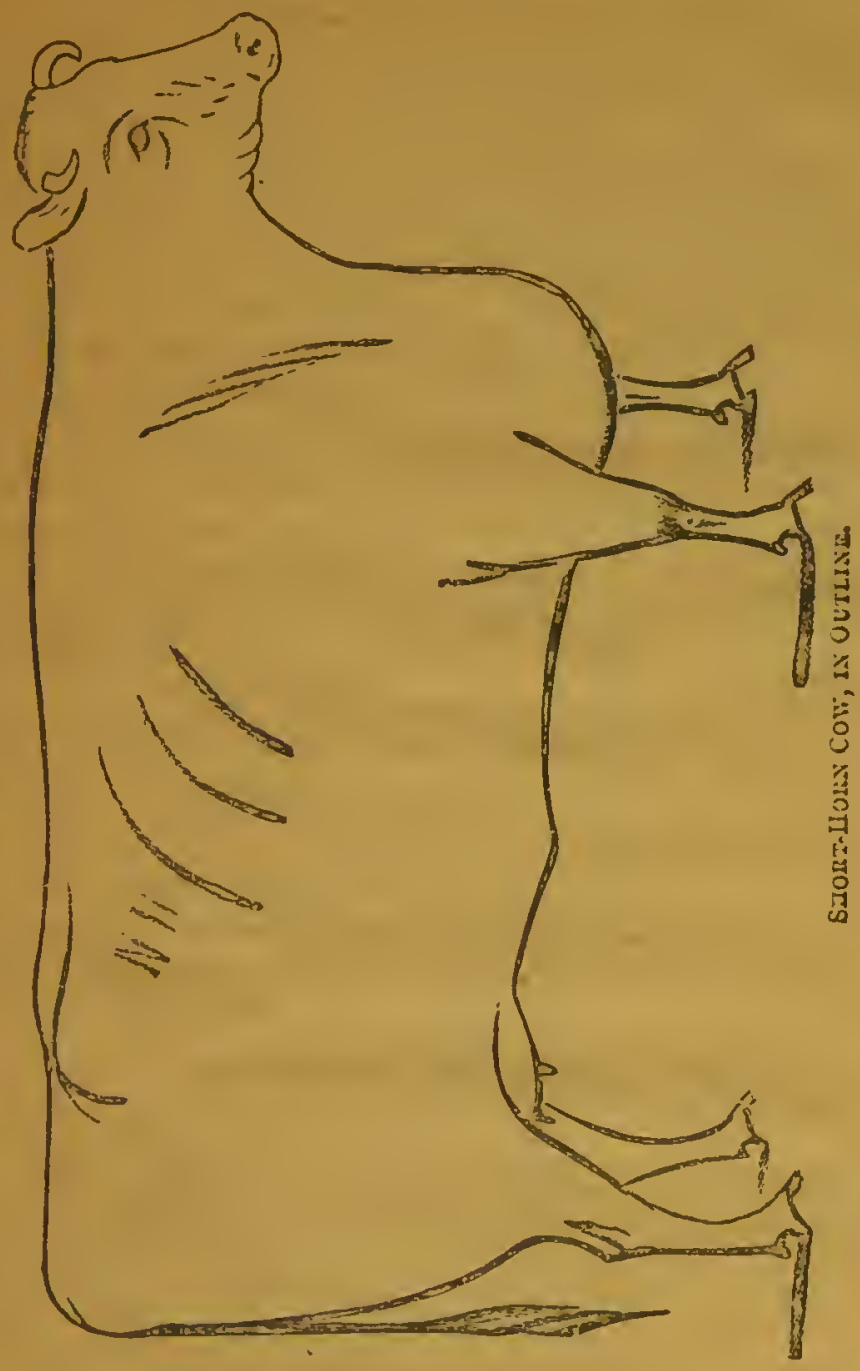

fullness well down to the hocks. It will he seen that she is characterized by massiveness, smoothmess, and that sho shows the appearance of carry. ing light offal. Tho brisfet is decp, the udder small, but compact, and 
extending well forward. The rump is smooth, but broad, and without patchiness-thut is, great lumps of fit stinding out like Wlubber. Tho hips are broad and well covered with tlesh and fitt; and the loins, and indeed the whole top, exceptionally good. In fact, she is an animal carying becf all over, where flesh miny he laid on, and full of fat irsicl?. She is a gind lepresentative of the breed, and one that may be fattened to a gireat weight.

\section{Short-Horng in Amcrica.}

Mr. Allen, the editor of the American Short-Horn Ilerd Book on American eattle, from a very exhustive rescareh of importations in relation to the introduction of this mosi valuable breed into the United States, says :

Soon after the termination of the Rerolutionary war witl England, a fer cattle supposed to be pure Short IIolus, were brought into Virginia by a Mr. Miller. These were said to be well fleshed aninals, and tho cows reminkiable for milk, giving as hirh as thirty-two quarts in a day. Some of the produce of these cattle, as early as 1797 , were talken into Kentucky by a Mr. Patton, wiere, as little was linown of "breeds," they were called, after the gentlemin who hrought them, the "Patton stock." They were well cared for", and made a decided immorement in the enttle of the "blue grass country," where they were first introduced. Some of this enrly Virginia stock also went out to the "south branch of the Potonia," in that State, a fine wraing rountry, whicle, fifty ycars ago, was famous for its good cattle. In the rear 1796 , it is said that. an Englishman, named IIeaton, bronght two or three Short Ilorin cattle from the north of Englonel to New Yoik. They mere talien to Westcoster county, ne:m by, and bred, lout no results, in pure blood, hatro been traced to thom.

In 18i5-16, a Mr. Cox, an Englishman, imported a hull and two heifers into Rensscicl eounty, New Tork. These were followed in 1822 by two bulls, imported by another Englishmin named Hingne. Iescendgnts fiom this Cox stock were said to be bred pure, and afterwarels crossed by Mr. Mayne's bulls. 'The stock now cxists in considerablo numbers and of good quality, in that and adjoining counties.

In 1817 Col. Tevis Sinders, of Lexington, Fentucky, made an importation of threc bulls and three lieifers from England. They wern of good quality and blood, and laicl the fomelition of many cxecllent herds in that State. In 1818. Mr. Cornclius Cooledge, of Boston, Massachusetts, imported a yearling heifer,_- Flom" - and a bull "Cicero" -iuto that city", from the herd of Mr. Mason, of Chilton, ia 
the county of Durlian, Englind. These were carefully bred, and many of their descendunts are now scattered throughout sereral States. About the same year Mr. Samuel Williams, then a inerehant in London, but a native of Missachusetts, sent out a bull — "Young Denton" — and somo cows of the sune and later importations, and their deseendants are still numerous among well bred Short Horns of the present day.

The same year, Mr. Gorhan Parsons, of Brighton, Massachusetts, imported a Short Horn bull__ "Fortunatus"_-bred by Geo. Faulkner, of North Allerton, Yorkshire, England. Ho was used considerably on the native cows of his State, but we have never traced any thorough-bred pedigrees to him.

In 1820, Mr. Theodore Lyman, of Boston, Massachusetts, imported a bull, which lie sold to Isracl Thorndike, of that city, and be sent him to bis fum in Minine. Of his produce we liear nothing.

Alsout the year 1820 , and during a few years succeding, scveral spirited gentlemen of Boston, and its neighborlood, imported a number of cows and bulls from soine of the best herds in England. They were Messi's. Derby, Willians, Lec, Prince, Mínson, and perhaps others. These were all fine cattle, and of approved blood in the English ShortHorn districts. Their descendants are still numerous in New England, and some other States.

About the yeur 1823, the late Admiral Sir Isaae Coffin, of the British nary, a native of Massachusetts, sent out a cow- "Aunbella"-and a bull-"Aclmiral" - as a gift to the Missachusetts Agrieultural Society. They were good animals, and bred with the other Massachusetts importations.

Shortly previous to 1821, the late John S. Shinner, of Saltimore, Maryland, imported for Govemor Lloyd, of that State, a bull - "Champion" - and two lieifer's_-"White Rose" and "Shepherdess"_from tho herd of $\mathrm{Ml}^{\circ}$. Champion, a noted English brecaer. From these, sereral good animals descended, some or which are now known.

In 1823, Mr. S7imner also imported for the late Gen. Stephen Van Rensslar, of Albany, New York, a bull_ "Washington"-and two heifers - "Conquest" and "Pansey" - from the same herd of Mr. Chanpion. Concyuest did not breed; Pansey was a successful breeder, and miuly of her desecndants me now seattered over the country.

During the years 1822 to 1830 , the late Mr. Charles Henry Hall, of New York, imported several Short-Hom bulls and cows, from some of the best Engrlish herds. Several of these he sold to persons in the neighborhood of that eity, soon after they arrived, and otlers he sent to his firm in Rensselar county, we:lr Albany, and there bred them. Their descende cats are now scattered through several good berds. 


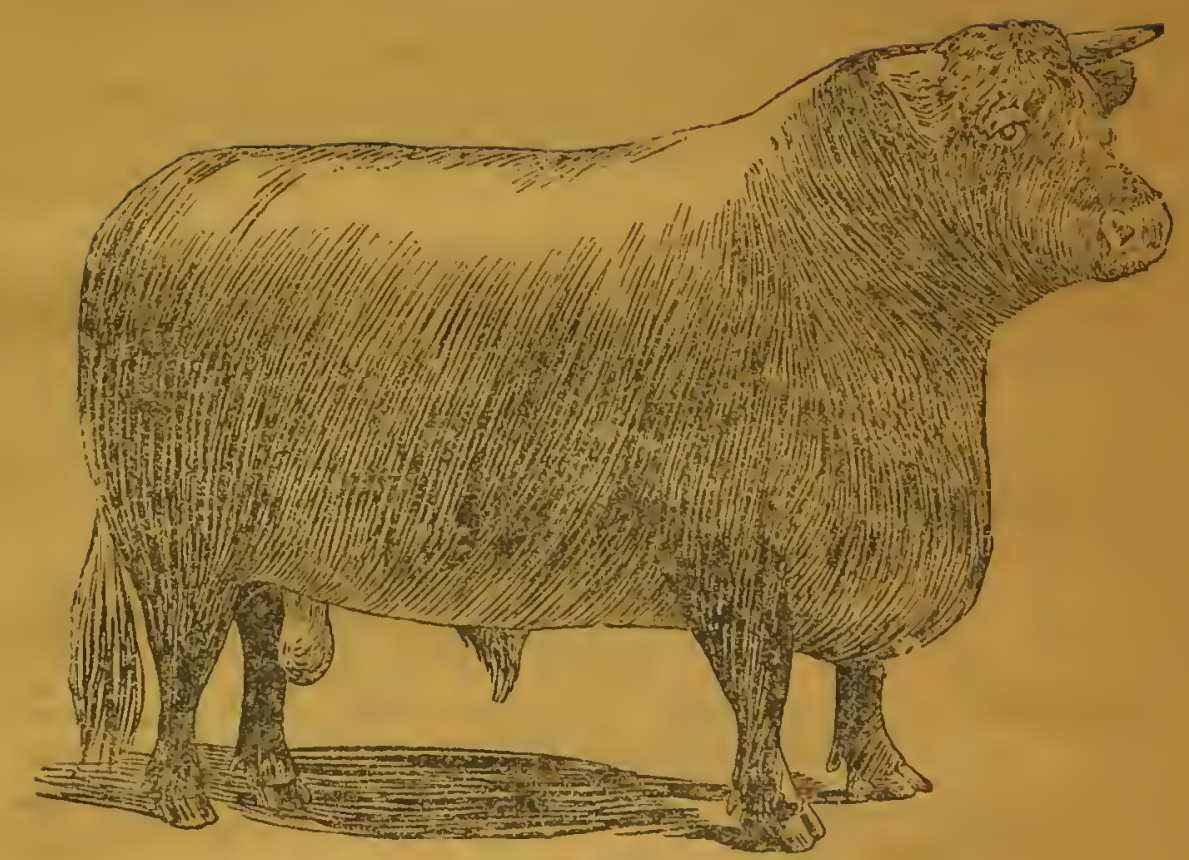

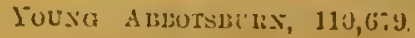

Tinner of the Sreepstakes for aged bulls in the Slorthorn class at the Worlul's Fate

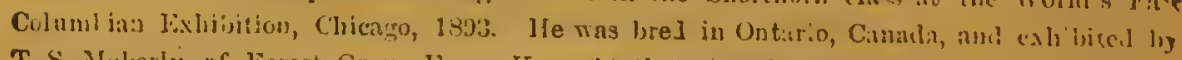
T. S. Muberly, of lorest Grove larm, Ky. It that time lo was cight gen:- oid, of a uulform light ront color, with white tassel. Wicight, 2,900 pounds. 
In 1824 the Inte Col. Joln H:re P'owell, of Philudclphin, Ca.. commenced importations, and for screrul yenrs continued theu with uruch spirit and juctgnent. His selections woro principally from the here's of Jonils Whitalier, of Otley, in Yorlishire, Englind. Io bred them assidcously at his tine estate at Povelton, near the city, and sold many to neigliboring breciers, and to go into Ohio and licntucky, where many of their descendants still reurin.

Whout the year 1828, Mr. Francis Roteh, then of Ne: Bedford, Mass., celected from the herd of Mr. Whit:ser, and sınt to Mr. Beij. Rodman, of Nei: Bedford, a bull and threc heifers. They were afterwads sold to cther breclers, aud their descendants are now found in scveral cxecllent tocrds.

In the year 1833, the Intc Mr. Walter Dum, neur Lexiagton, Ky., imported it bull and sereral valuable cows from choice herds in Yorkshire, England. He hred then with much eare, and their descendants are liow icund in miny grood western lierds.

bist the first cnterprise in inporting Short-Horns ripon a grand scalo ras commenecd in 1834, by an association of cuttle breeders of the Scioto Villey, and its adjoining countics, in Ohio. They formed a compuny, wisl: aderjunte cappital, and sent out an agent, who pireliased the besi cattle to he found, withont regard to priec, and brought out ninctecn animals in caro ship, landed them it Philidelphia, and drore them to Ohio. Further importations were made by the same company, in the years 1835 and 1836. Tine cattle were liept and bied togetlicr in one locility, for upwarcis of two years, and then sold by anction. They l:ronght l:arge prices- $\$ 500$ to $\$ 2,500$ circh-ind were distributed chicly among the steckliolders, who Wcre anong tho most cxtcnsive cattlc brecais and grazicrs of the fanous Scisto Valley.

I: 1837-8-9, inportitions were made into Kentucky, by Mícsss. Jimnc Shellyy and Inury Clay, Jr., and some cther parties, of screral wellselected silhort-Iorms, some of which were kept and bred by the importers, and the others sold in their vicinity.

In 1837-5-9, Mr. Whitaker, ahore mentioned, sent ont to Philadelplia, cil lis own account, upwarls of a hundred Short-ILn'us, fiom his own and ather herds, and put them on Col. I'owell's furm, where he sold them at auction. They were pul'dused at good prices, mostly loy irreders fiom Fennsylvania, Ohio, and Kentucliy, and distributed wilcly through thoso Sí..tc.3.

From 183.5 up to 1843 , screral importations of finc stock werc maüs by AI:. Viveddlc, an Furglish cmigrant, to Rochester, N. Y., and by Auncrican rentlemen, imongr whom were Mresse, E. P. Prentice, of Albsuy, IJ. X., ME. James Lcio: and MU. T, H. Slreuffe, of New York city, 
Mressra. LeRoy and Newbould, of Livingston county, the late Peter $\mathbf{A}$. Lemsen, of Gionesee county, N. Y., and Mr. Whitncy, of New Haven, Ct., Mr. Gibbons, of New Jersey, and scme others, not now recollected, - sill valuable animals. They were bred for some years by their owner?

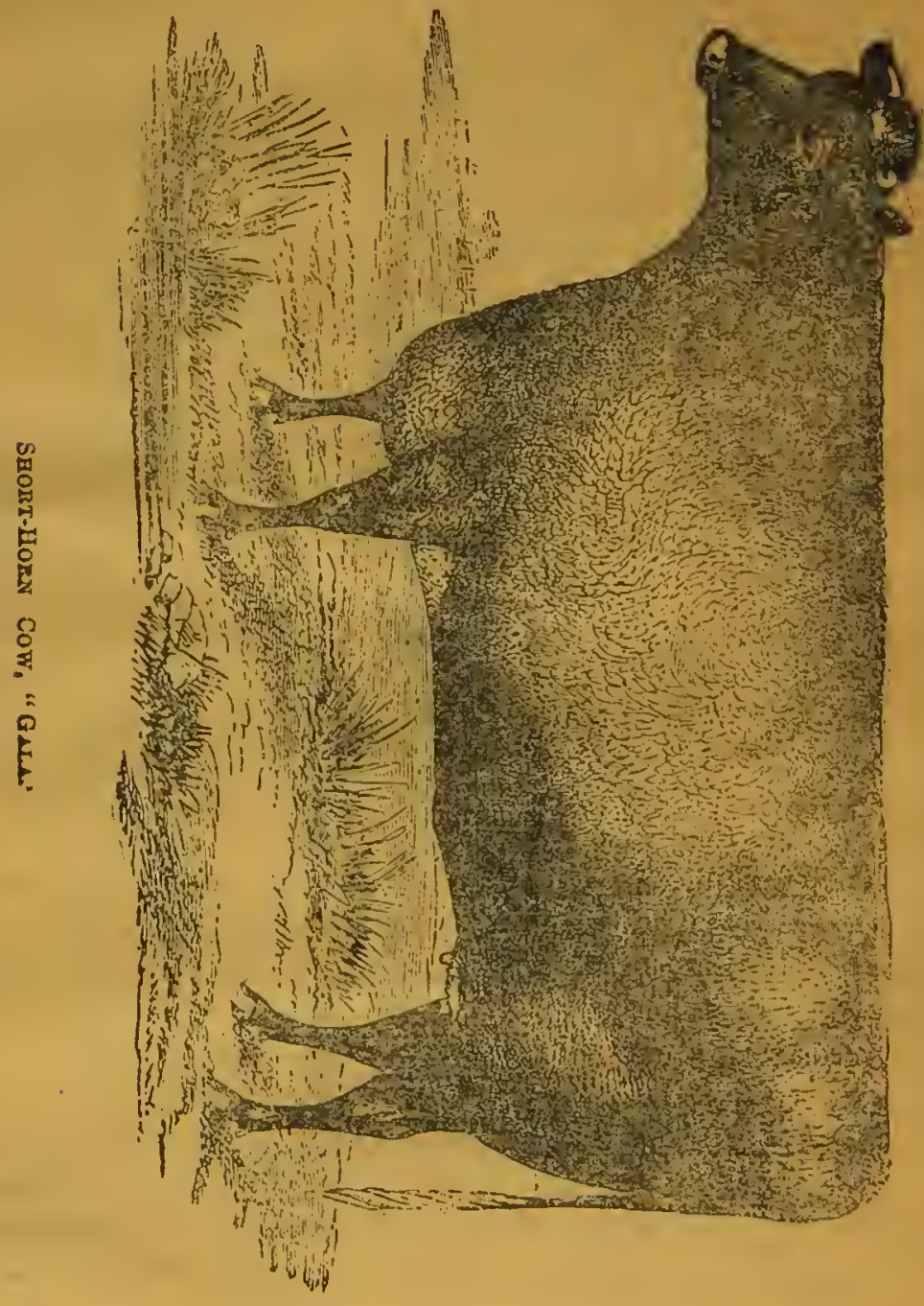

with much carc. Mr. Prentiee, for severnl ycars, häd a large and cxceilers herd on his home fam. After some yeurs all these herds were soltl and widely distributed. Their descendiuts still remain awong our valuablo berds. 
In tho yenr 1849-50, Col. J. M. Sherwood, of Aubun, nnd Mr. Ambroso Stephens, of butaviu, N. Y., imported from the herd of Mr. B:t.es a buil, and from Mr. Jno. Siephensoil, of Durhan, Energnd, three bulls and several heifers, all choice animals, and sureessfully bred them diring several years. 'The stock hecame widely distribnted, and woll linown among slock dicalers.

About the yeur 1839, Mr. Georgo Vail, of Troy, N. Y., made an inportation of a bull and hoifer, purchased of Mr. 'Thomas l3ates, of kirkcavington, the first cattle from that particular herd which had becn introdueed into tho Stute. A few years liter, he purrhased ancl inported several more cows from tho herd of Mr. Bates, crosses of lis "Dnehess" and other fanilies. He bred them with success and widely distributed their blood. Mr. Vail mado a final sale of his lierd in the year 1852.

A perios of some years now oceared, in which few more, if any, Short-Homs wero imported. Cattle, ats well as all linds of ngricultural produce, were execedingly low; but as things grow letter, the demand for "blood" "attle revived, and the spirit for their hreading was renewed. Mr. Thom:as Bates, a listinguished Short-Hom breeder in Englan!l, died in 1849. His loced, fully equal in quality to any in England, was sold in 18:0. The rlioicest of them-of the "Duihess" and "Oxford" tribesfoll mostly into tho linirls of the late Lord D.weic, at Fortwonth Pink, already the owner of a noble herel, to which the butes stock wis added. He was is shillful brecter, and of nos: liberal spirit, and luring the brief time he held them the reputation of the Bates stocli, if possible, inerensed.

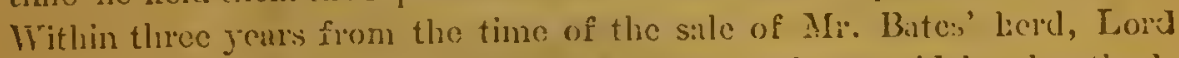
Dacic died. In 1853, perenptiony sale of his stoed was widely adrextised. Allured ly tho reputation of his herel, severnl Aneriuu gentlemen went rre: to witness it. Tho attendiunce of Linglish horders was very large, and the sales averaged highor priens in indivilual animals than had been renclied since the famous sale of Chirles Colling, in 1810. Mr. Simuel Thorne, of Duchese county, N. Y., hought screral of the hest and highest priced animals, of the "Duchess" and "Oxforcl" tribes, and adder to them screral more choice ones, from different herds. Messis. L. G. Morris, and tho late Nocl J. Becar, of New York, bought others of the "l)uchess", and "Oxfords," to which they "ldded more fiom other cluice herds. These were all hrought over here, and bred. Mr. Ezra Cornell, of Ithara, and Mr. Jumes O. Sheldon, of Gencvil, N. Y., soon nfterwards mads some importutions, and obtained some of the "Bates" hlood also. Tlie liste Gen. James S. Wadsworth, and other gentlenen of the Genes:o V:Iley, N. Y., also male inportations. These "Bitcs" insprortitions hitve sine been bred so sueze; 3 fully by their hoklers here, that serer: l young bulls and heifers, bred by M. 'Thorno and Mr. Shal 


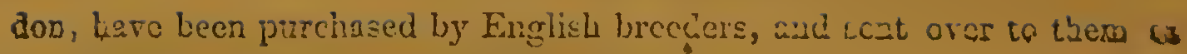
goo' prices, where tiey aro Ligbly rulued.

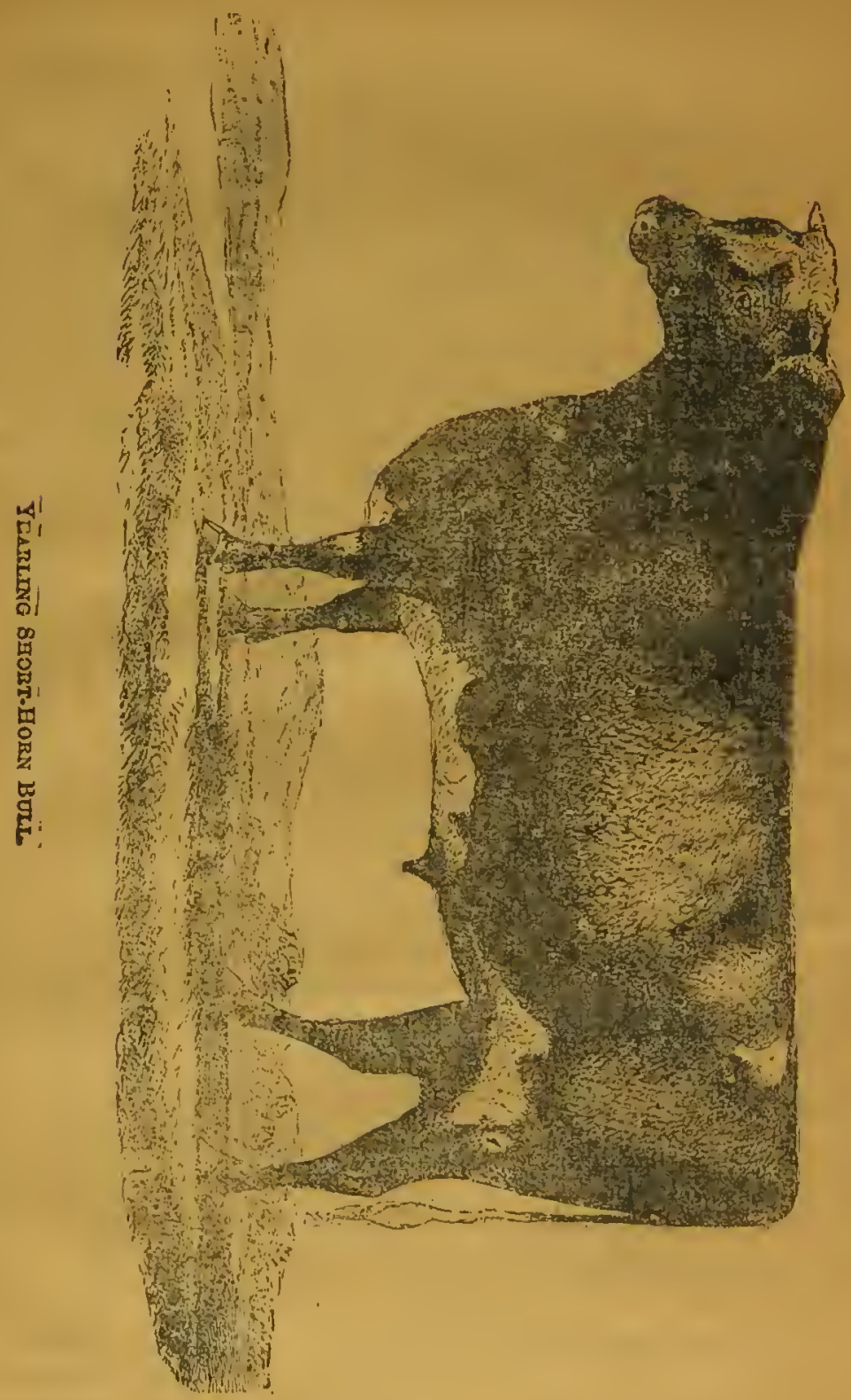

In 1852-3-4, sereral spirited compunes mere formed in Clinton, Madison, and other countics in Ohio, ind in Bourbon, Fayetts, asd surce 
other connties of Kentucky, and made importations of the best cali: is be found in the linglish herds, and after their arrival here, distributed

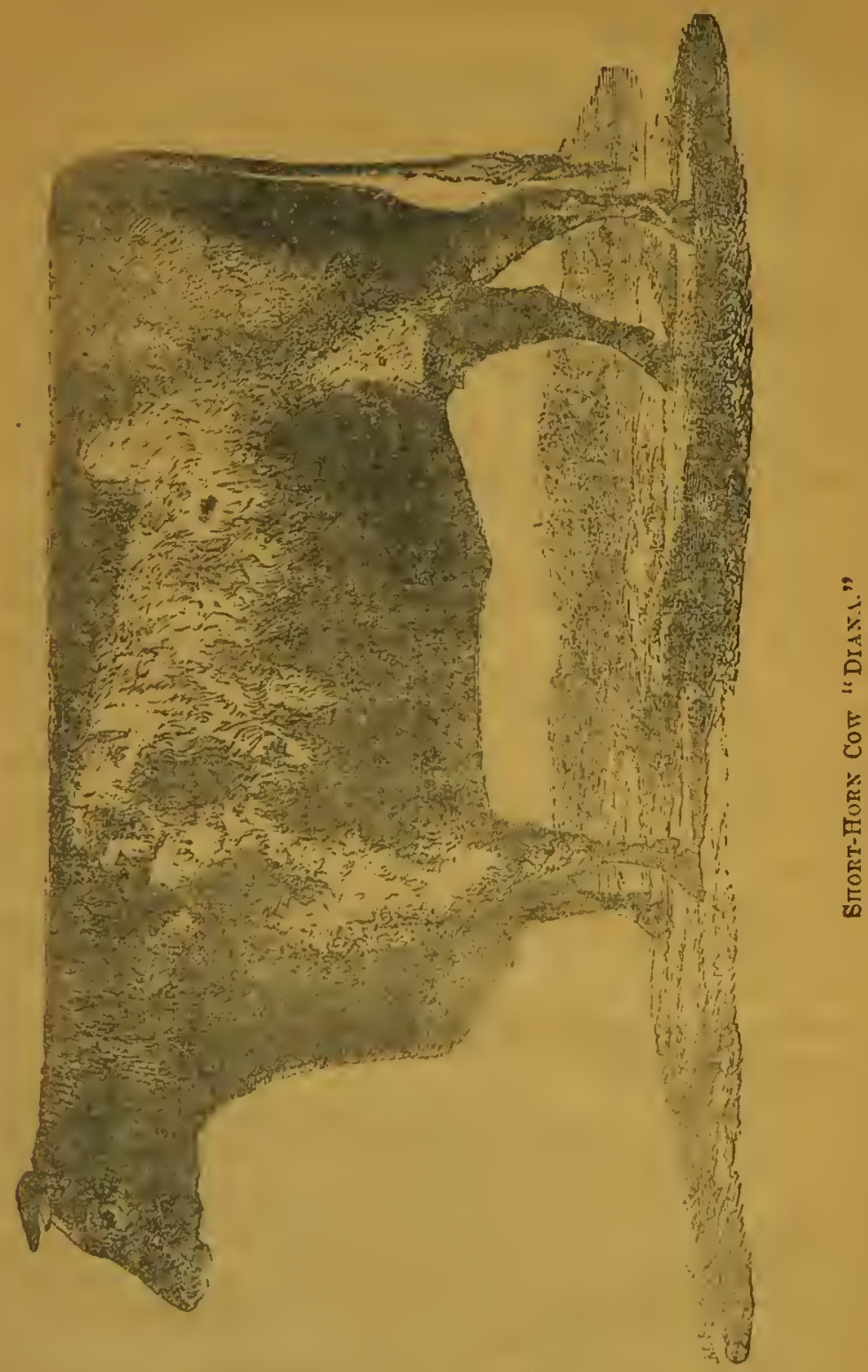

azang their s ockliolders. Mr. R. A. Alexinder, of Kentucky, also, durmor those years, made cxtcusive importations of choico blood for bo 
cown byeeding, so that in the year 1856 , it may be said that the United States possessed, acrording to their numbers, as valuable a selection of Short-Horns as could be found in England itself.

Iiecjing puee with the States, a number of enterprising Canudians, since the year 1835, mmong whom nuy be naned the lite Mr. Ldim Fergnsson, Mr. Howitt, Mr. Wade, the Millers, near Toronto, Mr. Frederick Wim. Stone, of Guclph, and Mr. David Christie, of Brantford, in Canada West, and Mr. M. H. Cochrane and otlers, in Lower Cimada, linve mido smndry importations of excellent cattle, and bred them with skill and spirit. Niny cattle from these importations, and their descenclants, have been interelinged between the United Stintes and Camada, and all may now be classed, without distinction, as American Short-Hords.

\section{Bhort-Horns in the West.}

In the Northwestern States tho first impontation of Short-Horns direet from England was by the Illinois Importing Complny, in 1858. This wals an association of gentlemen, a part of them members of the Stato Board of Agriculture, in connection with prominent breeders of tho State. They returned in July of the samo year with twenty Short-Horn cows and seven bulls, of approved blood, which were sold at auction on August 27th, at Springfield, to breeders throughout the State. They also brought over two stallions, three Cotswold rams, nine cwes, four Southdown rams, eight Southdown ewes, five Berlishire bonrs, four Berkshire sows, and ten boars and sows of Irish breeds; also Cumberland and Yorkshire boars and sows. From this time on, various States in the West have taken up the breeding of Short-Horns as they havo increased in weilth and population, until now no finer lierels ean ho found in any other locality; and, the fict that at the New York Mils sales mdividual animals brought prices all the way to over $\$ 30,000$, for exportation to Englimd - prices which before this time would have been considered fabulous-shows conclusirely that Short-IOHs, as lored in the United States, have not suffered in comparison with those bred in their native land. No such prices mere erer lenehed before in ary, coustry in the world; nor have they been since. To-dily they are found wherever civilization extends. As beef produeers they have no superiors; as milk producers there are fumilies eminent in this respect, and they have left their impress upon the stock of the country wherever introduced.

Short-Horns for the Dairy.

It has been held that the Short-Horns aro as good for milling as they aro for beef. That they onco were most excellent dairy cows there is no 
doubt. That American Short-Horns of the present aro not, as s class, even decent milkers, there is as little doubt. 'The early importations of Slort-Horns were of the milking strains. For the last thirty yeurs, however, they have been bred with such special reference to beef points and early maturity that it is now difficult to find a decent millser in any of the nore fashionable strains of blood, and very many of the cows will not give milk enouglı to properly raise a calf. Once in a while, howerer, a very superior milking animal appears, showing, by reversion, what the enpabilities of the breed might be in this direction.

Thut the early importations of Short-Homs were uniformly good in this direction, as well as admirable beef eattle there is no doubt. Ihat they have left their impress upon the native eattle in this direction is unquestioned. That they exist to some extent in England and America, in particular herds, is certain. We have seen thein here and know they are there. They have grown less, year by year, as the improvement of other dairy breeds became more and more manifest, until of late years little has been elaimed for them as milkers. Their great value as early maturity beef makers, -attiming great weight-having supereeded their purely inilking characteristies. Among the better milkers may be numed the descendants of the "Patton breed," the "seventeens," or the importation of 1817, and some descendants of the Olio importation of 1834. In fact, this latter importation was made solely with a view to loef and flesl points, and since this time milk lus been ignored by tho more fashionable breeders both in England and Anerien.

\section{Short-Iforns for Beef.}

Throughout the whole West, especially, becf was the object sought. The land was cheap, fertile, and the pastures flush. Until within the last few yeurs, butter and ehecse was not in exportable product, leef was. It is not strange that a class of animals was sought that would produco the most beef in the least possible tine. How this has been developed, the great herds of Ohio, Kentucky, Tennessee, Indiana, Michigan, Wis. consin, Illinois, Missouri, Iowat, and later, Minnesota, Nebraska, and Kan cas, srire ample proof.

In lreeding there are no superior eattle in the world. Their usefulness as ieen producers will continue to grow with the settlement of the eountry. The vilue of the bulls for crossing upon the ordinary stock of the country is beconing more and more appreciated every year. It will continue to be an increasing integrer for many years to come.

On the next page, as showing a modern lred Short-Horn bull, combining excollent beef points, with great stumina aud ccersitution, wo grve an illuc'ination of "Hiawatha." 
Thn modern Short-Mo:n has grent thichess of carenss, Equarish-rotund ehape, rapid growth, eirly miturity, and a ripeness at two, three, four, cr tive Jears, that is attined by no other breed. Manv aro also the buud.

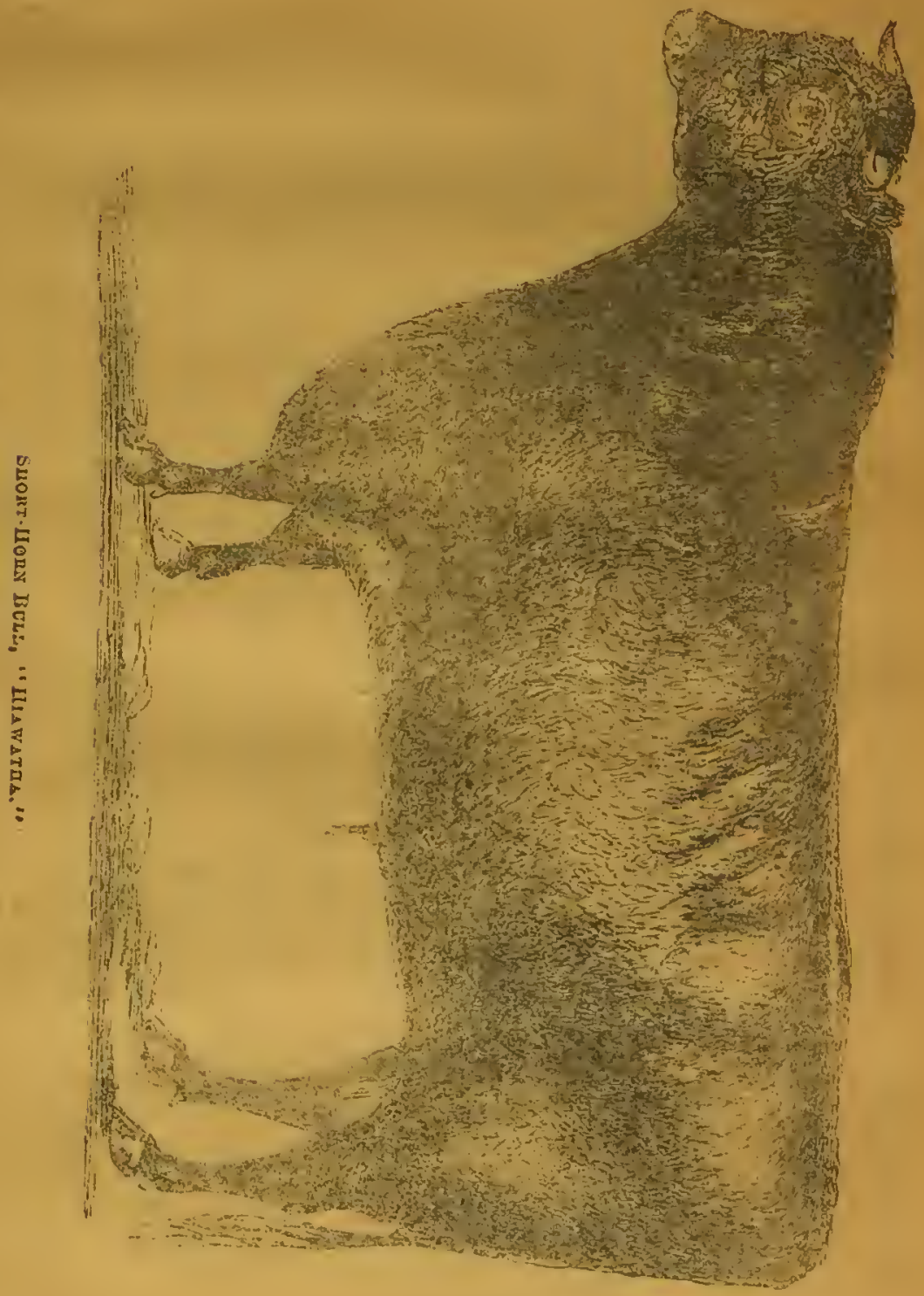

momest cattle to look at of any knom brecd-weimht, substance a at stele being taken into consideration. There is a wonderful fullness in the carcuss, extending to every part. I'be choice llesh is put on in purte 
whero ordinary cattle f:ill ; the offal is exceptionally light, as light as it rould be among common nitive cattle of two-thinds the veight. In tho milk-yelding Short-Horns there is a temlency to lnomess. Many aro

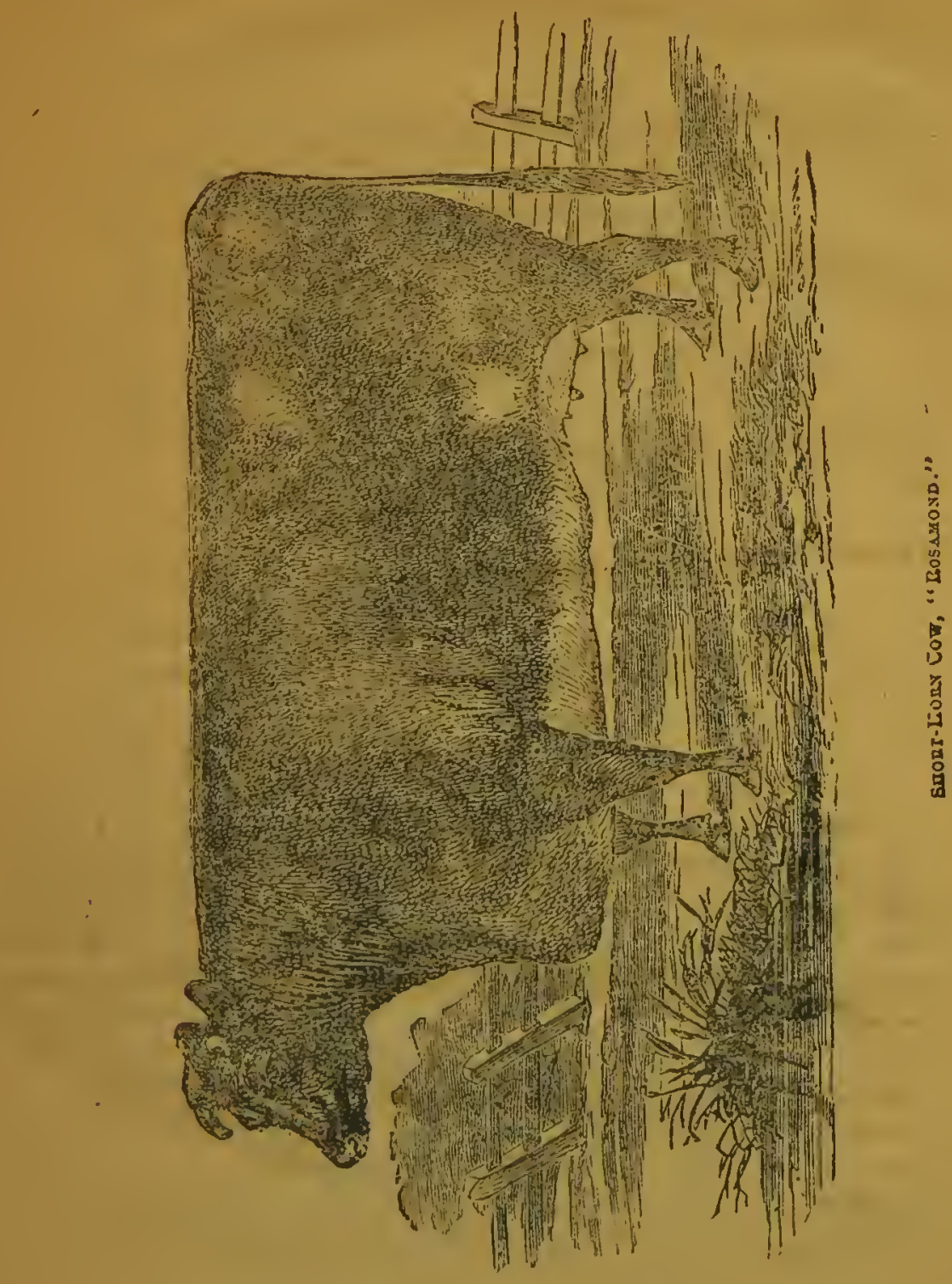

lighter hefore, fintter in the siç, but yet excedingly firm all over, from c dairyn:m's stundpoint. In the beof animals there is a rotund fullnegs, c cmootluness, a majesty, no where else seen. 
$\Lambda$ showing beof in the Short-IJorn cow, in sn rminent degrec, no givo a portluit of the cow "Irosinnond," showing not only rood beef "crints but wilking qualitics as well.

\section{Foints of Sucrt-프ora Describoc:}

The points of Short-Horns-aad which will apply in judging ail beef panimals, with sligint variations, to be lacreater described-are worthy of ia somewhat minute deseription. The points are of two classes-those observed with the eye and those felt hy the touch. By the cye ons observes the gencral contour of the anims ; sizc, length, breadih, thick:ness, fincness of body, head and limb; the loin, liack, thigh, the spring of the rib and the manner in which the animal is ribbed nip close to tho hip benes. The touch-thit is, the fecling under the rouch-shows .cugth and quality of the huir, thickness and clusticity of the slin. Tho cye and expression of countenance is indicative of disposition and tempel. An clustic, mellow and yet firm hide, of medium thickness, is an indication of well marbled fiesh, while a floating, soft skin will iudicate blubbery fat, und often dark colored flesì.

\section{Tho Iutcher's Proft.}

Tho butcher in louying cin animal fö beci lins now-n-lays luw a singlo object in view-the animal that will turn ont the greatest amount of leun meat in the prime parts, with the lenst offal, and only a noderate amount of fat for fat is now one of the cheupest portions of the animul. Ieurs ago, in the dilys of tallow candles, the re:"erse was tho cuse. The back, loin, and ribs are the choice bits; next tho rump and thich; their tho shoulders; while the neck and head are comparatively worthiess. Tho sagacious brecder, while leeping this constantly in view, seclis to add carly maturity to grood flesh. He who comes nearest to this has the best animal, whatever the breed, or the pedigree of the particular breed. This butcher's block is the final, the crucial test.

A description of the points of the Short-Hoin was so carefully and admirably given by $\mathrm{Dr}$. A. C. Stevenson, P'resident of the Indi:an: ShortIInrn I3recders' Association, at the first conrention thereof, that wo Eppend a synopsis, accompanied with an outline of is Short-Horll, to rihich reference can be made, illustrating the prineipal points.

In this it will be secn thist $a, b, c, d, f, h, m, j, l, x, y, z, r e p r e s e n t$ tho inferior parts ; from the girth $p$, lack, including $r, s, t, u, v$, the superior parts. From this it will le casy to understand the points and tho respective numbors as given in the scale.

\section{Tho sieac?.}

"s Thə Lead should be sma!l." This is a very imperfect description of 
the head, but in ico rany accounts, all that is given. If the sire of thes tead vere all that was of consequeiree, a pound difference in any cuso

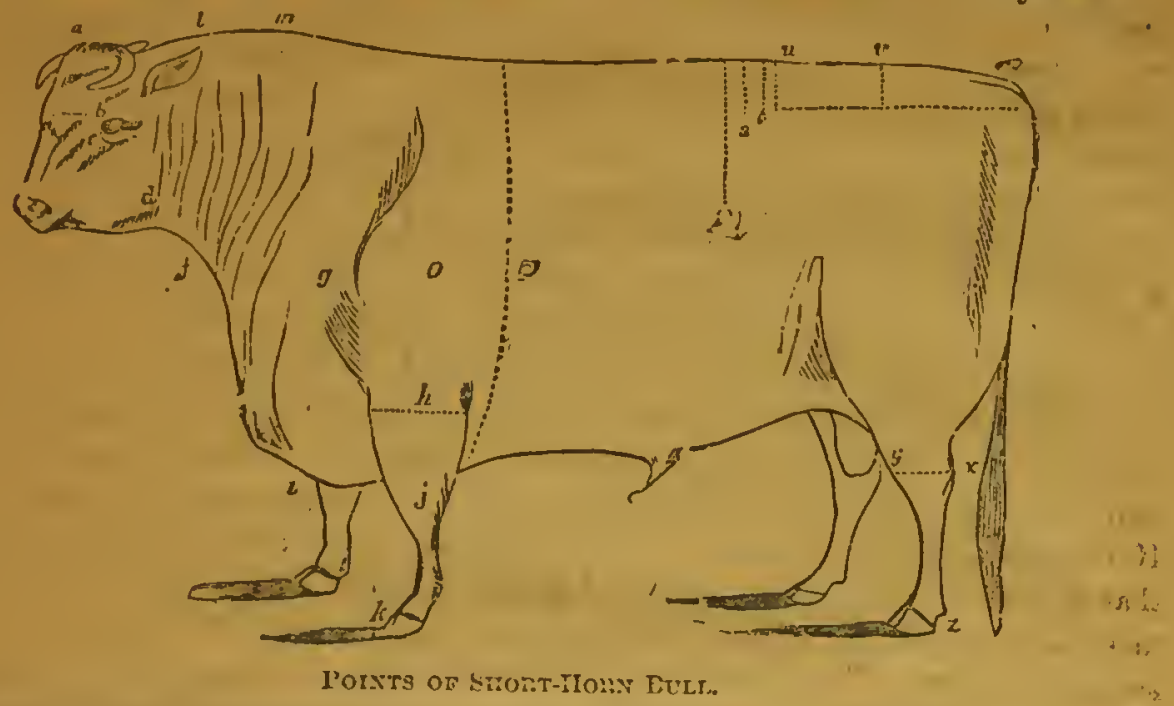

vould be of little consequence in the sale of a bulloc?-. 'It is the forra of the head that becomes of so much interest to the breeder. The lieat abore the cyes should be wide' giving epace for large cerebral derclopment. The intelligenee of the animal depends upon a well-cleveloped brain and nervous system; ipon which, also, so much depend the rigoorous and healthy artion of the orouns of digestion and assinitintion'; tho circulation and the vital functions mnenlly; the intelligence and temper of a cov depend:s much nijon a well-reveloped brain. It will be found by observation thet most ricious beasts have suall upper heads, and aro large below the eycs.' Again, tho upper lical shonld be wide, to giro width to the articulations of the lower j:tw. It is necessary that the part of the month where the food is to he masticated shoukl be lange, 1hut tho supplies reguired fer the stomach may bo vell misticuted and re-mistic:ted $j: 1$ claceng the cud. There is another reuson for widh it the hase of the lieal and between the angles of the lower jaw: it is licre that tho

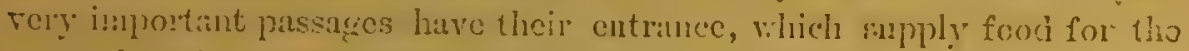
stonacls and air for the lungs. Close st land, also, is the inportant con. nection of the spinal manow and the irain, to si!y notling of many largo ... and inportant hlood-ressels that find their way to the head. These concielcrutions we think conclusire as to the necessity of gize of hend.

The portion helow the eyes, the face, should be companatively sasalls:! Its principal oftice is to grather food and sir. Thin lips and clestion or nostrils are wanted. The eyes should be lure, bright and lively, and yot: cuict. The pliysiognomy of the $\mathrm{cx}$ is as clesriy indicutive of his chlureter.. 
ns that of a man is written upon his face; and tho renson that less is indicatcd in the face of an ox is because he has fewer vices, and has been guilty of fewer trunsgressions. A small dark eye, set in a dark circle, with a large faeo bclow and a narrow head above, will indieate an animal that is bad tempered, wild, and consequently a poor feeder. 'The circle around the eye should be of a bright ycllow eolor, tho mose the sane. These considerations inay seem trifles, yet this eblor is the result of a poe culiar seeretion, and the inference is a probable one, at leust, that other secretions will be apt to resemble it in eolor. Hence, the secretion of milk will be apt to resemble it in eolor, and a bright colored flesh is betokened by these peculiar seeretions as indicated in the color of the noso and cireles about the oyes. As a very large ear mostly indicates sluggishness, one of medium size is preferable. A bullock of fine organization will manifest very elearly his impressions by the movement of his ears. If he flees from danger his ears aro erect, or a little inclined backward, that he may be the better warned of danger behind. If he is in haste to meet a kind master, who is bringing him a desired meal, the ear is presented forward. The horns should be clear, without black tips or any black marks whatever-some say of a waxy eolor, some again, elaim that they should be flat in Short-Horns. But these matters are, most of thems. non-essentials. We dismiss the head, ufter attaching it to the neck in its proper position-not at right angles, but at an angle of so many degrees that, with the under part of the neck it forms an arch. This gives a better throat and a freer passage for the food and air to the stomach and lungs, and is gruceful withal.

\section{The Neck.}

The neck expresses very mueh less to the breeder than the heal and fiee. The neck should be just long enough to enable the taking of food ensily from the ground. It should be strong and well muscled upon its sides, covering at its base the points of the shoulders well, and at its junction with the head it should be small and round, with its skin fitting it pretty much as a well-fitting stocking does the leg-the under line of the neck with the under line of the jaw. A thin, broad neck is sure to indicate weaknoss and poor feeding and fattening qualities. Animals kaving suçh may well be avoided as breedcrs.

\section{Contoux of tho Body.}

The butcher, the breeder and the stock dealcr, may now mect and consult profitably on the general contour of the body. Here the opinions of the formor may be adopted, as ne fixes the price of all 'butchers' stuff.'. 'The ox of given weight that will seli for most iu mar- 
ket possesses the points that must be adopted. These points are now, however, well established, nnd we have only to refer to them and notico the reasons on which they are founded. We proced to name them before we give their rationale. In genewl contour the hody sliould bo nearly a square. The crops should be wide. The line of the buek slionld be straight; tho line of the belly nearly so, swelling a little behind the ribs; the flank low; the ribs barrel-shraped; the loins wide, and the rump long and wide; the bick should be wide, and the thigh should be long and wide; the legs short and comparatively small, or at least not course; tail light; hair soft and finc. The color should be red or white, or a mixture of the two, as ron or pied.

As has already becu said, the body sliould be nearly a square. Tho vital currents moving in short lines are more effective thin when moving in those of great leigth. The blood moving from the henrt along very extended chinnels, flows with much less force as it recedes from tho cause that set it in motion. The same is probably true of the nervous currents. The great vitalizing orguns are located near the center of tho systen-a provision of nature by which the vital currents are slorter than under any other arrangement. Here is the lienrt sending ont its great currents of arterialized blood in all directions. to supply and nourish all the members of the body. Sitting over it is thist ronderful air machine, the lungs, receiving the entire venous currents - an atmospherio bath - by which they are so renovated and changed as to mako the blood again fit for the heart's use, to which it is returned lyy tho shortest possible route. These orgaus lic encased together, and nerer cease their operations night or day. But just hele in this creat center is another great vitalizer of fully equal importance-the stomuch. Hero. the food is received and changed into chyle, which is at once thrown inte the eirculation, where its offiee of supplying the system is performed. Now, the nearer a body is complacted around these great vitulizing systems the more effectual will be the supplics. Olsservation fully sustains these views. A very lengthy bullock never fintens so readily as a short one. The brecds of hogs with long lodies are linown not to fatten so readily us those of short, square forms, as the Siunese and Chinese. The same is true of sheep, and also of the liorse. And even in man, we larely find a corpulent man who will measure six feet. Ohesity will generally he found under six fect. Heilth and vigor is equally confinmed by observation, as a result of the square structure. Longevity mily also be elaimed with the greatest propriety for the samo proportions. A bullock with a square frame will be sure to possess al! the qualities of hralth and vigor, and will feed and fatten as well or better thau a long one. 


\section{Eroad in the Crops.}

The animal troad in the crops has a better back; but it is also ovidence of a better rib bencath the shoulder-blade, giving greater width to the chest within, and eolisequently greater pliy to the lungs. This position of tho shoulder-blade cnables the legs to be lirougrit more grisectully under the chest bencath. There are some beasts whose fore-legs stand so ivide apart that they very much resemble two sticks stuek into a largo pumpkin. Such animals are considered awkward and inconvenient at least.

\section{The Back should be Straiglit and Broad.}

$A$ broad back affords valuable roasting bits, and will be the delight of tho butcher. The straight back affords a better spinal column, and gives the proper space to the cavities bencath, which, as we have just seen, aro oceupied by the most important organs. $\Lambda$ straight line also gires to tho ribs a more graceful as well as more coivenient attachment.

\section{Ribs Should be Barrel-Shaped.}

The ribs rising well from the spine, giving to the lody a round or barreled shape, gives much more room to the organs within - the heart and lungs - than there would be if the ribs descended in such a mimner as to give a flat side. A beast with fiat sides, and consequently a narrow throit, will lack greatly in vigor and health, and all the essential qualities that constitute a good bullock. A bad rib gires poor space to the abdominal organs which lie immediately behind those of the clest, unlew:s the belly is greatly sagged, which is generally the case.

\section{The Loin Shouid be Wide.}

This is an interesting point to those who lore clonice bits and are willing to pay well for them. The buteher makes linge estimates here, and is suro to suit liberil purehisers. But nature is ever true to herself, for bere, is elsewhere, beneath a broad loin she has provided large space for anportant organs, as the bowels, kidneys, and the organs of the pelvis. The rump of a good Short-Horn is a very niee point. The back should axtend out straight to the setting on of the tail. The thigh sliould pass up to this point nearly straiglit, so as to make the junction a right angle. This point, in uiany beasts, will be found to be a cirele, which is unsightly cold causes a loss of prime beef.

The Legr,

Tho legs should be short. Tuere are preeisely the same 1 vasone fü 
objecting to long legs that thicre aro to long necks or long bodies. Observation proves a leggy animal to be not so good a fecder as one with short limbs. The bone of the leg should be tine and smooth, and not too linge. The legs should stand well under the animal, and the hocks directly in lino witl the body, so that in moving, the hocks will be well sepauritcd, or alout as far apart as the hind fect. The fore-legs should be struiglit and stand well under the chest, thit the animal may liavo an ensy and freo movement. The inner side of the fore-legrs, as it plasses the sternum, presents a beveled appearunce, to loring the limbs to their proper position bencath. Upon the proper position of the limbs depends that ense and gracefulncss with which a bullock should move. It may be thought of no conscquence how a blllock mored so that he is able to get to the market, but bo assured there is much in it, it evinces strength and health, which are indispensable in feeding. I havo seen Short-Horns currying two thousind pounds and upwards, with limbs so perfect that their movenents were as nimble as if they were earrying but a thousaud.

\section{The Touch.}

By this tho butchers ascertain beforehand the quality of the flesh. By it the breeder ascertains. the aptitude to fatten as well as the quality and quantity of flesh that tho animal will carry.

Of all tho qualities of the ox, this is probubly the most dificult to understand. It is the peculiar sensation of softness and elasticity that is produced by the pressure of the hand on different parts of the body. This sensation depends, in purt, upon a largo cellular derelopment bencath tho skin and between tho muscles, and part upon tho muscular structure, adupting itself to the laborious duties it has to perform. It is, thereforc, to the cellular and muscular tissue that this sensation of touch is to be attributed. It is very common to find a softening of tho muscular fibre as an acconipaniment or a precursor of discase that may mislead. The same may bo observed in the aged of both man and beast. What is 'touch,' or what is it to 'handle well?' How is it to be distinguished from that which portends bad health and old age? By its clasticity-its power to replace the parts when pressed-a springy sensation. Mellowness from disense has a sluggish feel and moves slowly when ander the hand; to a less extent, it is true, still something of tho same that is manifested in the pressure of the fingers on a dropsical limb as conpared with a healthy one. In the one the indentions replaco thenselves slnggishly, w:ilst in the other with a ready elasticity.

It will require much practice to become an adept in this knowledgo. Srill many useful lesions anay be daily had by the examination and handling of nne's own stock. Comparative handling will afford much 


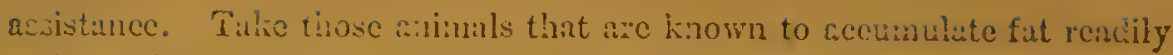

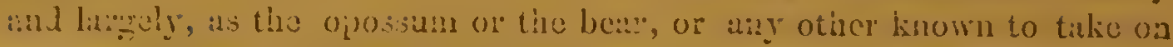
fit reatily, and you will find a peculingly soft and mellow 'touch.'

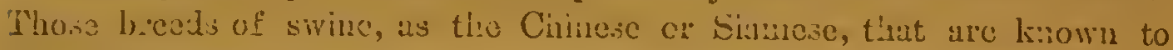
accumulate fat liagely, als compumed witl some of the poorer wod breds, will offer gool and ready illustrations. But probubly the mest raitly illustratio:1 will be found in man himse!f. All that class of pessons

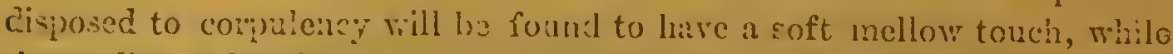
those disposed to leamess wil! ho found rigid and hard. This may l:o readily racognized in shaking hands. A rery delieate lady may somotimes be found to have a li:ul li:md as well as a sh:irp tonerue. Sisooth, soft skin will also bo found belonging to this class of persoins.

\section{The Skin.}

8: Tha shin shouid ba thick, soft and clastic-fitting alike e!ther a pocu! or fut ox. A lean unimal, with an inclistie skin stretched upon him, could not fitten for the want of space to expand in. But with an elastis ekin he maly be swelled to greut dincisions in what scence to be but i covering for his bones. The slin performs very importunt functions i: the animal economy. It is not only a covering for all the purts liencitas it-a protector against cold and hout, and all cxterlasl causes of clange:, laut it is the scat of a vast system of minute blcod ressels and cupillaries, of exinalents and absorbents. A vast ricrous tissue ccitcrs here tlant ronless the skin scusitive in the lighest degree. The graut vital vorth and importance of the skin mar be readily appreciated by any injuries done it. The r:mpility with which extensive burns destroy life, may serve as a sntfieient illustration. "Destroy my slin, and ycu chall haro my b,ones also.'

\section{The Hair.}

The hair should he thick and fine, forming a protection arrins, incicm. cncies of westher. It is not sensitive, and is, therefore, a proper slije!d to the whole body, and it is an evidence of the wisclon displayed in tho creation of this family of the animal lingdom, that its hair-its outer garment, against which all injuries must first come-should le withous sensition-a complete cont of mull, injurics to which causc no pnin. tine har is also an evidence of a fincly organized skin, a skin exorisitely finished in its whole structure of minute ressels and tistues. A skin thing delicatcly organized is also evidene that other orgatis are alike con. structed. Nature, in all her parts, undoulitedly produces a coimespondence, so that if one part is of a peculiar structure, either finc or co:1:se, 
tive of parts not seen. It may be permitted to add that in all tho scrub cattle that I have grazed and fed, I havo never found (ne witb fine silky bair that did not futtcn well and make a desirable bullock.

\section{Color.}

Short-Horns aro red or white, or these eolors blended as roan or pied. Fashion, for the time, muy make one or the other of these colors popular. This is probably so now with the red color. It may be so of anotber color in a few ycars. A caprice that cxcludes all but the red color is injurious. It limits improrement and eonfines it to a linited portion of the brecd. It encourages the use of inferior animals just to obtain a fashionable color, and rejects better ones because they are of different color. There is, iu consequence, great danger of detcrioration of this noblo brecd of cattlo as a result of such pucrile practices. If the hreed is to l:e kept up to its past high standard the very best sclections should ho bred regrardless of eolor, provided it is the one peculine to tho breed. We would admonish breeders and lovers of this noble rnec of cattlo to give 110 encouragement to such departures; they are cvil, and that continually.

\section{Perfection.}

Both ignorant and cultivated alike; the ordinary breeder and the scic:tific onc ; the practical inan and the visionary onc; each will establish in l.is own mind an ideal of what any object should bo. When this idonl in required to stand the test of practical experience, to be defined by a reale of points, not one in ten, cven among those who think thenisclica sompctent to establish in standurd of cxccllence can do so, point by point. 'ilhe jeason is he has never lead, nor' has he educated himself in any other way to that exactitude of judgment required in matters of such nicety; in other words we have not the scicntific idea of what is nccessary in the premises; no al:so!ute rulo to go by, and so tho whole amounts, after all, to something rery like merc guessing. For dairy purposes the udder of the cow is the strong point. In animals bred for tleir flesh, the ment is the esscntial thing and also that it be laid on in the prime punts.

To cuatle any person to judge more or less correctly aceording to tro study he mives, and the manner in which he has edueated his cyc and touch, we appond tho scale of points for judging Slort-Horns, as found in the American IIcrd-i3ook.

In studyng this senle it will do quite wcll for all becf breeders-alway bening in mind the diffe:cnes in make up of the breed. Tlus the Slon:-

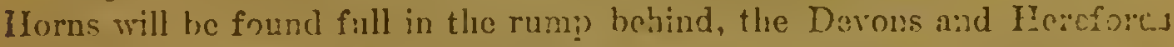
more poisted, sud escutially diffcrent in otlier respects; yet these very 
differences constituto their value : their becf is certainly better than that of tho Short-Horn; but still they fail in other prirticulars. 'There is no such thing as absolute perfection ial any thing finite. No simply come as ncar it as possible. 'lho Short-Horns, in all their attributes, ceitaing have but little more to be desired as heef muliors, and sone farnilice, alis too fow, are decp and excellont milkers.

\section{Bcalo of Points for Skort-Forn Bulls.}

PoL:⿱宀⿻一

Arт. 1.-Purity of bred on male :nd femele side; sire and dim reputed for docility of disposilion, carly maturity :mol aptitudo to fatten; sire a good stock-retter, dinn a pood brecder; and giving a large quantity of milk, on snch as is silycrior for mal:ing butter or cliacse.

ArT. 2.-Head muscular and fine; the lorns fine and gradually diminishing to a point, of a flat rather than a round shape at the base, short and inclined to turn up, those of a relcur, waxy color to be preferred, but sucle $n 3$ are of at transparent wlite, and tinged witl ycllow, admissille; ans musll, thin and corercel with soft hair, playing quicli, moving frecly; forchcad short, biond, especially betrecu the cyes, and slightly disher?; eyes bright, placid, and rather pominent than otherwiso, witl a yellow rim around them; lower part of the face clcan, dished Enil well developing the course of the reins; murzle sm:all, nose of a clear ormige or light chocelate color; nostrils wido and open; lower j:1w thin; tectl eleur and sound. - _ -

ArT. 3.-Neck fine and slightly arched, strongly and well set on the head and shoulders, hammoniously widening, decpening and rounding as it approneles the latter point; no dew?ilp. - -

ArT. 4.-Chest broud, decp and projecting, the brisl:et on a lower line than the belly.

Аrт. 5.-Shoulders hroad, stroing, fine and well placed; fore-legs Ehert, straight, and standing rather wide aplut th:m n:1row; forc-::sm muscul:re, hrond and powerful, shightly swelling and full ahove the kne; the bone fine snd flat ; lines well linit and strong; foot flat, and in shappe an obloner semi-circle; horn of the hoof sound and of a clenr waxy color. $\quad-\quad+\quad-\quad$ - 2

SRT. 6.-B:urel round and decp, and well ribbed up the lipes. - 1

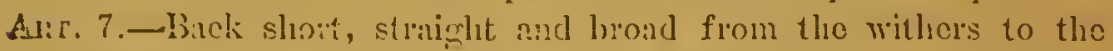
sctting on of the tinl; wops round and full; loins broad; huchic boacs on a love! with the hack; tail well sot, or: a lerel with tho back, fine and erralually diminishing to a peint, and hanging rithont the bus! an inch or so below achock, at right, angles nit's tho bact. 
Arï. 8. - ITind quanters from thic huckle to the point of the rump well filled up ; twiet well let clown inkl full; linel lexgs short, straight, and rell spread alpart, graclually swelling and rounding above the hock; the bone fire and flat below; leces rot to cross cach other in ralling, no: to strudtle hohind. - - -

A-3. 9. Skin of racdium thickness, movable and nollow; a whito color is admissible, but rich cream or ornge mucle preferable; luir well corering the hide, soft and finc, and if undercosted rith soft, thick fur in winter, so much the beticr; color, puro white, red roan, bright red, or reeldish yellor and whitc. (A black or dark brown nose or a rim around the eye, black or d:nrk spots on the slin and hair decidedly objectionabie, and indicitire of conrse meat and bad blocd.) - - - - 3

ART. 10._Good handling. - - - . - - - 4 .

Aит. 11.-Surc stock-retter. - - - - - - - 1

AnT. 12.-Stock, when minde stecr, ccrtain to fecd lindly for beafers at any age, and make prine becf. - - - - - 5

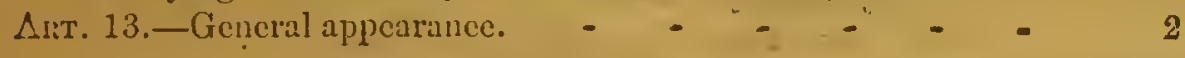

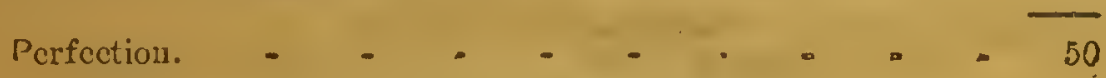

Scale of Points for Short-Forn Corrs.

Porkt3.

^RT. 1.-Purity of breed on male and female side; sire and dam reputed for docility of dispositioil, carly maturity and aptitudo to filten. Sire a good stock-gettcr. Dain a good breeder; giving a large quantity of milk, or such sujerior for making buttcr or cheese.

Arr. 2.-Head small and tapering; long and narrower in propicton thin that of the bull. Horns fine and gradually diminishing to a point; of a flat rather than of a round shape at the base; short, and inclined to turn up; those of a clear waxy color to be preferred; but such as are of a transparent white, alightly tinged with yellow, admissible. Lars small, thin, nd well covered with soft hair; playing quick, moving frecely. Forehead of good brearlth between the eyes, and slightly dished. Eyes bright, placid, and rather prominent than otherwise, with a yellow rim round them. The lower part of the face clean, dished, and well developing the course of the vcins. Muzzlo emall; nose of a clear lronze, or light chocolato color-the former methel preferred. Nostrils wide and well opencd. Lower juw thin. Tweth clear and sound. 
ArT. 3.-Neck fine and thin, straight, and well set on to tho head and shoulders, harmoniousty widening, decpening, and slightly rounding in a delicate fenriuine-mamer as it apploaches tho latter yoint. No dewlip.

AnT. 4.-Shoulders fine and well placed. Fore-leg's short, straight and rell spread apart. Fore-arm wide, inuscular, slightly swelling, and full abore the knee; the bone fine and flat below. Kuees well knit and strong. Foot flat and in the shape of an oblong semi-cirele. Horn of the hoof sound, and of a clear waxy color.

Anт. 5. - Chest broad, deep and projecting-the brisket on a lower

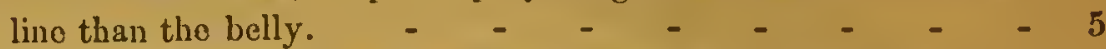

ArT. 6.-Barrel round, deep and well ribbed up to the hips. - 5

ArT. 7.-Back short, strong, straight from the withers to the setting of the tail. Crop round and full. Loin broad. ITucklo bones on a level with the. baek. Tuil well set, on a level with the back or very slightly below it ; fine and gradually diminishing to a point; and hanging, without the brash, an inch or so below the hock, at right angles with the back. - - -

Arx. 8.- Hind quarters from the hueliles to the point of the rump long and well filled up. Twist well let down and full. Hind lers short, straight and well spread apart; gradually swelling and rounding abovo the hock; the bone fine and flat below. Foot flat, and in shape of an oblong semi-cirele. Hor'n of tho hoof sound, and of a elear waxy color. Legs not to eross each other in walking, nor to straddle behind.

Arx. 9.-Udder broad, full, extending well forward along the belly, and well up behind. Teuts of a good size for tho hand; squarely placed with a slight oblique pointing out; wide apart; when pressed by the hand the milk flowing from them freely. Extra teats indieative of good milking qualities, but should never bo milked, as they draw the bag out of shape. Milk veins largo and swelling.

Ant. 10.-Skin of a medium thickness : moviblo and mellow; a white color is admissiole, but a rich cream or orange much preferable. Hair well eovering the hide; soft and fine, and if undereoated with soft, thick fur in the Winter, so much the bettor. Color puro white, red, roan, bright red, red and white, spotted roan, or reddish and yellow and white. (A black or dark brown nose, or rim around the eye, llack of darlis brown spots on the skin and the hair decidedly objectionable, and indicative of coarse meat and bad blood.) 

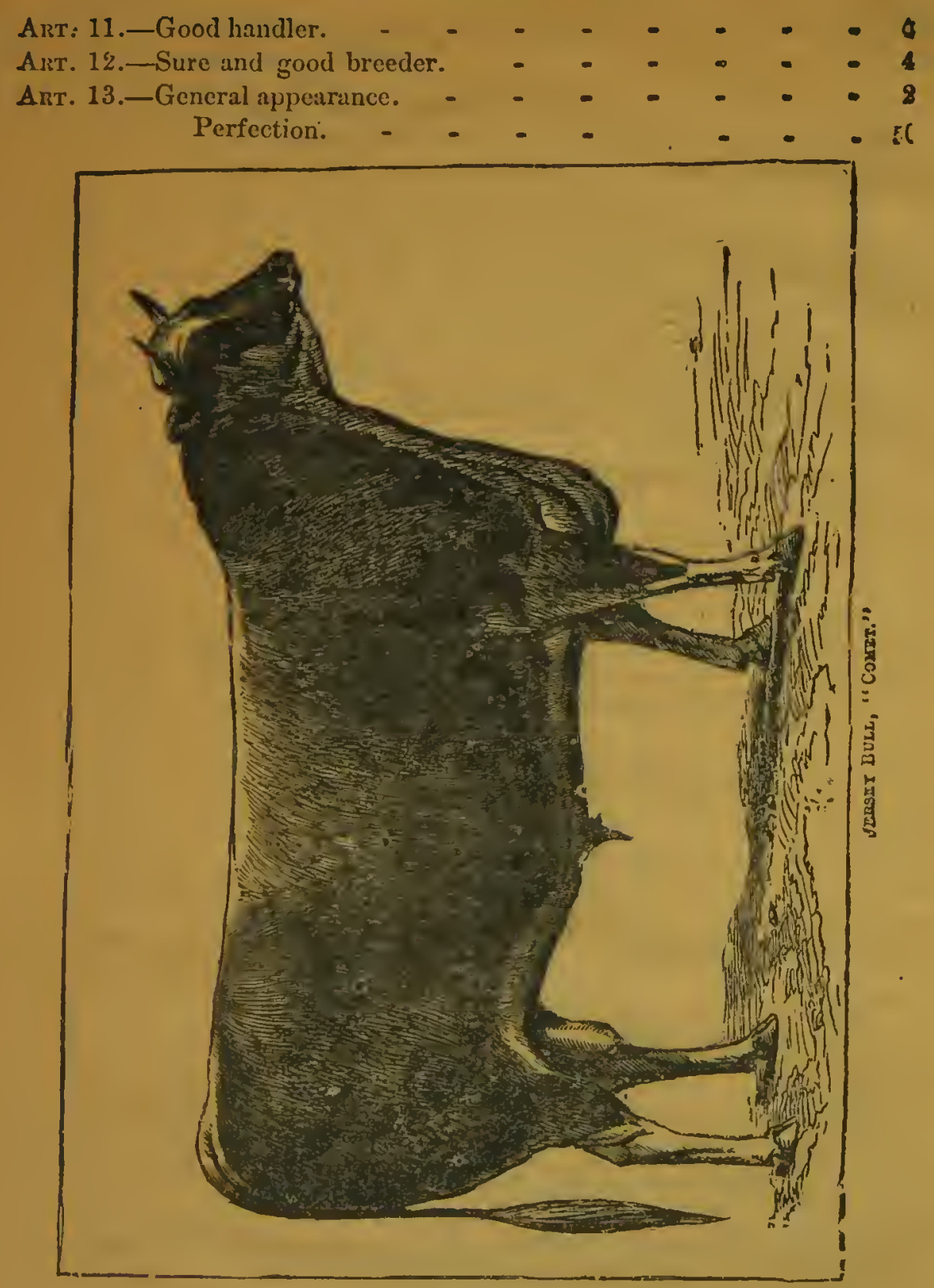

V. Tho Alderneys.

In the British Channel, between Great Britain and France, are a num. ter of islands noted for their salubrity of climate and fertility of soil. Many jears agro these islauds, particularly Jersey, were noted for theit 
Euperior fruit, and large quantities of cider and perry were sunually made tliere.

Of late years these islinds, Alderney, Jersey, and Gucrnsey, havo become celebrated throughout England and Ancrica, for their breed of cattle; the cows of which give milk of unsurpassed richness.

'Ihese cattle are undoubtedly of French origiu. The Normandy eattlo are larger than the Jerseys, and Youatt says, hare a greater tendency to fatten. He passes them by, in his admirable work on cattle, with scalcely more than a mention; this is to be regretted, since lie was so eareful and conscientious a historian. He sins:

"They are found mainly in gentlemen's parks and pleasure grounds, and they maintain their occupancy there, partly on account of the rich. ness of their mills, and the great quantity of butter which it yiclds, but nore from the diminutive size of the animals. Their real igliness is Jassed over on these accounts; and it is thought fashionable that tho view from the breakfast or drawing room of the house sliould present ap Alderney cow or two griziug at a little distance.

"They are light red, ycllow, farm or dun colored; short, wild-horned, decr-nccked, thin, and small-boucd; irregularly and oftou very awkwardly shaped."

\section{$\triangle$ Prejudiced Statement.}

Quoting from Mifr. Parkinscu, who, Mr. Tountt says, secms to havo had a determined prejudice against them, he writes:

"Their size is suall, and they are of as bad a form as can possibly bo cescribed; the bellies of many of them being four-fifths of their weight. The neck is very thin and hollow; the sloulder stands up, and is tho lighest part; they are hollow and narrow behind the shoulders; tho chine is nearly without flesh; the hucks are narrow and sliarp at tho ends; the rump is short, and they are narrow and light in the brisket." Mr. Yourtt adds for himself :

"This is about as bad a form as can possibly be described, and tho picture is very little exaggerated, when the aninial is analyzed, point by point; yet all these defects are so put together, as to make a not umpleasing whole."

Mi. Youatt, however, eompliments them with giving execedingly rich milk, and with fattening in a surprising mamer when dry.

We liare quoted the abore for two reasons: one as showing probably what may have been nearer the truth than we might naturally expect from secing the best specimens now, and the other as showing that this breed las made a grent advancement since his day, both in quantity of cills given, and in symmetry and perfection of form. 
From an American Standpoint:

Mr. Lewis F. Allen, the bost known historian of American cattle, says:

"Bcginning with tho head - the most characteristic feature-tins muzzlc is finc, the nose either dark brown or black, and occasionally a yellowisla shade, with a peculiur mculy, light-colored hair rumning up tho face into a smoky hue, when it gradually takes the color of tho body; the face is slightly dishing, clcan of flesh, mild and gentlo in expression, the cye clear and full, and cncircled with a distinct ring of the color of the $110 \mathrm{se}$; tho forchead is bold, horns short, curving inward, and waxy in color, with black tips; the car is sizable, thin, and quick in movement. Tho wholc head is original, and blood-like in sppearanco, more so than in

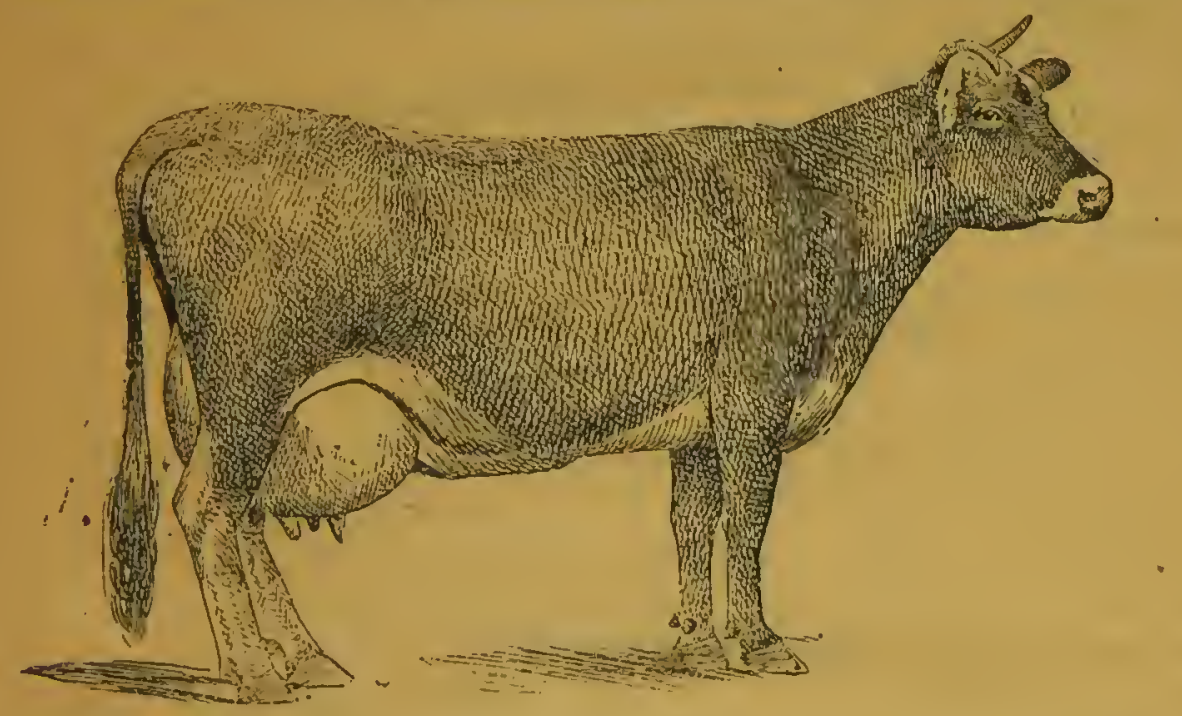

Jersey Cow, "Oreida." No. 4?.100, Property of Mr. C. I. Hood, Lowell, Mass

almost any other of the cattle racc-reminding one strongly of the head of our Americun Elk. The ncek is somewhat depressed-would to called 'cwe-neclsod,' by some---liat clem in the throat with moderate, or little dewlip); the shoulders are wido and somewhat ragged, with prominent points, running down to a dolicate arm and slender legs bencath; tho forc-quarters stand rather close together, with a thimish; yet well dereloped brisket between; the ribs are flat, yet giving sufficient play for good luniry; the lack depressed, and somewhat hollow, the belly decp and large, the hips tolcrably wide, the rump and tail high, tho loin and quarter medium in length, the thigh thin and decp, the twist wide, to accommodate a good sized udder, the flanks nicdiun, tho hocks or ganbrel joints c=ooled, the hind legs small, tho u:der capacious, squaro, 
set woll foriard, and corred wit! soft, sill-y hair ; the tents fuc, standing rell :luart, and nicely talering; the milk veins prominent."

\section{Cuaracteri:tic Colors.}

Tha coloris are mostly ligglt red or farn, and bleck, mixed and plashed rith white; the soid color's are, ve think, gonelally farored, and, to our mind, the best cittle, as showing careful bueding, though we have secn the nost superiol cattle anongr all these colors. So we hare seen somo distinetly rour, witl round, ruite sinooth forrers, called pure; they should alwiy be svoided, as there is more than a suspicion that such havo Sho:t-Ho:n blood in them, which cun do this breel no good, but on tho contlin:y, halm.

The breed is distinetly a miik bieed, and is of no value whatever cxecpt as yislaing fitu messes of excecdingly rich milk-giving largely of the most supcrior cream, producing hard, and most delicatcly flavored butter. 'linus any cross on this ancient and corefully lored stock must necessarily injure them in the points where they excel of her cows. Theso arc: Superiority of the milk, crean and buttcr, golder. in color', delicate in texture and flavor, and commanding prices in the merlet, from licalthy citizcus, that no other make can reach.

\section{Tizey cro Milling Cors.}

Whicherer of tha three varieties may bo chosen, they shonld be bred for this and nothing else. Whether they be from Alicincy, Jersey, or

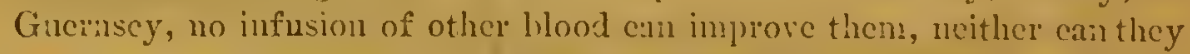
imisove any other b:ecd. The bulls may improve our natire cows, if the cows be sood milkers, the hereditary milling qualitics of the race being pre-potent in the progreny. For this improrement, howerer, none but pure bloog bulls should be wed, and this rule will loold goos in sill Lirecting.

The pure animal is pre-potent, the grade is not, and pure bred animals of all the superio: laces are now so plesty that ic will hot pay to lise grado bulis for the improrement of stock.

Tho Valino of Purity.

To sin the va!ue of purity, re will perhaps, fund no more approprinto place thin this.

A tholough-bied animal upoir nativesinck produces in the first. suececting generition an animul pintaking equally of the blood of the sire and dam, or what is called a half-bloof. The next generation, or the produce of a full-blood and a lialf-blood will griro a threc-quarters-bred unimal. 
Tho young of a pure-bred and threc-quarters-bred will give a seven-eighths bred. Following in tho sane line the next generation will give an aninnd possessing liftren-sixtcenths of puro blood.

In reality it will bo far more than we have stated, for tho pre-potens clement of pure blood, constintly present, will continually be an increasing integer in the progeny. IIcnce animals from scren-cighths to tiftecnsixtecnths-bred, cumnot bo distinguished fron one purcly bred, cxicept by a most critical, and at the same time expert judge. For all practical purposes they aro fully equal to nn mimal purely bred, that is to say, as dairy cows, but here tho comparison must end. $\Lambda$ taint of impurc blood once in, cumot be bred out for many gonorations-ncver in fact. Thero is always danger of reversion. Onc may, theorctically at least, brece? grades up for a thousnud years, and yet not have purcly hred animais. Henec the cxtraordinary prices paid for stock, the pediogres of whick havo becn kept absolutely without taint of adnixturc.

\section{Tho Veluo of Points.}

So important is the question of symmetry of form, and points of cxecllence, in stock, viewed as integers in the mal:c-up of an animal-leal valuo being adaptation to the necessitics required-that, of late Jears, all animals are judged thercby. As a study of these we give a figured portiait of a. model cow, illustrating perfection.

Theso points may be adopted in judging any cow, so far as genernl charactcristics are conccrned, devititions being only in matters oî foun, color, peculiar markings, shape of horns, and gencral contour. Tho Grecruscys, for instance, are larger, somowhat coarse:, and have of lato year's becn placed in a family by themselves.

The seale of points given arc those adopted by the Royal Jersey Agricultural and Horticultural Society, in dote:mining the merits of animals to be passed upon:

\section{Scclo of Pcintz-Cota and Iei:?r3.}

1. IneAn, -small, fine and tnpering

Poxitz

2. Cив

3. Tirost, - clenn

4. MIvzLLE,-flnc, and mecircled by at bright color.

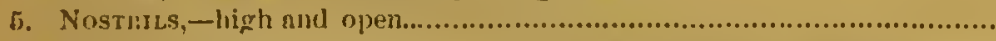

6. Honxs,-smooth, erumpled, not too thiek at the base, and taperire........

7. Fisns,-8mall and thin.

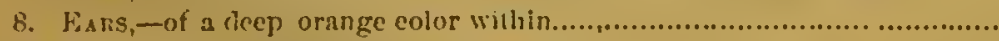

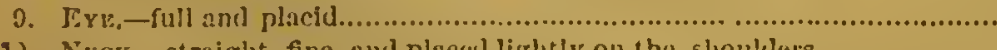

3). Nrek,-strajglit, fine, and placel lightity on the shoublers....................

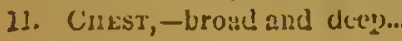


I3. BARRzL, -hnoped, broad and deep

Po:nra.

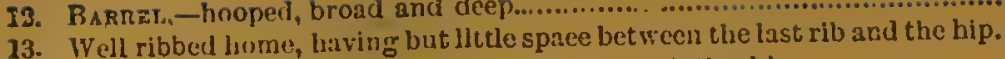

1

14. $\mathrm{B}_{\Delta \mathrm{CL}}$,-straight from the withers to the top of the hip....

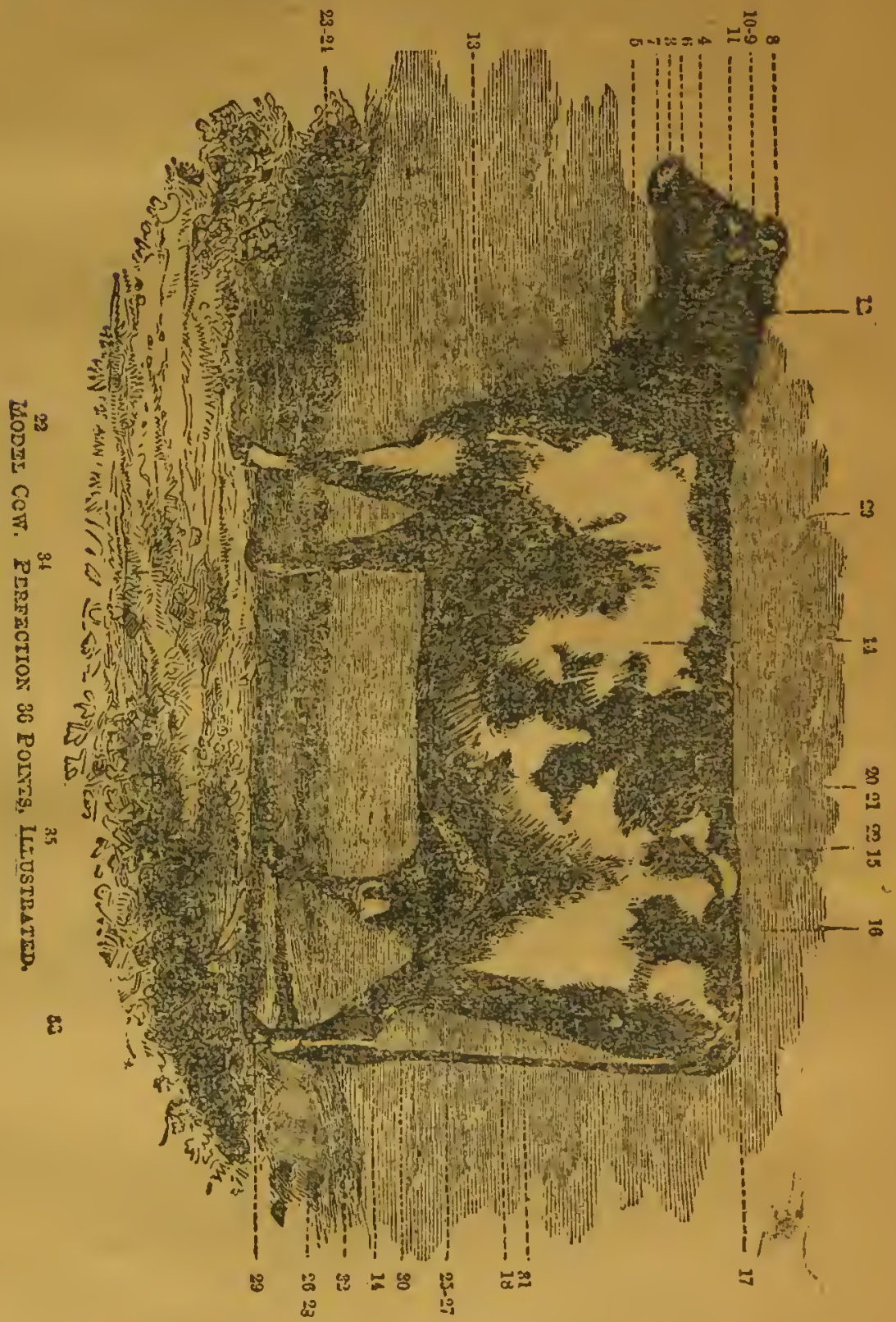

58. FACK,-straight from the top of the hip to the setting on of the fitil, and 15. 'T $\triangle I L,-$ line the tail at right angles with the back........................................ 


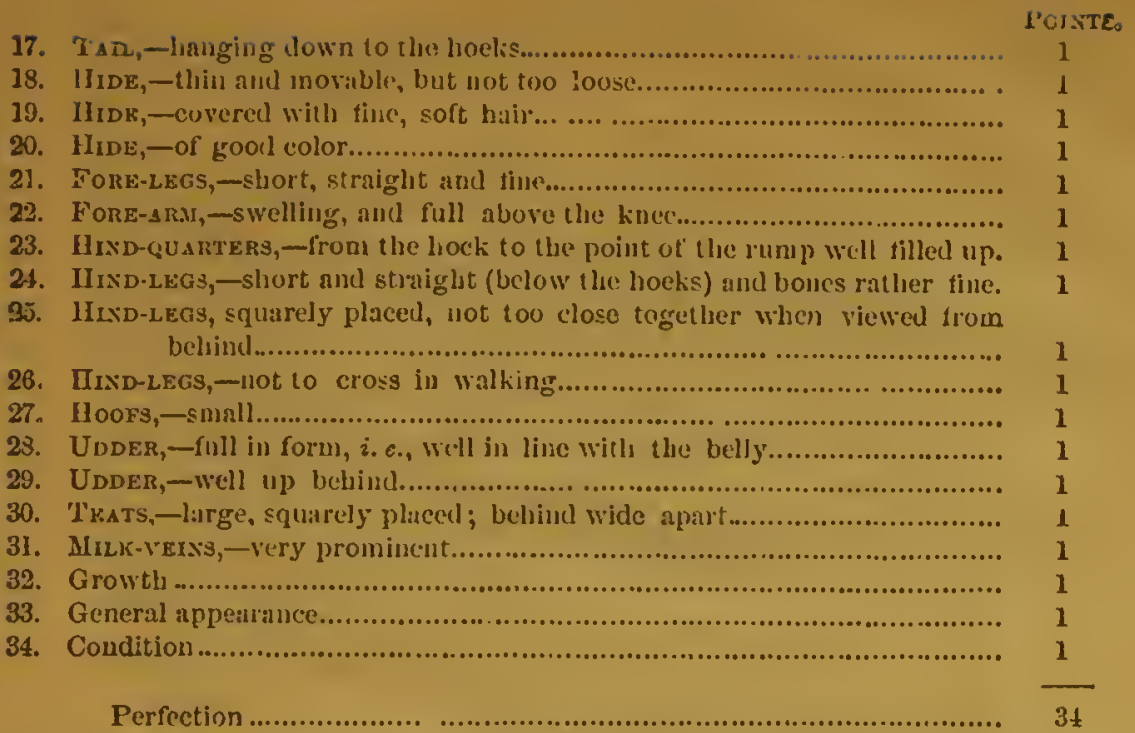

No prize shall be awarled to cows liaving less than twenty-nine points. No prize shall be awaded to heifers having less than twenty-six points.

Cows having obtained twenty-sewen points, and licifers twenty-four points, shall be allowed to be bianded, but cannot take a prize.

These points, namely, Nos. 28, 29, and 31 -shall bo deducted from the number required for perfection in heifers, as their udder and milkveins camnot be fully dereloped: a heife; will, therefore, be considered perfect at thirly-one points.

To this we add:

One point must be added for pedigree on wale side.

One point must be added for pedigree on fenale side.

Again, the size of the escutcheon, or milli-nimrors, is a point of especial attention. This, however, will be treated in another chapter, for the escutcheon is now coming to be accepter as an indication of the milking qualities of a cow, and whaterer the breed may be, strongly relicd upon. And those who discard it, that is, refuse a cow with a strong escutcheon, will surely go astrny.

In judging bulls, many of the same points will serve. The head will not be so small, and the forehead must be broad; the horms must be tipped with black; the neck, arched, powerful, but not too coarse and heavy; hide thicker than in the cow - certainly not thin - and mellow; fore legs short and straight, fore arm large and powerful, full abore the knee and firm below it. As in cows, pedigree must hare two points, ono for purity of blood ou the male side, and one for purity of blood on the female sido" 


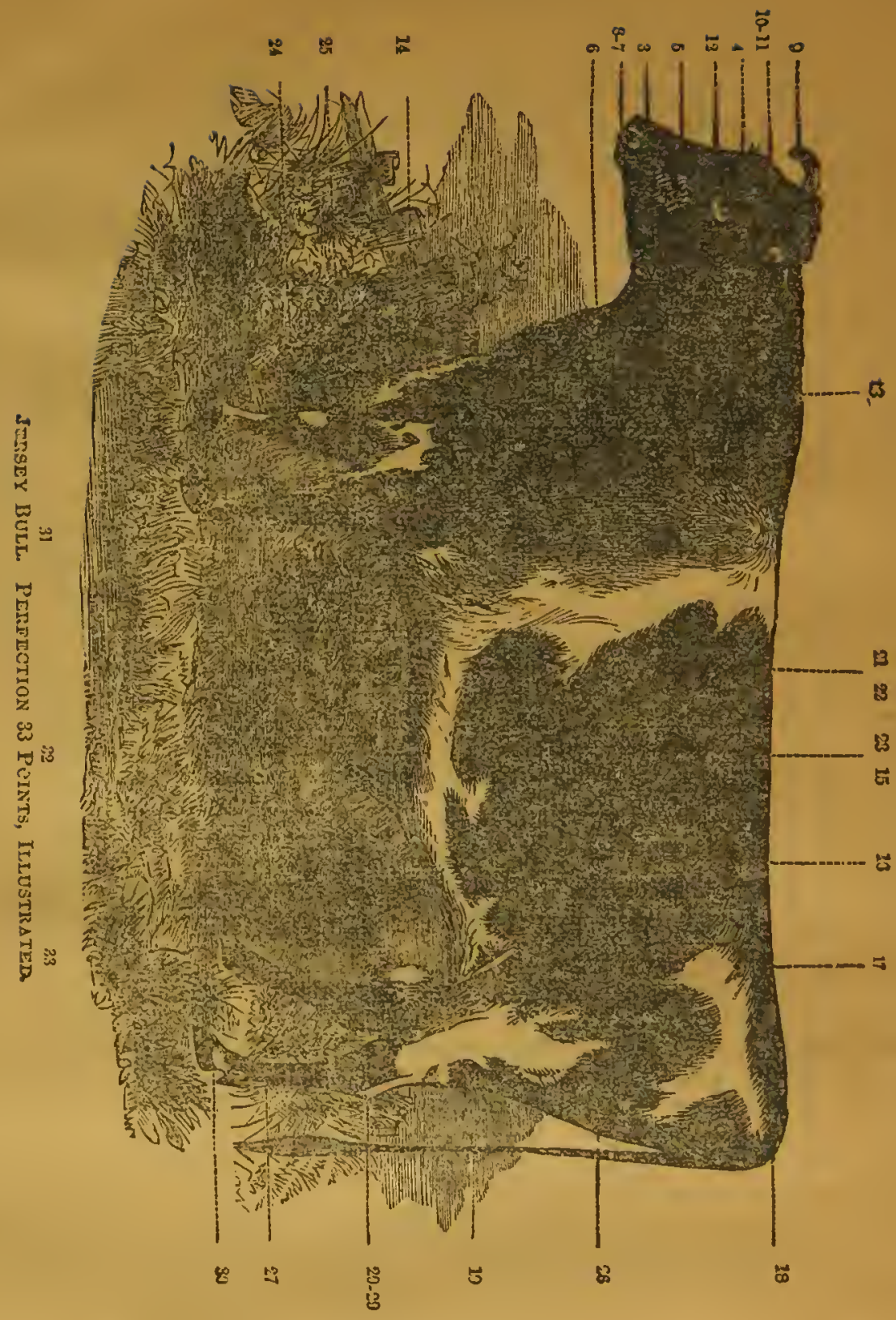

The portrait of a bull given above illustrites the "points" adopted by the Royal Jersey Agricultur:l Society, and continued after an experienco of ten years without alteration. Through it the reader will easily becoms conversunt with the points by which Jersey buils are judged. By refer- 
ence to the figures given below, and corresponding in the illustration with the points the reader will understand the following

\section{Scalo of Points for Bulls.}

$\triangle \mathrm{RTICLE}$.

1. PEDIGREE on male side.

2. P'edrake on female side

3. HєsD,-fine sund tapering

G. Tiro

7. ML'zzLE,-finc aid encircled wilh light color

8. Nustrits, -high and open.

D. Hows, - smooth, erumpled, not thick at the base and tapering, tipped with blick.

10. Fars, - small and thin

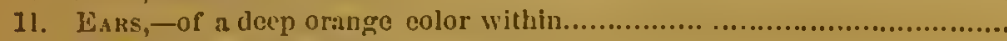

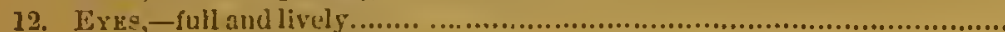

13. Neck, -arehed, powerful, but not coarsc or heavy............................

14. Cinst,-broad and clecp....

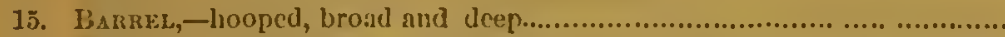

16. Well rlbbed home, having but litt le epace between the last rib and the hip.

17. 1 A $\mathrm{ck},-$ straight from the whlthers to the top of the hip..

13. Back, - stringlit fiom the top of the hips to the settling on of the tail, and the tail at right angles with the back.

10. TAIL, - inne.

20. 'SALL,-banging down to the rocks.

21. Hors, - thin and norable.

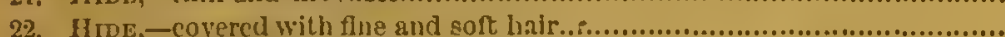

23. HiDe, - of a gond color.

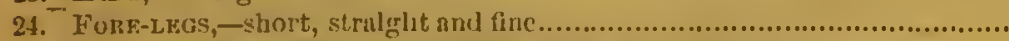

25. ForF-ARs, -large and powerful, swelling and full above the knce and finc below It.....

20. InxD-quarters, - from the look to the point of the rump long and well filled up.

27. IrxD-LrGs,--.hort aukl straight (below the hocks) and the bones rather dire

29. IIrsD-LIGa, -squarely plucel, not too elose together when vlewed from

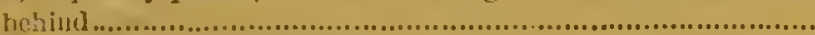

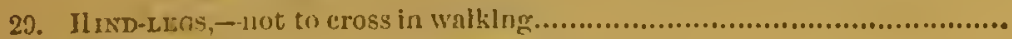

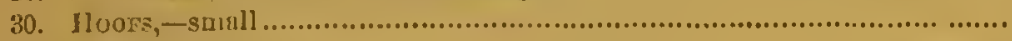

31. Growth

32. General appetarance..........................................................

33. Condition...

Perfection

\section{Judging by Points.}

The highest excellence of any millking cow lies in tho udder. This must not only be full in form, Inat is, in line with the belly, but it must not bo cut off square in front, like that of a goat. It should be rounded, full. 
presenting great hreadth belind, and carried well up between the thigh. The milk veins should be full and carricd well forwind toward the foro legs. If knotted and with curves, so much the better.

The tail is anotler essentinl point. Whaterer its size at the root, it must be large and tapering, and have a good switch of hair.

The chest should be broid and doep); this shows good respiration, essential to feeding and hentll. This, howerer, must not be taken in the gense in which we view it in the blood holse. It is then one of the essential points, necessary to fist and long continued exertion.

In the dairy cow, especially when viewed from bofore, there will be no appearince of mussiveness. On the eontrary, she will give an appealance of delicate fincucs, and will look lirge bohind, swelling gradually from behind the shoulders. She may not be elosely ribled, in fuet should not.

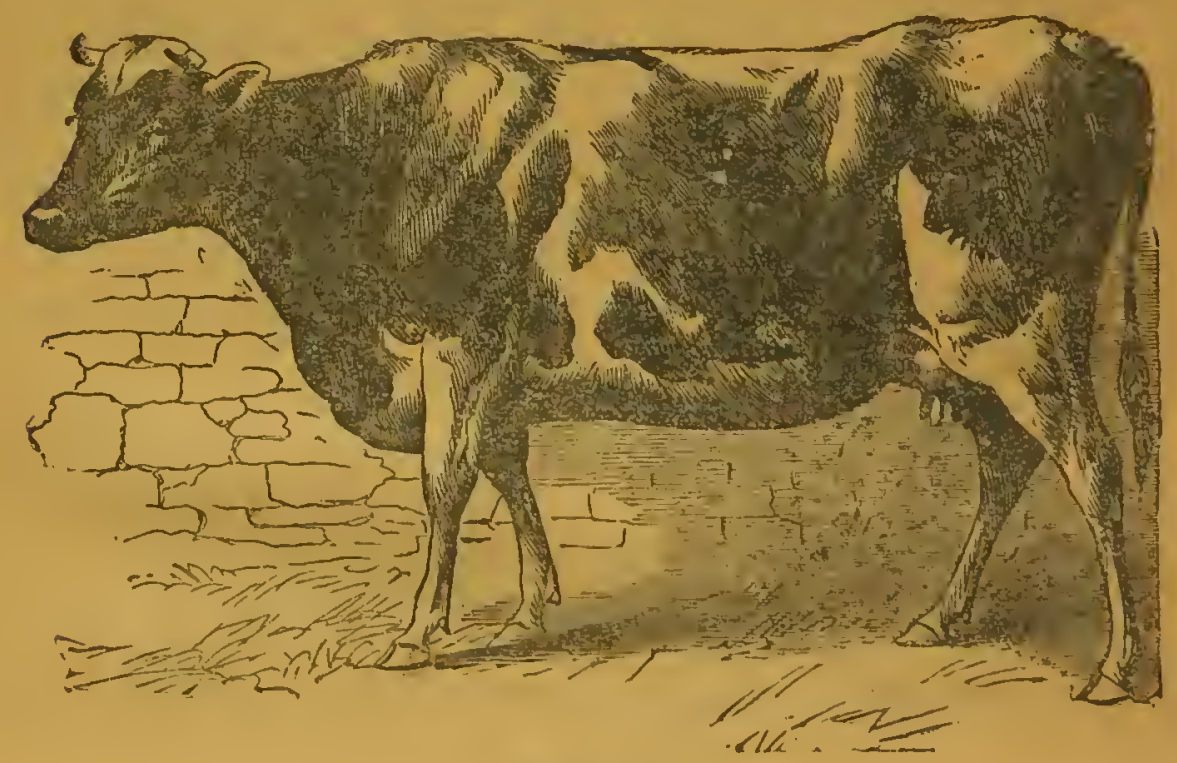

JYRSEY Cow.

be close, only compinatively so. The best millsers, every where, will bo found to be rather loosely put iogether between the list rib and the hips, and good milker's must be roomy in the llink.

The hind quarters must be long from the point of the rump to the hock, and well filled up; jet this does not mean rounded and massive in flesh; on the contrary, the best milliers will be rather lean and perliaps high boned. Norertheless, the sime imimal, when out of linlle and fat, may fill up, and perinips, present a fully rounded contour, while yet possessing all the delicacy of points characteristic of the high bred dairy cow. 
A cow may have large and leavy cars; her back may not be fulig straight from the withers to the top of the hips; her rump mizy be sloping; her tail may not reach the hocks;-all these are defects - the latter a sericus one-yet, if the milkingr organs are super-cxcellent it will outweigh all these.

A phenomenon may show absolute perfection in all the points: we havo never yet seen such an onc. In judging, the esscntials are to carefully consider cach point of excellence with reference to its bearing upon tho animal as a dairy cow.

A high open nostril would count but little as against a poor milk vein; a very delicate car, nothing as against a rery superior udder.

The Jersny, to the uncritical cyc, when in full inilk, is lean, scrawny, knd misshapen; are so, fat or lean, from the standpoint of a Short. Horo

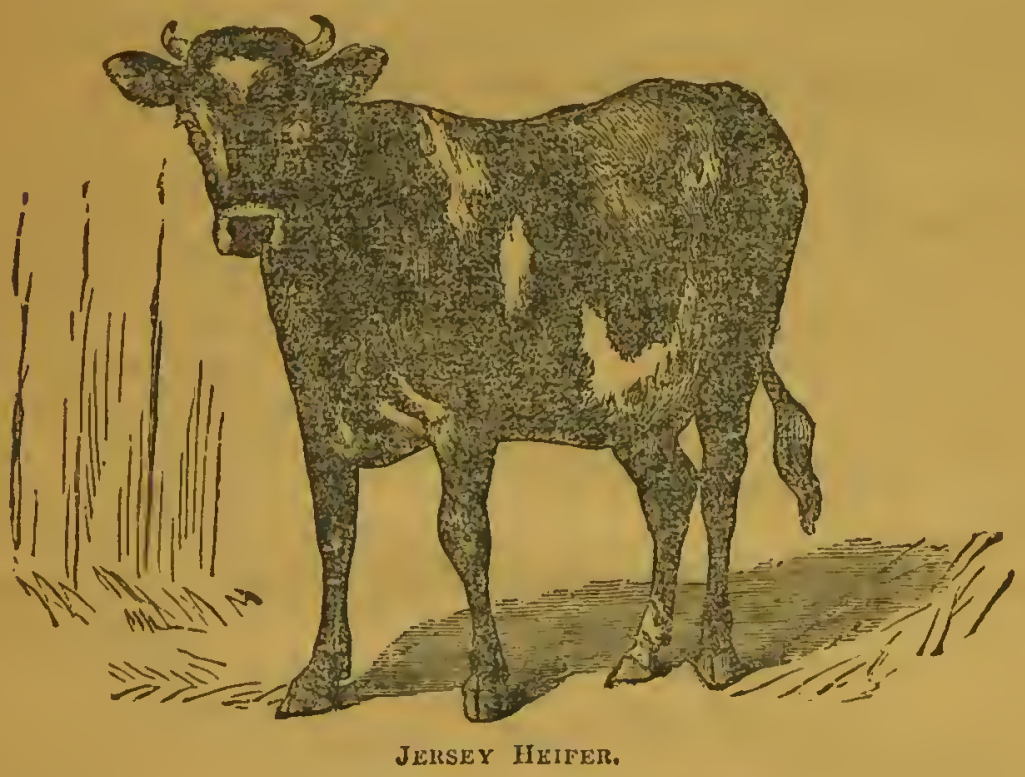

or Iereford brecder. The Short-Horn, or Hereford, is a gross, lubberiy disgusting, mountain of fat in tho cyes of a Jersey brecder.

Color, Temper, and Size.

Do not be too particular about eolor; solid colors, and black points look well in the show ring. The aninial that will turn out well at the pail, that is doeile and gentle, be she what eolor she miny, so long as she adberes to the distinguishing color-marks of the race, is tha ono for the milking yard. 
In relation to size, the Jerseys are a swall rueo ot eattlc. In ro breed are overgrown animals the most viluable. With the Jersey it is especialiy to be avoided. So, an undersized animal is not to ve countenameed. Ficir size, however, is dosirable.

He who sceks to increase the size of the Jersey unduly, will certainly go astray. They have been carcfully bred, for many gencrations, with especial reference to milk.

The Jersey is the product of islands peculinr in soil, climate, and people. Transplanted to our flush pastures, with good shelter in winter, they will recessarily inercuse in size 'This is to be expected.

If you fancy "solid colors," and can wert plenty of rich milk, with solid coinrs, well and good. If not, breed to whatever color, characteristic of the breed, which will give you this desirable result.

\section{As Dairy Cov.}

The Jersey eow ean hardly be called a dairy cerw, in the general acceptation of the term. She lacks size to grive quantity ; as a checsu maker, she is not a sucecs's, as butter makers, they stand withont cquals, if quality be the test.

The butter gle,umles of the milk are larger, and with a wealier coverng than in other: brecds; henec it churns quicker than the milk of cther eows.

The milk, sream, and butter, of the Jerseys are yellower than tint of other breesio. This is due to the cxecss of orange pigment seereted by this brecd.

Jerseys are especially adapted to the villager, or family, requiring a medium quantity of rich milk, and superior croam and butter. They hare taken kindly to our sunmer elimate, from Maine to Califormia. In winter, however, and in the carly spring and late fall, they should be as cavefully housed as Short-Horns, else they will fail to give even a moderate degroe of satisfaction.

The eors are always docile, gentle, and traetable, when properly treated. It is not to be denied, hovever, that the bulls are often vieious. An enthusiastic "xiter has attributed this to their long lincage of aristocratio breeding. The Short-Horns are far more aristocratic in their lineago of encicnt sises and dams; they are also notably peaecable.

It is a faet that animals kept in confinement are apt to heecme surly, and cross. The breeder of Jerseys must acept the fact that the bulls must be kept under strict discipline, and this by the exhibition of both firmness, careful handling, and gentloness. Otherwise, they themselves will bo troublesome, and their offspring also will bear these characteristics. 


\section{Ayrshire Cattle.}

The origin of these cattlc cannot be distinctly traced. That Ayrshire, in England, his long been noted for a very supe:ior breed of milking cows, is indisputable; yet anything like what were known as Ayrshircs, fifty years ago, did not exist one liundred years prior to that tine.

That the present breed was not produeed by a cross of Alderney, on the nativo cattle of Scotlind, as has been asserted, is evident cuough from their form and characteristics; that they were not produced by selection, is equally as well grounded. They may have origrinated in a happy cross, and carcful breeding thereafter.

That the Ayrshire orres much of its superiority to crosses of the better milking strains of the old Short-Horn race, would seen to be borno out, not only by tradition, but particularly by unistalsable characteristics of loth these breeds.

Ayrshirc indeed is eminertly adapted to the production of sunerior millking cows. The elinite is moist, vith plenty of soft mains; consequently, the grasses would naturally be suceulent, and tend to produes the greatest flow of miik of which a cow might be cupable.

Of the three divisions of Ayrshire-Carrick, Kyle, and Cumbingiamthe latter is regrirded as the true lome of this most viluable breed. Indeed, they unce went by the mame of Cunningham cattle.

\section{Ayrsizires of the Last Century.}

Mr. Aiton, an old English writer, who lias written more largeiy and intelligently than perliaps any one else of this breed, has given mueh ralunble information concerning then as they existed in Ayrshire eurly in the last century. Speaking of them, he says:

"The cows kept in the districts of Kyle and Cunninghan were diminutive in size, ill-fed, i!l-shaped, and they yielded lout a seanty return in milk; they were mostly of a blick color, with linge stripes of whito along the chine or lidgo of their back, alont the flanks, and on their fiecs. Their horns wero highl and crooked, having deep ringlets at tho reot, the plainest proof that the cattle were lut seantily fed; the chine of their hacks stood up high and narrow; their sides were lank, short and thin; their hides thick, and adhering to the bones; their pile (skin) was co:nr;e and open ; and few of them yielded more than six or eight quarts of n:ilk per day, when in their lost plight; or weighed, when fat, moro than from twelve or sixteen to twenty stone avoirlupois, sinking offul."

The IIrsbandry of Ayshire, published in 1793, stites upon the E: thoxity of Mr. Brne: Camplull, that the introduction of the improved breed vias male by the then lite Einl of Marchmont, and Mr. Youats

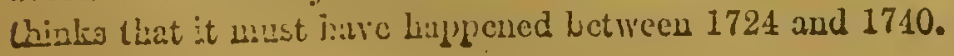


Thoje then ricre successive inlroductions of improved blood among them, the Dunlap strain of Short-Iorn about 1780, or one hundred years ago. This breed became well established in reputation, and in the eariy part of the present century became regularly known as Ayrshirc, acos. was widioly disseminated in England.

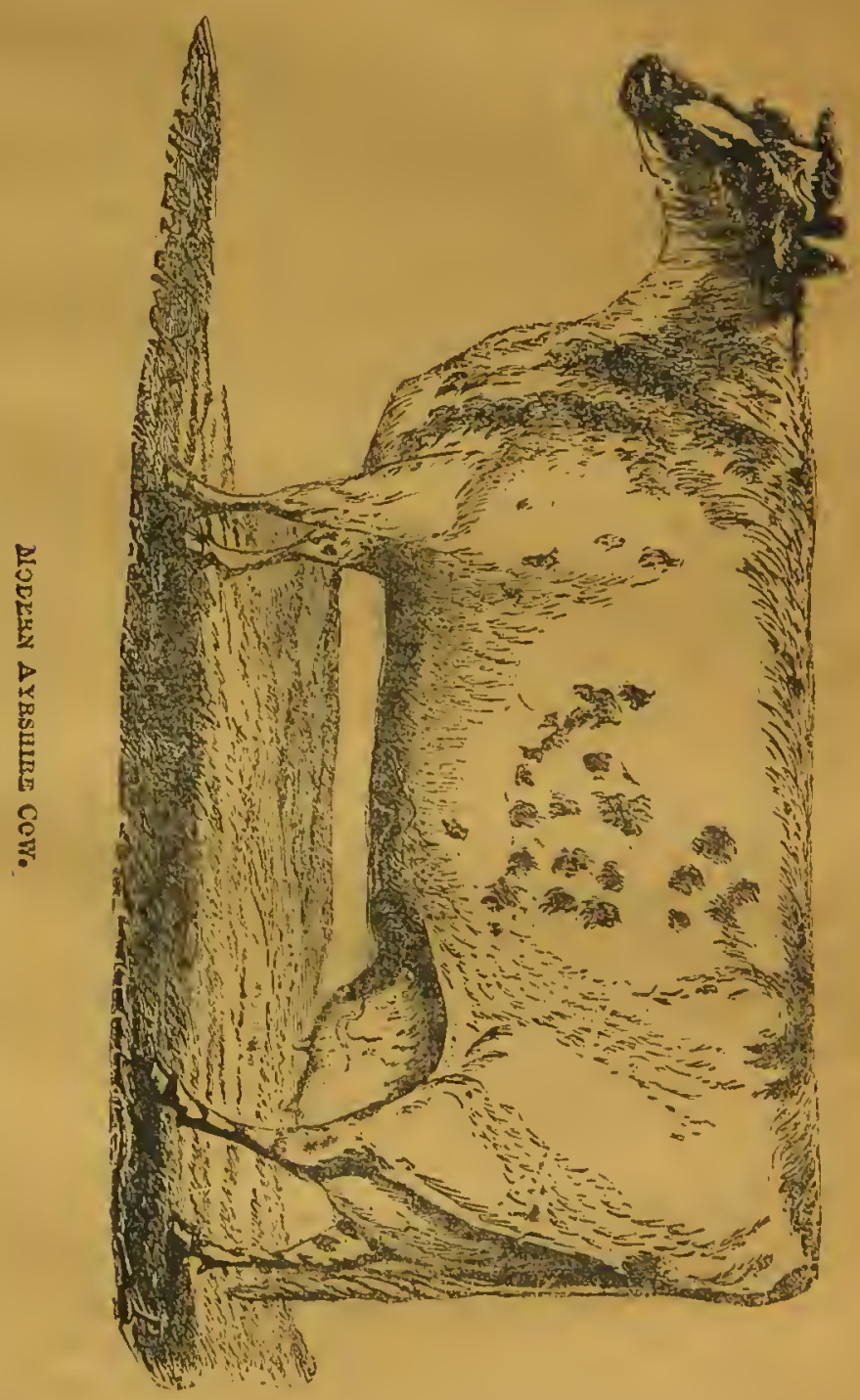

The ahrore likeness is a good one of the improved $\mathrm{c}^{-}$ ahine cory.

Mr. Aiton describes the breed in its improved form, late in the last centmry, and carly in this, as follows: 
"The shapes most approved of, are-head small, but rather long ara narrow at the muzzlo; the eye small, but smart and lively; the horns small, clear, erooked, and their roots at a consiäerablo distance from each other; neek long and slender, tapering toward tho head, with no looso ekin below; shoulders thin; fore-quarters light; hind-quarters ln'ge; baek straight, broad behind, tho joints rather loose and open; eareuss deep, and pelvis eapacious, and wide over tho hips, with round lleshy buttoeks; tail long, and small; legs small and short, with firm joints; udder capacious, broad and square, stretehing forward, and neither fleshy, low hung, nor loose; the milk-veins large, and prominent; teats ahort, all pointing outward, and at eonsiderable distanee from each other; ekin thin and loose; hair soft and woolly. The head, bonos, horns, and all parts of least value, smal!; and the general figure eompaet and well proportioned."

In this connection, it should always be remembered that the Ayrshire cows were always noted for their thighs, and in fact a general tiininess of body, as compared with beef breeds. The bulls were always seleeted for their feminine appearanee, especially about the neck and heac: they were not required to be roomy behind; they were required to be broad in the book bones and hips, and full in the flanl-s.

'Tameness and doeility of temper, hardiness, a sound constitntion, plenty of spirit and life, and the eapability of giving lurge messes of milk, rich in butter and eheese, aro noted ebaracteristics of this breed in an eminent degree.

Mr. Youatt says of them: "They yield much milk, and that of an oily, or butyraceous, or easeous nature; and that after she (a cow) has yielded very large quantities of milk for several years, she will be as valanble for beef as any other breed of eows known; her fat will be much more mixed through tho wholo llesh, and she will fatten faster than any other."

As far as milk is concerned, it is true of the Ayrshire of tho present day.

In Ameriea, tho breed has not yet been sufficiontly disseminatod to determine whether the quality of beef shall be borne out by the stata ment of the author quoted.

Mr. Youatt agrees that the breed has mueh improved since Mr. Aiton described it; that it is short in the leg, the neek a littlo thieker at the shoulder, but finely shaped toward tho inead; the borns smaller than hoso of the Highlinder, but elear and smooth, pointing forward, turning upward, and tapering to the points; they are deep in the eareass, but not cound and ample, and especially not so in the loins and haunehes.

Bomo, however, have suspocted, and not without reason, that an atten- 
fisen to the s!ape and beanty, and attempt to produco fat and sleck cattle, which would be admired at the sliows, has had a tendency to improvo what is only their quality as grazing cattle, and that at the certainty of ciminishing their value as milkers.

\section{Yiclds of Hille, Buttcr, and Checso.}

Experiments made carly in the century, to determine the relative valus' of difierent brecils for milk and buter, we find as follows:

"In some cxperinents conducted at the Enrl of Chesterficld's dairy at Bradley Hall fil'm, it appeared thut, in the height of the scason, tho Holdencss wonld yicld seven gallons and a quart; the Long-Horn and the Alderney, four gallons thee quarts; and the Deron, fomr gallons ono pint, per day. When this was made into butter, the result was, from this Holderness, thirty-cight and one-half ounces; from the Devon, twentycight ounces; : anl from the Alderney, twenty-fire ounces."

Ilis Ayrshires average five gallons per day, and from that is produced thiriy-four ounces of lrutter.

This shows the degree of supcriority the breed has obtained in Mr. Yonıtê's tine.

Mr. Aiton, indeci, asserted that $33-4$ to 4 gallons of this mille would yicld a pound and a linlf of butter, and that $271-2$ gallons of mills would yield 21 pounds of full milk checse ; and that Ayrshires in their best cona rition and well fed would yield 1,000 gallons of milk in a year.

Witil lespect to yield in the United States, we have the recold that tho first Ayrshire cow imported by the Massacliusetts Socicty for the Promotion of Asriculture, in 1837, yiclded 16 pounds of butter a weck, for sereral wecks in succession, on grass feed only.

Mr. Iimlin, a most reputable Englisl authority, reporting upon a Kylo farm in Ayrshire, holds that Mr. Aiton's estimate is too higli. In relatiou to two fims visited, upon one of which was licpt from twenty to thirty cows, and on the oflicr from thirty to forty rery superior cows, he says of the first, thit, "at the best of the season the average nilk from each cow, is 9 Scots pints (4 1-2 gallons,) and in a yeur 1,300 Scots pints (650 gallons,); that in the summer scason, 64 pints ( 32 gallons, ) of entire milk will make an Ayrshire stone (24 pounds) of cheese; and 96 pints (48 gallons) of skimmed milk will produee the same quantity; and that 180 pints (90 gallons) will makc 24 pounds of butter." Oi tho other farm, he states that "the averige produce of each is 1,375 pints (687 1-2 gallons);" and adds as his belicf, on the whole, that although there may be Ayrshire cows capable of giving 900 gallons in a year, it would be dificult to bring laalf a score of them togyether; and that in stouks 
of the greater number, most earefully selected and liberally fed, from 650 to 700 gallons is the very highest produce of each in the year.

Upon his own farm, the size of which, bo says, is of an inferior nature, bis cows produce only 550 gallons in a year

\section{Ayrshires in America.}

The Ayrshires were first imported to the United States in 1831. They rere different in appearance from what they are now, the colors being rither deep red, or brown flecked with whitc, many of them having black noses. They have been materially changed sinee then, and vary much in color. The most of them, however, retain the characteristic colors of tho breed, and whetlice they be dark red or black, they are generally more or less pied, mottled or blotehed with white.

Mr. Allen, himself a Short-Horn brecder, in his work, "Ameriean Cattle," sums up the Ayrshires as follows;

"'l'leir thirty-six years' trial herc has been successful. They are hardy, healthy, well fitted to our climate and pastures, and prove good milkers, both is to the imported originals and their progeny. Their flow of milk is good in quantity and fair in quality: yet, we must be permitted to say, thit in this country they do not yicld so much in quantity as is alleged they hare produced in Scotland. The chief reason for this is olvions. Ayrshire has a moist elimate-an almost continuous clrizale of rains, or moisture pervading it-making fresh, green pastures; a cooler and morc cquable temperature in summer, and it is warmer in wirter than with us.

Our Ancrican climate is liable to extremes of eold in winter, heat in cummer, and protricted drouglits, for weeks, drying up our herbige. These differences alone account for a diminished yield in milk from Scotch to the Ancrican Ayrshires. They have softer grasses for hay, and plenty of root-fceding in winter, which latter we have not. This fact of a diminisher yicld of milk on this side of the Atlantic is acknowlcolged liy those most conversant with them in both countrics.

In the year 1837, we visited the Ayrshire herd of the lato Mr. John P. Cushing, at Watertovu, near Boston, Mass. They were of the choicest, quality, imported by himself, on an order sent out to an expenienced dealer" in Ayrshire cattle, "without regard to price, so they are the best." Two or three of the cows were "prize" milkers at home, and certificites, duly verifed, were sent with then of the quantities of milk they had mado. They had then been a year or more at Mr. Cushing's farm, and hat the b)est of kecp. Wo questioned the manager as to the quantities of milk the cows gave since their arrival, compared with the certificate. His answer was, "about one-third less, on an average. The best 'preze' cow gavo 33 guarts per day when at her maximum in $\Lambda$ yrshire, und 22 guart 
nere, and the others in ahout liko proportion, but they aro all good milikers, and Mr. Cushing is satisfied with them."

Wo noto the faet of the declension in mills of tho Ayrshires in this counti'y, knowing the sime to have oceurred with cows of other breeds from England. It is neverthcless true, we think, that tho milk produced Lere is richer in the constituents, as it is undoubtedly true that cows on flush, soft pastures, or those fed on soft, sloppy food, give far poores milis, although more in quantity, than whon fed on shorter rich licribarce or' uryon other rich food.

\section{$\triangle$ yrshircs in tbo Wost.}

In the West the Ayrshires have not gaincd the colebrity that tho Jerseys or the Holsteins hinve. The probability is that the Jerseys owe much of their popularity to the fact that they are par excellence tho family cow, where quality of mill has greater weight than quantity. The latter are hard keepers; that is, they consume a large amount of food for the quantity of milk given, and probably moro than either tho Aryshires or Holsteins for the quantity of butter and cheese produeed. The Jersey must havo ricl food to enable her to sustain herself. Nevertheless, the texturc, solidity, hardness and delicaey of the butter amply compensates for this. The Holsteiu has grown in favor in the Wost rapidly within the last fow years. Our abundant pastnro and ehcap forage and grain in winter, has made them prime favorites with all that class who must have a large quantity of faily rich milk. As a cow for making cheese they are unsurpassed, as is the Jersey for butter. For a great flow of milk, rich in butter, our experience is that the Ayrshire carries off the palm, especially on pastures not good enough for tho Holsteins.

\section{Doscription of Ayrshire Points.}

In judging cattle of any deseription, reference must always be liad to the elaracteristies of their breed. Thus, whilc all cattle are judged by certain undeviating standards as respects feoding and assimilation, boef cattlo must be judged from a becf-nialing standard, and dairy ciattle from their milk-produeing powers. It is more than probable that, weight fer weight, tho Ayrshiro being a cow of medium size, will produce moro milk than any other breed. In selcetion no surer test can be had than a careful study of her points. Dr. G. Lewis Sturterant, of South Frumingham, Massacliusetts, who has given the Ayrshire particular attention, and who is one of tho most careful farmers and breeders in the East, thus iescribes the Ayrshire, and the same prinoiples may be appliod to tho whole raoo of dairy cattlo. 


\section{Uscfulness.}

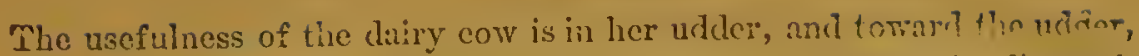
its shape and its yield, all the capabilities of the cor should be dirceted. We may frst view it a : a reservoir for the inilk. As stech, it must bo large and capacious, with broad foundations, extending well behind is wall forward, with distinct attuchments; broad and square, viewed from bchind, the sole level and broad, tho lobes cren-sized, and teats crenly distributed; the whole udder firmly attached, with slin loo:s anel ciustic. Such a form gives great spuce for the secreted milk, and for the lodignent of the glands, while allowing the changes from an empty to a full ressel. The glinds should be free from lumps of fit and muscle, well set up in tinc body when the cow is dry, ind loosely covered with the soft and clistic shin, without trace of Anbliness. Sucl a covering allows for criclasion when the anmal is in milk, while the glands are kept in proxinity witk the blood-ressels that supply them. The necessities of the lacteal glands are larger supplies of blood from which milk con be secroted, and this larmonizes with the demands ot the udder as a storchouse. For broud attachments means broad belly or alumdance of space for the digestive organs, from which all nutriment must originate. The blood is furnisherl to the glands of the udder by large and numerous anteries. As secretion is dependent on the freedom of sipply of blood to tlic prirt, and a copions flow, we find branches coming from different arterial trumls and frecly anastomozing with each other. Although these arteries are intelnal arci out of sight, yet fortunately the reins which car'ry the blood from tho udder pass a sng the surface, and from their size and otler characteristics indicate the wantity of blood not only which they carry away, but which must have pissed through the ginds from the arteries. These return r cins jass hoth backward and forward. Those passing forward are known as the milk veins, and the size of these superficinl veins on either fide of the belly, and the size of the orifices into which they disappear, are crecl. lent points to determine the milking probability of the cow. Sitill loctic is it to find, in addition, the veins in the porineum, which also return from the udder, prominent and circuitous.

\section{Escutcheon.}

The escutcheon is now genernlly eonecled to be a good indication of milk in the cow. This mink is sufferently well known not to require ciescription in detail. I think a broal escuteheon is fully as good a sign as a long one; that quantity or quality men more than shape, yet I would not discird the sh:ipe entirely. One error nust, lowever, be aroided. It may be well to compare the sizo of cscutclicon of cors of one lsece 
but never to compare the size of escutcheon in corrs of different breeds. I think this point means more relative to size in the Ayrshire than in tho Holstein or Dutch; and I an eertain that while it may be safe to follow it in the Ayrshire in the inajority of instances, it would be equally unsafo to adopt it in selecting a Short-Horn, for the obvious reason that that breed has been-bred for gcuerations for other purposes than those of tho dairy.

The udder and its dependencies, the milk veins, and the eseutcheon: mark, may be eonsidered the foundation of the Ayrshire cow. 'These influence profit, and also the shapes of the lody and the form of the animal. The milk vessel is placed in the pubic region of the cow, and is protected on oither side by the hind limbs. The breadth of its attachments secures breadth of body, and the weight requires also in depth of quarter and of fanks. The breadth below requires breadth of hip above, and length of loin here appears related to length of pelvis. So much for the pliysical prition. The physical function of nilk-prodneing denands a great and continnous flow of blood, for it must iiot be forgotten that mill; is blood, so to speak. This flow is dependent on the supply of food, and on tho facilities of digestion. 'To gain this, a large body is required in order to hold the suitable digestive organs.

"To gain further room for these, we desire to see arched ribs, depth, yet no heaviness, of flank, and breadtl of hips which we see was also required for the brond udder. To sustain this body, a strong, firm back is needed. To gain the most of our blood after it has absorbed the chylo from the digestive organs, reason shows that it should find its way freely Ind speedily through the system on its labors of supply and removal, eleanse itself in the lungs, and again pass on to its duties. All this pointo tto a healthy heart, not cramped, and lungs of sufficicnt crpacity; for the yield of milk drains nuch nutriment from the system, and the eonstitu'cion must needs have the rigor given by healthy and active heart and lungs. In this way the ehest is correlated with the udder.

"The reproductive functions require hock bones of good size, and a broad pelvis is desirable, as underlying within are the generative organs. Defects here are to be shumned.

"Thus the neeessities of the body of a good milking cow require the wedge shape, and this not only from the flanks, but also whon viewed from above."

\section{A Summing Up.}

The points of the Ayrshire cow, as given by the Ayrshire Agricultural Society, and the New York Stato Agricultural Society, bave bcen sunmod up as follows : 
"The whole fore-quarter's thin in front, and gradually increasing in depth incl width backward, yet of sufficient bre:adth and rounduess to insure coustitution; back should be struight and the loins wide, the hips rather high and well spread; pelvis roomy, long, broad and straight, hook boncs wide apart; quarter's iong, tolerably muscular, and full in their upper portion, but noulding into the thighs below, which should. have a degree of thatness, thus affording more space for a full udder; tho thanks well let down, but not heavy; ribs, behind, springing out very round and full, affording space for a large udder-the whole careass thus acquiring increased volune toward its posterior portion.

"We see that the points as given are those of ntility, and that at this stage the udder-points and body-peints are correlated.

\section{Tho Skin.}

"In connecticn with the hody and the udder, the slin is of great valuo In assisting our judgincut. Betwecn $\{1$ ie portion of the external covering used for leather, and the muscle, there occurs a layer of cellular tissue, which contains a larger or smaller anount of fat cells, and the nucllow handling caused by these cells indicates a free circulation throughout this meshwork.

"The slin varies from a thin, papery hice, covered with silky hair, to a thick, supple, elastic lide, well coated witl laair, on the one hand, ans a sinilar variation, with laush laxir and coarseness, on the other. Tho thin, p:1pery lide indieater quick fattening and a delicate constitution; the thick, clastic lide cushioned on fat, and which on the flank corres into the liand almost without grasping, indicates the licight of vigor, accompanied by the fattening tendency, and the possessor of this bandling endures climatic (hinirges, low quality in his food, and necrlect, with remarkable hotrdihood, and quickly respoirds to tull feed and good care. The harsh hondler is a dull feeder, consumes much food, and generally contains more tham a just proportion of offal or waste. In the Ayrshiro cow we desire neither of these extremes, for it is in the milk product that we wish the food to be utilized, and it is almost an unchanging law of nature, that deficiency in one direction must be compensated for by cxcess in another direction, and vice versa. At any rate, the eow that lays on fat too yuickly is seldom a first class milker; and how well known is it that the eow of large yicld milks down her condition! A cow that has il moderately thin, lonse skin, of sufficient elasticity nnd enppleness of touch, withnut being fat-cushioned, as it wore, with hair coft and mossy, or woolly, if of correct form otherwise, will usually milk 
a large quantity, and when she becomes dry, wili rapidly come into condition. In truth, the handling of the Ayrshire cow inust be good; it camnot be too good; lut it must not be of exactly that quality sought for ili the grazing loreds.

"There, as everywhere, the dairyman inust keep to his line; milk, rot fat, is his profit; and in sceking excess of both, ho will be liable to fall below the averugre of either."

\section{Relating Espocially to Mrilk.}

It is an axiom of brecder's to dininish the useless parts of fin anilial as much as possible, or, in other words, to reduce the proportion of those parts not conductive to profit to as great extent as possible. Applying this rule to a dairy breed, we should desire in small neck, sharp shoulders, smalil brieket and small bone. Morecrer, small hone usually accompanies tmift, and is universally found in improved breerls. We thus have a reason for these other Ayrshire points, which I now quote:

"Shoulders lying snugly to the body, thin at their tops, small at their prints, not long in the blade, nor loaded with muscle; brisket light; neek of medium length, elem in the thront, very light throughout, and tapering to the head; tail long and slender; legs short, bones fine, joints firm.

If the darryman's policy were otherwise, he would hatre to supply extran food for the support of parts useless to him, and whose larger development is of 110 especial vilue.

Tho Head.

"The heud should be smull, in shape either loug and narrow, or broad in the forehead and short, according to the type of animal preferred by the breeder, generally preferred somewhat dishing; the nose tapering to an expanded muzzle, with good clean nostrils. Opinions differ as to tho general shape of the head. A broad forehead and short faco occurs more frequently in bulls, and is grencrully estecmed a misculine characceristic; a more elongated face is called feminme. Yet some fimnilies of well-bred and good milking Ayrshire cows have the broad and short hear, rnd such were, at one time, if not now, the favorite in the show-yurd in Écotland.

"The eye should lo moderatciy full, lively yet placid looking. The eye is a mirror of the disposition, and interprets the character of tho cow; a fretful, irritable animal is seldom a quick fattener, and usually aisappoints at the pail. It also gives expression to the features, and pinysiognomy ails cur judgment. 
"The cars should be of a good size, but thin, and their slin of rich yellow color. Coarse cars are usually found on ill-bred animals, and these may be considered, to a certain extent, indientive of general coarseness. The color of the skin, as shown inside the ear, is usually considered indicative of the richness of the milk in butter.

"The liorns should be of niedium size, of fine texture, with an outward and upward turn, or inclining upwards and curving slightly inwards, according to the taste of the breeder. They should be set on rather widely apart. $\Lambda$ coarse lorm may indicate a consse and thick hide, as there secms an intimate relation between the composition of the horn, hair, and hide, and the influenee of elimate on horn and huir gives an appearance oftentimes of corrclation between the two.

The Top Points.

"The neck shoul e of medium lengtlı throughout, and tapering to the throat, which should be clcan or free from loose, hanging skin. Iet too thin a neck is not desirable, as it usually indieates a delieate animal. A thick-set neck, well covered yet not overliden with muscle, accompanies lardiness and vigor of constitution.

"The juuction of the neek with the body and over the shoulders is ealled the crops; on a horse it would be called the withers. $\Lambda$ hollow behind this point is a never-failing sign of weakness. The orops slould blend in easily with a thin shoulder, lying snugly to the body. This shoulder and a well defined spine produee the slispness of shoulder so much admired. The back should be struight, with spine well defincd, especially forward. The tail long, firm in the bone, and set on a level witl the back, without depression or noteh. A fine tail usually aecomjanies fine bone, and the fine bone is not only decrease of offul over heavy limbs, but accompanios enrly maturity, and a tendeney to thrift. The limbs slould be fine-boned, flat-honed, and with joints of mocierate size. On the forward limbs the cow should stand low. Largo joints and round bones are found very frequently on dull fieeders and on animals of little profit.

\section{The Teatc.}

"The teats should be of medium length, evenly set, and projeck alightly outward when the bag is full, of eren thickness throughout, and of fine texture. They should be pliced about nne-third of the length of the "vessel" apart in one direction, and about one-half the other. When the udder is not distended, they should hang perpendieularly. Large teats, however desirable to the milker, are usually acommanied by 
coarseness of build in the cow. They are seldom found on well-bred aninals, yet cxceptionally they occur, and are nuch liked. $\Lambda$ tent should be large enough to gra:ip, sily from two to two and a half inches in length. A shorte; one nould bo an objection; rith larger, I siould feuz courseness.

\section{Color and Carriago.}

"In eolor the Ayrshires vary giently. Brown, red, and wiste appenrs to good alvantage, and is fashionable. $\Lambda$ good quantity of white, well distributed, adds style and showiness to the anin!l. Yollow and white is frequently secn, yet while this color is sometimen stated $\mathbf{s}$ indioating lack of lundiness, I am not aware of any proofs of argunent having been brought forward to support this view. Color is as yet a mitter of taste, for its correlations are hardly ruessed at; and from anost pli:o black, through tho reas to almost pare white, are colors found on tho best cows. Black spots on the skin, barcly perceptible tirough the ha: often oceur on tho best enttle. Strawberry-blotehed and red and whito are perhaps the moro common coloris. $\Lambda$ self-colored aimal, or a roun,

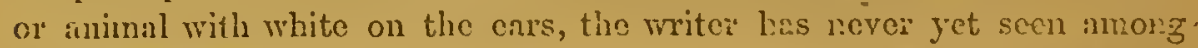
the Ayrshires in Scothand or in this exuntry, when tho podirrec was. unquestionable.

"The curringe shonld be light and active, the head well up), and tho hind legs should not cross in wallsing. The eondition should lo neitlier fit nor lesn, but that average which a good cow holds vhou in good Uesh at calving, liberally fed while in milk."

\section{IIolstcin Cattlo.}

Dutch cattlo rere undoubtedily among the first cattle erer brouglit to America. Canada was risited by the Ficnch in 1808 , when they founded Quebec. Soon after eolonists arrived and brought vit! them the litto Normandy cattle. The English first settled $0: 2$ tho Janes rirer, i: Virginia, in 1607, and New York wis settled by the Dutch in 101:. In 1625 the first eatte were imported from the nother count:y, and they wero undoubtedly tho Duteh eows roted for milk, or a race rewrly allied to what are now generully recognized as Holsteins. That th:s si?pijositioz is eorrect is probably true, since theso cattle were considered valushlo for milk and labor. It wonld natumaly follow that these two guslities sland he considered of prime importance by the practical Dntch set.lem, in a country where game in abundanco might bo had by all who hners hov properiy to aim a grm. Rearing cuttle for the salic of meat would be to acondary consideration there. 


\section{History of Holsteins.}

In the adaption of breeds to special purposes we must always bear in mind that feed, climate, care, and eareful breeding must be taker into eonsideration. Thus for the most exeellent dairy eattle, we must look to countries noted for dairy produets. In sueb distriets will always be found tolerably uniform and exeellent milkers. Renlly seientitio breeding has not been praticed until within a very fow years. It was more experiment than anything else. Yet so long ago as 1625, England, Holland and Switzerland were noted for dairy produets, and also for breeds of deep and lasting milkers. As education inereased, and wealth became more general, improvement by seleetion was supplemented by a careful study of certain points and eharacteristies that might be expected to perpetuate themselves. Thus wo now havo the Jerseys, the Ayrshires, the Swiss eattle, and Holsteins, eneh speeially adipted to the soil and requirements of their respectivo loealities. The Holstein eattle, or thoso of North Holland, aro noted for largo frames; for being of two distinet colors, blaek and whito mixed. They belong to the great sliort-liorned division of eattle, which raee, from the best aceounts extant, would seem to have been peeuliar to the transient inhabitants of Germany from time immemorial, and to havo been carried with them in all their migrations.

The size, adaptation to distriets yiclding strong, plentiful herbage, and extriordinary milking qualities, have made them universal fuvorites in the West, and whererer introdueed in all that great eomntry of tho Northwest that of late yenrs has so suddenly beeome celehrated for its dairy products. Within the last eentury this breed, like all other puro breeds, has been wonderfully improved by the astute and practical Hollanders, so that it may now be called as distinetly a breed as any other of the more reputable families. Like the Durhan and Teeswater eattle of a hundred years agro, they were then uoted for a fair uniformity in appearanee, and as deep milkers, good at the yoke, and as making heavy weights of fair beef when ready for fattening. The general characteristies of these two breeds would seem to point eonelusively to the faet that originally they had a common ancestry in eattle belonging to the ancient raees inhabiting the north of Europe, and that they were carried wherever these people, in their wanderings, migrated.

\section{Improvement.}

We have no definite knowledge when this wonderfully constitnted short-horned race of eattlo first beeamo broken up into the various families that have of late years beconc celebrated both as dairy eattle and as becf eattlo. It is probably within the last three centuries that 
cystematic attempts have been made to breed them with a riew to their careful improvement and toward fixing their charaeteristics - in Lingland with the Durhanns, now known ns Short-Horns, and in Holland with tho Dutch cattle, now known in the West through the importation of tho Holsteins, from the fact that in this district morc eare seems to liave been taken to breed their cattle, not only to type, but also in line as dairy cattle. It takes long generations of such breeding to fix undeviatingly peculinr traits and characteristies, so they may be transmitted with grent fixity to the resulting progeny. The Holsteins of the present century have presented uniformity, and to-day they may be called as persistent in the transmission of quality as the other grent fannilies of the genus Bos in any eountry.

These have superior exeollenee in their milking qualities. They are duiry cows noted for giving cnormous quantities of fairly rich milk. They have massive compact frames, and make good beef; as working oxen, from their strength, docility, patience, and fairly active habits, they should make exeellent workers. The horus of the Holsteins are short. 'The hair short, soft, and fine. The lides are of moderate thickness, of grood texture-that is, mellow. The color should be always black and white, eitler in bands, or else pies, mottled or spotted over the body. The udders of the cows are capacious, of great hreadtl aud depth. The teats we!l shaped and standing well apurt. The nilk-veins promineut, lurge, and running well forward.

\section{Ioistcins in $\Delta$ merica.}

A.s we previously stated, the old Dutch setters of New Iork lrought over with them this vil uable breed of cattle. 'They lave, however, become sutirely lost, except that they have left their inpioss in resulting generia tions of mixed blood.

Since the tine noted, there probably were none imported nutil the present century. In the enty part of the century, at the time of the inportation of Merino shecp, by Mr. William Jarvis, of Vermont, in one of lis royages he brought orer a bull and tro cows. They remained on has farm for some years; the bull was lred to the eommon stock of t.10 coune try, producing a decided impress, but at the end of a fow yeurs the puro blood wils lost.

It is recorded, that, somewhere betreen 1820 and 1825, Mr. Herman Te Roy, a public spiritod merchant of New Tork city, imported some improved Duteh cattlo which were sent to his farm near tlec city. Between 1827 and 1829 , sone of the produce of this herd were sent to the farm of his son, Ldward Le Fioy, on the Geuesee river. Mr. L. F. Alleu do- 
seribes this herd in 1833, as he then saw them, as being large, well-spread cattle, black and white in eolor, and remarkable for their uncommon yield of milk, and of great value as dairy animals; their qualitics in that liuo were universally acknowledged wherever known.

\section{About Dutch Cattlo Gencrally.}

In treating of Dutch eattle we have adopted the name IJolvein, and for the rewson that in the West ecrtainly the importers secm to have fincied the cattle found in Holstein, and to have inported more langely of then than any other of the Dutch eattle. 'That the right namo for all thos finnilies of ancient lineage, bred in North-IJolland, and recognized as having been for many generations great milkers and ais naking heavy beef eattle, of grood quility, when dry, should be Dutel cattle, theie is, from the testimony, little doubt. So also it would secin that the IIo!stein catto are a sub-race of the older Duteh, as the following letter from Prof. J. G. Hengweld, of the Netherlands Royal Veteriniry Instituic, to MIr. Charles Muller, United States Consul at Amsterdam, would secm to show. This is dated Utrecht, November, 1872, and pullished in tho licpoit of the - on Dutch Cattle in Agriculture of Massachusetts, second series, 1873-74. From it we cxtract as follows :

Quoting from Loiv's Agricultural Ilistory of the ioneatic Europen Animals, cte., he says: "In comparing these varieties of cattle to the breeds of the Continent, there is an amalogy found on the one side between the great breeders of the minshes and the black eattle, natives of tho plains and marshes of Holland ; and on the other, between the more various kinds on the north of the Humber and those of Holstein and Jutland, whence the best eattle of Northern Emrope have sprung." It is not unreasonable to suppose, that these latter breeds may have been introdnecl Gun:!ng the first period of Sixon colvnization by the jutes and Angles, who ecttled down in that part of England. But at a more approximate period to us, it appears that cattle were frequently imported from the neighboring continent, and that they were mixed with native breeds.

It was especially the Dutch cows that were considered the best mile' Einds of Northerm Europe.

There is hero a very clear and evident differenec made between the excellent Dutch eattle and the Holstein and Jutland breeds whose origin Low traces to a Sixon eolonization. How $\mathrm{L}_{4}(\mathrm{w}$, a few lines further on, ean make the Dutch cattle derive their origin from the Holstein eattle -from which lines the 'herd book' draws its inference (tho same ocenrs in the French version, 'whenee the best Duteh raees themselves originate') is incomprebensiblo; and it is evident Low errs, or is not sufticiently ao. 
quainted with the history of both countries. For aircady seren centuries before the colonization in England, of the Jutes and $\Lambda$ ngles, the Friesians [Hollanders] were kinown for the greater number of their cattle, as will further appear.

Every Spring, thousands of Ifolstem heriers are driven to the fields of Northern Germany and Holland, where people find it is more profitible to huy heifers thin to raise them; and the name of the breed got confused, so that the name "Holland cow," was here translated into "Dutch cow," otc.

\section{About Herd Books.}

The "herd-book" takes the unwarrunted liberty, whenever it should speak of Dutch eattle, of addiug immediately after, the word " Holstein." It gives to Holstein cattle purchased in North Holland-and of which the first importation took plize in Massachusetts in 1852, afterward in 1857, ete., but the greatest in 1861-all the honor the Duteh eattle so abundantly deserve, and appears to have mado the geographical blunder of supposing Nortl IIolland, Friesland, Groningen and Oldenburcr as belonging to Holstein.

The thesis so arbitrarily adopted and set forth by the "herd-book," , that the large black and white eattle imported into North America from the Netherland provinees of North Holland and Friesland have "undoubtedly desecnded from the original stock of Holstein," as it proclaims on page 9 , requires a most decided denial and refutation for the honor and reputation of Duteh eattle; and, witlout being led astray by the most strangely jumbled-np references mentioned, I wish to point out, -

\section{True History.}

1st. That the history of the Dutch or Holland eattle dates further back than that of IIolstein.

2nd. That the Holstein cattle descended from tho Duteh; and

3rd. "That the name of "Holstein eattle" is only a local appellation for a peculiar indigenous brecd, constituting only ouo of sereral appertaining to the sanc group, namely, to tho groups of the Lowlund raees, of which the Dutch breed is the fundamental type. To this I now proceed.

Aceording to the "Allgemeine Deutsche Real Encyclopedia," the origin of Holstein Schleswyck lies buried in obseurity, and Holstein was probably visited by the Cimbri; whilo a century after, the Romin Emperor, Cesar Tiberius, arrived with his army and flect before tho mouth of the Elbe, without, however, sctting foot on the Holstcin shore. According to Tacitus, it may be stated, that the Holstein Baltic coast was 
inhalited, as far as Mecklenburg and Schleswyck, by seven petty Germin tribes, of whom the Angles and Warnes have preserved their lumes down to the present time; while the others lave been melted down into that of the Saxoms. In the fifth century, the Saxons and Angles united with the Jutes and Friesians, and migrated to England. (This is Low's colonization.) Sulsequently, the Holstein Sixons, who dwelt to tiro north of the Elbe, were called by the name of Normans; while the namo of Holstein is not mentioned in history before eight hundred yeurs after Christ. In 1128-64, the Iolstein province Uagrien was conquered and converted to Christianity, and pantly peopled with strange colonists from Friesland, Holland and Westphalin.

It appears that, with regard to its fitness as a grazing and cattle-breeding country, Holstein is of lator date than Holland; which fict will appear the more prominent afte: some account has been made of the oldcst inlabitants of Ifolland and their pursuits.

\section{What History Says.}

For this purpose I at once direct the attention of the reader to tho coming of the Friesians and Batavians. The former were the oldest inhabitants of Iolland, and were known as herdsmen, hunters and fishermen. Their history in this country goes as far back as 300 years before Christ. The Batavians came $200 \mathrm{y}$ cars later (100 years before Christ) donu the In!hine; and, although they were likewise herdsmen, they oecu-• pied themselves more particulinly with hunting and fishing.

The lands of the Friesians comprised the whole country to the rorth of the Rhine as fur as the shore of the North Sea, to which West and Wist Friesland leclonged, composing the present Dutch provinees of Groningen, Firicsland, Lreuthe, and North Iolland, besides the provinees of Utrecht, Overyssell, and a part of Gulderland and South Hollond. Of all theso provinces, Groningen alone appertained to List Friesland.

Tacitus says of the Friesians and Batavians: "They owned cattle, nos cxcelling in beaty, but in number." Ile furtler states, as does also Julius Ciesar, that the Friesians and Batavians paid each other in cows, shecp and goats, and fore likewise to their children as dowry, oxen adapted to the joke and plough, cattle and horses. When they were sublucd by the Romans in the first century of our era, the conquero:3 del ived much advantage from this wealth in cattle, and imposed upon the Fricsians an annual tribute, consisting of cow-hides and meat; while they chose their most valicnt warriors from among the Batavians.

The Friesians and Batavians applied themselves to the draining of their carsliy lands and their islands, created meadows on the reciamed scil, 
r.bich they first protected against inundations by raising liils, breakers and dikes, of which the truees are everywhere discernible along the const throughont West friesland and Groningen. Something is cren known regarding the color of their cattle, numely, thit they held those of a whito color in religious veneration. It is a very plausible theory that the Friesians, who, at as early a date as three hundred years before Christ, peopled the north of the present Netherlunds, and wrought those alluvial plaine of Scandinavin clay into soil fit for the requirement of their cattle, did, in after-centuries, spread themselves in more northerly and casterly directions as far as the Elhe-as we already lnow they did, in the fifth century, unite with the Jutes and Anglo-Saxons in cmigratingto England; in nddition to which, we must observe that these vere probubly Last Friesians and not West Friesians.

The Friesians, fiom Oldenburg and the country nerr the mouth of tho Elbe, both south and nortl of that river, were compelled, through tho inclemency of those regions-then in their original condition of low alluvial swamps, inmolated at every tide-to desert them. It was owing to 1.hese locil circumstances that the Romins were prerented from endeavoring to land their nimy.

It cin be shown that the inlabitants of this territory were unable to malie sure prorision for their own wants berause of the robberies and piracies committed by the Normans, dweller's on the rest coast of Denmark, people from Holstein and Schleswyer, Jutes and Angles. 'ihese were by no means peaceful breeders of eattle, as were tl:e Friesians and Batarians, whose lands they constantly plundered and laid waste, bun'ning and raringing their possessions, massicring the inhabitants, making them pay tribute, penetrating fur inlend to the months of the Rhine and Yssel, and crerywhere griving unbridled vent to their ferocity and lore of plunder. This was between the eighth and cleventh centuries. Giving due neight to these statements, which, from the nature of the case must be recessurily brief, it cammot be doubted that the cultivition of eattle in the Netherlands existed a long time before such a thing could be thought of in Holstein. It is also quite as certain that the colonies from Friestand, Holland and Westphali:, carried with them their cattic into Holstein. Their wealtb largely consister in their licids.

Hence we see that, first, the Ditteh race of eattle date from an oider descent than those of Hoistein; while, probubly, second, the Holstcin enttle origninated from the Friesian breed and from that of the Duteh and Westphalinin emigrunts.

After this colonization, we have onr attention directed to another remarkable particular ia t!e rapidly aciva::cing history of tide Dutch cattlo c:altirntivo. 


\section{Regular Irarlets Established.}

From the fontcenth on till the eightecuth century, a lange number of Dinish oxen were anumlly turned for pastune into the grassy meadows of North Ilo!land-formerly Wost Friesland, and sold at the weokly Nonth Iolland cattle market. The oldest of these cattle nutrkets is that of the city of Hoorn. This minket was alleady estallished in 1311, and in 1839 the Danes and: the inhabitants of the Ejeler were allowed by Alhreeht, duke of liavaria, to hold a weekly market there. In 1605, tho D:mish cattle mirket was remored from Hoom and trasisfered to Enkluyzen, when, in 1624 , the number of 1,179 oxen were sold. There was also in Amsterdam a lean-("attle minket, begimning in the Spring, in the month of $A_{\text {pril }}$, but held at irregular periods, depending upon wind and weather, when cattlo were allowed to be conveyed from Demmakk and IIolstein hither to gruze. These were mostly hrought by ressel. Mre: Ilengereld says :

"These impontations of Dinish and Holstrili cattle into North IIolland, to which the herd-book' might refer, did not consist of 'heifers' but of lean oxen, which were pastured on the fertile mendows of the l'olders, and afterwards sold at the linarkets of Hoom, Enkhuyzen and Ansterdina as fat cuttle. As to heifers, rither then or now, having been imported from Holstein into frinstand : nd Forth Holland for the purpose of breed. ing, mo such thingr is known."

To withhold nothing; and to put nothing in a distorted light, I may add, that in the midile of the 1 sth century several importations took place into Iriestand of $D_{i}$ inish cattle, consisting of roung calves. This was at the tince of the ranger of the cittlo-plague, which desolating disease carried off thousinds of the finest cattle in Fricsland and Irolland.

For the purpose of leepring the cattle tade alive, and to fill the places of those destroyed by the julngue, small Danish breeds and German cows of diminutive size were substituted and crossed with the remaining and recovered natives.

"They were," says Scholtma, "Dinlisll, Holstcin and small Gorman cows, of whi-h the grenter part wore smaller in size than the nitive race." In the same work we find, "that one was redneed to the necessity, in 1769, of purchasing the needful cattle in the county of Iontheim, in the district of Oldenburg and Munster, in Minover and other parts of Giermany."

In the work, "Present State of Frieslind," it is mentioned that, "owing to the cattle-plague, the people were compelled to irport from abroad all kinds of small cattr, chicfly Dinish. But, what was remarkable, borrever small and ill-favored these animals might be, when com- 
CATTLE, IOLSTEIN3.

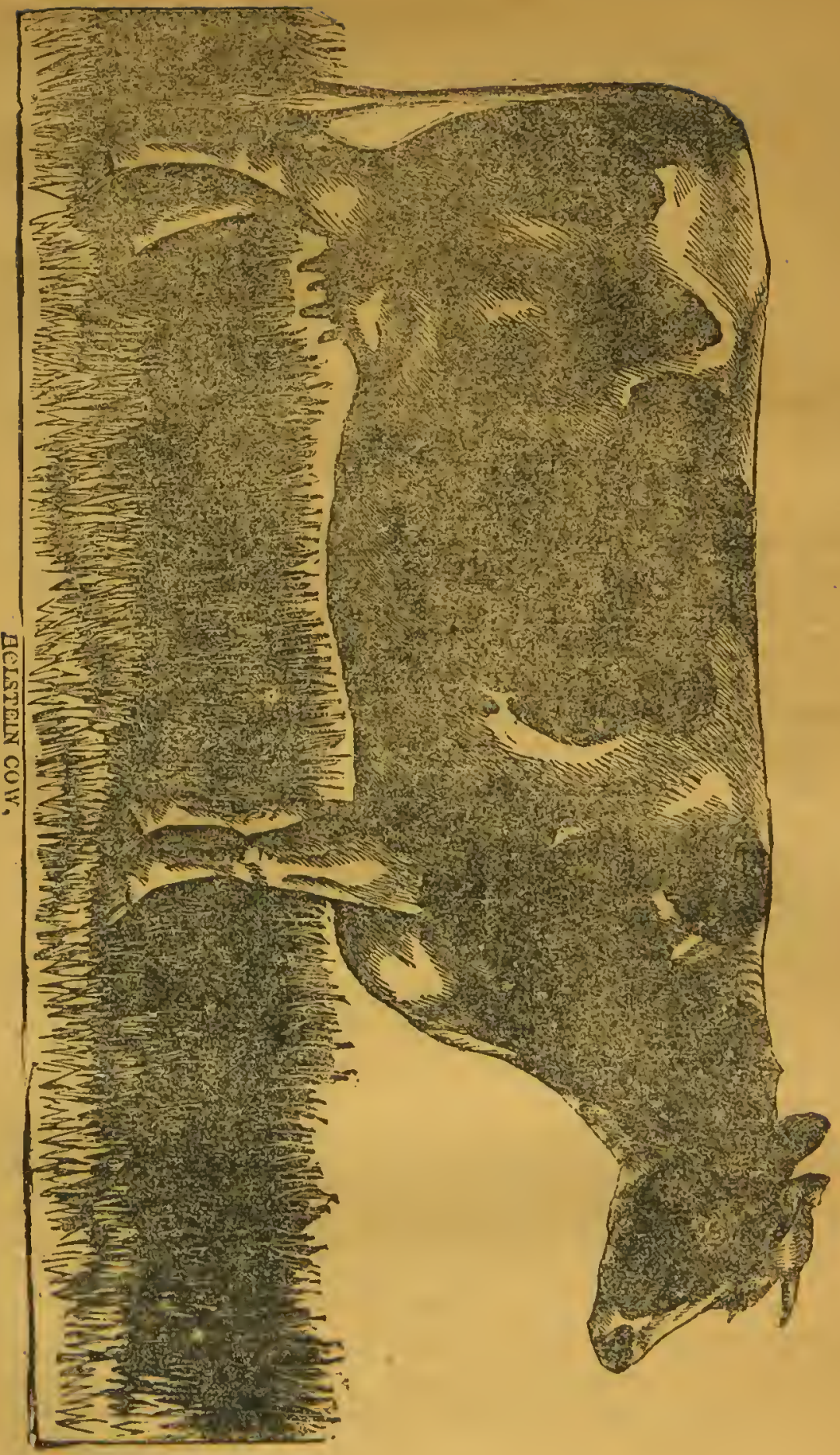


pared with the liandsome Friesian horned eattle, as a natural consequenee, an improvement of food induced a favorable developlulent of body, and, from the mixture of the two breeds, good and choice milch-kine were attained within two or three generations of the introduction of the foreign blood, no nutter how much the race had in the beginning deterioruted through the process, and, eventually, the type of Danish alid German cattle was quite lost." This is, however, already one hundred year's ago.

A fair consideration of what has been thus far stated will leare no justifieation of the "berd-book's" imputation upon the antiquity and purity of deseent of our Friesian or Dutch cattle; or its assumption that they are of Holstein origin. No; the genealogy of Netherland eattle is pure and unadulterated, and it is at least two thousand years old.

\section{Facts as to Dutch Cattlo.}

Our authority continues as follows :

"I come now to the present time, and the question whether it is tenablo to give to one variety of eattle the name of an entire group, and to reckon as appertaining to it all its several varieties or breeds, - as, for instance, the Dutch, Friesian, Oldenburg, Holstein, ete.,-and wonld it not be imperative in sueh a ease to give it the purely historical name by which it is generally known? If it eould be desirable to give a general name to the cattle of the just mentioned districts, then that of Holstein cattle would not be appropriate, and for it should be substituted that of Iriesian cattle, whence all the varictios origiuated.

"The chief characteristies of this Friesian breed-its eminent milkgiving and futtening qualities - we find in all the just nnentioned districts, and extending still further southward; with this difference, however, that wherever the land is more fertile, the climate milder, and the tending, seeding and biecling of the cattle obscrved with nore eare, in that measure, and according as these requisites stand to ench other in tho closest proportion and harmony, they aro moro developed, attain larger. size and are of a finer texture.

"If the intention be to convey a eorreet understanding of the true qualities of the several varieties or breeds mentioned in their own dwelling places, it is better that each breed should retain the mane by which it is known, and tlat no collective name, though a listorical one, should bo given them.

"In order to be able to readily classify a group of cattic of great extent, possessing the sane clief qualities in form and productiveness, Sturn* proposed, so long as fifty years ago, to give to a group, subject

Dr. Sturm: "Of Race, Crossing and Improvement of Indigenous Domestic Auimals" " Clbertield. 182\%. 


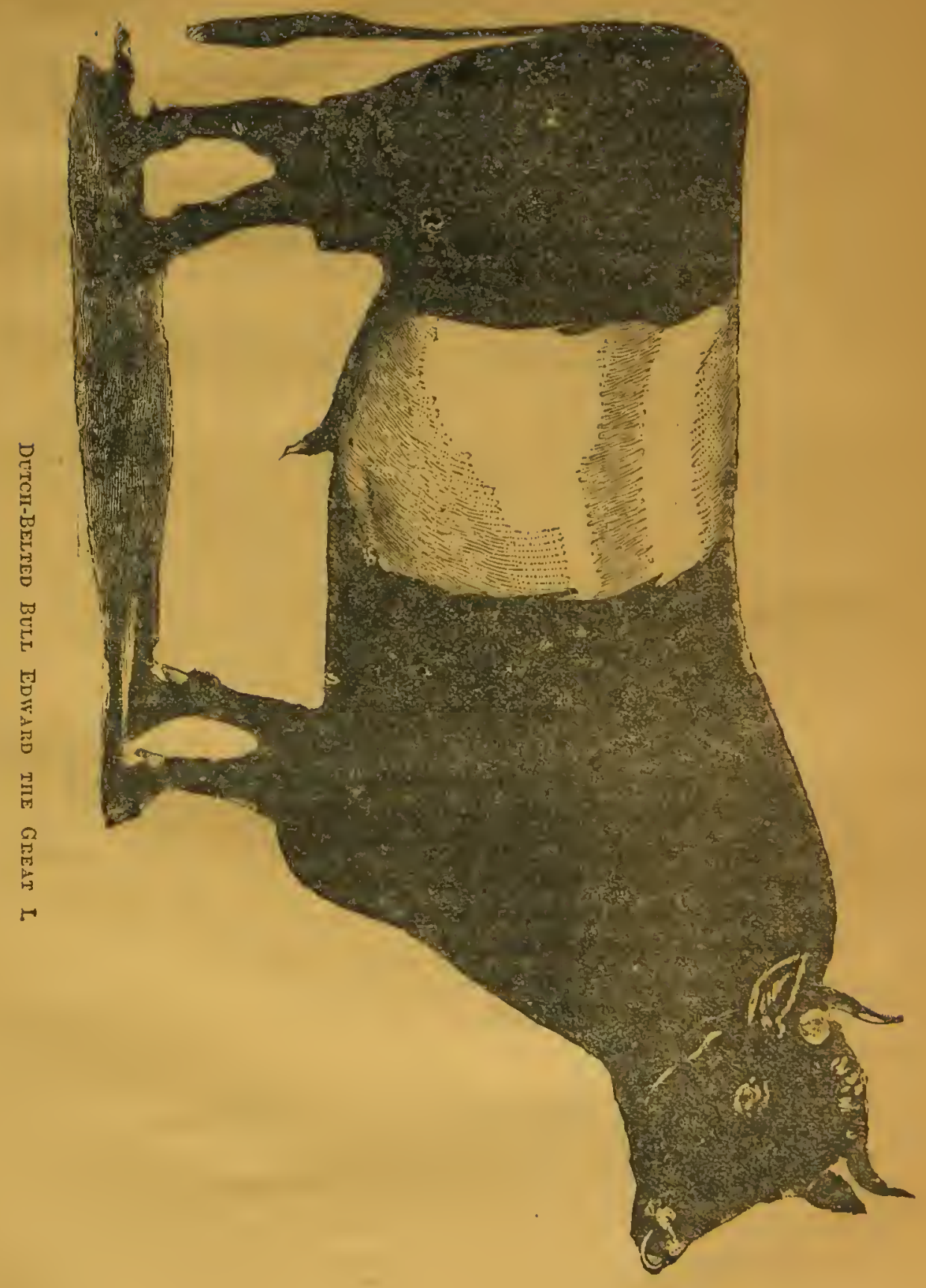


to the same conditions of soil and clinats, a name indicnting thoso conditions, and thus originated Mountain Cattle, Highland Catile, and Lowland Cattlc. II also heads cach of these divisions ly tho lneed best representing the distinctive fature of its class, cis its type It is under the denomination of Lowland Cattle that he places the difierent, breeds of the coast lands along the North Sea. Schmalz, Palst, and many subsequent witers, adopt this classification; some wilh a fer modificutions, but all in the plysical chancteristics of the country to which they are indigenous, the general denomination of the collectivo group, aceording to Sclminlz's statement, eattle, ndoptiner Sturw'is clussicication, maly bo distinguished in the following munnc: :

\section{Races cr Dutcı Cattle.}

"A. Inwland Race._Prinitive enw; Datch-Tiriesin: con.

“ B. Mountrin Race.-Degenerate, quite the contr:ay of $\Lambda$; Swiss cow.

“C. Middle Race.-Highland race; forms tho tr:usitio: fion $\Lambda$ to B; Irankish cow.

"Schmilz says, "To the race A belong tìe Dusch, cis representativen, the Fricsian, the Oldenburg, and chichy all Lowlusd races beaning tho peculiar characteristics which identify it with the place of its sojoum.'

"This is a purely natural division, and there is not the least arrogarco in asserting, what history points ont, that tl:e Dutch cattle constitute tl:o aye of tho oldest, purest, and best lreed. All other varicies are of less intrinsic value; they are conser or sinaller, possess less productiro rualitics, though of local excellenee in their nutive placar. "If cattle of ine genuine breed are bought, imported clsewhers, and there bred, sulwy is it not called by ils native name, and why must an appellation be given to "t quite foreigir am, unknown to it?"

"One henls in linrope of 'Lowland eattle,' lunt purehuses of then for the purpese of inproving other breeds have, for the list hundred ye:us, heci only made n!1 the chicf Netherland provinees, whero the cliosecst cattle of the Lowlands sre fomd. Thus, thonsands of Dutch and Friesiun cattle aro anulu:lly sout ab:on? uuder the n:me of Dutch catle."

\section{D:. Gzorga RTay's TestimonJ.}

Finally, I heg to sdd quotstinas from Dr. Geo*ge Mary, director of the agricutiral estal)lishment at Weihenstenhail, who visited Holland shout ten yeils ago.

"Tho Duteh cattle constitute the type of the proparly se-culled Iswland

ODr. Genrgo May: "Tho Calule." MLusich. 1863. Vol. III., 1. s3. 
race, whic'. extends throughout Netherlands. Flanders, Normandy, Oldenlsulge, and Demmok. The Oldenlurg cattle descended from tho Dutch race, and are likwise distinguished as Eals Friesin cattle, as still

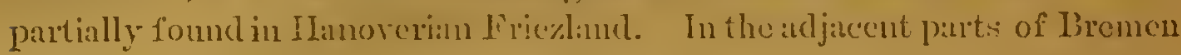

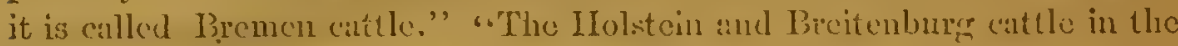
Wilster and Rempuer marlicts are edpul to ***; but vith respect to their squme build, the Breitenburgr cattle are in their properties moro like tho finer Dutch cattle.",

Other miters of repule m:ly le quoted, lut chough las been given to Ehow that the name of "IIolstem" is only a locil, and not a collective name, and maly not he given to cittle hought in Noith Ifolland. To do so is to underrate the Dutch eattle rice.

\section{Mr. Klippart's Testimony.}

In relation to the native eattle of IIolstein, the limented Inlipunt in his Ohio Agricultural Report of 1865 , says:

"The native cattle of IInlstein are the Angle eattle, which are fin moro numerous than any other lind or lace. They arc small animils, with fine bones, short legeged rather thin otherwiso; a very finc, small hoad, and delicately formed neck. 'The predominating eolor is red or brown, but there are many dum, black, or spotted ones. According to the amoun: of food ensumed, this race grive a mole abondant suply of milk than any other in the duchies. It is a rery highly cstecmed race-is mueh sought after for its milking qunlities and lindliness in taking on flesh. The flesh is rery fine, fender and juicy. On account of the rreat demind for stock of this riec, eattlo dealess live not unfrequently gone into Jutland and ofler points, and nurle purehases, which they represented as

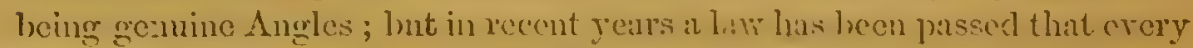
breeder of Angle stock must hind the culves with the letters $\Lambda$. R. (Angle Race, ) in oriler to prerent impositious.

"In these marshes are found a lance of eattle much larerer and heavice than the Angles, larwer bourd, and of a dink, reddist liown, and linown as the Marsh race. This rare secms to he arlapited to the marshes, but does not do well on the ligher and dryer mplands. Upon the rich pastures of tho mashes, for a timo after ealving, the best cows will givo from forty-cight to sixiy-fonr pounds, (from six to ciglat gallons), of milk daily. But tho milk is not near so rich as that of the Angles;-in fact, I was shown a statement, appanently welt autlienticated, to tho efiect that milk of the Minsish race contained no more than two per cent. of eream, while that of the Angle raee entained sirteen per cent. Ono thing is very certain, n:uncly: the hutter of the Marsh ruec is not near so sweet or ' nutty' as that of tho Anglo raco. 
"Iu Sehleswig, lather than in Iolsicin, are found many of the Juthand race of eattle. These have rery finc bones, and are long in proportion to their height, and anc, as a rule, short-leggred. The prevailing color is gray, black, or gray and black mixed with white, but rery rarely r'ed or brown. This race is more lighly estecmed for its carly. maturity and gnadiness to futten tlian for its milling qualities."

In the trinsuction of the Ohio Board of Agriculture, 1872, in an articlo on Duteh cattle, by Professor Furstenbure, we find the following: "The hreeds of eattle in Holland may be c.vidrd according to their locality as follows: 1. The bireeds in the provinees North and South IIolland and West Friesland, 2. The breeds in the provinees Groningen, Guelderland, Utrecht, and Overyssel. 3. The breeds in the provinees of Secland. Althougli these breeds are closely related, still they show difference result. ing from kecping and the various purposes for which they are bred.

\section{Breods in tho Provinces North and South Folland and West Friesland.}

"The breed most renowned in the kingdom for its milk-producmy trualities is found in these three provinees. But North IIvlland in particular is noted for the manner of kecping eattle, which are known by the namo of Amsterdun race, being no less renarkible on account of size than for the great production of milk. The pastures of North Holland are said to contain 100,000 morgen (158-100 morgen to an acre); every are furnislies nourishment for 49-100 head of cattle. 'The poasants are engaged almost sololy in cattle lreeding, and the liecping and care which these animals receive here has almost become proverbial on aceount of its perfection.

"Tilic cattle here are mostiy spotted hlack and white; however, brown and blue or gray mixed are found. The leight is considerable, being not under two Amsterdam clls ( $451-100$ feet) ; the length of the body in preportion to the height, the middle part of which is particularly developed, the quarters fleshy, neck rather short than long, with a strong dewlap; head narrow and long, with the foreliead sliglitly depressed; fine hoinz crooked forward, and large projecting ears. The witlers are often narrow ; tothe back, on the other hand, broad aeross the hips, which are not rery prominent; the tail fine and long, with a good tuft of hair; the position of the lind legs strong and straight (not knock-kneed), the hind-quarter:3 broad and roomy, and the bag well developed. The lower part of tho legs alove the hoofs is invirialbly white, which is regurded as a sign of the pure umnixed hreed. The live weight of the cows is 1,200 to 1,400 pounds; that of bulls reaches 2,000 pounds when full grown and fatted. The cows are unusually productive of milk. and give an average of 3,000 quarts and over per annum. 
36 A very excellent milch cow of the "Amsterdam race, from t,oc royal cow stable in Eldcia, which was brought with a few others to tho Iutcrnational Exhibition, took the Crst premium for milch cois of tho Nethorland race at the International Exhibition of lire stock at Stctin in 1865. This cow, fed in the stall only, gave in one year tho great quantity of 6,142 quarts of milk, and lsept up afterwards to 4,000 courts in :m equal leugtl of time.

"To the breed of North Holland are nearly related those of South Eolland and West Friesland, and differ perhaps only in that the latter are larger boned, and in general of not so pleasing a form. In regard to their milk-prodncing qualities they are about equal. The riduze of keeping the stock, and tho use of the milk, is also tho sume, in.: the manfacture of cheese, while the calves are raised and sold sis young stock at high prices. From these three provinces, tho formes two of which suffered so much lately from rinderpest, milch cows are bought for the best dairies in Germuny.

"Holland cattle are well adupted to soiling, although at hume they aro accustomed to pasturage. They are kept profitably on the latter only when its abundance facilitates grazing and inalkes corporul cxertion unnecessary. Therefore a great error would be made in placing these animals on a scant pasturage, and they are not at atl adapted to the pasturage of a light soil. The result of stall-fecding is moro favorable, because proper eale and fodder can be given the stock without its cxertion. Vo havo received from no other ruce an equal quanfity of milk with the samo feed, as years of observation in the cow stable of tho Academy at Eldena has showil.

"Three years ago (in 1865), differcnt races were kept here, viz. : milch cows of Toudern and Breitenburg, in Schleswig-Holstein, of Ayrshire, in Scotland, and of Holland.

\section{Yields of Mrilk.}

- The yicld of mille this year of these races was :

“1. Four Tondern cows gave 9,337 quarts, or an arerage of 2,334 quarts, or 6 3-10 quarts per daly for the year. The largest millier grive 2.345 quarts, thic smallest 2,020 quarts.

“2. Three Breitenburg cows gave 8,594 quarts, or an average of 2,864 2-3 quarts, or $785-100$ quarts per day for tho year. The largest milker gave 2,946 quarts, the smailest 2,820 quarts.

“3. Threc Ayrshire cows gave 5,386 quarts, or an arerage of 1,79:3 1-3 quarts, or 4 92-100 quarts per day for the year. The largest millicr gare $\mathbf{2}, 249$ quarts, the smallest 1,415 quarts. 

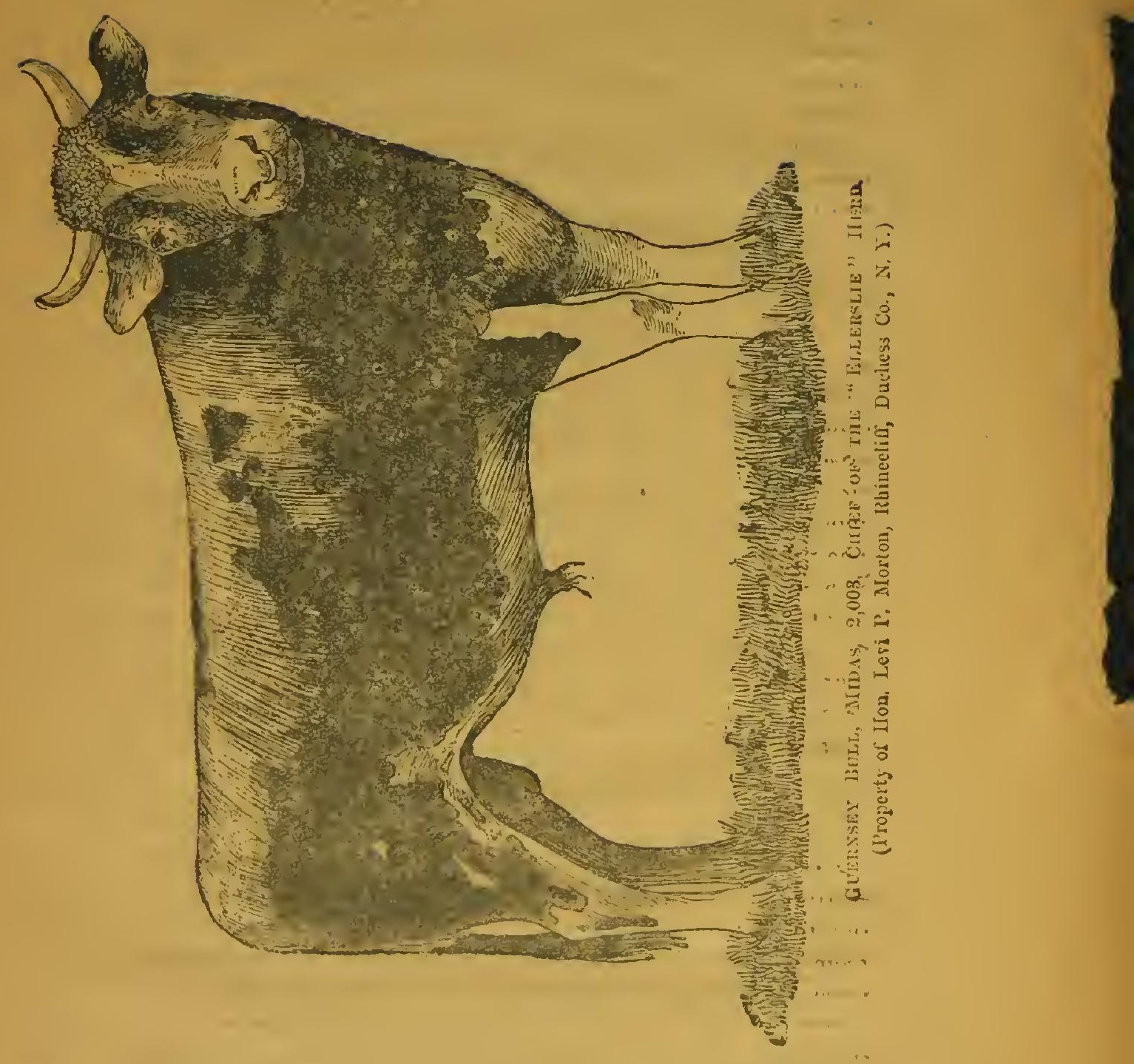
"Twenty-two Elolland cows gave 78,100 quarts, or an averago of 3,550 quarts, or $973-100$ quarts per day for the year. 'The largest millier gave 6,142 quarts, the smallest 2,526 quarts.

"The averuge feed per head in the Winter was daily-10 pounds Summer straw, cut fine: $21-2$ pounds oat and wheat cliff; 25 pounds beets; 10 pounds hay; 8 pounds refuse malt from beer brewery; 3 pounds ryo bran. This food is considered about equal to $429-10$; pounds lay.

"During the Summer the cows werc fed daily per" head 135 pounds' green fodder, viz., elover and vetches (of the lattcr very littlo was used), and three times a day 8 pounds of hay."

\section{Feeding Qualities.}

"Although there is no doubt that tho Holland cows cat more, generally, than the smaller Ayrshire and Toudern (for the fodder wis not weighed out for each animal separately), this is of minor importance in comparison with the greater amount of milk given by the former. Tho greater amount of fecd consumed by the Holland cows can be estimatcd, viz.: Nine of them stood at one crib, while ten of tho smaller stood at another of equal size; the fodder was, however, divided the sume in each. The proportion is as nine to ten, or when tho sniller cows eat 45 pounds of hay, the lirger oncs eat 50 pounds.

"From the quantity of milk given, the Holland cows used a trifle over 5 pounds weight of hay to produce ono quart of milk; Breitenburg used 6 25-100 pounds of hay; Toudern 7 pounds of hay; Ayrshire 9 pounds of hay. By these results it camot remain doubtful which race is preferable."

\section{Early Importations Ietainod Puro.}

"Le Roy, father and son, should not have allowed their herd to become scattered and lost as a pure breed, when they subsequently turned attention to the breeding of Short-Horns. That this was the fact is cvident from the record, that at the sale of the farms of these gentlemen, afterward, none but grades were found in tho herd or in the adjacent country.

"The first importation of animals that have been retained pure, wero those of Mr. W. C. Chenery, near Boston, in 1861. This was a bull and four cows, which were successfully bred and kept pure. Mr. Chenery, previous to that time, in 1852, imported a single cow; in 1857 he mado importations of a bull and two cows, and in 1859 a furtler importation of four more cows. With this latter importation he was so unfortumnte as on import pleuro-pneurnonia. The ravages of this dread disease extended 
to the entire brecd, and with the exception of a single young bull they were entirely destroyed. In $1861 \mathrm{Mr}$. Chenery made another importation of a bull and four cors, which came over sound. These and their desecudants were the only pure brod herd in Ameriea for years. That they Were the best representatives of their breed is certuin from tho fuct that they were selected with eare from the best dairy herds of North Holland, anc. were so certified to by the official authorities of the districts where thry were bred."

\section{Holsteing as Milkers.}

As being interesting history and also as a means of comparison with their descendants aud also with later importations, we rive some interest ing dutu :

The four year old bull girted 7 feet 10 inches. Iis lengtl was 8 feet 7 inches; height 4 feet 11 inches, and his weight was 2,465 pounds. His colol: was jet black and elear white, the white being confined to the forehead, with a large patch on the withers and top of the rump; the limbs, brisket, belly, and finks being also white.

In relation to yjeld and quality of milk, Mre. Allen says:

"The four imported cows, each seven years old, have an average weight of 1,325 pounds. The weight of a past two-year old heifer is 1,240 pounds. A past yearling heifer weighed 960 pounds; and the weight of six calves at an averagre of cight months, reared in the usual way, without forcing, was an average of 576 pounds each.

"The milling qualities of the breed may be judged by the following memoranda: One of the imported eows, when six years old, dropped a calf on the 15 th of May, weighing 101 pounds; and from the 26 th of Miay to the 26 th of July, by a careful and exact record, gave 4,018 pounds 14 ounees of milk. The largest yield in any one day was 76 pounds 5 ounees (35 1-3 quarts). In ten days she gare 744 pounds 12 ounees, ol an average of 74 47-100 pounds per day. She gare a good flow of mills during the season, continuing to the 24th of Miny following, and on the sueceding day dropped twin heifer ealves, which weighed 155 pounds. The amount of cremm produced from this cow's milk, in a ressel specially prepred for measuring it, produced $2270-100$ per ecut of the milk, as tested by an accurate eximination.

"The nutritive qualities of the mille were also tested by a thorough chemical analysis, and found to be execllent. It is also rich in its cascine, or eheese-naking properties. Six dilys' mills of this cow was set for cream, and the produce was 17 pounds 14 onnees of good butter-nenly 3 pounds per day; and it is cluimed by the owuer that she is not tho very best cow of tho kerd. 
"These results show not only the remarkable produetions of the cow, but the accurate and pains-taking earo of the proprietor of the herd in testing their ability at the pail. Of what the food given to the eow was composed, we are not informed. We are to presume, however, that it was of the best, as cvery cow should have, to test to the utmost her liveteal fincultics."

\section{Weights and Mills Produets.}

The IIolstein bulls weigh from 2,000 to 3,000 pounds, and aro kind, tractable, good tempered. A half-blood Holstein steer is reeorded that weighed 1,900 pounds, and some two-year olds that averaged 1,300 pounds.

In a large number of tests that have been made with Holsteins and natives at various factories in the $W^{\top}$ est, the results reported showing as follows: Natives range from 5.000 to 8,000 per year; Holsteins, from 8,000 to $12,000 \mathrm{lbs}$. per year of milk.

In a comparison of 1 Iolstein and Ayrshires, the following is the report of three herds of $\Lambda$ yrshires, including Dr. E. L. Sturterant's herd. The Dr. gives the record as follows: General average with 13 Ayrshires for four years, 5,543 lbs. The best ycar was 1872-13 Ayrshirc cows (no heifers ), 6, $047 \mathrm{lbs}$. Mr. E. F. Miles, of Massachusetts, gives the following yield of Ayrshires: Best year's average out of five ycars was 6,292 lbs., from a dairy of 11 cows; general arerage for five years, 5,614 lbs. Mr. F. H. Apyleton, of Massachusetts, gives the following record of three Ayrshire cows for one year, average, 7,055 lbs.

It is quite safe to say that these cattle will give from 8,000 pounds up to 12,000 pounds a year. Mr. Hubble, of Onarga, Ill., gives the record of one cow, which gave 14,000 pounds in less thau one year, and another which. in 1878, gave 15,960 1-8 pounds of milk.

\section{Herd Records.}

As shorring the great value of any pure breed in the prodaction of milk. Keeping in mind always that the Jerseys give exceptionally good milk, and the $\Lambda$ yrshire and Short-Horns the next in richness, we append a list of herds for a sories of years, showing the number milked, the averngo yielded per eow and the average of all given breeds, which is tabulated on nest pagc.

As milking cows the Holsteins are wonderful, as cheesc-makers they are superior, as butter-makers they do not stand the test so well. In. fact, Holstein breoders always tcll how much milk their cows will give; the Ayrshire men, how much milk, and butter, and cheese their cows will 
AYRSHIRE IRRDS.

\begin{tabular}{|c|c|c|c|c|}
\hline $\begin{array}{l}\text { No. of } \\
\text { Years. }\end{array}$ & $\begin{array}{l}\text { No. of } \\
\text { Yiclds. }\end{array}$ & Herds. & $\begin{array}{l}\text { Average } \\
\text { per } C\end{array}$ & $\begin{array}{l}\text { Ylelu } \\
\text { ow. }\end{array}$ \\
\hline $\begin{array}{r}11 \\
5 \\
2 \\
1 \\
5 \\
3 \\
4 \\
\frac{4}{3} \\
1 \\
1\end{array}$ & $\begin{array}{r}109 \\
44 \\
16 \\
4 \\
67 \\
18 \\
38 \\
12 \\
37 \\
8\end{array}$ & 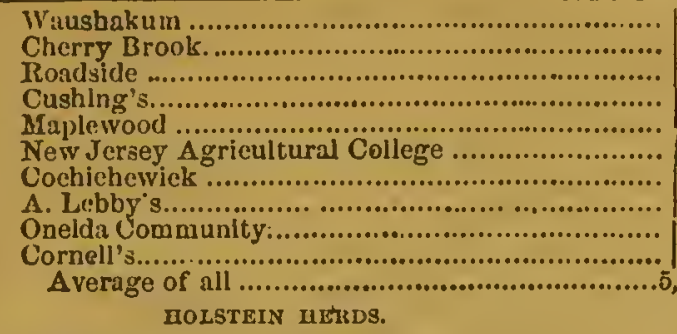 & $\begin{array}{r}5,220 \\
5.372 \\
5.334 \\
5.705 \\
5.583 \\
6.534 \\
5.671 \\
7,582 \\
5.498 \\
6,405 \\
8813.10\end{array}$ & $\begin{array}{l}\text { lbs. } \\
16 \\
16 \\
16 \\
16 \\
16 \\
16 \\
16 \\
16 \\
16\end{array}$ \\
\hline $\begin{array}{l}\mathbf{3} \\
\mathbf{1} \\
\mathbf{8}\end{array}$ & $\begin{array}{r}7 \\
5 \\
11\end{array}$ & 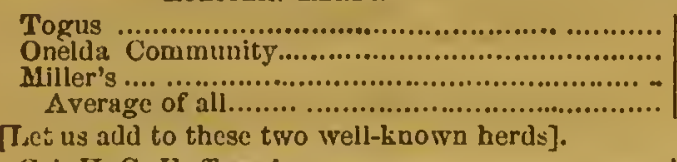 & $\begin{array}{l}5,922 \\
8,771 \\
8.590 \\
7,761\end{array}$ & $\begin{array}{l}16 \\
16 \\
16\end{array}$ \\
\hline$\frac{4}{1}$ & $\begin{array}{r}24 \\
9\end{array}$ & 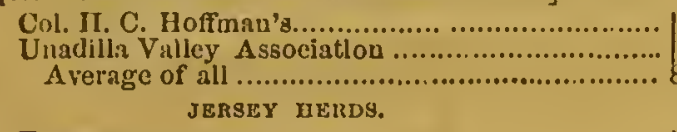 & $\begin{array}{r}9.369 \\
8.334 \\
8,8761-2\end{array}$ & "6 \\
\hline $\begin{array}{l}2 \\
3 \\
3 \\
1 \\
1 \\
1\end{array}$ & $\begin{array}{r}17 \\
8 \\
80 \\
4 \\
14\end{array}$ & 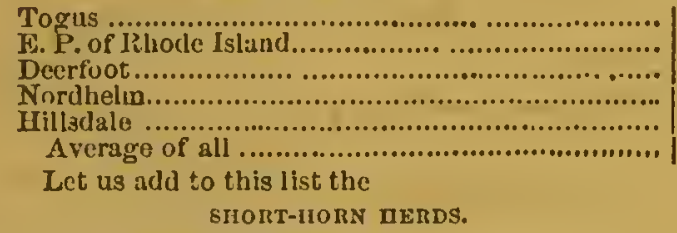 & $\begin{array}{l}4.129 \\
1.622 \\
4.658 \\
3.803 \\
4.269 \\
4,303\end{array}$ & $\begin{array}{l}\text { "6 } \\
16 \\
46 \\
16 \\
46\end{array}$ \\
\hline $\begin{array}{l}1 \\
3\end{array}$ & $\begin{array}{l}55 \\
60 \\
74\end{array}$ & 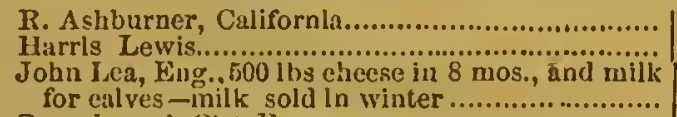 & $\begin{array}{l}6,870 \\
6,400\end{array}$ & $" 6$ \\
\hline 7 & 35 & 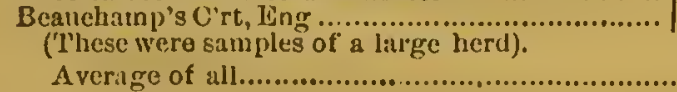 & $\begin{array}{l}8,000 \\
6,736\end{array}$ & "4 \\
\hline
\end{tabular}

make; the Jersey orners, how mueh butter and eream to the quart of milk. 'To show that the Holstein is not a butter' eow, tho following dedued from a table published by the London Agrieulture Jounal, the results of tests made by Mr. Amersfoordt, of Badhoeve, in the Lake of Haarlem, Holland, a most competent authority, who tested the milk of. 46 eows in June, and 49 cows in November, with Prof. Tesser's lactoscope, which is claimed to give a closc approximation to the actual fat in the milk.

In the table made by Mr. Amersfoordt, the yield of cach cow on the 15 th of June and the 24th of November is given with the per eentage of fat. The average yield of 46 corvs in June, is 13.87 lities, or 31 lbs. eaeh, and the per eentage of fat 5.217. Six of the largest milkers gave 2).2 litres, or 46 lbs. pot day, with 5.2 per cent, of fat. 
On the 26 th of Norcmber, 49 cows gave an average of 6.24 litres, or $13.9211 \mathrm{~s}$., with $6.32 \mathrm{per}$ cont. of fat. The largest per centage of fat vas 7.50. If the lactometcr of Dr. Fesser is accurate, this would show

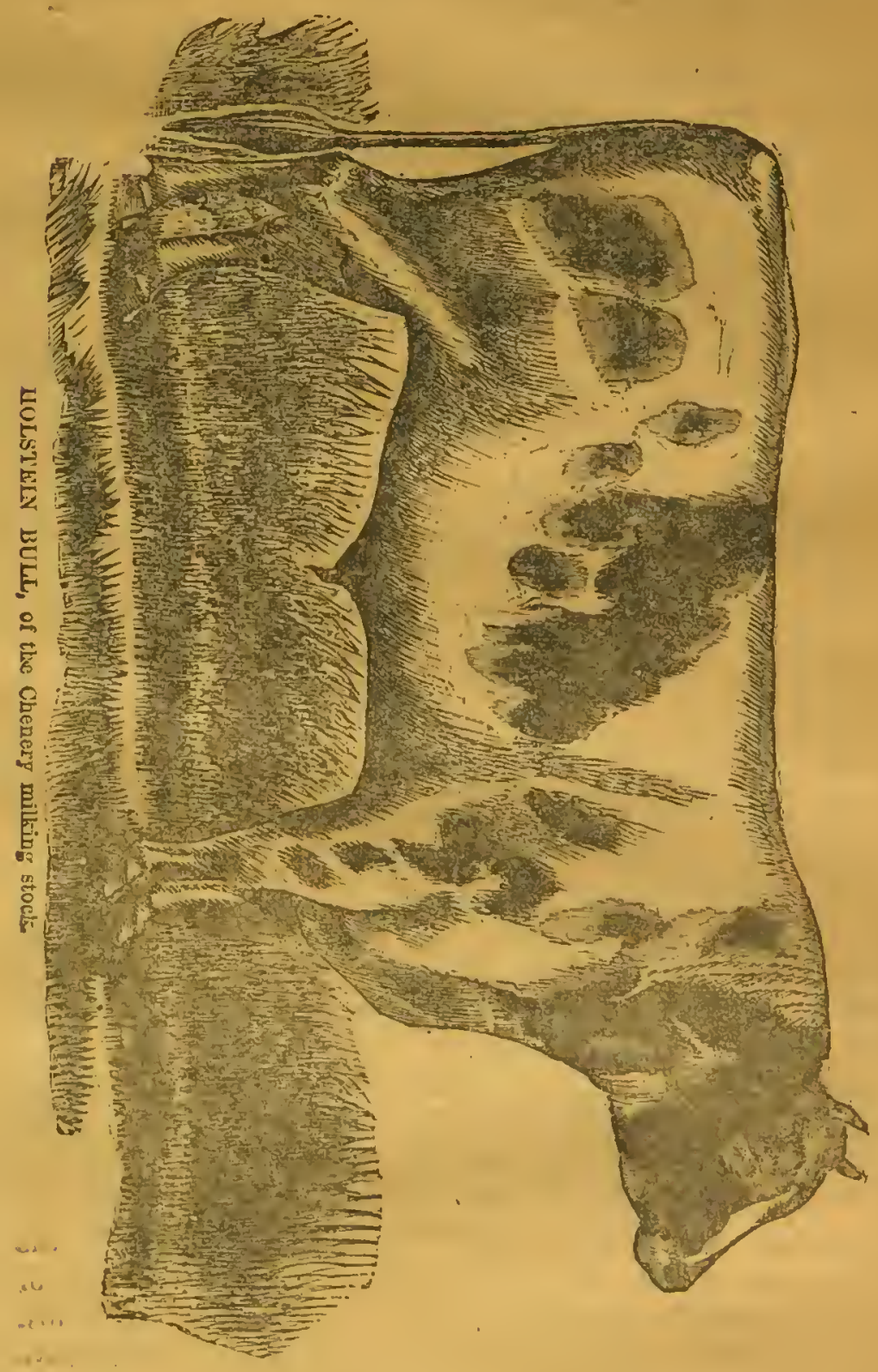

the Holsteins to give milk as rich as our native cors, whose mill wiil yicld $5 \mathrm{per}$ cent. of butter on flush grass in Junc, and 7 per cent. in 
November. So considering the noble milking powers of this breed, and their woll-kno:wn ability as cheesc-makers, their outcome in butter should be considered satisfictory.

\section{The Kerry Cow:}

In Iroland, from time immemorial, there has existed two distinet races of eattle that were valuable in their day and time; one a long-horned breed, and the other belonging to the middle-horns and considered an aboriginal breed. Of the long-horns we have already made what mention is necessary here, except that we may add that from their resenblanec to the English long-horns, they have been supposed to have had the same origin; but whether the English family came from Ireland, or vice versa, is not known; history is silent on the subject, and it matters but little to this generation. The middle-horns and the short-horns are the valuable eattle of the present day, and they will be the eattle of tho future.

The other representative branch of the genus $B o s$ in Ireland, the cattle of Kerry, or as they are now termed, Kerry eattle, are worth moro than a passing mention, beeause there liave been representative animals imported to the United States, and they may have value in some mountainous countrios of the United States, and the far Northwost, for their extrome hardiness, their facility in shifting for themselves, and their adaptability in fattening when not in milk. As a breed they are rare, and ovon in the last contury were not to be found except inland on the mountains. They are described by Youatt as small, light, active and wild.

\section{The Kerry at Home.}

The head is small, alfhough there aro exceptions to this in various parts ; and so numerous, indeed, are these exceptions, that some describe the native Irish eattlo as laving thick heads and neeks; the horns are short, is compared with the other breed, all of tham fine, some of them rather upright, and frequently, after projecting forward, then turning backward. Although somewhat deficient in the hind-quarters, they are high-boned, and wide over the hips, yet the bone generally is not heavy. The hair is coarse and long; they are black-brindled, black, or brindled, with whito faees. Some are finer in the bone, and finer in the neck, with a good eye and sharp muzzle, and great activity.

They are exeecdingly hardy; they live through the winter and sometimes fatten on their native mountains and moors; and when removed to - oetior olimate and soil they fatten with all the rapidity of the aboriginal 
caltle of the Highlands and Wales. They are generally very good milkers, and many of them are excellent.

The cow of Kerry is truly a poor man's cow, living everywhere hardy, yiclding (for her size) an abundance of mills and fattening rapidly.

These cattle usually are small, and aro confined to tho billy and moor grounds. Some are of considerably size, elsewhere, and aro improved in form as well as weight. The horns, usually of middle length, turn up, as do the horns of those on the mountains; they are shorter in the leg, shorter in tho body; their loins and haunches aro heavy and wide? although the hair is thick, the hide is mellow, and they thrive with rapidity. This is as they were known many years ago. They havo since been bred with carc. The London Stock Joumal of a late date says of them now : "These characteristic points of the breed are unmistalsably well marked. The size is small. The legs in most cases aro very short in proportion to the size of the body. The head is somewhat sinall, though the muzzlo is long and clean. The lips are thin; the expression of the countenance is plcasing, and the eyo is particularly elear and fairly prominent. $\Lambda$ symptom which is most indicative of purity of breed is the "tur"n up" of the horn, which is of inedium length. Oecasionally, howerer, the ho:u will, after turning up, turu backwards. The nicety of the horn and the manner in which it is set on adds immensoly to the stylo. Tho neck is not massive at the junction with the head, but it thickens gradually, and affords reasonable covering to the shoulders. Tho latter aro flat and thin. The dorsal vertebre riso more than in other eattle, which sometimes gives the back an irregulis appearance. The ribs spring well, especially the last of those approachng the hip; this makes the body very compact. The loins aro of medium width, and the hip not prominent. The distance between the hip and the setting on of the tail is not considerable; the latter hangs neatly, and is well concealed by the adjoining bones. The chest is full and cieep, and tho hind-quarters long, but rather light. The favorito color is biack, though black and white, brown, and red, aro by no meaus uncommon. Tho coat is invariably fine and thick, and tho hide elastic and mellow, showing great capacity for the production of flesh and fat.

"Sixtcen quarts of milk per" day may be regarded as the maximum quantity the besi specimens of the breed will give, and twelve quarts may be regarded as a good averago for the entire senson. T'his is, of eourse, on good keep. The milk is rich in cream, and the butter delicato in flavor, muperior in color, and, as in the case with the Jersey cows, one or two Kerries will give the milk of ten to fifteen other cows th the production of butter. As an indication of the richness of milk of the Kerry cow, eight to nino quarts are said to produce a pound of butter." 
In relation to their adaptability to fatten, it is said to be a remarkablo peculiarity of the breed, but they take a long time to mature. At three to four years of age they will not dress more than threo to four hundred pounds of beef to the fore quarters. They aro not howerer becf eattle, nor are they adapted, in this country, to dairying, except by mixing, to improro the messes. In fattening, howover, when of mature ago, they thrire most rapidly, and the becf in point of being well marbled, in flavor, and tenderness, is not exeelled by that of any other broed.

With proper care and brecding, there would seem to be eapabilities in this breed well worth perpetuating and improving, especially now that duirying as a distinetive branch of agriculture is assuming such proportions in the United States, and particularly in the Wrest.

In relation to constitution, hardiness, ete., the authority last quoted neys: "It is already observed, the hardy constitution of the Kerry most enlinees its value; for dairy purposes especially a remunerative yielí is obtuined on what would bo to other :mimals 'starvation fare.' In tho deptli of the winter scason I have not only known tho animals to livo jumping fiom rock to rock, and from cliff to cliff, picking an contse seanty bite from :mong tho mountains, but with rery small additional keep at the farmsteading, whither they come to bo milled moming and erening, to actually thivo under the circumstanes. Her people think of lousing the Kerry, either night or day, at any period of the ycar. When not giving any milk they remain for months away concealed in the mines of mountain passes, secking the best shelter they ran from the excessire riin and snow storins with which their abodes are periodically visited. The hair is thick but fine and long-a provision of naturo typical of cold latitudes.

"What, howerer, is fur more singular in the constitution of the breed, is the readiness with which it achapts itself to circunstances of a wholly reverse character. In acchimating breeds of eattle, shecp, or pigs, tho transition must be grudual ; but with the Kerry wo huve it suddenly and indiscriminately transferted from its lome in the mountains to the richest grazing valleys which our island ran houst of without experiencing the slightest change in regard to health. Not aloue this, lut, wo huvo seen the beast; nshored at once into the dairy sheds, and there confined for yens, in the closest bondage, without any apparent effect on the constitution. They further enjoyed the full bencfit of the change as well as if the new abode was their native habitation. It was for a tine boliered that the frame of the breed was impregnable to pleuro-punmonia, or other contagions diseases. Rerent experiments which havo been cono ducted have failed to establish this view." -- 


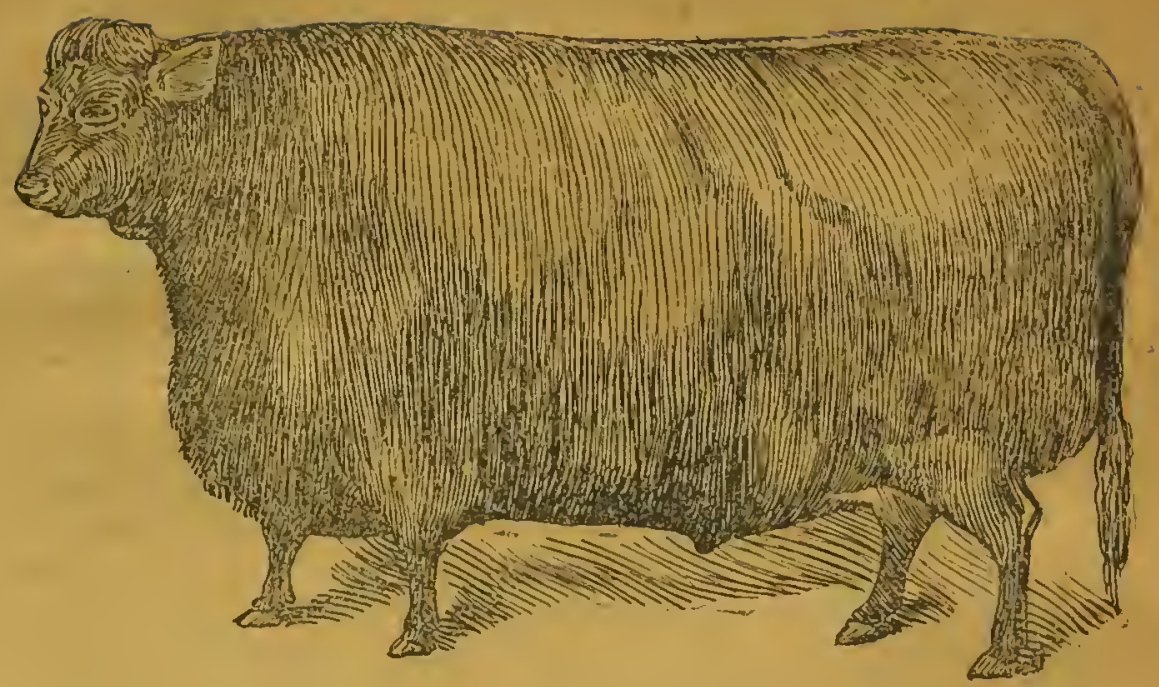

POLled ANGus Cow.

\section{Angus or Aberdeen Polls.}

There are but three prominent beefing breeds in the world : the Short Horn, Hereford, and Angus or Aberdecn poll.

Several others are eminent both in quality and adaptability to particular circumstances, but none of them have proved equal to these three in all that goes to make the modern model ox on pasture or in the stall. Angus, or Forfarshire, in Seotland, some fifty years ago, took up the important question of the improvement of its native cattlc upon the principles then well known through the suecesses of Short Horn breedcrs, and ere long immense progress resulted. Hngh Watson, of Keillor, was the principal agent and worker-up of all this. IIe was unquestionably the father of not only this braneh of these polls, but neeessarily, as we shall see, also of that of the Aberdeen line. These cattle were hornless, blaek, good milkers, somewhat etiff fatteners and good at living on "nothing" upon the somewhat bleak rolling pastures of Augus. The stamp of animal now on hand by Mr. Watson's skill and perseverance is eonsequently very hardy, grand graziers, fattening and ripening early on pasture, and, as a natural result of man's interfercnee, also good as stall feeders.

The men of those parts and times were not indifferent to the illustrious Durham, as several purchases were already in possession of the more elioice farms of the north of Seotland, but, in vicw of seeuring the more vaiuable aharaeteristics of Eugland's famous beefer, along with a hardier constitztion, 
or one then supposed to be more suitablo to the distriet, this Angus, or "Keillor Doddie" was established.

The growing importance of the Angus breed led the farmers of Aberdeenchire to consider the improvement of their own hornless black eattlc, and in order to render this more certain and rapid, they made use of the larger and best epecimens of the Angus.

William McCombie, of 'Tillyfour, stood pre-eminent in this work. His olject was to secure a larger frame, and, if possible, a lotter stall feeler than the "Watson" type, in short, a "Scotch Durham," and he succeeled beyond all expectation.

These breeds liad their separate lierd books until three years ago, when, in consideration of their essential oncness, in history, points and charaeteristics, they were joined, and henee the new name, Angus or $\Lambda$ berdeen polls.

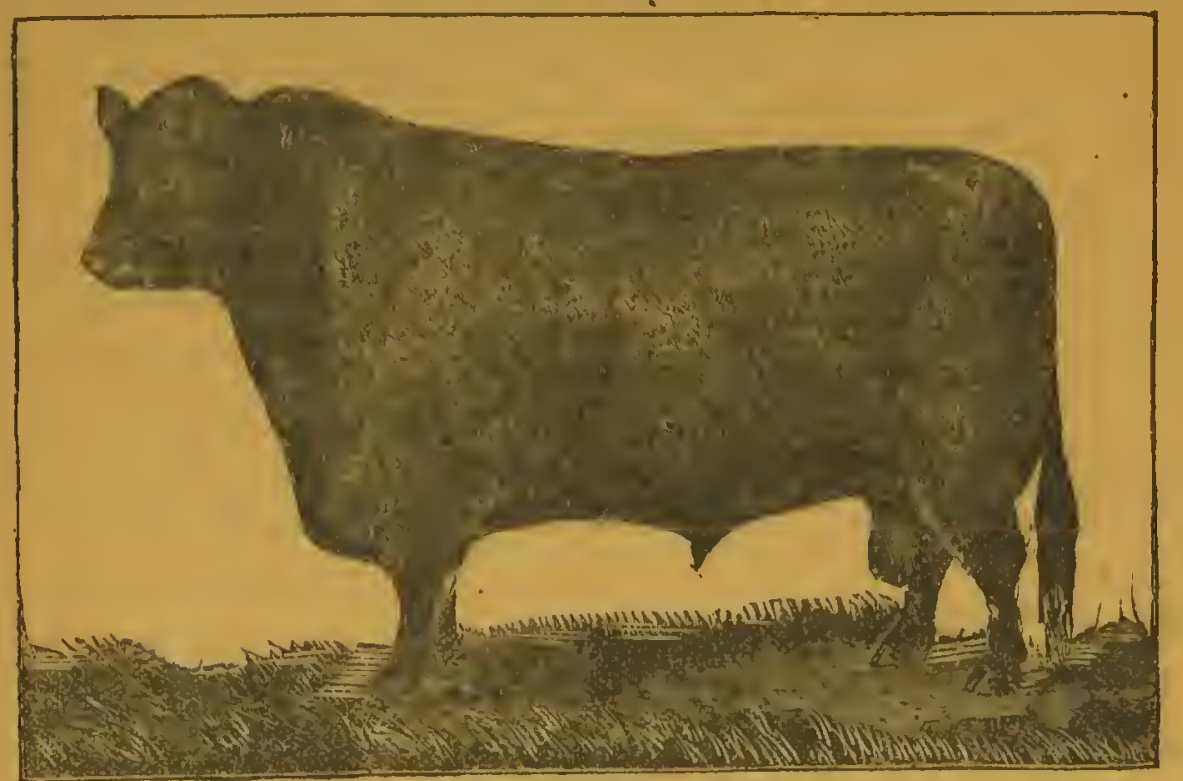

Polled ANaug Bull.

At the present day, therefore, we liave a polled or hornless breed of eattle, entirely black, with oeeasional spots of white on the belly and udder, a deep square frame, having all or nearly all the details that make up the modern Short Horn. With the exeeption, then, of the eolor and horn, the Angus or Aberdeen poll, is practically a Short Horn, but more able to do well on indifferent pastures, is as a whole better built behind the sloulder and arm, and deeidedly better in quality of nilk and producing good marbled flesh, though not so deep at the pail as the average Short Horn, nor probably so heavy when matured.

It is evident from the circumstanees under which this breed has been established-those of hill-side grazing, little grain, and plenty of hay, straw, and turnips, with severe winters and moderate summers, that for many parts of 
the world they are superior to the Short Horn and Hereford. They have every your cluring the last quarter of a century so successfully competed with all ather hreeds that their extension in Britain and importation to most civilized conntries is becoming a thing of common oceurrenes.

The Ontario Experimental Farm has had a herd of them for five years, and as we write (April, 18.81) we read of other purchases for other parts of Canalil, as well as for the Uinited States and Australia.

In view of the great ficlil now open for the raising of eattle upon the prairies of Nortl $\Lambda$ merica, sereral importations are being made of the best animals of this breed for the frurpose of improving the common herds:

\section{Gallotray Cattlo.}

The Gallomays we lave seen have proved to be most admirable eatfle, thich-neated, decp-flankel, short-lngeged, fine-hairel animals. That they were considered most valuable cattle, and wortly of heing brought liere in the einly settlenent of the country, is eridest from the finet that forty years ago thoso hormless or muley cultle, as they were termed, wero not extremely rare, often brecling back by reversion sntirely lornless or with lut tho rulinents of lorns, ans gentle and good milking cattle. Gentleness is a claracteristio of tho puro Galloway. Even the lualls aro noted for their docility and quiet temper's. Fol the renson that this breal of eattlo liave of late years been growing in faror in tho West as grazing aud milking cattle, and for the further reason that it is thought that crossing the Galloway on the linlf-wild 'lexan will he nost valuable, wo append tho following general chinacteristics of the breed.

The Gialloway cattle are strilight and broad in the back, and nearly level from the liead to the rump; are round in tho ribs, and also between the slioulders and the ribs, and tho ribs and tho loins, and broad in tho loin, willout any limge projecting hook-bones. In roundness of barrel and fullness of ribs they will compare with any breed, and also in the proportion which tho loins bear to tho hook-bones or protnberances of the rils. When riewed from alsovo the wholo body appenrs benutifully rounded, like tho longitudinal section of a roller. They are long in tho quarters and ribs, and decp in the chest, but not broad in the twist. 'Tlyere is less space between the hook or hip-bones and the rils thin in most other breeds, a consideration of much importanee, for the advantage of lengtl of earciss consists in an animal being well-ribbed home, or as little space as possible lost in tho flank.

Tho Gallowny is shont in the leg, and moderately fine in tho flank. bones-the happy medium preserved in the log, which sccures hurdihood and disposition to fatten. With tho samo clcanness and shortuess of 
shank, there is no breed so lirge and muscular above the knee, whils there is more room for the deep, broad and capacious eliest. IIe is clean, not fine and slender, but well proportioned in the neek and chaps; a thin and delicate neek would not correspond with the broad shoulders, decp chest and close, compact form of the breed. The neck of the Galloway bull is thiek almost to a fault. The head is rather heavy; the eyes aro not prominent; and the curs are large, rough and full of long hairs on the inside.

The Galloway is covered with a loose mellow skin of medium thickness, which is elothed with long, soft, silky hair; the skin is thinner than that of the Leicestershire, but not so fine as the hide of tho Short-Horn, although it handles soft and kindly.

The prevailing and fushionable color is black; a few are of a dark brindlo brown, and still fewer are speckled with white spots, and some of them are of a dun color. Dark colors are uniformly preferred, from the belief that they indicate hardiness of constitution.

The Galloway cows aro not good milkers; but although the quantity of milk is not great, it is rich in quality, and yields a larrec proportion of butter. $\Lambda$ cow that gives from twelve to sixtecn quarts per day is considered very superior, and that quantity produces more than a pound and a half of butter. The average, lowever, of a Galloway eow eannot bo reckoned at more than six or eight quarts per day, during the fivo summer months, after feeding her calf. During the next fire months sho does not give more than half that quantity, and for two or three months she is dry. There is, perhaps, no breed of cattle which ean be more truly said to be indigenous to the country, and ineapable of improrement by any forcign cross, than the Galloways. The Short-Horns almost everywhere else have improved the eattle of the districts to which they have traveled; at least in the first eross produed manifest improvement; but even in the first eross the Short-Horns have done little good in the Galloway, and, as a permanent mixture, tho choicest southern bulls have failed. The intelligent Galloway breeder is now perfectly satisfied that his stock can only be improved by adherence to the pure breed, and by care in the selection. While this is undoubtedly true of all pure or Mhorough-bred stock, it seems especially so of the Galloways to-day. It does rot however follow that pure breeds may not improve tho mixed stock of a country. They must and do, as the magnificent Short-Horn, Hereford and Devon grades amply testify in all our great markets. That the Galloways have many valuable points eannot be denied. One of these is their alssenee of horns; another is their extreme docility. If by crossing Galloway bulls with Texan cows their horns could bo toned down their wildness tamed, their frames thickened with superior flesh, 
their milking gualities improved, and tho whole animal amcliorated, it would seem as possible with tho Galloway as by auy other meaus wo know. It is certainly well worthy of trial.

Texan Cattlc.

Within the last few years certain theorists have harbored the iden that the inmense herds that cover the great plains of Texas, Mexico, and Anerica are a race native to the soil, and that havo existed there from time immemorial. Such howerer is well known not to be the fact. As well may the great droves of horses that occupy the sane region be said to he a nativo and wild race. On tho contrary, their well known characteristies, and similarity to the Spanish cattlo and all that country including Austria, Hungary, and other regions bordering the Mediterınean, Black and Caspian scas, points distinctly to their origin, if, indeed, it were not well known that they were introduced by the Spanish settlers about tho year 1500 and succeding years. In fact, ncither cattle or horses wero known in America prior to the Spanish invasion, and that they have multiplied so amazingly since is duc to the genial climate and abundant pasturage, so thit the original cattle brought by the Spaniards suceceding the discovery of the varions countrics along the Gulf of Mcxico and South America, has caused then to spread orer all the region from California to a lititude soutli, bound only by a line beyond which the coldness of the climate precluded constant Wintex and Summer licrbage.

Unlike the wild huffalo, a race indigenous to America, cattle are not migratory to any considerable extent. Not so much so as horses. Heneo while the buffalo is found in Summer far north, even into the British pose cessiens, cattle havo never been found beyond the linits of abundint Summer and Winter pasturage, and they have never been brought into subjection by the wild Indians of the plaius as were the horses, that escape ing from domestication gradually increased and occupied in a rild stato many valleys to which cattlo never reuched.

\section{Charactoristics of Spanish Cattlo.}

This lince of eattle should therefore be called Spanish cattle-miagi - they really are; gatunt, bony, long-horned cattle, semi-mild, capable of great curlurance of lieat, and adipted to the dry but fortile regrions they havo gradually overrun. So vast has becone their numbers that ten years agro these cattle wero estimated at 4,000,000 in Texas and New Mexioo, being in point of numbers about one-seventh of all the horned cattlo in the Union. Seni-wild, impatient of restraint, lean and lank in body, ligh-boned, furuishing but little meat, and that of an inferion 
quality, giving little moro milk than wild buffalo - scarcely enough for a few months Sammer support of a ealf - they were for generations run down like wild beasts and slaughtered for their hides and seanty tallow. The gradunl settlement of the eountry, and the incrensing demand for beef, both in Europe and America, at length eaused them to be moved forth into Kansas for summer pasturnge, whenee they were driven to the moarest ruilway station, shipped east and slaughtered, cither for packing, sold at an inferior price for consumption of flesh.

Various attempts have been made to reduce them to subjection to man o they might be divided into small herds to be eonfined in pastures or fed in winter. It bas been in every instance unsuceessful. Theyremain shy, wild, irritable, and refuse to fatten kindly. The writer, inmedintely

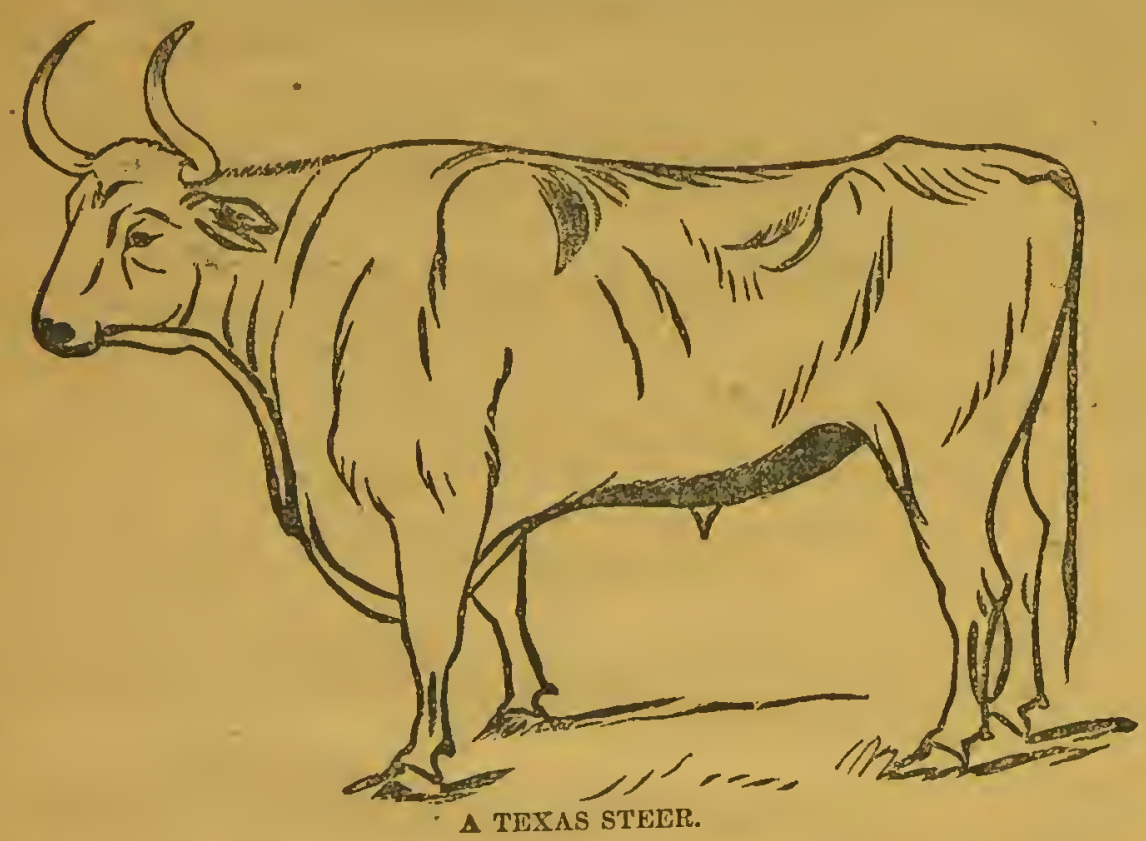

sfte. ie elose of the war, having a large quantity of forage and fattening matcrial, with mills for grinding corn, and stables for the accommodation of 450 cattle, on account of scarcity of stock was obliged to pub in Texans.

\section{Feeding Texans in Conflnemento}

They were bought in Kansas and were known as Cherokeo cattle, nodified form of Texans, bred by the civilized tribes of the Indian reserrations oceupying the territory between Kausas and Texas. They had to io lassoed and dragged into tho stables and made fast to the stanchions, 
from which they could not be allowed to eseape until turned off in the Splring. Underground pipes conveyed their drinking water, the feed, ground eorn and hay, together with residuum from a mill was conveyed to tham by cars on tramways rumning between eneh two lines of eattle. The stables were kept only light enough so that the workmen eould see to feed and elean; good ventilation was provided, and at the end of six months they were curned out, and shipped to New York, -good ripe catAe so far as Texans could bo mado such, - and brọught the price of fat cattle in tho market thero. Of this lot only two car-loads were culls or unfit for the New York market. They wero strietly eorn-fed, or rather meal-fed. For the first month they were sulky and savage, refusing to take kindly to their rations. They never beeame so quiet that strangers could be allowed in the barns without danger of throwing then off their feed, and yet they were altogether superior to the ordinary Texan enttle of ten ycars ago in point of docility, for they had been elosely herded. Nevertheless, the one experiment was suffieient. If other cattle eould have been had at a fair price it would not have paid to have fod them. $\Lambda$ that time good eattlo were high and searce, Texans were cheap. The ledger account eame out all right in the Spring, but the writer did not eare to try the experiment a second time. As to how they looked when

- off of grass and ready for the stablo in the Fall, the full page illustration we havo prepared will show:

\section{Weight of Texan Cattle.}

The averago weight of full grown Texan steers as usually sold from griss in the Western markets, may bo stated at 1,000 pounds; of this the average beef and bone will be 400 to 450 pounds; of the balance, exeept the hide, it is pretty mueh offal, tho tallow being exceeding light. Of late years very many Texas eattle are yearly bought for feeding in distillery stables, on the slop made in the manufacture of high wines. They are roped and fastened and remain there until sold to the butcher. Others again are bought in the Autumn and shipped to the vast corn-fields of Kansas, Iowa and Illinois, and fed in the fields during the Winter. They roally tako more kindly to this latter system of feeding than any other, and they will gain about two hundred pounds of flesh during the Winter, weighing an averago of 1,200 pounds, and making in the neighborhood of 700 pounds of beef.

From what we have stated it will readily be seen that there is no profit in breeding Texans, when other eattle nay be kept. There are, however, vast outlying territories where the herding of these eattle is found profitable. In Texns, New Mexieo, the Indian Territory, Western Kansas and 

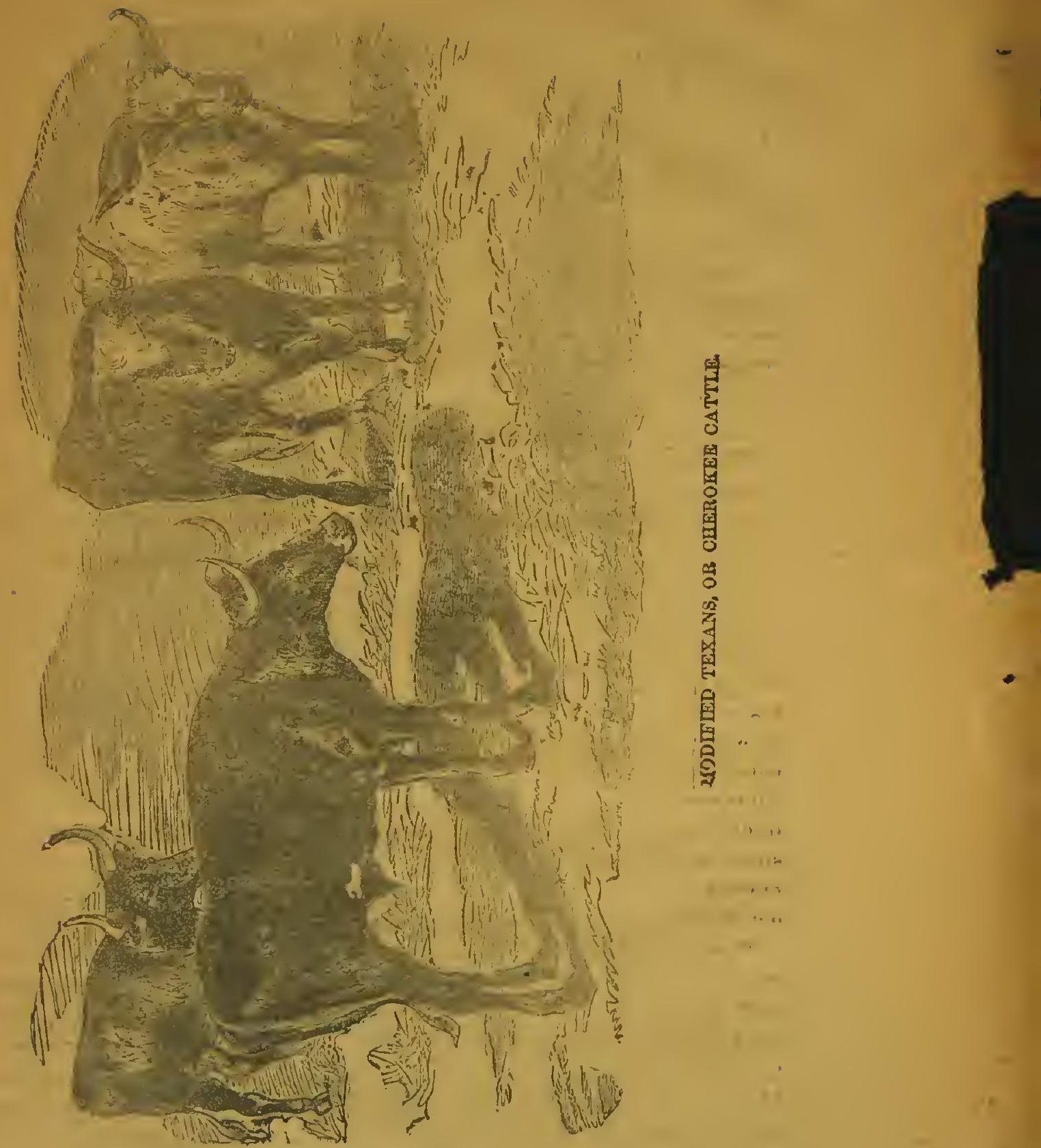
Nebraska and Dalsota, in the valleys of Montana and Wyoming, they may have unlimited range, and cujoy their seni-wild condition, and fattened on grass may be shipped east to be slaughtered and barreled for export, or fattened as we have previously stated. Of late years enterinris. ing herdsmen bave bought great quantities of Short-Horn and Hereford bulls to be used in the improvenent of their stock. The effects aro already apparent. It is well understood now that the produce of either of the bulls we lawe mentioned, in the first cross, procuce an animas much superior to the dan, and which will sell at three or four years old for nearly double what the natives will. The cows give a largely increased quantity of mills, they make better and fatter calves; and hero again is a conclusive illustration to the breeders of cattle everywhere, of the utility of improved breeds in inducing carly maturity, increasing tho weight and improving the quality of the beef.

\section{Profits in Brocding Gradss from Tex\&ns.}

Within the last ten years fortunes have been mado in herding Texas cattle, mot only in that State, but in va:ious Territories of the United States. There aro two essential requisites; plenty of good grass for Summer and Winter pasturage, and abundanco of water. The latter is the essential. Many persons have failed in their efforts to profitably breed Texas cat'le on the plains, for the reason, that water was either not near, or insufficient in supply. The cattle must go long distnuces to slake their t\} irst, and consequ ntly become very dry and uncomfortablo before start ing to the wate-ing place. Then they drink such immoderate quantities of wat :, as again to be uneomfortable for some time, and will, if allowed, hang about the water, on scant grass, until again foreed to take the range. Thus they camnot gain in flesh uniformly, but on the other hand, absolutely loso condition in the constant travel necessary to get water. Perhape some cpidemic sets in, and they die by hundreds, and the omner finds himself tho loser, simply from cntcring into a business hastily, and without studying carefully the absolute necessitics in the case.

Thore is auover class of failures. These have been persons who haro supposed they could take fifty cows, and make moncy by herding then until grown up. In all that wild region inhabited by Indians more or less prodatory, the foreo about a ranch must be strong enough for some proteetion. The profits must come principally from the increase in cattle. If the small berder has water privileges, he cun make money if he has stock enough. If ho has but few, the expense of herding will be the same as when the herd is larger. Owners of other and large herds, or those seeking to beeome such, will not take kindly to the appropriation of water 
privileges, for so small a drove. There will be quarrels; cattle will ho stampeded, and get mixed with other herds, and at last the owner will bo obliged either to leave, or talic a partner with sufficient capital to properly stock the ranch.

The yearly increase in value of cattle on the ranch will be all the way from 25 to 50 per cont. according as the business is mannged. In liorthwest Texas the value of cattle on the ranch is for yearlings $\$ 6$; two year old $\$ 10$; three year old $\$ 13$; cows $\$ 12$ to $\$ 15$; beeves $\$ 15$ to $\$ 20$.

\section{The Cattle Interest of Texas}

To give some ildea of the vast numbers of cattle in all that region whore there is abundant pasturage and water, it has becn estimated that, from the Red River, in Clay county, west to the Pease River, and south

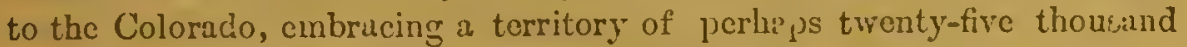
miles, the whole region is now stocked to its fullest capacity, and in the better portions thereof, it is estimated that an average of one liead may bo kopt to cight acres. 'The loss in cattle may be estiniated at about lour or five per cent. per year, and the expense of herding 300 head an $\lambda$ their produce, has becu given as follows:

To thre hundred entrs ant calres

Dle.

To tro imported bulls, $\$ 12$

To one man's tine and bour i for tive years, simo per year.

\$o one man's time and board fur threc year's, $\$ 3 \omega 0$ per year.

To audry items of expunsc.

'Total

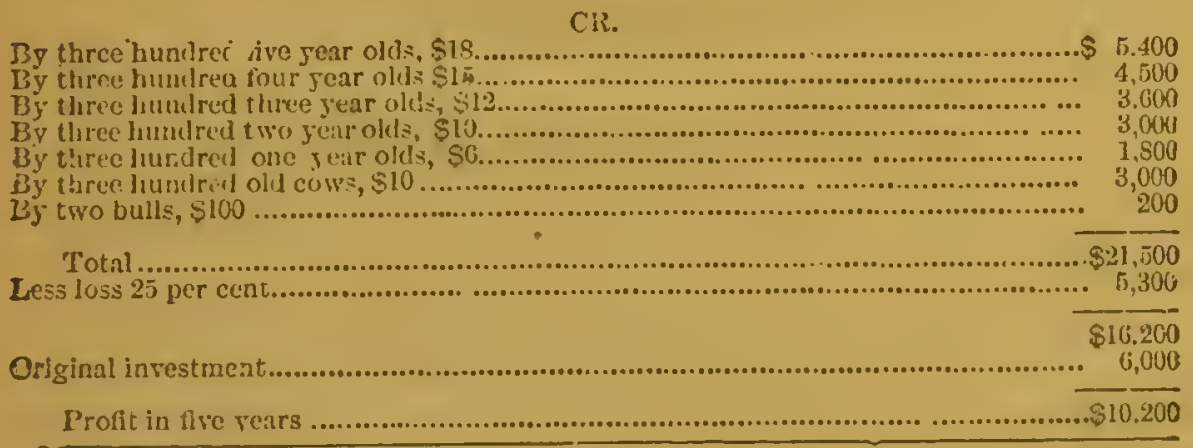

This is approximately correct, except as to the valuc of the bulls, if by these ace meant acclimated thornugh-bred bulls of Short-Horn, Hereford, or Galloway blood. It is well known that it is uscless to take mature bulls or other cattle raised iu the North, to Texas. They die off vith Texas fever before they havo time to leave their impress to any 
considerable extent. An acclimated bull two years old past, should bs worth $\$ 250$. Not less than three sueh bulls should be used in the herd of 300 cows. The sceond year 150 heifers will bo in breeding eondition, and the inerease will then be increasingly fast. The fourth year two moro bulls must be bought, and at the end of the five years, the three first bulls will be praetically of little value. With these exeeptions, the tigures may be taken as eorrect.

\section{Acelimating Improved Bulls.}

The scrious losses that have eonstantly occurred from the death of thorough-bred luuls sent to Texas for the purpose of infusion of bleod bas preventec, to a great extent, the improvement of the stock. In all the plains regions of the West this diffeulty las not becu so sere:-aly felt. The improved breads take lindly to the Summer elimnte and only require protection in Winter, and if put with a herd in which the germs of Texas fever have been eliminated are healthy. Not so those talsen to Texns. Whatever the cause of the discise, it is certain that nearly cvery animal taken there has sueeumbed to this dread disorder, if placed immediately in the herd, and generally before they have had time to serve more than from twenty to forty corrs, and from weakence eondition the impress they have left lias been defieicnt in vigor to that of either the sires or diuns.

\section{Seleet Your Dulle.}

To obviato this a thorough system of acelimation must be cstablished. And abovo all none but very young animals should be taken. In every ease they should be ealves of early Spring, bnught when they aro eight months old. The cars in which they aro carried should bo carefully prepared to provide for the comfort of the animals. Pay particular attention to feeding and watcring regularly so as to kecp the bulls vigorous and strong.

Buy none but animals of parents and families of linown souratiness and vigor of constitution. Avoid all funcy or highly in-bred fumilies. Abjure ezecssive stylo and fincness, and look only to the single points, constitutional sound ness and vigor, and thick bect. It is licter that they be a little rough from liaving been bred out of door's, and r ith out-o isdoor care, lather than stablo bred, pampered animals. Such a:e not cven fit to put with tho breeding herds of the plains. To carry them to tho very home of Spanish, or as it is now called Texas fever, can only lesult in

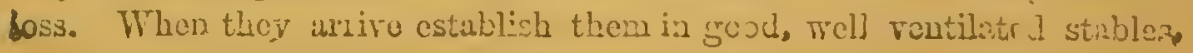


and under the supervision of a kecper who fully understands both breeding and raising, and do not allow them to mingle with the native cattle until they aro at lcast two years old; and, no contact should be allowed with Etock that are known to show indications of the malady. One more suggestion: the bulls should not bo freely used as breeders until they ars twenty months old. In acclimating the bulls, watch for the first symptoms of the fever, and give prompt treatment at tho first discovery of the dise easc. This may bo knom by the rost?essness of the animal. The eye will be dull, the movements constrained and moping, there will be mora or less straining in the attempt to urinafe; that roided will be scanty, high colored, and of bad odor; and the bowels may be costive or very much relaxed. Treatment, said to be most successful, is to give at the first indication of the disease one tablespoonful of finely pounded charcoal, and ono teaspoonful of ground ginger, to bo followed in an hour with a quart of strong decoction of marsh mallow, and ono quart of camomile ter. This to be repeated in ton hours if tho animal does not get rolief. If marsh mallow can not be obtained, sult peter is recommended. This remedy, however, had better be given under the direction of a veterinary Eurgeon. Above all, endeavor to keep the pores of the skin active by brushing and friction. By proper care in this direction it is stated that ninety per cent. of the cases treated can be saved.

In all this, eare of course must be taken in regard to the food of tha animal. Bran, boiled oats, and corn, or corn ineal, may be given; if roots, carrots, parsnips, or sugar bects call bo had thcy will be excellent. In fact they should always be kept in supply on breeding farms. Grass in vlenty and of good quality should also be supplied freely.

\section{A Teran's Vietr.}

An intelligent and educated correspondent of the Live Slock Journal, gives the following excellent advice in relation to the transportution, care, and feeding of stock bulls to be carried to Western Texas. Ho advises that care should bo used in the selection of calves of stout, robust frames, the offspring of sircs and dams of good constitutions. Calves cropped in the early Spring will be found most suitablo for shipment suy about tho last of November or carly in December. Plenty of milk from birth until September should be given them; then they should be fed on wheat bran; boiled oats, and crushed corn, until date of shipment; and if kept in stables during the day they should have a good grass lot to graze in during tho night. They should bo handled, mado very gentle, and well broken to the halter. The ears for transportation should bo woll bedded, and food for the eatire trip transported with the stock. 
Arrangemerits should also be made for throngh trip when starting. Food, watcr, and sireful witching by the herdemen will land them at the place of discmbarkation but little damaged by the trip. Care should be taken not to erorrd too many in one car-thirty head ean be taken if they are properly cared for-yet twenty-five head would do much better. Tho culves designed for shipment in one car, if more than one is to be cent, should be permitted to run together for some time previous to Etarting.

After reaching the terminus of their wearisome journcy by rail, a weck's rest, in dry lots, should be granterl them, with the same kind of food as was used boforo shipment. When talen any distanco slow and casy travel should be given them. If either eostiveness or its opposite is exhibited, simplo remedics should be giren to prerent the too actiro purging or relieve tho constipation. The preparation for thein leception at their Texas home should have been conuleted before their arrival; and in adäition to a supply of corn, oats, and wheat brnn, pure xmining water and free access to a growing oats or barley pateh, which should have heen sowed in early Autuinn for their bencfit, chould be allowed. Snitablo protection must be pirovided to gururd them from the cold blasts of the "northers;" then, by prompt attention to any symptomis of fever and the immediate use of charcoal and ginger, one table-spoonful of charcoal and one teat-spoonful of ginger will relieve them.

"If December and January are passed withont ferer you can fecl safo from its ravages until the rains of Spring, followed by the heat of June, when the ticks and vermin menace them. Then avoid exposing them to either rain or sun, and destroy the vermin by a frce use of coal oil and Ind, using tro pirts of the latter to one of the former. If only spring calves are brought there will be less of fever than if older animals were birought.

pw. Too miny spceulators, who bring yonng stock to Texas, stint and half otarie, them, thinking that to kecp them in good growing condition and zerouses the chunces of discase. My observation teaches the reverse to mbe asue. To sceure a complete development of.bone, flesli and growih, 1.. snd early, profitable matnrity, a calf nust have generous carc, plenty of 1. Lutritious food, good water, and lind treatment. I have heard mer nof oomplain that Texis Short-IIorns aro not thrifty aud handsome, like - chose exhibited at Northern fairs. The reason for the dissimilarity is - readily found on investigation to be that the one had excellent fecding and growing, while the ofher-in addition to a long winter, starvation, and acelimation, with a Spring and Sumncr witk rain and hot sun-had bis vitality almost destroyed by tichis and vermin. Cattle from the North cirinot be acclinatcd unless gencrous food, confortable qunters, and 
kind treatment are given to them during their first year in Texas; and unless this treatinent be kept up they are worthless when acclimated. They will be weak and sickly in spite of the best etforts to the contrary. Care a to condition of animals will always pay. That which costs us the greates pains in cattle raising will always reward us the best. 


\section{EREEDTY AND FE'SDING.}

In the brccuing of animals, one must have a definite object in view. TFe have aliealy stated that in this age of civilization, where industry is divided and suldivided, so thist cach set of workmen have scparate and distinct lines of labor in tho malio up and finish of the most simple articles, so in stock brecling, tho firmer riust understand the naturo and adaptatio:1 of his soil, and its aduptubility to certain erops and animals. In rocky, hilly, and comparatirely barren regions, or where the soil suffers under drought, the farmer eamot compete, cither in tho raising of beef eattle, or in diarying, with tho moro favorcd well maturcd countries of deep soils and flush pastures. Again, in a country noted fos its short, swect perennial pastures, and ecld springs of water, tho stock breeder cannot competo with the dairyman. The stock feeder of eattlo and hogs must be in a region whero corn, or other feeding grains can be cheaply and abundantly raised. Fortunately, such countries are well adapted to the meadow grusses. producing heavy erops of hay and pasture.

\section{About Grassej.}

Here again, the grasses cultivated will be somewhat different. 'The' otock feccier will depend shicfly upon blue grass, timothy, red top, orehard grass, and clover, and where bluo grass is natural to the soil, ho will depend almost solely upon this grass, for late fall and winter feeding, as he will upon blue grass and orchard grass for spring feeding, depending later on clover, timothy and red top. The dairyman, whilo he will depend upon elover, timothy, red top and orehard grass for hay, will not use these cor pasture exclusively. Ho must have in bis permanent pastures a greas 
rariety of grasses. His pastures, to produee the greatcr quantity and best quality of milk, must be permanent ones, and the older the better. This with a moist climate is what lais made some sections of Englind, and especially Ireland, Holland, and Denmark so celebrated for their dairy products. This, also, with the peculine cure given in feeding, has mado England and Scotland celcirated througnout the world, not only for tho hoivy weight, and superior quality of the heef, but it has resulted in such superior becf cattle as the world has never before linown. Some of theso breds, transplanted to the United States, have taken kindly to our soil and climate. The wonderful fertility of the land lying west of tho Alleghanies and north of the southern line of Tennessec, and especially thoso States hordering upon the Mississippi and Missouri rivers, and principal tributaries, and, also, the great Soutliwest - this teening fertility of soil has made all this great region of country the true home of the riost eelcbrated breeds of cattle-where they have reached weight, and ricinness of milk given, no where else attuined execpt in very confined ureas.

\section{What Ireeds aro Best?}

This beeomes a most important question. In all that great region of the West, of gentle undulating pruiries or grassy plains, Short-Homs and Herefords will be found the very best cattle to breed from, when only heef is the object. If libor and beef are winted, the Devons and Herefords will be found most raluable. If beef and milk are to be the products, the Duchess and Princess fumilies of Sbort-Horns, and the Holsteins will give the best returns. If darying is to be the chief industry, tircu, for butter, the Aylshire, with a few of Jerseys intermixed will produco the best results. If for butter and cheese, Ayrshire or Short-IIoris:- If cheesc alone, the Ifolstem, and for quantity of milk given this latter breed will ecrtanly carry the palm. If milk and butter, without reference to quantity, be requiled, the Jersey is the eow. All the breeds except the Jerseys will make good weights of beef and fatten readlly when dry - the Short-Horns, Holsteins, and Ayrshires making weirht in the order named. For milk, re lave not included the Derons; occissionally a com will be found giving a large mess fö her weight. Devons, however, are not dairy eows, at least, now-a-days; having been bred most c:aclusely for their superior quality of min hled beef, and their.uniform excellence, eourugrc, und kindliness in the yoke.

\section{How to Breed.}

All famers eannet beenme breeder's of highly bred, pure stock. For this the animals must be isolited from all other breeds of the sane rico. 
At least the males must bo strictly confined, so they may not intermix with others. Where farms join, divided only by fences, this will not bo found practicable in a majority of cases. One's neighbor may fancy scrub stock. 'They arc notoriously breachy. Once they interminglo with a pure breed, the taint of their blood is not only found in the calves, but in the dams themselves. In the ealves and their progeny, it may nerer be bred out. We sec the Kyloo eross in some families of Short-IIorns, even to this day, cropping out in single individuals after a lapse of nearly a century. The writer so saw it at tlo last fat-stock show in ChicagoChat of 1879. The animal was a most exeellent speeimen; fully as porfeet as many of the very highest brecding, yet the taint of the fimily was there and the breedcr of "high caste Short-Horns" would not havo 'bred from such a cow or to a bull showing the taint, at auy price.

\section{About Goneral Utility.}

Just hore is where the differenee comes in, as between breeding for general utility or absolute purity of blood. The brecder for general utility cares not so muel about a particular strain of blood, as he does to get certain characteristics that will furnish him, at the least cxpense, either the most beef, the best working oxen, ne the most and the best mills. Those who undertalic breeding, or in fact any other business, in a haphazard way, always fail ; the only exeeption to the rule being pure luck. Luek is not a good business integer to depend upon. Like lightning, it nerer strikes trice in the same place.

Thero is another thing in connection with luck that it is well to bear in mind. It is as apt to mar as to mark. The farmer, thorefore, who undertakes the breeding of stock, with a view to the money they will bring from the butcher, or from the salo of dairy products, must be guided by an entirely different set of rules from that of the breoder who breeds solely with a viow to selling sires and dams to other breedera of pure stock. So particular, now-a-days, havo brecders of this elass become that some of them will breed only particular families. Somo will not allow a Booth eross, others abstnin from the Butes blood.

Many high casto brecders aro pretty well agrecd that a top cross of what are known as seventeens, and some other sub-familics of later importations, and also of particular bulls of pure brecding, but which have been considere i more or less coarse, must be rigidly cxeluded. They have their particular iuncies. To gratify this fancy thoy will pay extraordinary prices, while the great mass of really superior and really puro Short-Horns will be passed unnoticed. It would bo unadvisable for the ordinary farmer, or even tho Short-Horn breeder to buy these 
"terribly bred cattle." And the farmer must earefully discriminato. I.et him get stauneh healthy cattle to sturt his herd, if beef be the object, and animals with good milk points if milk be the object, rather than to strive for color. So long as tho color of tho animal is characteristio of the race, the beef points and the milk points are what he should sceis. The body in the beef animal, and the udder in the dairy cow, is what Lo wants.

\section{Breeding in Line.}

Brecders of pure stock are especially particular in the selection of tires; so much so that many of them breed solely with reference to tho strain of blood particula families contain, the sclection often being without referenco to the uniformity or quality of the animals selected. Really, however, breeding in line means the selection of inales of a common type, and belonging to the same family. Thus in breeding in-iac-line, the expert, while lie oljeets to going out of a sub-family, nevertlieless seeks to couple animals togetlier whose uniformity is identical, or, when one is rieak in some essential, to improve it by coupling therewith an animal of superior exeellenco in this partieular. Thus, if the head and horns be rather eoarse in an animal, it is bred to one fine in head and lorns, lut not lacking in other essentials. It is one of tho most fatal mistakes that can possibly bo made in breeding, that to nequire one essential other disabilities be allowed to enter. Many lreeders have committed irreparable injury to their stock by not understanding the necessity, while trying to improve ono essential, of kecping all others intaet. Therefore the sagacious breeder will pay more attention to those points indicative of heary sueeulent becf laid in tho primer points and without an undue proportion of fat, if combined with general symmetry, rather thru style and earriage, connected with deficient characteristies in flesh. The ono animal may be striking to tho eye, while the other will bring the butcher's money. This is really all there is to beef cattlo.

\section{Form as an Index to Quality.}

Whatever the animal, its form, organization and general make up, will Bo an indication of its true type and eharaeter. It is a fixed law of naturo that this should be so. A few illustrations will suffee, and which wiil easily conmend themselves to the reader.

The thorough-bred horse, is courageous, ligh strung, active, sinewy, impatient under restraint, and not given to carry mueh flesh or fat. The besvy draft horse, earrics much llesh, is docilo, honest at the collar, pos 
sessing grent bone and sinew, and is on the whole more sluggish. The - horse of all work should be a modification of hoth inese characteristics. All horses have great chests, and consequently great lung power, fitting them for severe and long continued muscular exertion. They must be juclged ly a standard where muscular exertion is the important integer. Cattle lave been bred so long with reference to their bodies, as beef or milk producers, that they have hecome so distinct from the supposed wild type as to possess but little in common therewith. The head, neck and limbs, have been lefined, the lings have less power, since it is only necessary that they supply sufficient oxygen to the blood to licep up a uniform animal heat under exereise, never violent. The loin and rump are broad. ened, the ribs spring out more to give capacity for a stomich of size to digest a lurge quantity of food. In swine the diminution of lumg power is particularly seen. They are essentially slow in all their movements, ancl arerse to excrtion. Their forte is simply cating, sleeping and laying on fat. No one would nistake a hog for cither an ox or a horse. Tho intelligent brecier so elueates his eye and bis toucl, that he ean distinguish hetwecn animals of any given race as to their capahilities for the furpose intended. The external conformation enmes at length to be so lieenly associated with the correlited structural affinities, that he tells at onec, and cxactly, the important points that would entirely escupe the uncducuted eje and touch.

\section{Practical Suggestions.}

As the greatest execllence in the production of ment, milk or labor in cattic; of wool and carcass in sheep; and of hams, loin, side meat and lard in hogs, inrolves peculiurities of structure and function-andinting the animal to the specinl purpose for which it was intended, and as all theso require close study of anatomy, plyysiology, and the correlations cxisting in the difichent forms of proluction; and since scientifie lreeders hare for the last hundred years leen secking to extablish a higher and higher execllenee, the intending breeder would be unvise to undertako to breed up from the common herds of the country. It would be time ill spent. He should first inform limself of the practical necessitica within lis reach, and breed from types already existing rather than ereato one. This will simplify his study, he must educate his eye hy points and the obscrvation of the best animals, and his toneh by feeling them accord. irgo to the rule heretofore giren; and this brings us to

Brceding Grades.

At the meeting of the American Association of Short-IIorns, at Ind's 
napolis, 1872, "pure-bred," "full-blood," and "thorough-bred," wero defined as being synonymous terms, and to indieate "animals of a distinet and well-defined breed, without any admixture of other blood." The following definitions were adopted by the association.

"CCross-bred'-Animals produeed by breeding together distines breeds."

"GGrades'-Tho produce of a cross between a 'pure-brecl' and a 'native.",

" "High grade'-An animal of mired blood, in whieh the blood of a pure-bred predominates."

The produce of a Devon and a Short-Horn would be a cross bred animal. In-and-in breeding is considered to be the coupling of animals of the elosest relationship, as the produee of one sire and dam, ete. Close breeding is the breeding of animals together that are elosely related; as animals one or two removes from the parent stock, in relationship. High breeding is sometimes ineorrectly used in this connection; it is wrong. Many of our most highly bred horses are not elosely related, and the same may be said of our pure cattle. High breeding properly Eignifies the selection of the breeding stoek, within the limits of some farticular family, and within a definito standard of exeellenee and characteristies.

\section{İow to Breed Grades.}

Seieet the best cows you ean find, that is, those that come the nearest to the standard of exeellenee for the purpose wanted; then select a bull combining in the most eminent degree possible the points of real exeellenec for the outeome expeeted, not in fancy breeding but in adaptability to the end sought. Thus, if for beef, he should be of fair size, not too * large, certainly not too small, but of exeellent fineness combined with great loins, rumps and thighs, round-ribbed, and well ribbed to tho hip bones,-in other words, what a breeder would call a well-bred, serviceable animal.

If for milk, the bull nust have come of a line of uniform milkers, for here the udder and milk-veins are the essential part. In fact, the malo must possess the peculiarities charactcristic of the breed, and better if from a family of extraordinary excellenee. IVhy? Such animals are prepotent; that is, they will impress upon their progeny the distinguishing characteristics and excellence of their race. By following the directions we shall give, in ten years one may have grades bred to such excelleneo that none but the nost critical judges of stock can tell them from pure bred caltic. 


\section{Start the Ferd}

With one yearling bull for cach ten two-year-old heifors, sclected as we have stated, and which have not been bred. Kicep them from contact with other cattle, and especially kcep their own bull as much in their sight as possible. 'The paxt year's produce should be ten calves, onehalf of which should be weifers. Geld the stecrs, and milse whint use may be desired of thom. Rear the hoifer calves in the best manner possible, and with their sire and dams whon in the pasture, and at other times do not allow them to see strangely marked animals, especially when in heat.

- At the age of two ycars breed them to their sire. Hc will now be four years old, and should be kept simply in good flesh, not really fat, ccrtainly not lean ; but strong, vigorous and healthy. When these calves are two years old, breed again to the same sirc, and so on to the fourth gencration, if he last so loug with vigor.

-Thus this produce will inherit 15-16 of the blood of the sire, being the fourtl generation from the original sire and dam. It may be formulated tlius: at one year from starting the herd, you have the first generation: at four years the second; at seven years the third; and at ten yenrs the fourth generation. They will grade as follows: First, one-half bloods ; second, three-quirter bloods: third, scren-eighths bred; and fourth, fiftecn-sixtecuth bred.

Besides these you will also have gencrations suceessively from the orig= inal cows, or scren-eighths, thrce-fourths and one-lalf bred heifers corresponding with the succeeding years from the first. If these again hare been bred to the same bull, or another pure bred bull, their produce will be respectively fifteenth-sixtecnths and seven-eighths bred.

\section{Ten Years' Producs.}

.. Let us now figure how much stock, young and old, will be the produce of this systen, allowing that none have died. In one year, from the ten cows and one bull, we have ten calres, five heifers and fivo stecrs; the second yeur, ten calves, the third year ten culves, the fourth yoar ten calves. This year we have also five calves, the produce of the first year's chlvês." The sixth year wo will have twenty-five ealves, the seventh year thirty', the eighth year thirty-five, the ninth year forty, and the tenth year' forty-fivo calves as the produce of the original cows and their progeny, making in all two hundred and forty animals ranging in age from calves to thirteen years old, of which one hundred and twenty-five should be femalos, 
Seloction.

Just here selection may come in. Some of the cows and thoir progeng will have proved superior beef makors or milkors, aecording as thoy wero criginally ehosen. Their progeny should bo earefully raised and bred. It may seem dreadful, this ineestuous breeding, but please remember, it is animals that are the subjeets. The records of the improvoment of animals and their erection into fixed breeds, will show very much eloser in-and-in breeding than this. The object is not only to throw the good qualities in a lump, but to fix them by concentration. Thus a eow bred during her whole breeding lifo to one bull, never having had contact with another, will bring her ealves nearer and nearer to the sire your by year, through the infusion of the blood of the sire into the dam, through intercireulation by means of the fotus, during its growth.

As showing elose in-and-in we find in the first volume of the Ameriean Herd Book a diagram of the breoding of Cumet from Hubback, and Lady Maynard. It is explained as follows :

1. Bull, Hubbaek.

2. Dam of Haughton.

3. Richard Barker's Bull.

4. Cow, Haughton.

5. Bull, Foljambe.

B. Cow, Young Strawberry.

7. Bull, Dalton Duke.
8. Cow, Lady Maynard.

9. Bull, Bolingbroke.

10. Cow, Lady Maynard.

11. Cow, Phoenix.

12. Cow, Young Phœnix.

13. Bull, Favorite.

14. Bull, Comet.

In relation to Favorite or Lady Maynard, Mr. A. B. Allen says : It was conceded by a company of old breeders in 1812 , in diseussing the question of the improvement of Short Horns, that no stoek of Mr. Colling's ever equalled Lady "Maynard" the dam of Phœnix, and granddam of Favorito (by Foljambe) and of young Phœnix (by Favorite, ter son, upon his own mother,) the dam of Conet 155) so eelebrated as having been sold for 1000 guineas $\$ 5000$ ) also by Favorite, a specimen of as elose-in-and-inbreeding as ean perhaps be found on reeord.

To show wonderful deptl of in-breeding with eontinued good results, the eow Clarissa may be mentioned; she possessed sixty-three sixty-fourths of the blood of Favorite. Her pedigree runs thus: "Cow Clarissa, roan, alved in 1814. Bred by Mr. R. Colling, got by Wellington (680) out of-by Favorite, (852)-by Favorite,-by Favorite,-by Favorite-by Eavorite-by Favorite-by a son of Hubback.

Wellington, the sire of Clarissa. was also deeply inbred with the blood 
of Favorite. Taking the two pedigrees - that of Clarissa and Wcllington together-they will read thus:

1. Bull, Hublanck.

2. Son of Hubback.

3. Cow, by son of Hubback.

4. Bull Favorite.

5. 1st cow by Favorite.

6. 2nd cow by Favorite.

7. 3rd cow by Favorite.

8. 4th cow by Favorite.

0. 5th cow by Favorito.
10. 6th cow by Farorite.

11. Clarissa.

12. Bull Wellington, sire of Clarissa.

13. Bull, Connet.

14. Cow, Wildair.

15. Cow, Young Plønix.

16. Cow Phonix.

4. Same bull Favorite on the side of Clarissa's sire as on the side of her dan.

17. Bull, Bolingrbroke.

18. Granddaughter of Hulback.

\section{Ixeroise Common Sense.}

In breeding so closely as we have advised it will be necessary that intelligeut judgment be used. The effect of in-and-in breeding is to refine and render delicate the constitution. Animals closely in-bred, in fact all highly bred animals require better care than those of a courser nature. They are not as able to take care of themselves, to shift for themselves; are in fact artificial. But on the other hand they will repay the care and attention bestowed, in increased profits for the food given. In in-and-in, or other very close breeding, care must be taken to give the animals an out cross as soon as you find they are suffering in constitution and hardiness; in fact when you find they are no longer getting better and better seck another sire, and so continue until you bave got animals fully equal to any thorough-bred for all practical purposes, and that shall at the same time be marked with vigor as well as the charncteristice winted, whether they be for beef or milk, or both.

Once having begum, however, with pure sires on mative stock, never by any chance allow a grade aninal to become a sire, no matter how good he may be. It can only result in loss, whitcver the attempt at iniprovement be in animals of any kind. In swine in-ind-in breeding may not be carried so close as in other animals. They are scrofulous and wenk lunged at best, and close breeding soon shows in the progeny. As a rule one-half or three-fourths bred are good enough to bring enhaneed profits over those usually denominated land-piles, a picture of which may bo found in another part of this worls: 


\section{Gestation of Cows.}

Thero has been nuch surmised first and last upon the subject of the length of time of gestation, and its effect upon the sex of animils produced. It is a prevalent. idea that if an animal gocs over her time a male will be the result: Let us sce how eareful records kept by scientific men will tally with this.

Mr. Tessier, a most accurate and acute observer for orer fortyn years, embracing various animals, gives results of over 575 cows and these oubsequently having been extended to 1,131 cows the extremes were not changed but results as to arerages are as stated below.

Upon the 575 eows the results were as follows: Trenty-one valved between the 240 th and 270 th days, the mean time being 259 days:"

Five hundred and forty-four ealved between the 270th and 299th days, the mean time being 282 dàys.

Ten ealved between the 299th and 321 st diny, the nean time being 303 days.

Larl Spencer has also earefully tabulated the period of gestation of cows as we find in the table on the following page.

In these 766 cows the least period was 220 days; the mean 285 days; the longest period 313 days. He states that he was able to rear no ealf rroduced at an earlier period than 240 days. Thus it may be aceepted that, aecording to Tessicr, a cow may earry a calf 321 days and produce it sound; and from the fact that Tessier and Earl Spencer agree almost vixaetly as to the meantime af gestation, (1,895 cows being observed), 285 days or nine and al lialf months may be taken as the average time of gestation of eows, slight rariations being allowed fron this for different breeds.

Earl Spencer was inelined to the belief that a cow would earry a bulk calf longer than a cow-ealf. "In stating the case, he says:

"In order to try this, the cows who calved before the 260th day, and those who ealved after the 300 th, ought to be omitted as being anomalous cases, as well as in eases in which twins were produced; and it will then appear that, from the eows whoso period of gestation did not exceed 286 days, the number of eorr-ealres produeed was 283 , and the number of bull-calves 234; while, from those whose period exceeded 286 days, the number of cow-calves was only 90 , while the number of bull-calve Tas 152."

The antlior, however, omitted to notice that all the calves born after the 299 th day were females, and of those born before the 260th day, 10 were fernales and 15 males. And again, omitting the twin-calves, 340 rero females and 401 males-a large excess of bull over cow-calves. 
TABLE RELATIVE TO TTE GESTATION OF COWS.

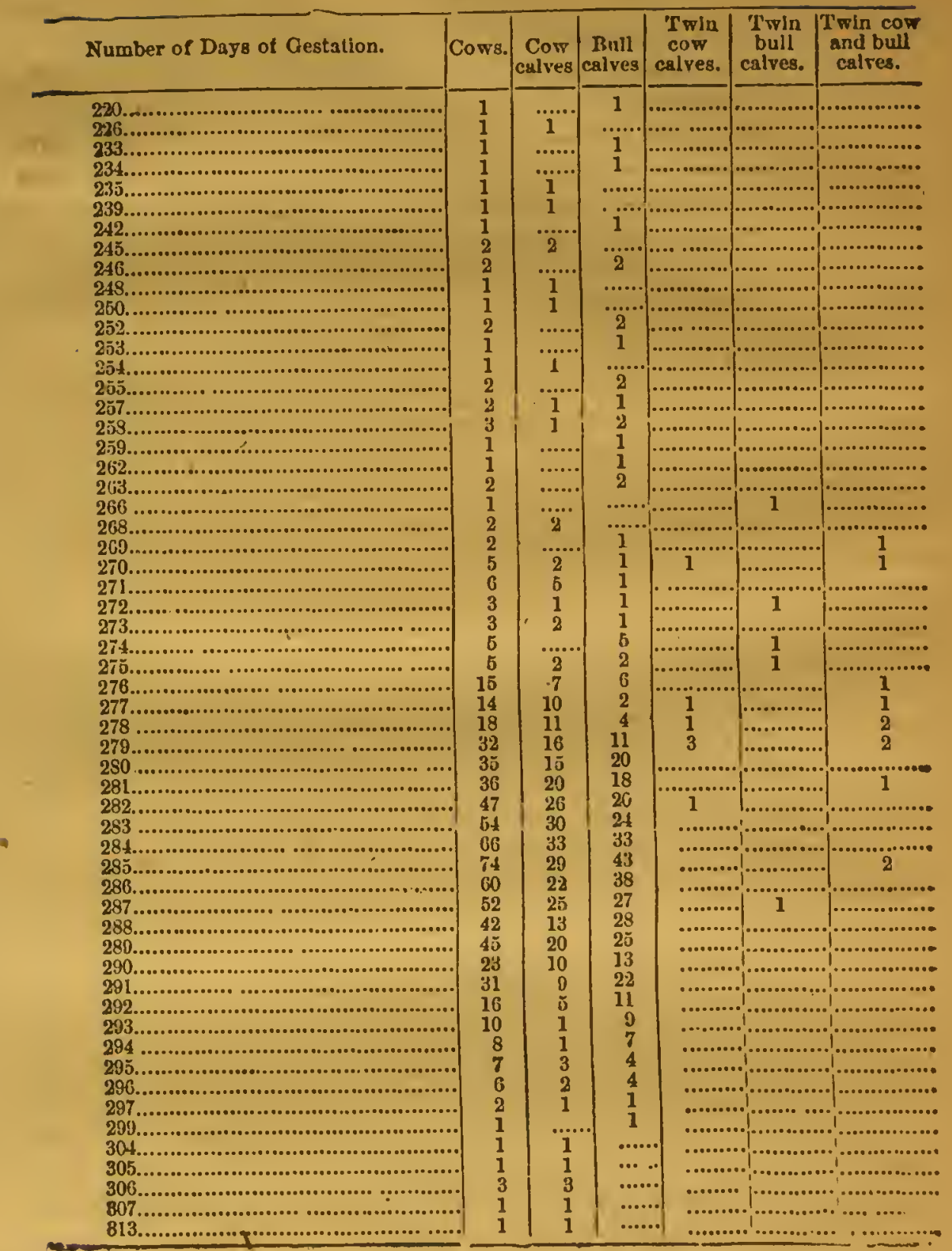


is also curious in this connection to note, that of the 764 cows, 23 pro duced twins, or one cow in $331-3$ of these; 7 cows had twin females; 5 , twin males, and cleven had twin male and fomalo calves. Those in tho twins produced their orrner 18 fcmale calres and 16 male ealves.

From the many facts collected in various races of animals, it is quite safe to conclude that the sex of the young has no particular influence on the period of gestation. It is more probable that heredity, sires, carly maturity, and various other integers in the problem, unay control tho tendency to long or short gestition.

\section{Food vs. Product.}

The value of an animal depends upon the profit it wiil give in comparison with the care and expense in rearing and fattening, in the case of becf cattle, and, of the cost of fecding, in comparison with the milk yield, in connection with dairying. In this we may safely conclude that an animal will produce less and less gain the longer it is kept, and thus carly maturity becomes the most important integer in the breeding of: stock, whether it be for beef or milk. The reason why the mature animal consumes more in proportion to gain than the younger one is, that it takes a certain anount per pound of live weight to supply wastc. Tho animal of a given age, according to breed and adaptability to fattening, can only arrive at a certain weight. Hence this ultimate weight reached, it will not increase. Long before this ultimate wcight is reached, the aninal will increase only in fat. Thus the flesh-forming element in the food is rasted, save that which supplies the daily waste in the animal cconomy. Thus from the data which we now present it will be scen how much may be considered necessary as food, under various conditions.

\section{Conclusions from Experimente.}

Prof. W. S. Johnson, in his report of the Connecticut Agriculturc Str. tion for 1877, gives the following translations from Dr. Wolff, a German experimenter. These, of course, must only be considered as approximative. They, however, will show as being the result of practical experiment-principles upon which ratios may be made up of other matcrial.

Dr. Wolff, in illustrating the standard for a milch cow, says that 30 lbs. of young clover hay will keep a cow in good milk; that this contrins of dry organic substance $23 \mathrm{lbs}$, of which is digestible-albuminoids 3.21, carbo-hydrates 11.28 , and fat 0.63 . This is $71 \mathrm{lbs}$. albuminoids more, and $.22 \mathrm{lbs}$. of carbo-hydrates less, with $.13 \mathrm{lbs}$. of fat more, than the standard. The richest and best meadow hay contains in $30 \mathrm{lbs}$. , of orgsnic substance 23.2 lbs., having digcstibie albuminoids 2.49 lbs., carbo-hydrates $12.75 \mathrm{lbs}$. and fat $.42 \mathrm{lbs}$. This comes very near the fecding standas\}?. 
Feeding Standards.

PER DAT, AND PER 1, 00 LBS. LTVE WEIGET:

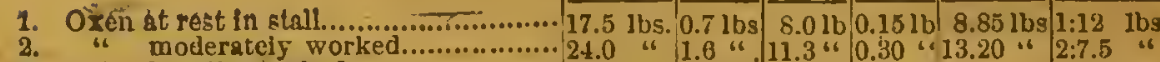

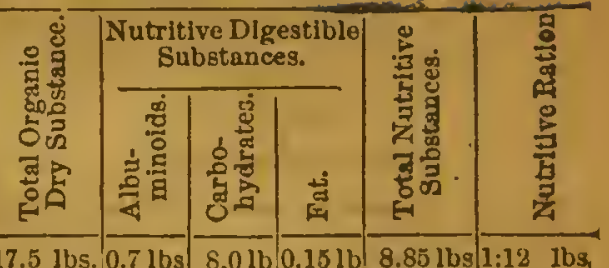

3. " heavily worked................... 26.0 " 62.4 "

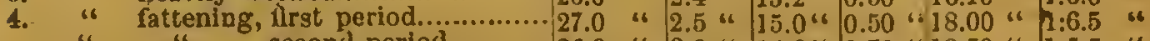

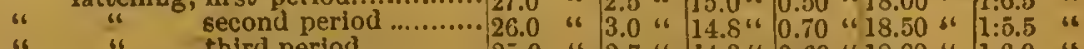

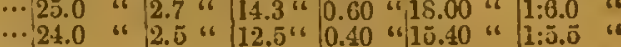

6. Growing Cáttle:

AGF-MONTHS. AYE. IIVE WT. PER HFAD

$2-3 \quad 150$ pounds

$3-6$

6-12

$12-18$

300

is

.......... 23.4

.........24.0 24.0

$18-24$

700

" $\quad . . . . . . . .24 .0$

.24 .0 66 1.6 "6 12.0 "6 0.3

" 2.5 "6 13.5 " 0.0

TER DAY AND PER HEAD,

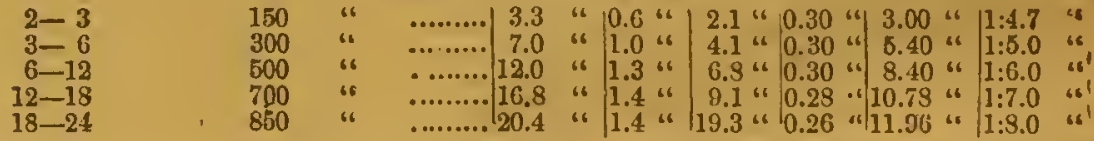

To show how a ration for milk cows may be arranged of various matcrial, ho gives the following:

Ration for Milch Cows.

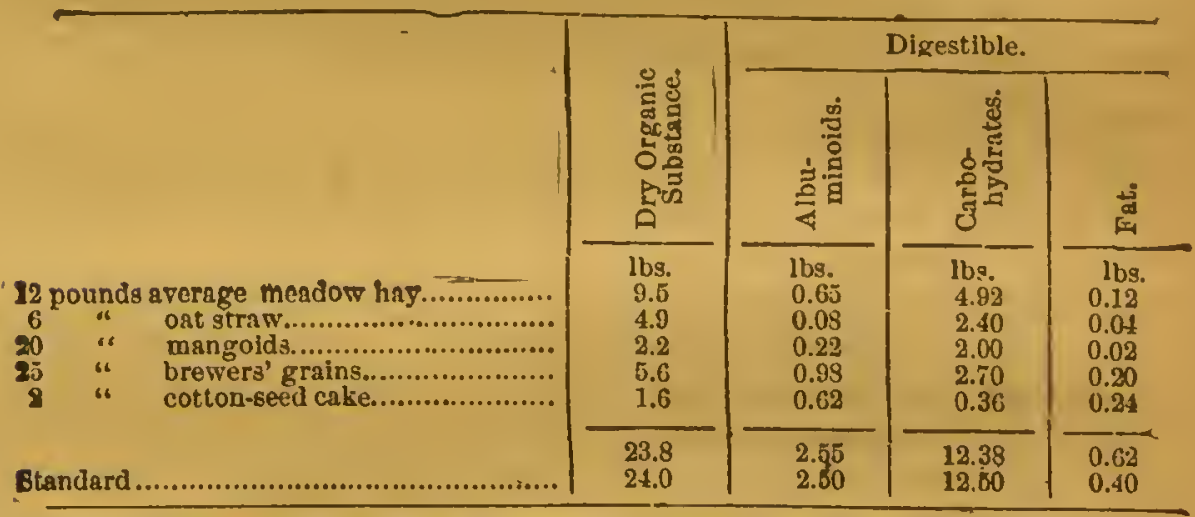

Prof. Johnson gives the following rations, calculated from the table:

\begin{tabular}{|c|c|c|c|c|}
\hline 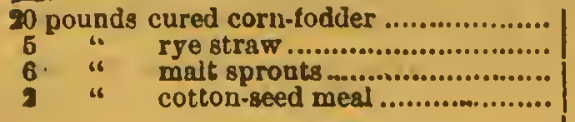 & $\begin{array}{r}13.7 \\
4.1 \\
5.0 \\
1.6\end{array}$ & $\begin{array}{l}0.64 \\
0.04 \\
1.16 \\
0.62\end{array}$ & $\begin{array}{l}8.88 \\
1.83 \\
2.70 \\
0.36\end{array}$ & $\begin{array}{l}0.20 \\
0.02 \\
0.10 \\
0.24\end{array}$ \\
\hline Qtandard.............................................. & $\begin{array}{r}24.4 \\
24.0 \\
\end{array}$ & $\begin{array}{l}2.40 \\
2.60 \\
\end{array}$ & $\begin{array}{l}13.56 \\
12.60 \\
\end{array}$ & $\begin{array}{l}0.56 \\
0.40\end{array}$ \\
\hline
\end{tabular}


Or, agaia :

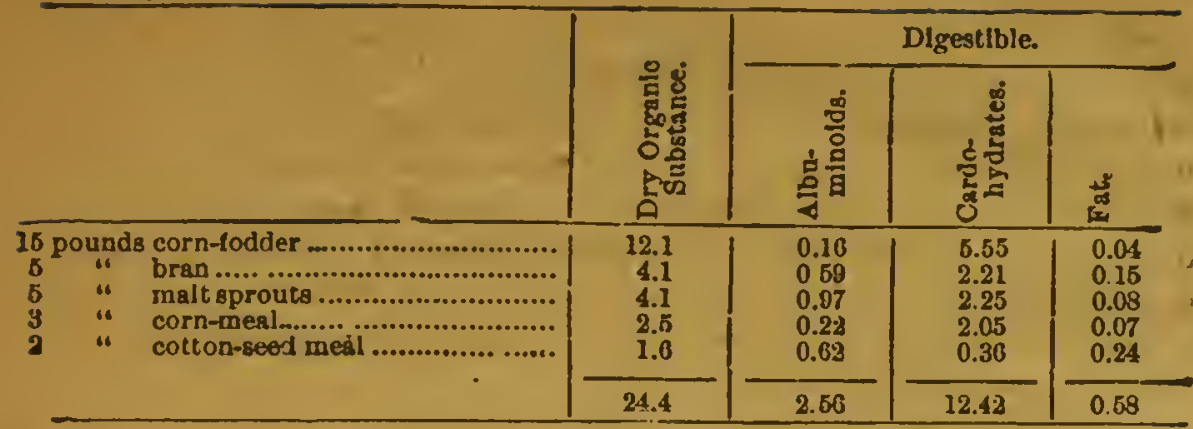

A eorrespondent of the National Live Stock Journal gives the followIng as a practical ration which he used to feed forty steers, weighing an average of $900 \mathrm{lbs}$. , and gaining $21-2 \mathrm{lbs} .$, per head, per day:

\begin{tabular}{|c|c|c|c|c|}
\hline 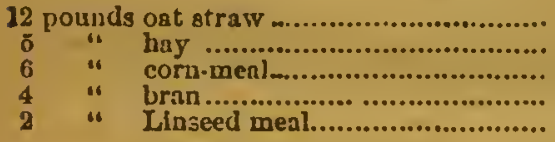 & $\begin{array}{l}9.80 \\
3.98 \\
6.04 \\
3.22 \\
1.61\end{array}$ & $\begin{array}{l}0.17 \\
0.27 \\
0.30 \\
0.50 \\
0.17\end{array}$ & $\begin{array}{l}4.81 \\
2.05 \\
3.04 \\
1.70 \\
0.70\end{array}$ & $\begin{array}{l}0.08 \\
0.03 \\
0.28 \\
0.10 \\
0.18\end{array}$ \\
\hline Standard for fattening cattle of thits weight & $\begin{array}{l}23.65 \\
24.30\end{array}$ & $\begin{array}{l}1.91 \\
2.23\end{array}$ & $\begin{array}{l}12.90 \\
13.00\end{array}$ & $\begin{array}{l}0.69 \\
0.45\end{array}$ \\
\hline
\end{tabular}

This corresponds quite closely with the German standard. The albuminoids we slightly less, and the fat more. Ono gallon of cheap molasses added to the rations of hay for forty head, would nearly bring up the carbo-hydrates to the standard. Again he says: The following is a practical ration fedoto 10 steers for 90 days : their average weight for the 90 days being $1,34.8 \mathrm{lbs}$.; and this was the average ration fed-the average gain being 3 lbs. per head, per day:

\begin{tabular}{|c|c|c|c|c|}
\hline 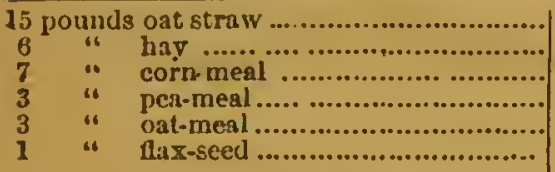 & $\begin{array}{r}12.25 \\
4.77 \\
5.86 \\
2.48 \\
2.48 \\
0.86\end{array}$ & $\begin{array}{l}0.21 \\
0.32 \\
0.69 \\
0.61 \\
0.20 \\
0.17\end{array}$ & $\begin{array}{l}6.01 \\
2.46 \\
4.24 \\
1.32 \\
1.29 \\
0.18\end{array}$ & $\begin{array}{l}0.10 \\
0.06 \\
0.33 \\
0.05 \\
0.14 \\
0.29\end{array}$ \\
\hline 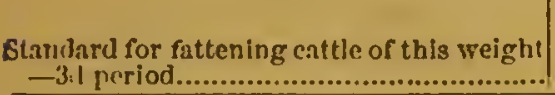 & $\begin{array}{l}28.70 \\
83.70\end{array}$ & $\begin{array}{l}2.09 \\
3.63\end{array}$ & $\begin{array}{l}15.50 \\
19.95 \\
\end{array}$ & $\begin{array}{l}0.97 \\
0.80 \\
\end{array}$ \\
\hline
\end{tabular}

This seems a wide departure from the German standard; but that all the conditions may be understood, it is stated that the corn, pease, oats and riax-seed, in the proportions siated, were mixed and ground togetler, and then $14 \mathrm{lbs}$. of the nixed meal was mixed with the $15 \mathrm{lbs}$. of oat striw, cut into inclı lengths, and all well eooked together; that is, 420 lbs. of the ground ineal was mixed with 450 lbs. of cut oat straw, piliced in a steam-box and well cookod with steam, and this served for throo 
days' rations for the 10 head, exeept that 6 jbs. of long hay was given to each at noon. Perhaps the explanation is, that the cooking rendered a so mueh larger per eentage diges ible, that it was, in effeet, equal to the German stundard. These steers weighed 1,210 lbs. when tho experiment began, and $1,485 \mathrm{lbs}$. at the end of 90 days; so that $1,348 \mathrm{lbs}$. was the average weight during the period. The meal ration was but $10 \mathrm{lbs}$. during the first two weeks, and inereased gradually up to $16 \mathrm{lbs} .$, at tho endrof 60 days; making the averago ration 14 llss. per duy.

As supplementary to this we give three rations applicuble to the East, South and West, in the order named:

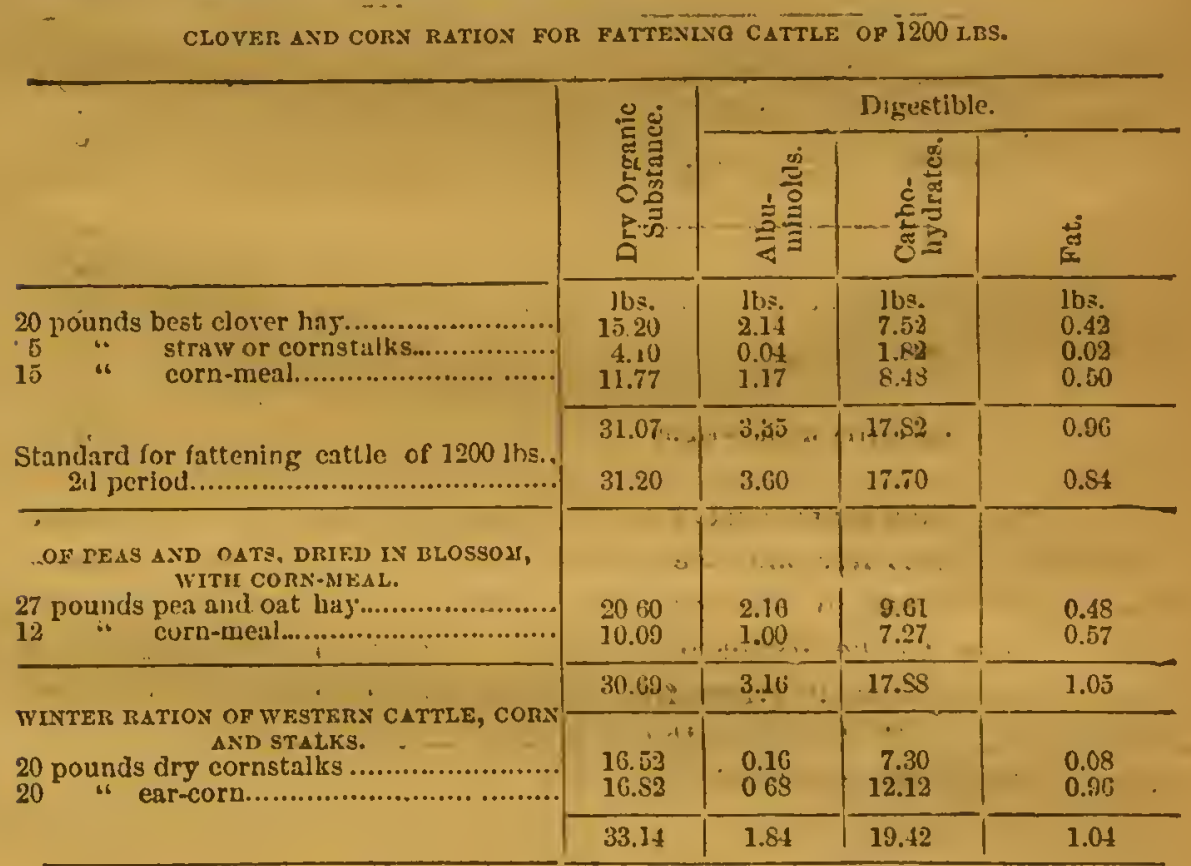

It will be of interest now to show the chemical composition, digestibility and money value, aceording to the German standard, for 2,000 lbs. of clover hay, meadow hay, eorn fodder, oat straw, oil eake, wheat bran, corn meal and oats. These foods, used more in the United States than any like number of others, are also eomplementary to each other: (Seo table on following page).

\section{Comparing $\nabla$ alues.}

The eomparisons of values by the ton of these very dissimilar foocls is 2. follows; We fnd clover hay worth $\$ 17.82$ and oit straw per ton; but it cannot be iaferred that oat straw would bo as cheap at that price as clover hay to make an entire food for eattle, or other animals, becauso clover hay is a well balanced food for catllo and oat stras is mily a 
RELATITE VALUE OF DIFFERENT ISLDS OF FOOD.

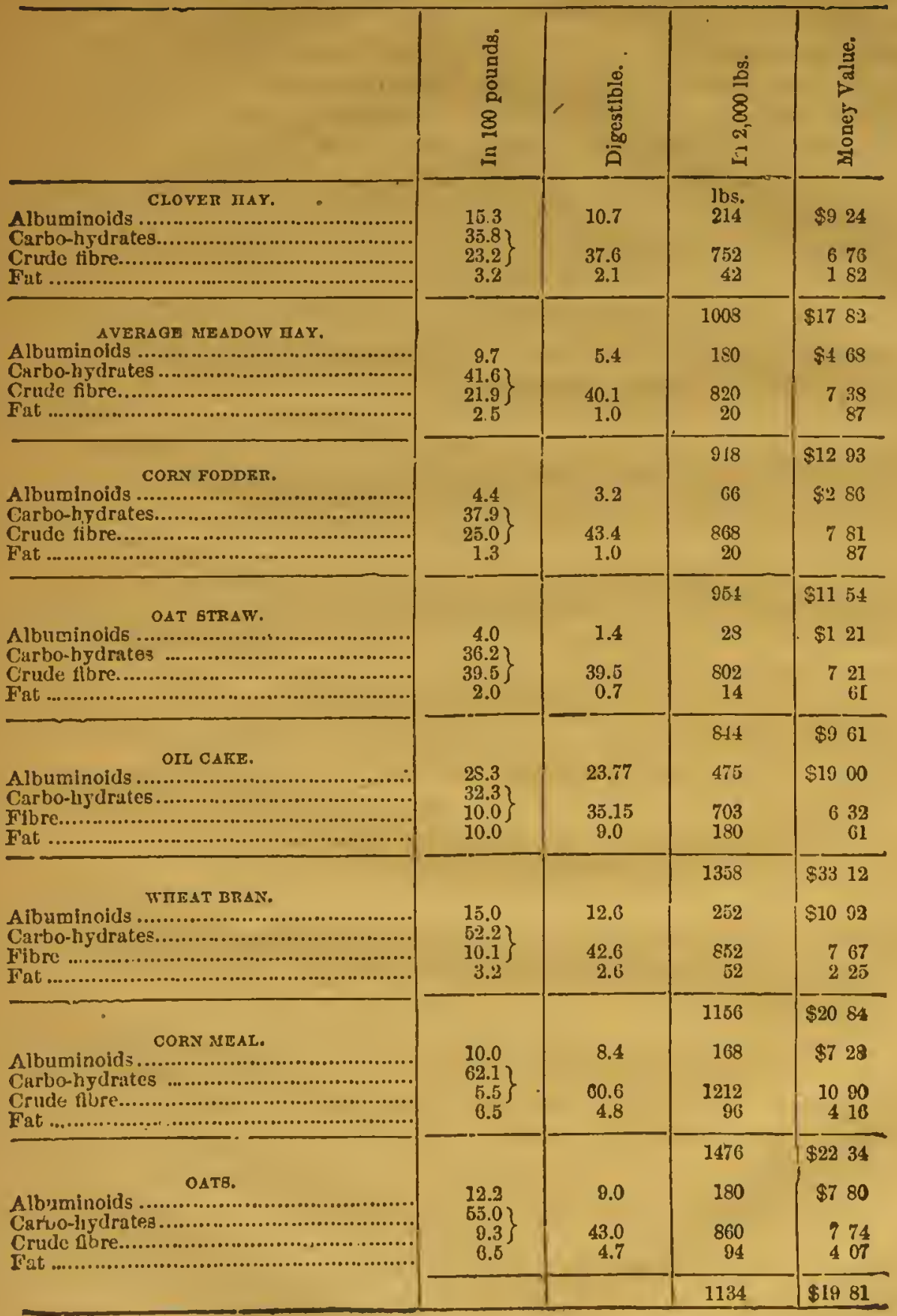


partial food, containing so little albuminoids and fat that cattle would starve to death upon it if fed long cnoigh. The muscles and nerves could not be nourished upon it; and yet a good article of oat straw is worth the price named, because of the digestible heat and fat formers it contains. Now, put a ton of tlic best oat straw with a ton of the best: ciover hay, and you have a fairly balaneed food. It compares well with common meadow hay. The digestible albuminoids in clover 10.7, in straw 1.4, malsing the two added 12.1, and the average per cent of the mixture is 6.05 , whilst meadow hay is only 5.04 . Tho digestible carbohydrates in the mixture is about 39.0 to 41.0 in hay, and the fat is 1.4 to 1.0 in moadow hay. The parillel is very close; and as the mixturo has slightly more albuminoids and fat, it may be considered the better ration. Theso valuations of tho different clements simply mean that each is worth the relative prico named when fed in due proportion with the other clcments. Oil-calie, for exanple, is as far from being a balanced ration as oat straw, for it contains as much too large a proportion of albuminoids as straw does too small. It has also oil in excess. Like straw it inust be fed with other foods. If $400 \mathrm{lbs}$. of oil-calke be mixcd with a ton of oat straw, the mixture will make a ration equal to meadow hay.

\section{Feeding Whero Corn is Cheap.}

When stock of any lind is lrept and fattened in stables, on ground or cooked food, these tables will bo found valuable. So far as our own expericnec goes we have found that for growing animals there is nothing letter than equil weights of corn and onts, or corn and barlcy, with what good hay or shocked com fodder they will eat. We have also found that whon corn was less than 30 conts per bushcl it did not pay for grinding eren for eattle, if it could be fed in the ear or in the husk, the experiments being based on the toll talien, and tho cost of hauling ten miles to mill. For shcep, horses, and hogs it will not pay for grinding when it is less in price than 40 cents per bushcl.

In all that great scope of country in the West known as the corn zone, the most conomical mumer we have ever found in fattening eattle was to feed, first, shock-coru; next, snapped corn ; and, third, husked corn in the ear. In feeding the two latter, the animal weighing 1,000 pounds should have about 25 pounds of corn and 10 pounds of best lay.

In fecding shock corn the animal will eat no more than it requires, and it should have twice a day whatever it will eat up clean, of cars. In feeding in this manner in tho fields or diy yards with abundanee of water, allowing hogs to run after the cattle after they have finished the ears, to pick up wasted corn and droppings-if the eattle are sleltered from wind and storm, they may be most ceonomically fed and to very beavy weights 
Here again tho breeder. must be guided by sound judgment... It will not pay to starverefen the commonest stock. A ealf, to use a eommon expression, s 4mooked in tho head with a pail of skimmed milk,", will never make a first elass steer or eow. Neither is it necessary that they suek the eow. In fnot; in the easo of dairy eows or heifers intended for the dairy, they should not suek, for it surely tends to diminish the flow of milk, execpt tho ealf is turned with the eow at stated intervals, and the eow milked elean at the "samo time. In the easo of heifers, they should be milked as soon as the ealf has drawn the first milk, both as a means of training and to develop tho fiow of milk as mueh as possible; besides this; a ealf taken at two or three days old is easily taught to suck tho finger or an artificial teat attached to a reservoir.

\section{The First Two Weoks,}

They should hare nothing but new milk. It should be as warm as it eomes from the eow, and the ealf should be fed four times a day. Then they may havo milk twelve hours old, from whieh the eream has been taken, adding four ounees of finely ground meal made into thoroughly cooked mush, to each incal, for strong, hearty ealves. Thus they may be fed for two weeks more, changing to oat-meal or wheat flour if the calf is inelined to scour. Some feeders add a teuspoonful of linseed meal onee a day. It is not a bad plan. When the ealf is four weeks old it need be fed but twice a day, giving milk warmed to about ninety or ninety-five degrees, which last is the natural animal heat. From this time on more and more mush, or its equivalent may bo added as the ealf inereases in size and strength, until it begins to eat grass and threshed oats, which it should be encouraged to do.

\section{Feed Early.}

At ten weeks old it should eat freely, and at three months old it may be gradually menned from milk and taught to subsist on grass and oats. - During all this time the ealf should be sheltered from the hot sun and rain, by providing a shelter to which it may retire, well ventilated, dry nud elean, and sufficiently dark to keep out green-head and other biting flies. In the autumn its rations of grain should be inereased, and as grass fails the finest meadow hay should be substituted-whatever it will eat elean of both. Offer it water oecasionally after it is a mouth old, and when weaned see that it uover lacks for water. 


\section{Figı ring Profts.}

During the winter knep tho calves in the warmest quarters flossible: fced liberally with grain and hay, and in the spring you will huve the satisfaction of knowing that you huve received the best profit that you will ever reap from the animal at any subsequent age; but upon comparing debit and eredit with your neighbor who has fed skim-milk alone in sum-1 mer and poor hay in winter, you will find that the loss on his calves lias gonc in the shape of profit in yours.

From this time on feed liberally of grain in the winter, and give a little all summer when they will eat it. Let them in winter be so warm that they never become chilled. So continue until the animal is within six months of being ripe for the butcher. Then feed the best you can, and you will bo rejoiced to find that you may get two to three cents a pound gross weight more than your neighbor who hus only balf fed and has turned off lis cattle totally unipe for the butcher.

-The same rulo will hold good for those calves intended for cows. To make a good cow, she must be fed well to bring carly development and maturity. She may thus be brought forward strong and lusty, and in better condition at two years past to bring you a perfect calf, than those of your neighbor at twice that age, whose policy has been to grudge them feed and allow them to shift for themselves.

\section{Castration.}

Whon the ball calves are three wcelss old, if in good health, they should be castrated. It should certainly be done before they are four weeks old. Many of our best stock raisers incline to the opinion that as soon as the calf begins fairly to gain size and flesh, say at two weeks old, is the proper timc. We have never had better success than at this time. Every person who purposes to breed eattle should know how to do this. The operation is quite simple, and easily performed.

Secure the calf so it may romain standing on its foet, but cannot strugglo severcly. Have a knife ready with a kecn-edged blade. The blade of a ' hudding-knife is the proper shape. Seize the scrotum from behind, and with two light, swift, sharp strokes cut through and into tho testicle. Separate the mombrane where it unitcs, pull the testicle out until the cord shows from four to six inches, and cut it with a pair of nippers or rather dull shcars. It mill save loss of blood. So operate with the other, and the work is done. If from any cause severe bleeding onsues, injcct a little timcturc of muriate of iron into the cavities, and wet a soft rag with the tincture and press it wcll into the cavity. If these be not at hand, push a littlc salt and lard into the cavity. If the operation has been care 
fully performed, nothing will generally be required. The calf should bo kept fice from interference by other animals

\section{Until the Parts are Heoled,}

which will ususlly occur in a week. If they have becn used to the com-1 pany of other ealves, they should not be deprived of it now, elsc they will pine. One reason why wo adrise early gelding, is, it should be dono before the calf is taken off of new milk, and it should not bo doprived of the ratural milk until it reeovers from the shoek. Care must. be taken that flies do not get near, to deposit their eggs in the parts operated on. To prevent this, if there are flies, keep the ealves in a pretty dark, but vell ventilated place. Most persons will find it awkward at first to gold as $\pi c$ have directed. A little praetice, however, with tact and firmness, will render all casy, especially if ono can have thc advantage of sceing an expert operate once.

\section{Sometimos Suppuration Ensues.}

In this case recourse must be had to mild palliative measures. Kecp the parts washed clean, twice a day, with warm rainwater and castile soap, und injeet a small quantity of tineture of alocs and myrrh. If the parts become unhealthy, or uleerated (for mero suppuration is healthy action), wash with a weak and clcar solution of sal soda, or hard wood ashes. If proud flesh should arise (a rare occurrence), burnt alum, pounded verJ fine may be applied, or the parts may be touched with luarar caustic. 


\section{CHAPTER III.}

\section{PRAINING AND WORIITG,}

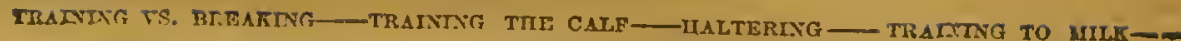

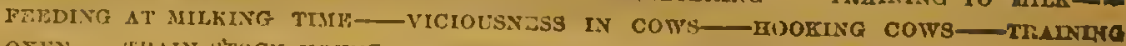

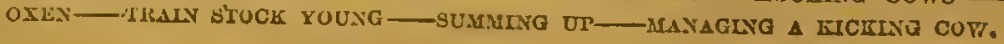

Training Cattlo vs. Brcaking。

The word "brealing" horses or steers to work, or breaking a heifer in to milk, has now-a-days become pretty well obsolete. Breaking by bruto force may male a kind of a machine of an aninal; it may do stupidly

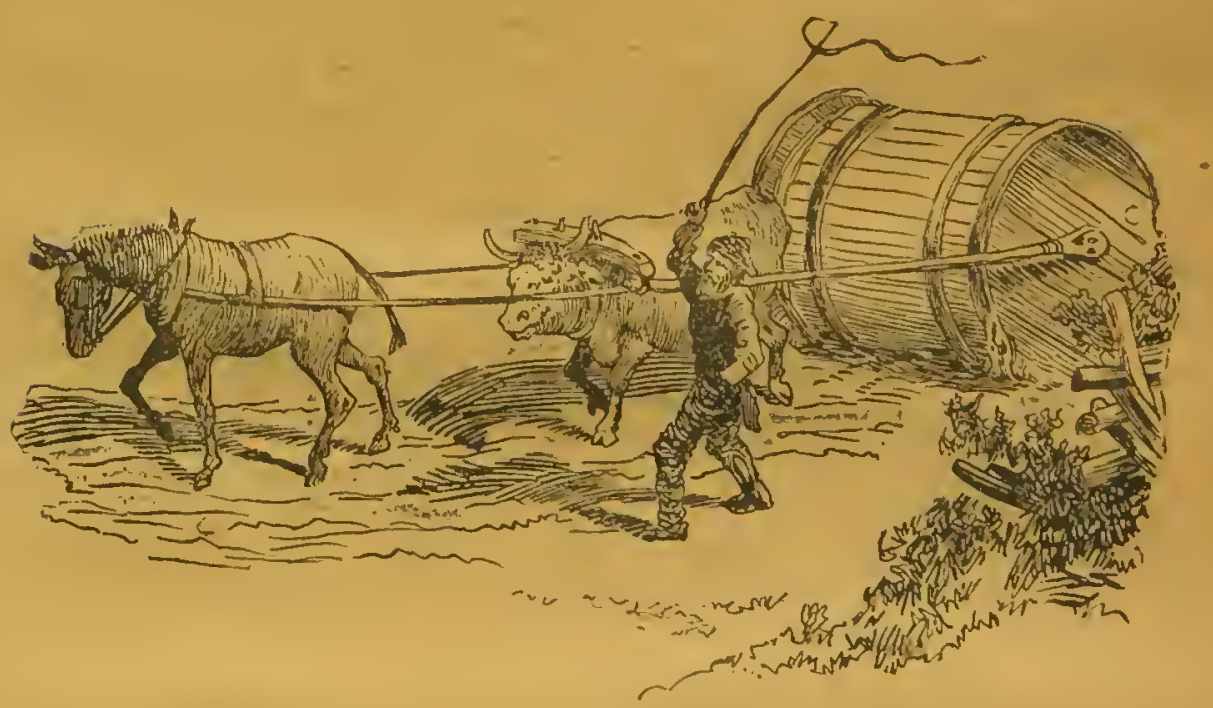

FORKUNG BY MACY FORCE. 
what is destred, and yet not do it to the best advantage. Intelligent per sons now do not break an animal by destroying its will, they simply make it subservient to that of man, by letting it know at the first hampering for training that it will not be hurt, if it does not resist. All domestic animals are naturally subservient to the will of man; they require to be taught what is wanted, and the individual should know that no good can come out of any system of training which compcls the use of tho whip constantly. The whip is necessary only as a means of correction, when an animal is refractory after understanding the will of the master. An intelligent trainer will casily distinquish between stubborn antagonism and a want of comprehension. We have sever seen young animals stubborn, except that they did not understand what was wanted of them; and in animals that have at length been made to work in the yoke, or to stand quictly to be milked, but which have " freaks," as they are called. when they seem wild or stubborn, it is usually the result of bad treat". ment in "breaking," and the aninal is actuated almost solely by fer.. If, in the struggle which ensues, the animal becomes master, it is there. after of but little use. It is better in training that the struggle be noli paado necessary

\section{Training tine Calf.}

If the ealf has been raised by hand, that is, fed with milk from tho pail, it will, or should have, become so gentle and familiar as to allow itself to be approached readily, and to respond to the call of its master. Many persons at this time name every ealf, and thus they soon come to know their names when ealled. If firmness and at the same time gentleness have been used, so that the calf will understand that there is nothing to fear; if no struggle is made, it is well on the way to understand what is further expected of it. It should be rubbed and curried occasionally, especially on those parts of the body that itself eannot reach, as the head, neck and shoulders; or, if kept in the stable constantly, it should be brushed all over at least once a day. Here is one of the first and most importaut lessons. At first, the calf does not know what is intended. If the master gets angry and beats it, it will ever after associnte currying and brushing with a beating; and when it gets older and otronger, in the constant successions of struggles to escape punishment, it will at length find it is the stronger animal of the two. Thereafter itself and not the nian is master. The object of currying is not to give pain. It is an operation of elsaning that the animal cannot perform for itself, becauso confined in a stable. If the animal is turned out during 
the day, and confined .only at night; or if, it have the range of the yard and sheds day and night, the eleaning is not needed. Animals can and do perform these offiees for themselves and for each other by lieking, so far as is neessary. The aecumulating seurf in an out-door life is a provision of nature for the protection if, the animal. It should not be tonehed. In the stable, however, it is different. The lack of exercise tends to a sluggish movement of the blood, and henee a elean skin bocomes one of the most aetive integers in preserving the health of the animal. In using the comb or brush, or, in the ease of eattle, the eard and brush, light hand with the eomb and card will do better work than a heavy hand. It should be unnecessary to say that about the bony parts the eurd or eurry-comb should never be used.

\section{Haltering.}

The first thing a calf should be taught is to stand quictly when tiod, and under all eireumstanees. If it is taught this by being tied up immodiately upon being taken from the eow to be fed milk, or at from three days to a week old, there will be no diffieulty. If ${ }_{\text {, the ealf has run with }}$ the cow, it will be strong and lusty. In this case, the lot if they are to be stabled, should be put into a elose pen, and a strong halter fastened to the head, of one of them, using diseretion and time so as not to frighten the animal. Onee seeured, two men will easily plaee it in position iu the stahlc. So proeeed until all are handled. Here they may be gently laindled until quieted, whatsoever the manipulation.

The next step will be terehing it to lead. Take it into a closely feneed yard, having the ealf haltered at the end of a ten-foot ropie : stand in front iof it and utter the word "eomc." Of eourbe, it will not move. Utter ihe word again, ard at the same time let an assistant tap' it lightly with a huggy whip on the legs, from behind, or hold the whip yourself and tap it.on the forelegs at the utteranee of the word. The animal will sooll u'yderstand what is wanted and eome forward. It should then have something it likes, the least possible liek of salt, for instance. From this time on you will have no dittieulty in teaehing the ealf to follow quietly; in fact it may be taught to do many things : to baek or come forward at the order: to turn to the right or left. In faet, it should be half broken to milk bo fore it has had a calf, or should be half broken to labor before the yolko
is put on.

To illustrate the differenee between this plan of uniting iirmness with gentleness in the training of cattle, one has only to ohserve the difference in cattle on different farins. The stoek of the brutal fiamer will never willingly allow the owner to came veur them. If 8 master's snimal be in 
a corner and he approaches, there is a dash to eseape, and perhaps somo young animal is maimed. Such stock soon aequire the habits of their master: they are morose, ugly, often vicious; for in a herd under bad management animats sometimes get the better of the master, and are apt to become breachy, trieky, and genorally unmungeable.

\section{Training to Milk.}

In training to stand quietly while being milked, the udder should be often handlea while the hoifer is growing up; the bag should be rubbed; it should be pressed and tho teats gently pulled, This need tilke but very little time. ?he real worl comes when the animal is to be milked. There are many things to be taken into consideration here. The heifer must bo put in a pen whôre she cannot hurt herself, und where the milker can ops erate easily; a pen just long enough and just wide enough for the heifer to stand in, five feet ligh and tight enough so there will be no danger of the heifer injuring herself, and witl an opening for the milker to operato through, will thoroughly subdue the waldest. Generally, all that is needed will be to tie the lieifer

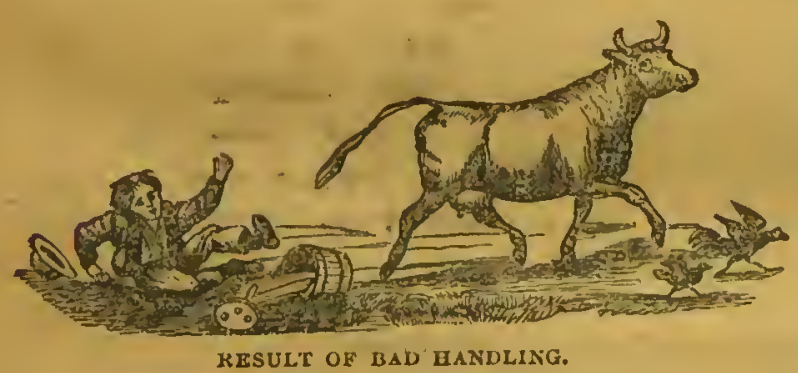

RESULT OF BAD HANDLING. by the head, and then patiently show lier that she will not be liurt. She will soon eome to associate the act of milking as easing the udder and thenceforward will stand quietly, unless the bag

or teats hurt her. If so, seck the eause of the difficulty and cure it.

If the animal hes never been tied up, but has been handled in the yard, one person may take the heifer by the horns, while another milks. If she be very refractory she may have to be "nosed." Seize the off horn firmly witl the rigit hand, and thrust the two first fingers and thuml, of the left hand into the nostrils, elasping the nembrane tightly if she otruggles severely. So soon as the struggles ecase, ease the pressure of the fingers in the nostrils. If she again struggles, again tighten the grasp. Let the milker use geutleness. It does no good to kick an animal ; it may do much harm. If the heifer kiek, it is probably becauso she is hurt. A person of ordinary strength need not be kicked whilo milking, unless in the ease of a eow of extraordinary strength and vielousness. The wrist of the left hand holding the teat, if kept well egainst tho stifle, and pressed firmly back when the foot is raisod, will 
Generally cause it to be set down in place again. Uso soothing words when the animal is quict, and low but firm words of eommand when refractory. If the udder is influned, as is very often the ease soon after culving, bathe it eurefully with cold water, so as not to shock the animal. She will soon conne to associate a fecling of relief with tho operation and like it. In fuet, the whole art of training may bo sunmed up in the 'sentense: Use discretion and judgment, and show yourself superior to the brute-in truth, its friendly master. The eonquering of brute foree by brute force is a relic of barbarism. There aro vicious animals as there are vicious men; there are dingerous animals as thero are dangerous men. Both may lave been bred or edueated thus. Vicioue men are placed where they camnot injure their fellows; vicious animals 1 e,d better go to the buteher-they are as unprofitablo to breed from as jucy are useless for what may be got out of them.

As showing the effects of bad and good handling, wo give the picture of a eôw made wild and ricious by bad handling, and that of a eow used to kind treatment and gentle but firm handling. The reader ean draw his own eonelusions as to which is tho best system,

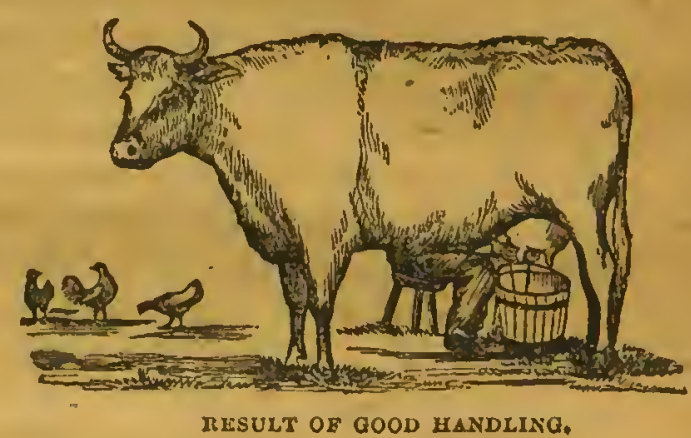

Foeding at Milking Time.

Some persons, to induce gentleness, give tho cow a mess before sitting down to milk. This is a bad plan. It leads the animal to expect it, and if it is not given, even if she is gentle, she is restloss and diseon. tented. The very aet of feeding indueos moving about moro or less, and prevents standing as quictly as sho otherwise would. On the other hand, if she be fed after milking time she will stand quietly and entirely at ease. Many good handlers feed beforo millking. By tho time the whole are fed and the stablo eleaused the eows will havo finished and ho ready for milking. This is the plan wo havo always pursued, and wo think the better one: Before sitting down to inilk we have been aceustomed to have the milker givo the eow to be nulked the slightest liek of salt froin the hand, or a single mouthful of extra niee soft hay. When you begin milking do not intermit until the eow is milked entirely elean. Milk fast. Slow milking not only worries tho cow but teuds to dry he 
np. If the mills is not drawn as fast as it is given down it is apt in the end to bo withbeld.

\section{How to Milk.}

Supposing the corrs to be in the stable, after feeding, and cleaning tho stable and the animals themselves, carefully wash the udder and teats, if they are dirty, or thoroughly brush with a soft brush, or wipe with a cloth if only dusty: Sit down quietly on the off or right side of the cow, the face slightly to the rear ; take hold of the rear teat furthest from you with the lcft hand, and speaking the word "hoist," slowly and in a low but firm tone, press the arm against the $l \mathrm{cg}$, to carry the foot in placo slightly bchind the other. In milking, grasp the upper portion of tho forward teat nearest you, so the hands operate the teats diagonally. In grasping the teats, do so well up towards tho bag, according to the length of the teats, with the thumb and forefinger, and pulling gently down, at the same time, close tho other fingers, thus forcing out the milk. So proeecd, first with one hand and then with the other, until the milk is pretty much diawn. Then change to the other teats and finish them.

In stripping do not use the thumb and finger, pulling the teat from the root to the cnd. It is a senseless plan. Every drop can bo had by pressing the top of the hand well up under the bag, gathering the milk with the thumb and forefinger, and drawing the millk with the others.

\section{Viciousness in Cows.}

Scmetimes a person will have a cow that is given to viciousness from bad training, and which may be so valuable in other respects that the owner may not wish to part with her. She may be a kicker. If so, and she be strong and decidedly ugly, use the following apparatus, which will explain itself, and which, by the lever and notches, may be made to grip tightly into the flank. Another plan is to draw a strong cord quito tightly around the girth. Tho most usual plan, in the stable, is to buckle a strap around the legs and to fasten it to a ring in the wall behind, so the eord will be loose when at rest, and yet so tight that the cow cannot gei her leg forward to do mischief. The cut we give will show the first device mentioned and the manner of fastening:

\section{Cows Sucking Themselves.}

Sucking themselves is another bad habit which cows sometimes acquire. There are two objections to such cows. The first is, we lose their milk, ad not rarely othor cows will acquire the habit from them. It is a woll 
known fact that self-sueking cows aro generally good milkers. It is quito certain that they acquiro the habit from the fuet that the milk pressure in the bag lurts them, and in rubbing the udder with the nose they at length get a taste of the milk, and thus become fixed in the habit. Hence the necessity of regular milking, and often enough to keep the udder from

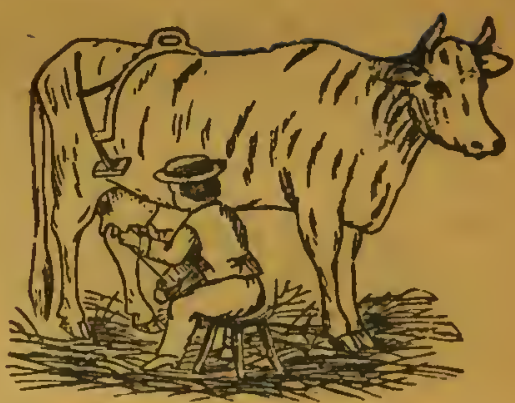

TO IREVENT A COW FROM KICKING. being unduly strained. Thero are various devices for preventing this vice. One is a haltor and noso pieee, with spikes, similar but larger than thoso used upon ealves to prevent sueking. It is given below, but besides lampering the animal to a considerable extent in gathering her food, it is not always effectual.

A very simple, and said to bo effective incans, is to take a tough hickory stick, fourteen inches long, three-fourths of su incli thick in the center, sharpened to a point at each end; cut a grove around the center, half an inch wide, and half the depth of the thiekness of the wood. Whittle eacl cond nicely to a point, or leave it somewhat blunt, and insert a sharpened piece of wire in each end. Make a hole in the animal's nose, in the soft portion, but close up to the lrard membrane of the nostrils, as you would for ringing a bull, and small enough so it

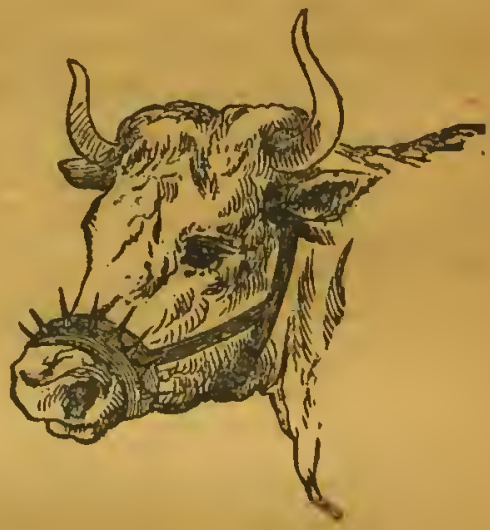

TO PIEVENT SUCKIVG. will require eonsiderablo pressuro to slip the bulgo of the stick until it reaches the middlo notch, when it will remain fixed. This does not prevent the animil from feeding, 11or being fastened in stanchions, and it must bo an inlveterito sucker that will draw her milk with this jewel in hor nose. Still another but moro eom plicated yet quite cffectual plan is given in the eut on wext page.

\section{Hooking. Cows.}

Another vicious habit sometimes acquired by otherwise exeellent enws. is the viee of attempting to gore every animal that comes near, that they can master, and cren individuals. Various devices have been recommended to prevent this. One is a bar aeross tho horns, to which is 


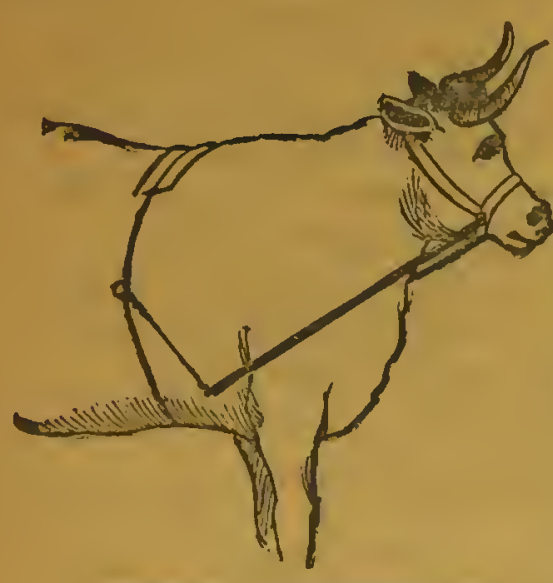

HARNESS TO PREVENT SUCKING.

fastened a slender, springy piece of Lickory to reach a position just above the nostrils and armed with a sharp peg underneath, so that the slightest prossure will cause it to wound the nose. In a majority of cases balls placed on the tips of the horns, and which may be purchased at any hardware store, will suffice, if the animal is not vicious to mankind.

Tinese are made to screrv on. To do so fasten the cow securely, and if the horn is too large to take the ball pare it down till it will fit. Stick a large potato baked soft, and thoroughly hot, on each tip of the horn. It will soon soften it, when tho ball may be easily screwed on with the proper tool, and will never come off. In the case of animals vicious to man, the following device, which the cut fully explains, will prove entirely effectuil.

\section{Training Ozen.}

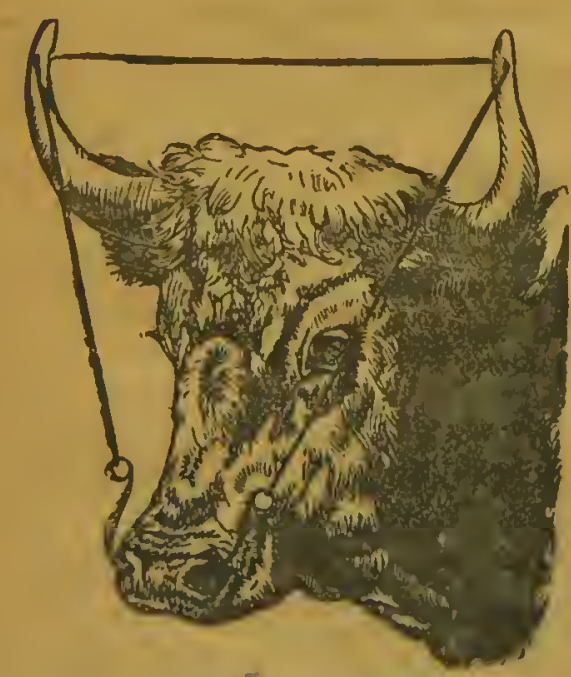

TO PREVENT HOOKING.

The value of a working ox lies not only in its ability to draw a heavy load fortward; to be thoroughly good in mud, or on roads; to be able to back whatever he ean draw forward, and to be quick-paced. It is truc you cannot makc a slow breed fast, nor a lazy ox activo; neither can you make an ox that lacks muscle do heavy work. If the reader has studicd the characteristics of the Devons as we have presented them, he will bo pretty well ablo to judge whether án animal under inspection will be fis for the yoko. If not fairly perfect in the principal points, discard him.

It will not pay to train an inferior steer. If he is to be used for very beary work, agility must to a considerablo degrce be sacrificed to weight and muscular power. As a rule, however, it is better that you uso tisreo 
goko of medium sized active steers in the team rather than two yoke of hoavy, lubserly, snul-paeed brutes that are always vexing the driver.

Select such as will wa!k evenly, look as nearly alıke as possible so that they may be hitched togcther : first, for disposition, carriagr, and pace; and second, for color and gencral appearance. If they arc thrce years old, and to be put to work immediately in a breaking or freighting team, Belect $n$ puir of mates, hamper by first roping and tying, and then yoking, together. So proceed until you linve the tean, whatever the number; made up Once voked, they slovuld not again be released until they cease strugoling, and work quictly in the team. "asten them together, threc, four, or five yolze, as the casc may be, putting a well broken stcady yolic of oxen on tho lead. Thus you may have a team in a few days that will lcarn to puli steadily forwird and turn "liaw", or "gøe"

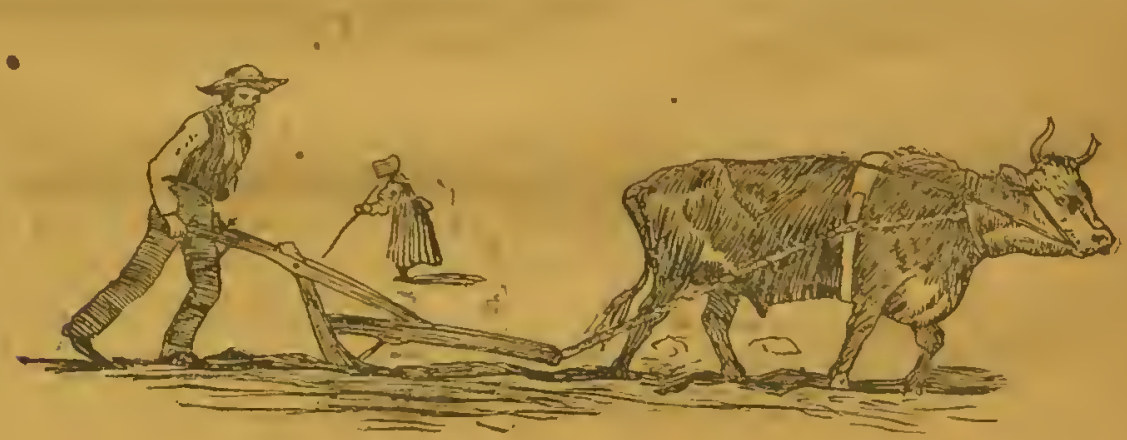

A IRLMTIVE TACILE, BUT GOOD TRAINER,

- to the left or right - as is wanted. They, howerer, will never becomo a team, in tho sensc of the word, as used by those who know what a trained yolke of oxen are.

To properly train stcers, they should be taken when quite young. Selecting one at a time, halter-break him as hcretofore directed, ciluse him to come close to you by tapping him on the forelegs with a light whip. Teach him to walk quictly, but at a quick pace, at your side, you bolding him lightly by the halter, ncither before nor behind, but drectly and closely at your side. Make him turn to the right or left at will, and teach him to stand quietly when so ordered. In all this do not hurry. Be quict, low-voiced, patient but firm. Angry demonstrations and outeries may producc some spnsmodic results, but the real, paticnt, working forec of, the auimal will not be brought iato eflective opcration by asy such means, 


\section{Train Stock Young.}

Let the steer, which should not exceed one year old-eight months is better-bo taught one lesson at a time, and that thorougiiiy. It will renaer the next lesson easier. When they are quiet and will do your bjdding : I the yoke without halter or strap, they may be left until three years .ld before being worked, though it is bettor to begin at two years of age, sepecially if thoy are to be used on the wagon. They will not pull much, iut they may thus bo taught to walk fast, to do their share of the work, and to become thoroughly " way wise."

The greatest difficulty in training oxen, as a single yolke, is teaching sem to back promptly and well. To do this requires patience. Never overload them. Make them back promptly twelve to fifteen feet at a ime, and then come forward, stopping instantly at the word, with beads wp ready to back again. In traveling along the road nover allow them o flag, nor exert thom so long at any one timo as to seriously weary whem. Patience alone will secure the end sought. When you have occaoion to speak sharply to them, do not let it be in a'very loud voice, but 'at it be accompanied by a touch of the goad or a blow of the whip sufsiciently sharp so the animals feel it., To touch both animals so near zogether that it seers almost simultaneous, is a fino art. It is acquirsd iy always touching the slow ox first, for scarcely ever will two animals io found so evenly matched as to be exartly alike. When you find them jou have a prize. When not so, we have always found it best to Lave the slower ox on the near side.

\section{Bumming Up.}

In summing up the whole matter of training, the individual must keep tho points aimed at steadily in view. First, the animal must bo rendered nntirely subserviont to man, and this by showing it that man is its friend; that under no circumstances is it to be injured. A well traincd yoke or a team of cxen will command a fancy price as easily as a well trainerd spars of horses. There will be, for maly years to come, uses to which re: : Ser horses nor mulos are so well adapted as are oxen. In lumbering, capecislly in breaking prairies, in much of the work of the farm, and fo: teaming in wild regions generally, where there is nothing but rank, wild girasy feed, they will be incispensabio. In these cases the traincd team will do one-third more work than the untruined team, and do it easier fos themselves, and much more satisfactory to the driver. Here again tho driver should be himself trained. A brutal driter will soon ruin a goed team, zet cannot entirely destroy their valuo. 
An intelligent driver will accomplish what he wants vithout uaduo severity; his voice and signs are the potent powers. In starting a beavy load each ox is ealled by name, howeve: largo the team be:' They under. ofand that they aro to place thenselves in position 'for action; every clain is straightened, every musele is brougkt into tension " they get well iato the yolkes, and at the signal all start togothor. With sareh a team the load must oome.

So with eows. The training of the heifor is begun in calflood: sho' luans to rely entirely upon the master. They know his voice either in the va'd or field, and eome elustering about him, expecting some "til-bit,"! or at least a kindly word or earess. When tho first ealf is dropped thero is no fear of the master; he may tako it and do with it what he willcnly fond solieitude is shown. Let a stranger conı about, and instantly this solieitude is ehanged to fear. If a person who has beaten them cr otherwise ill-rised them approaches, the foar is intensified, and if he offer: to bandle the ealf, a battle for the mastery is likely to ensue.

Wo have never had any trouble in teaching a heifer to stand to hit milked. If the wàder is tender, as in nine cases out of ten it will be, they will gently submit to the means used for relief and secm grateful for th/s effort. If strange Loifers are to be operated on, the first thing to teaeh them is, that you are a friend; whatever the timo it takes, whether half an hour or half a day, do not intermit the effort until the animal is subdued. If refraetory it is better that the heifer or cow be ticd up at oneo sad kept there until entirely quiet and without fear. . Then fully half the work is done and the subsequent work is only a question of time and of: patience.

\section{Kanaging \& Kioking Cow.}

Wo onee subdued an unusually refractory and kicking cow, by having ner held firmly by tho head while we seized the teats firmly one with eaeh hand. There was no attempt to milk. The lesson to be given was that she eould do no injury by kicking. It took threc-quarters of an hour to accomplish tho objeet. When she kicked the grasp was tightened; the wrist was brought baek firmly against the leg above the hoek. When she ceased kieking the grasp was relaxed, and the motion of milking was performed so far as pulling gently on the teats when sho kieked, or rather aitempted to do so by bringing her foot forward. She soon found it was invarably hrought down again nearly in its proper position in the rear of its inate. In the end she gave up and submitted to be milked. Ono now lesson she had to learn, to stand without holding. This was accomplished by following her about until she was content to staud, which sho 
did after three or four breaks. Within a weck, there was no moro quict cow in the yard than this heretofore incorrigible vixen.

\section{A IIspp Family.}

As showing tho bencfits of superior care and training, it enn be demonstrated how nicely all farm stock will get along together in peace, wien owned by a small farmer who cannot afford to scparate into distinct herds on account of scareity of numbers. If raised together in the same yard each will find its proper level. They will agrec kindly in a small pasture, and if the pigs aro ringed there will be no difficulty about rooting up tho soil ; and of the different classes of aninals each will eat grasses and plants not relished by the others. "Tho fict well illustrates the adage, "A merciful man is merciful to his bcast." 
CHAPTER TV.

\section{HOW TO SHELTER.}

\section{Necessity of Sheiter.}

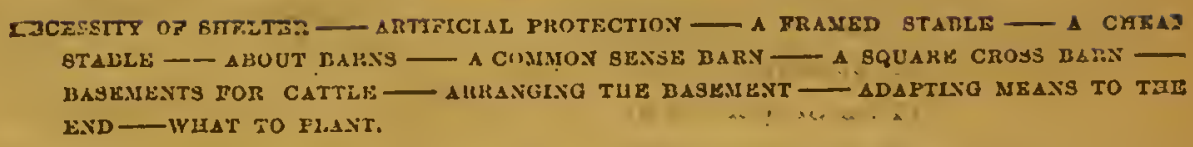

In all climates where cattle have to bo fed nearly half the year, tho question of shelter becomes of the first importance. In the middle corr region of the West, cattle must be fed from four to five months; ana farther north, from tive to six montlis. If the pasture in October be only suficient to supply the animal waste, then suel feeding is entirely lost so far as piofit is eoncerned. The object of keeping eattle is to get y:owth and weight. The extra food given over and above the nitural waste, represents the profit. Hence in the artificial feeding of cattle the question of shelter comes in. A eold storn will often seriously reduee the weight of stock. They will begin to fill awray, and before they get ready to ngain inerease in weight they will have had a senson either longer or shorter when they will perhaps neither have gained or lost. The natural heat of the animal must be kept to about 100 degrees. In fact, the natural heat is 96 degrees whatever the temperature of the air. If it fallis below this the animal begins to elinll, and the body is called on to furnish additional heat. So long as this ean be supplied the animal lives.! When it is exhausted the animal dies.

The food given may be eompared to the fuel used under the boiler of a stenm engme. So long as the water stands at 200 degrees no stewris is produced; above 212 steam aecumulates, until at length enough power is raised to start the wheels in motion. Thus it is with stock. Food must be given in proportion to the animal waste. With the thermometer at zero, and air stirring, whatever the feeding may be the animal sar\%ot gain if exposed to the wind. Under shelter the natural heat of tho 
animal is conserved, and it remains comfortable. If the tcmperature or tinc stable can be kept at 60 degrees, the minimum of food only will bo required. Just herentwo integers come in ; tho chcapness of food as against sliclter, and the cost of labor. It is possible for food to be so cheap and labor so-dear, and the pricc of cattle so low, that the intercst.

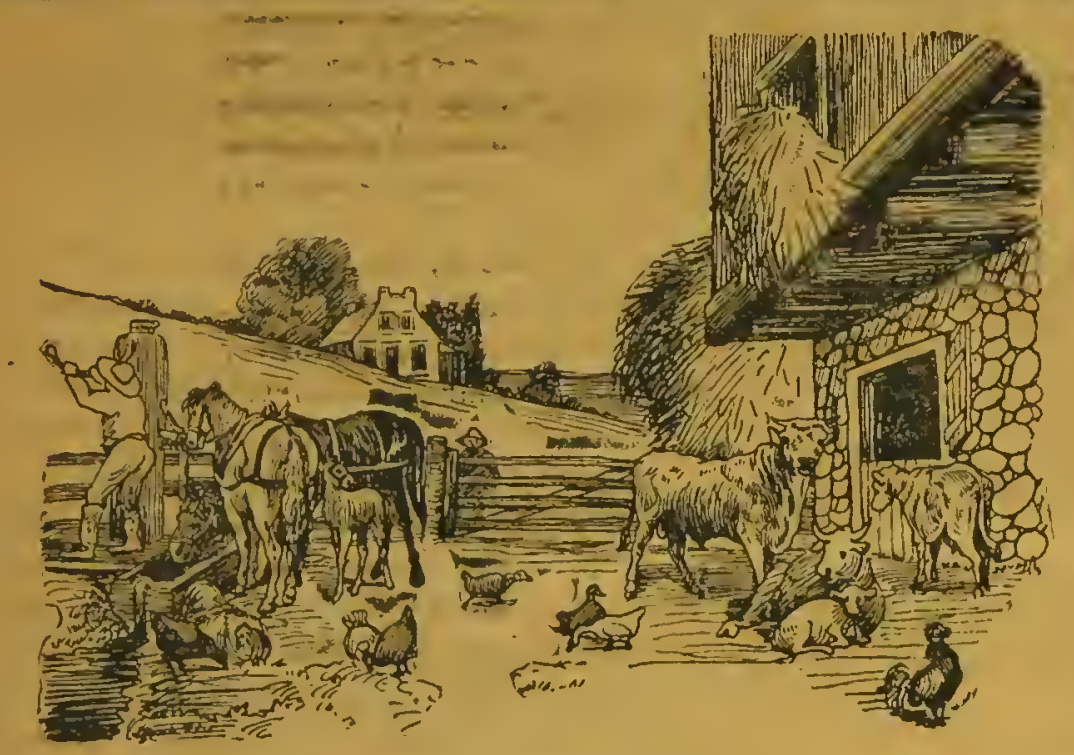

OLD STYLE FARY YARD.

on the shclter and the cost of libor would cat off the profits. It has been so in every scetion of the West first and last, and is so still in some new sections; but nowhere so low that cattlc could be profitably fed without the protecting influcnce of gullies or timber to break the force of the wind. This is natural protection, and is the groundwork upon which all other is to be built.

\section{Artificial Protection.}

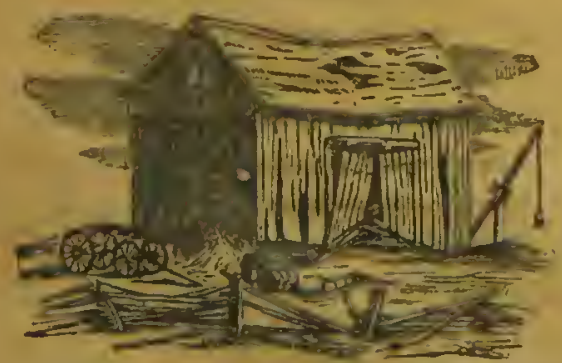

TARMER TURIFTLESS' MODE OF PROTECTION.

(n) -

If the stock brceder lats not timber, then the sooner be plauts wind-breaks to protect his yards and farm buildings the soonce will the rcap profit therefrom.

This is the crudest of artificial protection and yet one of grcat importance, both in Winter and Summer. In Winter it breaks the force of storms of wind, rain, sleet, and snow, and in Summer furnishes shade.

Whe rext crudest means of slueiter is a shed of posts and polcs, and 
covered with slough hay or straw, and slajs, or poles, filled in betwcen with suoh litter as stoek will not eat, the whole firmly pounded down to make it wind proof.

This, if well made and Bo low as just to admit a man to walk under, is both cheap and warm.

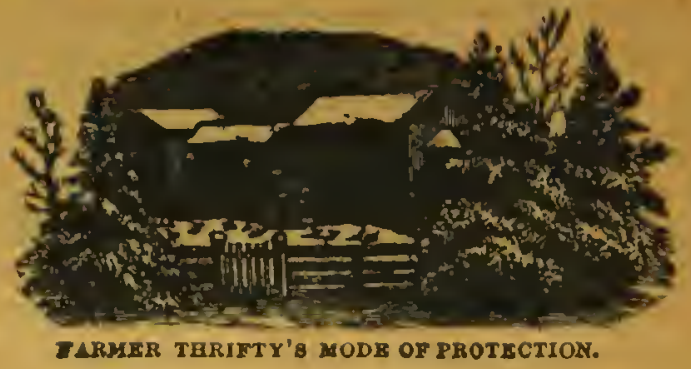

Another - eheap form of sbed or shelter from storms is made oy ceising posts firmly in tho ground in two lines, sawing the tops levol, fastening on plate pieces, laying on seantiing for the peak, supported tenporarily, and nailing on boards, for a roof, at one-quarter piteh, up and down from the plates to the peak, covering tho joints with wide battens and boarding up the siono from whenee tho prevailing winds eome. If twelve fect boards are used for the roof, a shed may thus be made over twenty s $3 e^{\prime}$ wic.c, that will furnish good shelter for stock eattlo where forage is cheap.

\section{$\Delta$ Framed shed.}

A still better shed may bo made by ruming the posts up eightecn feot, framing in eross-ties to support a flool. In the upper twelve feet of this shed a good deal of fodder may be stored, to bo fed from when tho weather is ton inclement to allow it to be handled on wagons. From this we msy go on to more and moro elaborato struetures until we eome to the barn proper.

On all well ordered farms the owner fully appreeiates the importanee of sholter. Henee we see the feeding yards with one or two sides protected with more or less serviceablo shed, until upon some faims we find the feeding yards entirely surrounded with this means of Winter protection.

In all this the owner must be guided by his pecuniary mears. If he have not money enough to put up the bettor class of buildings, it by no means follows that ho is to lenye his stock rithout shelter until he is able to build.

So far as tho simplest sheds aro concerined, it is almost entirely a ques. tion of labor. In tho cuso of simple sheds of lumber, it is simply a ques. tion of tho eost of boards and nails.

Any intelligent firmer, assisted

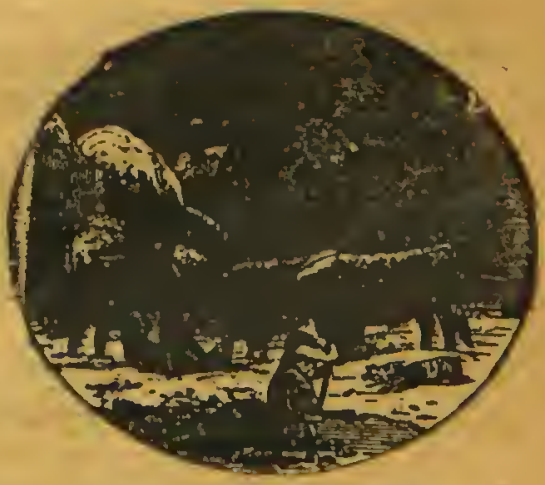

PRIXITIVE PRO' lictios 
by his hired help, can do the work. It is true, however, that few persons, the first time they build, do so eeonomieally. Let us see how this may be fairly aeeomplished. Suppose the strueture is to be a simple roofed shed affair. Deeide upon the length. The width should not be more than twelve feet for a single pitch roof. Allow that it is to be ninety-eight feet long. Set four heary posts for the eorners, three feet in the ground, and of the required height. The lower it is the warmer it will be, so it be high enough for the eattlo to walk under the plates. Between the two end posts set, exactly in line, six posts eaeh fourteen feet apart, and five and one-half feet high from the average ground line. Proeed in the same manner with the front, the posts to be nine feet above ground. At the back, now set seven lighter posts in the fourteen feet spaees. Saw them all off to an equal height, spike on four ineh seantling from post to post in front, and two by four for the back. It is now ready for the roof, whieh is to bo firmly nailed from front to rear. Board the front down to within five and a half feet of the ground, and the ends and baek entirely to the ground. Thus the shed is eomplete, except banking up. This is important and will add fully one-half to its warmth. A good way to do this is to lay a line of sods one foot from the rear, and fill in with earth or old litter, earrying the banking at least four fect high; or, posts may be set two feet from the wall, with suffieient strips nailed thereon to hold the litter, and the whole filled in and rammed tight.

\section{A Cheap Stable.}

Do you prefer a stable, take the form given for a hip or doublc-roofed thed. Board the whole tight all around, leaving spuee for doors and 'windows; batten the eracks, lay the floor, put in stanehions or uprights for fastening the eattle, leaving a feeding plaee in front, and tho whole is eomplete.

We prefer rings to slide up and down, upon standards three inehes thiek, to stanchions. Now this style of stable will not be strong enough to allow their being fastencd to the floor above. Set strong posts seven fect apart and four and a half feet high, sawed off square on top, and three feet out from the wall. Prepare six-inel seantling to be pinned firmly to the posts, twelve inches from the ground, and on the inside next the wall; the scantling bored, eaeh three feet, with two-ineh holes. This will be wide cnough for cows. Larger eattle must have three feet, threo inches. Prepare other scantling bored in similar manner for the tops of the posts. Take three-inch smooth saplings; sharpen the lower ends just so they will drive firmly into the holes in the lower scantling when it is 
pounded in place below. Shave the upper ends so they will fit the holes in the scantling above. Drive them solidly into the holes below, piuning each one fast with a half-inch pin. Slip a four-inch iron ring over euch stake. Lay the upper scantling on top, entering the standards as you go. It is better that they have some play. Lower the scantling on top of the posts, and pin and spike them firmly to the posts. Cut stout rope six feet, six inches long, splice a four-inch loop on one end, whip the other end with small cord so it will not unravel; pass the rope through the ring and back to the loop so the' end of the loop will be eight inches from the ring; pass tho end of the rope through the loop, draw tight and make fast with two half hitches, or, better, whip the two portions of rope together as far as the loop. The cuttle are then ready to be tied up, by passing the rope about the neck and through the loop, and drawing just tight enough so the animal camot slip it over the horns. Iron chain hails that will last a life-tine are kcpt ready made by agricultural implement men, and are much the chenpest in the cnd. Tied thus, cattle can easily reach thcir food, can lick thcmselves, can rest perfectly, but caunot reach to injure each other. A six-inch board nailed along the standard at a proper height, say about six inches below the tops of the shoulders of the cows, will prevent their reaching too far into the feeling passage.

\section{About Barna.}

The sirst thing to do in the erection of any building is planning to ccrtainty what accommodations are wanted and the probable cost. The farm barn, if there is to be only one, must be made to answer a varicty of purposes. It must contain stables for cattle and horses, calf pcis, shelter for sheep, a threshing floor, bays or mows for hay and grain, room for vehicles and many tools, harness room, granary, and, if the barn is a large one, room for placing a horse-power.

Years ago balns were seldom made higher than eighteen-feat posts. In theso days of improved machinery it is as easy to fill a barn twcity-five or thirty feet high as one that is lower. The nearer square or octigonal a barn is and the higher, the less its relative cost, so that now barns aro built of two or three stories when a slight declivity may be had for the site. If of two stories, the basement is cut up into stables for catile and sheep, storage for heavy tools and machinery, calf pens, etc., ctc.

The nuain floor will contain bays for hay and grain, threshing floor, a harness room and granary. Practically there is no advantage in tho third story. The barn may be as higl as is needed, the bay continued to the roof; the stable, barness zoom, granary, etc., may bo floored over, and is 
mow be had overhead; so, a floor may be carricd over the threshing floor, and this space utilized in the same way. Practically you have the space at less exponse.

\section{A Quarter Section Farm Barn.}

In the West and South, the farmer of 160 to 200 aeres may get along , very well with a side-hill barn forty-two by sixty feet. It will givo ample room for a bay 16 by 60 ; a floor 13 by 60 ; horso stable 13 by 60 , containing 5 single and 1 double stall, or 2 single stalls and 3 double stalls; a room for implements 10 by 13 ; a granary 12 by 13 , and a tool room half that sizo; while the basement mày bo devoted entirely to tho stabling of cattle, with calf pens, a sheep pen, and, if necessary, a shed euelosed on three sides. The granary will hold over 600 bushels of grain, and may be divided into bins for Winter and $\mathrm{S}_{\mathrm{i}}$ rilig whent, onts, barley, and ground feed for stock. Tho basement may contain two rows of cattle stalls, with passage way between, six feet wide, with shoots leading to tho upper part of the barn for delivering hay, grain, and other foed. This will leave a space 12 by 60 , which may contain ealf-pens and a place for sheep, and it may be so arranged by means of sliding doors that it may be entirely closed in inclement weather. This basement will contain stalls for thirty-two eattlo, and the manure may be thrown diroctly into a cart or wagon and hauled directly where it is wanted.

This barn may, of eourse, bo enlarged by adding on, to accommodate any required amount of stock; but, if a much larger barn than this is wanted, the square or oetagonal form should be used. It will give largely inereased room in proportion to the cost.

A Common-senso Barn.

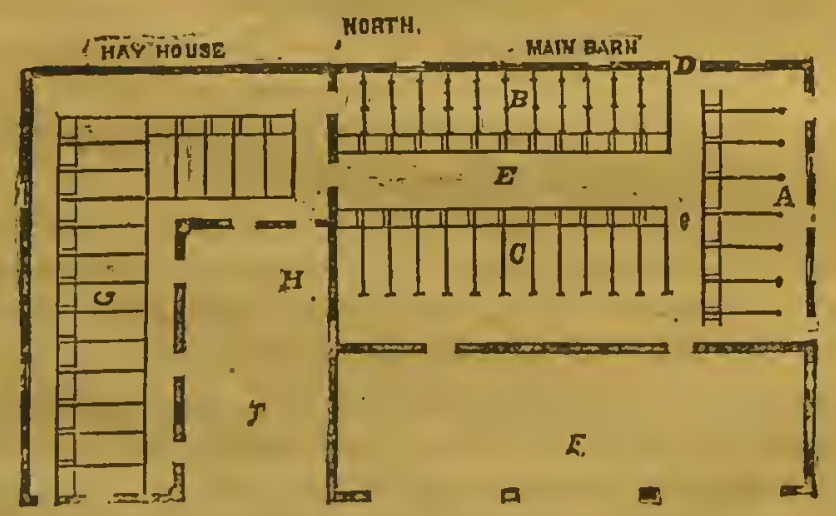

IÄAZI FLOOR OF DAIRY BARN.

Lhove tre give an outline of the basement of a barn forty feet ride and sixty feet loug, with a lean-to arershot extending twsity feet in frent. 
This barn will contain about 100 tons of hay: "The barr "would bo better facing the South if the lay of the land as to declivity twill allow. The hay-house may extend trenty fect in width and height in the form of an $\mathbf{L}$ and of sueh a length as may be wanted for storage, say forty feet. This barn, if the space below the hay-house is utilized, will stable six horses and forty cattlc.

The bascment of the nain baru may be divided into stabling as follows. $\mathbb{A}$, horse stables 12 feet decp, with mangers two and a half feet wide for hay, with suitable troughs for grain and manger for hay. B and $C$ are cattle stalls. Thoso in B linng with swinging gates, opening side ways, G the same, but éach stall having a separate gate entering direct from tho yard. E is the nrain entrance eight feet wide and may contrin feed ehests; $e$ is an entry five feet wide, with steps up to door D, and having an entrance into the horse stables at each end. $F$ is the overshot or shed. $G$ is tho portion under the hay-house to be utilized in stalls, if the hay is not desired to run clear to the ground; and $\mathrm{H}$ is the yard eonneeted therewith. If necessary this may be roofed over making additioual shed room

\section{Square and Oetagonal Barns.}

In the square or octagonal barn the bay is in the centre, in which o vast compaet mass of hay can be kept, and this will run from the basement to the peals. The basenent will be used as a stable, and if desired the main floor may also be so used; modern builders understand perfectly tho art of making a floor proof against the leakage of liquids.

One especial adrantage in the oetagonal sliape for barns, when a largo number of eattle are to be fed, is, the roof is easily supported and eontains moro economy of spaee for its size than any other form except the cireular. In this the liay will be in the center, and the cattle next the wall, faeing invards. Above the cattle will also be a mow for hay, except such portions as are wanted for granaries, grinding maehinery and other conveniences. At the peak may be a windmill of sufficient power to do the pumping of water for the stock, unless it be feasible to eonduct water by its own gravity. In this case it may be used for grinding and cutting fodder.

Let us seo what an octagonal barn sixty feet in diameter will $\mathrm{l}$ old. The width of the stablo will be twelve feet, and the feed next the bay six feet, making eighteen feet in all. This running elear around will have a eentral core of twenty-four feet, besides the entire area, from the flooz above the stock. The stable will be one hundred and cighty feet in eircumferenee, and, allowing three feet, six inches to each, stecr, will accommodate fifty head of steers, or if cows, a still greater, number. 
Below we give the plan of the dairy barn which will explain itself. Wo have represonted a eistern and also the meal room, proteeted by an earth embankment, so it may be used for roots ald other feeding material than rould be injured by freezing.

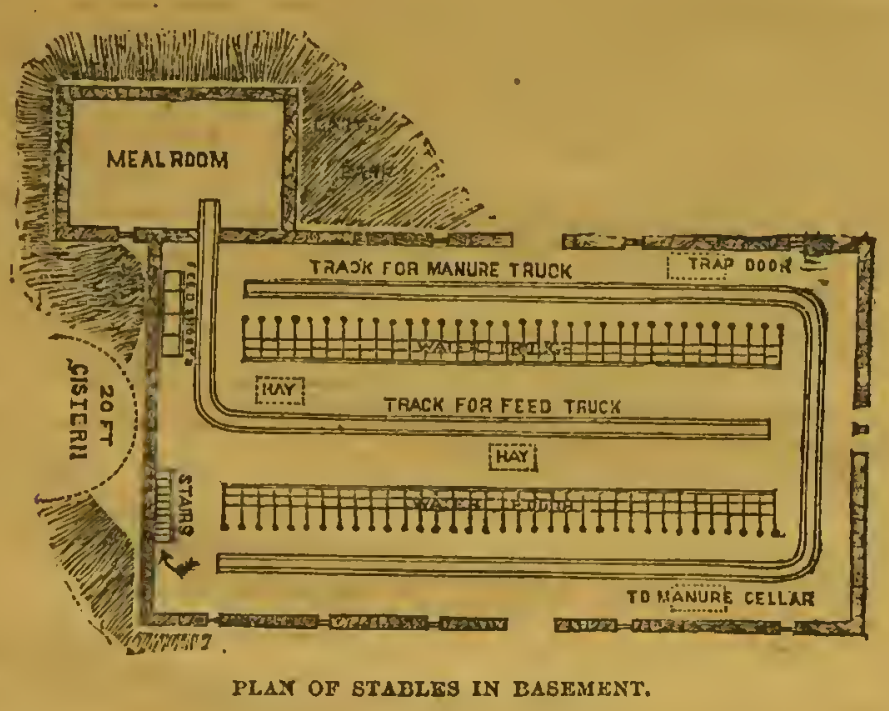

The following diagran will show a compact basement for a Bank Barn for feeding catilo and also aeeommodating a limited number of horses ead milch eows, to be seventy by oue hundred feet square.

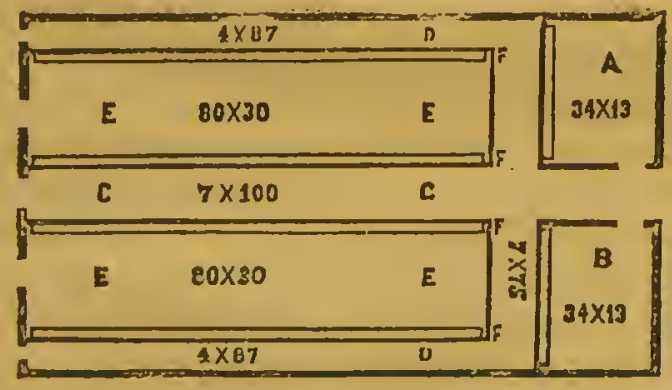

CATTLE-FEediNa Base.Meyt.

$A$ is the horse stable with six stalls; $B$, eow stable for six or eicht cows: I. C inaiu entry; D D two small entries, runping on either sicio of the 
cattle stables; E E E E are the eattle stables, 80 by 30 feet each; and if the cattlo are placed 4 feet apart, will acrommodate forty head of stcera for fattening.

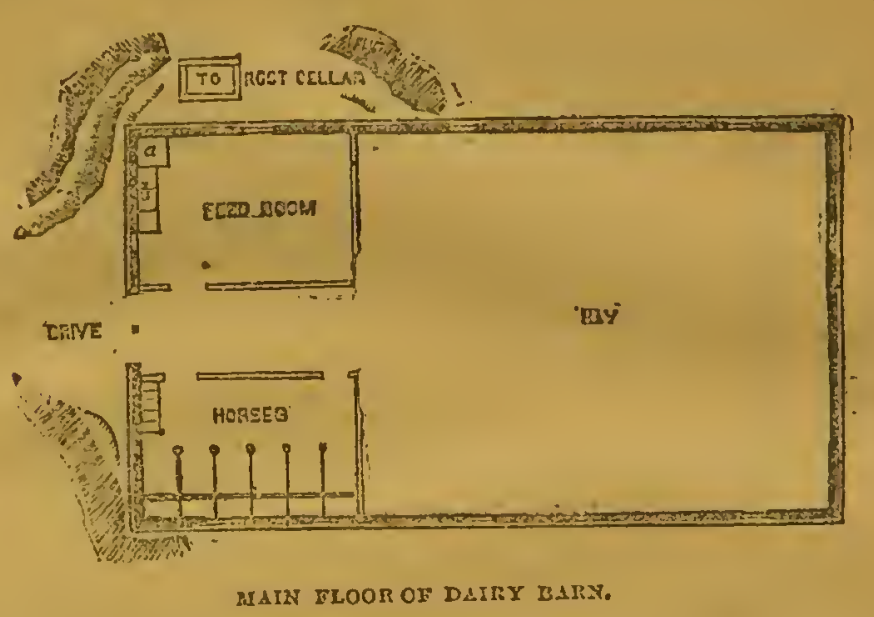

To show unother plan tie give a diagram of a dairy barn fifty by one bunired fect. In the plan of the main fioor $a$ is a rentilating shaft, nud $b$ feed shoots to basenent through trap door which will bo shown in the plan of the basoment.

\section{A Equzre Crose Bars.}

For a large number of eattle we know of no better form than a squars barn for the center, with four wings running therefrom, cach 30 feet wido by any desired length. In this arrangement the cuttlo might bo placed with their heads to the wall, leaving a passage-way betweon each two rows, by which the manure might be taken up and carried away in carts. In somo parts of the West eattle-fecding is carricd out on an inmense seale. Feeders are already beginning to ask, how best they may build stables to save cost in fecding, and at the same time place the cattlo in the best possible position for economical feeding.

A writer in tho National Live Slock Journal, under the signature of "Alimentation," gives data for a barn to feed 1,000 head of cattle. Tho prineipal objection to the plan is the concrete wall advised for the basement. In a building of this size and weight, it will be found to be quite unreliable in the West. The basement should bo built of good solid atone, or the best hard burned brick. In licu of this, if concreto must the used, the weight of tlio building should be on stone viars. Tre detrils 
for building the barn aro giren as follows, the wings being 30 feet wiito and 200 feet long:

"This square cross barn will have all its extreme parts equi-clistant from the ecuter. It will be the sunc distance from the quadiangnlar center to the extreme animal in either wing as from the oetagonal ecnter. By doubling the width of the wings, we dispense with eight long sides 200 feet cael, or 1,600 feet; and as the ends of the four wings are the same length as the ciglit wings, tho saving in outside wall is 1,600 fect. And if these sides are 20 feet high, and boarded up and down with a twoinch batten, it will take 36,933 feet to cover these sides thus dispensed with. It will also save all the outside and interior posts of the four wings dispensed with, as it will requiro no more posts in a wing 60 feet wide than in one 30 feet wille. This will make a saving of adout 22,000 feet; and tho outsiclo sills and plates on theso

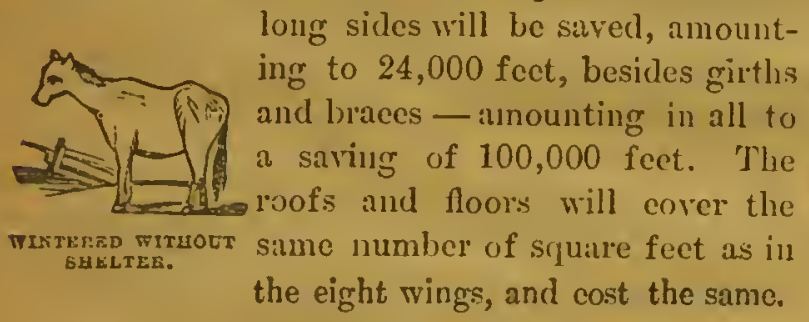

"It would also save 14,400 cubie feet of wall. The whole saving by bullding the wings 60 fect wirle could not be less than two-fifths of tho whole cost of the birn; and the convenicnce and economy of labor nust be cron greater than with the eight narrow wings. This square cross barn has the eapacity to feed conveniently and comfortably one thousand head of cattle; and it now remains to notice some of the rletails of construction.

"The quadrangular center, 60 feet in diameter, may be built with largo corner posts, say 14 by 1.1 inches square, 37 feet long, and the plates and ginths of the wing mily be framed into tlese posts; but it probably would be betcer that the wing should have seprarate enrnex-posts, and they be holted to the posts of the center. The guadrangulall center should be high enough above the wings to elear tlis lidere of its roof. Thi: would require the posts of the center building to be 17 or 18 feet longer than the wing posts, as the ridge of the wing roof slonld rise at least 17 fect in 60 feet, and come up under the cornice of the eenter building; as these wings will cost about the same money with posts 20 feet, and the l:tter herght will hold about 40 pere ent more, and as this stor:ace loom will he wanted for so miny animals, it will bo better to provide room in abundance, and nake the posts twenty feet long. 
"Tho floor in the wing aboro tho bascment will run lengthwiso of the building, and it will bo 16 feet wide, so that the posts on eitler sido of the floor, ruming up to the cross-beam over tho floor, may stand on a sill running lengthwise orer the basement, and eight feet from the center, supported by tho stanclion timbers. Theso two sills will be strongly supported the whole length by tho stanchion posts, placed only 38 inches from center to center, and will consequently hold the whole interior structure above. The bays on cach side of the floor will be 22 fect wido; there will bo no loss in 50 wide a lloor, as the hay may be mowed omo or two feet upon eacl edge of tho floor if moro room is desired. There will be 42 bents, the outside posts being about 18 fect 2 inclies from center to center. The top of the cross-beams, ruming from side to side of the barn, will be 13 fect abore the sill, and will be spliced at the post, or between the posts, on either side of the floor. On three of tho beuts tho cross-beams should be carried up nearly to the plates, and the posts at tho side of the floor must also be carried up to support the beam. The three bents (every third one) will tic the barn together, and being so far apart, will not obstruct pitching with a horse-fork. These bigh beams, besides being pinned to the outside posts should havo a stirrup around the post coming back ten inches upon tho beam, with a threc-cighth inch bolt through the stirrup and the beam, turned up tight with a nut, and if the beams are well spliced in tho middle, this will hold the barn firmly from spreading at the plates. Now, to prevent this long wing from rocking or swaying by a strong broadside wind, these bents with the high beams should havo a long stiff brace running from the foot of the post on the side of the lloor to the outside post just under tho high beam. Such a long brace on each side will hold the barn rigidly from rocking. And whilo spealing of braces, let it be remembered that A brace is valuable just in proportion to its length. Tho braces from tho nutside posts up to the plates show a four-foot run. They will issist rery much in sustaining any weight upon the plates.

"It is not intended to have any purlins in these wings to support the roof, even though they bo 60 feet wide. The brace on top of the beam will have a run on beam from post of 8 or 9 feet, running up the post just under the plates and fastened by a bolt. This will hold tho plates absolutely rigid, and the roof will not spread them. The rafters should not be placed moro than two fect apart, and tho collar-beams should be 1 1-4 by 5 inches, and placed six feet below tho ridge, with every other pair of rafters double collar-beamed; that is, with a collar-beam nailed upon each side of tho rafters. This will mako a strong shingle roof. The collarbeans will be some 20 fect long, and will bo about as good a support to the roof as purlin-beams. The collar-beams should be as high as tho 
barn monld be likeiy to bo filled, so that no room will be Inst, and the barn will be practicilly frec from obstruction to pitcling with a horse-fork. "In the bents, where the cross-bcams are raised ncarly to tho plates, there must be a beam francd into the posts on cach side of the floor, 13 fect above the sills, to correspond with the other beans orer the floor, upon which scaffolding may be placed for using the room crer the floor. It remains only to be mentioned that the interior sills are four cioss-sills, (40 feet apart, to tie the binn together at the hottom, and two sills ruming longthwise, one on each side of the flool-that is, the centre of cach of these long sills is placed 8 feet from the ecntre of the barn. The joits for the bays will run from these long sills on each side of the floor to tho outside sill-about 21 feet. Each of these long sills come over a row of atanchion timbers in the basement below."

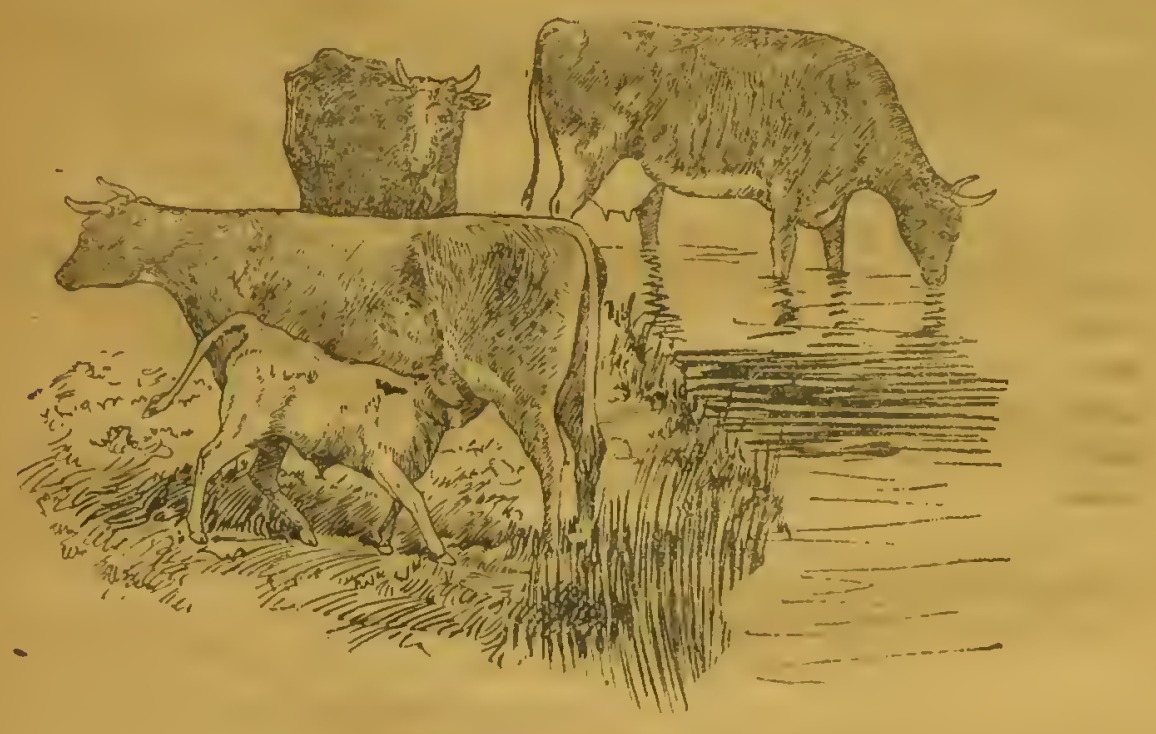

ITARMEI THIIFTY'S CAITLE,

The reader will see that these wings above the bisement are built in the simplest manner, using no surplus material. and as cheap as may be oosistent with strength and durability.

\section{Basements for Cattlo.}

"We will now examine the construction of the bascments of these iong wings. The wall under each of these wings, if built of concrete. 15 inclies thick at bottom, 12 iuches at the top and cight fect high, being 460 fcet long, would contuin 4,140 cubic feet, and could bo buiit in most 
plaees for 10 cents per cubic foot, or $\$ 414$ per wing. The wall under the center would be 1,440 cubic feet, and cost $\$ 114$. Tho wall under the cutire square cross barn would cost $\$ 1800$. The long sides would require something to stifien the wall sidewise; but a pier built against tho wall on the iniside would be in the way, and on the ontside would look unsightly; so to avoid the necessity of such picrs, let a $T$ be mado of wing iron, say three-fourths by two inches. The long end of the $T$ would be about 20 inches, and built into the wall, and the eross lio acros: the top of the wall directly under the sill. The end of the $T$ should project beyond the sill on each sido far enough to have a three-quarter inch hole punched, into which to insert a piece of the same flat iron, six inches long, rounded at one end. This will attuch the wall to tho sill. There should be four of theso $T$ 's for each side-one nar each cross sill 40 fect aprirt. This will hold the whole wall to the benn, and prevent any swaying. These long sides will give room for inserting

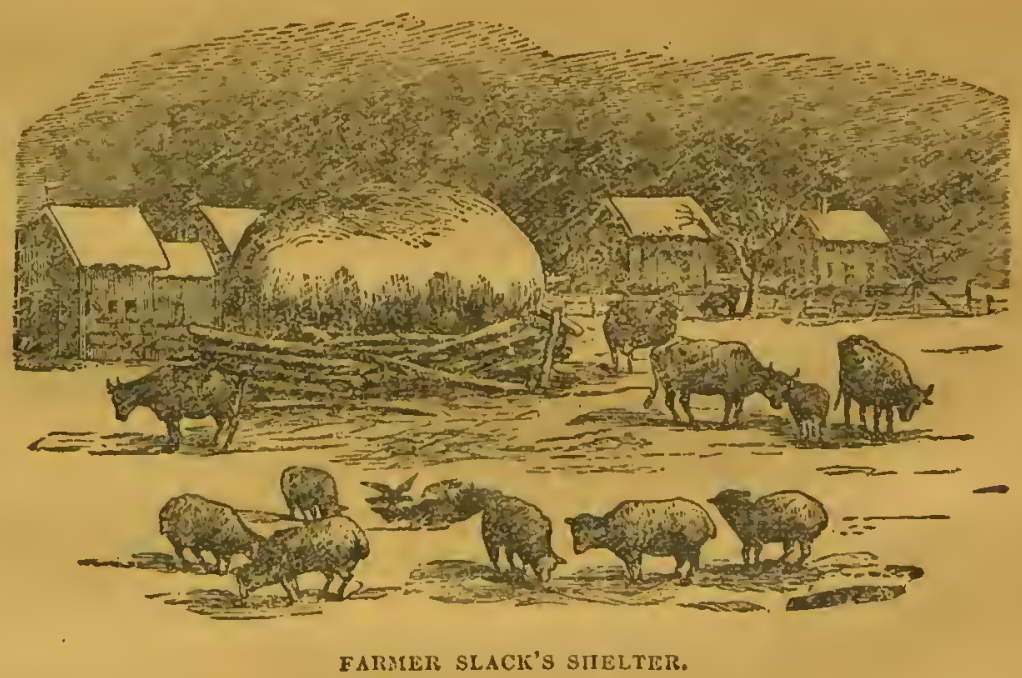

plenty of windows for light, the frames being into the boxes, and the concreto built over them. 'The sash may be hung on a pivot in tho centre, so as to open easily to givo rentilation at ecrtain seasons; but the fresh sir should bo introduced through the wall near the bottom, through hard burued earthen or pottery pipes, 15 -inch bore, just long enough to reach through tho wall. These pipes may be laid in the boxes, bedded in the conerete, and the concrete tamped down upon them. They may be plaeed ten feet apart, and will not weaken the wall. Close eovers may be fitter to the inside, so as to shut them out at will ; and with proper vecitilators 
to discharge the hented and vitiated air through the upper part of the bara, there will be a constant circulation of fresh air through the busement.

One other point must bo mentioned in refereuce to the wall. A conereto wall contains a large amount of moisture, aud if the sills are to be placed on before the wall becomes quito dry, which is usually the ease, the moisture will pass up into the green timber of the sill, form a coating of lime on it, and prevent the sap from escaping, and the result is a rapid decay of the timber. To prevent this, tako well-seasoned pine boards, 12 inches wide, cont one side with gas tar, and bed this tarred side in the mortar on top of the wall. The sills are laid on this leveled board, and no moisture can come through this board into the sill to rot it.

\section{Arrangiog the Basemont.}

These long stables must be laid out so as to render the labor as convenient as pussible. There must be casy aceess to every animal in the stable, and this becomes more important when one thousand eattle are to be provided for. Cattle are most casily attended when placed in double rows with their heads turned towards one feeding floor.

In the long basement, the first row of stinchion posts will be plaeed seren fect from tho first wall, on the side of the first feeding floor, 14 feet wide. On the other side of the feeding floor is the second row of stanchion posts, coming up under one of the long sills, as deseribed befors. Tro and one-linlf fect being occupied by mangers on each side of this floor, will leare nine fect for a drive-way. Along this thoor may pass a cart or wagon, with green food in Summer, or fodder in Winter. The third row of stanchion posts will be 16 fect from the last, under the sccond long sill, on the side of the second fceding floor ; and the fourth row will be fourtecn fect fron the third, on the other side of the second fecding floor, and seven fect from the other wall. Here two rows of cattle stand, with their tails to tho walls, and the two middle rows stand tall to tail, facing upon opposite floors. The largest animals should be placed in middle rows, as there is the most room. These stanchion posts are placed 3 fect 2 inches from eenter to center, and the enttle are best fastened to the ecnter of a chuin stretehing from staple to staple driven into each stanchion post. These chains slide up and down on staples. The mangers may be placed 20 inches from the ground, and, with long staples, the cattle may lie down comfortably. One of the best ways to feed cattle, with plenty of bedding and muck for deodorizing, is to let them stand three or four months on tan inanure, and, the mangers being placed high, the manuro may accumulate two feet deep under them, and they may keep quict clean, with the bedding and muck, and the manure 
will be trodden so hard as to ferment rery litilc. When a lot of cattlo are sold, then wagons may be driven through to earry off manure. I have secir cattle fed in this manner, ended daily, and kept quite clean, stinding on their maure for four months.

These feeding floors, as described, streteh through the whole length of the barn. A fecaing car pisses through two wings, and, liaving a turntable, may pass through any wing. Feed may be dropped through a chute on the side of the upper floor into tho car whererer placed on any feeding floor. This form of barn gives every facility for cutting and cooking the food-a larger engine, pliced in tho center, cutting, grinding and coolking all the food; and this also offers the best ficility for soiling three thousand head in Summer, if such should be necessary. In the West, however, where only the fecding of such large numbers of cattlo would be profitable, soiling is out of the question.

\section{Adapting Means to the End.}

No pcrson can possibly know so well what an individun wants as himself, if he bo a refiecting nan. The architect scarcely ever gives atlcution to tho planning of barns. Tho best barns in a country are those of intelligent farmer's who lave carefully observed tho conreniences of various kinds in tho barns of their friends in tho loenlities risited, and who when in building their own varied them to snit their own wants. For this reason wo havo simply gircu outlines of those illustrated with descriptions of other's adapted to various numbers of eattle. See pl). 588, 590,591 . To give the cost would be a waste of space that mily be better employed. This will vary with lumlity and tho prico of material, and any master carpenter or mason will quiclily estimato them. As a rulc, the eliborate and well furnished strueture is not the nost convenient one, but those which havo the grentest number of permanent convenicnces, and in which the spiree is most thoroughly economized. Hences within the last few years, or since the general introduction of inproved inadincry, farm barns liave undergono a complote change in the manner of construction.

Formerly barns wero comparatively low structures where crerything had to be done by manual labor ; it wats not economy to pile up hay, grain, or other farm produce, story after story; tho labor of lifting, or carrying did not pay. Since tho invention of hoisting machines and hay carriers, the invention of modern windmills, grinding mills, horse powcrs and other labor-saving machinery, trenty-five feet posts are not unusz:al, and no barn should be built of less than two stories. The gain thus secured is abuudantly worth what it costs. 
There are few farms whore the drainage is so poor or the lant so level but that a declivity sufficient for a basencut barn may be had, by throwing the excavated portion up to assist in forming the trackway or riso to the main floor. Windmills ste now so ncarly automatic in their working that they may very safely be trusted to pretty much take care of themsclves. Thereforc, in all the more pretentious furm barns, thay should be built with special referenco to the crection of a windmill on top. This may be used for a varicty of purposes, cutting foddcr, grinding grain, pumping water, being its principal work. If the water is collected in a rescrvoir in the center of tho mow it will not freeze, and the pressuro will always be equal, and thus the water may be carried in pipes any distance, to the house or the dajy, and becomo a most valuable ecouoniy.

In the building of barns of supcrior size wo hare given descriptions of all but the circular barn, which can hardly be callcd a practical or economical structure, and the octagon harns will como under the same catcrory; for while cononical in respect to space, they are more enstly to build, if for no other reason than that they are unusual. We thercfore recommend the squaro barn in every caso when the width is to be forty or more fect, with not less than twenty fect posts. This, with tho the bascment, will give tro or threc stories as nccessity may require. The basement of course will be used for the stables, and if additional room be needed one or two wings may be added, and when further space is needed two more. The diagrams showing the internal arringements may casily be obtained to suit such a structure whilo pursuing the general features of economical and labor-saving atility.

\section{Summer shelter.}

While the question of Winter shelter is of tho first importance, it is necessary that Summer shelter be provided, and also for protection against the inclement storms of Spring after stock has been put upon pasturc. During the fecding seison the sheds and barns will suffice; before pastures are flush the Winter shelter can be utilized, for somo food must be given night and morning. During the prevalence of storms the stock will of course be kept up and fed. Later, however, it will not be found practicable. What is wanted is a range where stock may not only be securc from the winds of driving storms, but whero they may retire for shclter during the extreme heat of Summer days.

We do not belicve in shaded pastures. They aro poctic but not prace. tical. The object in kceping stock is to make them eat as mucli as possible. The pasture should be devoted to grass. If shaded by single trees berc and there, stock will very often haunt these when they should be 
fecding. While in motion in the act of grazing they do not sufice from heat. Therefore it is better that they be obliged to do some trayel to reuch the shade, and this shade if natural will generally live water near. If not, the artificial sliade should be given at such places where water may be had from mills or ponds most cheaply.

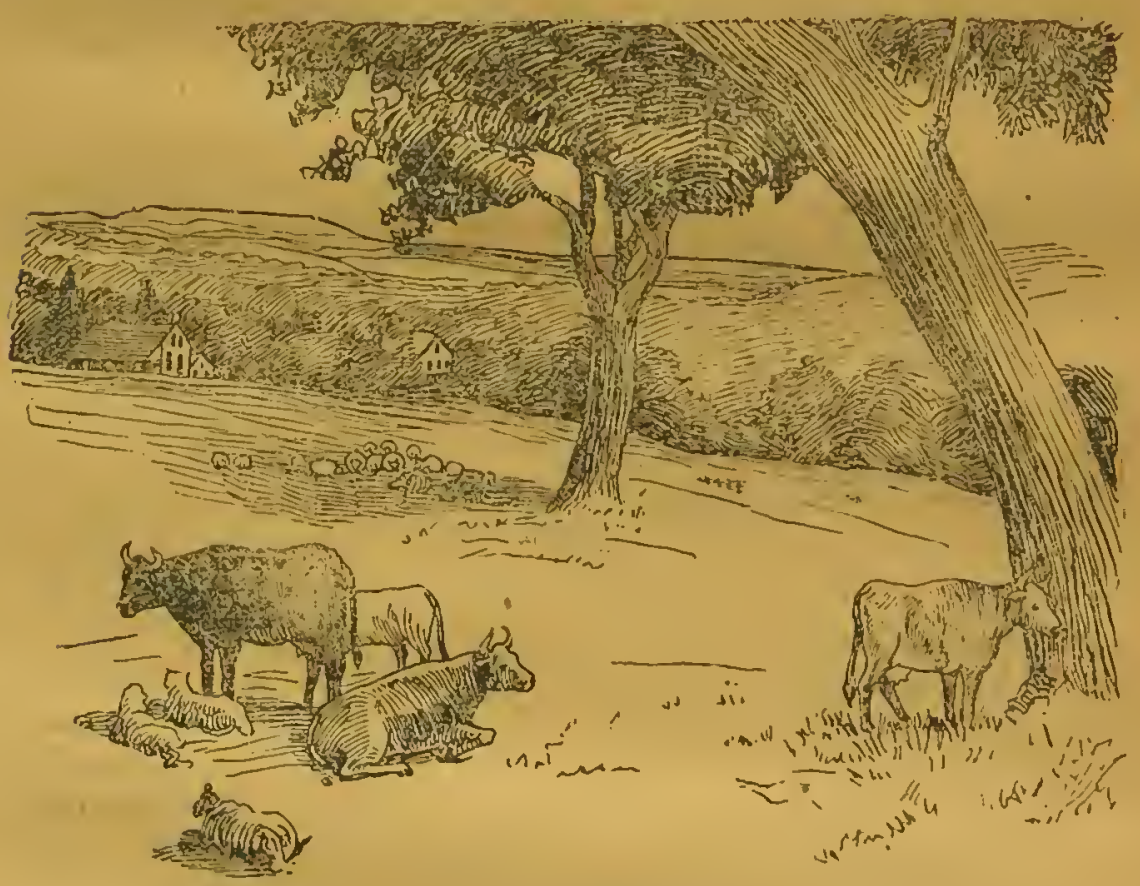

PASTORAL GCENR.

; Tho accompanyng cut will show how this artificial shelter is accomplished both by isolated trees in the pasture and by clumps and groves in the distance. As previously stated, the single trees we condemn, and they have been introduced to illustrate tho point, and at the same time give effect to a most pleasant pastoral scene, and which any farmer may obtain in a gently undulating country.

\section{Where to Plant Shelter.}

Tliis shelter should le planted along the crest of ridges, about gulies and ravines, and in fact wherover the soil is not adapted to cultivation. These points will be especially sought during the heat of Summer, and tho timber will eventually more than pay the cost of planting in any prairic country. All high points are generally frec to a great extent from biting insects. The ravinos will afford shclter from wiuds and driving 
storms, and also will be valuable as places where permanent water may be had either liaturally or artificially by draining. In lieu of this plint shelter belts and groves ucar the low places where water may be had, or near natural water holes on the farm.

\section{What to Plant.}

For dry soil, anywhere south of 42 degrces, the Catalpa (Speci osc) will be found hardy. The variety Big nonioides is not hardy in the West north of about 38 derrees. Black walnut is valuable, so are all the maples, the cotton-wood does well almost anywhere, and if care is taken to procure cuttings of the male variety, (this tree bears male and female flowers on separate trees), you will have no trouble with the blowing about of the cotton during seeding time. Evergreens may be planted almost anywhere if the soil be moderately dry. The Norway spruce is most valuable, and next to this the white pine. For low lands, cottonwood, the soft maples, and the white, the black and the golden willow will be indicated. Thus the farmer will find that this question of sliclter, while one of the most important of the many connected with farm economy - the points relating to Summer shelter - will in the end prove one of the hest paying investments w a praire country of any in the hole category. 


\section{CIIAPTER V.}

\section{IIOW TO PASTURE, FEED AND WATER.}

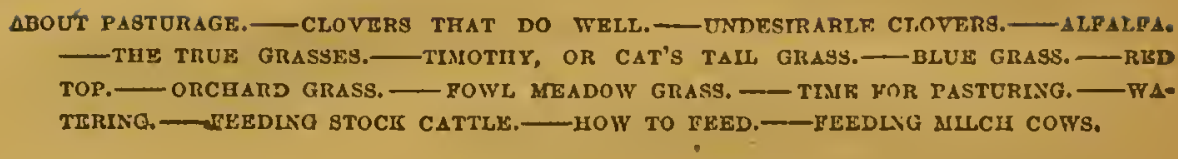

\section{About Pasturage.}

The subject of pasture and meadow is one of the most important with which the farmor has to deal. It mikes fecd in Summer and forage in Winter. Yet, in the United States, nemly all our meadows consist of one clover and one grass; in other words, timothy and clover are our grcat meadow plants, and the addition of blue grass to this forms the bulk of our pasturage, always cxcepting, of coursc, the vast areas of wild grasses that still cover the great prairies and vast plains of the West, yet to be brought into cultivation by man.

Until within the last few years, or until the dairy intcrest began to assume such gigantic proportions, farmers got along well enough with thesc; for, where stock raising for beef is the solo object, and wild grasses are plenty and grain casily raiscd, and consequently cheap, a very few grasses will suffice; but the impetus given to dairying within the last few ycars, has fairly shown that the best rcsults, nay, that evon fair suooess cannot bo had with a few grasses. This the dairymen in New York State came to understand years ago, and yet so little was known of the adaptability of varioties to soils and climate, that our best farmers worked blindly in experimenting, and unfortunately, our botenists could do litcle wore than furnish long strings of mere classical names of varieties as they were known in books, and could give almost no information es to their adaptability. 


\section{Clovers thet Do Well.}

Practieally, the clovers are confined to three specics. Fin'st, red clorer, natural to all soils that are adapted to the cereal crops, as whent, rye, barley, oats and corn, or such rich soils as do not lieave under the frosts of Winter and Spring. If so, elover is apt to he thrown out, or at least to be so heaved as to be practically worthless, especially so from the fact that it is really a biennial plant; that is, dying out at the end of the seco ond year if allowed to seed.

The next elover in general use is Dutch, or white clover. This does well on soils somewhat moist, although it will not stand flooding. It is not especially relished by cattle, and at some seasons is apt to give horses what is termed the slobbers; that is, it causes them to form saliva to such a degree that it drops from the mouth frecly. Cattle do not relish it, and it ean hardly be called good feed for horses. A small portion of it in a permanent pasture does not come amiss, yet it is so natural to many soils that, like the plantain, which the Indians have termed tho whito man's foot, white clover they kave called the white man's grass.

The only other varicty of elorer that we ean recommend for cultivatiou, is Alsike, sometimes ealled Swedish clover. This does well on moist land, and even bears some flooding. We eonsider it the next in value to red elover, and altogether better pasture than white elover. It also makes good hay on soils too wet for red clover.

\section{Undesirabie Clovers.}

There are a number of other species of elover, some of them indigenous fo the West, which we only mention as a caution against their being sown. These are; two species of so called Buffalo elover; the upright and the ruming Buffalo elovers; the upright or yellow clover; and the low hop elover, a half-erecping variety. There is only one more varicty wortl mentioning, and this simply as a warning to farmers not to sow it, except for bec pasturage, and then only when it may not become a troublesome weed. We have reference to the tree elover or Bokhara elover, specifienlly the white-flowered melilotus. It has been recommended as valuable for soiling; that is, for eutting green for feeding to stock in stables. We give the same adviee uhout sowing this elover that the crabbed lawyer did to a young client who asked his adviee about getting married-Don't.

Alfalfa.

The ease is different with alfalfa, the Spanish name for a plant known botanically as medicago, and, in English by its French name Luzeruo. 
This is valuable in soils adipted to it, decp dry soils not subjeet to hard freezing in Winter. In California it has become cno of the standard forage crops. In some of the far west plains country it will undoubtedly be found to stand well, as it will in Texas and New Mexico. In South America, in the rast grazing region, it has become thoroughly naturalized, and is well wortly of trial wherever the Winters will rot be ton cold for it, say soutl of forty degrees north latitude.

\section{The True Grasses.}

It is to these that we must really look for our pasture piants, outsido the few elovers we have nentioned. It is a vist, an it is the ricst important of plants to man, comprising some 230 hotanical genera, and not less than 3,000 species, and includes all our cereal grains, as whent, rye, barley, oats, corn, etr.

It would not he in place in this nork to enter into a history of grass, and the characteristies of the several species, valuable as they may be. Our readers must therefore be content with a list of somo of the more important varieties, as they have been tried, and their seasons, and zomo of their characteristics; and this more for their value as pasturs than hay, and for reásons previously giren.

\section{Timothy, or Cat's Tail Grass.}

The first in importance is timothy ; a better name, as more perfectly deseribing its characteristics, wonld be eats-tail grass, by which it is known in England. It does well in all elaycy or clay loam soils that are not too wet, and malkes the best liny of any of our grasses. For pastirre it is among the least valualle, if we exeept cattle, since one peenliarity: is that just at the gromnd it forms a bulb, which if bitten in elose grazing, as horses, shecp and hogrs are apt to do, it dics. It is also a grass that will not bear hard tramping.

\section{Bluo Grass.}

This is the great pasture grass of the Western States, in its two varieties, Ksntucky bluo grass, which flourishes best south of forty degrees north latitude, and wire grass, which is found well up into Wisconsin and Mimmesota. Here again is eonfusion of common names. In Pennsylvania it is ealled green grass, and this is really a suggestive name. It really remains green early and late, longer than any other of our cultivated grasses.

Blue grass forms a tough, firm sward, springing early in the Spring, 
growing late in the Fall, and holding its substance well in the Winter. So that after being pastured in Spring if allowed to grow on through the Suminer and Autumn, cattle and other stock may be wintered on it admirably, when deep snow does not cover the ground. Both varietics arc found in their best perfection in limestone soils, ulthough they do well according to latitude on all strong, rich, and even on some rather thin soils if well drained. Neitler variety is adapted to wet soils. It cannot be called a hay grass, its great value being for pasturage.

\section{Red-Top.}

The next grass in importance, because found to do well on $\Omega$ great variety of soils, is red-top. It makes good hay and is valuable for pasturage. It should be moro generally cultivated than it is, being adapted to a very considcrable range of soils, neither very wet nor very dry. As before stated, in Pcnnsylvania this is called herd's grass, and we may add in Rhode Island it is known as Burden's grass. While red-top has a goodly range of soils ti which it adapts itself fairly, it does best on a lather moist soil, flowering lather late, or about the same time or later than timothy. It dries out considerably in curing into hay, and is not very rich in sugar, gum or starch, threc important clemcnts in feeding. It is a strictly perennial species, and forms a pretty dense sod, when well established.

\section{Orehard Grass.}

This is really one of the most valuable grasses for extensive trial as a first-class pasture grass in the whole list of cultivated grasses. The wollder is that a grass so generally regarded as excellentin Europc, should have made its way so tardily in this grass country. This is probably from its habit of growing in tufts where sown thinly. It is one of the earliest of the grasses to start in the Spring, is strictly a perennial, starts frecly after bcing grazed or mown, and if sown thickly makes excellent hay. It thrives better than most of the grasses in a partial shade, and hence its common name, orchard grass.

For pasture it should be sown at the ratc of not less than two bushels of seed per acre,- - threc bushels is better. It is very light, weighing only fourteen pounds per bushel. When sown for hay we have liad excellent success by sceding at the rate of sixtecn pounds of orchard grass, and ten pounds of clover per acre. It is cxcellently adapted to sowing witl red clover, since it blossoms more nearly with clover than almost any othor of the urasses. 


\section{Fowl Mendow Grass.}

This is another most valuable grass, considered espeeially so for liay, and to our mind quite valuable for pasturage, particularly for dairy stock. Like prairic hay it is quite free from dust, and at the same timo it possesses all the essential elements of nutrition in a high degrce. In all new eountries the first dependenee must be on the wild grasses. The real difieulty is, furmers do not undertake the cultivated grasses until foreed to. If a trial of the important rarieties here noticed sliall loud to the testiug of still other scits, the time will soon eome when our finmers will wouder how they could have gone on so long without appreeiating at their true vilue muy varieties, that the ain and scope of this work precludes evea the wention.

\section{Time for Pasturing.}

It is important that cattle be not only fully fer but that they have their feed at regular intervals. Where stock are driven to and from pasturo they should be turned on soon af er daylight in the norning, wnd not talien out until sundowi. It is ospecially necossary that ihey gu: tho grass while yet it is covered with dew. So, where stock al'e birt and fed in stalples, the first feed should be given early in the morning, just what they will ent clem. This should be supplied not less than three times a day; and at night, to insure full stomachs, some cxtra feed as meal, shorts, ete., shonld be added.

Salt should be liept where the animals can gret it at will. They will thus get enough for their wants, and just as they want it, and will eat less than where supplied at the slables, on out-of-dools, at irregular cimes. Irregular feeding of silt is one of tho worst possible pratices. Salt is a catlaretic when given in larege doses, and this dmece should be aroided.

In Winter, whether the animals are linet in stibles, in sheds, in feodingyarde or in the sheller of groves, the same reanumity of fecling should be observed. Stock should also be graded, if possitile, so there will be no very strong and very reak ones together. And those of a given ago clonld be fed together. Where mimais are fed in groves or in fields inich larger, and, in fact, more irregular drove, as to age and strength, my be kept together, them under open sheds or in elose feoling-yards. Feed early always, as soon afier daytight as the animals can see to feed, nud let the last mess at night be given so as to be woll finished just hefore dirk. When fed in strbles the same rule should be ols pred. Early and late feeding of good fodder, and in sueh quintitic liey will ont wierably cleau, is what keeps growing animals gromg ifrai along. This 
is what the mise feeder sceks, for thus he secures the best possible gain, Fith the least loss in daily natural waste of the physical systew.

Watering.

Whetncr it he "Tintcr or Summer, it is absolutcly nccessary that cattio bave an abumdance of water. Without this, given at regular times, thcre can oe no grofit to the fceder. Cattle may be driven to it twice a day, if tha empitions are such that thcy cannot be fed in the same range whero tho water lics. When cattle are kept in stables, it is altogether better that the watcr be conducted there in pipes so as to run direetly into their drinking troughs. It will be found cheapest in the end. If there is no living water, do not depend upon holcs cut in the iee of ponds. It is not only dangerous to the eattle, but will cost more in the end than any other plan of watering. If the water is to be taken from wells, or pouds, erect a good windmill, with suitable tanks, with pipes so they will not frecze, leading to ample troughs. Let these be in the yards where the stock tuke their rest, or olse in the feeding range. Then sec that they hawo plenty of it, and plenty of salt where they can lick it at will. If the eattle are to be fcd out-of-doors on ear corn and hay, see that proper troughs are provided for corn and racks for hay; let them be large and ample. Where this is donc, close yards should be provided with warm shclter and water.

\section{Fooding Stock Cattlo.'}

In wintering stock cattle the main dependenec will be hay or com fodder. These, if good, are perfect food, that is fed together, or hay fed alone will keep eattle growing, if they do not suffer from the cold. In fecding the samo rule should be adoptcd as in fattening eattlc. Seo that thcy are not gircn enough to wastc, but do not force them to "eat rough, coarse, stalky or weedy hay clean. No animal ever did well on food it did not likc. To make money in growing cattle they must not go bungry Winter or Summer. If the fodder is prairio bay see that tho best and softcst is rescrved for the ealves, and next best for tho cows. Tho oxen and steers will do fairly wcll on hay somewhat coaiser.

\section{How to Feed.}

Calves should have some grain daily; oats are best, one quart each, or the equivalent in other grain. Cows expected to calve the sueceeding Spring, should have from foul to six ears of corn daily, or its equivalent in some other grain; and oxcu when not working, about the samo. 
When working, give the same as to a fattening steer, or about a half bushel a day.

Cittle intended for fattcning the succeeding year should haro especial care the prcvious Winter. They should have fced enough to keep them growing right along, say about balf the quantity of grain given to fattening stcers, that is, allowing the fecters do not believe in foreing the animal from calfhood coistantly, until ready for the butcher. The best and most successful feeders do forcc, and none that we know who have ever tried it could ever be induced to go back to the old way of letting stock. make a gain in Summcr, to lose balf or morc of it in Winter.

\section{Feeding Milch Cows.}

Whatever the plan of feeding or sheltering cattio for the butcher - of course, fattening cattle will have more attention given them, so far as food, water, and shelter are concerncd-nilch cows must have soft food. No dairyman ever made any money by feeding cows in milk on dry hay, ear corn, or dry grain ; for cows it must be ground.

In feeding, the owner will, of course, be guided by the relative valuo of food in the market. If possible, a little ground oil-cake should form a daily portion, about half a pound per cow. In all the West, corn-meal is the cheapest food, except in the neighborhood of large merchant flouring mills. One great difficulty with corn-meal is it is heating. It should be fed almost measure for measure with bram; ten pounds of this with the addition of half a pound of ground oil-cakc, with plenty of good hay, will be liberal feeding. If the cow will cat fifteen pounds of meal and bran, it will be wise economy to give it to her. Shc will not eat so much hay, and in a corn country liay is dcarcr than corn, and as a rulc ais acro of corn is raiscd fully as cheap as an acro of hay. 


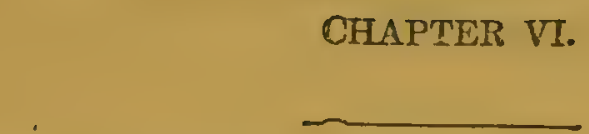

BENEFITS OT KIND AND CAREFUT TREATMENT.

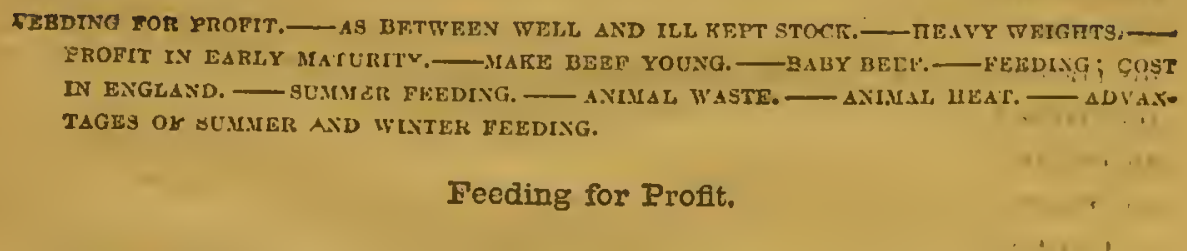

It should require no argument to slow the benefits of kind and eonsiderate tratment in the rearing of live stock of any kind, and in the treatment after they become mature. One reason why so many persolss fitil to be successful in fattening stock is that they do not use due consideration in their treatment. The man who kicks and cluls his stock, ror nllows his hired help to do so, never yet produced a prize steer, and never will. Obesity and activity do not go together, neither will unduc excitability allow of a steady increaso in fitt. Hence the fecder, for the sake of his pocket, should see that fattening cattle are kept entirely quict. To insure this the sagacious breeder avoids not only cattle naturally irritable, but those raised lyy persons of known bad or lonutal teniper. We havo known a stable of cattle thrown off their feed foi days by a sudden fright. Those friglats are quite apt to occur from the slightest canses. Where strange cattle, raised half wild, ure confined together-and this is uot rare among stock that have becn picked up indiscriminately, and what are known as woocis or prairic eattle-the first effort of the sagacious feeder is to get the confidence of the stock. This is only accomilisiend by gentleness, not by any means ineonsistent with firmness. The cuttlo must know and obey their master. Their knowledge of him must be that they receive food and kind trentment at his lauds, and not stabs with the 
fork, nor beatings with the handle, or kicks, because they happen to stame within reach of some brutal feeder. The inference is that the humano man is apt to have humane help; the brutal stock man will harc brutal help, and the stock will be very apt to partake of the character of their master.

\section{As botwoon woll and ill-kept stock.}

Aside from some wealthy professional men, having suburban farms, stock is kept solely for the profit it will bring. The stock of amatcurs are not only carefully houscd and fed, but they are licpt at the height of perfcetion, so far as costly appointments and earcful grooming is concorned. The practical man arrives at the same results in a different and cheaper way, but nono the less certainly. His shelters may be of the most homely kind, even made with poles and slough hay, but are warm and comfortable. He camnot afiord iron mangers and water pipes through his stables, but his troughs aro tight and solidly brilt, and his aninals aro regularly fed and watered. He will not have blankets in winter and shects in summer, but his animals will be well and carefully fed, and sheltered from the earlicst ago until ready for sale.

The humane man will get ten dollars more for a cow because she will be gentle and well trained to giro down her milk without resistance. His stecrs will bring from ono to two cents per pound extra in market, for the reason that the constant care giren them will have resulted in extra weight and condition. Let us sec what two cents per pound amounts to. His stcer of a giren age, say three years, is fed from birth so that it has inever fallen in condition, but has constantly gained, and will weigh from 1300 to 1600 pounds, according to the breed. The stecr of the man who does not beliove in fecding nor properly treating jis animals, will reigh off of grass 900 or 1000 pounds. The good fecd-r will get fivc-and-i2Lnlf cents per pound gross weight, or $\$ 71.50$ for the : 0 in. stcer, and $\$ 88$ for the heavier one. Tho poor feeder will get, say three er per pound, or $\$ 27$ to $\$ 30$. One may see this every day of the year at 'he stock-yards of our western cities. It does not cost $\$ 20$ more to make the good stecr than the poor one; so the enhanced profits aro ncarly $\$ 25$ in the one caso and $\$ 48$ in the other; in other words, the good and humane feeder gets the enhanced price on the poor feoder's 1000 pounds, and on whist he han put on besides by his considerate carc and constant good feeding. Wo have partially shown this in another part of tho work, in alluding to the daily animal waste. That is an integer. This animal waste may be produccd excessively, whatever the system of fceding, if animals aro subjected to frights and bruises, as well as by exposure to storms and lack of sufficiont food. 


\section{Heavy Weights.}

Until the inauguration of the Chicago Fat Stoek Show, under tho auspices of the Board of Agriculture of Illinois, very little relisble data could be had as to gain in feeding animals of various ages. It was well anderstood, however, that the young animal gained faster in proportion to the amount of food consumed, than the nature animal, and that the 'older and fatter the animal became, the less the daily gain. As showing actual facts we append the statements of exhibitors, sworn to in some of the more important elasses shown there, and the reports of committeo thereon:

"Among the heary eattle were the following, and eredited to weigh, as taken from the pasture and feeding yiuds, as follows: The steer Gov. Morton, 3,190 lbs; Burnside, 2,870; Hoosier Boy, 2,640; Nels. Morris, 2,810 pounds. The following are the actual. weights as given by tho conmittee, on animals 1 year to 4 years old:

Messis. Grures \& Co., one stcer 4 years old, 2,445 ; one stcer 3 yeurs old, 2,060 .

A. F. Moore, one steer 2 years old, 1,786.

J. D. Gillett, one steer 3 years eld, 2,139.

Wing \& Thompson, one stecr, 4 years old, 2,240; one steer f years cid, 2,166; one eow, 1,525 ; onc cow, 1,610 .

John B. Sherman, one steer 3 year's old, 2,019.

J. N. Brown's Sons, one steer 2 year's old, 1,446 ; one stecr 2 yeary old, 1,4.19; one steer 2 years old, 1,636; one stecr 2 rears old, 1,316; one stecr 2 years old, 1,216; one steer 1 yen old, 1,338 ; one steer 1 year old, 1,249; one stecl 1 yeil old, 1,193.

Dexter Curtis, one cow, 1,832 ; one cow, 2,012 ; one eow, $1,936$. ."

In this, of the interesting facts shown, is the great weight attainer by one, two and Inree-your-old stcers, as well as the great ultimate weiwhts attained by inature oxen, viz.: Best one-year-old, woight $1,33.8$ pounds ; best two-year-old, weiglit 1,786 pounds; best three-year-old, 2,133 pounds; and the heariest 3,190 pounds. The crucial test in every examinatim being simply the value of the animal for the buteher. 'Tho records fircu beiow will repay the study, and the reports of the committes, as given, will show the points upon which the several decisions havo been made:

Ille maninittee on Short-Hom steers, 4 years old and over, make the following report on ages, weightis, nus gains per day, and add tic curisucits wicl: are appended: 
CLASS $\triangle$-CATTLE. BHORT-HORNS-THOROUGEBREDS.

[TABLE 1].

\begin{tabular}{|c|c|c|c|}
\hline EXIIBITOR. & $\begin{array}{l}\text { Ago in } \\
\text { dayss. }\end{array}$ & $\begin{array}{l}\text { Weight } \\
\text { Nas. } 10 \text {, } \\
1879 .\end{array}$ & $\begin{array}{l}\text { Average } \\
\text { gain per diay } \\
\text { in pounds } \\
\text { since blrth. }\end{array}$ \\
\hline 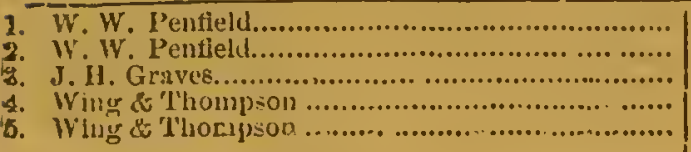 & $\begin{array}{l}2.035 \\
2,1,5 \\
1,015 \\
1,508 \\
1,573\end{array}$ & $\begin{array}{l}2,600 \\
2.438 \\
2.415 \\
2,160 \\
2,2.50\end{array}$ & $\begin{array}{l}1.23 \\
1.13 \\
1.25 \\
1.36 \\
1.42\end{array}$ \\
\hline A vernge & 1,801 & $2,3.38$ & 1.28 \\
\hline
\end{tabular}

The commitiss, in their report on this ring say:

The ring was made up of a remarkaly tine bunch of well-dereloped Eteris; all wera uniformly fat, with llesh well distributed ia the most viluable jorticus of the curciss.

The animals refested grest eredit upon the States in which they were fod, namaly: Ohio, Kentucky, and Bllinois.

The first-premium steer was deep red in color, smooth and eren throughout, rith straight top and bottom lines; broad, decp loin, well filled out; round, smooth, comjact barrel; short in legr, with fine bone and small head.

'I'lis steer excelled the others in the ring in having mole good flesh on the back and loin, with a small portion of cheap, unsilable fit ment, with square, decp, symmetrical quartors, well covered down to the ince and gambrel joint.

The second-premiun steer was a decip red stcer of superior quality, and in choice condition for the block, and, in the main, as good as the firste premium stecr, but was not as free from bunches of fat, ospecially on the rumlp.

The remaining stecrs in the ring, while worthy of special commendation, were coarser and older than the prize-winners, and not as well filled out in the shoulder and thigh, and were patched.

The first-premiun stece was the youngest in the ring, and shorred tho largest aveinge gain per day since birth.

The sccond-premium steer stood second in this respect.

EJORT-HORNS-THOROUGHBREDS. COW3 TIREE YFARS OR OVER. RTPORT OF COMMTTEE.

Tho ring consisted of cight cows of unusull excellence as a lot, showing great difference, howerer, in the matter of age, type, form and mude of handling.

The aged animals were uncren, and earried too large a portion of meat of inferior quality; too gross; some were very badly patched. 
[TABLE 2].

\begin{tabular}{|c|c|c|c|c|}
\hline INo. & EXRIBITOR. & $\begin{array}{l}\text { Age in } \\
\text { days. }\end{array}$ & $\begin{array}{l}\text { IVeight } \\
\text { Nov, 10, } \\
\text { 1sio. }\end{array}$ & $\begin{array}{l}\text { A versge gain } \\
\text { per day } \\
\text { since birth. }\end{array}$ \\
\hline \multirow[t]{2}{*}{$\begin{array}{l}1 . \\
2 . \\
3 . \\
4 . \\
5 . \\
6 . \\
7 . \\
8 .\end{array}$} & 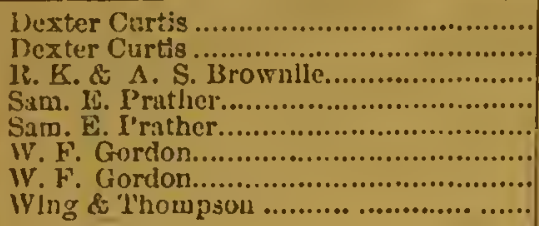 & $\begin{array}{l}2,560 \\
3,667 \\
2.065 \\
2.731 \\
1,186 \\
3064 \\
2.241 \\
1,423\end{array}$ & $\begin{array}{l}3.043 \\
1.936 \\
1.769 \\
1.833 \\
1.025 \\
1.001 \\
1,069 \\
1,610\end{array}$ & $\begin{array}{l}0.90 \\
0.52 \\
0.86 \\
0.67 \\
1.25 \\
0.63 \\
0.74 \\
1.13\end{array}$ \\
\hline & Aversge...................................... & 2,361 & 1,780 &. $\mathrm{s1}$ \\
\hline
\end{tabular}

The cows averaged over six years in age, and some were oroz ten years old. Some of the old brecling cows were very undesirable for the block, and the meat would not be rated as even medium.

The first-premium cow was a deep red and of tho lot the finest in bone, load and neck, the smoothest and best proportioned throughout, with an extra well-filled fore and hind quarter. In the great depth and even distribution of solid, mellow flesh, straight top and bottom line, broad back, and thick loin, this cow excelled.

The second-premium cow was somorhat conrser in head and not is smooth or evenly fatted, and rather delicient in back and loin; otherwiso as grood as the first-premium animal.

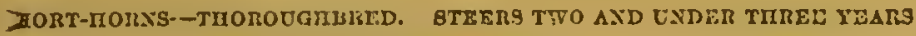

[TABLE 3].

\begin{tabular}{|c|c|c|c|c|}
\hline ITo. & E:TIBITOR. & $\begin{array}{l}\text { Ago in } \\
\text { Uays. }\end{array}$ & $\begin{array}{l}\text { Weight } \\
\text { Nov. 10, } \\
1870 .\end{array}$ & $\begin{array}{l}\text { Average } \\
\text { gain per ving } \\
\text { since birth. }\end{array}$ \\
\hline \multirow[t]{2}{*}{$\begin{array}{l}1 . \\
\text { g. } \\
3 .\end{array}$} & 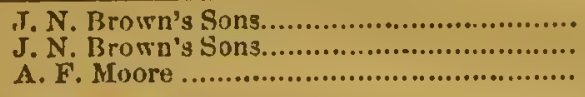 & $\begin{array}{l}815 \\
814 \\
053\end{array}$ & $\begin{array}{l}1,630 \\
1,419 \\
1,786\end{array}$ & $\begin{array}{l}1.93 \\
1.78 \\
1.87\end{array}$ \\
\hline & Average .......................... & 871 & 1,621 & 1.86 \\
\hline
\end{tabular}

Tho committco reported on this ring as follows:

This ring was composed of threo very superior steers, showing unusual cevelopment and riponess for ago. In size, symmetry, and distribution of meat in the best cuts, thoy would pay the butcher tho most profit, and furnish the consumer with the best quality of first-class meat.

The first premium steer was red in color, had tho best back and loin of the three steers, and showed the greatest development for age. Was the smoothost stoer, with smaller bead and lighter in horn; small, neat, short neek, with the widest and deepost breast; better in width of back and 
thicker in loin. This stecr was smooth and free from bunches, with firm, solid and nellow tlesh. 'The quinters were heavy and well proportioned and well filled down to knee and gambrel joint. The shortness in leg p.nd the fineness of bone is worthy of special mention.

The sceond premium steer was a rich roan, not as crenly fatted as the first prenium stecr-more uncven top and bottow line than the first premium stecr.

DTERIS THREE AND UNDER FOUR YEARS.

[TABLE 4].

\begin{tabular}{|c|c|c|c|c|}
\hline No. & EIHIBITOR. & $\begin{array}{c}\text { Age in } \\
\text { days. }\end{array}$ & $\begin{array}{c}\text { Weight } \\
\text { Nov, } 10, \\
1879 .\end{array}$ & $\begin{array}{l}\text { A rersge } \\
\text { gain perday } \\
\text { since birth. }\end{array}$ \\
\hline \multirow[t]{2}{*}{ 2. } & 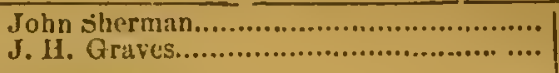 & 1,3112 & $\begin{array}{l}2,019 \\
2,060\end{array}$ & $\begin{array}{l}1.53 \\
1.40\end{array}$ \\
\hline & Average. & 1,326 & 2,030 & 1.531 .2 \\
\hline
\end{tabular}

The committee's report on this ring is as follows:

"This ring consisted of two very superior, well-dereloped and erenlymatehed steers in point of age and weight.

The superior quality of the flesh and the proper distribution of the meat in the best parts of the careass was particularly noticeable in both steers.

The first premium steer, a light roan, was perfectly smooth and freo from bunches, and a good handler. He was straighter on the back than his competitor, with better hind-quarters. This stecr was a low blocky, heavy-set stecr, short in leg, fine bone, neat head, well cut up under throat, short neck, broad and deep in brisket, broad, straight back, neary loin, with thick round, well meated down to the knee and gambrel joint.

The ment was firmer and more solid than on the first premium animal, wlich was fatter, and from all appearances would cut to better advantage and furnish meat of a superior quality.

The second premium stcel was an cxtra well fatted red stecr of great merit; was rathor more leggy and courser in head and bowo than tho other steer.",

\section{… $\quad$ Profl in Early Maturity. :}

In the foregoing reports it will be noticed that the best gain was in stcer one year old and under two; the next best gain was in steer two year old and under three, 1.93 pounds per day; the next best gain was in stecr threo years old and under four, 1.54 pounds per day. Then 
in following the gain in cors over three ycars old, the average will bo diminishing quantity, until in the case of the cow ten years old, table 2, No. 12, the daily gain is but 0.52 of a pound; and in the case of the oldest stecr, nearly six years old, table $1, \mathrm{No} .2$, the daily gain was 1.13 pounds per day. These great results were arrived at by wiin shelter, carcful feeding, and as careful care from birth - most potent fisctors in any case when money is to be made in cattle, either for beef or the dairy.

As a rule, a yearling, as it is ordinarily wintered, will weigh muein less in the Spring than in the previous Autumn. The next Spring and Summer it must first regain tho flesh lost, and then add to growtl and weight. The next Winter it again loses flesh, and at two years old often will not weigh as much as it did at cight montlis old. So it goes on gaining a little in Summer and losing as constantly in IVinter, until at the end of the fourth year the animal will weigh 1,000 pounds-less than the samo animal would have been made to weigh at cighteen montlis old with good common shelter and feed. There aro eases in new countries where feeding, except lay, cannot be laad; where this is plenty, and the range good, cattle may be raised at a minimum cost-simply salting and herding in Summer, and feeding in Winter. Here again the question of shelter must be considered and will be found to pay, and without which no profit can be realized.

This-system of feeding, however, is no longer feasilble exeept in limited arens. 'The great West is fast settling up and increasing in wealth. Ierds are yearly inproving through attention to breeding and feedinigthe result of the cultivation of vast areas in coln, the secding of meadors and pastures, and in superior buildings for wintering stock. The history of the thickly settled portions must be the listory of the newer regions in the future. The profits, in farming in the West, are in the stoek sold. Pastures and meadows are tho groundwork of good faming everywhere. Thus verifying the Belgian maxim: No pasture no cattle; no cattlo no manure; no manure no erops.

\section{Mako Boef YounE.}

The time has gone by when it rould be believed that an animal must reach the age of four or five years before it could malke good beef. The time has also passed when the mere tallow in an aninal would sell it. The reason why we have so little beef fit for export to the English market, and which will bring in Vestern maket from five to six cents per pound gross weight, is that very few western farmers have adopted the Euglish standard of forcing a calf from the time it is born until it is killed, the nge never exceeding three years. This tendeney of English breeders and 
feeders has been the growth of ycars. They had first to eombat the idea that becf must have age befoic it could be healthy meat. First, thcy compromised on three years; the becf was pronounced good. Then tho cattle were pronounced at thirty months fully as good and ripe : they also found that they got enlaneod profits from this manner of feeding. Then two-year olds were forced to the same weight that had previously been, attained at thrce years. Last year beef from eleven to twenty months; was sold, and from an article prepared by Mr. Ienry Evershed, for the Royal Agriculiural Joumat, in which the expericnce of some eminent farmers given, we find interestingr matter in relation to very young beef, or, as they term it,

\section{Baby Jorf.}

Among others, Mr. Stanford, of Charlton Court, is eredited with hiving sold the following heifers and steers in 1878 , the animals being high-grado Short-Horns, at ages and pricos given boluw:

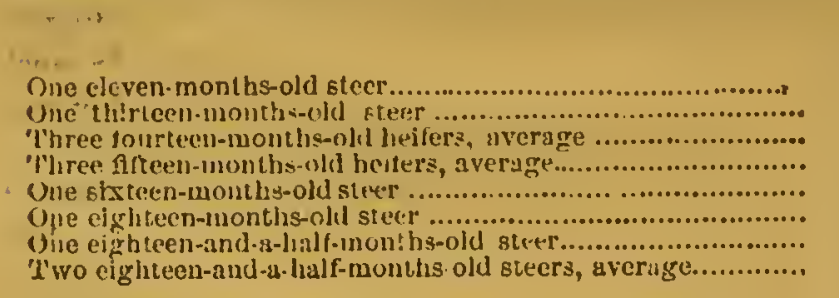

$\begin{array}{cc} & \text { Return per month } \\ \text { Price. } & \text { from: birth. } \\ \$ 7400 & \$ 673 \\ 10164 & 783 \\ 0240 & 660 \\ 10164 & 677 \\ 10233 & 639 \\ 11560 & 642 \\ 12936 & 700 \\ 12310 & 660\end{array}$

The weights of these, some of them werc ealves, is not given, but the price is stated at froin 16 to 18 cents (our money) per pound, net woight - meaning, we suppose, the four quarters. The best 16 months old steer must have weighed something like 1,200 lbs. alive, allowing the quarters to have been 65 per cent. of the whole weight-a not vory large allowance for such young cattle. In tho last Chicago Fat Stock Show, the best steer, 28 months old, weighed 1,636 lbs. The best steer ono year old and under two $1,338 \mathrm{lbs}$., showing that our best feeders not only show fully as early maturity as English feeders, but likewiso as wonderfully good weights.

In relation to the English animals mentioned above, Mr. Evershed wites:

"The abovo figures show that tolerably-bred Short-Horns will return 7 s. a week from birth on this system, at from 13 to 18 months old. Those Short-Horns whieh afforded the least return wero bought in the market, and those whicl gave the highest were by Mr. Stanford's pedigroo bull, out of his well bred, but not pedigree cows. The bost feedors of 
country-bred cattlc in Sussex and Surrey inform me that they consider a fair average weight for animals, well fed from birth, 100 Smithfield stone at one hundred wcchs, giving a return of onc stone (8 lbs. dresscd weight) per week, or $6 s$. (\$1.32) per weck."

Our authority mentions a stecr lilled that dresscd 132 stono at one hundred wecks, equivalent to $1,760 \mathrm{lbs}$. live weight. Somc sixteen months stecrs dressed, in the quartcrs, $600 \mathrm{lbs}$, having $120 \mathrm{lbs}$. of rough fat, and a very small proportion of offal. He states that the best feeders arc ablc to reach an averagc of $\$ 1.43$ per weck at sixtcen to twenty mouths, from a Short-Horn cross on common cows.

\section{F'eeding-Cost in England.}

The Englisl fecder is content with the manure resulting from this manncr of feeding stock, if indecd ho can get this for his trouble. As to the cost of making what is tcrmed a "baby bulloek" of sevcnty-one weeks, the following is given. reduced to our standard of dollars and ceuts :

Pirchase of ealf.

Four weeks' new

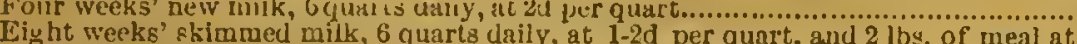

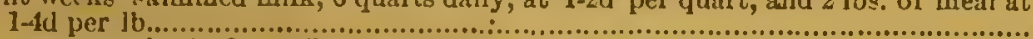

Seventeen weeks in June. July, $\mathrm{Augu}$ t and september, on a daily diet of 2 ibs. of

linseed cake, 2 lbs. bean meil, mingel, lay. grass, elorer, cte..........................

'Twenty-six weeks to end of Marel -5 ibs. of cake and meal daily, 34 bushel of roots, hay and straw for fodker......................................................

Sixteen weeks to harvest-8 Ibs. of cake and meal dally, mangel, grass, elover-total,

\$1 50 per week .................................................................. 25 in 44

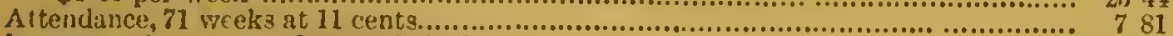
Iusuranee, interest, and rent of shed............................................................. 54

Total.

$\$ 10735$

Our authority estimates the valuc of the manurc at $20 \mathrm{pcr}$ ccnt. of the cost of the food, $\$ 85.12$, or value of manure $\$ 17.02$. His account.... stands thus:

DR.

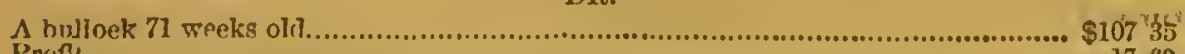

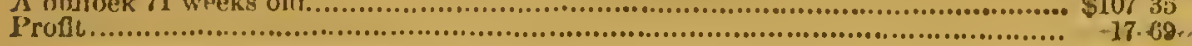

Total $\$ 12301 \cdots 1$

CR.

i... B.

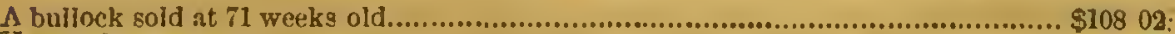

Vuluo of mauure........................................................................... $17 \quad 02$

Total.

$\$ 12504$

Let any feeder take a calf at five dollars at birth, figure the cost of cverything fed in raising, new milk, skim milk, oil-cake, and ground food if raised by haud, or the interest on the cow if allowed to run, care, 
insuranec, ete., it will, if earefully managed, show figures on the right side of the ledger. Unfortunately there is no data to show, but our best feeder's for carly maturity seem perfectly satisfied with the outeoine on stcers of from two to three ycars of age, and probably might be so with younger ones if it woro not the fact that animals do so well until tlireo yoars of age that they disliko to kill them younger; besides, in the West it is found eheaper to grow the cattle rather slowly and give them somerhat longer time. It is a question of cheap food as against labor in tho caro of eattle in stalles, in Winter, and soiling; that is, feeding in stables on grass and other food, artificially prepared, in Summer.

From what we have shown, the reader will come to the conclusion that we aro a firm believer in shelter and humanc treatment. The facts wo have givon will, wo think, fully substantiate tho correctness of theso premises. No sensible person will, wo think, doubt the soundness of tho proposition that the animal should be kept growing during the cold scason, when both feeding and shelter are neecssary. The object with eny fecder is to got the grcatest net gain for the food consumed, and in the shortest time.

Under this system of fecding the profit was seen. The humanity lics in tho faet that the animals had during their lives the greatest enjoyment that brutcs are eapablo of - that of feeding and quict rest. The owner has his reward both in a poruniary and eonseientious sense.

Summer Feedirg.

It is only within the last fow ycars that our best feeders hare supple. mented pasturage in Summer with grain. In England this has beci dono for ycars. The rational " the matter is this. To keep animals in the higliest possible condition, the pastures must be flush, that is, thoy nust produeo full feed at all times. Every master-fecder knows this is not praetieable during some of tho Summer months. The July and August pastures will not earry what the May and Juno pastures will. Gradually they began to adopt the practico of fully stocking the pastures and giving the animals what grain they would eat in conneetion with grass. At times they will ent vory little, espeeially when pastures are in their full suceuleneo of young grconness; but a little moal will bo caten overy day. The systems of tho eattle thus remain in bettor avorago eondition than when fed on grass only, in Summer, and on lay and grain in Winter. Animals when on suceulent pastures require some dry food; they will often cat hay at such times. The moal or soaked eorn, if animals are usod to it, modifies the suceulence of the grass and clover, eontaining as they do from scventy to oighty per cont. of water. Full grain feeding, with hay 
in only small quantitics, tends to the creation of umnatural heat and fever. Food ground, and fed moist with considerable hay, obviates this tendency somewhat, and the more the stomach is distended with fodder the less the tendency to fever.

\section{Naturel per cent. of Water in Food.}

The proportion of water to flesh-forming and fat-forming substance in natural food, (herbage), will range from serenty to eighty per cent. The proportion of water necessary with dry feed mily be stated at about sixty per cent. in Winter, and more in Summer, varying with the heat and humidity of the atnosphere. Upon suceulent lierbage in Summer the animal tissues will continin more fluid than in Winter, on dry food; hence the neessity and economy in Winter-feediug to keep the animils fully supplied with water, so that certain portions of their systems will not be obliged to abstract the natural fiuids from other parts of the body. Upon turning cattle to pasture in Spring they oftcn seen to fatten suddenly. Much of this is due to inereased assimilation of water in the tissues. The advantage of pasturage in Summer is that it tends to ancli. orate the condition of the animal by reducing the feverish state of the system, acquired during the Winter feeding on dry food. Hence tho value of roots, where easily and eheiply raised-tumips in Englind; turnips, earrots, and beets, in the Listern Stites; and beets and carrots in the West. In the West, roots are not given so mucli for their fattening quality; but when these are fed at the rate of one quirter bushel or less per day, they act as a digestive element to the other food, causing moro perfect assimilation. When these are not to be had, bran should const:tute a portion of the food giren.

\section{Animal Waste.}

It is generally considered as true that about two-thirds of the food consumed goes to supply the animal heat and waste. All grasis-feeding animals that have to sustain themselves for long periods in the wild stute, ou sennty food, accumulate large masses of fut in the Smmmer montlis. During the Winter this is gradially dissipated (consuned) in the effort to keep up the animal heat, and by Spring the animals are thin and weak. Precisely the sane thing oceurs in the ordinary way of wintering stock on hay out-of-doors. They become thin, often emaciated, and sometimes die, in the effort of the owner to see upon low little food he ean bring them through alive. Not only all the food given has been consunner, burned up, in the effort to keep warm, but also all the fat, where accumin lated in masses about the body. Not only this; before the animal finilly 
suceumbs, the fat mingled with the muscles and other leat-forming substances, will have been eonsumed. Yet many persons who consider themselves humane and Christian men, follow this plan year after year. It is true they suffer in purse and in vexation. Is it possible to be supposed that their depleted pockets will compensate for the suffering of the ponr brutes under their care? It is hardly a supposable case that it should be so.

\section{Animal Heat.}

The natural temperatine of the body is 100 degrees. If the tempera ture gro above that it indreates ferer ; if below it is a chill; either condition, if not counteracted, will be fatal to life. The adrantuge and eeonony of full feeding in Summer, as well as in Winter, will be under stood when we remember, that, whatever the temperiture of the air, tho animal heat will be 100 . When the temperature will arerage 60 to lis degrees, as it will during the senson of pasturare, it will require only food enough to raise this temperature by 35 to 40 degrees to lring it to Iuo. All clse the animal eats goes to make weight. If daring the Winto: the arerage temperature be 30 degrees, it will require food enougl to los eatcon to raise the temperature by 70 degrees to reach blood heat and kecp up the animal integrity. Here again all food taken in execss of tho animal waste is gain. But another integer here steps in. It requires less proportionate fond to keep the animal forec intact with a high thermometer than with a low one; that is, it requires more than double to supply the waste with the thermoneter at 20 than it does with the thermoneter at 60.

There is a limit of cold beyond which neither aninal nor plant ean enclure. In other words, whon the cold becomes so intense that tho eapacity of the stomach to digest is counterieted by the animal wiste, death ensues. Thus wo often hear of whole dhores being destroged, where exposed to the foree of strong chilling winds, as the "Blizzirds" of Minnesota, "Northwesters" of the plains, and "Northers" of Texis. In a still atmosphere the animals would hare withstood a mech greater degree of "old, for the reason that they would have carried an atmosphero of heat about them. In the wind the heat was blown away, and in tha attempt to supply heat as fast as destroyed the animal cconomy gave rily snd refused longer to cxert itself.

\section{Advantagez of Full Summor and Winter Feeding:}

From what we have written the reader will have learned that there is no economy in seant feeding of animals either in Summer or Winter. 
The facts are, those feeders make the most monez who not only give the warmest shelter in Winter, with liberal feeding, but who carry their stock fully up to the foeding point in Summer. Where corn is as easily raised as it is in the West, many of our best farmers will tell jou they can produce an acro of corn for las tinan an ncre of lay. We have cultivated 65 acres to the land in a field of 1,500 acres, and at a cost of one and one-third clays' work for tean and man per acre, up to the time of, but not including, the husking.

One advantage of feeding grain the year round is that you may stock your pastures so fully that the grass will be licpt eveuly grnzed, thus enabling you to carry more cattle in Summer on a given area of pasturo, and enabling you to produce moro corn for Winter feeding. Another adrantage is, the animals becomo fatter, and thus do not lose so much animal heat in Vinter. Still nnother advantage is, you hasten maturity, and thus save interest on enpital, insurance and other items of cost.

These facts should bo enough to convince the sensible man of tho value of high feeding in connection with shelter, aside from the animus of this chapter, that the liumane feeder-he who treats his animals most bindly and feedo best-is really the one who mulies the most moncy. 


\section{CHLPTER VTI:}

\section{IOW TO BUP AND HOW TO SELL.}

TEE VALUE OF GOOD CARE, — ESTIMATING WEIGTT. —- TSTIMATINT EF MEAS-

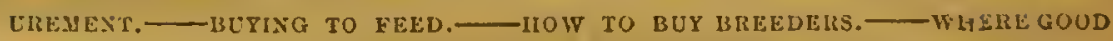
BEEF LIES, - BCYING FEEDING STOCK. - ANALYZING TIE CARCAES.PROPEIR SHAPE OF WELL-BRED FATTENING STOCK, — HOW TO LUY. - BUY* ING MIL.CH COWS. — BUYING DAIRY MILIKERS. — MILK MIRRGRS. - TUE TREE VALLE OF MILK MIRRORS.—-VALCE OF ESCCTCIIEON MARES.—-MILIKCRS IN ALL BREEDS. L IIEREDITY. DIGESTION. — RESPIRATION. - SYM. METIYY.

\section{The Value of Good Care.}

There are very many farmers who, by care and attention to detnils in feeding their stock, and by lindly treatment, have done so with profit to themselves. They have raised them from ealfhood. Let them undertake to buy cattlo for feeding their surplus grain and fodder, and they are very apt to overrate tho weight and true value of the cattle purehased. One point should always bo kept steadily in mind: Never buy an old stecr or cow for fattening. 'They merer repay the cost and trouble they give. Thin cattle, ready for grass, if healthy, may give good returns on flush Summer pasture, if bought at the price per pound that you expect to get in the Fill. You will not only get the price of the flesh put on, but the cattle being thin and the museles dry, your profits will be added to in the fluids absorbed, and the loss will lie with the former owner in making mere frumes to be built upon. So animals bought in the Fall in common grass flesh, will inereaso wonderfully with good feeding and shelter. If you buy at $\$ 2.50$ per $100 \mathrm{lbs}$, and so add $200 \mathrm{lbs}$. in flesh, and sell at $\$ 4$ per 100 lbs., you not only get $\$ 3$ for the flesh put on, but the difference betreen $\$ 2.50$ and $\$ 4$, or $\$ 1.50$ per 100 lbs. on the original weight. That is, you buy steers at 1,000 lbs. each, feer 50 busbols 
of corn per head, and sell them weighing 1,200 lbs. average. They eost $\$ 25$ and sell for $\$ 48$, leaving $\$ 23$ as the value of the corn fed and care given. The manuro in any country will pay for tho care talien; so, your corn will have netted you near forty-six eents per bushel. From this, knowing the cost and price expected when fat, it will be casy to figure on profits, fluctuations and accidents execpted.

\section{Estimating Weight.}

An expert judge will estimate from sceing and himdling steers often within ten pounds of their live weight. The buyer will always underestimate weight, and in nine cuses out of ten convince the inexpert orviner that the guess is right; in fact, moro than half the time the seller will bo eonvineed that he has the best of the bargain. The only safe way in such cases is for the seller to weigh. Every inan who makes a business of fattening eattle should own a proper scale. He may save the cost in a single year. The merchant, the manufacturer and the builder, who work by guess, always end in bankruptcy. The only reason why farmers do not, is, they have that gellerous bank, motlier carth, which never fails to respond, even to indifferent managers.

In weighing eattle note carcfully why certain ones weigh nut of pros portion to others, and study whether the weight is in the primo parts, a broad loin and hips, and good barrel, or in heavy forc-quarters, with thick neek and big head and horns. Study carefully the points as given in detail elsewhere in this book, and as carefully remember them for futuro use. Thus you may in time become yourself an expert judgo of stock. If an animal is to bo killed, estimato his weight alive, how much he will shrink in offal and hide. When the quarters are weighed, if the record is not as you expect, examine earefully wherein the diserepancy lies. It is an especially interesting study for the young man, who expects himself to become a breeder and feeder of eattle. If a breeder, he must know how to sell; and if a fecder, he must know both how to buy and sell.

\section{Fstimating by Measurement.}

Many breeders have rules of estimating the weight by measurements. There is no rulo that eomes nearer than good guessing, and all guessing should bo aroided, especially when the guessing is to lic on the part of the buyer; that is, tho scller should avoid trusting to tho guoss of tho buyer, based upon measurement. No two animals will weigh aliko according to nicasurement.

Ono rule, perhaps as good as any and for this reason given, is to find the superficial fect by multiplying the girth, just behind the shoulder- 
blade, by the length from the fore part of the shoulder-blade to the root of the tail. 'Thus an ox girthing 7 feet 9 iuches and measuriug 6 fect in length would contain 7 3-4 tines 6 , or 46 1-2 superficial feet. For cattlo griass fat the following is given as the weight per superficial foot:

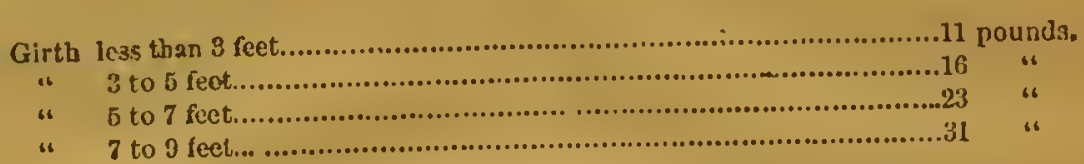

Thus the steer as per above measurements should weigh 46.50 by 31 , or 1,441 lbs. gross. Under this rule it is usual to deduct one pound in tirenty on half-fatted cattle, from 15 to 20 lbs. on a cow having had caives, and if not fat nn equal amount. The rule as above stated is of little or no value, except to those having no other means. In taking account of stock, this may come somewhat near the weight. For buying or selling tire scale is the only true standard.

\section{Buying to reed.}

In buying cattle either to glaze or to feed fat, ehonse enttic that aro young, that is, that will not have become inature before ready for salc. If to be kept a year, three year old past to four year old for natives and Devons, and one jear less for Short-Horns or Hereford grades. Buy no overgrown, leggy animals; they are hard feeders. Neither should they be undersized, as this iudicates want of thrift. The cattlo for inoney, whatcver their breed, are compact, smooth, fine boned, meck-eyed, soft baired stocrs, with skin of medium thickness; thick througl the lieart, lound barreled, well ribbed, with broad rump, and the twist well down to the linck. Such cattle, whatever their brecd, will fatten linaly and the meat will be of excellent quality. So far as age is enncerned, the tecth must bo the test. In this no person can crr wilen bas carcfully studicd the chant of the tecth in auother part of this work.

\section{IIow to Buy Breaders.}

If the intention is to raise beef cattle the same rulc will apply as in buying steers. In no ease should the $\mathrm{cow}$ be more thin three years old, and it is better that she nerer had a culf. In brecding for becf, milk is not the first essential. It is ncessary, however, that the dam givo a fair amount of milk, since the proper sustenance of the en! is what lays tho foundation of the future value of the stecr. No calf starved when young can make a valuahle cow to biced from, and as is the dam so aiaturally will be the produce. Whatever is to be the outcone, avoid at 
any price a vicious cow, ol one with a wild eyc or having a dished faco. Hel progeny will be sure to give you trouble, and will not give you cattlo that will fatten to the standard of the picture we give you of Larl

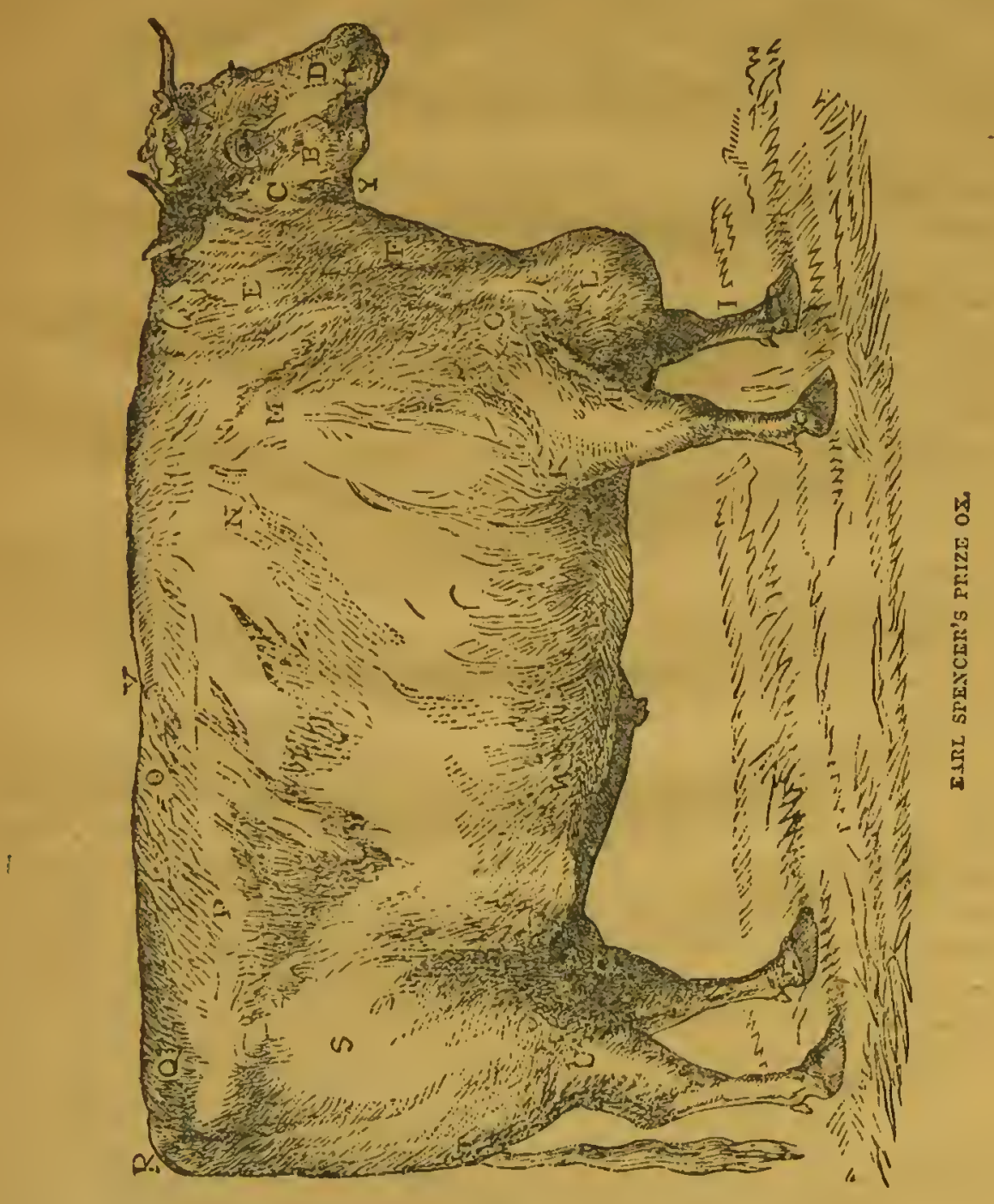

Sipencex's prize ox; giren not only s. shouing what Short-Forns wero

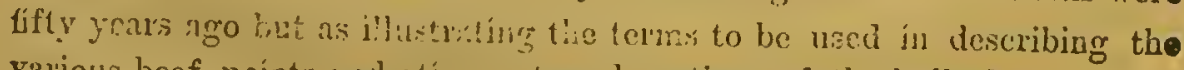
various beef proints sud oinc: vitward portions of the bullock. 
Explanation,-A-Forehead. B-Face. $C$-Cheek. $D$-Muzzle. $C$-Neck. $\quad F-$ Neck-vein. $G$-Shoulder-point. $\quad H-A$ rm. $I \rightarrow$ Cambrel or lock. IK-Elbow. $L-$ Brisket, bosom or breast. $N-$ Crops. C-Loin. P-Hip. Q-liump. $R$-Pin-bone. S-Roundbone, thurl or whirl. $T$-Buttock. $U$-Thigh, or gasket. $V$-Flauk. W-Plates. $\quad X$-Back, or' chine. ' $Y$-Throat. $Z$-Chest.

\section{Where Good Beef Lies:}

The prime parts of the ox lic, as shown in eut, from $N$ to $R$, thenee to $\Delta$, and back to $N$. Between $P, Q$ and $V$ are the primcst parts. The sccond best are between $M, S, T, V, W$, and $K$. Between $S$ and $U$ are valuable picees for smoked or dried meat. The ribs betwecn $M$, and $S$; the fianks $V, W$, and thence to the brisket $I$ are good corning pieces. It will be seen that this animal has a very small proportion of offal, and a very large proportion of valuable meat, being full and broad in the loin, thick ribbed, with the rump massive, square behind, and carrying beef below the twist, or junction of the thighs, well down to the hocks.

\section{Buying eeding Stoek.}

Ihe noviee in buying stock should carefully note the shape and make up. To the supcrficial eye the superior aninals when thin will appcar rorse than the inferior ones; the bony parts will appear more prominent, and for this reason their breadth, when thin, will seem to be exaggerated; this, Inwever, is only apparently so. An animal of no particular charaeter miay secm fairly sinooth to the eye. Those aceustomed to handling stock will know that superficial olsservation goes for little. The touch is what decides the valuc of an animal. The well-bred animal carrios softer, smoother, and finer hair thian the ill-bred one; its breadtl from the shouldcr to the rump gives it a bony appearanoe when thin, that in the scrub steer is partly eoncealcd by the higher backbone and enarser hair. We are now speaking of 110 particular brecd, but of all brecds and crosscs that have characteristic points enabling tlicm to lay on flesh. The scale of points for Short-Horns will make a good study. The illustrations of fat cattle show what they should be when fat. The picture of the Deron' ox will show what a good feeder should look like off of good grass, and may be taken as the typo for our best native cattle.

\section{Analyzing the Careass.}

In all first-elass steers every part of the animal, except the bones, hide, tallow, and offal, will be good consumable fiesh. 'The rousts, steaks, and corning picces will bo of the best, so that when the four quarters are hung 
up there will be no loss exeept hone. Let us now sac what such an us we have shown will give. In the first place, his quarters will iress sixty-five per ecent. of his gross weight. The loin abore $P$ and from thence to the top of the shoulder abore $\nu$ will give inost superiol steak and roasting-pieces. The shoulder-point or neck-vein back of ' $T$ ' and the thigh at 5 make the hest smoking-pieces. The plates $W$ will malie the richest of corned beef, while $R, S$, and $L$ (the rump, round and brisket) make the best pieces for packing-good thick, juicy meat, and iu largo quantities. In fact such an animal will eonvert the food he cats into good beef, and plenty of it

\section{Froper Shape of Well-bred Fattening Stocl.}

Cut off the head, neck, legs, and tail, and well-bred beef cuttle will present the appearance of an oblong square. Thus there is ample room

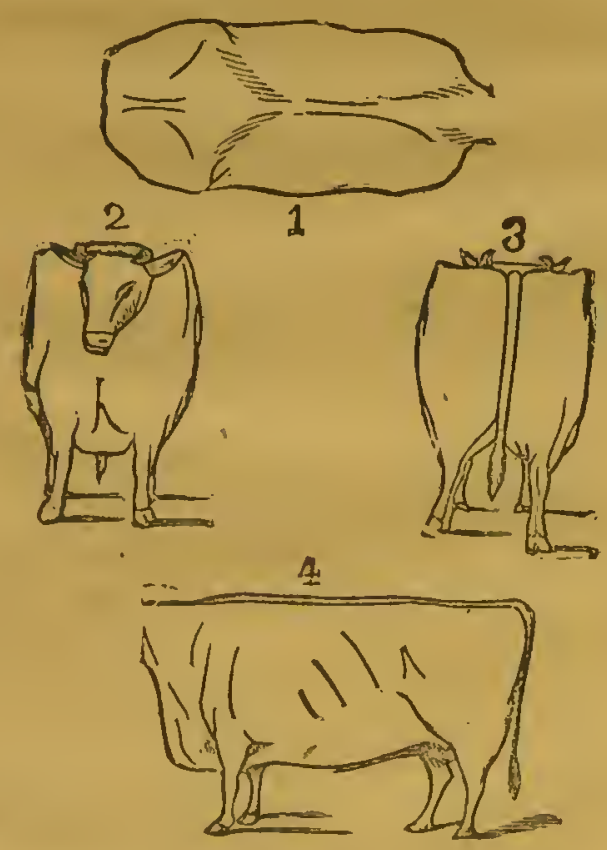

DUTLINE OF PRIZE FAT BULLOCKS.

for the legs and risecra through the width of the bosom and spring of the ribs, and this earries corresponding lreadth bohind, giving a broad loin and massive rump. Such an animal will feed heartily and kindly, satisty the butcher when brought to the block, and be profitable to the fecder. Above we give four outlines showing animals mado very fat, and 
cut square to show the slape. There is no profit, however, to the fecder in eattle fattened to obese or inmense weights; they are inere mountains of fat, and contain no moro lean meat than animuls fattened fairly ripe. There are few people who do not like well-fatteued beef. Few, however, care to eat any bit the lean. An animal, therefore, that is fatiened just ripe is the heaviest in musele, well marbled with fat. This is what tho consumer wants, and what the feeder should seck to makc. Snooth, finchorned, medium cattle, according to the breed sclected, are what giro profits in this respect.

\section{How to Buy.}

In buying ordinary (that is native) enttle for pasturing and feeding fat during the Summer and Fall, always buy in the Spring. If the grass is good at the time of purchase, as it should be, no matter how thin the stoek, if healthy and hearty. The thin stock will weigh less, and you will havo to pay less for it. The loss will be with the farmer who grudges his mimals sufficient to eat in Winter, rather than with the buyer. Generally all this elass will sell cheaper in the Spring than in the Fall, and as a rule yearlings may be bought for less inoney in the Spring than tho sane calves would have brought in the Fall. If they have been fairly wintered they will be profitable to feed; if badly wintered, it will be questionable, unless the priec paid is low enough to warrant the purchase. In any erent the feeder must usually depend upon buying stecrs off of common keep. Good feeders are not apt to sell half-grown stecrs, nor those that one more season's keep will make ripe. The best moneymaking friends of the sagacious buyer are, after all, those who never read, and will not belicre that anything in print relating to agriculture in any of its various departments can he of value. They do not know that as great advanees have been made in agrienltural art within the last thirty years as in any other industry, and that the best praetieal talent in Europe, and within the last few years in America, have been earnestly engaged in elucidating and applying practical seience to agrienlture.

In selecting milking cows the following doggerel verses from an old English magrazine are as true now as when written as to what constitutes a cow for both milk and becf:

She's long in her face, she's fine in her horn, She'll quickily get fat without ealie or corn; She's clean in her jaws, and full in her chine, She's heavy in llank, and wide in her ioin.

She's broad in her ribs, and long in her rump; A straight and flat back, without $\mathrm{e}^{\circ} \mathrm{cr}$ a hump; Slie's wido in her hips, and calm in her ejes;

Ghe's fine in her shoulders, and lhin in her thighs. 
She's light in her neck, and small in her tail;

She's wide in lier breast, and good at the pail;

She's fine in her bone, and silky of skin -

She's a grazier's without, and a butcher's withis.

\section{Buying Mileh Cows.}

In selecting eow's for milk, or heifers from whieh to breed milking stoek' the breeder must be guided by the same general prineiples as in buying becf-making steers. That is to say, the animals must be fine, with mellow though rather thin skin, and mossy hair; the head small, but fueo straight and rather long; the horms should be fine, short, and if somewhat eurved it is a good indieation. The eye must be bright and yet placid. The barrel, pelvis, rump and thighs should be roomy; and, for obvious reasons, avoid a dish-faced, and espeeially a wild-cyed eow, or one witl a dull, heary eye. The first shows vieiousness, the last stupidity - loth dangerous and both unprofitable.

In buying for milk, the object being to breed your stoek, seleet heifers of three years old ready to eome in, provided the stoek bulls were suitable; if not, have nothing to do with them. In this ease buy heifers of two years old that have never been bred. Then, by attention to what we have suid upon breeding, you eannot go amiss.

\section{Buying Dairy Milkers.}

When the buyer is seleeting eows simply to wear out in the dairy, and without any referenee to retaining or improving the breed, all he has to look to is an animal that will give a good flow of milk, and liold the flow for a long period. Many eows will start out with large inesses, and at the end of three months will hardly give enough to keep a ealf; others will continue in milk for six montlis; others, again, will continue in milk well up to the time for again dropping a ealf. These latter are the cows to buy. Seleet them aecording to the rules heretofore given, and of from three to five years old, but not unless they are well along in calf. A dairy cow will eontinue to improve in liel milking qualities until she is six years old, sonetines until sle is seven or eight; they will continue to give ample returns until ten years old, and often until eleven or twelve.

\section{Milk Mirrors,}

Besides the rules already laid down, there is an infallible sign in tho milk inirror- or "eseutcheon," as it is now called-in eows, heifers, calves, and also shown distinctly in the bulls of milking brecis. We lave studied and bred by it sinee its first publieation in the United States. It is the result of ycars of study by M. Franeois Guenon, a practical 
farmer of Libournc, France, and first reduced to a system in 1822 . In 1828, at a public test and careful examination by thc Agricultural Socicty of Bordeaux, the committee mado an absolute and cxhaustive report, in which they uscd this strong language: "This system we do not fear to say is infalluble."

The socicty decreod Mr. Gucnon a gold medal, made him a member of the society, ordered fifty copies of his work, and distributed one thousand copies of thcir full report among all the agricultural societies of France.

This systcm was first made known in the United States, if we remenn ber aright, between 1838 and 1840, and has becn studied, believed, and acted on by many practical men; yet, curiously enough, it has never attracted general attention until within the last few years, since which timc dairying and the breeding of dairy corvs has come to be a regular profession. While wo should not rely entirely upon the many classes and thcir variations, including a bastard escutcheon to each class, the signs as given by the author are most valuable in connection with other matters which are given. In the Gucnon theory there are twenty-seven cuts or diagrams to illustrate his idea, varying from the fullest development in the growth of hair turned uprard, to as near nothing, as is ever shown in the cow, but all having morc or less of this pcculiar development of hair on the parts named; this hair, to indicate a good milker, should turn upward, be short, fine and close; the skin easily raiscd, and with peculiar oval marks and scurf spots.

\section{The True Value of Milk Mirrors.}

So far as wo have studicd these signs, wo have found them whilc not constant marks by which the quality and flow of milk could be accuratcly judged, yet most valuable in conncction with other characteristic signs and configurations, which we have given for judging accurately what should coustitute a good dairy cow. We have found it a most valuable aid in judging the milking qualities and time of continuance in milk. That in itself it does not constitute an infallible test is no proof of its being an unsound theory. That it is correct, as a rule, is sufficient to causc it to be given careful study and attcntion.

Wre do not hesitate to say that he who will study carcfully the illustrations we give, and the statements made, while ho will find many varying signs, will not only be convinced of the accuracy of the system, but will be ablc, either in the cow or calf to select with judgment. Thə milk sign also follows in the bulls as we shall show.

Mr. Charles L. Sharpless, of Pcunsylvania, a closo obscrver and good 
breeder, in relation to the value of the escutcheon, as secn in Jersey enttio, gives his experience, which we eondense as follows:

There is no point in judging a cow so little understood as the escutcheon. The crnclusion of almost every one is, that her escutcheon is good, if there is broar band of up-running liair from the udder to the vulva, and around ito

Fra. 1.
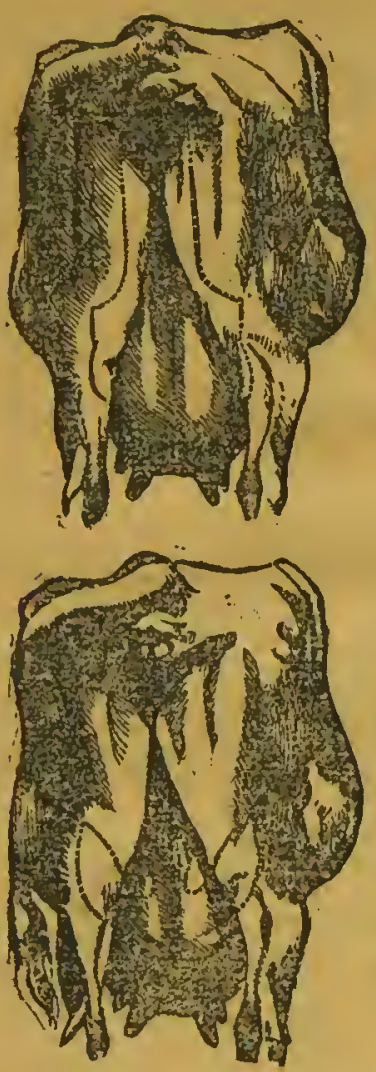

Fia. 3.
Fia. 2.
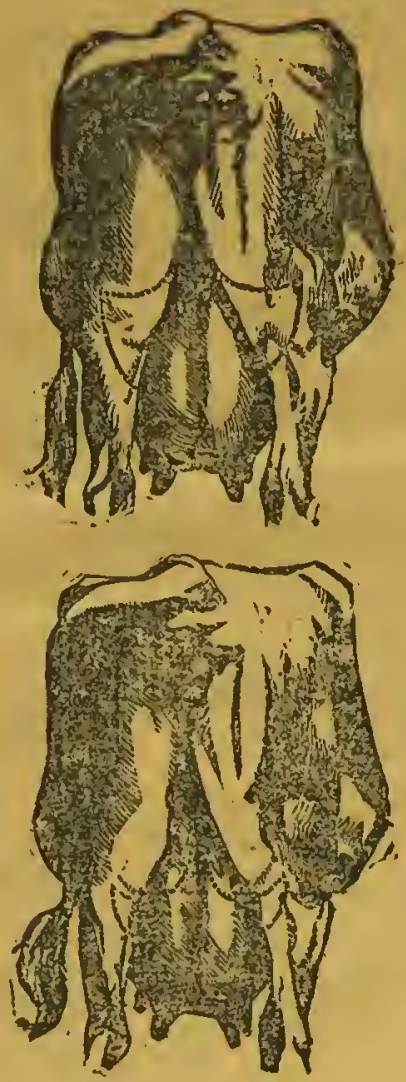

FIG. 4.

Theso cors with the broad vertical eseuteheon are near!y always paral?el eows; that is, with bodies long but not large, and witll the under line parallel with the back. Their thighss are thin, and the thigh eseuteheou shows on the inside of the thigh rather than on its rear.

Next enlues the wedge-shaped eow, with the body shorter but very lurge, deep in the flank, and vory eapacious. This form does not usually 
exhibit the vertical escutelicon running up to the vulva, but with a broader thigh may exhibit a thigh escutcheon, which is preferable to the other, thus-sce Fig. 2.-Milk mirror of Jerseys.

In both rertical and thigh mirrors, where the hair runs down, intruding on the udder (as low as above the dotted lines) as in Figs. 3 and 4, it damages the escutcheon. If you find a cow with the hair all ruming down, and between the thighs-that is, with no up-running hair-stamp her as a cipher for yielding milk.

There are times when the udder of a cow with an escutcheon like Fig. 1. will be enlarged by non-milking, for the purpose of deception. It is always safer to judge by the escutcheon rather than by the linge size of the udder.

The escutcheons of the best cors - those yiclding the most and continaing the longest - will be found to be those which conform to Fig. 2.

The vertical escutcheon of Fig. 1 would not injure it; but if that ornamental feature has to be at the expense of the thigh escutcheon, Fig. 2 is best as it is.

Whenever an escutchcon is aceompanied by a curl on each hind-quarte? of the udder, it indieates a yield of the highest order.

So far, we have noticed only the rear escutcheon, or that which repreEents the two hind quarters of the udder. The two front quarters are just as important, and should be eapacious and run well forward under the body. If the udder in front be concave, or cut up, indieating small capacity, it represents reduced yield.

This front or level escutcheon is distinctly marked in the young heifer cr bull, and ean be secn by laying the animal on its back. The udder hair under the body all rums backward, commencing at the forward line of the escutcheon. This dividing line is very perceptible, from the fact that the hair in iront of it all runs forward towards the head of the unimal, while tho escutclicon, or udder huir, all runs backward, over tho forw:ald quarters of the udder, around and beyond the teats, and ceases at the minkings of the rear escutcheon on and between the thighs.

The breadth and extent forward of this front escutchcon indicates the capacity, in the mature animal, of the front quarters of her udder. In some cises this front escuteheon will be found of twice the extent that it is in others, and is evidence of that nuch more yicld.

This examination cuables one to see the size of the teats and their distance apart, and to test the looseness and softness of the udder skin It is marked preciseiy the sime in bulls, and cau be easily examimed at any age between one and ten months 
Many think that the cscutcheon of the bull is of little moment, so the ho has a good look. So far is this from bcing the case, that a bull with a mirror like Fig. 4, or worse, will stamp his escutcheon on, and to that extent damage, his daughters out of cows with escutcheons as ehoice as I.ig. 2. In this way the daughters of some of the best cows come very ordinary, while, if you usc a bull marked like Fig. 2, he will make a por escutcheon better, and will improve the best. His injury or benefit will be doubled according to the escutcheon markings under the body in front of his scrotum. Hence the importanee of the dam of a bull being unexeeptionable in her udder and escutchcon. Her qualities inheritcd by ber sou will be transmitted to his daughters.

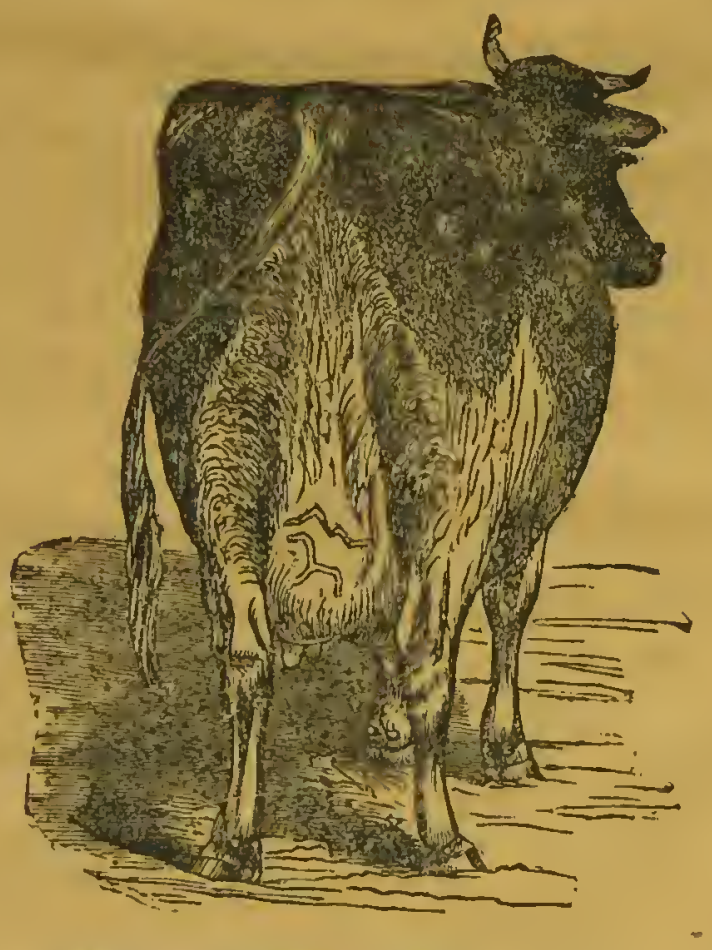

GREA T MLK MIRRORS ON ROLSTEIY COT.

While careful as to eseutchoons, we must not neglect the othcr esscntial rantures of a good cow-the back, skin, hide, the rich colored skin, and the finc bonc. Let the hair be soft and thickly sct, and let the skin be mellow. This latter quality is easily determined by grasping betwecn the thumb and forcfinger the skin at the rear of the libs, or the doublo thickness at the base of the flank that joins the stifle-joint to the body, or that ou thas inside of tho rump-bone at the setting on of the tail. Let the 
teats be well apart; let them yield a full and free stream, and be large enough without the neeessity, in milking, of pulling them between the thumb and forefingers. And let us ever keep in mind that the largs yielder must be well fed.

Prof. Magne, V. S., of the Veterinary Sehool, Alfort, some thirty years ago, as to the relations below the eseuteheons and the funetions of the milky glands, and as differing from M. Guenon in some of the details, gives the following explieit information:

"The direetion of the harr is subordinate to that of the arteries; when a largo plate of hair is direeted from below, upwards, on the posterior faee of the udder, and on the twist, it proves that the arteries that supply the milky system are large, sinee they pass baekwards beyond it, convey inueh blood, and eonsequently give aetivity to its functions. Upper tufts, plaeed on the sides of the vulva, prove that the arteries of the generative organs are strongly developed, reach even to the skin, and give great aetivity to those orgars. The eonsequenee is, that after a eow is again with ealf, it draws off the blood which was flowing to the milky glands, lessens, and even stops the seeretions of milk.

"In the bull, the arteries, corresponding to the mammary arteries of the cow, being intended only for coverings of the testicles, are very slightly developed; and there, accordingly, the escutcheons are of small extent."

\section{Value of Escutcheon Marks.}

After the explanation, which accords very well with all that has been observed, it is easy to eomprehend the value of the eseuteheons. The more the lower ones are developed, the greater the quantity of nilk; but shape is of eonsequence.

Still, whatever be the eause of the relations existing between the produetion of milk and the eseuteheons, these marks eannot furnish data so certain as some have affirmed them to be.

In faet, the quantity of milk, and its quality, do not depend solely on the form and size of the eseuteheon; they depend on the food, the pirrtieular management, the elimate, the season, the temperamenc, the size and energy of the prineipal internal organs, the capacity of the chest, the influenee of the generative system, etc. All these circunstances cause the quantity of milk to vary, without making any change on the extent of the escuteheon; consequently, it is impossible that the s:lme relation ean always exist between the escutcheons and the quantitic:s of milk. Wo often see cows equally well shaned, having exactly the same eseutehcon, and plasol under the same hyginnie eonditions, yet not giving equal cyan- 
tities, or equal qualities of milk. It could not be otherwise. Assuring that a given tuft has the sime value at birth, it cannot be the san's in adult age; since, during life, an infinite number of circumstances occur to diversify the activity of the milky glands, without changing the firruro or size of the tuft.

Is it not sufficient to refer to the inequality of milk given by the simo cows, according as they have had one, two, or three ealves, in order to malke clear that $M$. Guenon has assigned too much value to the mark. which he has discovered?

It often happens that two horses, having exactly the same construeture, and the same cxternal forms, have not the samo energy, the sane fitness for work. The difference is owing, evidently, to the tenperament, and the activity of the principal external organs; in other words, to conditions which it is often impossible to estimate by any direct netlod.

Now, sccing that temperament has an influence on muscles and bones, the action of which, however, is partly mechanical, rescmbling that of a lever, and exerts this influenec so powerfully as to render their movements unequal in respect both of power and promptness, can wo suppose that it has no influcice on the entircly vital, or, at least, the entirely nolecular working of the mammary gland?

It might, therefore, have been argued a priori that the matheinatical precision assigned to a classifieation of cows is contrary to the most gencral laws of physiology; to propose a mark indicating that a cow will givo so much milk daily, and for so many days, is to deceive ourselves, or to attempt to deceive others : the study of the phenomena of life proves that the action of the organs depends not merely on the size and their form, but on the general condition of each individual

We are able not only to olpose arroment to the assertion of M. Guenon, but we can appeal to the difficulties hitherto experienced in applying his clissification to practice. M. Guenon has not yet found a single pupil worthy of him. And among the thousands of persons who ocenpy thenselves with his meliod, is there a single one who has acquired sufficient ekill to justify the claims which the author makes for it?

It may be affirmed tlat, to form pupils as shillful as himself in judging of cows, M. Guenon would not only have to teach them that a certain fig. ure for the tuft corresponds to a certain number of pints of millr, but he would have, above all, to communieate to them his perspicuity, his talent for observation, and his great experience; he would, in fine, have to fit them for estimating, in addition to the dircetion of the hair of the twist, the whole of the inarlss usually employed in making choice of milel eows.

All the attcmpts made on the Gucnun method, not excepting those of 
(he author himself, prove the soundness of our opinion. The most skillful, when called to decide on the qualities of cows, whose yield of mill: was well known, crred scren times on eight cows, and fifteen times on twenty-one. And, lest these errors may be attributed to chance, on account of the sninll number of cows submitted for trial, we should mention thut other estimates prored crroneous 152 times on 174 cows, and 321 times on 352 , and that the crror anounted to 921 pints of milk on a total of 2,683 pints; in other words, thcre was error in regard to almost all the cows; and error amounting on an average, on each, to more than a third of the yield. On some individuals tho estimates were wrong to the extent of from 17 1-2 to 21 , and even from 26 to 28 pints a day.

Such is the truth as to the perfect nicety clained for the cscutcheon systcm. The system eannot do more than furnish an approximate estimatc of the quantity of milk, and that in regard not to all, but only to rhe majority of cors.

What, then, has led so many persons to put confidence in M. Guenon's discovery? 'The great talents and knowledge of the author. Tho system hos obtainer the eredit due ro the experience of him who applied it.

By his discovery M. Guenon has rendered great seryice to agrieulture; the cscatcheon has the advantage of furnishing a mark which can be easily diseerned, and estimited even by persons of no great experience in the selcetion of cows - a mark perceptible on very young animals, and on bulls as well as heifers - a mark which, when disencumbered of the complieatcd systen in which it has been wrapped up will be in eommon use and facilitate the increasc of good cows, by not allowing any but those of good promise to be reared.

\section{IIilkers in all Breeds.}

Professor Magne also gives the following concisc directions in relation to choosing a good $\mathrm{cow}$, where he silys:

"Wo find good milkers in all brecds, but they are lare in some and very common in others. It could not be otherwise. Milk properties, depending on the conditions which determine the formation of brecds, are duc partly to the climate, the soil, the air, and the plants of tho countrics where the breeds have originated; and must therefore vary in our different brecds of hormed cattle, with the hygienic condition pceniiar to each locality.

"Milkcrs, and more especially animals intended for brecding, must bo An'ceted among brceds celebrated for abundance of milk. Not that we eas Lreng to import into our department, with a dry and warm climate 
nil the qualities of the excellent milling hreeds possessed by countrics in which the soil is tertile, the air moist, and the sky often eloudy; but as the influenee of elimate, though very marked, takes effect only in the long rum, the properties of the animals imported are maintained-though subject, doubtless, to gradual deterioration - during a period which varies with the precaution taken to preserve them; and for several generations the desecudants of a good imported breed give more nilk than individuals belonging to a breed found on the spot, where lygricuic cireumstallecs are uot favorable to milking properties.

It is not to be forgotten, moreover, that under the iufluence of particular circumstances, which it is sometimes impossible to call into existence, animals manifest properties which we cannot produce directly. This explains why it is often more advantageous to import qualities possessed by foreign stock than to try to develop them in native stock.

As milking qualities are in a great measure dependent on structure and, temperament, which are more or less hereditay, descent excrciscs a, great influcuce.

\section{'IIeredity.}

In each breed, therefore, we should choose individuais helonging to the best stocks, and the offspring of parents remarkable for their inilking qualitics; for it is ccrtain that good milch cows produec others which resemble them.

But it is especially necessary when selecting stock for the purpose of brecding milch cows, that particular care should be taken to select individuals belonging to good families. A cow of a bad milling family, or cren breed, inay occasionally be an excellent inilker, and more than this is not wanted when it is not meant to breed from her. The same cannot be said when breeding is intended, because there would be little ehance of her transmitting the recidental or exceptional qualities possessed by her; whereas the qualities forming the fixed and constant characters of the stock would almost to a certainty be transmitted to descendants.

These remarks, with regard to breed and parentage, apply to tho selecs tioll of the bull, which, as experience demonstrates, acts like the eow do transmitting the milking qualities which distinguish the breed and stock

\section{Digestion.}

The digestive ormans have a great influence on the exercise of all the functions, and particularly on the secretion of the milk-glauds. Where the digestive organs are defective, good milch cows are rarely met with.

Good digestive organs are knowu by a belly of mouesuto suce, with 
yielding sides, free from tightness, (in aged mimals the belly is often large, though the organs which it contains are in good condition); a largo mouth, thick and strong lips, a good appetite, easy and quick digestion, glossy hair, supple skin, yet firm, and somewhat oily to the touch. Animals possessing these characteristics may be expeeted to feed and drink heavily, and, if they are properly fed, make unuch blood, and yield largo quantitics of milk.

\section{Recpiration.}

The respiratory organs completo the system of nutrition. The lung3 bring the air breathed into contact with the blood, and render the system of nourishment complete. Hence, a good form, quick digestion and a he:slthy condition of the lungs are necessary to the production of a largo flow of milk.

\section{Milk Veins.}

If the veins which surround the udder are large, winding, and varicoso (dilated at intervals), they show that the glands receive much blood, and, consequently, that their functions are active, and that the milk is abundant. The veins on the lateral parts of the belly aro most easily observed, and all authors decide them to be among the host tests for uscertaining the activity of the glands.

'These reins issue from the udder, in front, and at the outer angle, whero they form, in very good cows; a considerable varicose sweliing. They proceed toward the frout part of the body, forning angles, more or less bistinet, often divide towards thoir anterior extrenity, and sink into tho body by several openings.

We can make the size of the milk reins prominent iy compressing them in their passage, by pressing them at the place where they penetrate into the body. If wo press the thumb strongly into the opening through which the vein passes: tho width of the opening represents the diameter of the rein, and the thickness of the thumb which stops it, represerits the volume of blood whose place it occupies. Sometimes the veins are divided. It is then meessary to examine all the openings by which they pass, in order to form a corroct estimate.

\section{Velis of the Tdder and Trist.}

The veins of the udder and twist are able to furnish valuable irdications. They should, in both eases, be highly derelopel, large and varicoso; that is, nppear swollen and knotty. The reins of tho udder have 
no definite direction. They present themselves irregularly, with zigzs: lines, knotted, and more or less oblique. They are never of very largo sizc, except in cows that give large quantities of nilk.

The reins of the twist directed from above downwurd, forming a winding line, interspersed with knots, rescmble those of the udder in not being visible either in heifers or in cows of only fair milking quality. Wo cannot ascertain their presenec in any but very good cows.

Of all the marks of abundant milk sceretion, the best, and in fact the only iufallible uarks, are furnished by the reins of the twist and of the udder. To estimate them correctly it is necessary to trke into aceount the state of the cow in respect to flesh, the thickness of skin, food, ability to stand fatigue, hout; all the circumstanecs, in fact, which cause variations in the generai state of the cireulation, and in the dilation of tho veins. It is necessiny, morcorcr, to recollect that in both sexes all tho veins are linger in the old than in the young; that the veins which cncircle the udder are those which, if the cows are in milk, vary most according to the age of the snimal. Small when the animal is young, they continue to increase in size until after the cow has hod oeverul calves, when they come to their full development.

This proportion between the size of the resus and the milk secreted, is observed in all fentales without exception. The size of the veins and their variense state being dne to the blond attracted by the increased actirity of the milk-glands, is not only the sign, but also the mcasure, of this activity-this comncetion. In fact, this connection is so closo that, if the glands do not give an equal quantity of milk, the lirger veins are on the side of the udder which gires the largest quantity.

The length of time during which milk is given corresponds with tho activity of the organs which supply it. Cows which give most nilk a day, slso give it the longrest; and hence, if no special mark is perccived, wo e:n judge much of the duration of milk ly the marks which determine its quantity. It may therefore be acecpted that as a rule an abundant miliker may be expectod to grive a longr continued flow of milk.

\section{Judging $\Lambda$ zo by the Teoth.}

For the reason that the age of eattle can only lee approximately judged by the horns, and in conserquence of the liallility to error, and especially the doctoring of the horns by the use of the file, saud payer and oil, wo grive a chart, showing from the cuts presented, the ages of cattle, from birth until they :lre five year's old, when the tecth are fully devcloped, and also the appearance of the tecth at ten year's of age. Thus at birth, it will be secin, there will be but two ecntial tecth, figure 1 ; at two weeks it will have four tecth, figure 2 ; at three weels it will have sis tecth, 
figure 3 ; at a month old the jaw will contain cight incisors, and present the appearaneo as in figure 4. The mouth is then called full, as containing the ultimate number of incisors. These are not permanent, but temporary, or milk tecth, as they are called. At six to eight months old the ecntrin tecth begin to be woln, and show smaller than the othel's, seo figure 5. At ten months absorption and the widening of the jaw will havo carried the two ecntral tecth still farther away from cach other, and two other tecth, one on each side, will have begun to diminish, in fact will have distinct spaces between them, see figure 6 . At trolve months absorption will have continued to two more tecth, leaviug intact only the two outside tecth, figure 7. At tiftecn months the whole of the tecth will present the appenrance as secn in figure 8. At this timo the true or permanent tecth will have becn growing in tlic jaw, between and back of tho milk tecth. Figure 9 shows the appearance at fiftecn months of age, the two permanent central tecth appearing in the place of tho two first milk teeth which have disnppeared, and the other permancent tecth aro shown in their sereral stiges of giowth. Figures 10,11 and 12 show the tecth at two, three and four years past. At the age of fivo years the aninial will have a full mouth, as shown in figure 13 , and at ten years the incisors will present the appearance as in figure 14.

Thus any person by the use of the chart, and by examination of the tecth of eows, of ages known to correspond therewith, may casily become an accurate and prompt judge of the age of cattle, up to the age of fous years. It will be secn, howerer, that in the four year old mouth, tho two central pairs of tceth are beginning to be worn down at tho edges, and in a flat clirection, or inclining sliglitly to the inside; yet the animal lias not a full mouth - that is, the incisors are not all fully up until it is five years old. Sec figure 14 .

At five years old the tecth are all fully grown, and the peculiar mark on the tecth, ealled the enp, is shown in all. At the same timo all will have become flattened, while on the two ecnter ones there begins to be a distinct darker line in the middle, bounded by a line of harder bono. From this time on we may depend both on the incisors and the grinders. At six years old the animal will have acquired the last grinding tooth. 'This is the sixtl molar and is, from the beginning, a permancut tooth. From this time until the cighth year, and indeed thereafter, in determining the age of the animal, the nature of the soil upon which it has been fed must be taken into account. Gritty, close fed pastures will wenr them faster, and thish pastures slower. Thus in all the pasturo regions of the West, and Sonthwest, the wear will be light. As a gencral rule, but admitting of many cxecptions, at seven yours old this line is becoming broader and more irregular in all of the teeth; and a second and broader, 
and more eircular mark appears within the eenter of the former one, tho most distinct in the central, or two central pairs - and whieh at cight years has spread ovcr the six central incisors.

At eight ycars, a ehange takes plnee which eannot be mistaken. Tlio process of absorption has again comncuecd in the eentral ineisol's; it is slow in progress, and io nercr earried to thc extent seen in the milk tecth, but is sufficiently plain, and the two central tcetl are evidently sraaller than their neighbors. A eonsiderable change has also taken plaee on the surface of the teeth; the two dark marks are rorn into one in all but the corner teeth.

At ten the four eentral ineisors are diminished in size, and the mark is heoming smaller and fuinter, as shown in figure 14 . The six ccutral incisors are smaller, and at tivclve, all of them are very considerably dininished; but not to the sume extent as in tho young animal. 'Tho mark is now nearly obliterated, cxeept in the corner teeth, and the insido edge is worn down to the gum.

From this time on they continue to diminish in size, and it is difficult to aceurately determine the age. In faet cxccpt in the ease of valuablo blooded eows, bulls, or extra trained wosk oxen, and oeeasionally cxtria milkers in the dairy, few steers are now kept in the West past six years old, and few cows over nine or ten years of age. 


\section{CIAPTER VII,}

TII DAIRY.

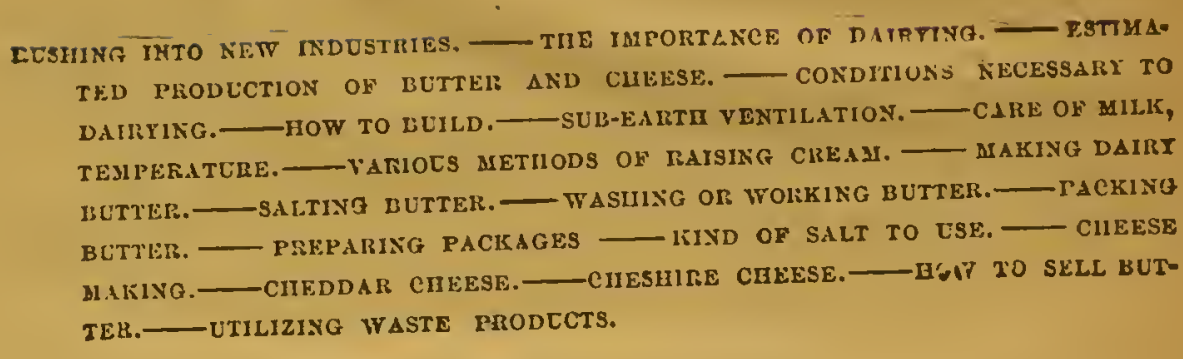

\section{Rushing Into Norr Industries.}

The impetus given to dairy farming within the last ton years, caused by the increasing export demand, and the large price which superior products both of butter and ehcese brought in tho inarkets at boine and abroad, caused many persons all orer the West to rush into the business, supposing that flush pastures and cheap grain were the sole conditions of success. Unscrupulous persons also made eheese of skinmed milk adulterated with olen-margarine. Butter makers adulterated their products with oleo-margarine, and cstensive factories liust and West, backed by large eapital, entered into the manufacture of oleo-margarine ; vast quantitics of which were sold as butter. In aduition to this many persons supposed it was only necessary to stock their farms with cors, mills them, secure the eream, churn it, salt the butter and thus get rich. The result was, the markets were glutted with grease butter and skim or grind-stano cheese, as they were aptly termed, eausing the degradation of really good checse of Amcrisan make in the English market, for the reason that tho markets being flooded with dishonest checse, and the industry being in its infancy here, but few malicrs had established a reputation, considered 
good beyond doubt in foreign markets. During 1878, especially, tho price of cheese went so low as to cuuse much moncy to be lost in its manuficture. The consequence was, many, who went into the business hastily and with few natural facilities for the inanufacture, or knorledge of the business, as hastily went out of it. In 1879 a reaction took place, and both hutter and cheese during the latter half of the year again paid the manufacturers large profits. These variations are not peculiar to this business alone, but they belong to every branch.

\section{The Iraportance of Dairying.}

Within the last ten years, Ohio, Michigan, the northern half of Indians and Illinois, southern and central Wisconsin, ecntral Iown, and later some portions of Missonri, Kansas, and Nobraska hive beeome great butter and cheese producing States, and the premiums awarded to Wisconsin, Iowa, and Illinois for clairy products at International and Inter-State fair's, show conclueively that there is plenty of territory in the West, where the eonditions are of the lighest order for the munufacture of first cliss butter and clicese.

As showing the worth and importance of this industry in the Trest, wo need only slow the receipts and shipments, at two pincipal marlets, Chicago and Milwauke, the first for hutter from 1869 to 1878 , inclusive, and Milwakec for butter and cheese for the yesr 1878. That of Chicago was as follows:

\begin{tabular}{|c|c|c|}
\hline 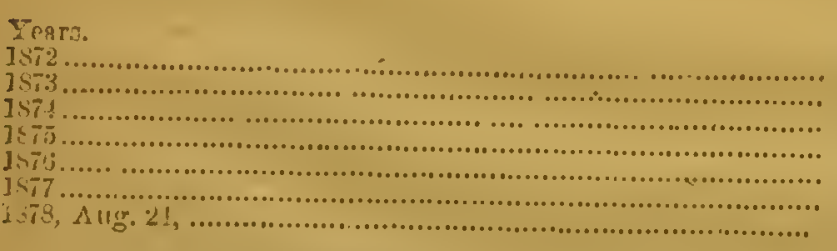 & 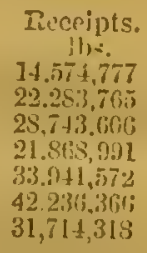 & 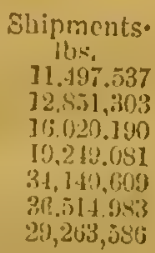 \\
\hline
\end{tabular}

For the regular butter scrson-May, Junc, oluly and to August 2\%, 1878 , inrolusive, the receipts have agreregated $21,414,520$ pounds, aginst 16 ,$\$ 23,031$ pounds for the sime tinc 1877 -an increase of $4,921,489$ pounds. :Che shiptnents for the same period-Mily to August 2 isth inclusive, angregafed $19,821,6, j()$ pounds, agninst $14,495,864$ pound for the comersponding time in 1877 -an increase of $5,325,796$ pounds.

In Milwaulec the receipts for 1878 were:

Rnceipts of linter.

Slipments of Butter.

Herecipts of cherese

6.111.280 lhs,

Elizicuts of Chorse 
The exports of butter and checse from tho United States, and value, for 1877 and 1878 are given by the Chief of the Bureau of Statistics at Vashington as follows:

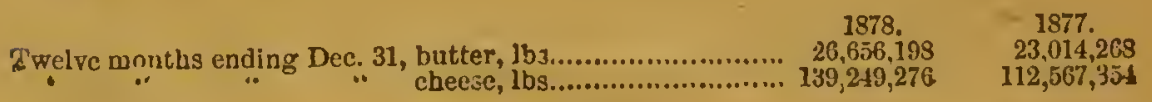

\section{Estimated Production of Butter and Cheose.}

The value of land and cows in the United States employed in furnishing milk, butter, and cheese, is not less than $\$ 1,300,000,000$, or the sum of nearly half the national debt at its highest point. Over three thousund factories are engaged in the manufacture of these articles.

The production of elcese is estimated at $350,000,000$ lbs. per annum, and of butter about 1,500,000,000; of the former, 130,000,000 lbs. will be exported this year, and $25,000,000 \mathrm{lbs}$. of the latter. The valuo of the two is about $\$ 350,000,000$ or $\$ 50,000,000$ more tinan the wheat crop) of the country: three times mo: than the oat erop; four times moro than the potato erop; one-seventh more than the hay crop; one-third more than the cotton crop, and but onc-fifth less than the eorn crop. The number of cows in the United States is over 13,000,000, which is six times tlie number in Great Britain, over twice the number in Frince, two and a half times more than in Prussia, and nore than in the comntries of England, Ireland, Scotland, Wales, Denmark, Norway, Sweden, Russia, Finland, Austria, Hungary and Switzerland eonbined-although these countries together contain four times the population of the United States. The proportion of cows to the inhabitants bere is twenty-threo to each one hundreal persons.

The production of eheese and butter inereased thirty-threc per cort. in 1877 and the exports have been in like proportion.

The cheese and butter exported in 1878 have paid freight to the amount of over $\$ 1,000,000$ to the ocean commeree, or a sum alnost suflicicnt to support a line of ocean steamers. Theso articles pay to tho railroad companics over $\$ 5,006,000$ annually for transportation, and the article of milk pays nearly as much more. Loaded on railway cars, ton tons to each ear, the butter and ehcese produecd in the United States in one year would fill 22,000 ears, and make a compact line 135 miles long.

It is estimated that Great Britain, with a population of $32,000,000$, consumes about $260,000,000$ pounds of eheese annually, while the United States, with 50,000,000 inhabitants, eonsumes about 200,000,000 pounds annually. It is elaimed that when only a good quatity is pnt into the bome market Americans will beçome as great cheese eaters as Englishmen. 


\section{Conditions Necessary for Dairying:}

There are three natural conditions necessary for the successful prose cution of dairying : abundance of pure water, plenty of grass and cheap grain. There are also three essentials in its manufacture without which no person can sueceod. These are, good cows, proper buildings and fixtures, and absolute cleanliness, from the stable to the packago in which it is sold. Of course a thorough knowledge of the business must be possessed or aequired. If the dairy is conducted on the factory, associated, or co-operative system, only ono person, the superintendent, need bo an expert. Cold water is absolutely essential. In the West recourse must be had to ico for cooling purposes, cxeept for the family dairy, and it is better there. The great drawback to dairying in the West has been the absence of cold springs and spring brooks. Decp wells, with windmill pumps, fully supply this need when there is an abundant now beneath the surfuce, and when there is not, ice is used for eooling purposes. In fact, no large dairy, whero butter is made, is completo without an ice house of sufficient eapacity, not only for cooling the milk, but also, to afford cold storage for butter. Whatever the size of tho dairy, whether large or small, no person can make money in the manufacture without facilities so that the temperature of the milk and butter can bo kept at 60 degrees or less. It is not our purpose to enter into details as to the minutia of dairy work on a large scale. The person undertaking tho business must employ a competent dairyman as superintendent. The owner will have plenty to do in atteuding to the farm, the business detrils of manufacturing, shippiug, selling, otc. To cnable those having good fueilities for the business to get an idea of the building, we give an illustration showing ground plan of model ereamery.

The cut given is a model in overy respect, not only in arrangement, but in cheapuess. The main building is two stories, 52 by. 26 feet, with two annexes as shown, and eost all told, including all the fixtures and apparatus, only $\$ 2,500$, the building itself eosting $\$ 1,800$. The arrangeincrits are made with spceial reference to oconomy of space, labor and travel; to securing an equallo temperature, and to the isolation of the eream and butter from odors that raty ariso in the manufucture or curing of eheeso. The walls have three air spaces, one between the clapboarding and sficathing, one between thz shoathing and building paper, and one between the luilding paper and piastering, thus making most perfect isolation. The windows are double. The milk, as received and weighed, is strained directly into the cleese vats, or into the cieep cans, fod tho pool. This is about 20 inches deep, and is nude by laying a brick wall "o that height, and cementing it on the inside. It is supplied with water 
from a well near the rear of the building, pipes bni $z \rightarrow$ carrauged that the steam-pump ean deliver either hot or cold wan ur steam whero needed. Ice is used for this pool as nected. The piess-room jeins tho manufacturing-room, and from the door of this a stairway leads to tho curing-room, which occupies nearly all the second floor; the front stairway leading to an office and to a bed-room for the attendant, in front of the curing-room, which is designed not only for the cheese made here, but as a curing and storing-room for that from sereral factories in tho vicinity. The cheesc is delivered, as sold, from a door in the rear of tho curing $\rightarrow$ room.

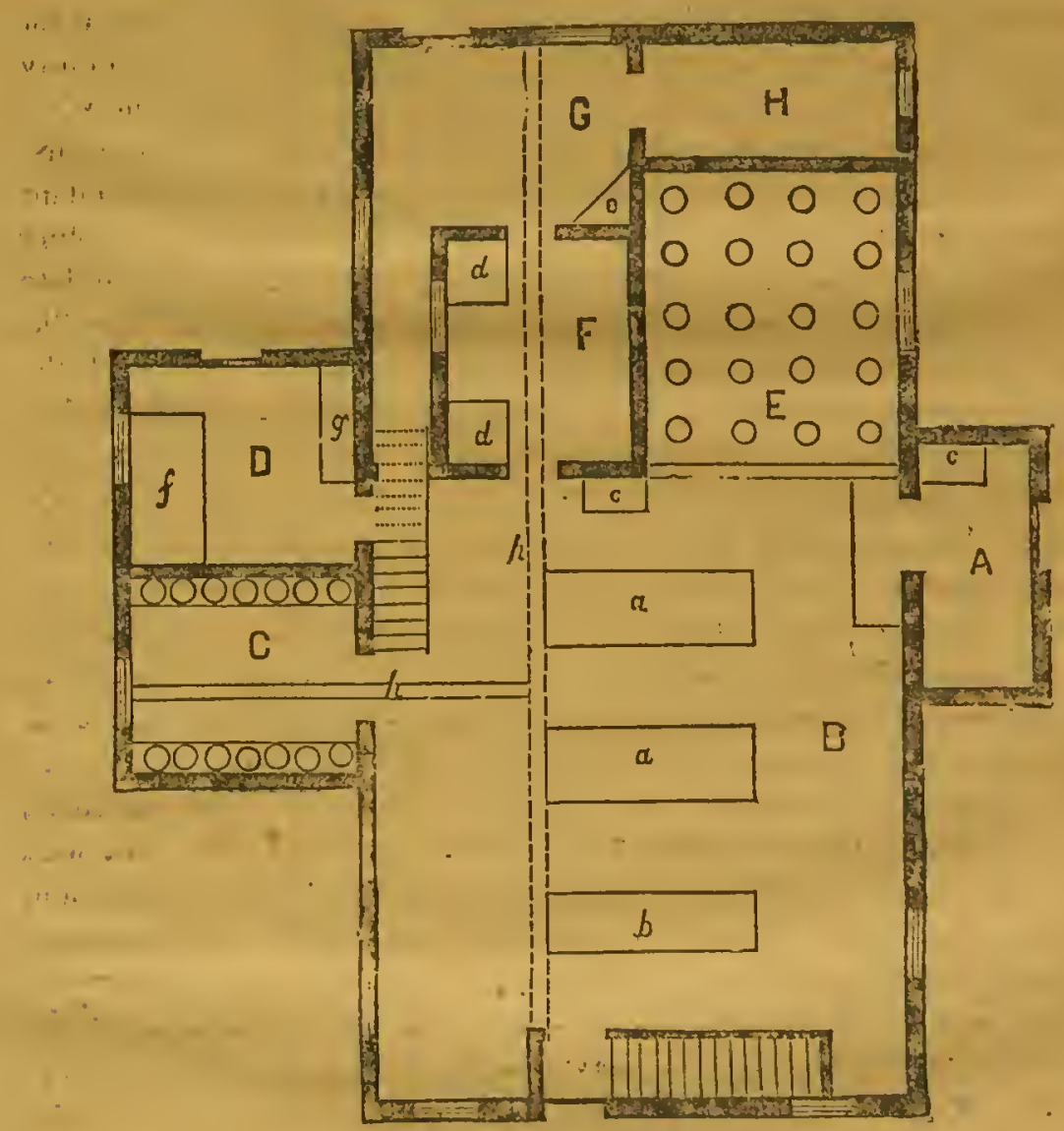

GROUXD PLAN OF MODEL CIEAMTIY.

Ex.janation-A-Mrilk reeeiving rosm. $B$-Cheese manufactriting ronrs. C-Press room. D-Engine room. E-Pool. F-Cream and ehurning room. if-Butter rorking and deliveriug room. $I I$-Refrigerntor, a $a$-Cheese viats b-Curd siots. c c-Wash vats. $d$ d-Churns. e-Butter workcr. f-Boiler. $c$-Engine. $\pi k$-Whey drains. 
It will be eeen that the eream and elurning-room $F$ is a separate cnelcoure within the main building, and which nuy be entirely enclosed from the main room, so that when the eream is placed it may he entirely isolated and kept so until churned and storod in the refrigerator. 'Those coutemplating ereeting a ereamery eamot well improve upon this plan, one of the most modern known, exeept it bo in somo minor details to suit loeal wants.,

\section{How to suild:}

Where tho drainago is grood the lower story may consist of a basement sunk three feet into the ground, of stone or brick, and it will be better if the whole building bo of briek. The system of drainage should be mapped out, and a chart made. The drains should be laid in the most perfect manner, and with fall enough so they will not elog. Besicies the fuetory drains leading to tho wasto vats, there should also be tile drains to carry off surface water. The foundation of the floor of the factory should, if possible, have a thin coating of tin shavings, or broken glass, say six inches thiek well pounded down, and eovered with water lime ecment. Upon this a flooring of Alags or bricks may bo laid, eovered with cement of wator lime, which in timo will becomo entirely hard, and the tin or glass below will prevent all burrowing of rats. The pipes, leading to and from tho eisterns, ete., should bo placed before the floor is laid, and the mortar earefully fitted to them. The ice-house should be plastered with Fiter-lime, and a little vaeaney left between the ice and the bottom of the house, to allow the water a small space. The top and sido walls of the dairy-house should be finished with plaster, by which means a uniform temperature, indispensabla to curing cheeso, is moro perfeetly sceured.

\section{Sub-Earth Ventilaticn.}

Of late ycars Mr. J. Wilkinson has advocated a system of sub-earth ventilation, simply by a six-ineh tile, laid six fect deep and 300 or poro feet long from tho building. Two of this length, - or better, one of twico tho longth, with a wing, and vano connected with tho out-door end, to cateh air and convey it to fie tile-will lreep tho basement woll ventilated,. and of tho earth temperai, re of the depth at which tho tile is laid.

\section{Care of Milk}

The first requisi, is absuluto and unqualified cleanliness. Wo have already giver direcious us to cleaning auimals beforo milking. Tho least 
clorcnliness in the hely, in this respect, should be severely reprimanded, sud if this does unt : vail, discharge him, or her, at once; it is as neecssury is kind treatmont of the eows.

If the milk is set in shillow pans, see that there is good ventilation to the dairy roons, and that the pans are regularly scialded, and with hot, bublling water-siight sealding will not do. Wipe dry, and sun, when possible. Allow no bad odors to accumulate near by from garbage or other causes. For this reason the family dairy should never be in tho bouse, since the stcin and odne from cooking, the dust fro's sweeping, etc., will taint the milk, eream and butter. English dairy women aro many of them so particular that they will not allow the men who carry the will from the yard to enter the dairy house. It is poured into a roceiver cutside and conducted in through a pipe, regularly scalded each time used, and covered tight from dust.

\section{IIodern Fome Dairioa}

One plan of setting milk is by the "Hardin system." Iy this system the miik is strained, immediately after being drawn, into deep pails and covered with a well-fitting lid, to exelucle both air and water. It is then placed in a refrigerator, with ice above it. The drippings fall upon the pails of nilk and form a pool of watcr, in which they are allowed to stand.

When a cold spring of ruming water can be had the milk may be inlmersed in decp open pails, in the conl waters. Unfortunately, in tho W

Another excellent plan for small dairies is that known as the Conley system, setting tlie milk in deel) cans; a medium sized refrigcrator box, containing spice enough for from ten to twenty cows. These cams liave close fitting covers, and are surrounded by ice cold water, and thus, if the heat and animal odor bo expelled before putting in, there is no tainting or souring. The cream is taken perfectly sweet, in from twelve to twenty-four hours. It is very compact, and may be economically used even in small family dairies, of from ten to twenty cows, if the fillur cares to pay the royalty, the system being patented.

\section{Animal Odor.}

Expelling the animal odor is most mportant. To do this the milk is poured into a receiver, in the bottom of which are a few small holes, through which the milk is allowed to drop into a takk, largo cnough and high cnough to eateh all without spattering. This tank stands in eold water neariy to its orim; in this the milk may remain about fiftecn miz- 
ates, when it may be set in any of the ways we have mentinned. Asother plan is to beat the wilk to 100 or 110 degrees and then allow it sluwly
to cool.

\section{Tomperature.}

Good butter ean be made, if the temperature of the dairy-room does not go above 60 degrees. This is the proper temperature for churning" and working the butter. The temperature for milk may be nuch lorver;" it should not be higher from the time the milk is brouglit in until the butter is earried away. So far as storing the butter is concerned, if the temperature be kept at 40 degrees, so much the better. This, however, caunot be done without iec.

\section{Various Methods of Rsising Cream.}

¿G. C. Caldwell, Professor of Agricultural Chemistry, in Cornell University, located at Ithaca, $\Lambda$. $Y_{\text {., in relation to some European methods, }}$
eays:

"Among tho different systems prevalent in Europe, we notiec the Dutch method in which the mill is eooled down to 60 degrees in a water tank, which requires usually from ono and a half to two hours, and tho milk is then set to the deptl of four or five inches in a room where the temperature ranges from 54 to 60 degrees, and remains about twentyfour lours; the Holstein method, in which the milk is set at about tho same temporature, without being first eooled in water, to the depth "of onc and onc-half to two and one-half inches; the Devonslive method, deseribed as long ago as 1784 , where the milk is put in a eool rooin, standing at a deptlı not greater than from three to four inehes for twelro hours; the vessel contrining it is then set orer the fire and heated till blisters begin to appear in the cream, or to about 200 degrees, when it is set aside again for twelvo hours; the eream is very firm in consistency and can be inade into butter by simple kneading, and has a sweet, pleasant taste. Mueller stites that the skimmed milk does not retain noro than one per cent. of ercam; the Cussander method makes no necount of temperature, except that it shall not exceed 61 degrees, so that no milk cellar or lut only a light, dry and airy room is required; the milk is put in large shallow pans, filling thein to the depth no more thin from one to one and one-half inehes; the milk is skimmed after twenty-tliree hours, in such a thin layer the wilk is so well rerated that it remains sircei to the on 1 , and the eream is swect and very rieh in fat."

These various experiences should be very suggew'ivo. 


\section{Making Dairy Buttor.}

Mr. C. C. Buell, ono of the makers of high-caste dairy butter in tho West, stated his mod as reported by the Secretary of the Illinois Dairyman's Association:

"Cows were common stock-Durham grades and sprinkling of Jerscy. Fed by running in fresh corn stalks during day tims, on timothy and clover at night in stable, with two messes of mcal daily, consising, by moasure, of two parts corn and one part oats, togeth-r vith the greater part of the sour milk and buttermilk from tho dairy room. Iiumber of sows, forty. The milk was strained through an iron strainer into dzep pails, as soon as drawn, standing in open air until the milking was fnished. It was then strained again into tho samo pails througl a choublo thickness cloth strainer. The milk was set in a room without fire, temperature being between 40 and 50 degrees, Fahrenheit. During a purt of the time, the temperature boing above 50 degrees, tho milk was set in water for twelve hours. The milk was skimmed after standing twelve to forty-eight hours, it being considered desirablo to mix tho newer and older cream, for the sako of flavor; but the whole stood mixed together from two to four hours after the last skimming and ciuring the process of warming to proper tempcraturo for churning. Most of the milk was skimmed a second time, the cream being included in succeding churning. Tho churn (a dash churn with solid dasher, suriace undsineath concave), was started at a temperature of 62 degrees; as cho buttermilk began to appear a couple of gallons of tolerably strong brius was added at a temperature of 58 degrees, and the cuurn stopped a moment afterward, - as with the addition of the brino, at the proper temperature, the butter separates very rapidly. As much brine as necessary was used in washing down sides of churn, corer and dasher. The butter was then dipped into a bath of not more than two gallons of brine; a churning of forty or fifty pounds being washed in four parts, in the sumo brime. Re. moved to a worker with rolling lever; the butter was so handled as to mix with the proper amount of salt with the least working possible. It was then placed in a tub slightly packod, covered with brine and allowed to stand three or four hours, when it was again placed on the wcrker? lightly worked and packed for market."

\section{Caro of Iallis.'}

We have given the modes of some of the best butter-mokers in tho world. Now the principal points to be observed aro: warm siclter, ve:foct quict, tor tho animals, ubscluto cloantiness in all pyerations comectod 
With the milk, from the time it is drawn until it is made into liuttcz. Just as the butter is forming in little granules, suddenly reduce th $t \mathrm{~cm}$ perature to 56 or 58 degrees, so the butter will not se togetlicr. i; should never take less than half an hour to churn; quicker churuirg carses the b tter to come salvy.

\section{Coloring Butter.}

Tha best coloring for butter is plenty of succulent grass in Summer, and rich feed in Winter. For home consumption we should-never color butter. For sale it may be advisable. If so, use any of the pure preparations of annotto. It is perfectly harmless. If used, stir it in the cream. As to quantity, this camnot be stated. It will vary with tha season. Every person must experiment, only do not use too inuch.

-

\section{Salting Butter.}

Take the butter from the churn in its granular state, and salt at the rate of two-thirds of an ounce to the pound of butter. Do not work it moie than cnough to fairly distribute the salt; and this by folding and pressing; let the grains of salt dissolve. It may stand from 12 to 24 lours before being worked the last time. Butter, through all the timo and precess of working, from the time it is churned until packed, shou'd be kept in a pliable, waxy condition, about 60 degrees Farenheit is right, so as to work casily, and the salt all the time be in a dissolving condition. It is utterly impossible to work butter well that is operated upon whilo cither too warm or too cold, or that is allowed to become so betreen times of rorking. The bonefit derived by standing after the first salting, awaiting the sccond working, is to di solve the salt by the moisture in the butter, and so sat th? butter-milk free, that it maty be the more casily pressed out. The amoum should not be more thail will dissolve cniricly, and this moisture should be well worked out before adding more. After this add salt cufficiont to scason to your taste, working to mix it eveniy through the butter; then leave it there to eure and preserve.

1 grood itverage is about one ounce of salt to a pound of butter; soma tastes prefer less and some more. Three-fourths of an omee to tho pound is light salting, while one and obe-fourth ounees to the pound is heavy siliting. We use to the first salting just two-thirds of the amount, and after the seend working add the balanee. Never go by guess, but use the scalcs, and in this way insure uniformity. No one can acquire a reputation for good butter, who does not make a uniform article. It rever yet was made by guessing. If on a churning of butter you gues 
it three pounds less than it is, and ou the salt three ounces more tinan it is, you will make it far too salt. There should be a slight allowane of salt macle for the eondition of the butter, for when it comes soft it usullly contains more butter-milk than whon it comes hard, and a greater percentage of the salt will be carried off in the extra whey.

\section{Washing v8. Working.}

Equally good results can he obtained by washing or working the mills from butter, when skillfully done inder favorable circunstances. In either ease the only object is to free the butter from the milk, with as littlo injury to the flavor or grain of the butter as possible. In washing butter, the danger is mostly in injuring the fluvor by introducing forcign matter in the witer, while in the other case, there is more dauger iu over-working and so injuring the grain. In localities where pure water caunot be obtained, washing should not be resorted to, for butter is always sure to take up the impurities contained, as it will the taint of any decaying vogetable or animal matter that may bo near. Many wells and springs which the owners of, or user's from, beliere to be puro and good, have in them decaying substances which rencler then cutirely unfit for any use, much less to wash butter with. Decaying organic inatter so intreduced into butter acts vory much like yeast in dough ; at least, it starts a fermentition, so to speak, which soon destroys the butter. Allow no surface water to get into spring or well, or any filth to remain in theux, and if they aro not highly ohnrged with lime, mineral or salts of any kind, thero is no better or easicr method than to wash the milk out quickly and thoroughly beforo salting.

\section{Packing Butter.}

If for sale pack in good, strong, oak packages, whaterer the size tius mily be decided on, and let them be miform, elean, and nice looking. A good packnge will not sell poor butter, but a slovenly packige will often condem the hast. Nerer use the round wooden boxes, with himdley, they are an abomination. In packing have the butter still at 60 degrees. it is then firm and yet nethed. First rub the package, botiom and sides, with salt, just what will adlere. Put a quantity of butter in the miduio of the packigo, and press dorn firmly-do not rub, but press, thus causing a perpendiculax and lateral pressure ; thus you nake all firm and exelub air. Then what brine remains in the butter will work to the sides and with the salt prevent it from sticking to the wood. So continue until tho butter is within an inch of tho top. Lay on a eloth cut half an iuch larger 
than the pacriage, and wet with brine, working the edgês down smกn's," cover with a quarter inch of salt, cut another cloth an inch larger thiu the pacliage, lay this on the salt, woiking smooth, as before. Head tight, boro a small hole through the head, fill full with brine, cork tight, and if kept level, and the butter has been properly made, it will come out a!l right when wanted.

\section{Preparing Prekages.}

Use nothing but white oak; scrub them thoroughly inside and nut with hot water and a clean brush; fill with clean, pure water; let them stand forty-cight hours in a cool place; turn out, scrub again with hot water, rinse thoinughly with cold water, and, while wet, sprinlle with ealt, what will adhere. It is then ready for use.

\section{What Kind of Salt to Usc.}

Ione but absoluteîy pure dairy salt should bo used. So far as tho manufacture is concorned there secms little to choose between the best American or English make. There is one thing about English goods, if warranted good they are so-laws against adulteration being very strict in England while they aro very lax in the United, States. At a butter test some years ago before a committco of experts to decide if it could be cliscovered whether the samples wero salted with Eiglish or American salt, the coumittec were very much at sea, guessing sometimes one way and sometimes another. Price being equal, wo should use the best English dairy salt. Yet in all the best dairy salt, whether English or American, the impuritics are so slight that in tho salting of cither butter or checse there could be no taste whatever. If the impurity bo sulphate of lime it would amount to nothing. It requires 400 times its weight to dissolve it, and there is almost no moisture in good butter. Another impurity is sulphato of magnosia, (Epsom Salts) which is present in sufficient quantity would givo butter a peculiar but not a bad taste. Chloride of calcium wonld give butter a sharp, pungent tuste. and which would scriously depreciate the value both of the butter and cheese in which it was used.

Cheose Iraking.

The maxing of butter is both chemical and mechanical. It has this cdvautage, thut any person can make butter as good as the best if absoInto clcanliness is used; if there are no foul odors about tho promises; if 
the temperature of the dairy be liept equal, and if pure rater he used. This is all that is required, besides attention to a few simple rulor These we have given, and there leave the subject.

The making of cheese depends almost cntirely upon chemienl action. Unless the conditions are right, good and uniform cheese cumnot be mide. 'These conditions can hitrdly be obtained in a farm house. Hence cheeso so made is never uniform, except in rare irstances now and then in the hands of a perfect cheese mikel. Such, if this strilies their view, should lose no time in building a fuctory, or enguging one alleady built. Hence it would be a waste of spece to cnter into the details of cheeso making. even in a general way. Yot many will want to male some chese and we append an account of the process of some colebrated English brands from the pen of Mr. John Chilmer's Morton, of England, who has written upon the subject in the following concise yet comprehensivo mauner :

\section{Cheddar Choese.}

"The Cheddar cheese shall be described as it was carricd on upon the firm of the late Mr. Harding, of Mrursbury, Somersetshire, who was onc of the best makers in England, and who did grood work for cheesemaking in Ayrshire and other counties and districts which lie and MIrs. Hurding visited on the invitation of agricultural socicties and others for the purpose of giving instruction in the manufucture of this lind of aheese.

"The morning s and evening's milk a:c together brouglit to a temperature of 80 degrecs Iralu. If the night li.s been wam, a temperiture of 78 degrees will gire as grent effectivono, to a given quantity of rennct as one of $82 \mathrm{or} 8 \mathrm{Ader}$. would give if the milk liad becn at a bower temperature for some hours of a eold night. 'The crening's mille naving beei placed in sh..llow vessels during the night to cool, and having been stired at intervals during the evening $:$. $i$ med in the morning, and the cienm, with a portion of the milk, is heated up to 100 deg. lyy flonting it in tin ressels on the boiler. The whole $f$ it is then poured through a proper sicre into the tub - into which the morning's mille is baing ulso strained as it arrices - so as to raise the whole, as I have said, to flom 78 to 82 dog. Fallo. This tub may he a large tin vessel, cupablo of holding 150 anllons, and provical with false bottom and sides, cuabling hot oi cold witer to be passed under and around its contents. The renuet, made from two ol three dozen velis, in as many quarts of salt water, ant allowed to stind three weeks, is added-half a pint to 100 gallous - and the curd sets in about half an hour. The small vells $c^{\text {s }}$ 
Irish ealves, which are killed at about a week old, are preferred, and they should be eightecn months old before use. The eurd is slowly eut with a single long blade to and fro throughout its depth, in lines forming a 4-inel mesh upon the surface, and the whole mass is gontly turned orer from the bottom with a skinming dish and the hand. Tho whole is then again worked throughout with a "shovel breaker," a four-fingered paddle with wires across the fingers-great care being taken to do it gently, so that the whey shall not become too white. Tho curd is thus broken up inta picees not mueh larger than peas, and at least lialf an hour is taken in the proeess. Hot water is then let into the space around and below tho ehecse tub, and tho wholo is raised to $100 \mathrm{deg}$. Fahr.; and this, too, is done gradually, so as to raise the whole by dogrees, not heating any portion to cxeess. This also takes half an hour. The hot water is then d'avin off, and tho curd is stirred by the hand and a slimming dish for another half hour in the midst of its hot whey, heing at last reducod to a mass of soparate bits the size of small peas. The whey, after settling for half an hour, is then removed-ladled, syphonod, or drawn-to its vat, where it stinds about six inches deep, and is skimmed next day, yiclding a butter, which should not exeecd in quantity six to cight ounces per cow per weck.

The curd stands half an hour after the whey is drawn off, and it is then cut in four or five pices, turned orer and left for half an hour, after which it is again cut and left for a quarter of an hour. After this, it should bo in the slightest degrec acid to the taste. If allowed to beeome too acid, it will not press into a solid, well-shaped cheese, but will be apt to sink broad misshapeir. It is now tom into picecs by hand and left to cool: and thereafter it is packed in sueecssive thin layers in the rat-a cylindrical or wcoden vessel twelve inches or more wide and twelve inches deepwhence, after being pressed for half an hour, it is taken out (it is then probably midday, ) and broken up by hand, and allowed again to eool. Then, when cool, and lard, and sour, and dry, and tough cnough, (all this, of course, being left to the judgment of the misker), it is ground up in the curd mill; two pounds of salt are added to the ewt. of curd, and the whole is allowed to cool, and as soon is eold, it is put in the rat, and taken to press. It is then probably $3 \mathrm{p} . \mathrm{m}$. The pressure on the cheeso may be 18 cwt. The cloth is changed next numing. A calico coating is laced $m$ it the second diry, and the third day llie cheese may be tulien from the press, placed in the cliceso room, landaged, and turned daily, and afterwards less frequently. The cheese roon should be liept at nearly 65 degrees Falur. The cheese will not be ready for sale for the montlis.

The process lasts nearly all th. diy, but it is believed to produce tho hest eheeso in the world; and its use is everywliere extending. Tuling 
Its nañe from a single parish, it now prevails all ovcr North Somersetelire, and is gradually extending into Wiltshire. Many dairies in Gloucestershire adopt the system; and some of its charaetcristic details are followed in Chcshire; and it is well known in Lancashire, Ayrshire, and Galloway.

The Cheddar eheese is made of various sizes, generally twelve inches wide and a foot high, but somctimcs larger in both dimentions, and from 70 to 100 pounds in weight; the objeet being to malse all the milk of ono day on a farm of thirty to forty cows into a singlc chcese.

\section{Cheshire Cheese.}

Chochire cheese, like the Cheddar, is made only once a day. Tho erriag's milk is placed, not more than six to seven inches deep, in tin vesseis to cool during the night, on the floor of the dairy; it is skimmed in the morning, and a certain portion is kcpt for butter-in e:rrly Sumer, (nily enough, perhaps, for the use of the house, but in Autumn more, and in some dairies at least, ncarly all the morning's crcam is thus taken for chuming. The skimmed ercan, with a portion of milk, is heated up to 130 deg. Fahr. by floating the tins whieh hold it, on the boilcr-sufficient quintity being taken to raise the whole of the evening's and morning's milk together to $90 \mathrm{deg}$. or thereabouts. The rennet is made the diy hefore it is used; 12 or 14 square inches of "vell" (rennet skin) standing in a pint of salt water, kept in a warm place, making rennet enough for 100 gatlons of milk. The Irish vell (reunet skin) is used, as it is obtained from very young and milk-fed calves.

'The eurd is set about 50 minutes; it is then cut with the usual curd. breaker, a sieve-shaped cuttcr, very slowly. The whey is syphoned, punped, or liftcd out as soon as possibie; but before it is all removed a portion is (on some farms where the Cheddar system is followed), heited Ind returned to the tub, and the eurd is left in this hot whey for half an kou:. The whey is then drained away and the eurd is left to get firm. When firm enougln to stand on the hand in cubes of about a pound weight -this is an intclligent indieation-without breaking asunder, it is lifted out on the drainer (a false bottom of rods), in a long tub with a stop-eock to it, and there left covered up for 45 minutes, after whieh it is broken up and well mixed with the haud with 3 1-2 to 4 1-2 lbs. of salt per cirt. It is then allowed to stand with a light weight upon it for about three. quarters of an 'hour longer, and is turned over once or twice during the time, bcing cut for the purpose into squares with a knife. It is then tmico passed through the curd mill, and at length put into the vat, a cloth bcing first pressed into place by a tin boop, and tho salted curd being packed 
gently by hand within it. The vats will hold a chcese of $70 \mathrm{or}^{\circ} 80$ up te, $100 \mathrm{lbs}$; and tin hoops, placed within them, ale used to eke then out, and give capacity for a larger quantity of curd if necessury. After sturiding in the vat, with a weight upon it, from one to two hours, according to tho weather, it is tumed over and put, still in its vat, into the oven, a warm clamber in or near the brickwork of the dairy chimney-where it remains at a temperature of $90 \mathrm{deg}$. to $100 \mathrm{deg}$. during the night. "Both when in the press and here the checse is skewered, skewers being thirutst into it through holes in the vat and crery now and then withdrawn, seds to fucilitate the drainage of the whey. The cheese is taken out of tho vat in the morning and turned upside down in a fresh cloth. It is in tho press three days, and it is turned in tho press twice a day, being drycluthed cacli time. It is then taken out dry-clothed, bandaged, and removed to the cheese room, where it is turned daily, and at length outy occasionally; until it is ready for sale. In some dairies all skcvering is dispensed with, and no pressure is used at the time of making, nor for two days afterwards, but the whey is allowed to run out of its own accord. Checso manufactured in this way requires from 5 to 7 days in drying, but aftcrwards matures morc quickly for market.

The cheose varies considcrably in quality throughout the year, the earlier make of March and April being consiclerably less valuable than that of Summer and oarly Autumn. Some of this varying quality is owing to the quality of the mill-, the cows being house-fed; but more of it is, in all probability, owiln to the necessity of holding a portion of curd over from day to day, when the quantity is insufficient to make crenn one, or it may be tro, full-sized cheses daily. In such cases it is common to make one full-sized cheese, and hold the remainder of the curd over till the next diy, keeping it wrupped up on the drainer or pan, and grinding it up in the curd-mill along with the curd of the next morning.

\section{How to Sell Butter.}

There is never any difficulty in sclling good butter at a liberal price in any market, however low grease hutter may be. The malker of prime butter necd never be in a burry to sell. The butter once made, wiLL KEIP. But it will not be nccessary to keep it. There aro always particular people in every town, however small, who are ready to take good butter at good prices. Thus it is usual for makers to contract to supply during the year at a stipulated price. During the flush season of grass, buttcr is packed down, to be drawn on when needed. Thus the manufacturcralways has a supply on hand, and the customer is morc than satis. fod to have a good, sweet luwp of butter on his tablo every day in the 
year, and does not grudge the extra five ecnts above what he would haro to pay the grocer, for what thoso who do not know the difference might suppose was good.

If a larger quantity is made than will supply the family trade of tho village, the large markets are always open, and there good butter will always bring a good priee. All that is wanted to know is that the butter is made by one whose reputation is established and who would not sell a bad article, and all that ean be made will be eagerly taken. It is simply a question of clcanliness, uttructive paekage, earcful attention to the dctails in making, and as careful a deternination never to ship when thero is dinger of the thermometer going below 60 degrees. The rest is all plain, elear sailing, with large profits accruing. To insure large profits from dairying, the master must be about early and late, night and day. and Sundays as wcll.

\section{Utilizing Wasto Produets.}

The skim milk, buttermilk, and whey, must be fed either to calves or hogs. As far as whey is concerned, there is not much good in it for tho nourishnent of ealves, unless it be supplemented largely with meal and oil-cake. A shoat will fatten on the waste products of the dairy; cile to eaeh cow, by using a very little corn. Some dairymen prefer to feed tho waste to the cows. This is probably not the best use to which it could be put. Skim nillk and buttermilk is worth more to feed to ealves, wo belicve, than disposed of in any other way. Here again we will give tho experience of Mr. I. H. Wanzer, of Illinois, who bclieves with us that to make dairying permanently profitable, the raising of dairy cows must bo a part of the business. To elose the ehapter we append his statement:

I tried the experiment, last season (1875), of raising calves upon tho nkimmed milk from my ercamery; and as the result of this experiment may interest some of you, I will give you a few figures kept in eonncc. tion with the experinent, from which you may draw conelusions as to whether it pays to raise calves in comection with a creamery or not.

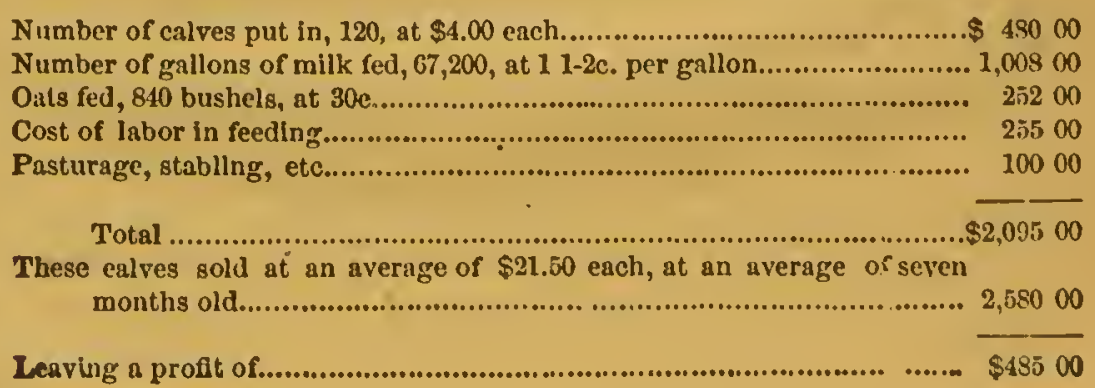


This amount passed to the eredit of the milk would bring it up to two cents per gallon, which is equal to six eents per pound for eheese, and this kind of cheese would not have brought three eents per pound as the senson 1 fed it, for it will be remembered that this milk set thirty-six to forty-eight hours, and all the eream was taken out.

$I \mathrm{am}$ so much encouraged in this way of raising ealves that I expeet to stock again the coming season. I have now fifty-five young ealves and ten older oues. Many of my neighbors and patrons are bringiug their best heifer ealves to me, and marking them, expecting to bid them in at my salc uext I'all, I vaying tharket price for them when received 


\section{Diseases of Cattle.}

\section{THEIR CAUSES AND PREVENTION; HOW TO KNOW THEM; WHAT TO DO}




\section{DISEASES OF CATTLE.}

\section{THRTR CAUSES; HOW TO KNOW THEM; WHAT TO DO.}

\section{CHAPTER I.}

\section{Diseases in General-Reeognizing and Distinguishing Thom.}

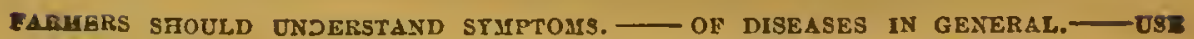
COMMON SENSE. — GRADUATION OF DOSES, - FREQCENCY OF ADMIMISTERING.— - FORMS OF DOSES.— HOW TO GIVE MEDIEINE, - INJECTIONS. VAPORS, SFRAYING AND FUMIGATION. - ANASTHETIES, - TO DEPIVE OP SENSATION.—BLISTERISG.— FIRING.—- SETONS.— ROWELS.—SEWING UP WOUNDS. — FOMENTATIONS. - OPERATION OF BLEEDING. — RECOGNIZIXG AND DISTINGUISHING DISEASES.- THE PULSE.-THE BREATHING.TEE ANIMAL HEAT.—THE SKIN AND HAIR. - THE POSTURE. - INDICAIIONS OF PAIN.— SPEEIAL SIGNS IN CATTLE.

\section{Introductory.}

The immense value of the stoek interests of the United States and the frequent outbreak of introduced eontagious plagues, and of enzootie, epizootie and various epidemie diseases, that at intervals have visited localities or swept over whole eontinents, would seem to call for special training in veterinary seienee and art in every agricultural collego in tho United States; yet, until within the last few years, but little attention has been paid to this profession, and to-day the subjeet is not given that sttention its importanee demands, except in a few instanees. Veterinary surgery has heretoforo been flippantly termed "horse doetoring" by professors and heads of too many of the colleges, endowed with the people's money "to teach such branches as relate to agriculture and the meehanie arts" 
Of late, however, a more enlightened course has been pursued. Many of the agricultural collcges are paying attention to this important study, sspecially since the violent outbreak of splenic fever over the Wcst and East from the introduction of Texas cattle, and still more lately from the outbreak and sprcad of contagious pleuro-pncumonia in a number of the Atlantic States. Owing to the low state of veterinary science generally, and the disdain with which the fow highly educated and thoroughly scientific investigators in the United States - mostly French and German graduates - have been looked down upon by those who should have been too glad to welcome them to the profession of medicine, and the esteem in which mere quacks and leeches have been regarded by the community two notable facts are made patcnt: First, the exclusiveness of certain puffed up "college Dons," who suppose that all knowledge must come from classic sources. Second, that the people at large, farmers and stock raisers, who from their habits and training could not be supposed to understand surgery or medicine, except in its simplest forms, have been thrown into the clutches of mere pretenders to anatomical knowledge and the treatment of diseases. Of late there have been many honorable exceptions, until now nearly or quite all of these people's colleg ss, forced thus in many instances by public outcry, are taking strong means to foster veterinary science, and make it what it should be, and really long has been in other enlightened countries, an important, as it is an honorable branch of human science.

There are many valuable works extant in various langunges, upon veterinary science and practice. They will be of little value to farmers enci swockmen; all that this class ean deal with must necessarily be only those symptoms that can readily be diseerned, and remedies so simple in their nature that thcy can be easily procured and applied. In fact great care and attention should be given to first symptoms, as also to good nursing. Discard all strong physics, and heroie treatment by purging, blecding, and the surgery of main strength. Grood care and nursing in the treatment of animais is now regarded (as it is in the trentment of human paticnts) as among the most important means of curc. Indeed with animals it is of the greatcst importaice, since brutes are only able to indicate the region of pain and disease by mute signs, entirely unintelligible in the majority of cases to the ordinary observer.

\section{Of Diserses in General.}

In the description of symptoms, and the treatment of diseases, it would be out of place here to go into lcarned discussions on the nature and pathology of discases; so also it would be futile to dilate upon the 
symptoms and treatment of diseases. Only those most coinmon, or fatal, will be specially noted. Fortunatcly veterinary art is eongenial with the medieal treatment of the human family, and the same paths that lead to a knowledge of human diseases will indicate to any in teiligent loeal physician the means to be used with brutes. Humanc physicions, now-a-days, - to their eredit be it said - are not slow in coming to tho relicf of the farmer and stockman in preseribing and giving dvicc in the absenee of regular veterinary surgeons. Sueh are veritable b nefactors; inasmueh as they greatiy alleviate distress and do mueh is dis nurage quaekery; and when found, they should be freely consulted. This deviation from the regular medieal praetiee, owing to the sparsely settled nature of many portions of the eountry, seems very necessary and even imperative.

In the preseriptions for eattle, we shall use the most simple formulas possible, wherever found, and whatever simple medicines will avail, especially those eompounded of herbs, as better adapted to the treatment of domestic animals. In commeetion with these, other agents, both mineral and mechanieal, must be employed. In short, what we have aimed at is to stato symptoms and remedies for sueh diseases as may be treated without the adviee of a regular veterinary surgeon, and in such languago as any intelligent person may understand.

In this, whil we shall not attempt originality, except it may be in tho mitter of presentation in sore instances, we shall use and quote from the very latest authorities in veterinary seience in the United States, England, France, Germany, Austri , Bclgium, Holland, Sweden, Italy, and other minor eointries, where veterinary seienee has been aeeorded that respectability wirieh shculd aecrue to a labor having for its aims the saving of life, and the amelioration of suffering, in a direction second in importanee only to that of the human family; and in preventing loss, so far as it may be possible, of live stoek, the raising of which is of greater importanee to mankind than any other single human industry. Thus, in presenting symptoms, we shall use and quote fresly from tle latest works in reformed practiee. What we present will not be as seeking so much to aid the veterinary practitioner, as the farmer limself; not a nork to supersede other authorities, but a substitute, in a limited sense, as to the treatment of eertain diseases, so th.t the intelligent reader may coinprehend; advising, in every ease, when the operator does not understand the symptoms clearly, to seek the adviee of the professional reterinari $n$, if sueh may be had. If sueh be not within reach, then ccisult the best physician in the neighborhood. Diseases are substantially the same in causes, symptoms and treatment, whether men or beasts bc their subjecto Remembering this may suggest a helpful course of treatment in many cases 


\section{Use Common senso.}

Why, in the sickness of animals, the owner should try random remedies, and go from one to another, at the suggestion of each different adviser, as the matter may seem to strike them, is inexplicable. In nine cases out of te:., with proper nursing and care the animal will recover, simply by kceping the bowele moderately open by mild physics and injections (which will be indicated) when costiveness and inpaction is present; or by sedatives, stimúlants and astringents when the reverse condition is exhibited.

Such conditions as are often fatal during the gravid state of female animals, and succeeding "delivery, abortion, false presentation, etc., and the means of relief; contagious and epidemic diseases - these from their special importance will receive due prominence. Of the non-contagious and local diseases every farmer should seek to make himself familiar with the symptoms, so that ready means may be used for the rclief of suffering animals.

In all this detection and treatment the operator must be guided by intclligence and use the least possible exhibition of force. It may be necessary to hamper an animal for the performance of some operation. When neccssary, it is not mcrciful to use half-way measures. The humane man, however, will do so with as little pain to the animal as possible. If necessity should require killing as the best means of dealing with the ailment, the humane man will be actuated by no sentimentality about taking the life of an animal. He will kill promptly and surely, as the best means of alleviating the suffering of the animal, or of preventing the sprcad of infectious and contagious diseases. Prompt measures under these conditions will often save the loss of many lives.

\section{Graduation of Doses. .}

As a. rule cattle require one and a half times as much as horscs; shcep and pigs require one-third as much. Professor James Law, of Cornell Univcrsity, in his work, Veterinary Adviser, has presented the manncr of graduation, frequency, and form of administcring doses, in the following concise language :

The doses givcn may be held applicable to full-grown animals of mcdium size, therefore son.e allowance must be made in any cases in which the patient excceds or comes short of the average of hi: kind. A similar modification must be made as regards young animals, not only on account of thcir smaller size but also of their greater susccptibility. Tho following table may serve as a guide: 
TABLE OF DOSES FOK DIFFERENT ANIMALS.

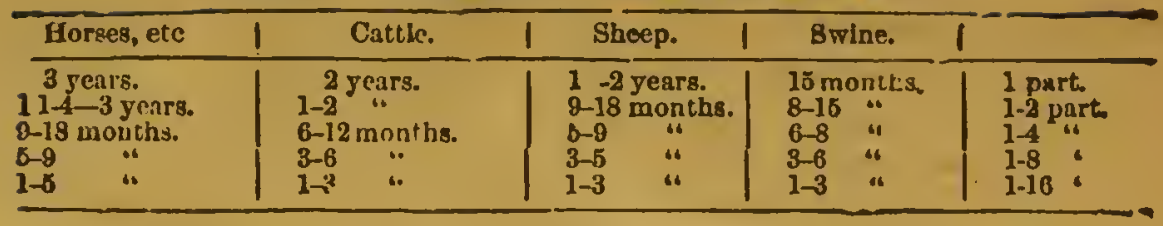

Allowance must a!so be mado for a nervous temperament, which usually renders an animal $m$ re impressibls; for habit, or continued use, which tends to decrease the suseeptibility for individual drugs; for idiosynerasy, which eiz only bo diseovered by observing the action of the agent on the particular sujject, and for the influenee of diseass when that is likely to aff zet the aetion Thus, in most diseases of the brain and spinal cord, and in some impactions of the stomach, double the usual quantities of purgative medicine will bo necessary: while in influenza, and other low fevers, half the usual doses may prove fatal. In acute e ngestion of the brain, stimulating nareoties (opium, belladonna, hyosoyannus) would aggravate the symptoms, ete.

\section{Frequency of Administering.}

Anodynes, antispasmodies, nareoties, sedatives, and stimulants, may gencrally bo repeated once in four or six hours in order to maintuin their effect. Alteratives, diaphoretics, febrifuges, refrigerants, and tonies, may be administered twice daily. Purgatives should only be given when necessary, and should never be repeated until from the lapse of time we are assured that the first dose remains inoperative. Thus, unless in urgent need, a horse should not take a second dose of physic under thirty-six hours after the exhibition of the first; and in all eases, until the medicine has worked off, he should be kept at rest and allowed only warm bran mashes and water with the chill taken off. In ruminants a second dose may be ventured on in twelve or sixteen hours, and in earnivora (dogs, ote.) and omnivora (swine, etc,) in from seven to ten hours. Emotic should be given in full doses, and repented in five or ten minutes if they fail to take effect, their action being further provoked by copious draught of tepid water and tickling the roof of the mouth with a feather.

\section{Forms of Doses.}

Drugs may often be given as powder or solution in the food or water ; they may be inade into a soft solid with syrup and linseed meal, rolled into a short eylinder and eovered with soft paper; they may be converted into an infusion with warn or eold water, or into a decoction by boiling; 
or they may be powdered and suspended in thiek gruel or miciage. They may be given, in a liquid form, from a horn or bottle; or, as short cylinder or pill, which may be lodged over the middle of the root of the tongue; or, as a sticky mass, they may be smeared on the back of the tongue; may be given as an injeetion into tho rectum; or, finally, in the ease of eertain powerful and non-irritating agents, they may bo injected under the skin.

No agent should bo given until sufficiently diluted to prevent irritation, if retained a few minutes in the mouth, and irritants that will not mix with water (oil of turpentine, Croton oil, etc.,) should be given in a bland oil, in milk, or in eggs after being thoroughly mixed.

\section{How to Give Medicine.}

Fow things are so awkwardly done, as a rule, as giving medicino to farm animals. In the hands of a careful and expert person, a strong glass bottle is good. A better instrument is a flattened bottle of block tin, which for eattle should hold two quarts. The most usual instrument, and on the whole the best for ordinary operations, is the horn. Select one of which the point turus down and the largo end up; form this of the proper size and fashion so the opening will be oblique.

Dreuches should always be thoroughly mixed, and well shaken before they are gives. If a fit of eoughing ensues, free the animul at once and until it be cnded. In operating with eattlo do not irritate the animal unduly. Always operate from the right or off side. Pass the left hand over the head, and in front of the horn, seize the upper jaw firmly in front of the grinders, turn the head firmly back, the operator stauding well braced, the back firm against, and as wcll forward of the shoulders as possible. Thus having the animal with one side against a wall, or tho side of the stall, it must be a very vieious cow or bull that a strong, expert man cannot handle. If, however, the operator does not stand well forward and well braeed, he may be severely licked, since an ox, like a decr, can reach well forward with their hind feet. The usual quantity for an ox is from one to two quarts at a dose, if liquid, of ordinary doe coctions and solutions.

\section{Injections, or Clysters.}

A large number of medieines, both liquid and solid, may be as easity administered per rectum as by the mouth. In administering injections, it is not neeessary that much pressure be used. The intestinal eanal of animals is lower than the opening. Thus fluid substances will fall by 
their gravity. $\Lambda$ good instrument for use may be a pail, with a tube extending from the bottom connecting with a half-inch rubber hose, of suitable length, so that the pail may hang just high enough above the animal to be out of their reach in moving about. Oil the end to be inv serted into the rectum, and the fluid may be passed into the gut, as much or as little as may be desired, and with mueh better effect than when, strong pressure is brought to bear on the fluid.

When solid substances are administered per reetum, they are called suppositories. They are often useful and simple, as in the ease of a small cylinder of soap, for young ealves, to eneourage the action of the bowels and ducts: and in the case of cows, in the use of disinfeetants, to purify the discharges and lessen the danger of puerperal ferer; suppositories are made into form by means of soap, starch, lard, etc.

\section{Vapors, Spraying and Fumigation.}

These are medieaments drawn in with the breath. Chloroform and other may be administered by means of a sponge filled with the agent and

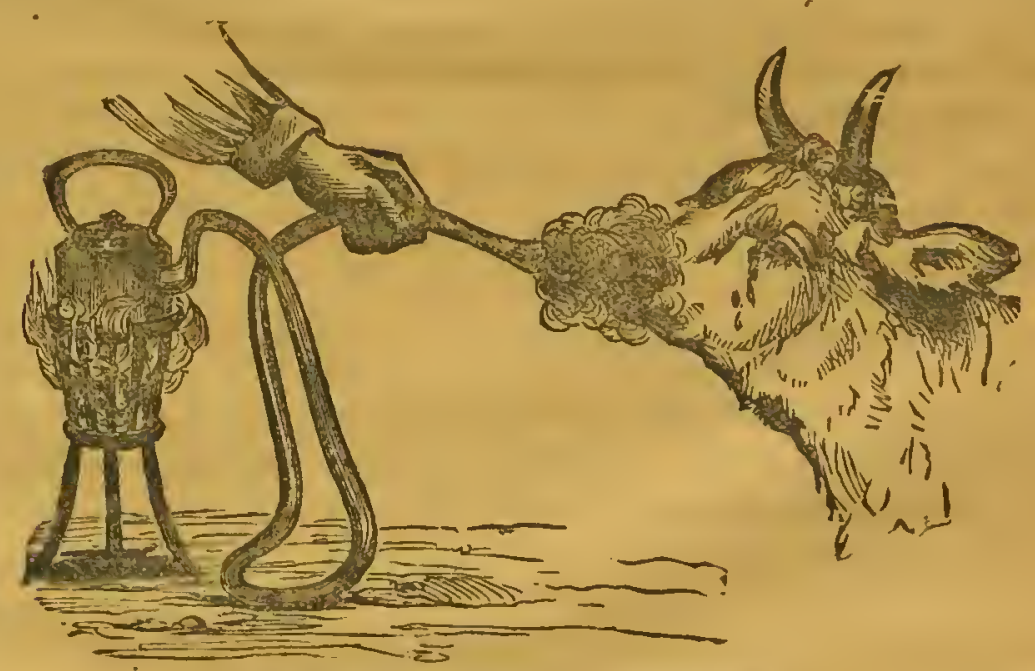

APPLICATION OF STEAM TO THE NOSTRIL.

beld to the nose. Vapors are easily produced from liquid substances by means of an atomizer, sold by all druggists.

Steaming is often of great benefit. Hot water, either plain or mediv cated, may be held under the animal's nose, and the stean strongly driven off by plunging a hot iron into it at intervals. A hot bran mash. in a nose bag, readily gives off steam. A better form for steaming the mostrils would be that giren abovo. 
For the promotion of discharge of the nostrils, the nose-bag will bo Indicated; its form and fastenings are shown in the gnnexed cut.

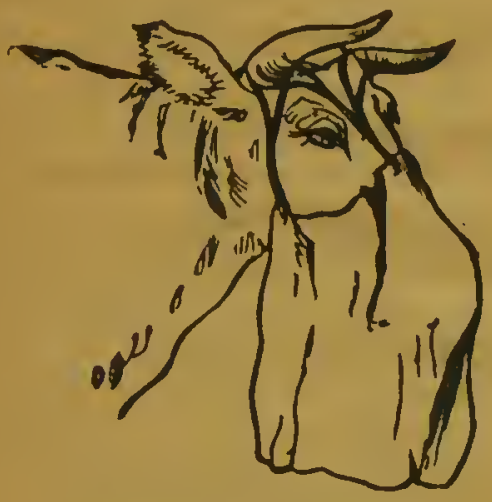

TUSE BAG FOR STEAMING.

Powders for casing the expulsion of the secretions of the nostrils, or for local application to diseases of the inncr surface of tho nose, may be a simple tube of tin in two parts, which may bc taken apart and put together like the joints of a stovc-pipe, with a rubber tube on one end and a mouthpiecc on the othcr. Charge with the powder, and blow with sufficicnt force to carry the agent where wanted.

When an anzsthetic is used, it should not be beld to tho nosc continuously, sincc, if undilutcd with air, it is fatal. Watch carefully and sus-

pend the use of the anæsthetic as soon as unconsciousness is produced, to be renewed from time to timc as may be necessary: 'They should not be used unless under the advice of a surgeon or physician, since the need can bardly be expected except for the performance of some intricate surgical operation. The following is endorsed by high veterinary authority :

\section{No 1.}

$$
\begin{aligned}
& 10 z \text {. alcohol, } \\
& 2 \text { Oz. chloroform, } \\
& 8 \text { Oz. ether. }
\end{aligned}
$$

Shake the bottle well before using it; pour a teaspoonful or more at a timc on a sponge; hold it to the nostrils. Two or three moments should be enough to overpower the strongest ox.

\section{Blistering.}

Blistering is a valuablo rcmedy, when it is required to easo the absorption of deposit, to stimulate the vessels to cffect organic ehange, a hastcning the ripening of an absccss, or the reduction of an enlarged gland; thcy should be cntirely confined to cases whero the acuto inflammatory symptoms havc ceased. Blistcrs do no good in dcep-seated inflammations. Yct the quack, if he suspect internal inflammation, claps on a blister, which only agonizcs the dumb brute, and gencrally lcaves a permanent blemsh. When a blister is found necessary, before applying, always as 
an ointment or fluid, and never as a plaster, cut or shave the hair from the part, wash and dry thoroughly, and apply with strong friction for several minutes. The following, if thoroughly applied, will raise a blister, and will not leave a blemish:

No. 2.

$10 z$. Powdered Cantharides,

$12 \mathrm{Oz}$. Lard heated to $212 \mathrm{deg}$. Fahr.

Mix well together and stir until cool.

A sweating blister of medium strength to be used to produce irritation and a watery discharge without laising a full blister, and which may bo applied scparately to the same spot and without rewroving the bair, is made as follows:

No. 3.

1 Oz. Powdered Cantharides,

1 Pt. Alcohol.

Add neither corrosive sublimate, arsenic, acids, nor turpentine to blistering agents. They are not useful, are often injurious, and always give unnecessury pain.

As ar rule, sufticient irritation ean be produced on cattle by mustard and hot water, well rubbed in, and this form should be used except in particular eases. The following rules should be carefully remembered :

1.-Never blister more than one or tro spots at the same time.

2.-Be careful about blistering in hot weather.

3.-Nerer blister an inflamed part when there are symptoms of mortification.

4.- There is always danger of produeing strangury in horses from blistering.

5.-When a blister causes great nervous irritability, loss of appetite, or difficult urination, wash the blistered surface with stroug soapsuds of soft soap, dress it with sweet oil, and gire a full dose of opiun.

6.-The seeond day after a blister has been applied, foment the part with warm water, and dress it with lard or oil.

7.-An animal that has been blistered should be prevented from biting, rubbing, or otherwise irritating the blistered part.

Firing.

The actual cautery is most valuable in hone discases, or cluronic limeness. In eertain diseases it eannot be sticcessfully replaced by any otiel counterIrritint. The iron should he at a full red or white beat, and used with a ligat hand, so that a distiuct impression is made. More than ouo leg 
should not be operated on at one time. It should never be performed hy inexpert hands. The huir must be closely shaved, and the animal securely fastened. A better way for the noviee is to eut a pieee of baeon rind with some of the fat attached. The iroi, whicl should be flat or slightly hollowed, is to be heated to a dull red heat. Plaee the baeon rind on the Eprain or tumor, and apply the iron firmly for two or three minutes, and afterwards more lightly, until the rind is dried or burned. This may bo repeated at intervals of two or three days. The influenee will be potent, and will leave no sear. It should never be used on cattle, exeept in the case of a tumor, where the animal is valuable.

\section{Setons.}

Setons are used in eases of bono diseases, in the healing of old fistulas, by produeing a now and healthy inflammation in its sides. They should be inserted the whole length of the canal.

Setors are eomposed of tajes, threads, or fine wires, pushed just underneath the skin by means of a seton needle, enteling at olie point and eoming out at another. Fasten the ends, to prevent dropping out, smear with irritant salve and turn every day or two to keep up a eonstant irritation and diseharge. The following will be found good ointments for smearing the setous:

No.1.

$$
\begin{aligned}
& 1 \text { Part powdered canthances, } \\
& 8 \text { Parts oil of turpentine, } \\
& 8 \text { Parts Canada balsam. }
\end{aligned}
$$

Put the two first in a bottle and keep warm for two days and add the balsam

A simple ointment rould be:

No. 5.

$$
\begin{aligned}
& \text { \& Parts citrine ointment, } \\
& 1 \text { Part oll of turpentine. } \\
& \text { Mix. }
\end{aligned}
$$

\section{Rowels.}

These are wounds made with rowel seissors or a bistoury, and kept open with a pledget of tow or other substanee, smeared with ointment, as used for setous. They are rarely used now by good surgeons, and are not to be recommended, sinee their aetion is that of the seton.

\section{Sewing up Wounds.}

The bleeding of wounds having been eheeked and properly eleanod, tho edges are brought together and held in position by means of stitches 
or sutures. The interrupted suturo is made by earryng a suture needlo armed with white silk or white linen thread, through tho two edges of the wound and cutting off, leaving about three-inch ends on each side of the eut; bring together and tic. So proceed until you have the wound nicely closed, the lips of the wound or skin being carefully brought togetlier.

The twisted suture is better in inexpert hands when it ean be used. Bring the edges of the wound together, pass a strong pin through to hold in plaee, and twist a fine wire or laee a strong thread aeross tho protruding ends of the pin to hold the edges of the wound firmly together. So proeecd at intervals of threc-eights of an inch until tho wound is closed.

The wound thus serred, dress with a plaster or ointment and bandago to prevent threads or pins from being torn out. Remore them as soon as the surfaces have united, which should be in four or tivo days.

\section{Fomentations.}

These are applicd by wrapping the part to be treated with flannel bandages or woolen clotlis, and keep the wrappings constantly wet with hot or cold water, or mixed with any appropriate addition as vinegar, laudanum, cte. They are used to cleause or soothe irritable wounds, to reduce internal inflummation, or relieve external inflammation. Unless persistently used for hours and kept eonstantly wet, they had better not be attempted. After the operation is finished, rub dry and elothe warmly, to prevent chill, which will surely occur. As an additional precaution, a little mustard rubbed in would be bencficial. When it can be applicd, a sheepskin with the wool on, wrung out of hot water, wakes a good egent for fomentation.

\section{The Operation of Blceding.}

There is no operation in veterinary practice that has been more abused by quacks and other persons ignorant of the true necessity, than bleeding. It should never be performed exeept by those who have been jnstructed in the operation, and only in those cases where by common cousent of the profession it is allowed. If a decided impression is to be made, as in apoplexy, from five to seren quarts should be talien from an ox, according to the conditions. If the jugular vein is pressed upon just below where the incision is to be made, it will soon show prominently. Use a thumb lancet in preference to a fleam. When sufficient has been taken, raise the two lips of the wound, and bring them together between 
the thranb and finger, pass a common small pin througli the edges and weave thread across and over to keep all in place.

\section{Recognizing and Distinguishing Diseases.}

The following explicit and detailed rules for reeognizing diseases in animals, should be earefully studied: Anyone who would liceome expert in recognizing discases in animals, must study them carefully in the healthy. state, and make himself thoroughly familiar with their habits, appearance and general physiology. He must practice feeling their pulse and the heart, listening to the sounds of their lungs in breathing, and taking their temperature, by feoling the skin and also by using a properly constructed thermometer. He should watch the appearanees of the eye and tongue, and note the positions assumed when asleep and awake. He should observe the eharacter and frequency of their appetite. For it is in the variations from health in these particulars that the veterinarian discovers the guides which lead him to the recognition of the particular disease he has to treat. We will examine each of these items separately, and assure our readers that if they will verify our statements by practice on the living animals, they will soon be in a position to take charge of them when sick, quite as well and often a great deal better than the average furricr, as $\mathrm{bc}$ is to be found in this country.

\section{The Pulse.}

The pulse differs very much in the domestie animals. In the full grown horse at rest, its beats are about forty per minute; in the ox from fifty to fifty-five; and in the sheep and pig, about as in man, that is, averaging seventy to eighty beats in the minute. In calves and colts, and in animals well advanced in years, the pulse inereases, in health, to about twice these figures; and it is also increased by hot, close stables, full feeding, and the condition of pregnancy.

The pulse may be felt wherever a considerable artery passes over a bone. It is usually examined in the horse on the eord which runs over the bone of the lower jaw, just in front of its curved portion; or on the bony ridge extending upward from the eye, or inside the elbow. In cattlo conveniently reached over the middle of the first rib, or beneath the tail. There is a marked difference of foree in the pulse of the two species; that of the horse being full and rather tensc, while in the ox it is soft and rolling.

When the pulse differs materially from these eonditions in any direction, it is a sign of diseaso. If rapid, full and hard, there is high fover 
or acute inflammation; if rapid, small and weak there is low fever, losw of blood, or weakness. If very slow we may suspect brain disease; if irregular, now fast and in a ferv scconds slow, we should look for a discased condition of the heart.

In the sheep, the pulse if felt by placing the hand on the left side, where the beatings of the heart can be felt; or at about the middle of the inside of the thigh, where the femoral artery passes obliquely acrosa the boue.

\section{The Breathing}

The breathing is next in importance. If the ear is applied to tne throat of a healthy horse or ox the air will be heard passing through the windpipe with a regular, steady, blowing sound; if applied to the chest a soft rustling nurnur will be heard, like a gentle breeze in the treo tops, eaused by the air passing in and out of the fine tubes and vessels of the lungs. But where the lung or throat is discased, these sounds aro very much chinged and in many directions, whieh it is not necessary to dwell on here, but which will at once indiente the presence of sometling amiss with these inportant organs.

If the forefinger of the the left hand is placed firmly on the ehest and smartly tapped with the ends of the three first fingers of the right hand, the sound will be notiecd to be more resonant and clear than when the sume procedure is praeticed on the solid thigh. This is beciuse the lungs are not solid, but are always in heilth well expanded with air. But in various diseases, as pneumonia and pleurisy, they fill up with fluid and become solid, then the sound given out, by thus pereussing them, as it is ealled, is like that on any other solid puit of the anmal. Hence this is another very important indieation of diseas?

By practice on liealthy animals the charneter and boundaries of these sounds can be learned so elosely that any varintion from them will be at once deteeted, and will sometimes reveal the prosence of an unsound condition when mothing else will.

The rapidity with which the act of breathing is performed ean easily be counted by the leaving of the chest. In health in the adult horse at rest it is from eight to twelve times a minute, and in the ox a little fister. Any great incense without obvious cause, is a positive sign of discased conditiou.

\section{Tho Animal Ileat.}

The temperature of auimals cuц bo uscertaiued, to a slight extent, cy 
the fecl of the skin, the ears, and the legs. A hot, dry skin in a horse gencrally aeeompanies a fererish condition. Cold ears and legs are a sign of serious disease. But the only scientifie, that is, aceurate plan, is to use what is called a "clinical thermometer ;" that is, one, the bulb of which ean be bared and inserted into the rectum. After it has remained there two or three minutes, the mercury will aceurately indieate the temperature of the blood. This in healtl is 98 degrees, and any deviation from this, even of a few degrees, is a eertain sign of disease. Those veterinarians who have practiced sufficiently with this instrument to beeome skilled in its use, declare it invaluable in their business, as affording them grounds for opinions about discases which no other symptoms could.

Thus it has been found that every disease has its own degree, a temperature at which it is either farorable or fatal. For example, if in that sometinnes prevalent epidenie antong horses, cerebro-spinal meningitis, the thermometer rises as Jigh as 104 degrees, it is a certain indiention that the horse will shortly die; while in such a disease as inflammation of the lungs, the mereury will register 108 degrees, or 109 degrees, and the horse recover. If in gastrie or typhoid fever the heat has becin 103 degrees, and falls to 100 degrees, and then suddenly rises again to its previous figure, the chances are terribly against the patient, no matter what the other appearances may seem to say. These few examples will serve to show how valuable the instrument may become in the lrands of an intelligent person.

\section{The Skin and Hair.'}

The slin in its general fecling and appearance is an important guide to the condicion of an animal. A dry, scurfy appearance is a system of indigestion, and liability to joint affeetions. What is ealled "hide bound" is a symptom of a general state of poor nutrition, arising from indigestion, improper food, wolus, or a want of ploper exereise. 'The skin fecls stretelied and hard, as if too small for the body. The condition known as "staring eoat," when the hairs stand out like bristles, is often the only symptom of a low state of health. Whenerer an animal is disposed to shiver, with shedding of the eoat, when exposed to moderate cold, or without such exposure, it is on the edge of some disease. $\Lambda$ persistently staring coat, without other symptons of disease, often indicates the approach of an attack of farcy or glanders; and when with this are repeated shivers or chills. we may expect the strangles, weed, or other diseases with suppuration. When in an attack of disease the skin becones covered with a cold sweat, the life of the animal is in great danger. 
The Post:ure.

'Le position of an animal, its mode of standing and lying down, are all eignificant. Lying persistently on cne side, or obstinately maintainiug one position, shows that any other is painful. Horses staud as long is they possibly can, as they breathe nuch casier in the upright position; and if they once lio down, they soon despair and die. Hence the rule is with a horse to sling him up, in various ailments. With cuttle it is different, and it is much less importunt to keep theru erect. When animals cannot rise, it may be from weakness, or from palsied limbs, or frow severo iujurics or spruins.

\section{Indication of Pain.}

The feelin $n_{j}$ of pain in anımals is indicated by their funching when tto painful part is touched; by the care which they take iu lying down, walking or standing to "favor" the part, and by the appearance of the cye. Distress and suffering are generally plainly appurent in the fuce of sick borses and cattle.

\section{Special Sigñs in Cattle.}

In cattle, the horn at its root yields, by tho sensation it imparts to the band, a rough idca of the temperature of the blood, and the cow-lecel generally feels it as tho loctor does the pulse, as a part of the inclispens. . able programmo of a professional visit. If the temperature is natural, he coucludes there is no ferer; if cold, and the tips of tho cars also cold, it is a sign of some serious internal congestion; the blood no louger circulating in natural foree through the extreuities.

'The muzzle is another part. he takes note of. In health this is moist, covered with "dew," as the saying is ; but in disease, especiully fever, il is dry, lotter or colder than natural, and sometimes changed in color, paler or injected with blood. By looking at the flauks, the regularity of the respiration is noted, lapid and irregular heaving there betraying the disturbance of the important function of breatling. In ruminants also, the second masticatiou of tho food is among the first of the vital processes to become disturbed in discase. When a cow or an ox "loses the cud," as it is called by herdsmen, that is, ceases to ruminate without appurent culuso, there is sure to be a fecling of sickness about the animal which is thus interfering with one of its processes of digestion. No aniual can thrive in this condition, it needs attention. 


\section{CHAPTER I.}

\section{CESTATION, DISEASES AND ACCIDENTS THEREOন.}

PIURAL AND MOLIPIE GESTATION.- TREATMENT DERING GESTATION.——BIRTH. - PROLUNGED LABOR.—LARGE PHESENTATION. — UNNATUIEA POSITIUNS OF THE CALF.—ZLOOUING. - PRESENTATION OF AFTER-BIRTY.——INVERSION OF THE WOMB. L LANGUID LABOR. Z IRRTTABILITY AND STRAINING.

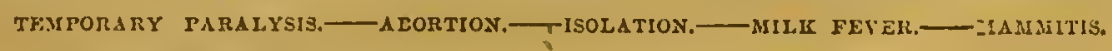
THEATMENT OF CALVES.

\section{Plural and Multiplo Gestation.}

Fleming, in his work on Veterinary Obstetrics, gives a lucid ind accurate account of single, plural, and multiple gestation in animals.

Among the domestic animals there are specics which are naturally $u n i$ parous-produce only one at a birth; and others which, in a norinal or physiological mianner, bring forth two, three, or more, at a time, and aro therefore dcsignated gemelliparous or multiparous gestation, heing known us double, triple, quadruple, \&c.

It is seldom that twins are produced by the larger domesticated animals, und particularly by the maro and ass, though instances are recorcied of these; whilo in tho cow, sheep, and goat, tho occurrence of twins, triplets, or even moro young creatures at a birth, aro not so scarce.

The causes of multiparity aro not well ascertained. It miy bo due to ginultaneous ripening of two or more Graafian vesicles, which, :"vpturing at the same time, allow tho escape of the ovules they contain, a ma become impregnated at a single coitus. Or a Granfina recicle may contain two or more ovules, as Brischoff has witnessed in women; ans these arriving together in the uterus, may be fecundated at o:se time. Or it may even happen that the vitelline membrine mituins tivo yolks, $\mathrm{m}$ cometimes occurs in the fowl's egg ; and as the vitel.:- wass is the essar, 
lial part of the exg, it is eviclent that when this contains two of theso masses, they ought, if fecindated, to produce two cmbryos.

In the first case, as Saint Cyr points out, each fotus has ordinarily all its ammexes distinct and completely independent; or it may be that the two churions are fused together, in which circumstince the two foetuses will then have a common envelope. In the second lypothusis, this fusion of the charions appears to be the rule, althongh the envelopes may also be independent; and in the third case-that of the two vitelluses contained in the same vitelline membrane-not only the envelopes but also tho fotuses may become united more or less closely and thus give rise to double monster's.

Finally, it is also possible that two ovules may become detached from the ovarian cluster, though not simultaneously, but successively, and be fecundated, one after another, at two successive eopulations rithin a brief period. Occurrences of this kind are by no menus rare, yet havo been wrongly adduced as instunces of superfoctution.

\section{What to Do During Gestation.}

As a rule the cow should be dried about the sixth or serenth month when stock breeding is the object. When milk and not calves is the object the flow may be continued to within six weeks of ealving.

Grazing should always bo allowed as much as possible, the exercise and grass both being favorable to healthy gestation. In Winter the food given should be nutritive, easy of digestion, cooling, and of such quality as not to induee either constipation or undue laxity. Water should be especially pure and plentiful, and not excessively cold; in fact, all frozen food is to be avoided. Cleanliness is essential. Harsh or cruel treatment, rumning by dogs, all danger of fright must be avoided. Surgical operations and severe medication is to be aroided, especially drasties. Suitable diet is to be used as a regulator of the bowels; powerful narcotics, sedatives, and other strong physics, if they do not impair the dam may imperil the life of the fotus. "The veterinary anomalies in gestation are fully treated in Fleming's work on'Veterinary Obstetrics. to which we are indebted for much valuable information.

\section{Births.}

As a rule in natural parturition there is nothing gained by undue hasta The animal should have quiet and be left to itself so long as everythir:g is going on tolerably well. In the majority of cases nature will assist herself to a safe delivery. A roomy stall, in Winter well warmed, should 
be provided with rather thin but compact bedding. In Summer, or other mild weather, let the cow be out-of-doors by all means; in a small grass lot is best.

\section{Prolonged Labor.}

When the labor is prolonged from excessive sizc of the fotus, and this is suspected beforehand, or if time do not press and there is ne special excitement in the cow, and there is delay in the descent of the calf, oil the hand and arm and feel for the neck of the womb in the vagina. If it be rigid carry extract of belladonna up the vagina and smear the neck of the womb for a few times. This should cause relaxation of the parts. If the time is passing carry a narrow-bladed, blunt-pointed knife in the hand in the vagina; find the mouth of tho womb with the forefinger, slip the knife along the finger until it encers the neck of the womb about a quarter of an inch, and make a slight cut in all four sides of the neck by turning the knife. A slight nicking will suffice, since the mouth once loosened in its contraction, the neck will give way, and the bag of water will accomplish the rest. The utınost care is needed in such work, however.

\section{Large Presentation.}

Sometimes the calf is so large that the muscular efforts of the cow can not force the mass forward. In this case do not resort to strong mcans until all others fail. Let a small-handed man introduce both hands, well oiled, up the vagina, carefully working forward beside the calf, gradually pressing apart the orifice; pass closely to the calf with the hands, and as the pains commence, pull forward as strongly by pressure against the fotus. When a main effort is made pull forward, and at the same time slip the hands slowly back, and the calf will often follow. Repeat this again and again as the pains are renewed. We have never failed in but one case in so delivering the calf, and in this case the calf had to be dissected in the body. This no person unskilled in surgery should attempt.

\section{Unnatural Positions of the Calf.}

These are various, and, except in the six cases we mention, and in the order of their frequency, resort should be had to a vetcrinary surgeon. The following manner of relief is endorsed by various reliable and wellknown authorities:

Unnatural Positions of the calf.-The natural position of the calf an 
Its exit from the womb, is with its head and fore-fect first, the head hetween the feet and the baek upwards. Six unnatural positions aro enumerated by writers, which demand the assistance of the surgeoll. Wo give them in the order of their frequency, with the appropriate treatment they require.

First-Position with tail first. Press the haunches back with the palm of the hand, take hold of the bend of the hough of one $\operatorname{leg}$, pull at it and reach the foot; seize the other foot in the same mamer, bring them forth and deliver the body.

Second-Position with fore-fect appearing without the head. Push the feet baek until the head eam be seized either by the jaw or nose, and pull it down between the feet. No further aid will be required. This needs a long alm, and prompt action between the pains.

Third-Position with belly upward, hcad over one shoulder, fore-lega first. Gently push the ealf back between the pains, and bring the head down between the legrs.

Fourth-Fore-fect first, with head under the brisket. Push the eolf back, find the hear, and draw it down between the fore-fect.

Fifth-Head alone, or only one fore-foot with it. Push the ealf back and seareh for the fore-fect, or foot, under the belly; when found, bring forward one at a time, by placing the hand under the knee and using gentlo pressure.

Sixth-Belly upwards, the fore-legs folded and against the mother's back, the head, side or hind-leg appcaring. If the hind-leg appear, put it back; seck for the head, and if possible turn the calf, to bring the fore-feet and head to the mouth. When this fails, throw the cow, put her on her back, and with a rope and pulley, or two or three stout assistants, raise her hind-quarters considerably higher than her shoulders. In this position the calf can be easily pushed back in the uterus, so that it can be turned and brought to the natural position.

Many surgeons make it a rule to fasten the part presenting with a cord and slip-knot before going in seareh of the part they desire to bring to the mouth. The eord is held by an assistant, and serves as a guide.

The principal obstetric instrument in the eow is the hook. This is made of wrought iron, four inches long, with a loop for the eord at the strinight end. When by no other means the ealf ean be delivered, 0 r when removing a dead foetus, this hook is fastened in the socket of an eyc, under the jaw or in an ear, and by gentle and steady traetion tha resistance is overeome.

Finally, the fotus may have to be taken out picee-meal, an operation which requires considerable skill on the part of the operator, to avoid wounding the womb and vagina when he is dissecting the calf. 
in all such operations certain general rules should bo observed, as follows :

First-Thoroughly anoint the hand with lard, or oil, bcfore iutroducing it into the vagina.

Sccond-Makc the examiuations while tho cow is standing, and between the pains.

Third-In pulling at tho fect; enclose the claws in the hollow of the palm, so that they will not tear the delicate eoats of the womb.

\section{Flooding.}

Sometimes after a natural birth which has bcen rapid, nnd often afte: nil abortion which has beeu brought on hy violence, there is a severc at. tack of "flooding," or blceding from the womb. It may escapo from the vagina, or it may be indicated by paleness of the mouth and nose, weak pulsc, great weakness and coldness of the surface, aud the womb, be found to be filled with clottcd blood.

Treatment.-The hand should bc introduced into the womb, the clotis and any remaining portion of the aftcr-birth seizcd and cxtracted, and i spongo dipped in hot vincgar and water, or very hot or very cold water. alone, be wrung out in the uterus. A full dose of fresh ergot of rye, one to two ounces, should be given without delay.

If these measures fail, a piecc of ice the size of a walnut should be car.. ricd into the womb and left therc; or a tea-spoonful of powdered alum. should be stirred in a tca-cupful of milk, and a sponge of this be squeezcd out in the womb. Intcrnally, Prof. Gangee rccommends, for either tho marc or cow,

No. 6

Mix and give two table-spoonfuls for a dose every one or two hours, in a quart of water.

\section{Retention of After-birth.}

There are many eauses leading to this. The most common of these are burried deliveries, adherenco of the after-birth to the walls of tho won., and poverty of the animal. Retention for two or even threo days under ordinary circumstances is not especially scrious. If loft to putrify, fetid discharges will exhaust the animal. The blood is poisoned, and tho animal either dies or remains unhealthy for life. After forty-eight hours, if trouble still exists, the hand and arm well oiled should be introdueed, 
and the after-birth carefully separated from the walls of the womb by picking with the fingers and nails, and gradual but firm pulling. Tho whole having been completely removed, syringe the vagina thoroughls with the following:
No. 2.
1 0z. Chloride of lime
1 Qt. int rator.

Give the following as a physies
No. 8.
8 Oz. Epsom alts;
z $\mathrm{Oz}$. Ginger puiverized.
3/. Oz. Caraway seed pulyerlzed,
2. Drachms Coparia.

Give as a drench. If there is a tendency to bleec........... che following

No. 9.

2. Oz. T-got of rye, powdered.

\section{Inversion of the Womk.}

This occurs from long-continued and excessive stian …… and thero hangs from the birthplace a large red or violet colored b... Cleau tho

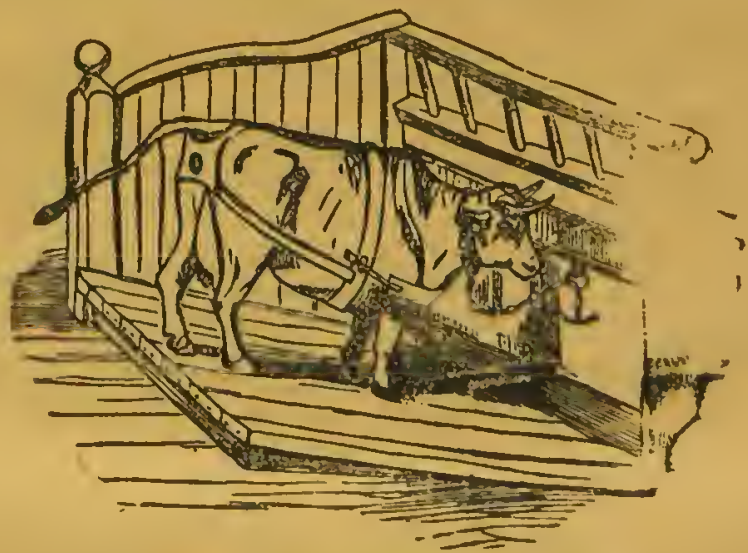

TO PREVENT INVRRSION OF THE VAGLA.

iag thorcughly by the frec usc of warm water. If it is much swollea end enlarred, puncture slightly with the lance in several places to let out enromed whod. When sufficiently reduced, stop the effusion with cold wier. Stand the cow so that her head will be permanently lowest in the 1:1. Let tro assistants place a cloth underneath the bag and raise it if: ito level of the vagina. Tho operutor with bis right hand well nilod. 
after oiling the surface of the bag, places his hand against the point or bow of the bag farthest from the vagina, presses it steadily but grently back, and as far up the vagina as possible. With the left hand, also 'oiled, he now presses in the depencent portions in and up in a similar manner. The assistants follow the retracting bag until $i$ is restored. A ball of tow is introduced to keep it in place, and a harness (as shown in the foregoi $g$ cut), which includes a raised stall. In any event the bowels should be restrained for a day or two by doses of laudanum. After twenty-four hours, if the pains have ceased and the animal is quier, the ball of tow may be removed, and later the harness. A simplification of the harness will easily suggest itself to the operator.

\section{Languid Labor.}

If the presentation, is all right and there is no obstrictiun, and the mouth of the womb is dilated bit the labor pains are infr:quent and weak, eareful mechanieal assistance shonil be given with the hands as heretofore stated, or try first full doses of ergot i: rye, one to two ounces. It is often inefficient in eows and must be given in large doses.

\section{Irritability and Straining.}

If this is seen after birtl, unless it subsides promptly, or if it show itself by repeated spasms and convulsions, give the following in a quart of warm milk: Chloroform and laudanum, cach half an ounce. If the muzzle is dry and the horns hot, showing tendency to fever, the following will be better :

No. 10.

$2 \mathrm{Oz}$. eweet spirits of nitre, 2 Oz. Iaudanum,

$4 \mathrm{Oz}$. solution of acetate of ammonia.

This dose to be given in a quart of tepid milk every hour until relieved.

Temporary Paralysis.

Cows are frequently paralyzed in their limbs before parturition. If they does not regain the use of their limbs soon, or if they improvo slowly, give the following:

No.11. 2 Drachms powdered nux romica, 2 Drachms sulphate of iron.

Give in a pint or two of gruel twice a day. Avoid all somealled cleans. ing drinks; they are generally injurious. When there is unusual debility the following will bo indieated: 
No. 12.

$$
\begin{aligned}
& 1 \text { Oz. powdered anise seed, } \\
& 1 \mathrm{Oz.} \text { ". myirh, } \\
& 1 \mathrm{Oz} \text { " " allspice, } \\
& 1 \text { Uz. " cusnmin geed. }
\end{aligned}
$$

To be stirred in a quart of warin gruel as a drench.

If constipation is strong and persistent give:

$$
\begin{aligned}
& \text { No.13. } \\
& \begin{array}{l}
1 \mathrm{Lb} \text {. sulphate of magnesia, } \\
6 \mathrm{Oz} \text {. olive oll. }
\end{array}
\end{aligned}
$$

Give in a pint of gruel, and repent daily if needed.

If therc is strong relaxation with continued diarrhea, tho foliowing rill be indicated:

IT. 14.

2 Drachms powclered catechu,

$10 z . \quad$ "ginger,

30 Drops sulphurie acid,

$10 z$. las

Give in a quart of gruel, ale or weak whisiny and wates.

Or,

No. 15.

10z. powdered ginger,

$1 \mathrm{Oz}$. bicarbonate of soda,

1 Oz. laudanun,

$1 \mathrm{Oz}$. decoetion of oak bark.

Give several times a day in gruel or ale. Half this cose suffices for sig months' calves, in similar conditions of the bowels.

Antiseptic washes for cleansing the vagina when the discharge is foul:

No. 16.

1 Quart elean wood tar,

2 Ouarts boiling rainwater.

Stir, settle and pour off.

Another,

No. 17. $1 \mathrm{Lb}$. ehloride of lime,

2 Gallons cool soft water.

Let it settlc and pour off clear. A pint or tro of either may be injos ted twice a day.

\section{Abortion.}

Abortion may be said to take place in cows when the foetus is expelled thirty-five days before the normal period. It may occur from a varioty 
of reasons, and is much more common during the first half of the normal period than in the latter. It nayy be sporadic, that is, induced by aceidental or local causes, as atmospherical iuflucnecs, such as bad weather, and irregular seasons-severe suddenly succeeding mild wcather. Cold torms, ctc., are cspecially to be guarded against. As external causcs, access by the male, explorations in vagina, surgical opcrations, throwing the animal down, bleeding, and bad or improper food, are among the most common of extcrnal causes. Excitcment, fear, surprise, certain odors, contagion, are eredited with playing an active part in this dis. ability. Various discascs are also activc partics in this direction. Whes cases occur simultancously over wide extents of country and without known causation, it may be cuzootic or epizootic. Ravagcs of this kind ar uot uncommon, and have attracted the attention of vetcrinarians.

\section{Isolation.}

When abortion is about to occur in a stable, at the very first symptom the animal should be entirely separated from the others, and the stall choroughly disinfected with carbolic acid. In relation to mcasures pre. ventive and remedial, these will be found in the list of properly labeled drugs to bc kept for that purposc ; they may be referred to at wi-l. Isofation, lowever, is of absolutc importance, lest the cause extend to other or perhaps all the corvs in the stablc. Elgot or other fungus spores in the food mily be the cause. All possible eauses should be earefully examined and remcdied. A thorough clcansing of the stables should bo made, and disinfectants and fumigants used. The following in the form ef powder is good as a disinfectant in any casc.

No. 18.

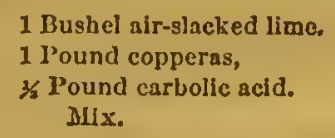

$\Delta$ liquid form:

No. 19.

$$
\begin{aligned}
& 1 \text { 1. Pounds chloride of alumioum, } \\
& 1 \text { Gallon water. } \\
& \text { Dissolve. This is not poisonous. }
\end{aligned}
$$

\section{Milk Fever.}

This fever occurs from the first to the third day after calving; rarcly later than this timc. Sclect brceds and good milkers seem specially liable to atta:ks from this disorder.

The primary trouble in this disease is inflammation of the lining membranes of the womb, cxtending sometimes to its substancc and adjaccnt parts; and in camc cases involving the bowcls themselves. Aroong its nore remotc effects 
are affcetions of the brain, congestion of the spinal eord, apoplexy, bloodpoisoning and deatl.

Canses-Injury to the womb in calving; the retention of the after-birth; exposure to ehill and cold by sudden changes of teinperature, poor management, ete., may eause milk fever. At times a eontagious eharaeter seems to attaeh to the discase, and many eows of the same herd suffer. It is also regarded as quite eertain. that a cow having once had tlie fever, will have it with her next calf. Over-feeding as the time of ealving appronehes is also prominent among the the supposed eauses of the discase.

Autlıorities differ somewhat as to whether "milk fever" ls identical with inflammation of the romb. Some think it is not identieal ; others, that it is the saine disease in different stages, or different degrèes of violenec.

Symptoms. - The suspension of the milk seeretions is one of the earliest in dieations of this tronble. The eow hangs her head, negleets to feed, ceases to chew the eud, moves her hind feet restlessly, stagrgers if she attempts to walk, looks wild, falls and eannot rise, sways her liearl from sidle tö side. In this stage of disease the head is intensely hot. Power to see and to swallow is lost early in the discase; paralysis of the hind-quarters sometimes oeeurs; if not relieved, the breatling beeomes hard and rapid; the pulse beeomes faint and quick; and sometimes the animal dies in convulsions, or siuks away in stupor.

Usually the bowels do not move, and the bladder eeases to aet. The turn of the disease for the better usually eomes in thirty or forty lours, when the aninal beeomes rational, is able to arise, and the seeretions all begin to resume thcir funetions.

Treatment.-When trouble of this elaraeter is antieipated, preliminary treatment is strongly reeommended for about a wesk before calving. 'This may consist in a purgative of

\author{
1 Lu. Eprom aalts, \\ Lb. table salt, \\ I Oz. ground ginger,
}

Mixed with suitable quantity of eold water, and sweetened with molasses.

At this time the cow's food slould be of the lightest kind also, aroiding meal and grain. The eow should be carefully sheltered also. After calving, if fever be antieipated, give twenty-five drops of tineture of aeonite in water, repeating the dose every six hours, till foul loses liave been given. This has a very direet effeet upon the leart and cireulation generally.

If the disease has set in elearly, but exlaustion is not apparent, free-blcedIng is reeommended by good authorities. When the pulse is weak and thready, however, and when exhaustion is apparent, blecding is not called for, but a stimulant is required. Whisky may meet this case, or

1 Or. carbonate of ammonia,

1 Pint of water. 
If the cow be unable to sivallow, a ball may answer better. It should bs well oiled and puslicd far back into the gullet. Active purges are always an advantagc, and injections of soap and warm water may bc used frcquently when swallowing is impossible.

To relieve a heated head, cold water may be used. Carbonate of ammonia given as a ball may relieve swelling of the bowcls. When the attack comcas a, the following formula may be used as a laxative and sedative.

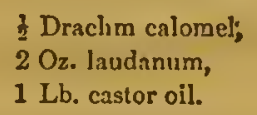

Mix with hot water and molasses, and give in four doses at intervals of four hours.

For the exhaustion following the more acute stages of the disease, the fol lowing is lighly commended:

$1 \mathrm{Oz}$. spirits of turpentine,

2 Oz. carbonate of amnusua

To be given in a quart of cold grucl.

Mammitis.

This disease is known as caked-bag, or garget, and is sometimes erroneously called milk fever. It is a diseaze of rare occurrence in the mare, but is commonly met with in cattle and sheep.

Definition.-It consists in acute inflammation of the whole or part of tho manmary gland (udder).

Ciuses. - These are numcrous; sometimes it is the result of external injury, such as blows of any lescription. Another common source of this discase is the cruel practice of "over stocking," which consists in the preparation of the pow for show or market, by allowing lier to go unmilked until the udder becomes enormously clistended with milk. This is done to give the gland a fine appearance. Cows giving no milk, when being fattened for the buteher, eometines undergo a modified form of this disease; this is eaused by some of the milk remaining in the gland and acting as an irritant.

Symptoms.-This disease seldom attacks the whole gland, but is usually confined to one or two quarters. The affected parts become hot, hard, swollen, tender, and red; the milk is enrdled and whey-like, and usually mixed with blood. The constitutional symptoms depend upon the severity of the attack, the disease being often ushered in with rigors (trembling), followed by inerensed heat of the skin; the bowels are usually eostive, but are sometimes unnaturally loose. The muzzle more or less dry, appetite slightly impaired, pulse quicirened, together with general fever.

Treatment.-The first thing is to determine the cause, which must be at onze removed. If the bowels are costive, 2 brisk purgative must be given-suel a 
one pound common salt mixed with one pound Epsom salts and half an ounce of ginger-the whole stirred in a quart of boiling water and given as a drench when cool-for sheep, about one-third of the above will suffice-for mares, about eight drachms of aloes with a drachm of ginger must be substituted for the salt, etc. After the purgative has done operating, diuretics in the shape of alt-petre, may be given night and morning, for about three days-dose, cattle, wo drachms; mare, one drachm; sheep, half a draclim, in say a pint of water.

The local treatment, which is of great importance, consists in fomenting the part thoroughly with warm water, for half an hour at a time, three times a day, drying and hand-rubbing; after which, the parts may be smeared with olive oil, or goose grease. Poultices of various descriptions are also advantageously applied to the part, and may bc made of spent hops, marsh-mallows, or some sucli substance, bearing in mind that the heat and moisturc must be kept up, for the poultice to be effectual.

The animal must be fed upon food which is not calculated to produce milk, auch as bran-mash, and the like. The milk must be frequently removed for a wcek or ten days. In serious cases, the nearest veterinarian should at onoe bo consulted, as individual cases differ so much.

\section{Treatment of Calves.}

The Calf's First Need. - Every new-born calf needs early cleansing by the licking of its dam. If this is neglected, it may be induced by sprinkling salt on the calf. If after the naval string is severed (which the cow does with her teeth) it should bleed, it must be tied with a strong thread. If there be inflammation at the navel a mollifying ointment may be used; if a tumor appear, it nay be lanced and poulticed (sce Poultices, p. 785). The mother's milk is the best nourishment for the young ealf. It also furnishes needed correction and regulation for the bowels and other organs.

Diarrhoea, etc.-Affections of this nature destroy many calves. Unsuitable food may induce it, or overheating of the dam. Two ounces of castor bil containing one teaspoonful of powdered ginger is a valuable corrective. It should be followed by gentian root tea mixed with two ounces of limewater, a pint being given'three or four times daily. Where this treatment and attention to the diet of mother and calf fail, resort may be had to strong teas of oak bark, or willow bark, with ginger added in either case. See also remedies under Diarrhœa in cattle, (p. 762).

Colic.-A form of colic, sometimes called the Shoote, is common among young calves, frequently affecting many in the herd. Isolation of the diseased animal is the first step in treatment. The disease shows itself in loss of appetite, listlessness, gripings, frequent watery discharges from the bowels, exhaustion and death. The pronipt administration of a mixture of eggs, flour and linsced oil is desirable. One $\mathrm{drachm}$ of essence of ginger and two drachm a laudanum, nixed in gruel, may be given at intervals until relieved. 
Croup.-Young calves if exposed to dampness, fogs, eto., are liable to in flammation of the upper portlon of the throat and the formation of a whitish cubstance or false membrane, on these parts. This disorder is shown by a hoarse cough, running at the nose, and in breathing by a whistling or croaking noise. All these symptoms increase as the disease progresses. Mild purges must be used at once; small quantities of saltpeter should be given in drinking water; and the vapor of slacking lime may be inbaled to relieve the throat of the false membrane.

Lung Worms. - This title designates the white, thread-ltke, parasitic worms, which are often found in the wind pipe, bronchial tubes and lungs of calves aud lambs. Low, marshy pasture lands, especlally in August and September, are conducive to this disease. The accumulation of these parasites is sometimes so great, as to choke the afflicted animal to death. A hoarse, husky, bronchial cough, loss of flesh and difficulty in breathing, are the more evident symptoms. Sometimes the worms may be seen in the saliva or mucus' which is coughed up; but where the disease is suspected, careful examination. for them should be made.

Separate the afflicted animals from the herd; place them in a warm, dry, stable; burn sulphur so that they shall inhale its fumes, which are destructive to the parasites. A half ounce of turpentine may be given daily in gruel Half a pint of lime-water with a teaspoonful of turpentine, given once a day, is very effective. Relief from the disease should be followed with a tonis wartment, giving twice a day a tablespoonful of the following mixture; 


\section{CHAPTER III.}

\section{INFECTIOUS, CONTAGIOUS AND FPIDEMTC DISEASRS.}

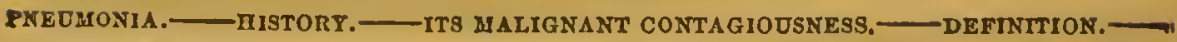
HOW THE INECTION ENTERS THE SYSTEM.- HOW LONG IS A DISEASBD AX IMAL INFECTIOUS.— HOW TO KNOW IT.—WHAT TO DO.-TEXAS FEVEF, —HOW TO KNOW IT.—BLOODT MURRAIN. -ITS MALIGNANT CBARACTER. - PREVENTIVES.—WHAT TO DO.—FOOT AND MOETH DISEASB.—CON. TAGIOUS PIEURA.—LICE ON CATTLE.—FOULS IN CATTLE.— MORN-AIL, OB HOLLOW HORN.- CHOKING.—-DLAREHCA, DYSRNTERY, BTC.-COW POX.

\section{Infectious, Cantagious and Epidemic Diseases.}

Ainong the most terrible of the diseases ever imported into the United States is pleuro pneumonia contagiosa known scientifically by a largo number of names, but now generally designated as Bovine Pneumonia Plague, and the Lung Plaguo in eattle; Texas Fever, known also as Spanish Fever and Texas Cattlo Disease, and seientifieally as Splenio F'ever ; Bloody Murrain, also known as "Black Quarter" (Quatran) and "Quarter Ail," is known among veterinarians by its French name Charbon, and also as Contagious Anthrax. Thus these will be all that it will be necessary to treat at considerablo length as among contagious diseases.

\section{Contagious Plouro-pneumonia.}

This disease which has lately exeited so much attention in the United States from its violent outbreak in the Atlantic States, and tho well grounded fear that for the lack of national legislation it might overrun the whule country, is the most malignant with which the farmers of the couatry have had to deal, Once fairly established in the West there 
will be no possible means of eradicating it. It will roman $\mathrm{a}$ fixture forever.

\section{Pustory:-}

This disease has been known in Europe and Asia from the remotest civilization, and has been treated since the first gathering together of cattle in large herds. Aristotle, evidently writing of this disease three hundred years before Christ, describes the symptoms accurately, inasmuch as he says: "The cattle which live in herds are subject to a malady during which the breathing becomes hot and frequent; the ears droop and they cannot eat. They dio rapidly, and the lungs are found spoiled." Greek and Roman writers also describe what appears to bo the same disease, and Valentine particularizes a futal lung plague which evidently correspouds to this malignant and terrible scourge.

\section{Its Malignant Contagiousness.}

Unfortunately veterinary science has never yet discovered a remedy. Its attack is so insidious, and often occupies so long a time in the stago of incubation, that a whole herd may be infected almost before it is known. As in the case of all German plagues, nothing is known of its origin; but just as soon as it is apparent that a caso is being well developed, the only safe plan is prompt killing, deep burying of the carcass, skin and all, and the frec use of quick-limo (a barrel to the carcass) before being covered up.

\section{Dofnition:}

This disease is defined as follows:

A specific contagious diseaso peculiar to cattlc, and manifested by a long period of incubation (ten days to three months) by a slow insidious onset, by a low type of fever, and by the occurrence of inflammation in the air-passages, lungs and their coverings, with an cxtensive cxudation into the lungs and pleurre.

That tho infection is carried by the animals whercver they go is certain. That it is carried in the air to a very considerably extent seems altogether probable. That it is calried by inoculation is well demonstrated; and also by contact of diseased portions of an animal with the membranes of a well ono, is as certain as that the contagion is carried by attendants on sick animals and is proved almost beyond controversy. That the contas gion will hold in stablos for months cren after being thoroughly cleancd and washed with disinfectant liquids, is proved just as clearly as that is 
may be carried by the many. That it may be taken in pastures and with fodder is too well authenticated to leave room for doubt.

\section{'Vitality of the Virus:}

There is much difference of opinion with regard to the power of the virus to resist ordinary destructive influences. In many eases the freo exposure of an infected place for three or four months to the action of the air has purified it so that fresh stock have been introduced with impunity. Oll the other hand, instances can be addueed in which eattle have been infected by being placed in stables in which eattle had not been kept at least four months previously. Other things being equal, it will be preserved longcst where it has been dried up and covered from the free aecess of the air. Thus in very dry and elose buildings, in those having rotten wood-work, or deep dust-filled eracks in the masonry, anl. in those with a closed spaoe beneath a wooden floor, it elings with tho greatest tcnacity. Again, when the buildings contain piles of lumber, litter, hay, fodder, or clothing, the virus is corcred up, secreted and preserved for a much longcr time than if left quite empty. In these last it is preserved just as it is in woolen or other textile fabrics, and carried from placo to place by human bcings.

As carried through the air, the distance at which tho virus retains its infecting properties varies much with varying conditions. The author has seen a sick herd separated from a healthy one by not more than fifteen yards and a modcratcly close board fencc of seven feet high, and in the abscincc of all intcr-communication of attendants, the exposed herd kept perfectly sound for six months in succession. On the other hand, infection will sometimes take place at a much greater distance without any known means of conveyance on solid objects. Roll quotes 150 to 100 feet, while others claim to have seen infection at a distance of $\mathbf{2 0 0}$ and 300 feet. But it may well be questioned whether in sueh ease the virus had not been dricd up on light objects, liko feathers, paper, straw, or hay, which could be borne on tho wind. This, from being in thicker layers, would eseape the destruction that would have befallen it had it been carried in the air only as invisiblo particles!

How the Infoction Enters the System.

The seat of the disease, its progress, and the result of all attempts at moculation, favor the prcsumption that the virus is usually taken in with the air breathed. Not only are the lesions concentrated in the lungs, but they begin with cloudiness and swelling of the smaller air-tubes and surrounding connective tissues. 
The exudation into the interlobular tissue, the congestion of the lung tissuc itself, and the implication of the lung covering, are secondary phenomena. In other words, the disease bcgius where the inspired air must lodge the germs. Thus the inoculation of the virulent lung products on distant parts of the body of a sound beast rarely determines the characteristic lesions in the lungs, in lieu of which it induces in the seat of inoculation an exudation less abundant, as might be expected from the greater density and resistance of the integument, but which can, like the morbid lung products, be inoculated on sound animals with protective effect. It seems probable that the poison is multiplied in both cases, but that the special loose and susceptible texture of the lung renders its production incomparably more abundant, as the continuous ingress and egress of air through the diseased organ renders it immeasurably moro infecting.

How Long a Diseased Animal is Infectious.

Proof is wanting as to the infectious nature of the disease during the incubative stage. If ncgative evidence wcre of any value in a case like this, it would be easy to adduce cases in which the removal of an animal as soon as it showed symptoms of the plague had apparently saved the rest of the herd. In other cases, the malady has been eradicated from a lierd by careful watching, and the prompt renoval of every animal as soon as sickness appeared. The period of greatest virulence is that at

- which the fever runs highest and when the lung is being loaded with the morbid exudation.

But it must not be inferred that with the subsidence of the fever the danger is removed. It is a matter of every day observation that animals which have passed through the fever, that are now thriving well, or giving a free supply of milk, and to ordinary observers would appear in perfect bealth, retain the power of transmitting the discase to others. This may co itinue for three, six, nine, twelve, or, according to some, even fiftecis months after all signs of acute illness have disuppeared. This is easily explained. The tendency of the disease is to interrupt the circulation in the most severely affected parts of the lungs; the exudation around this bccomes developed into a tough fibrous envelope, which closes off the dead mass from the adjacent lung and from all communication with the external air. The dead and imprisoned mass now undergoes a process of brcuking down, liquefaction, and absorption, conımencing at the surface, and slowly advancing towards the centre. The encysted portion of the dead lung is one mass of infecting material, and as it undergoes no change exccpt that of liquefaction, and exhales at no time any putrid odor, it romains infertious so long as it retains the solid form. At the outset moro than half a lung may be thus eneysted, and five or six months after allegad 
recovery we still find masses of from one to two pounds weight waiting for the slow proeess of solution. Whenever there are indieations of the existence of sueh encysted masses, the animal should be looked on as infeetious, and disposed of as summarily as if in the aeute stages of the disease. Mr. Law gives the following rules when the disease is suspeeted :

1. Remove all litter, manure, feed and fodder from the stables; scrape the walls and floor-wash them if neeessary; remove all rotten wood.

2. Take ehloride of lime one-half Ib., erude earbolie aeid, 4 ozs., and water, $1 \mathrm{gal}$; add freshly-burned quiek-lime till thiek enough to make a good whitewash; whitewash with this the walls, roof, floors, posts, man gers, drains and othor fixtures in the eow stables.

3. Wash so as to thoroughly eleanso all pails, buekets, stools, forks, shovels, brooms and other movable artieles used in tho buildings; then wet them all over with a solution of carbolie aeid 1-2 lb., water 1 gal.

4. When the empty building has been eleansed and disinfeeted as abore, elose the doors and windows, plaee in the eonter of the building a metallic dish holding $1 \mathrm{lb}$. flowers of sulphur; set firo to this and lot the cow-shed stand closed until filled with the fumes for at least two hours. The above should suffice for a elose stable eapable of holding twelvo cows. For larger, or very open buildings, more will be required.

5. The manuro from a stablo where sick cattle have boen kept, must be turned over and mixed with quicklime, two bushels to every load; then hauled by horses to ficlds to which no cattle have aecess, and at onee plowed under by horses.

6. Tho pits, where the manure has been, must be eleansed and washed with the disinfectant fluid ordered for the building.

7. The surviving herd should be shut up in a close building for half an hour, onee or twice a day, and made to broatho the fumes of burning sulphur. Closo doors and windows, place a pieee of paper on a elcan shovel, lay a few pinehes of flowers of sulphur upon it, and set it on fire; \&dding more sulphur, pineh by pineh, as long as the eattle ean stand it without coughing. Continue for a month.

8. Give two draehms powdered copperas (green vitriol) daily to each cow in moal or grains : or, divide $1 \mathrm{lb}$. copperas into 50 porrders, and give one daily to each adult animal.

9. Do not use for the surviving eattle any feed, fodder or litter that has been in the samo stables with the sick. They may safely be used for horses and sheep.

What to Do.

There is only ono remedy-entire isolation of the herd infectod. The prompt killing and slashing of the hides of diseased animals, deop burial, 
and covering the bodies with quick-lime. It may be stamped out only by the-fiee use of the poll-axe, and the thorough disinfection by the most severe means of the premises, utensils and attendants. It is ono of those cases where heroic treatment is of supreme value.

\section{How to Know It.}

The symptom most easily known in the early stage is an increased tem perature of the body. If a elinical thermometer be introduced into the rectum of a beast in an infected district, and an abnormal heat is ascertained, it is safe to suspect the disease; therefore send for a veterinarian at once. Next a slight cough will show itself; the hair will be erected along the back; there may be shivering and always tenderness of the back when pinehed; the breathing and pulse is accelerated; the bowels are enstive, rumination is irregular. The urine is scanty and high colered, the appetite fails, the milk-flow is diminished, the nose will be alter" nately moist and dry. The horns and other extremities will be alternately hot and cold. In the field, the siek animals will separate from the lierd. All the symptoms become more and more apparent until the animal remains in a fixed posture, the head rigidly extended, the mouth open, at every inspiration a moan, until at length the aximal succumbs, a loathBome and noxious muss of contagion.

\section{What to Do.}

A resort to remedies should not be had unless the animals are taken early in hand, and ean be isolated in a building far from any herd. It will not pay except in the case of thorough-bred or otherwise valuable stock. This is especially the ease in the West, if that section should be unfortunate enough to import the disease. Prof. Gamgee, who made an elaborate report for the Government in 1871 , strongly and wisely condemns purgatives and bleeding, but believes the disense may bo checked, if taken in time, by isolating the whole herd, and depending on active internal astringents. Ho advises daily doses of sulphate of iron, one-half to one drachm to the bullock, mixed with an equal weiglit of linseed and coriander seeds, given in bran to disguise it; this he has found to mitigate the cough, fuliowed by the disappearanee of the disease.

In the second stage of the disease, he advises light but nutritious food, sopious warm water injections, and the following stimulant:

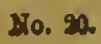


Mix, and give this dose two or three times a day. When only ono lung is involved, recovery occasionally takes place; when both are inrolved, there is little or no hope. For cough and debility during convalescence, he advises the following tonic:

No. 21.

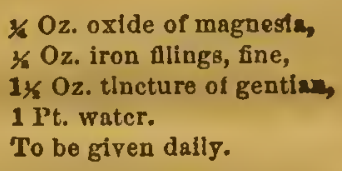

Another prescription is recommended-

No. 23.

1 Drachm carbolic acid, 1 Pint water.

To be given as a dose three times a day.

The reader will see, upon a careful study of the foregoing, that but one prescription-killing-is the only safe plan.

\section{Texas Fever.}

This disease, now called Splenic Fever, rescmbles in some of its phases the terrible Rinderpest of Asiatic Russia, but it is far less malignant and less contagious. It also disappears with the first frost, being effectually stamped out during the Winter, not to be again seen until again reintroduced by tho passage of Tcxas cattle. So again it is not given by our Northern cattle to other beasts.' The disease has its home on the coast of Texas, but how it originated is not clearly known. After death the splecn is found grcatly enlarged and softened, the kidneys broken, dung and the blood fluid.

\section{How to $\dot{\mathbf{K}}$ now It.}

The period of incubation extends over four or five weeks aftor the poicon has been introduced. The fever will at first be modcrate, the temperature as shown by a elinical thermometer, introduced into the reetum, will be 103 to 107 degrees. Then follows dullness, cough, trembling, jerking of the muscles, drooping of the head, arching of the back. The horns are hot, rumination ceases, and the appetite not good. The eyes become glassy and watery, the urine deep red or blaek from the blood oontained; the dung is hard and conted with blood; the mouth and rectum will be a dark red or copper color; and the animal dies in a stupor or convulsions.

Gamgee always found present in the examination of nearly 5,000 animals that the fourth stomach was distinctly inflamed and the spleon 
always enlarged and of a purplish eolor-on cutting tho pulp oozing out soft like currant jelly. Hcnco the name, "Splenic Fever."

\section{What to Do.}

Put the animal in a roomy stable with good rcntilation, and give soft food. As an internal remedy givo

No. 23.

3/. Oz. chlorate of potash,

1 Oz. tincture of chloride of iron,

1 Quart water.

Mlix and give as a dose to to be followed two or three times a day.

The most dangerous symptoms being passcd, give plentiful food and the following tonie.

No. 24

$$
\begin{aligned}
& \text { K Oz. sulphate of iron, } \\
& 1 \text { Oz. tincture of ginger, } \\
& 1 \text { Qt. watcr. } \\
& \text { This amount twice dally. }
\end{aligned}
$$

Professor Gamgee does not regard medieal treatment as being hopeful. In addition he advises that the limbs be well rubbed, and the bowels moved by injections. During the first two or three days he recommends ounce doses of laudanum, and later as a stimulant the foilowing:

$$
\begin{aligned}
& \text { No. 24. } \\
& 4 \text { Oz. suiphuric etber, } \\
&
\end{aligned}
$$

Giro in a quart of linseed tea three times a day.

\section{Bloody Murrain.}

Contagious Anthrax, known also.as charbon, black leg, black quarter, black tongue- is so ealled because the parts attacked turn blaek, owing to decomposition of the blood. It arises undoubtedly from eontagion, eating bad food, pasturing on swamp iands in summer, drinking stagnant water, etc. Whatever the poison, certain it is it has wonderful tenaeity of life; evcry part of the animal will carry it, eves the exeroment. Flies will carry it, a yoke worn by a diseased ox retains it. Even aleohol is said not be able to kill the poison. Fortunately it rarely oceur in its truly malignant form. There are many types of the diseaso attreking particular parts. In the tongue it is known as black tongue, or blain; in the throat as putrid sore throat. When it attacks the bowele it is called bloody murrain. 


\section{Its Nalignant Character.}

In this disease it must be remembered that in its malignant form it attaciss not only cattlc and horses, but all the herbivora, swine and birds. It is communicable to other and different animals by inoculation, showing itself in different forms, but all characterized by the breaking down of the blood globules, rupture of tissues and letting out blood and albuminous fluids, with gangrene, yellow or brown mucous membrane, enlargement and soinctimes rupture of the spleen, and a very high death rate. Immense numbers of human beings have died first and last from eating the flesh of diseased animals. This is especially the ease among the Tartars, who do not refrain from eating even the flesh of anthrax horses. As many as a thousand persons are recordod as having died in six weeks in San Domingo from eating the flesh of such diseascd animals. Mosquitoes, and otler biting insects are supposed to cause breaking out of the malignant pustule in man, from the fact of its always arising on exposed portions of the body. In relation to the various manifestations of the malignant anthrax Professor Law says :

"Malignant anthrax may be manifested by external disease, or swelling or without such appearances. To the first class belong the carbuncular, erysipelas, of shecp and swinc, malignant sore throat of hogs, glossanthrax or black tongue, black quarter or bloody murrain, the boilcd plaguc of Siberia, and the malignant pustule of man. To the second belong all those forms of disease in which there are the specific changes in blood, with engorgement of the splecn, blood-staining, and exudations into internal organs only.

\section{Preventives.}

Upon the first intimation of the disease the well animals of the herd should be removed to clean, now pasture, where there is pure water. Avoid all bleeding, purging, and lowering medicines. The animals must be kept up. So all local applications to the swellings seem useless. A seton, composed of a yard of broad coarse tape, inscrted in the dewiap turned every day and smeared with irritating ointment might provo beneficial. This slould remain in from four to six wecks.

Youatt and others advise the following:

No. 25.

2 to 4 Drachms ehloride of lime,

$1 \mathrm{Oz}$. prepared ehalk,

2 Drachms laudanum.

Mix and give in a pint of warm gruel every two or threc hours.

Recent French authors, in treating the malignaut form of the discaso, 
recommend quinine, one or two drachms, repeated every two or three bours in severo cases. Also hypodermic injections of a solution of iodino as follows:

No. 20.

\section{Grains lodine, 6 Grains todide of potsssium, $1 \mathrm{Oz}$. water.}

Use a syringeful every hour in severe eases. In extreme ones, it is advised that this be thrown direetly into the veins; also that the strength be kept up by stimulants; among thoso recommended most strongly is carbonate of ammonia.

\section{:Blain.}

When bloody murrain attacks the tongue it is called blain. In the easo of blain it is recommended to open the pustule freely from end to end, with a sharp laneet, before the poison has been absorbed. Treat the same surface freely with the following:

$$
\text { No, } 27 .
$$

20 Grains chloride of lime,

$10 z$. water.

Mop the parts freely.

Sulphurie or nitric acid, nitrate of mercury, lunar caustic, and other strong eaustics, are equally good. When it may bo sceomplished, burning with a hot iron is advised.

\section{Foot and Mouth Disease,}

One other contagious disease will be necessary to be treated of hero, as beginning to be of common occurrence, having prevailed more or less since its introduction into the United States in 1869. This is epizootio aptha, generally known as foot and mouth disease. Although a contagious febrile disease oceurring in cattle and sheop, and communicable by transa mission to swine and even man, it is fortunately rarely fatal, and is sharacterized in animals by an eruption of small blisters in the mouth, Lnd between the olefts of the hoofs, and along the upper margin of the soronet. It is a specifis poison of obseure origin, remaining in the system 'rom one to four days before producing its characteristic symptoms.

\section{How to Know It.}

There, is an increase of temperature in the body, followed by an erupion of small blisters, of the size of a dime, situatcd on the tongue, the of of the mouth, inside the lips, and occasionally on the udder. The 
blisters in the cleft of the hoofs and around the coronet and beels, are identical with the others, but smaller.

When the disease is mild, it is easily cured by daily applications of a portio of the following, applying by means of a swab or sponge

$2 \mathrm{Oz}$. powdered golden Beal, $1 \mathrm{Oz}$. tincture of matico, $4 \mathrm{Oz}$. honej.

When the disease is violent and of long standing, it is apt to extend througte the whole course of the alimentary canal. The method of eure, in this event, is by tonics and astringents. The remedies are tineture of matieo, golden seal, and sulphur, in the following proportions:

4 drachms tincture of matico, 2 drachms sulphur,
2 drachms powdered golden seal." 1 pint water.

The patient's dict should eonsist of oatmeal gruel, slightly alkalized with byposulphite of soda.

\section{Malignant Catarrh.}

Caused by feeding in damp, cold situatious, and feeding on marshes in peculiar seasons. Low, wet river bottoms are most subject to give it to stock. The disease somewhat resembles the Rnssian catthe plague, but is not usually contagious. Professor James Law gives symptoms and treatment as follows :

A slight diarrhoa may be followed by eostiveness, the dung being black, firm and scanty. The hair is rough and erect; shivering ensues; the head is depressed; the roots of the horus and forchead hot;

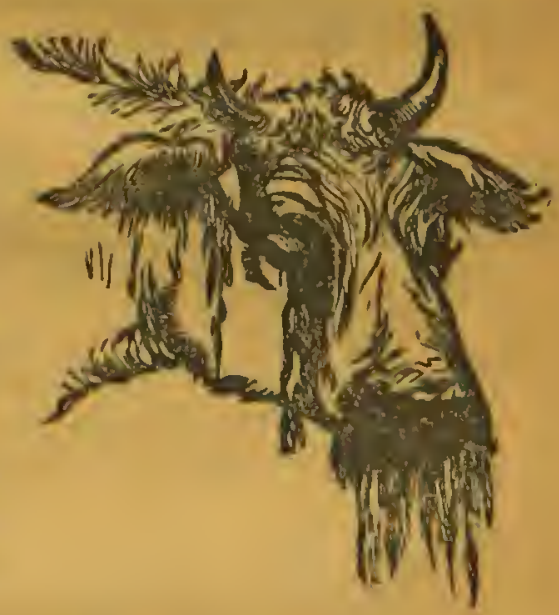

MALIGNANT OATARRT-SLOUGHIN! eyes sunken, red, watery, with turbidity in the interior and intoleranee of light; muzzle dry and hot; mouth hot with mueh saliva ; the membrancs, mouth, nose and vagina bluish-red; pulse rapid; impulse of the heart weak; breathing hurried; eough; urine seanty and high colored, and surfaee of the body alternately hot and cold. In twenty-four hours all the symtoms are aggravated; the nose disoharges a slimy fluid; forehead is warmer and duller on percussion; the mouth eovered with dark red blotches, from which the cuticle soon peels off, leaving raw sores; appetite is completely lost; dung and urine passed with mueh pain and straining, and there is generally stiffuess and indisposition to move. From the fourth to the sixth day ulcers appear oul the nose and muzzle, swellings take place beneath tho FWB $_{\mathrm{a}}$ chost and abdomen, and ou the legs the skin may wen slough off 
in patches; a foetid saliva drivels from the mouth and a stinking diarrhos succeeds the costiveness. Death usually ensucs from the eighth to tho tenth day, preceded perhaps by convulsions or signs of suffocation.

The treatment is to clean the bowels with the following:

$$
\begin{aligned}
& \text { 20. 28. - } 1 \text { Pint olive oll, } \\
& 1 \text { Oz. Iaudsnuma. }
\end{aligned}
$$

In eight or ten hours, if it do not operate, give another. Follow this with diuretics, sweet spirits of nitre in half-ounce doses, and also with antiseptics, potassa chlorate, in doses of one-quarter drachm. Wet cloths should be kept on the head; the mouth and nose sponged with quite a weal solution of earbolic acid. Give as food only soft mashes.

\section{Lice on Cattlo.}

All cattle, and especially those in poor condition, are liable to attacks of lice of various species, which will propagate very rapidly, soon infesting other stock and even the stables and barns themselves. Treatment must, thercfore, be dirccted promptly at the animals, and their surroundings also. Stables should be cleancd and whitewashed. Their scratching places should be coated with petroleum or coal tal.

For treatment of the cattle, poisonous substances must be shunied carcfully, as their liabit of licking themselves would result in their injury. One of the simplest preparatious is a strong solution of tobacco leaves saturated with rock salt. This may be applied thoroughly on several occasions at intervals of three ar four days. Repetition is necessary to the extirpation of the young, which may be liatched after the first application. If alcohol be used in the decoction of tobacco leaves it will destroy the nits as well as the lice, and prove the quickest relief from the pests.

$\Delta$ good preparation which will remain well upon the lide is this:

$$
\begin{aligned}
& \text { Linseed oil, } 1 \text { parts } \\
& \text { Common creosote, } 1 \text { part }
\end{aligned}
$$

An ointment of caycnne pepper, or Scotch snuff mixed with hog's lard, well rubbed in, will be found very effective. Especially look out for vermin in young stock, or stock in poor condition.

\section{Fouls in Cattle.}

Foul claw, or foul in the foot, is a disease characterized by inflamination and suppuration of the substance in the cleft of the loof. Sometimes it extends to the cntire foot, and even includes the whole leg, causing fever, failurc, and dcath in some cases. Usually it affects the hind feet. Forcign mbstances betwcen the claws, excessive weight and strain upon the foot, or a croinlous condition of the system nuay cause this troublc. Its best treatment consists of carcful cleansing of the sore; poultioing, if mucb inflamed, and 
astringent applications. In eleansing, a syringe may be needed, using a solution of carbolic acid. Cloths saturated with the solution sliould be pressed into the opening and bound there. A elean stable, or a dry pasture ground are essential. For a wash, use:

Carbolic acid, one drachm,

Water, six ounces

For an ointment, use:

Oil of turpentine, four ounces;

Lard, four ounces;

Powdered sulphiate of copper, one ouncer

Horn-Ail, or Hollow Horn.

What is popularly known by these names is not a disease originating in the horns or located there. A peeuliar coldness of the horns is one of its symptoms, but the cause of the discase is a degenerated condition of the blood, resulting from other diseases, or from exposure, foul air, unclean stables, poor food, bad water, etc. Uniformity of food may produce these ill conditions.

General debility, loss of flesh, rough, lousy hide, loose or constipated bowels, whiteness of tongue and cold horns are the usual symptoms.

All local treatment of the liorns is worthless. Good food, eleanly and comfortable housing and treatment for vermin if they be present are the first requisites. Cleansing the bowels and tonic treatment are then, in order

Use for one week daily in dry food, the following:

Sulphate of iron, two draclims;

Powdered nux vomica, one drschm,

Porrdered gentian, one ounce.

\section{Choking.}

For detailed directions for determining and treating this dangerous diffculty, see under Horses, pages $474-476$.

\section{Diarrhcea, Dysentery, etc.}

'I'he symptoms of these disorders are so fully understood as scarcely to need description. Reference may be made, however, to the full discussion covering both horses and eattle given in Chapter. VI., Diseases of Horses, pages 362-364. See Reeipes, No.67, 69, page 790, and "Astringents," pago 502

\section{Cow-Por.}

This disorder is akin to small-pox in man, though it is far less to bo dreaded. It sometimes appears without diseoverable eause, but inoculation or contact with the disease is regarded as essential to its propagation. It begins with slight fever; pimples then appear on the teats, udder and belly; the milk diminishes, the cow droops and its appetite fails. It is not uncommon for several crops of pustules to form, break, and dry up. The sick aninal ahould be isolated and subjected to a mild, sedative treatment, keeping the 
bowels free, but not loose. See "Cathartics," page 502; and "Sedatives," page 506. The teats may need washing with warm water or a healing lotion. Cow-pox is seldom nevere, and scarce ever fatal, but its inoculation may readily be taken by man in handling the sick corw. 


\section{CHAPTER IV:}

\section{MEDIOINES AND INSTRUMENTS-WHAT TO KEEP.}

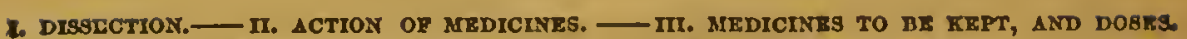
-IV. SIMPLE AND VALUABLE RICIPAS. - V. FOFMS OR CLYBTERS. - VI. INFUSIONS, VII. ANTI-BPASNODICS. - VUI. FOMIENTATIONS. - IX. MUCILAGIS.- X, WLSHES

-XI. POULTICES. - XIU, BUMIGATIONS. - XIU. TLLCTURR FOR WOUNDS,

\section{Dissection.}

In the disseetion of cattle the axe and meat şaw, and buteher's knifo must be largely depended on, in the hands of farmers, since all that is necessary is to get at the diseased parts to note their appearance and tho seat of the disease, the symptoms having becn previously carefully noted. This matter has been treated of in diseases of the horse, chapter XIX., article Dissection, to which the reader is referred. See page 509.

\section{Action of Medicines.}

The action of medicines, doses for horse, ox, sheep and swine is also treated of in chaptcr, XIX., of the horse, together with much other val uable matter applicable to animals generally. See pages 500-516.

\section{Medicines to be Kept, and Doses.}

It will not be necessary to kccp more than a small stock of the medicines in most common use, or such as may be required in an emergency. Those adapted to the horse, will, as a rule be aiso adapted to other stock. In chapter XIX. a pretty full list will be found, with the appropriato doses for cattle, shcep and swinc, as well as the horse; also the proper proportionate dose for animals of various ages up to the adult. It will not be necessary to repeat them hcre. See page 511 . 
For the purpose of enabling our readers to become familiar with the bony structure of cuttle we give an illustration of the skeleton of the ox with the correct names of the various parts as known in veterinary science. It will be found valuable for roference, not only to the student in veterinary art, but also to every ono who proposes to kcep and breed cattle.

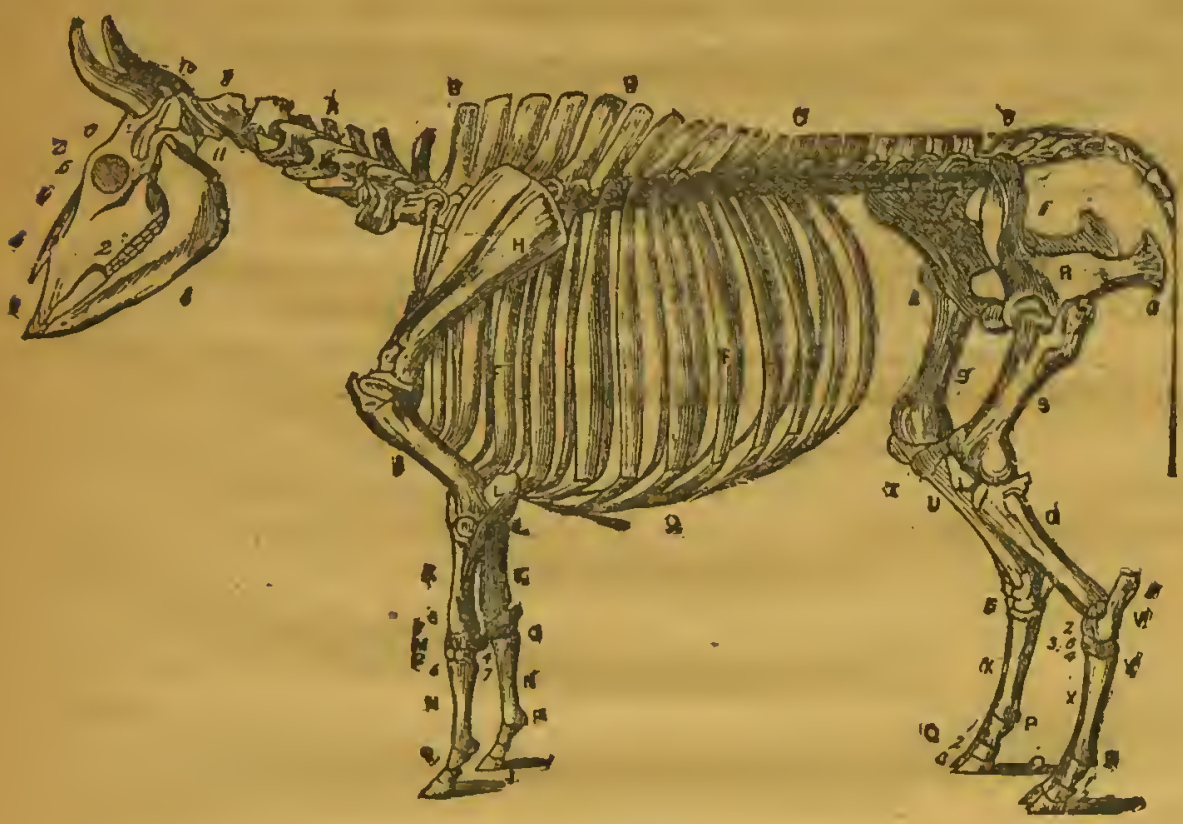

SKELETON OF THE OX.

Explanation of Cut.- $A$-Cervical Vertchrac. $B B-$ Dorsal Vertebrae. $C$-Lumbar Vertcbrae. $D$-Sacrum. $E E$-Concygeal Bones. $F^{\prime} F^{\prime}$ -Ribs. $G$-Costal Cartilages. $I I$-Scapula. $I_{- \text {-Humcrus. } I K-}$ Radius. $L$-Ulna. $M$-Carpus or Ińnce. 1-Scaphoid. 2-Semilunar. 3-Cuneiform. 4-Trapezium. 5-Trapezoid. 6-Os Magnum. 7Unceiform. 8-Pisiform. $N$-Large Mctacarpel or Cannon. $O-$ Small Metecarpel. P P-Scsamoid Boncs. Q Q-Phalarges. 1-Os Suffraginis or Pastern Bone. 2-Os Coronae. 3-Os Pcdis. $R$-Pelvis. 1-Illium. 2-Pubis. 3-Ischium. S-Femur. T-Patella. $U-$ Tibia. V-Fibula. W-Hocks. 1-Os Calcis. 2-Ostragulus. 3Cuneiform Magnum. 4-Cuneiform Median. 5-Cunciform Parvum. 6-Cuboid. $X$-Large Metatarsal.' 1, 2, 3-Phalanges. $Y$-Small Metatarsal. Z-Head. 1-Inferior Maxilla. 2-Superior Maxilla. 3Anterior Maxilla. 4-Nasal Bonc. 5-Molar. 6-Frontal. 7-Parietal. 8-Occipital. 9-Láchrymal. 10-Squamous. 11-Petrous. 
In comparing the skeleton of the ox with that of tho horse, wo can readily perceive the difference in the length of the limb and neck possessed by the latter. Speed scems to have been an object at the ereation, and as the body was elevated the neek needed proportionate length in order to feed. The body of the horse corresponds to a square, whilo that of the ox to a long rectangle. The limbs of the ox are straighter than those of the horse, much less speed being demanded. The ribs of the former are botly longer and larger than those of the latter, greater protection with sluggardness of movement being required. In the head of the ox we find the two plates or tables noticed in the horse; in the latter, however, they lie elose together, while in the former, as in all horned animals, there is considerable space between them. This diversity ereates a number of eells, having bony ridges passing from the inner to the outer plate, which secures the firmness of the parts. These cells form roomy and strong sockets for the horus. The cavity containing the brain of the ox is about one-fourth the size of the other parts of the sliull; the organs of mastication and those of smell taking up the remaining portions. In, cattle the frontal bonos extend from the nose to the superior ridge of tho skull, presenting a flat, irregular surface, totally bare of any muscular or fleshy covering. The weapon of defense and offense empioycd by cattle is the horn and nature has securely based it and rendered it effectivo by this expanse of the frontal bone. 'There is the same division in the center of the frontal sinuses as in tho horse, but the perfection of division between the nostrils is wanting. Commeneing about half way up the nose, tho septum is wanting at the lower part, and the two nostrils are, as it were, thrown into one; the frontal sinuses conneet with tho nasal, thus forming a continuous cavity from the muzzle to the horn, and fiom one inuzzlo to the other. In polled cattle the frontal bone holds the same situstion-reaching from the nasal bones to the parietal ridge-but as they were not designed for the base of horns, they narrow off towards the poll. The temporal bones in eattle are small, deep in the temporal fossa and destitute of the squamons structure. The occipital bone is, in the ox, deprired of almost all the importance attached to it in the eonformation of the horse. Tho sphemoid and ithmoid bones aro in tho sume relative position.

\section{Simple and Valuable Medical Recipes for Cattlo.}

Dr. G. H. Dadd, M.D., V.S., a medical practitioner - of repute, and celebrated as a veterinary surgeon, up to the time of his death, some fifteen years ago, attributed much of his success to not being bound by any rigid rules of practice. Thus he, while having been bred under the Allopathic system of medieino, used largely of hotanical agents, as in 
faet do all our best physicians now, more largely than formerly. In the appendix to his work on the diseases of euttlo ho gives a serios of reeipes under appropriate headings, whieh wo reproduee in a somewhat different and condensed form, as being at the same time simple and efferoious. In his observations on the aetion of medieine, and external agents on the snimal body, he says, that warmth and moisture always expand it, and bayberxy bark, tannin, and gun eateehu always contraet it; and that these agents have these effeets at all times (provided, however, there be ouffieient vitality in the part to manifest these peculiar ehanges) and under all eireumstanees. If a blister be applied to the external surface of an animal, and it produees irritation, it always has a tendency to produeo that effeet, whatever part of the living organism it may be applied to. So aleohol alvarys has a tendeney to stimulate, whether given by the mouth or rubbed on the external surface, it will produce an exeitement of nerves, heart and arteries, and of eourse the museles partake of the influenee. Again, marsh mallows, gum acaeia, slippery elm, ete., always lubricate the mucous surfaees, quiet irritation, and relieve inflammatory symptoms.

It follows, of course, 1st. That when any other effeets than those just mamed are seen to follow the administration of these articles, they must be attributed to the morbid state of the parts to which they are applied; 2d. That a medieine whieh is good to promote a given effeet in ono form of disease, will be equally good for the same purpose in another form of disease in the same tissue. Thus, if an infusion of mallows is good for inflammation of the stomach, and will lubricate the surfaee, and allay irritation in that organ, then it is equally good for the same purpose in inflammation of the bowels and bladder. What we wish tho reader to understand is this: that a medieine used for any particular symptom in one form of disease, if it be a sanative agent, is equally good for the same symptom in every form.

The medieines we reeommend owe their diuretie, astringent, diaphoretio and eathartic power's to their aromatie, relaxing, antispasmodie, lubrieating and irritating properties; and if we give them with a view of produeing a eertain result, and they do not aet just as we wish, it is no proof that they have not done good. 'The faet is, all our medieines act on the parts where nature is making the greatest efforts to restore equilibrium; henee they relieve the constitution, whatever may be the nature of their results.

\section{v. Forms of Clysters.}

Laxative elyster :

No. 29.
$B$ or 1 Quarts warm water, 8 Ounces linseed oil, 1 Table-8poonful common salt (fineh. 
Another:

No. 30 .

1 Quarts warm water,

1 Giil soft soap,

3. Table-spoonful fine salt.

Useful in obstinate constipation, "stoppagc," or whenever the excrement is hard and dark colored.

Emollient clyster :

No. 31.
2 Quaces slippery elm bark,

Simmer over the fire a fow minutes, strain through a fine siove, and inject, when nearly cool. The following articles may be substituted for elm : flaxsced, lily roots, gum arabic, poplar bark, Iccland moss.

Use.-In all cases of irritation and iutammation of the intestines and bladder.

Stimulating clyster :

No, 32.

8 Quarts of thin mucilage of sllppery elm or linseed ten,

1 Teaspoonful Africau cayenne, pure.

Another :

No. 33. 3 Table-spoonful powdered glnger, 3 Quarts bolling water.

When cool, inject.

Use.-In all cases when the rectum and small intestines are inactire and loadcd with excrement, or gas.

Anodyne clyster :

No. 34.

1 Ounce lady's sllpper (cypripedium),

1 Ounce enmomile flowers,

3 Quarts bolling water.

Let the mixture stand a short timc, then strain through a fine sioro when it will bo fit for use.

Use.-To relicve pain and relax spisms.

Diuretic clyster:

พิ้. $3 \bar{x}$

8 Quarts linseed tea,

1 Tabie-spoonful oll of juniper.

Or, substitute for thc latter, cream of tartar, half an ounce.

Use. - This form of clystcr may be uscd with decided advantage in all acutc discascs of the urinary organs. This injection is useful in cases of red water, both in cattle and shecp; and when the malady is supposed to 
result from general or loeal debility, the addition of tonics (golden seal or gentian) will be indieated. Their aetive properties may be extructed by iufusion.

Astringent elyster :

Take an infusion of hardhaek, struin, and add a table-spoonful of finely-pulverized eharcoal to every three quarts of tiuid.

Another is an infusion of witch hazel.

Another :

No. 30 .

1 Table-spoonful powdered basberry bark,

8 Quurts boillng water.

When eool, it is fit for use.

Use.-Astringent injeetions are used in all eases where it is desired to contrat the living fibre, as in seouring, dysentery, seouring rot, diarrhea, bloody flux, falling of the womb, fundament, ete.

Nourishing clystcrs :

Nourishing elysters are composed of thin gruel made from flour, etc.

Injection for worms:

Make an infusion of pomegranate (rind of the fruit), and injeet every night for a few days. This will rid the animal of worns that infest tho reetum: but if the animal is infested with the long, round worm (teres), then half a pint of the above iufusion must be given for a few mornings. before feeding.

Another for worm :

No. 37.

1 Ounee porrdered lobelis,

1 Handrul wood ashes,

3 Quarts boillng water.

When cool, it is fit for use.

\section{Infusiọns.}

These are made by steeping herbs, roots, and other medical substances in boiling water. No partieular rules ean be laid down as to the quantity of each artiele rcquired. It will, however, serve as some sort of a guide, that we generally use from one to two ounces of the aromatie herbs and roots to every quart of fluid. A bitter infusion sueh as wormwood or camomile requires less of the herb. All kinds of infusions ean be rendered palatable by the addition of a small quantity of honey or molasses. As a general rule, the human palate is a good eriterion; for if an infusion be too strong or unpalatable for a man, it is unfit for eattle or sheep.

Au infusion of either of the following artieles is valuable in eolie, both fatuleat and spasmodie, in all elasses of animals: earaway, peppermint. 
spearmint, fennel seed, angeliea, bergamot, snake root, anise seed, giuseng, cte.

\section{Anti-spasmodics.}

By anti-spasmodics are meant those articles that assist, through their physiologieal action in relaxing the nervous and muscular systems.

\section{Fomentations.}

This elass of remedies is usually eomposed of relaxants, etc., of several kinds, eombined with tonies, stimulants, and anodynes. They are very useful to relieve pain, to remove rigidity, to restore tone, and to stimulate the parts to whieh they are applied.

Common fomcntation:

No. 33.

$$
\begin{aligned}
& 1 \text { Part wormwood, } \\
& 1 \text { Part tansy, } \\
& 1 \text { Part lops. }
\end{aligned}
$$

Moisten then with equal parts of boiling water and vinegar, and apply when blood warm.

Use.-For all kinds of bruises and sprains. They should be confined to the injured parts, and kept moist with the superabundant fluid. Where it is not practicable to eonfine a fomentation to the injured parts, as in shoulder or hip laneness, eonstant bathing with the decoction will apswer the same purpose.

Arodyne fomentation:

$$
\text { No. } 39 .
$$

1 Handful of hops,

1 Ounce white poppy beads,

Equal parts water and viuegan.

Simmer a fer minutes.

Use.-In all painful bruises.

Relaxing fomentation:

No. 40. 2 Ounces powdered lobelis, 2 Quarts boiling water.

Sinmer for a fer minutes, and when sufficiently cool, bathe the part with a soft sponge.

$U_{s e}$. In all eases of stiff joints, and rigidity of the muscles.

Cedar buds, or boughs, any quantity, to which add a small quantity of red pepper and ginger, with boiling water sufficient. 
Use.-Efficacious in chronic lameness and paralysis, for i, ucid soro throat, and when the glunds are enlarged from cold and caturrh.

\section{Murcilages.}

Mucilages are soft, bland substances, madc by dissolving gum arabio in hot water; or by boiling marsh mallows, slippery elin, or lily roots, until their mucilaginous properties arc extracted. A trble-spoonful of either of the above articles, when powdered, will generally suffice for a quart of water.

Use.-In all cases of catarrh, diarrhoea, inflammation of the kidneys, womb, bladder, and intestines. They shield the mucous membranes, and defend them from the action of poisons and drastic cathartics.

\section{Z. Washes.}

Washes generally contain some medical agent, and are principally used externally.

Wash for diseases of the fect:

No. 41. 4 Ounces pyrollg'enous aeid, 8 Ounces water.

Use-This wash excels any other in point of efficacy, and removes rot and its kindred diseases sooner than any other.

Cooling wash for the eye:

No. 42.

1 Pint rain water, 20 Drops a eetic seed.

Use.-In ophthalmia.

Touic and anti-spasmodic wash:

No. 43.

Y. Ounce eamomile torrers, 1 Plat bolling water.

When cool, strain through fine linen.

Use.-In chronic discases of the eye, and when a weeping remains after an acute attack.

Wash for unhealthy or ulcerated sores:

A weak solution of soda or wood ashes.

Wash for diseases of the skin :

Take one ounce of finely-pulverized charcoal, pour on it one ounce of pyroligenous acid, then add a pint of wator. Bottle, and keep it well corked. It may be applied to the skin by meass of a spongo. It is also an excellent remedy for ill-conditioned ulcers. 
Physie for cattle:

$$
\begin{aligned}
& \text { No. 44. } \\
& \text { 1/ Or nce extract of butternut (juglans ciacreo), } \\
& \text { y Quarts bolling water. }
\end{aligned}
$$

Mix. When cool, administer.

\section{Another:}

$$
\begin{aligned}
& \text { No. 45. } \quad \text { \% Ounce eztract of blackroot (leptazdra Furgialca), } \\
& 1 \text { Ounce Rocbelle saits, } \\
& \text { 4. Tea-spoonful powlered ginger. }
\end{aligned}
$$

Dissolve in two quarts of warm water.

Another :

$$
\begin{aligned}
& \text { No. 46. } 1 \text { Tsble-spoonful powdered mandralse, } \\
& 1 \text { Tea-spoonful cream of tartar } \\
& 2 \text { Quarts Lot water. }
\end{aligned}
$$

Here are three different forms of physie for cattle, which do not dobilitate the system, like aloes and salts, beause they determine to the surface as well as the bowels. Thoy may be given in au cases where purges are necessary. One-third of the above forms will sumce tor nnoop.

Milu physic for eattlo:

No. 47.

Aperient :

No. 48

Mix.

Another:

No. 49

Mix.

A sheep will require about one-half of the abovo. Etimulating tincture :

No. Bo.

1 PInt boillng vinegar, 2 Ounces tincture of myrrh, 2 Tcaspooufule powiered capslcum.

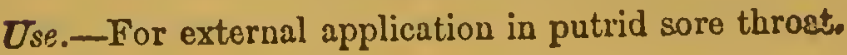

2 Ounces syrup of buckthorn, $\hbar$ Table-spoonful sulphur,

2 Quarts hot water.

1 Pint linsecd oil, Yoixs of 2 cggu.

1 Pint swect oil, 3. Tea-spoonful powäerea cayenno. y. Tea-spoourul ginger, 
No. 61.

4 Ounces tineture of camphor, 3. Ounce oil of cedar, 4 Ounces tincture of eapsicum (hot drope),

To be rubbed around throat night and morning.

Stimulating tincture for ehronie rheumatism :

N̦o. 52.

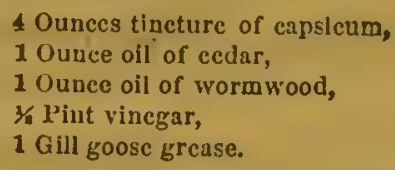

Mix. To be applied night and morning. The mixture should be kent in a well corked bottle, and shaken before being used.

\section{Poultices.}

If a foreign substance enters the flesh the formation of matter is a part of the process by which nature rids the system of the eneny. A poultice relaxing and lubricating will then he indicated. If, however, the foreign body shall have entered at a point where it is impossible to confine a poultiee, then the suppurative stage may be shortened by the application of relaxing fomentations, and lastly by stimulants.

Mr. Cobbett says of marsh mallow plant: If i: among the most valua. ble that ever grew. Its leaves stewed, and applied wet, will eure, and almost instantly ease, any eut, or bruise, or wound of any sort. Poultices mide of it will eure sprains; fomenting with it will renove swellings : applications made of it will cure ehafes made by saddle and harness; and its operation, in all eases, is so quiek that it is hardly to be belicved Those who have this weed at hand need not put themselves to the trouble and expense of sending to doetors and farriers on tritling oceasions.

If the use of this weed was generally adopted the art and mystery of healing wounds, and of euring sprains, swellings, and other external maladies, would very quickly be reduced to an unprofitable trade.

Lubrieating and healing poultiees:

No. 63. 1 Part powdered mareh mallow roots, 1 Purt marsh mallow leaves.

Moisten with boiling water, and apply.

Use.--In ragged cuts, wounds and bruisos.

Stimulating poultice:

No. 04.

1 Part Indian meal, 1 Part slippery elm.

Mix them together, and add sufficient boiling water to mosten the 
mass. Spread it on a eloth, and sprinkle a small quantity of powdercd cayenne on its surface.

Use.-To stimulato ill-conditioned ulcers to healthy action. Whero there is danger of putrescence add a small quantity of powdered charcoal.

f'oultice for bruises :

Nothing makes so good a poultice for recent bruises as boiled carrots or marsh mallows.

Poultice to promote suppuration:

No. 53

A sufficlent quantity of Indisn meal,

1 IIandful of IInseed,

1 'easpoonful of cayenne.

To be moistened with vinegar and applied at the usual temperature.

Styptics to arrest bleeding :

Witch hazel, (Winter bloom,) bark or leaves, 2 ounees.

Make a decoction with the smallest possible quantity of water, and if the blecding is from the nose, throw it up by means of a syringe; if froin the stoniach, lungs, or bowels, add more water, and let the animal drink it, and give some by injection.

Styptic to arrest external bleeding:

Wet a pices of lint with tincture of muriate of iron, and bind it on tho part.

Thero aro various other styptics, such as alum water, strong tineturo of nutgalls, bloodroot, common salt, fino flour, etc.

Absorbents : (for Hoven, etc.)

Absorbents are composed of materials partaking of an alkaline character, and are used for the purpose of neutralizing acid mattor. The formation of an acid in the stomach arises from some derangement of the digestive organs, sometimes brought on by the improper quantity or quality of the food. It is uscless, therefore, to give absorbents, with a view of neutralizing acid, unless the former are combined with tonics, or agents that are capable of restoring the stomach to a healthy statc.

A mixture of chalk, salarntus, and soda is often given by farmers; yet they do not afford pormanent relief. They do somo good by correcting the acidity of the stomach, but the animals are often affected with diarrhen or costiveness, loss of appetite, colic, and convulsions. Attention to the diet would probably do more good than all the medieino in the world. Yet, if they do get sick, something must bo dono. The best forms of absorbents are the following which have been very carefully selected. They restore healthy action to the lost function, at the same time that they peutralize the gas:

Forms of absorbents: 
No. 62.

1 Table-spoonful powdered charcoal, 3. Table-apoonful powdered snakeroot, 1 Tea-spoonful powdered caraways, 1 Quart hot water.

Mix. To be given at one dose for a cow; half the quantity, or indeed one-third, is sufficient for a calf, sheep or pig.

Another :

No. 67. 1 Table-spoonful powdered charcoal.

To be given in thoroughwort tea, to which may be added a vory small portion of vinegar.

Another, adapted to city uso:

No. 68.

1 Tea-spoonful sub-carbonate of soda,

1 Ounce tincture of gentian,

1 Pint infusion of spearmint.

Mix. Give a cow the whole at a dose, and repeat daily, ror a short time, if necessary. One-half the quantity will suffice for a smaller animal.

Drink for coughs :

No. 59.

$$
\begin{aligned}
& \text { 3. Ounce balm of Gilead buds, } \\
& 2 \text { Table-spoonfuls honey, } \\
& 1 \text { Wine-glassful vinegar, } \\
& 1 \text { Pint water. }
\end{aligned}
$$

Set the mixture on the fire, in an earthen vessel; let it simmer a few minutes. When cool, strain, and it is fit for use. Dose, a wine-glassful twice a day.

Another:

No. 6 .

$$
\begin{aligned}
& 1 \text { Ouace balsama copaibs, } \\
& 1 \text { Ouace powdered licorice, } \\
& 2 \text { Table-8poonfuls boney, } \\
& 1 \text { Quart bolling water. }
\end{aligned}
$$

Rub the copaiba, licorice and honey together in a mortar; after they are well mixed, add the water. Dose, half a pint, night and morning.

Anothe:

No. 61.

$$
\begin{aligned}
& \text { 3. Ounce balsam of Tolu, } \\
& 1 \text { Ounce powdered marshmallow roota, } \\
& \text { 3/ Gill boney, } \\
& 2 \text { Quarts boiling water: }
\end{aligned}
$$

Mix. Dose, balf a pint, night and morning. 
Drink for a cow after calving:

No. 62

1 Ounce bethwort,

1 Ounce marabmallow.

First make an infusion of bethwort by simmering it in a quart of water. When cool, atrain, and stir in the mallows. Dose, half a pint, evcry two hours.

Diuretic :

Bearberry (uva ursi), is a popular diuretic, and is usoful when combined with marshmallows. When the urine is thick and deticient in quantity, or voided with difficulty, it may be given in tho following form:

No. 63.

1 Ounce powdered bearberry,

2 Ounces powdered marshmallows,

2 Pounds Indian meal.

Mix. Dose, half a pound daily, in the cow's feed.

Eruption wash :

Borax is a valuable remcdy for eruptive diseases of the tongre ana mouth. Powdercd and dissolved in water, it forms an astringent, ant: septic wash. The usual form is:

T̄o. 6 .

3. Ounce powdered borax,

2 Ounces holley.

Mix.

\section{Fumigations,}

For foul barns and stables, take,

No. 65.

4 Ounces common salt,

1\% Dunce manganese.

Let these be well mixed, and placed in shallow earthern vessel; then pour on the mixture, gradually, sulphurio acid, four ounces. 'The inhalation of the gas which arises from this mixture is highly injurious; thercfore, as soon as the acid is pourcd on, all persons should lcave the building, which should inmediately be shut, and not opened agnin for several hours. Dr. Whitc, V.S., says, "Then glanderous or infectious matter is exposed to it a short time, it is rendered perfectly harmlcss."

Uleeration of the mouth:

A strong infusion of goldthrend (coptis trifolia), makes a valuablo. application for eruptions and ulcerations of the wouth. We use is is the following form: 
No. 68.

1 Ounce goldthread,

1 Pint bolling water.

Set the mixture aside to cool ; then strain, and add a table-spoonful of boney, and bathe the parts twice a day.

Astringent :

Kino is a powerful astringent, and may be used in diarrhea, dysentery, and red water, after the inflammatory symptoms have subsided. We occisionally use it in the following form for red water aud chronic dysentery:

$$
\begin{aligned}
& 20 \text { Grains powdered klno, } \\
& \text { I Quart thin four gruel. }
\end{aligned}
$$

To be given at a dose, and repeated nighc and morning, as occasios requires.

Simple cough remedy:

The following makes an excellent cough remedy:

No. 68.

$$
\begin{aligned}
& 1 \text { Ounce powdered licorice, } \\
& 1 \text { Tea-spoonful balsam of Tolu, } \\
& 1 \text { Quart boiling water. }
\end{aligned}
$$

To bo given at a dose:

Antacid for hoven:

Lime water is used in diarrhœa, and when the discharge of urine is excessive. Being an antacid, it is very usefully employed when cattio are hoven or blown. It is unsufe to adninister alone, as it often doranges the digestive organs; it is therefore very propcrly combined with tonics. The following will serve as an example:

No. 69. 2 Ounces limo water, 2 Quarts infusion of snakehead (baimony),

Dose, a quart, night and moruing.

\section{Tincture for Wounde.}

Myrrh makes án excellent tincture for wounds, prepared as follows :

No. 70.

$$
\begin{aligned}
& 2 \text { Ounces powdered myrrh, } \\
& 1 \text { PInt proof spirlts. }
\end{aligned}
$$

Set in a close covered vessel for two wceks, then strain through a fine coive, and bottle for use. It should be always kept on hand.

Opodeldoc:

Used for strains and bruises, after the inflammatory action has somen what subsided. 
Liquid opodcldoc:

No. 71 .

6 Ounces soft soap,

13. Plnts New Eugland rum,

1/3 Pint vinegar,

2 Ounces oil of lavender.

The oil of lavender should first be dissolved in an equal quantity of alcohol, and then added to the mixture.

Mucilages for eatarrh, ete. :

We have given pleurisy root, (asclepias tuberosa), a fair trial in eattlo practice, and find it to be invaluable in the treatment of catarrh, bronchitis pleurisy, pneumonia and consumption. Take :

No. 72. 3/2 Table-spoonful powdered pleurisy root,

1 Ounce powdered narshmallow roots.

Boiling water suffieient to make a thin mueilage. The addition of small quantity of honey increases its diaphoretie properties.

For eruptivo diseases:

The bark of sassafras root is stimulant, and possesses alterativo properties. Used in eomnection with sulphur, for eruptive diseases, and for measles in swine, in the following proportions, it will be found valuables

No. 73 .

1 Ounce powdered sassafras,

1-2 Table-spoonful powdered sulphur.

Mix, and divide into four parts, one of which may be given night and morning, in a hot mash. 


$$
:
$$

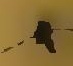




\section{SHREP AND SHEEP HUSBANDRY.}

ORIGIN, BREEDS, CHARACTERISTICS

AND MANAGEMENT. 



\title{
SHEEP AND SHEEP HUSBANDRY.
}

\author{
CHAPTER I. \\ ORIGIN, PRINCTPAL BRETDS AND CHARACTERISTICB.
}

COSMOPOLITAN NATURE OF SHEEP.—LONGTOOLED SHEEP.—-I. LEICESTER, II. BORDER LEICESTER. - III. COTSWOLD.-GOOD QUALITIES OF COTSWOLDS. -COTSWOLDS IN THE WFST.—IV. LINCOLN SHEEP.—V. NEW OXFORDSHIRE - SHELP. - VI. MIDDLE.WOOLED SHEEP. — VII. CHEVIOT SHEEP. — VII. WHITE-FACED IIGHLAND SHEEP.- - $X$. DORSET SHEEP. - $X$. SOUTHDOWNS. - X1. HAMPSHTRE DOWNS. - XI. SHROPSHIRE DOWNS. - XII. OXFORD DOWNS. - FINE WOOLED SIEEP. - XIV. AMERICAN MERINOS. - THE FLEECE.—TIE UEAD.—THE BODT.—THE MOST PRONITABLE SHEEP.— DIVISIONS OF WOOL.

\section{Cosmopolitan Nature of Shoep.}

Where sheep originated is a question difficult to answer. They are the frst of the animals domesticated by man, and reasonably so, since they supply the two principal wants of the barbarian, food and clothing. They are found in every inhabited country, not entirely savage, from the Arctic to the Torrid zone.

To show the great diversity in character of sheep, it is only necessary to quote the classification of Linnæus, which is: The Hornless, Horned, Black-faced, Spanish, Many-horned, African, Guinea, Broad-tailed, Fatrumped, Bucharian, Long-tailed, Cap-bearded, and Borant. To theso may bo added tho Siberian sheep of Asia, found also in Corsica and 
Barbary and the Cretan sheep of the Greciun Islands, Hungary, and come portions of Austria, and we have about all the prineipal species.

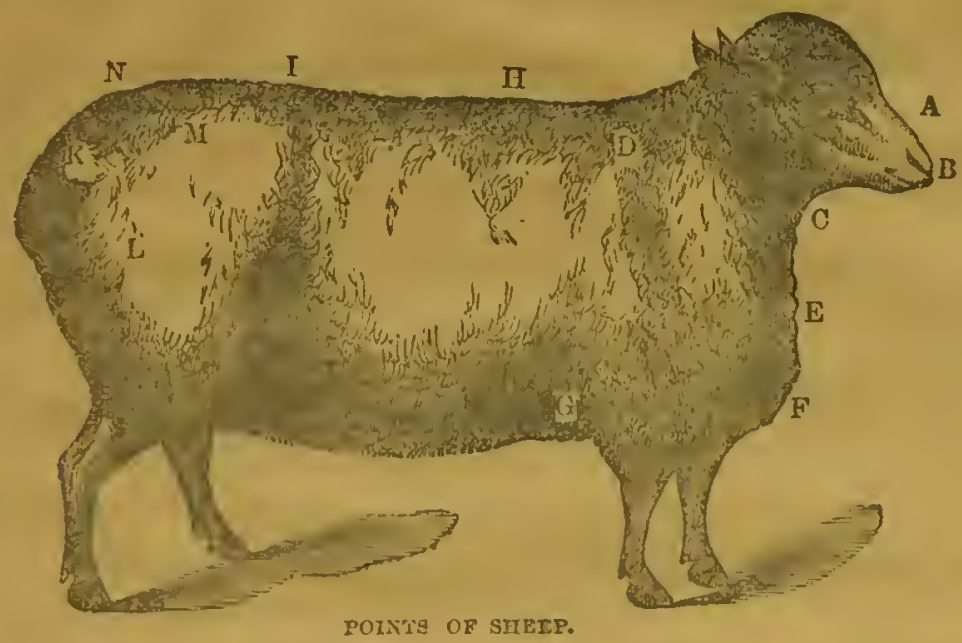

Explanation-A-Free. B-Nuzzle. $C-N c c k$. D-Shoulder. E-Poix of the Slioulder. F-Breast. $G$-Girth-place. H-Burk. I-Loin. IRuinp. L-Tbigh. $M L-$ Hip. N-Root of tail.

Notwithstanding the fact that sheep aro among the principal sourees of wealth of all peoples, it is unly among enlightened nations that they havo reached their highest development; and among these, Spain, France, Germany, Great Britain and her colonies, and the United States may bo mentioned as those where systematic breeding lave proluced the most practical results. In no country las this been attained in the production of fine wool, to a more execllent degres than among what are now known as Amcriem merinces, the result of scientific breeding of the Spanish sheep. Irrem prescnt appearances, it will he but a few years before wo shall execl in the production of long-wooled, and mutton slieep. The United States has of course, no native sheep, if wo exeept the Ovis Montana, which really is a sheep and not a goat (Capra) as many per. cons suppose. It inhabits the highest ranges of the Rocky Mountains from well north down to New Mexico. The hair, for it is not wool, although it is crimped, resembles the hair of the elk-is coarse, but soft to the touch, and slightly crimped throughout its length; about two inches long on its baek, and on the sides onc and a half inches. We belicve they have never been bred in contipement. In passing it may be interesting to our readers to know that at the Paris Exhibition of 1865 there were exbibited the wild sheep of Barbary, Ovis Tragelapus, moro resembling 
a reat than our wild species. There were also shown there the runjaub wild sheen, Ovis Cycloceras, a native of Northern India, and the European moufllon, Oris MTusinan. belonging to Corsica and Sardinia, but

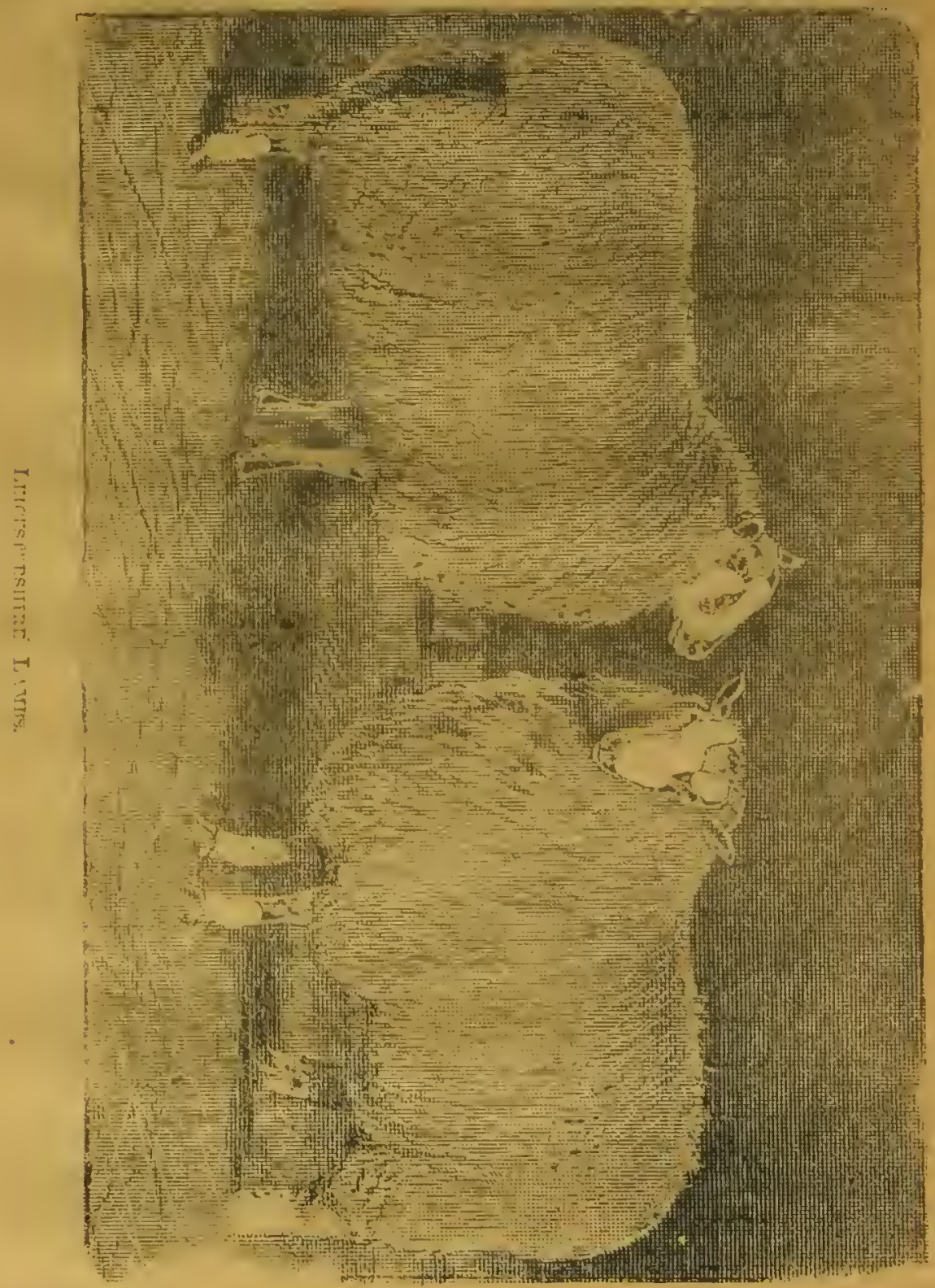

hoth bred in confinement. As illustranng sonsctiing of the characteristica of the wild sheop, as well as to illustrate points the cut we give on preceding page may serve as an example. 


\section{Long-wooled Sheep.}

There are but a few kinds of long-wooled sheep that have held their own in the improvement of the race for the last 100 years, sufficiently to bo widely disseminated in the United States. These are the Lcicester, Cotswold, Lineoln and Romney Marsh. Of these, Leieestor, as improved by Bakowell and succeeding breeders, has perhaps exereised a more potent jeffeet in erossing than any other of the long-wooled varieties. They fatten very kindly, and the best wethers will weigh at twelve to fifteen months old from 20 to 25 pounds per quarter, and at two years old from 30 to 38 pounds per quarter. The fleces are valuable as long eombing wool, and will weigh from 7 to 8 pounds each.

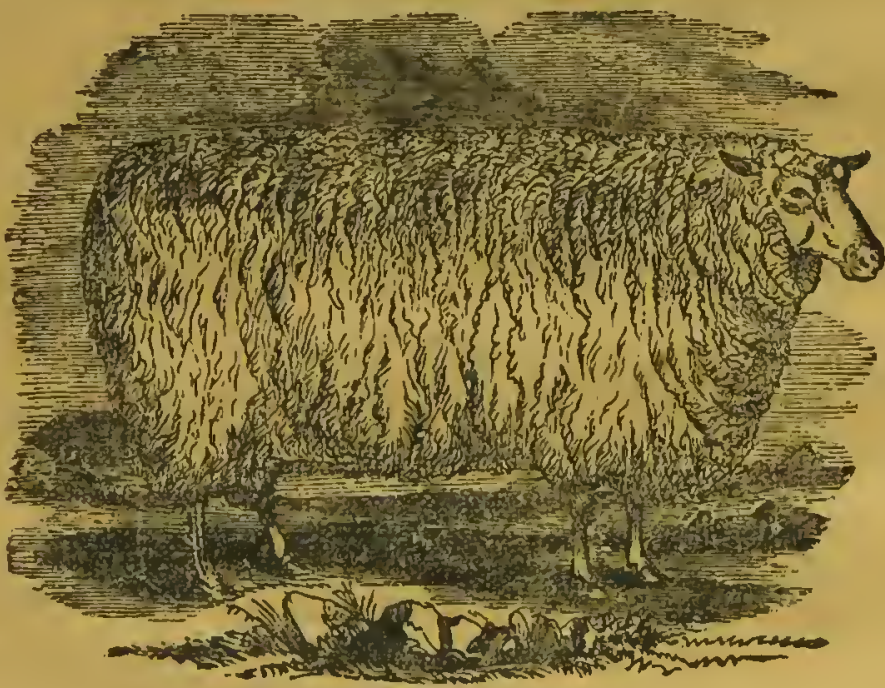

LEICESTEP RAM.

\section{Leicesters.}

This breed is pure white, tolerably kardy, without horns, the head omall and elean, eyes bright, neek and chculders square and deep, the back straight, careass full, hind-quarters tapering io the tail, legs clean, with fine bone, flesh sueeulent in quality, not the best, being mueh too fat for American palates; nevertheless, the grades make good meat with the single exeeption of possessing too mueh outside tat. Leieesters require the best of eare and shelter, and of eourse good feecing. The ewes are not the best of mothers, and the young lambs requir special attention. The wool is among the most valuable of any, being in esperial 
request for combing, and will avernge scren pounds per bead in good Alocks.

The Leicesters are well thought of in miny parts of the West, and aro increavi $g$ in popularity: The true type of the breed is as follows: The head should be liornless, long; small, tapering tomard the muzzlo, and projecting liorizontally forward. The eyes prominent, but with a quiet exprescion. The cars thin, rather long, and directed backward. Tho ficek full and broal at its base, where it proceeds from the chest, so that theie is, with the sliglatest possible cleration, one continued lorizontal line fro:: the rumi) to the poll. The bresst broad and round, and no un-

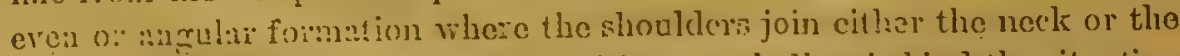
back; puticulaly uo rising of the withers, or lollow hohind the situation of theso bones. The arm fieshy t!uroura its whole extent, and eren down to the taee. The bones of the log swill, stancing wide apart; no looseness of skin about tiom, and comparatively lino of vool. The chest and barrel at once decp and round, the ribs fo:ming a considerable arch from the splue, so as in some cases, and especitilly when the animal is in good

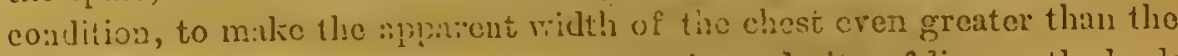
depth. The barel ribued weil lome; no irragularity of lins on the back or belly, bat on the sides; lae carcess rery gartunlly diminishing in widh teward the rump. The quarters long ind full, and, as with the fore-legs, the museles extending cown to the lock; the thighs also wido and full. The legs of a moderate leirgth; the slin also moderately thin, but soft and elastic, and covered with a good quantity of white wool.

\section{Bord=r Leicester.}

The infusion of the blood, of the Dishley, or new Leicester as they were called, but which are now classified simply as Leicester shecp, upon the border flocks of England, gave rise to a sub-family, known as Border Leicester, and which have won a distinct position in English show yards. Their good and bad cliaracteristics are as follows: The most marked featuro in their structure, is the smallness of their heads, and of their bones generally, as contrasted with the weight of carenss. They are elean in the jaws, with a full eye, thin ears, and placid countenance. Their backs are straight, broad and flat; the ribs arched, the belly carried very light, so that they present ncarly as straight a line below as above; the chest wide, the skin very mellow, and covered with a benutiful fleece of long, soft wool, which weighs, on the average, from six to seven pounds. On good soils, and under careful treatnent, the sheep are usunlly brough co weigh from eighteen to twenty pounds a quarter at fourtecu montus 
old, at which age they are now generally slaughiured. At this ago their flesh is tender and juicy, but when earried on until they are older and heavier, fat accumulates so unduly in proportion to the lean meat as to detract from its palatableness and market value. This fat aecumulation on muture auimals is pretty constant in all the large and improved breeds.

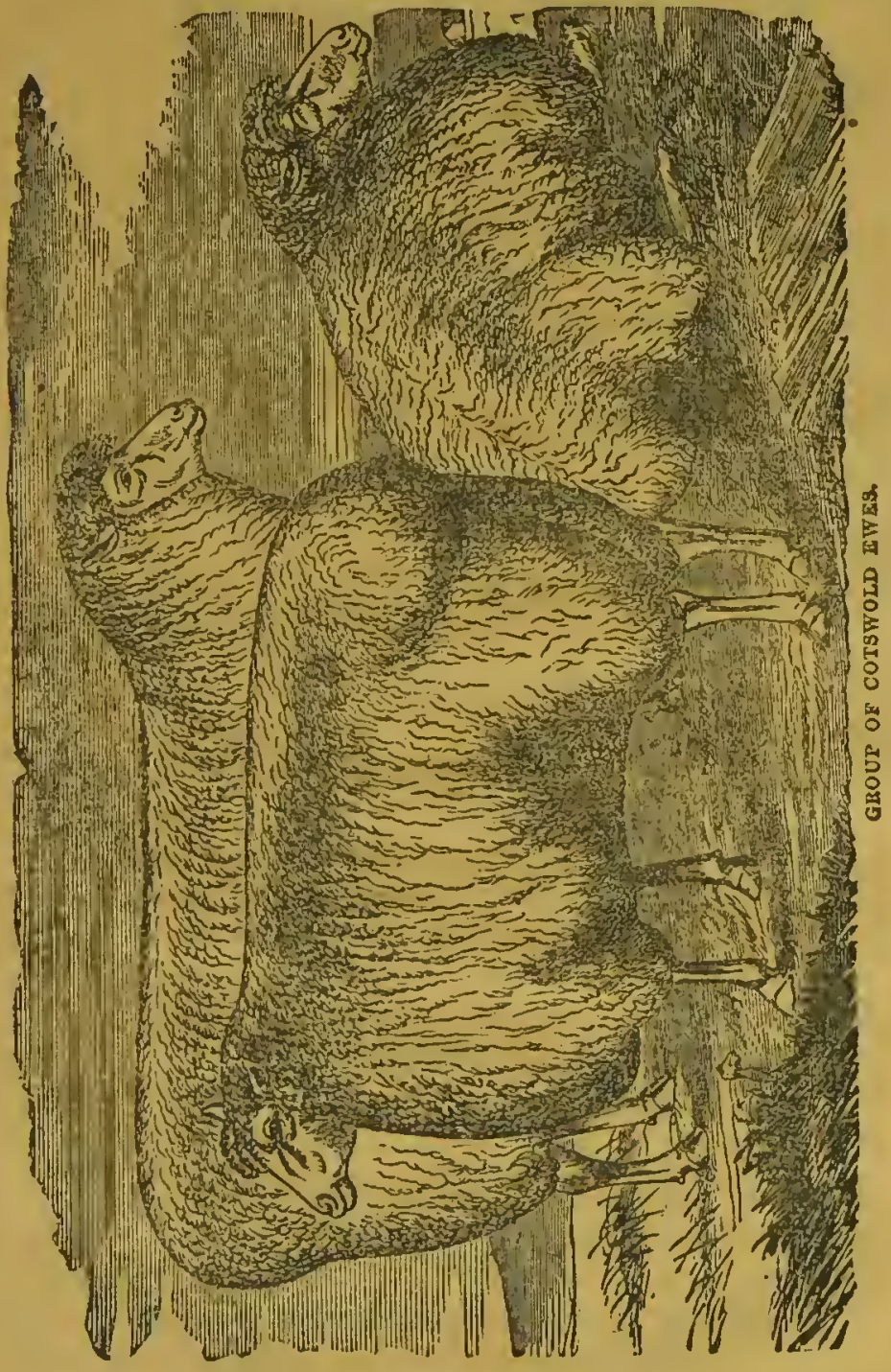

III. Cotswold Sheep.

The Cotswolds were imported into the United States about 1832, suice which time they have been reinforced from time to time by successivo 
importations, and now stand in the West, in the front rank of longwooled shcep.

This is one of the largest English breeds, though the improved race is smaller than the originals, on account of the intiuence of the Leicester element in its amelioration. As a breed, it is of great antiquity. It has gained in flecee and form, and comes to maturity earlier; is more prolific than the Leicester, and has greater strength of eonstitution; is often fato tencd at fourteen months, yielding fifteen to twenty pounds of mutton per quarter, and twenty to thirty, if kept till two years old. They have a large head, but well set on, a broad ehest, a well-rounded barrel, and a straight back. They are oftell used for crossing upon other breeds, and for obtaining carlicr market-lambs, hoth in this country and in Europe. They are more widely disseminated in this country than any other longwooled breed, and preserve.well the popularity which they have attained here. Some imported sheep of this breed have borne flececs in this country of eightecn pounds. A great weight when we remember that the wool shrinks comparatively little in washing.

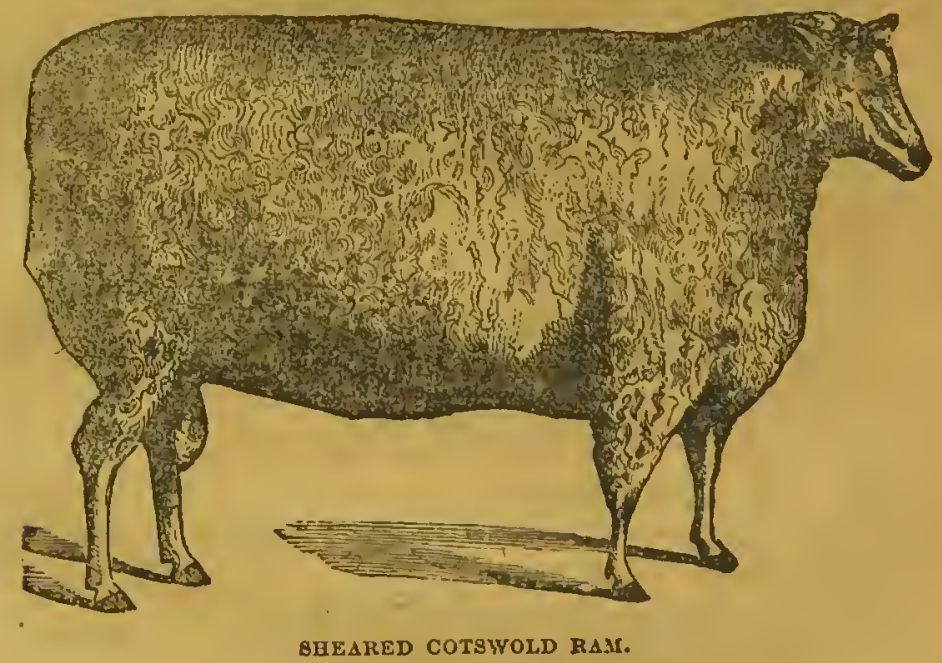

The Cotswolds have been extensively crossed with Leicester sheep in England, by which their size has been somewhat diminished, but their carcass notably improved, and in addition, earlier maturity has been attained. The wool is strong, mellow and of good color, though rather coarse, 6 to 8 inches in length, and from 7 to 8 pounds per fleece.

\section{Good Qualities of Cotstrolds.}

The superior hardihood of the improved Cotswold over the Lcicester, 
and their adiptation to common treatment, together with ${ }^{2}$ the proifige nature of the ewes, and their abuudanee of milk, live rendered then in many places rivals of the new Leicester, and has obtained for them of late years, more attention to their selection and general treatment, under which management still further improrement appens very probilnle. The quality of the nutton is superior. to that of the Leicester, the tallow heing less abundant, witlia larger developinent of muscle or llesh. I'be ewes kre prolific, and good motherș and nurșes.

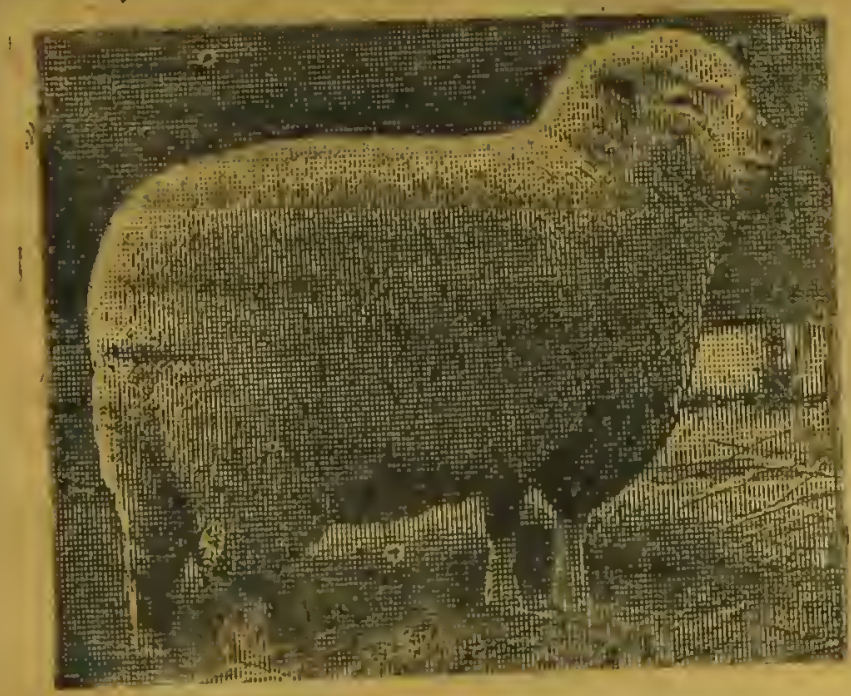

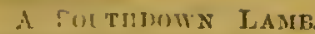

Cotswolds in tho West.

Throughout the entire West, the Cotswold has hecome a most favorito breed, and this not only on account of their long, liandsome lleeces, specially adapted to the purpose of combing wosl, but firom the kindliness with which they take to our licep and climate. For this reason we lave given this breed special prominence in our illustrations. It is not our province to go into long dissertations or detailed description, it would take too much space, and be productive of 110 grood end. The illustrations we give will furnish a better index of value and characteristics. The eut on next page will show the appearance at one year old.

In reiation to the aduptability of this breed Soutl, a prominent Clark county, Virginia, farmer says: It is far more profitable to keep the different varieties of mutton breeds, than the fine wools, or Merino breed in this portion of Virginia." I say this from ny own experience, and that of many intelligent gentlemen witl whom I lave conversed. 'The Cotswold sheep, and its crosses, with the Southdown are less liable to diseaseo 
of all kinds; they are more prolifie, better nurses, and less liable to losi heir lambs than the Merino. The lambs are more vigorous and hordy

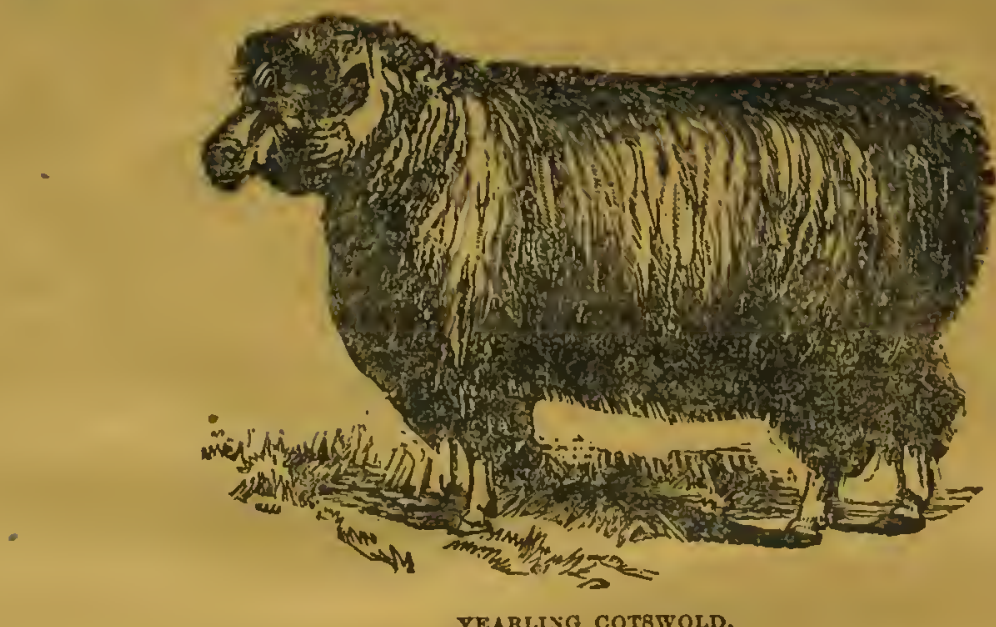

then add their early maturty, their fitness for market at 18 months old and their almost double value when in market. and you have advantago

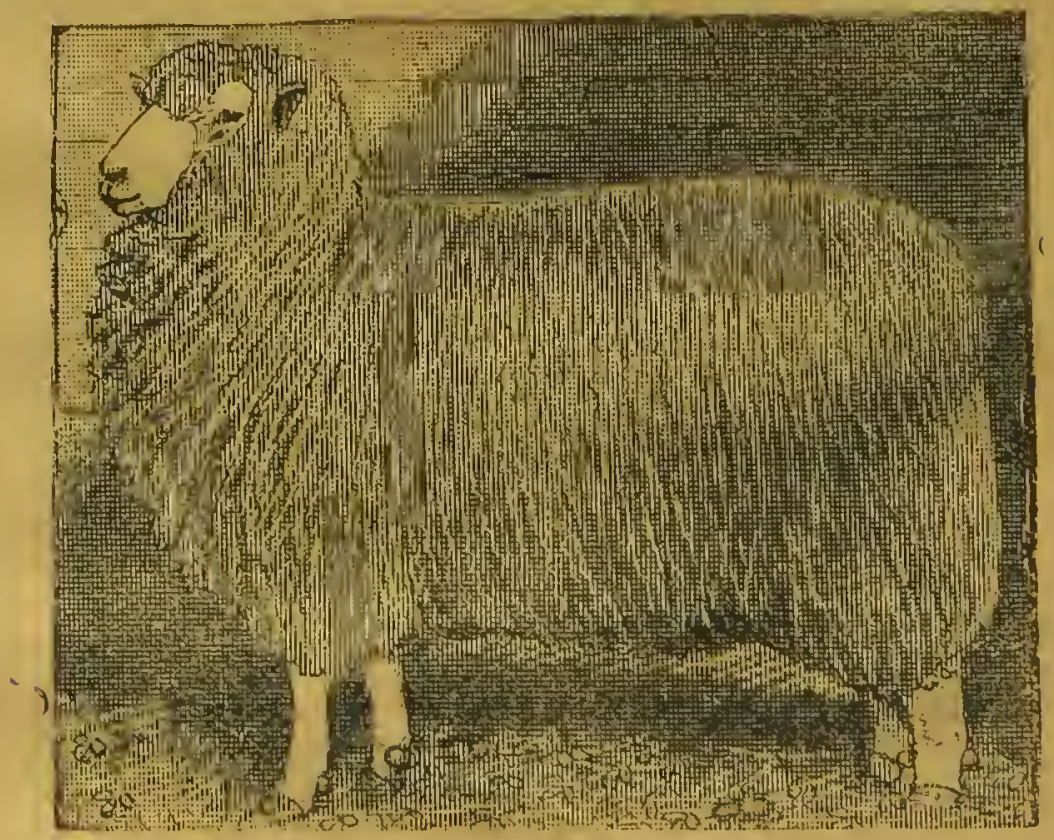

a Cotsingl Lavir.

Which far outwcigh the additional amount of food which the mutton sheep may consume in proportion to his size. Therc is one thing in con- 
nection with all the long-wooled and large lreeds of sheep that niay bo appropriately mentioned here: they cannot be kept in large flocks, like the smaller and fine-wooled breeds. Merinoes are often linjt in flocks of 1,000 or more in the fir West. The long-wooled, the middle-rrouls and the mutton breeds are especially adipted for farmers, when both mutton and wool are the considerations, and are seldon lierded together in fic ds exceeding one hundred.

Thus in all the hetter settled portions of the VI'est and South, where pasture and grain are abundant, and where the nearness to market affords sale for the mutton, the long wools are incrasing in numbers from year to year, and with profit to the breeders and feeders, as well as in the just appreciation of those who cousume tho llesh.

\section{Lincoln Sheep.}

The Lineoln sheep are both lneger and henvier than either the Leicester or Cotswold, and are bred to a limited extent in the Tnited Stintes. Tho first importation was made in 1835. They are hindy, luroe forders, prolifie, yield fleces of from of to 10 pounds each, and the earcasses huvo been known to ciress 125 poundr.

\section{จ. Ton Csfordsiro Sheep.}

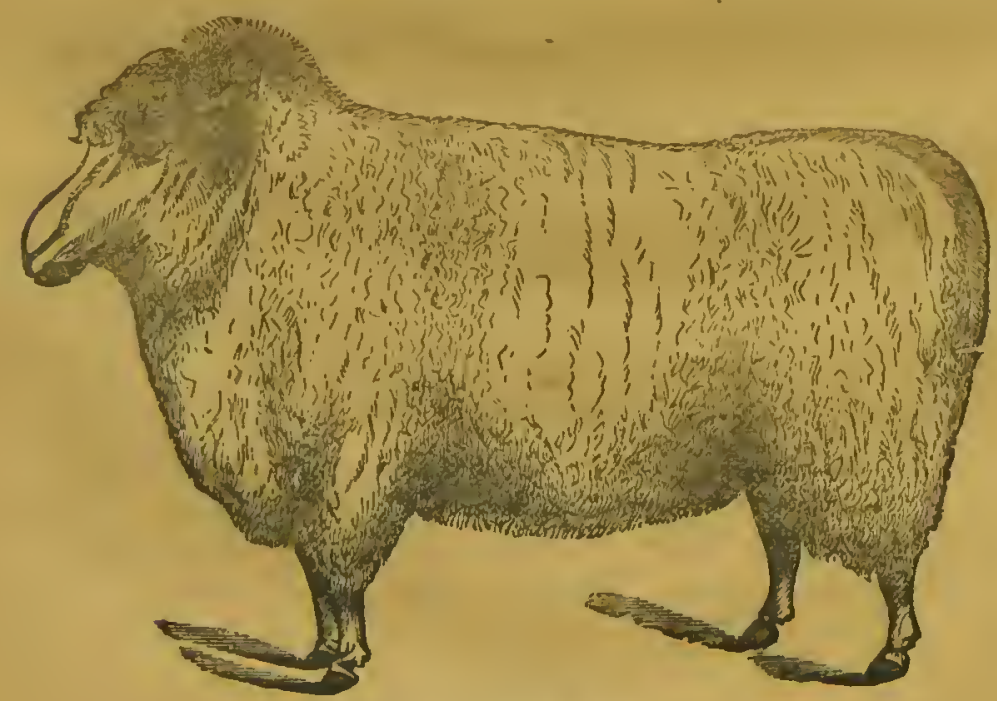

NEW OXFORDSEIRE XWR.

This breed should not be confounded with the Oxford Downs, a cross breed between Cotswold and Hampshire Downs, and which have dark leces. They are less hardy than the Cotswolds, and have not made much 
progress in the United States. They are the result of a eross between the New Lcicester and Cotswold, the latter blood being in exeess. However they may be regarded in England, and they are regarded highly, they have not become popular in the West, as against the Cotswold. On the preceding page, we give a eut of a New Oxfordshire ewe, to cinse the subject of improved long wools in the United States as em. bracing the more prominent breeds.

\section{Middle-Wooled Sheep.}

The Blaek-fiaed Scotrh Highland sheep are small, aetive and docilo when we eonsider that they are a purely mountain race. They stand great hardship, and work kindly in lirge flocks, subsisting on scanty fare when neccssury. Henec they may be valuable in cold and mountain regions of the United States, for crossing on other breerts. They havo open hairy flecees, and black faces, weigh to averuge 65 pounds, and vill shenr about 3 pounds of elean wool. Their mutton is of most excellent quality, and erossed on larger breeds their fleces will go to 6 or 8 pounds and their live weight to 128 pounds for wethers.

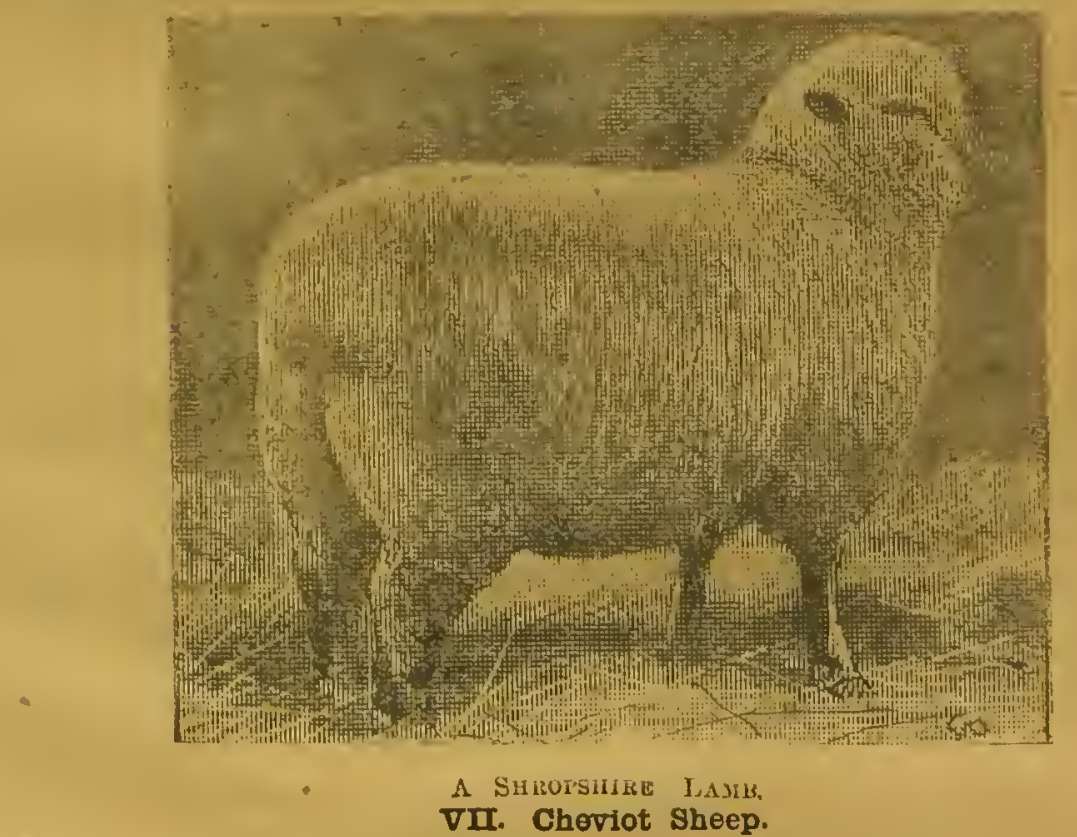

This is another mountain breed that has been introdueed, to a sman extent in the United States. Thoir fleeees however, are too coarse for carding wool. They are less bardy than the blaek-faced highlands, but 
are quiet and docile, easily managed, giving fleeces averaging about 3 1-9 pounds, furnishing good mutton, weighing 12 to 18 pounds per quartor, if throe years old.

\section{White-faced IIighland Sheep.}

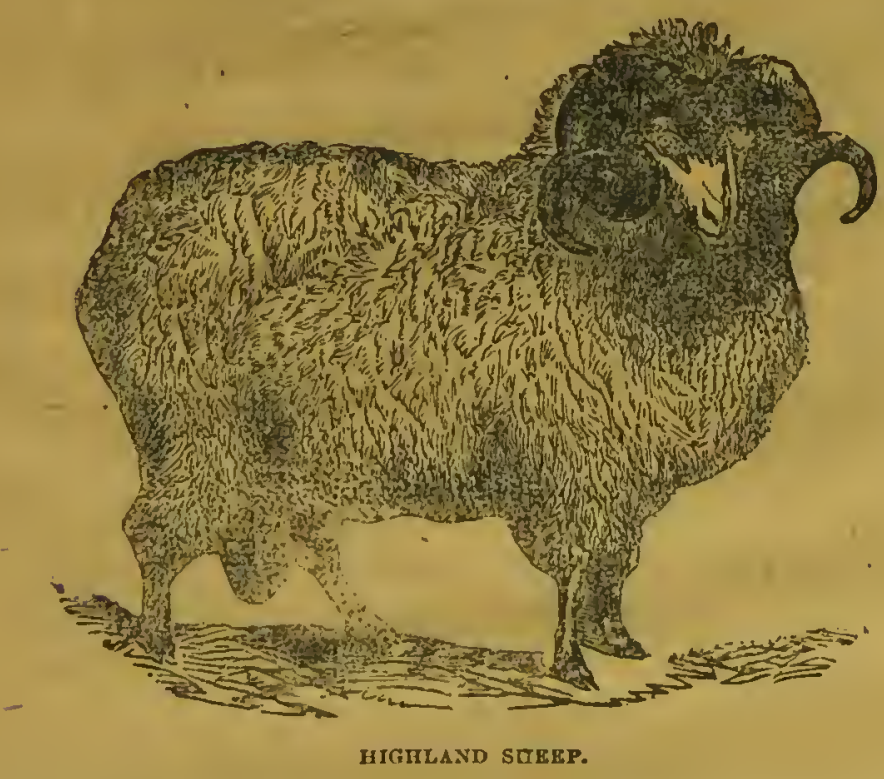

This is a sheep of great hardiness, furnishing good mutton, but not i wool of much value, and is introduced only as necessary to illustrate a breed adapted to sterile regions, where better breeds would not survive. Many such regions are found in our own land, especially in the Rocky Mountain sections, where the trial of this race might well be made.

\section{Dorset Shecp.}

\section{.4.}

Dorsetshire has a breed peculiar to itself. Strong, active, and wel able to take care of itself : heavier in every respeet than the highlands, and like this breed, a strong horned race. On this aceount, neither of these breeds would be consiclered valuable, exeept in regions where the better fleeed breeds wonld not live. The cut is given like that of the hichland long horned family, as affording possible value in Alpine regions. Fortunately there is but little country of this nature on this Western eontinent. Anl yet there are rigorous climates, where this breed wonkl undonbtedly thrive and make a good return to its cultivator. 'd'ae experiment may bo made with much hope of success. 
Bhort-wooled English Broods:;

Ot the mutton breeds, the Downs undoubtedly stand at the head in

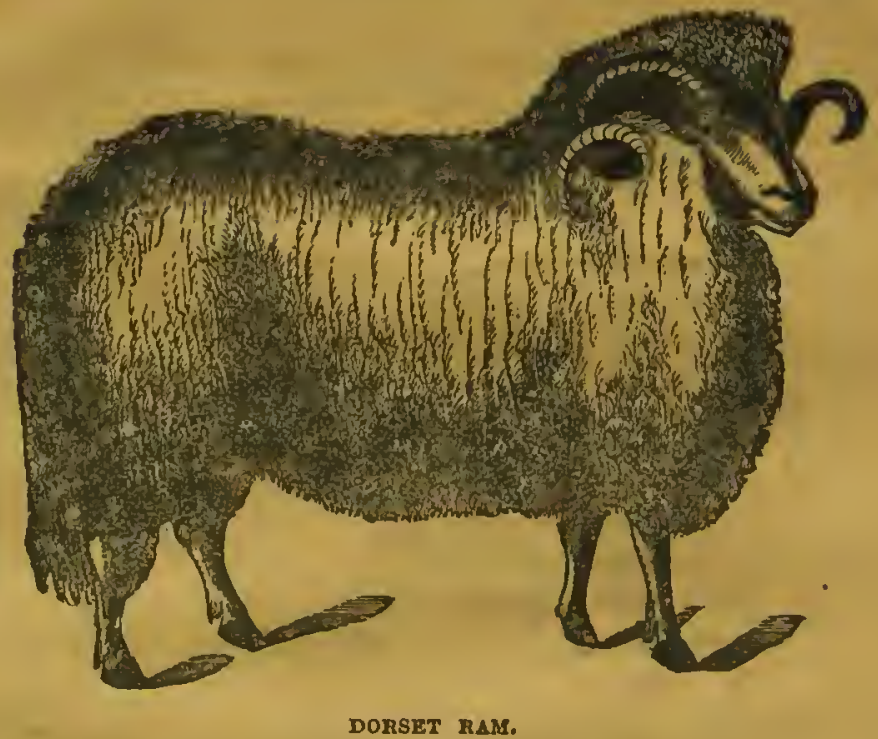

both England and America. 'They are all compact, hardy, docile, horoless, and of early maturity in feeding; and with flesh of most excellent quality, that always commands the best price in धny market.

z. Bouthdowns,

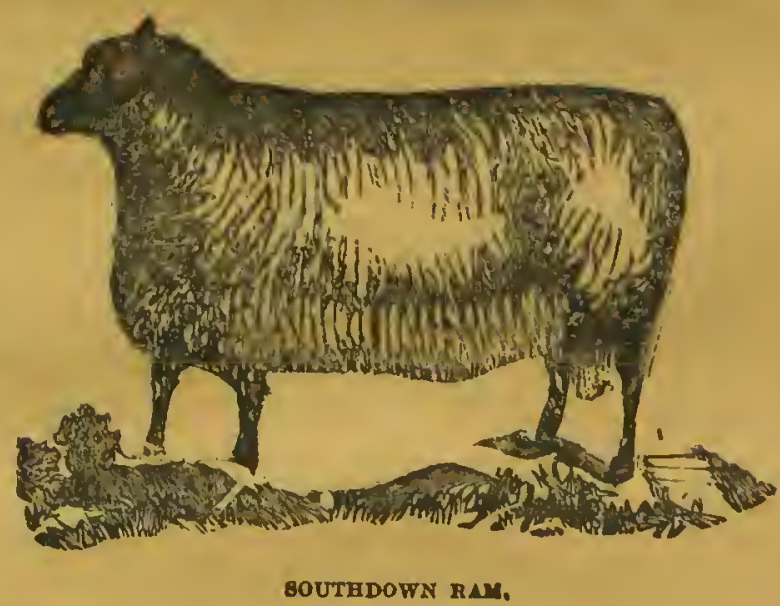

These are without doubt the most superior, taken as a whole, of ary of the mutton biens, and have for many yeurs been bred with the greatest 
care in both England and America. Their faces and legs are dark brown, the fore quarters wide and deep, the back and loin broad, with round bodies, and square and full hind quarters.

The ewes are prolific, producing from 120 to 140 lamts, to the fock of 100 ewes. The staple of the wool is fino and curled, wirn spiral ends well adapted to carding, and will sheur on yearling lams and wether's, from 6 to 9 pounds, In the neighborhood of large cities, where there is a demand. fer mutton, they are most valuable as a distinct breed, or for crossing . with the $;$ mmon sheep of the country.

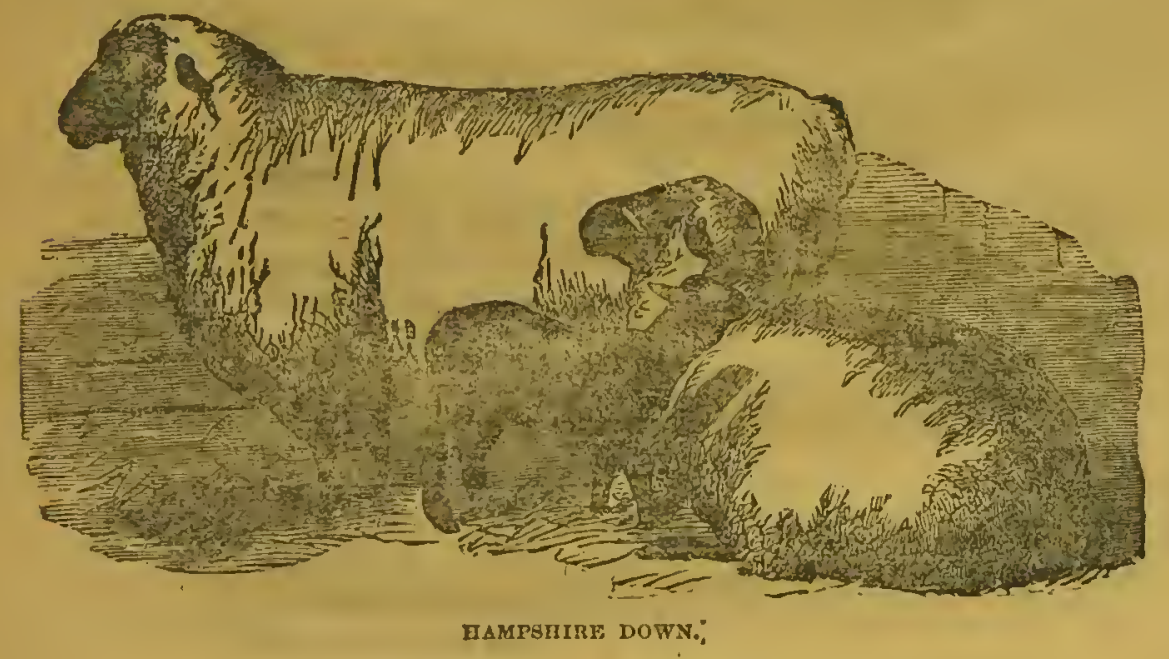

XI. Hampshire Downs.

This breed had its rise in Hampshire, through an infusion of Southdown bluod, followed later with Cotswold, and of course, since the Cotswold lave an infusion of Leicester, they have this blood also. It has given them increased size, more wool, and at the same time they have preserved their great hardiness of constitution. For many years they have been bred pure, and so far as introduced into the United States, they have given satisfaction, especially in the South, where, before the war, they were in good repute. Those who have used them, claim that they are more liardy than Southdowns. It is also claimed that they have been crossed upon Cotswold and Leicester grades, with benefit to both, and this we do not doubt, where mutton was to be the object.

\section{Shropshire Dowas.}

Df late years this breed has grown into repute in the West, and it Canadi. They are heavy sheep, nearly as large as the Cotswold, yield 
nearly as much wool, with thick compact flecees, are hardy and healthy, have even, conpact, uniformly symmetrical bodies, with dark brown faces and limbs, and are about one third heavier than Southdowns.

\section{Ozford Dowas.}

This comparatively new fanily, which has come into prominence in the United States within the last twenty years, was originally made by crosa ing the Hampshire or Southrlown ewe with a Cotswold ram. They are easyfattening sheep, producing mutton of superior quality, with fleces of 8 to 10 prounds for ewes and 12 to 13 pounds for rams, and in length from seven to cirht inches; a wool of good luster; neither hairy nor harsh.

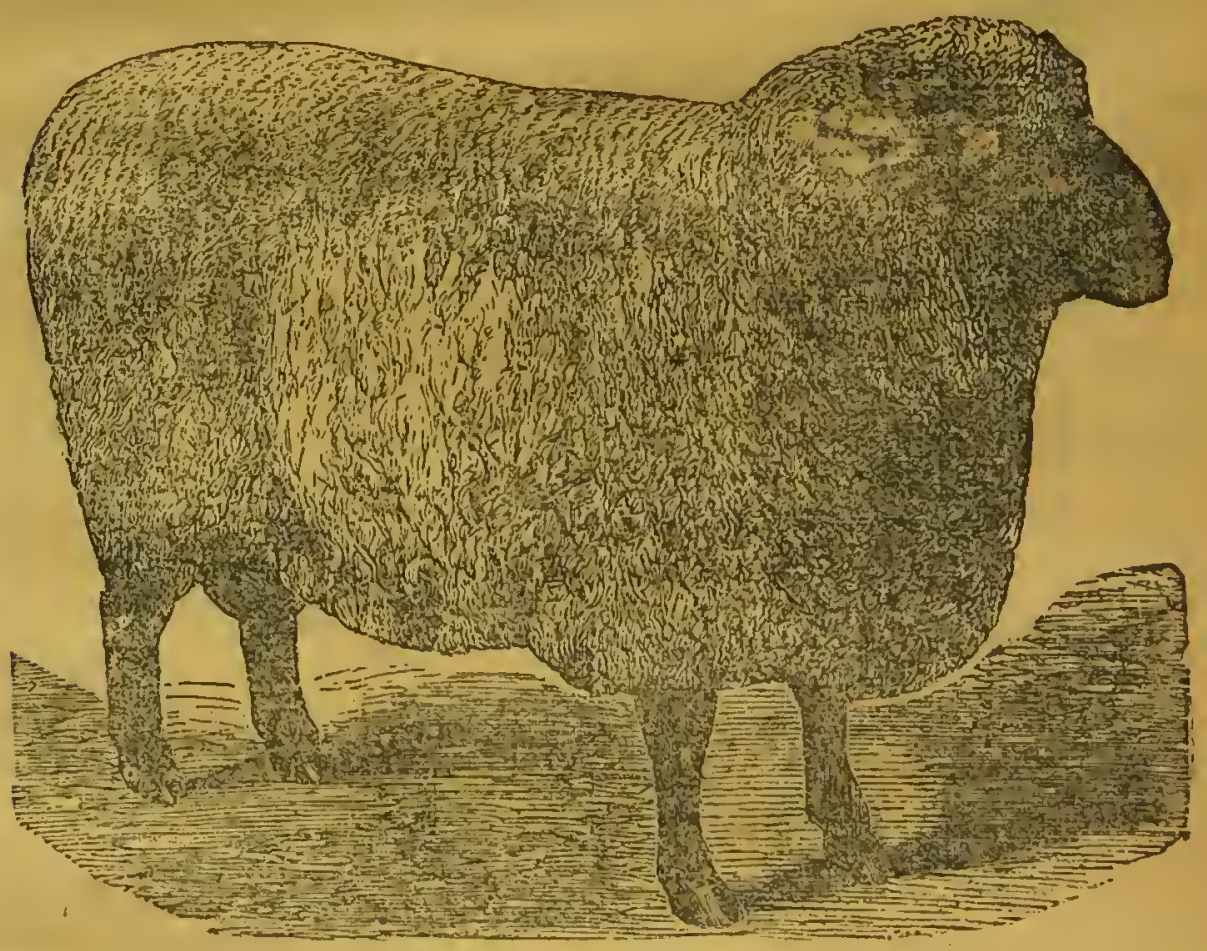

OXFordDUW:XIIRE KAJ.

In reality the only reason why these sheep should be called Downs, isy from their dark legs and faees. They really arc not a short-wooled. brecd, in fact, as we have shown, they are a long-wooled race, and the characteristic has been earefully cultivated by breeders of this variety of sheep. In color, they are much lighter than the Southdown, their faces and legs being gray, instead of brown. The ewes are prolific, producing with good eare, 150 lambs to the 100 ewes. They herd close together, 
are not particular about their feed; they mature carly, and upon hill pastures produce mutton of high quality.

\section{Fine-Wooled Sheep.-American Merinos.}

In treating of fine-wooled shcep, it will not be necessary to go into their history. It is enough to say that Spain and France have contributed from time to time their best specimens, whicl, under such management as that given by Mr. Jarvis, - sclecting from five fanilies of Spanish aheep, the Paulars predominating, - produced what was known as the mixed Leonese or. Jarvis Merinos. In $1813 \mathrm{Mr}$. Atwood commenced the breeding of pure Mcrinos, from what was then kuown as the Humphrey stock. About 1844, Edwin Hammond, of Middlcbury, Vermont, commenced breeding, taking for his stock selections fiom the Atwood family. To the judgment and skill of $\mathbf{M r}$. Atwood, and later followed by $\mathbf{M r}$. Haminond and other Ameri an brecders, we have seen produced what have been known distinctly as American Merinos; perfect in all that

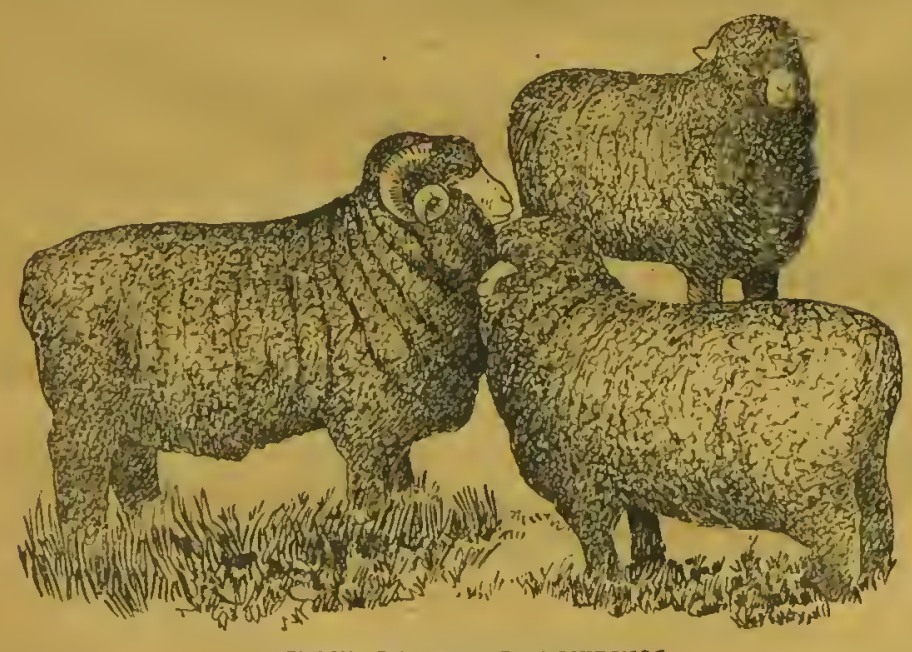

GHOUY OF AMERICAN MERINOS.

gocs to constitute length and thickness of wool, erenness and fincness of staple, that looscness of skin which, while it Lits in low, rounded, soft ridges over the body, offers no olstruction to the shears. These were the points sought, and for the last twenty years well met and sustained by the best brecders, East and West; so that we now have as thoroughly established, the descendants of the Infantado-large and of good length, and the descendants of the Paulars, a smaller breed, originally established in the United Statis by Mr. Silas Rich and his son, of Shoreham, Ver mont. Thus making two well marked families, which it is altogether probable would be injured by the infusion of foreign blood. 
The Fleeco.

The fleceo is the important point in Mcrinos; they are not mutton sheev, ind their curcuss is of sccondary importance. Dr. Randall, nearly twenty ycars ago, in his work cntitled "Tho Practical Shepherd," in writing of Amcrican Mcrinos, as they then werc, says: "The grcatest attainable combination of lcugth and thickness of wool, of given quality, ia the first to be regarded in a marliet where all lengths are in cqual demand: And the more evenly this length and thickncss cxtend over every covered part, unless below the linees and hocks, the higher the excollence of tho animals."

It is in this point especially thet the modcru breeder has improved on his predecessors; and it is this, in a very considerable degree, which gires the improved Americin Mcrino its vast supcriority in weight of flece, over all other finc shecp, of the sume size, in the world.

Wool of full length below the linecs and hocks would hardly bo desirable, on account of its liability to become filliy : but a thick shortish coat, purticularly on the hind legs-maling them appear us linge "as a man's arm" - is rerarded by inany as in fine, shor:y point, though it does not add inuch to the value of the flecee.

\section{Thэ Head.}

The wool should extend in an unbroken and undirided mass from tho back of the neck over the top of the head and down the face for an inch or two below the eycs, and there abruptly termin:te in a squine or rounded shape; it should cover the lowel side of the jaws nearly to the mouth, and rise on the checlis so as to lesve only the front face bare, terminating abruptly like the forchead wool. The cheek and forchead wool should mect unbroken, immediately over the eye, between it and the ear. But it nust by no means unite under the cye-though its outside ends mity touch there for a little way. The eye sivould latre just nalied space cnough about it to learo the sight uninpecicd, witlout any resort to the scissors.

The noso shouk be covered with sloort, soft, thick, perfectly white hair. Pale, tan-colored spots or "freckles" al out the mouth, and the same color on the outer half of the car are not bjected to by the breed. ers of the Paulars - but Infantando brecders usually prefer pure whito; Wool on the lower part of the face, as is often secn on the French Merinos, whether short or long, is regarded as decidedly objectionab!e, and any wool which obstruets the sight in any degrec, is a fiult..

Those who grow such fleeces now need not be ashamed to cahib:a to-day in tho best show rings of the country. 


\section{The Body.}

The frame upon which the wool is to grow is important, for upon form and constitutional vigor depends the value of the animal. Below we give an illustration of a ram that would leave little to be desired. so far as ability to produce tho best wool is concermed.

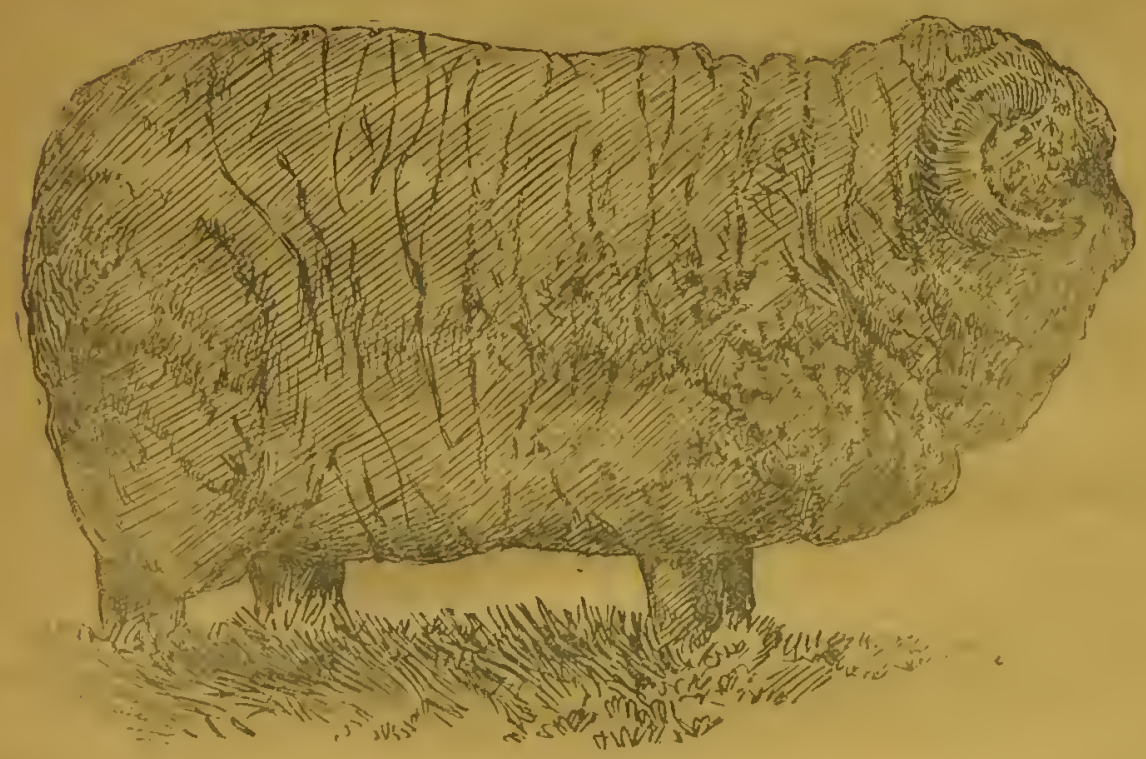

P.i:Y Iof:n. (from plontorrajls) A Kansas brecl American Merino, beating the world's rent with a llece of 5 ? pounds of 12 months 16 days growth. Weight after shearing at four years old, 120 pounds.

Medium size, for the family, will hold in sheep as well as in other animals. An overgrown animal is not profitablo in any breed. The body should be round, deep, of moderate leagtl, the head and neek short and thick, back straight and broad, the legs short, straight, but well apart and strong, giving a decp full bosom and buttock. -The forearm ample, and the junction of the thighs well down the hocks. The skin should be rather thin; mellow, elastic, and loose. If it be thick and rigid, it will evidence a bad fecter, and consequently inferiur wool.

\section{The Most Profltable Sheep.}

Of all the breeds of sheep ever introdueed into the United States, the Merino has more than beld its own in the estimation of brecders every 
जhere. Ever in the neighborhood of our large cities, to-day, there are more grade Merino: sold for uluttol, thin of all the mutton breeds, distinctively. It is ouly near our great cities that the brecding and feeding of Cotswold, Leicester, and tlis Downs, could be made profitable, and this his mainly come about through the ehange in wearing apparel. Since the fashion came a!)out among beth ladies and gentlomen, of woaring garinents of medium wool, a strong impetus has been given to the breedzag of the Downs, aud longr wooled breeds. They are wore tender and

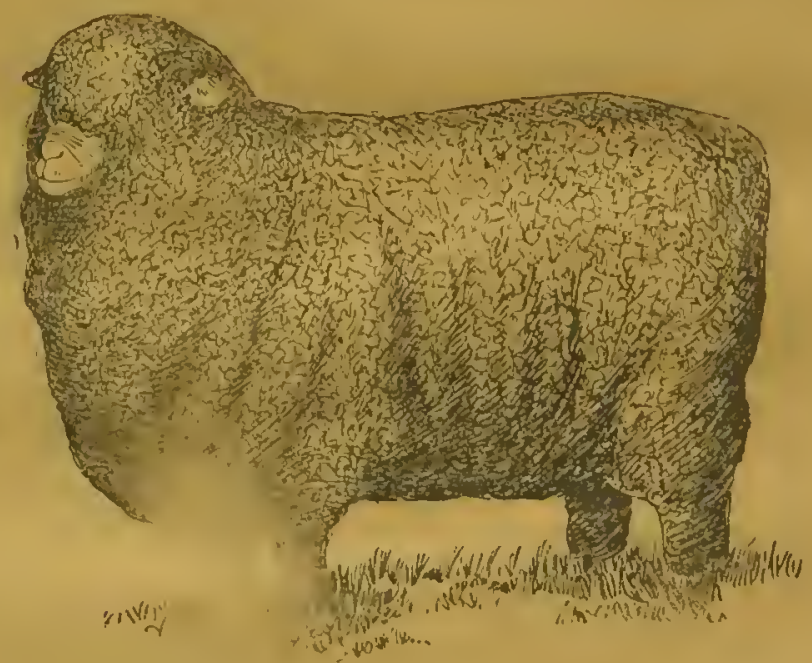

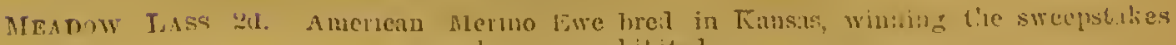
whereser exhibited.

delicwe hin their constitution, cannot stand extremes of cold and hent, as the Merisos; camuot shift for the:aselves as well, and for the reason that they cantist be kept in larghe flocks, are only suitable to small farms, in thickly seitled districts, whern good shelter and suceulent food may bo obtained. Tlius the Merinos, and their grades and crosses will always bo found the most profitable in all that great regrion West and Southwest, and in much of the conntry South, where the flocks to be protitable must number from one thousand to miny thousands.

\section{Division of Wools.}

Most persons suppose that the wool of a sheep is uniform in quality. Such, howover, is not the fact. As showing divisions and quality of wool, we give a eut of sheep with divisions aceurately numbered, wheh shows points in the pure Merimo and Sason, and where the different qualitios of 
the wool are found. Some grades of sheep will often exhibit seven ox oight qualities in the same fleeee, whereas unalloyed breeds show but four qualities. The refina, or pick wool, (1) begins at the withers, and extends along the baek, to the setting on of the tail. It renehes oniy a little way down on the quarters, but dipping down at the flanks, takes in all the sipperior part of the chest, and the middlo of the side of the neek to the angle of the lower jaw. The fina, (2) a raluable wool, but

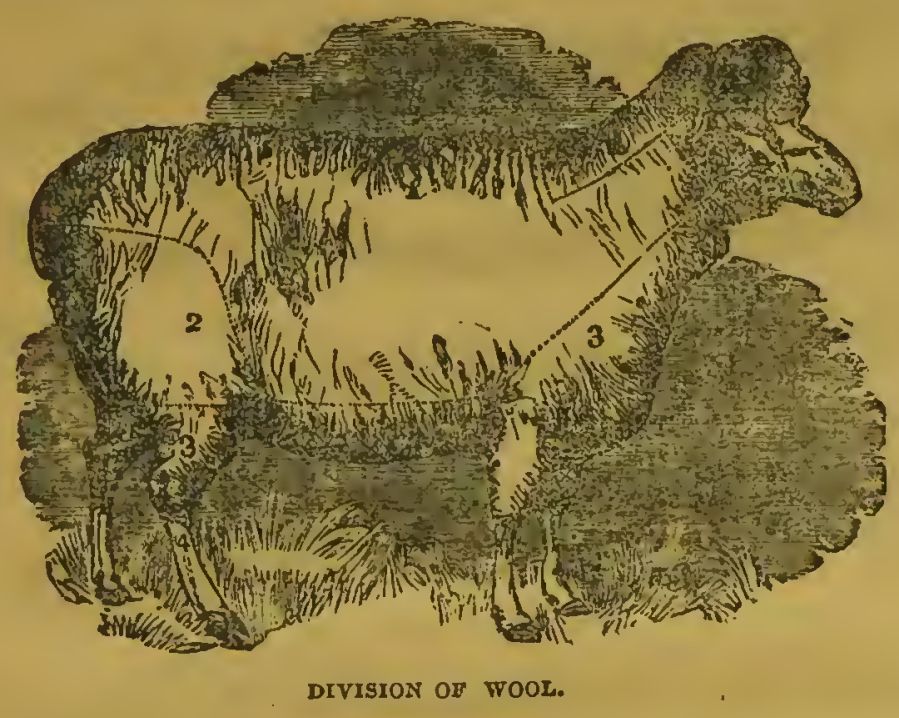

not so deeply serrated, or possessing so many eurves as the refma, nccupies the belly, and the quarters and thighs, down to the stifle joint; (3) is found on the head, the throat, the lower part of the neck, and the shoulders, terminating at the elbow, fore legs, and reaching from the stifle to a little below the hoek; (4) is procured from the tuft that grows on the furchead and chcelss, from the tail, and frem the legs below the hock. 


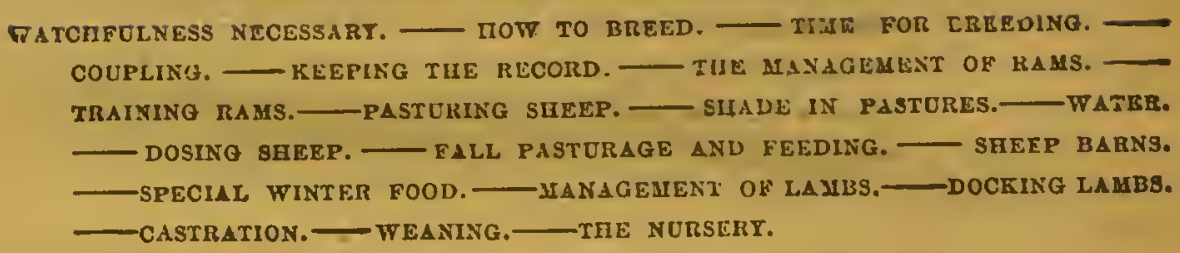

\section{Watchfulness Necessary.}

The fecundity of shecp soon cnables the breeder to gather a Hlock: To keep them healthy is one of the most difficult problems of the breeder, since they are generally kept in large flocks, and herding closely together as they do, if an epidemic or contagious disease gets among them, it surely goes through the whole flock unless the shepherd is ever vigilant. The lack of care and vigilance causcs more than half the losses in shcep, and hence, no person should undertake sheep breeding unless ho mako up his mind that they are to have not only gentle treatment but daily caro and watchfulness, even in the Summer.

\section{How to Breed.}

The ewe may bo bred to the buck at the age of eighteen months, and the buck will be fit for service at the same age. If the object be to breed grades, it wll be found to be money squandered to buy an inferior buck, 
whatever his blood may be. So, if to save a few dollars, the breeder so. leet a grade buck for breeding purposes, the money is as good as thrown away. One buek if properly kept vill serve one hundred ewes, so that the cost por lamb is really light. Thus in breeding grades, pursue the same rourse as advised for eattle. Select a good staunch ram, of well known purity of blood, avoiding the exeessively ligh priced animals that are simply the best breeders of pure bloods. Such an one may be bred to tho common stock of the country, and to his own progeny, to the third generation. As a rule tho siro will give the leading eharaeteristics of form, size, length and density of fleeco and its yolkiness, he will do this eminently in proportion to the purity of his blood. The fineness and principal characteristies will be probably eontrolled by the dain. Heneo the importance of none but the best sires.

In crossing, the Merino may be bred upon the common ewes of the ccuntry, always with benefit to the fleee, and never at the expense of tho careass. So the Southdown will improve them in mutton and wool. The Cotswold and Leicester will give increased size, early maturity and length of staple. To breed Merinos on any of the long wooled varieties would be useless. It would detract from the valuable qualities of the wool of either, reduce the value of the mutton, the size, propensity to fatten, and prolific qualities of the long wool. In the West the sheep for money aro either pure Merinos, or pure Merino rams bred unto the common sheep of the country, with the exception before stated, whero farms are small and near markets where prime mutton is in demand.

\section{Time for Breeding-}

The average period of gestation in tho sheep does not vary mueh from one huudred and fifty-two days. They usually earry a male longer than a female, the period of gestation varying a week and sometimes two weeks. Therefore the shepherd eam easily ealeulate when to have his ewes served by knowing when he wants his lumbs in the Spring. This as a rule should be at the time of new grass in the Spring. Allowing that this oecurs the first of March the ewes should begin to be served about the middle of September, and the season will then probably eontinue to the middle of Oetober. If lambs for slaughter be tho object then the ewes should be served fully a month earlier than usual, and extra shelter, warmed with fire heat provided for lambing time. This always pays. They are the carly lanbs that eommand the high prices in the important mar kets of the eountry, and he who furnishes these must use proper means to watieipate his neighbors. 
Coupling.

We do not advise the use of tensers-that is, eommon rams aproned to show the rutting ewes. Whe better way is to drive the flock up to tho yard trice a day and let the ram out with the flock. Immediately lie has served a ewe cutch and separate her from the flock. Keep all served ewes together, snd under no consicleration allow but one service. If they come argain in lient it will ixe from the fourtecnth to the serenteentli day. Thus they may be : Ifin rourned to the ram after the thirteenth day, and if not in leat it mily be set down thit they have been properly served.

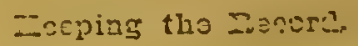

In hrecuing graries it is only necessa:y to kncy a cn:rect racord of tho

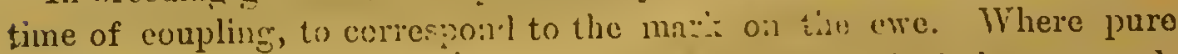

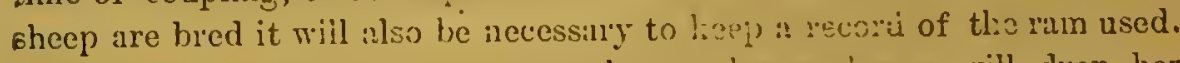
In the first ease it is liccessilly to linww wan cact eve will drop her lamb. In the caso of pure bred slreep it is imperstive that a full and acenrate record be kept, clse confusiou will cnsue mu the breeder will

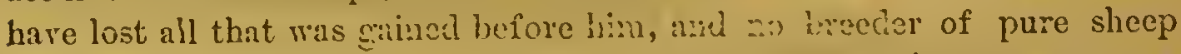
will buy from his flock. In order to bring tire erres into senson at a specitic time in seusons of drouth, or scunt partive, the ewes should hevo extra feed for three weelis before thev are renur..ed to take the ran.

\section{Ino Managoment of inams.}

The rams sloould never be allowed to run ritil tl:o ewes at any season of the year. 'Ihoy are brutal always in their teasing, and if allowed so to run they not only exhaust themselves, but the ewes drop their lambs out of season. His separate cuelosme should be dry and confortable, and kept strictly clean, and be entively away from the sight and hearing of the ewes, except when admittri to them. Ilis feed must be the best of hay, or fresh grass, with what oats he will eat clean daily, beginining - six weeks before the season witb lalf a pound daily, and inereasing tho feed gradually to two pounds daily, if he will eat so much. Some flock masters sow oats and peas together, two bushels of the former to three pecks of the latter. This when thresied and ground together and fed, gradually inereasing to a quart a day, makes most execllent feed for a hard-worked ram. On such feed, with puro water within reach at all times, a ram may be expected to properly serve ono hundred to ono 
hundred and fifty cres, and but few of them should come back tho second time.

Never kecp two rams in the same enclosure. They are cssentially pugnaeious, and very often a valuable ran is thus sacrificcd, through the mistaken eeonomy of the owner. In the begrinning of the season, a ram should not be allowed to serve more than two or at most three cwes a day. This may be gradually increased to five, and agnin towards thro elose of the season, he inay be again only allowed two or thrce. To do justiee and retain full power of feeundation, he nust hare a good amount of exercise. To insure this, if inclined to be inaetive, he should be driven about the yard for an hour every day. As a last word of caution we add: Keep the rams away from the ewes in Winter. They often seriously injure them, and by their teasing are a eause of abortion, to say nothing of other serious injuries they may infliet. 'The best exnarienee of sheep-raisings confirms this rule.

\section{Trainirg Rams.}

It is quite necessary that rams should be made to undcrstand that any vice will be severely punished. Thcy should be early trained to stand quietly when tied, to lead at the end of the halter. They should never be tied with a rope about the roots of the horns. It is apt to gall, and inake lodgment for maggots. Fastcn polled sheep by a strap about the neck, and horned brecds in the same manner while they are young. When their horns arc. large enough, drill a hole through the left horn. near the tip and put in a bolt with eye and two inch ring, the whole fastened with a nut. Ncrer tease, or allow a ram to be teased. It is sure to make them vicious. Handle kindly and gently, yet with a firm hand. If inelined to be vieious, punish them severely and until they are thoroughly eowed. A vicious old ram is dangerous at all times. Sometimes they beeome ineorrigible; when this is the ease geld them at once. It is useless to wusto time and patience on them.

\section{Pasturing Sheep.}

The floek should go in the pasturc as early in Summer as possible, bat ohould be housed nights, and during cold storms. They should be regu?arly salied, at least every otlier day, and when salted should he counted and examined for any ailment that may occur. The best shepherds eount every day, and salt every day, graduating the doses so the sheep will eat It entirely elean; and once or twice a week, giving a larger quantity. Care in salting, as in feeding, pays abundantly. Change of pasture and the utmost cleuuliuess of ztabling place is always helpful. 
Saeep are eager for shade in warm weather. We do not bejicve is shacing pastures with trees. It is better and cheaver to huve sheds, open on all sides, and of ample size to sheiter the fio k. The covering may b3 of boughs, or anything that is cheup. We hare used common factory muslin, stretehed on a light frame, double pitched roof, with a two foot space at the peak, for the ascine of wind: the shed twelve feet wid's and running north and south. 'inis gives free rentilation, and ist the coolest shade we know.

\section{Water.}

Water is not grenerally considered an absointe necessity to shecp when on pasture. Where they are allowed to grazo when the dew is on tho grass, or the gryss is succulent, they secm to get along pretty well. Wo like then, however, to have a chance at water once a day. In the caso of ewes suckling lanbs it is necessary that they have water in plenty. Alssolute purity of water hotvever is always indispensable. 'Sheen object to drin!ing foul water, and their instinct ought to satisfy any prean that

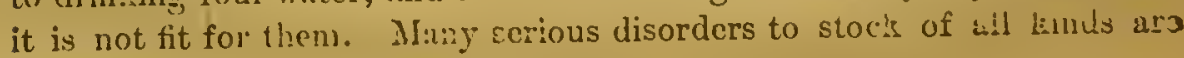
occusioned by drinting injureo water.

\section{Dosing Shecp.}

Trot, low, or mucky pastures are not fit for sheep. It is an entirely truo adage thr.it the sheep's foot must be kept dry; nevertheless the:o are many sheep licpt other than anong firm, dry, hill pastures. Somo shepherds are continually dosing with salt and alum, salt and sulphur, and various other compounds under the supposition that it tends to health. Give them what salt they need, always, and examine them often for cisease. Wuen they are well, however, let well enough alone.

\section{Tall Pasturage and Feeding.}

In the Antumn, as the senson advances, sheep should have somo fodder. It is the time of year when, if allowed to fail in fresh a mis. chicf is done that cannot be remedied. There is a peculiarity aloout wool that one shepherd in twenty knows nothing alout. To hare a uniform. growth, and of equal strength, the wool must grow stcadily, as the ceason advances. If the sheep are allowed to fall suddenly away, tho growth of wool ceases. When growth again conmences, the wool, instead of continuing even in texture will have what is termed a joint. This is often so weak that very slight force will break it. The microseopo will reveal every period of starvation and subsequent. good feeding that cbeep rasy have cxpericnced in the course of the yeur's growti of wool. 
Thus the shepherd who would do well for himself must do well for his finek. He inust not only feed and water well, and attend to the genoral health of the sheep, but he must liouse well.

\section{Sheep Berns.}

These need not be expensive struetures, but they must protect thor oughly against wind and drifting snow, and at the same time be well ventilated. The barn is to be entirely enclosed with doors and windows, rwhieh, if made to slide, will serve for ventilation. Along the peak

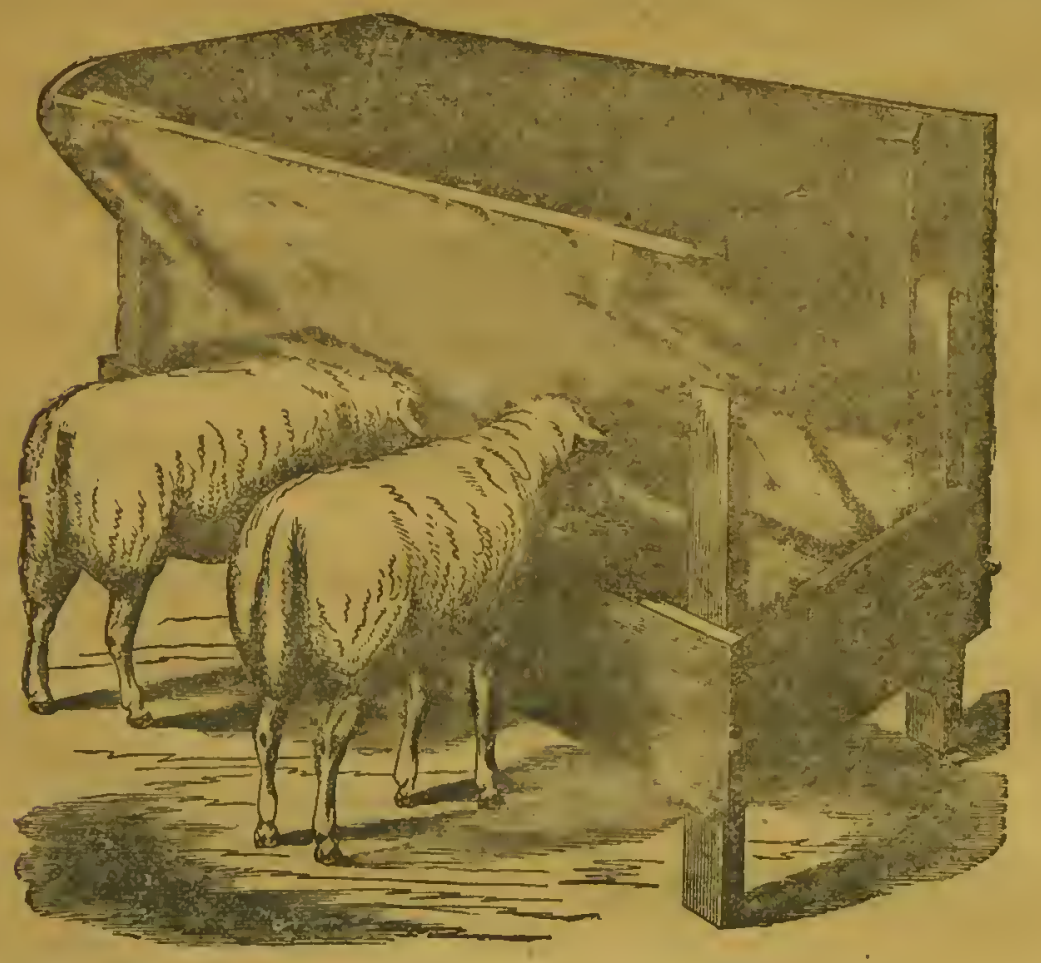

CONVENIENT FEEDING TROUGH FOR BHEEP.

Whould be slatted ehimneys of wood to assist ventilation. The stable should be divided into suitable pens to eontain from twenty to fifty sheep each, aeeording to the size of the floek, with doors from one to the other, racks for feeding hay, and troughs for grain, and for water also, if the sheep are to be wintered in the barn. There should also be suitable passage ways for feeding, ete. The arrangement of these racks, troughs and other eonvenienees, will readily suggest themselves, by referring to the plan for feeding cattle in barns. There is to bo 110 tying up, of 
course, but the same general arvangement way be followed, and when the basenent of a barn is to be used, the bay, grain, ete., miny be baudled in the same manner as there given. 'There is one thing, however, indispensable: As an attuchment to every sheep barn, each pen should have a yard in which the sheep may be turned out in plensant weather, for air and excrcise. They may also be fed here in pleasant weather.

The aumexed cut will show a good and substantial rack for outsido fceding.

\section{Special Winter Food.}

Whils it is the fact that sheep may he fairly wintered on hay, it is not the most economical food in all the regions of the. West and South, whero corn and cereal grains are aleaply mised. Many shepherds object to corn as being too heating. We hive never found any difficulty when it was fed with hay, and with a small feed of roots daily. It scems almost necessary to the health of sheep, that they have sueculent food. In all the $W^{T}$ cst, turnips are out of the question. Our hot Summers, and dry Autumns are not suited to this crop. Swedish turnips do better, since ihey inaj be sown late in May, or early in June and get root, so they

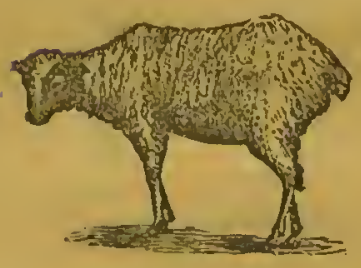

ALLOWVD TO SHIT FOR ITSELF.

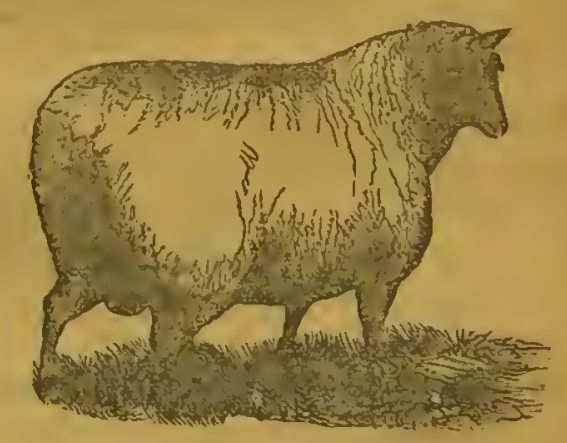

WINTERED WITI GOUD SIELTER AXD FEED.

will stand and produce good crops late in Autumn. They are also easily saved by kecping them nearly down to the freezing point in the winter pits. Sugar bects or mangel wurzel may also be raised at a cost-placed in the pits or cellur-that need not excecd two dollars a ton. Carrots and parsuips may be raised at a cost not excecding three dollars per ion. With carrots, beets and parsnips so that ench sheep may have even balf a pound weight of root food onee a day, they may be kept in admirable health, corn and hay being the only other food. Not only this, but wo have wintered lambs in this way, and had them come out Spring after Spring, in the most admirable condition. Kept in this moner, they wil 
look like the young buck, shown at the right hand side of the page. Allowed to shift for thomselves as lest they may, they will resemble tho sheep shown on the left side of the page. Which would you choose?

There is oue thing that should be observed in feeding roots. Carrota may be fed at all times. In feeding other roots, feed the Swedish turnips first, and after they are gone, the beets. Bcets fed early in tho Winter I have not found profitable. They have an acrid quality, that after the new year seems to be lost. Parsnips may be kept in the ground until Spring, and will be found, in connection with grain, most cxcellent for ewes, after lambing. Until lambing time we prefer to feed carrots, and corn, with enough bran mixed to keep the borrels fairly open. Thus fed, the fleces will be heavy and even in texture. The sheep will not shed their wool rihen put on to grass, and the shepherd, if he has attended to the general health of the flock, will find that shecp realiy pay twice; ouce in the fleece, and once in the carcass.

\section{Management of Lambs.}

It is absolutely necessary, when early lambs aro expected, that a warm place be provided for the ewe at lambing time. The room need not be large, and nay be divided into pens suitable for each ewe whec there are anumber to lamb at one time. Heat the room by means of is stove, and if the ewcs are healthy and hearty they will take care of themselves as a rule. But the shepherd should be present in ease tho young lambs want assistance, and here will be found tho advantage in having inade the sheep perfectly familiar with and relying on the keeper, for thus there will be no fear displayed. If tho lamb appear weak and disinclined to suck, handle it carefully and hold it to the dam. A young lamb is at first the wenkest and nost foolish animal imaginable. Once it Las got on its feet and sucked it is all right.

\section{Doeking Lambs.}

This should be performed as soon as thic lamb is fairly strong, and growing; say when a week old. Let an attendant pick up thelamb, and holding his rump pretty firm against a post of suitable height, tho sheplacrd seizes the tail, and pressing the skin back toward the body, places a two inch chisel at the point of scparation, holding it firmly cncurgh so that it will not slip, when with a light blow of a mallet it is severed. Throw the tails of rams in one pile and those of ewes in another, and enter in the sheplerd's book the sexes and numbers. It is well at the same timo to place a paint mark on tho rump for future resiysition. A pinch os 
powdered copperas on the end of the tail will stop bleeding. Occasionally a lamb will bleed severely. If so, tie a ligature tightly nround the stump, to be removed in about ten hours, or a touch of red hot iron will bo more effective.

\section{Castration.}

Many perform this operation immediately before docking. It has always been practiced by myself and I lave never found any reason to discontinue the plan. In any event the sooner it is done the better for the lamb. I have docked and gelded at three days old, and witl the best success. An attendant holds the lamb, rump clown, and with the back pressed against his own body; drawing the hind legs up, the body is pressed strong enough to cause the belly to be forced between the thighs, and the scrotuin is thus well exposed. Seizing the scrotum the opcrator cuts away one-third of it; talke ench testicle in turn and sliding back and off the enveloping membrane, with a quick jerk the whole cord and connecting tissues suap and come away. The object in cutting : way a part of the scrotum is that it malkes a better surface in shearing. This pulling away of the cord may scem cruel. It is not so; there is almost un bleeding, and the violence of the rupture destlens the pain. It is sometimes necessary to geld an old ram. The best way is to tic a wased linen cord as tightly as possible about the bag, being concful that it is tied entircly above the testicles, and that there slanll be no possibility of slipping of the knot. Thus circulation is stopised and in a few days the etrangulated part will drop aw:1y; or the opeation maly be performed precisely as in the case of the horse. We have however never used any otlier means eitlor witl bulls or rams than that indicated abuve, and with buccess.

\section{Weaning,}

Spring lambs should be weancd early cnough in the Fall so they may become fully accustomed to grass and to grain before Winter sets in. If a corn-field lias at the last cultivating been sown with rye, it will afford nicc feed for lanbs in the Fall, and in the following Spring it will ho found most valuable for breeding ewes. If there is stubble ground, in which green oats or whent have started, it makes excellent pasture for lambs, since they will also pick up some grain. In any event, they should be learned to eat grain by having their salt sprinkled on grain in a trough under cover, so they may learn to eat it. So far as Winter manngement is concerned, the same rulo will apply as to ather animals. Give then 
the best of the hay and a liberal quantity of grain, to keep them growing right along.

\section{The Iursery.}

In all large floeks there will always be some lambs that do not do well. These should always be separated from the others and have extra care. "So in the older sheep-the floek should be graded as to age, size and sex. It is better that the wethers and the ewes be kept apart, and that in the sexes that very strong animals be not put with weak ones. If they do 110 other misehief, they rob the weak ones of their food, the very thing they most need. In faet, every farm should have a nursery, lowever small the floek, where woak ones and wethers may reeeive speeial attention and eare. Sheep upon farms suited to them are very profitable, but however suitable the farm, the profits will be in direet pruportion to the intelligent caro and attention the animals recoivo. 


\section{Diseases of Sheep. CAUSES, PREVENTION AND REMEDIES.}




\section{CRAPTER \&.}

\section{ANATOMY AND DISEASZS OF BEREPP.}

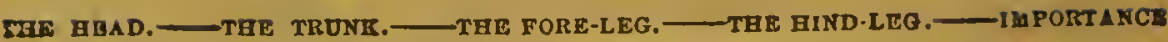
OF THE HEAD TO BREEDERS. — DISEASE3 OF THE HEAD AND BRAYN. THE TERTH.— SWELLED HEAD, - VEGETABLE POISONING. — INFLAMMAMON OF THE EYE.- - SHEEP DISTEMPER.——HOW TO ENOW IT.—WHAT TO DO.—GRUBS IN THE HEAD. - HOW TO SAVE THE SIEEP. - DPOPLEXY. -PREVENTION. - IXFLAMMATION OF THE BRAIN. - TETANUS, OR LOCKJAW.-PALSY.-RABIES.- IIYDATIOS ON THE BRAN. - PARABITES OF THE BODY AND SEIN.—TEE SCAB.—-HOW TO IRNOW IT. — WHAT TO DO. - DISEASES OF TEE GENERATIVE ANB URINARY ORGANS. - DISEASIT OZ THE LIMBS AND HOOFS, —TI AVEL-SORE FEET,- GRAVEL.—-THE BIFLEX CANAL. — MAGGOTX EIERP. - LUNG WORMS, —INTESTINAL WORMS. - ROTTEN LIVER.—COLIO.

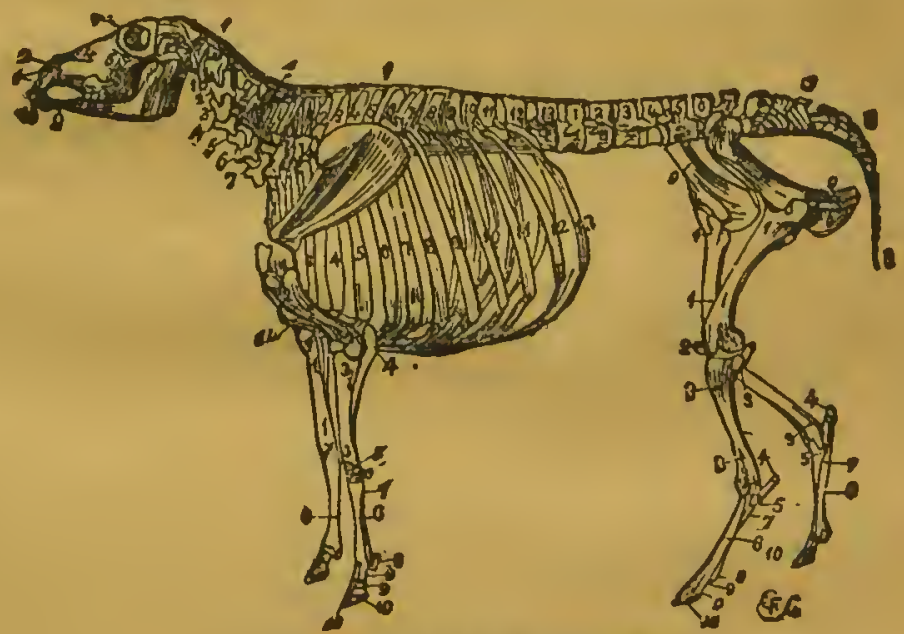

ATCLETON OF LEICESTER BEEEP.

Tho Herd.

Explanation.-1-Tue intermaxillary bone. 2-Tho nasal bones. 3-Tho 325 
upper jaw. 4-The uuion of the nasal and upper jaw bone. 5-The union of the molar and lachrymal bones. 6-The orbits of the eje. 7-The frontal bone. 9-The lower jaw. 10-The incisor teeth or nippers. 11-The wolurg - grinders.

\section{Phe Trunk.}

1,1-The ligament of the neek, supporting the head. $1,2,3,4,5,6,7$ The seven vertebræ, or bones of the neck. 1-13-The thirteen vertebræ, or bones of the back. 1-6-Tie six vertebre of the loins. 7-The sacral bone. $8-$ The bones of the tail, varying in different breeds from twelve to twenty-oue. 9-The haunch and pelvis. 1-8-The eight true ribs with their eartilages. 9-13-The five false ribs, or those that are not attached to the breast bune. 14-The breast bone.

\section{The Fore-leg.}

1-The scapula or shoulder-blade. 2-The humerus, bone of the arm, or lower part of the shoulder. 3- The radius, or bone of the forearm. 4-The uln t, or elbow. 5-The knee, with its different bones. 6-The metacarpal, or slankbones; the larger bones of the leg. 7-A rudiment of the smaller metaearpal. 8-One of the sessamoid bones. 9-The two first bones of the foot; the pasterns. 10 -'The proper bones of the foot.

\section{The Hind-log}

1-The thigh bone. 2-The stifle joint and its bone, the patella. 3-The tibia, or boue of the upper part of the leg. 4-The point of the hock. 5-Tho other bones of the look. 6-The metatarsal bone, or bone of the hind-leg. 7 -Rudiment of the small metatarsal. 8-A sessamoid bone. 9-The two first bones of the foot, the pasterns. 10-The proper bone of the foot.

The bones of the loins bear a strong resemblance to those in the baek, but instead of springing from the sides, as do the ribs, they are fixed, bony procosses, several inches in length, and their peculiar duty is to afford protection to the abdomen. They are the timbers that support the roof, or covering of this part of the system. Next in position to the loin comes the sacrum, which is formed in young animals of separate bones, but at maturity is consolidated into one. At this point the passage for the spinal cord becomes very much diminished, and, at the end of the bone, terminates in several nerves, which continue their eourse into the tail. The bones of the latter are numerous, but not perforated. Wo pass now to the limbs, and find that the number of joint 3 are the same in' the horse, ox, and sheep, but in the latter animals, at the fetloek, these become divided and the four bones beneath it are thus doubled. 
The bone which forms the elbow-ulna does not support much of the weight of the animal, but serves to attacl the powerful museles, so noticnble in bones, with good fore-arms. The attaehment of the ulna to the radins forms a lever. The earpas or knee is eomposed of seven distince bones, plaeed in two rows. The upper low artieulates with the radius; the ractacurpus.

Explanation-1-Oceipital bone, depressed out of dinger. 2-The parietal hones, the zuture having clisappenred, and also out of ranger. 3-The squamous portions of the temporal bone-the buttress of the arch of the skull. 4 -The ineatus auditorius, or

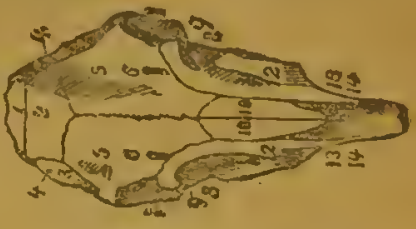

STULL OF A POLLED SUBEP. bony opening into the ear. 5-ihe frontai bones. 6-The oponings through which lolood-ressels pass, to sup. ply the forchend. 7 -The bony orloits of the cye. 8-The zygomatic or molar boncs, very much derelojed. 9, 10-The bones of the nose. 11-The upper jaw honc. 12-The formen, through which the nerve and blood-vessels nass, to supply the lower part of the face. 13-The nasal processes of the intermixillury houes. 14-The palatine processes. 15-'The intcrmaxi!lary bone, snyporting the cartiliginous pad, instead of contrining tceth.

Explanation-1-Nasall bone. 2Upper jaw bone. 3-Intermuxillary bone supporting the pad, supplies the place of upper front tecth. 4, 4The fiontal sinus. 5-Cavity or sinus of the horn, communieuting with the frontal sinus. It is here shown by removal of a scetion of the base of tho

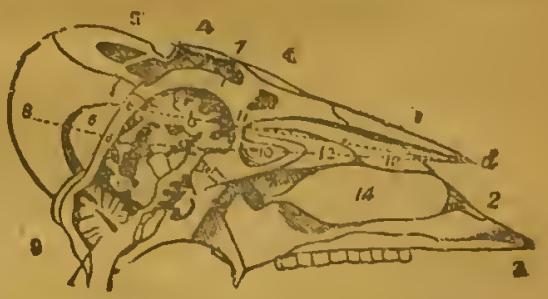

IEAD OF SUEXP-VERTACAL STCTION. horn. 7-The frontal hone. 8-Vcrtical section of the brain. 9-Vertical section of the cerebellum. aThe eincritious portion of the brain. $b$-The medullary poition of the brain. 10-The etlmmoid bone. 11-The cribiform or perforated plato of the ethmoid bonc. 12-The lower cell of the etlmoid bone, 13 -The superior turbinated bone. 14-The inferior turbinated bone. 1 ? -'The sphenoid bone.

\section{Imaportance of the Head to Breeders.}

The head of the shecp is one of the important points by which to estimate the quality and profitableness of the animal. The frontal bone (1) projects both forward and laterally, and gives to the sheep a peculiar 
appearanee as regards breadth of forehcad and prominewce of the eyo. This design of nature is intended for the base of the horns, though in breeds known as hornless, or polled, the samo formation is observable. The rooin from eye to eye is oceasioned by the frontal bones $(5,5$, of polled sheep) reaching as far below the range of vision as above it, and very materially shortening the nasal $(10,10$, ) bones. These reach upward to the parictal bones (2) which latter constitute an important portion of the posterior, slanting portion of the skull, just below the junction of the frontal and parietal bones; the head falls off in fullness-a backward sloping, so to speak, and the part of the frontal bone most important because covering the brain, is removed from the danger resulting from coneussion of the head in fighting. The form of the brain in the sheep, is similar to that of the horso and $o x$, but is longer in proportion to size, and broader in the back than in the front. The brain of the sheep so closely resembles, in its conformation and structure, that of a man, though smaller in proportion, that it furnishes the medieal stulent with a good substitute for the human subject. Tho membrane covering the brain is technically eallod the pia maler. The dura mater lines the skull, and between the latter and the former is a delicate membrame ealled ternica arachmides. The ncrves, of which ten pairs are eonuected with the brain, and thirty with the spinal eord, supply the sense of feeling, seeing, hearing, tasting, smelling; \&e., and a portion ennveying the volition of the brain to all parts of the body, are termed nerves of motion.

\section{Diseases of tho Head and Brain.}

In Europe, and especially in Great Britain, sheep are subject to a long category of diseases. Fortunately, in this country sheep thus far have been subject to eomparatively few discases, and cspecially so in the West; owing probably to the faet that, except in the Spring, and sometimes for a short period in tho Autumn, the elimate and the soil are dry. $\mathbf{M r}_{1}$. Spooner, the able English veterinary writer, lemarks upon the rarity of inflammatory diseases in Americall sheep. This he attributes to the muscular and vaseului strueture of the sheep, comparing the indifferently kept sheep of his day with highly fed British sheep. The real eause, however, of exemption from disease lies more in the elimate than anything clsc. Another special reason prohably is that our flock masters are, as a rule, men of intelligence, who trust but little to ignorant shepherds, as is not tle case in Great Britain and on the continent. We shall thereforo touch lightly upon mony diseases spccially treated of in forcign works, and pay more particular attention to that cluss of diseuses most prevalcat with us, 
The Toeth.

The shep has efght incisors in the lower jaw, and twelve grinders six on a side in each jaw, - making in all thirty-two teeth. At birth the lamb should have the two central incisors just pushing through. At a month old all the ineisors should be up. At one year, sometimes not qntil fifteen months old, the two first milk incisors will be shed, and two y tywo more permanent teeth, or four in all. At three years old past it will have six permanent incisols, and at four years old past the eight permanent teeth, or a full mouth, as it is ealled, will be shown. This will be an aceurate test as to the age of sheep, up to four years, varied of course by care and kcep; highly fed shcep developing fastcr than illy kept ones. At six the incisors begin to decrease in breadth, and lose their fan shape, as seen at four ycars old. At seven they become longer and narrower, and each ycar this shrinkage continues, until at last they becoine quite slender, the middle oncs long, and at ten years they loosen and begin to drop out. In the West fer sheep are kept to the age of ten years, except in the case of valuable ewes and bucks. The principal care necessary with the teeth is, if decay is suspected, to examine, and extract the decayed ones, or picrce the nerve with a hot irom.

\section{Swelled Head.}

Sheep sometimes are bitten by venomous snakes, but this seldum occurs, and when so the animal is usually beyond help before being found. The bites of insects however, sometimes give trouble. Whien s.welling from this cause is discovered, eut the wool from sround the wound, wash with warm water, dry, rub thoroughly with lard oil, and if the insect may have bcen a venomous one, give the following dose each hour until relief is obtained:

No. 1.

$$
\begin{aligned}
& \text { 3 Scruple hartshorn, } \\
& 1 \text { Ounce rainwater. }
\end{aligned}
$$

Vegetable Poisoning.

The faces of the sheep sometimes become poisoned from feed ding inar noxious plants. Bathe the sore place with warm water. and ther moisten with the following ?

No. 2 
This is also excellent for burns, bruises, irritable and moist ulers, in flamod tendors, moist skin diseascs, and crucked and itching surfaces, and also for sore lips.

\section{Inflammation of the Eyes.}

Simple ophthalmy sometimes occurs in shcep. If there is serious inflammation, bleed slightly from the facial vein-the vein running down obliquely from the eyc, and bathe with the following:

No. 3.

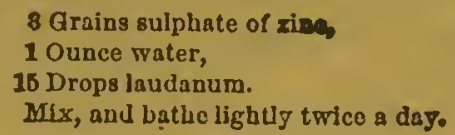

\section{Sheep Distemper.}

Malignant epizootic catarrh is an epidemic accompanicd by screre congestion and inflammation of the lining membrane of the nasal cavities and sometimes extending into the stomach and bowels, is as to its causo unknown, but has occasionally bcen very fatal, both East and West.

\section{Iow to Know It.}

There is depression, a slight watery discharge from the nostrils and the eycs, which are partly elosed and palcr than natural. There is mole or less lnss of appetite. The pulsc is normal as to frequeney, but is weaker than usual. There is no cougl, and the breatling is not changed unless the bronchial tubes arc affected. The symptoms inerease, until the cnd of a week the discharge from the noso is thick and glutinous, some. times tinged with blood; cycs half closed, the lids gummed with a yellow sccretion. The respiration is difficult, emaciation and prostraticn great; the pulse very low, the appetite is gonc, and in from ten to fifteen days the animal dies.

\section{What to Do.}

At tho first symptoms, remove the sheep to a dry, wcll ventilated place, where they may be kept comfortably warm. Give them eonecntrated and nourishing food and stimulants. If the bowols are costive. give them, say:

No. 4 
Simmer the last thrce in a quart of watcr for ten or fifteen minutes; strain, and add the first. Give two table-spoonfuls twice a day. In any case, avoid all strong purging or bleeding. An equable warmth, good feeding, nourishing drinks, and good nursing, is what will save, when possible, if taken early. If not well nursed the patient will be sure to die.

\section{Grubs in the Head.}

In July and Augrast, if shecp are seen standing crowded together with the heads close to the ground, oecasionally stamping violently, or striking with their fore feet, be surc the sheep gad-fiy OEstrus Ovis, is attempting to deposit her eggs in the nostrils of the sheep. This fly is somewhat like the ox gad-fiy, but smallor. The egg dcposited, the maggot soon hatches, aseends the sinuses of the nose, causing much irritation. Then it grows during Winter, and in the Spring descends and falls on the ground, burrows thcrcin, assumes the form of a chrysalis, to be again transforused into a perfect fly.

\section{How to Bave the Sheop.}

Prevent the flies from laying thcir eggss. Plow a portion of the field mto furrows of loose soil ; kecp the sheep's noses smeared with tar, by tarring once a day through the season of the fly. I have caught them in a light bag net, such as boys use in eatching insects. A rcward of five ccnts for evcry fly caught would well rcpay the sheep owner.

The maggots affix themselves by their strong hooks, and arc not easily dislodged. Violent sneezing will somctimes dislodge them. Thus Scotch cnuff may be blown up the nostrils. The infested sheep may be driven in a close placc, and horn shavings or leather burned to irritate the memirane of the lostrils. A bctter way, when carefully done, is to securc the shccp, hold the head up, and pour into each nostril a tcaspoonful of equal parts of sweet oil and turpentinc, well shaken together. Bo careful, however, that the shecp is not strangled by the mixturc entering the lungs. The grubs are sometimes extracted by the surgeon. It is a nice operation, and as a rule will not pay its cost.

\section{Apoplexy.}

This is a disease scldom seen in the United States, and confined to shecp of a plethoric habit, and is generally fatal if not taken carly. Tho shcep leaps suddenly in the air, falls and dies in a fow moments. Tho remedy is carly and copious bleeding from the neck (jugular) vein, until 
the sheep shows signs of weakness. A pint of blood is somctimes taken from full-bodied, large shcep and less for smaller ones.

\section{Prevention.}

This is better than eure. If a sheep be dull, and apparently unconcious of what is going on; if the membranes of the nose are deep red or violet, the nostrils and pupils of the eye dilated, the pulse hard, and the breathing stertorous, bleed immediately, and afterwards give two ounees of salt, to be followed by an ounee every six hours until a eopious svacuation is produeed.

\section{Inflammation of the Brain.}

This is a secondary effect of the eauses which produce apoplexy. Tho animal is dull and inaetive. The eyes are red and protruding, and at length the animal rushes about in the wildest delirium. The same remedy is prescribed as for apoplexy.

\section{Lock-jaw.}

This is produced from a variety of eauses, among the more common, being inflammation of the membranes from improper gelding, injuring the hoofs, horns, etc. The animal is unable to walk, or only so with diffieulty; the jaws are set, and death ensues in a short time. Warmth, quiet, and bleeding from the jugular vein, is recommended. We should omit the bleeding and give one-half to three-quarters of an ounee of castor oil, according to the age of the sheep, tho disease being confined mostly to lambs, and sheep after gelding. Follow the dose of castor oil, in half an hour, with ten grains of opium, and at the end of an hour, give another ten grains of opium if a deeided sedative effect is not produced. Epilepsy is a kindred diseaso, in faet tetanus is considered to bo an aggravated state of epilcpsy. The remedial means will be the same.

Palsy.

This is the opposite of epilepsy. The sheep is unable to move its limbs. It is supposed to be produeed by cold and impropor treatment. It is rare in this eountry. Take the lamb to a warm plaee, give it warm gruel, with a little ginger mixed in it. If a purgative is indicatedgive:

No. 4

2 Oz. epsom Balts,

\% Drachm ginger.

Mix in half pint of ale or water: to be followed by two drachms of laudanum in an tour. 


\section{Rabies.}

Sheep are apt to be bitten by rabid dogs. The only preventive is to kill all strange or suspiciously acting clogs. The remedy is to kill the sheep as soon as attacked. The perils atteuding treatment, aud the hopelessness of the casc, dietate this course.

\section{Hydatids on the Brain.}

This is a discase of rare occurrence in America, probably from the fact that range is greater and dogs fewer to the square mile. 'The disease once fixed, nothing, practically, ean be done, at least except a thorough veterinary surgeon be ealled, since it involves a delieute surgical operation. The bladder worm or hydatid is a form of the tape worm of the dog, in an earlier stage of existance. The mature tape worm lives in the bowels of the dog, its eggrs are voided with the exerement, and in close pasturage the sheep take the eggss while grazing; hatehing, they make their way to the brain, where they grow, and nust remain until eaten by some other animal. Thus the dog eats the sheep's head, aequires the tape worm, and the inseet again goes its round of life. Allow no sheep's heads to bo eaten without thorough eooking, kill all strange dogs, and give your shepherd dogs a good vermifuge oceasionally.

One of the plans adopted to get rid of the hydatid when it ean be loeated is to picree the eyst with the needle of a strong hypodermic syringo, and inject into it half a tea-spoonful of the following:

No. 6.

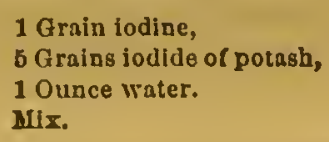

\section{Parasites of the Body and Bkin.}

Sheep are infested with lice, three different forms of parasites which produce scab, also with ticks, intestinal worms, parasitcs of the liver, lungs, etc.

\section{The Scab.}

This is produecd by a minute, almost microseopic insect, which burrows under the eutiele, produeing intense irritation, the esenpe of serum, und which drying, brings off with it wool and all, and, spreading with great rapidity, soon infests the whole flock. The tenacity of life of these insects is so great that a seabby pacture has been said to spread the eontagion after three years. The prevention of infection should be imperative with every flock master. 
How to Know It.

The sheep is restless and constantly rubbing itself against posts and other objects it ean get near. It bites itself with its teeth, and scratches itself with its hoofs. Soon the fleeee becomes ragged and begins to fall out, aud the animal appears wretehed and unsightly, and at length dies

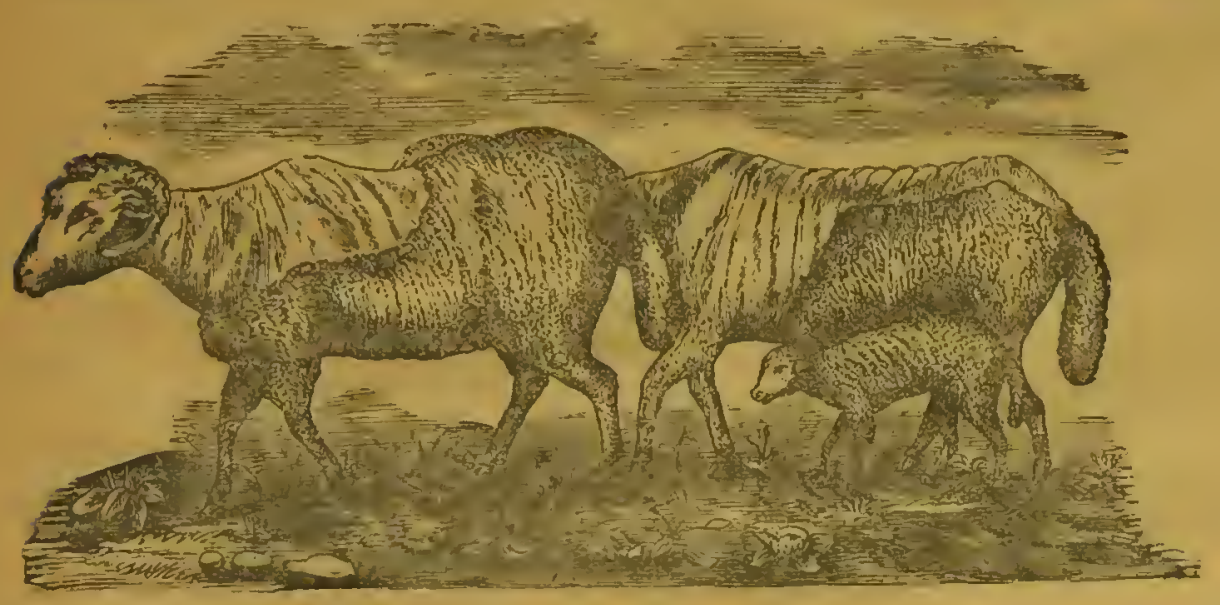

A BAD CASE OF SCAB.

What to Do.

The remedies are both liquid and oily. A good dip, and ono ro garued in England as most effcetive, is the following:

No. 7.

$$
\begin{aligned}
& 3 \text { Pounds arsenic, } \\
& 3 \text { Pounds pearl ash, } \\
& 3 \text { Pounds sulphur, }
\end{aligned}
$$

3 Pounds soft soap.

Mix in ten gallons of boiling water, stir, but aroid the fumes, and add nincty gallons of eold water. Prepare a tank that will easily allow a sheep to be dipped, having a slanted, slatted drain at tha side, tight bot tom underneath to allow the drip to run back. Dip the sheep, back dowu, being careful not to allow tho head to enter the poisonous mixture, letting the aninal remain one minute. Lift on to the slats and rub and squeeze the wool, until pretty well drained, and place in a yard until dry. When dry, go over the flock again. as to the heads, with the fol lowing :

No. 8. 
Mix the mercurial ointment witn the lard by heating gently and stir ring. Dissolve the resin in the turpentine and rub all together when the lard is cold. Part the wool on the head between the ears, on the fores head, along the neck and under the jaws, and rub in the ointment.

In the Unitcd States, tobacco is often uscd in the place of arsenic; if used, substitute tell pounds of strong tobacco leaves for the arsenic in the formula as given above.

A formula in great repute among Australian shepherds, is the following:

Nio. 9.

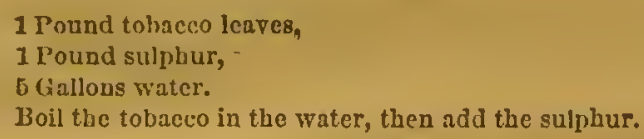

The sheep is dipped in this solution while quite hot, and retained in it four or five minutes, its head being from time to time thrust under so as not to enter the eyes, nose, or mouth, and the wool pressed and dried as before stated.

\section{Diseases of the Goneretive and Urinary Organs.}

Use the remedies prescribed for enttle, noting the doses as given for sheep in the list of medicines for aninals.

\section{Diseases of the Limbs and Hoofs-Foot Rot.}

This is an infcetious discase often aggravated by grit and dirt increasing the inflammation. The indieations of rot are described minutely by Dr. Randall :

The first symptom is the disappcarance of the naturally, smooth, dry, pale condition of the skin at the top of the cleft, over the heels. It becomes somewhat red, warm and moist, and slightly rough or chafed. Next, the moisture increases to a discharge, and an uleer is formed which extends down to the upper portion of the inner wall of the hoof. These walls are then attacked, become disorganized, and the discasc penetrates between the fleshy sole and the bottom of the hoof. The hoof is thickened at the heel by an unnatural deposition of horn. The crack betrreen it and the fleshy sole pours out an offensive and purulent inatter. Soon all parts of the foot are penetrated by the burrowing ulceration, the horny sole is disorganized, and the fleshy sole becomes a black and swollen mass of corruption, shapeless, spongy, and often filled witl maggots. Tho fore-fect are usually first attackod; lameness is early noticed and soon 
becomes eomplete: the appetite is lost, and the animal dies from exhaustion. 'The offensive odor of the true foot rot is eharaeteristic, and once made familiar will serve as a certain guide in recognizing the disense. The disease may present itself in a malignant and rapid form, or in a mild one. The first attack on a flock is generally of the severe eharacter. When it is kept under the first year, its appearance the next Summer will be mild; and the third season still milder.

\section{How to Cure Rot.}

Every part of the disensed structure must be cut away, cleaning the knife from time to time. This thoroughly acromplished, prepare a tauk, which is to be filled to a depth of four inches, with a strong, saturated solution of sulphate of eopper, blue vitriol; let each sheep stand in this, heated as hot as they can beal, for ten or more minutes, keeping the wlole hot by oeeasicnally plashing a piece of heated iron in it, or adding a quantity of the solution boiling, hot. It is also well to eover the hoof with ehlorice of lime, and fill the cleft of the hoof with a piece of tow long ellough so the ends ean by twisted into a cord to be fastened around the fetloek. . This makes a good bandage. The hoofs should be examined daily for sometime and the ehloride renewed if necessary. Keep the sheep in a dry, well-littered yard, or on a dry, short pasture, and feed well. If the ease is bad, the following tonic given internally will be necess3ry :

No. 10.

$$
\begin{aligned}
& 2 \text { Drachms common salt, } \\
& \text { 3 Drachm sulphate of iron, } \\
& \text { K Drachm nitrate of potash. } \\
& \text { Mix as a powder and glve daily. }
\end{aligned}
$$

\section{Fouls and Travel-sore.}

These may be cured, the first by washing the eleft of the hoof with warm water and applying a strong solution of blue vitriol, and the latter by touching the thin plaees in the hoofs with a feather dipped in oil of vitriol, and smearing over with tar. Or better, prepare the following lotion and use occasionally:

No.11. I Part solution of chloride of antimony,

2 Part compound tincture of myrrb.

Gravel.

Sheep often become graveled. If lame in the least examine them, and wat the lorn of the boof to expose the gravel; extract it and cover tho wound rith tar. 
The Biflex Canal.

The issue as it is ealled (biflex canal) in the front and upper part of the hoof, sometimes beeomes irritated and swollen. Do not follow the savice of ignorant persons and "eut out the worm." If any thing is embedded therein, extraet it. If simply swollen and inflamed, and perhaps ulecrated, lance it in two or three places slightly and dress with compound tinctur's of myrrh.

\section{Maggoíy Sheep.}

Often in hot weather, from one cause or another, flics will lay their eggs, either in a wound, or, if the sheep is dirty, in the aceumulated dung about the thighs. The prevention is eleanliness. Keep the sheep well tagred. that is shear the wool from urier the sides of the tail, and diagonally thence some ways down the thighs. If maggots exist they must be taken out, and the wounds touehed with

No. 12. 1 Part creosote, 4 larts alcohol.

And afterwards bathed daily, until relieved, with tincture of myrrk.

\section{Othor Diseases.-Jung-Worms.}

This diseasc is eaused by the presence of worms, the strongulus filaria, which sometimes make their way into the lungs, but are usually found in the windpipe and bronehial tubes and bowels of sheep. If there is dysentery, with fetid stools, examine the evactations and the mueus of the mouth and throat for indieations of the worms. If there is a husky cough and quiekened breathing; if the sheep rulss its nose on the ground; if it lose its appetite and flesh prepare the following:

No. 13.

$6 \mathrm{Oz}$, sulphate of mngnesia, $4 \mathrm{Oz}$. nitrate of potash.

Pour on these three pints boiling water, and when the solution is mils 5arn add:

No. 14. $4 \mathrm{Oz}$. oil of turpentine, Y $\mathrm{Oz}$. bolo armenisc.

Mix well and give two or three tablespoonfuls every other day.

When the worms are supposed to prevail, the following may be made into twelve doses, one to be given once in two weeks, as a preventives

No. 16.

20z. oll of turpentine,

$2 \mathrm{Oz}$. powdered gentian,

2 Oz. laudanum.

This is enough for twelvo sheep. 


\section{Intestinal Vorms.}

The presenes of intestinal worms and other parasite affections may b3 often found if bhepherds would take the trouble to dissect a dead sheep. When found in one, tho presumption is good that inany are laffected, for these parasites seldom appear in individual cases only. As a preventive, when feared, plenty of salt should be allowed, and the following prepared to be given once in two weeks.

No. 16.

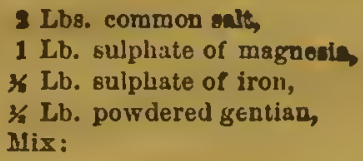

This is sufficient for 80 to 100 sheep to be given in ground feed.

Dr. Tellor says: Ordinary wood soot, as it can be collected from the chimney is a very efficient vermifuge, often used, both in children and the lower animals. It may be mixed with salt, or sprinkled on the fodder. Another cheap and useful vermifuge, in the form of a drink, is-

No. 17.

1 Lb. quick lime,

b Oz. sulphatc of iron.

Mix with five gallons of water, and give a pint twice a week.

As a rermifuge in round and thread-worms, the shepherd may use-

INo. 18

2 Oz. linseed oil,

* Oz. oil of turpentine.

For a drench.

For tape worm, the following :-

No. 19.

* to 1 Drachm, powdered areca nct, 10 to 20 Drops, oil of small fern.

Give in molasses and water, and follow next day with a purgo.

The Rot, or Liver-Fluke.

This is a disease caused by flat worms, (Fasciola hepatica,) in the liver. If by rubbing the skin of a sheep backward and forward at tho mall of the back as taken between the thumb and fingers, it is soft and flabby and there is a crackling feeling in the fingers, as if there were water underneath : if there is weakness and tenderness about the loins; if the belly swells, and the eye becomes jaundiced; if there is a diarrhea, a weak heart and general stupor, and no veterinarian is near, isolate the animals in a high dry pasture, give abundant and nutritious food and prepare the sollowing: 
I. \& 2

3 Lb. Bulphate or magraesla, 3 D:achras oil of turpentine.

kif for \& kreach, sad give erery two days, ono-thind of tho quantity ct a duso.

\title{
Tho following is as Frylish remedy and said to bo very effectivo:
}

No. 22.

\author{
13. Drachms yellow resin, \\ 1 Oz. oil of turpertine, \\ 10 Orasna calcmel, \\ 20 Dropa tincture of lodine.
}

For three desss, ono to be given ercry morning for threo dayg, in gruol.

Cotio.

Tho bast prorsitito is to kecp sheep off of pastures liablo to inundation, cince the worm issecs one stage of its existazco in shell fish and water insecta, which cre carried into such pastures by floods, and the sheep get the germs rith ise grass.

Lish pistlro to hurgry sheep, ergot in fodder, wusty or blighted gra n, will proculuce colic or hoven in sheep as in cattls. The presence of grs is sometimes so strong as to rupture the walls of the rumen or third Etomach. If the cos? is not evrious, press and lnead the stomanh, ard give the following :

20. 22

3 Dracbms sulphate sif potash,

$10 x$. cominon salt,

$1 \mathrm{Oz}$. oweet oll.

Mis ta a wine glass full of water,

If the infation is great, get $a$ rubber tube, of Lalf inch calibre, fiaten a pledget of wool over the end to prevent clegging, oil thoroughly and introduce gently down the thront to the stomach. If this moans fail and the swelling continues, remove the wool from the most prominent part and plinge a trocar into the stomach. If a troenr is not to be had use a common sharp pointed pen knife, ard keep the oswice open by inserting a govoso quill. 



\section{SWINE。}

\section{HISTORY, BREEDS, CHARACTERISTICS}

AND MANAGEMENT. 


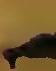

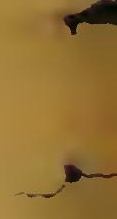

I

$-$

$-$ 


\section{SWINE.}

\section{Elistory, Breeds and Characteristics.}

\section{CHAPTER I.}

\section{IISTOEY $\triangle$ IND EREEDS.}

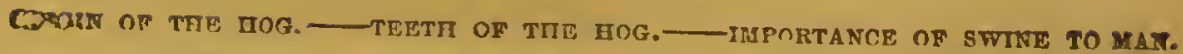
-I. IMPTBOVED BILEDS OF SWINE. 一 ENGLISII BREEDS.-11. TIE BERKSIIIRS - ESTABLISHING THE IMPROVHD BERKSHIRE. - STANDARD CHARACTERIS TICS OF BERKSUIIES III. NEAPOLITAN ROGS. -1V. ESSEX BREED.—-V. YORKSIIRIS HOG. - VI. SUFFOLKS.-VII. LANCASHIRE HOGS, - VIII. LANCASUIRE MIDDLS-BREED. -IX. LARGE I $\triangle$ NCASTIRE. - AMERICAN BREEDS.-X. PN UAND CHINA.—XI. CIVSTER WIITES. - XII. JEMSEY REDS. - CHESHIRES. - XII. CHARAOTEIISTIES. - RECAPITULATION OF BRLEDS.

\section{Origin of the Hog.}

The great antiquity of the hog, sus scrofa of Linnæus, is fixed from the faet that remains of several fossil speeies have veen found in the tertiary and diluvial deposits of Europe, and allied speeies in India. The wild hogs, from which the domestie breeds have taken their rise, are native of Europe, Asia and Afriea, and are found wherever the elimato is mild enough to aftord sustenanee in Winter, and in a domestie state wherever eivilization has been extended. The faet of the origin of the domestic hog is well established from the faet that it will interbreed and continue entirely fertile, the sueceeding fertility of the offspring, to the romotest gonerations, proving the homogeneity of the species. 
In America, in Australia and in the Polynesian group, hngs were unknown until introduced. In England the wild species lias long been extinct. In France they are nearly so, but in some parts of Germuny, Denmark, Italy, Greece, and in Asia Minor they are will niet with. In Ameriea swine are saicl to lave been introdueed into Hispaniola by Columbus in 1493; into Florida by Do Soto in 1538; into Nova Scotia and Newfoundland in 1553, into Canuda in 1608, and into Virginia in 1609. So great was the fecundi'y of swino in Virminiun forests, that in cighteen years after their introdiction the inhabitants of Jamestown Lind to palisade the town to kecp tham out.

\section{Tueth of the Hog.}

The domestio hog has, when full grown, forty-four permanont teeti, twenty-eight of which aro preeded by temporary, or milk teeth. 'íio teeth are classified as follows: 'Lwelve incisors or front tecth, six in tlo upper and six in the lower jaw. The incisors in each jaw are divided equally, thiee on each side of tho medion line, of which the forcmost are ealled the nippers; the nest outside of these, intermediary incisors, and the remainder, outside of these wre called enrner incisois. Next in order are the four tusks, one on each upper and one in each under jaw on each side. The true grinders or molars are six in number, not including the so-ealled "wolf tceth," four in number, but which aro now classed with the molars, making really seren on a side in each jaw. Each of the three hinclmost molurs in tho four rows are permanent teeth, or not preceded by milk teeth. The three next in frout of these ilyear 600: after birth, one after another, and are called milis teeth (or premolars) and in the course of time are shed one after another, in the order in which they appeared, to give place for tho permanent molits. These sis ralars a:e counted from tho hindmost one forward. The seventle molas tooth, or the fourth premolar, apyears later, in the space lietween tho third premolar and the tusk. This small, npparentiy superumerary tootin is sometimes called a rolf's tnoth, and was once considered as at independent tooth, not belonging to the molirs. It is now elassed with ing molars, to which it undoub.edly bolongs. It is a permanent toot!, and is sometimes very small and imperfect, which is accounted for ly tho penr proximity of the large and strong tusk.

The teeth of the hog way therefore be represcuted by tho followin? formula: Ineisors, six upper six lower; eanines, one upyer one lower on euch side; wolf teeth, so-called, now deternined to be molars, nno uppe: one lower on each side; inolars, six upper six luwer on each side; in ald 44 teeth. 


\section{To Tell the Age of Swine.}

Furstenturgr, a well known German authority, has given the following cismmary for determining the age of swine:

The animal is born with eight teeth-four corner meisors and four tusks.

Un the eighth or tenth day appears the seeond or third temporary Rciolar.

At four weeks old the four nippers appen-two in the upper and two in the lower jaw.

At the fifth or sixth week the foremost temporary molars appear in the upper and lower jaw.

At the age of three months the intermediary ineisors have appeared above the gums.

At the sixth month the so-called wolf's teeth will have appeared; and at the same age appear the third permanent molars.

At the ninth month the following teeth will have appeared: xamely the permment eorner ineisors, the permanent tusks, and also the second permanent molars.

At the twelfth month the permanent nippers will be in view.

With the twelfth and thirteenth months the three temporary molars will have been shed, and their pernanent substitutes, which, at fifteen months of age, will have fully appeared, are now just cutting through the gums.

With the eighteenth month the permanent intermediary ineisors and the hindniost permanent molar will have made their appearanee; and with the tiventy-first inouth, they will be fully developed.

\section{Importance of Swine to Man.}

- Next to cattle, swine are the most important to man as an article of food. In the adaptability of pork for suceessfully standing long voyages, either barreled or smoked, in the value of lard for various eulinary, lubri. cuting and burning purposes, its place could not easily be supplied now.

As showing the inpo:tance of swine breeding in the United States, the following table is given, extending from 1871 to 1878 inclusive:

$1871-29,457,500$,

$1872-31,796,300$,

$1873-32,682,050$,

$1874-39,860,900$.

$$
\begin{aligned}
& 1875-28,062,200, \\
& 1876-25,726,800, \\
& 1877-28,077,100, \\
& 1878-32,362,500
\end{aligned}
$$

In the year 1878 the three greatest hog producing States wero Iown, 
Ohio and Illinois ; of these Iowa contained 2,244,800; Ohio, 2,341,411, and Ilinois, 3,355,500 hogs. In 1878 there wcre preked in Chicago alone over 5,000,000 swine, or one-sixth the whole number raised in tho United States.

\section{Improved Breeds of Swine.}

To the India hog, the Chinese and the Neapolitan is due more than to any other, the improvement in English broeds, and from those introduced into the United Statcs are due our own American breeds, that havo now beeome unexcelled in any quarter of the globe for tho purpose for which they are intended; early maturity, aptitude to fatten at any age, and ultimate weight of the mature animal. Of these the Chinese hog hae given great fattening proponsitie:.

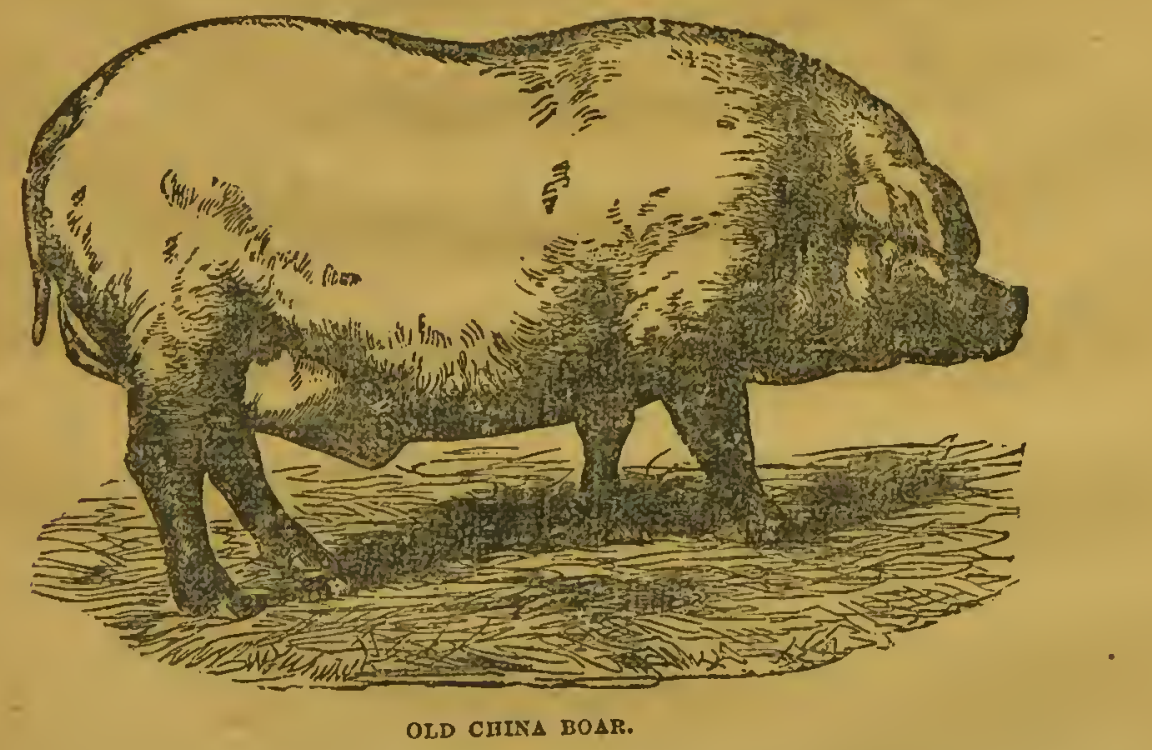

The illustration we give will show first, the appearance of the boar a known years ago, and on the next page the sow. This breed has had a very marked influence as one of the bases of the Poland-China breed of tho present day, and is said to have been introduced in the West, in Ohio, in 1816.

Civilization in China antedates that of all other nations. Henco it is quite probable that the systematic breeding of swine among that people antedates that of other ancient nations. This again is proved by the prepoteney of the blood of this hog. It has formed the basis of im 
provement in all our modern breeds, both in England and America. In England its prepotency lias been strongly felt in all the breeds and has transferred the long-legged, course-boned, elephant-cared, and big-teuled - wine of Old Encland into the deep-bodicd, broad-neeked, short-nosed, compact, and early-maturing Berkshire, Essex, Suffolk, Small Yorkshire and other representativo breeds, which have been further impas:ea by tuo

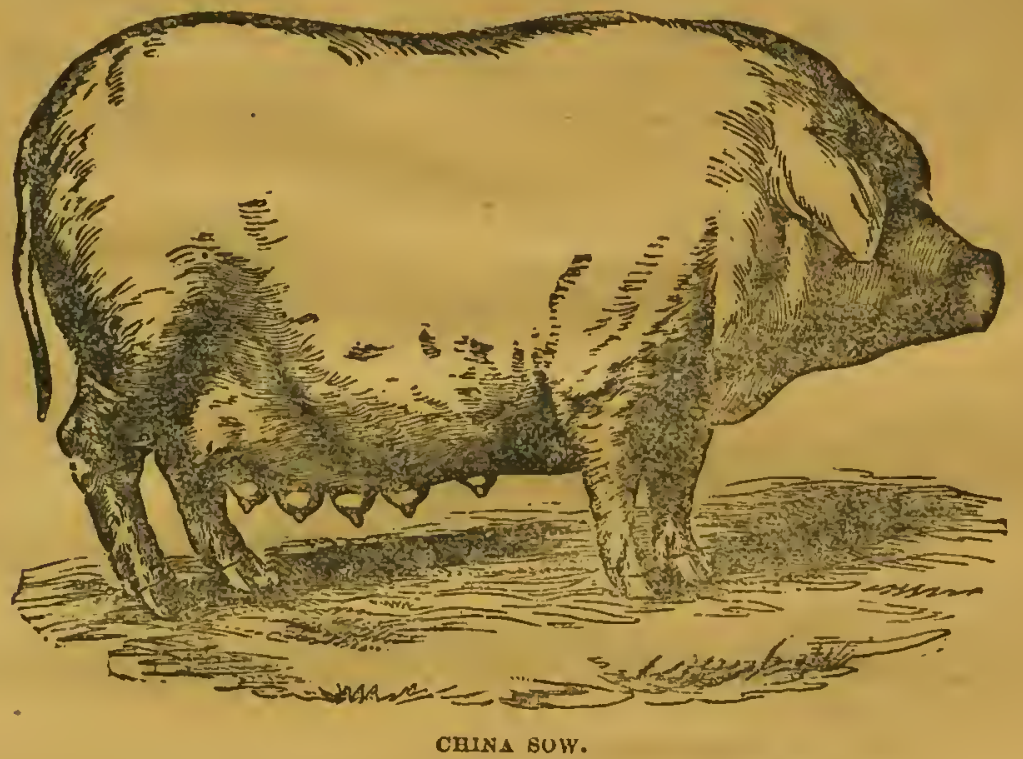

Infision of Neapolitan blood, redueing the hair, lice and bone until ron but little more is to be desired: And in our own conntry it has given uz the Poland-China, Chester whites, improved Cheshires and New Jersez reds, - breeds which may compete most furolabiy with any others ia the United Statc:-

\section{Inglish Broedy-Tho ßerlishirce.}

Tnis now magnificent breed has been bred in Brrlshire, England and in adjannnt countries from a very early day. Their origin is thus reprerted: The family of hogs in Berkshire, Englund, which was the foundation of tha present improved breed, was of a sandy or buff eolor, about equaly spotted with black; was of a large size, a slow fecder, and did not fully mature till two and a half or threo years old. But as such it was very highly estecmed for tho proportion of lean to fat in its meat, and for the superior woight of its hams and shoulders, thas rendering the wholo carcass poculiarly fittod for smoking, for which purposo it was suid to 
excel all other English brecds. The improvennent is reported to have commenced somctime during the last ccitury, through the importation and crossing on the females of a Siamcse boar. This breed was, iu color from a jet black to a dark slate, or rich plum color; of nicdium size, quick to mature; very fine in all points, with short, small legs and hcá; thin jowls; a dished face ; slender, crect ear's ; broad, decp, compact body, wcll ribbed up; extra heavy hans and shoulders; a slender tail; thiu skin, and firm, elastic flesh.

\section{Establishing the Improved Berisshire.}

After using the Siamese boar in Berkshirc to the old style of females as long as it was considered best, he was discarded, and the cross pigs then bred together. In 1838 as wc and others bred this swine in Illinois, thcy were in eolor a deep, rich plun, with a slight flecking on the body, of white, or buff, ol a ulixture of the two; having a small blaze in the face; two to four white feet, and more or less white hair on the tail. The plum color was preferred to the blackor slate, becanse it carried rather higher style and higher points with it, and a supcrior quality of flesh, softer hair, and fincr skin. Since that time the Berkshircs lave becn much iuproved in style and compactucss, but probably uot in excellent meat points. In lean meat in the bacon pieces, and in superior lams and shoulders, they excel all other breeds. It must be acknowledged, bowever, they were always somewhat harder feeders than the best of the very fat breeds.

\section{Btandard Characteristics of Berkshires.}

The following may bo accepted as a standard of eharacteristics and (narks: Color black, white on fect, face, tip of tail, and occasional splash of white on the arm. While a snall spot of whitc on some other part of the body does not argue an impurity of blood, yet, it is to bo discouraged, to the end that uniformity of color may be attained by brecders. White upon the ear, or a bronze or copper spot ou some part of the body argues no impurity, but rather a reappearing of original colors, by revcrsion. Markings of white other than those named aborc, are suspicious, and a pig so marked should be rejected. Face short, fine and well dished; broad between the eyes; ears generally almost erect, sometimes inclined forward with advancing age, always smal-, thin, soft and showing veins; jowl full ; neck short and thick; shoulde: short from neck but moderately decp from back down; back broad and straight, or very little arched; ribs long and well sprung, giving rotundity 
of body; short ribs of good length, giving brendth and levelness of loin; hips good length from joint of hips to rump; hans thick, round and

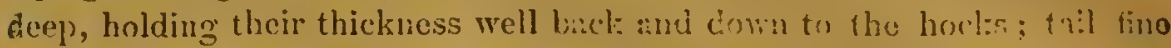

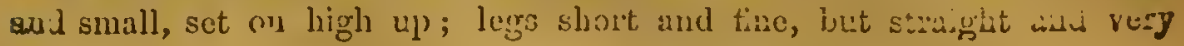

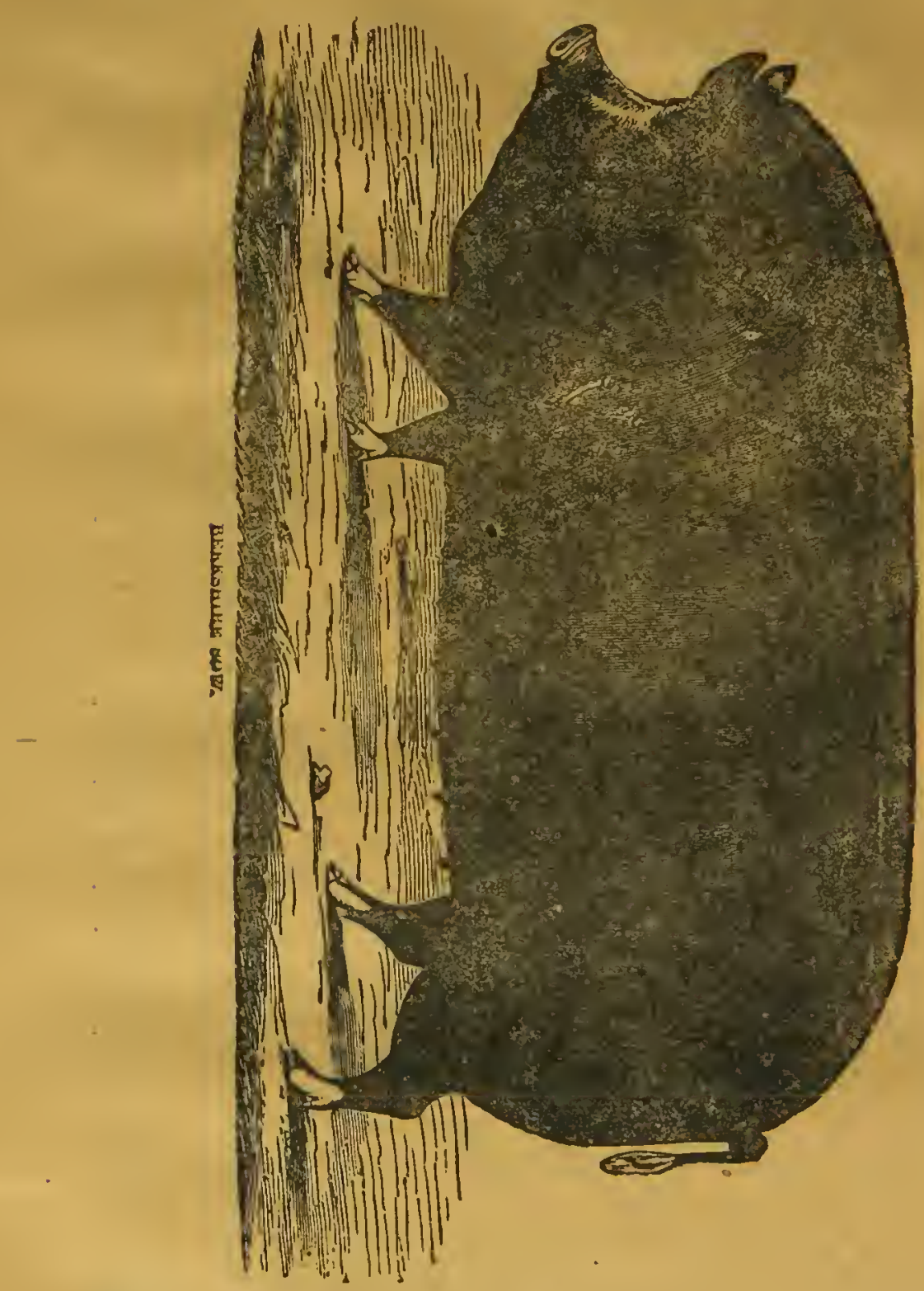

etrong, with liowfs erect and legs set wide npert; size medium ; ienot a mediurn, sinee extremes are to be avoided; lone fine aud compict; ots very light; hair fine and soft: no bristles: slin pliable. 


\section{Neapolitan Hogs.}

Sidney, in writing of the Neapolitin pig, says: "The Neapolitan pig fis black, or rather brown, without bristles, eonsequently delicate when tirsi introduced into our northern climate. The flesh is of fine grain, and tho fat is suid to be free from the rankuess of the coarser tribes." Referring to the supposed descent of the breed irom the wild har of Europe, he adds: "It is more probable that the Neapolitans are the deseendants of the darls Eastern swine irnported by early Italian voyagers and eultivated to perfection by the farorable climate and welcome food." Neapolitan pigs have been for many yoars frequently taken to England. Martin eredits the great improvement in English swine, which his talken plaee withiu thirty years, chiefly to the agency of the Neapolitan and Chinese breeds, a ajointly, or to either aloue. He names especially the Essex, H:tmpshire, Berkshire and Yorkshire, and to these Youatt adds the Wiltshire, and enforces Martin's tatement as to the Berkshire and Essex. Their earliest introduction into the United States was in 1840-41. They seem, however, not to have been woll bred specimens. About 1850 a Mir. Chamberlain of Red Hook, Now York, made an importation direet from Sorrento. They were all of a dark slate color, and their pigs were l.ke themselves and none with white, ash or drail eolor on them. The following may be aceepted as a perfeet description of this breed and their points :

Head sinall : forehead bony and flat; tace slightly dishing; snout rather ling and very slender; cars small, thin, standing forward nearly horizontally, and quite lively; jowls very full; neek short, broad and heavy above; trunk long, cylindrical and well ribbed baek; baek flat, and ribs arching, even in low flesh; belly horizontal on the lower line; hind-quarters higher than the fore, but not very mueh so; legs very fine, the bones and joints being smaller than those of any other breed; hams and shoulders well developed and menty; tail fine, curled, flat at the extremity, and fringed with hair on each side; generial color slaty, or bluish plum color, with a cast of coppery red; skin soft and fine, nearly free from hair, which, when found upon the sides of the head and behind the fore legs, is black and soft, and rather long; flesh firm and elastic to the touch.

\section{The Eseex Broed.}

It is well known that the Neapolitan was a prime integer in the improve ment of the Essex breed of swine. In eomparing speeimens of the two brceds one can see plainly the cross of a broad, deep, gross feeder with an animal of great deheacy and refinement-the cross proving, whon 
Calished, to combine those qualities which are of greatest value in the parent breeds, and bcing capable of imparting them to crosses with broods less finciy organizer

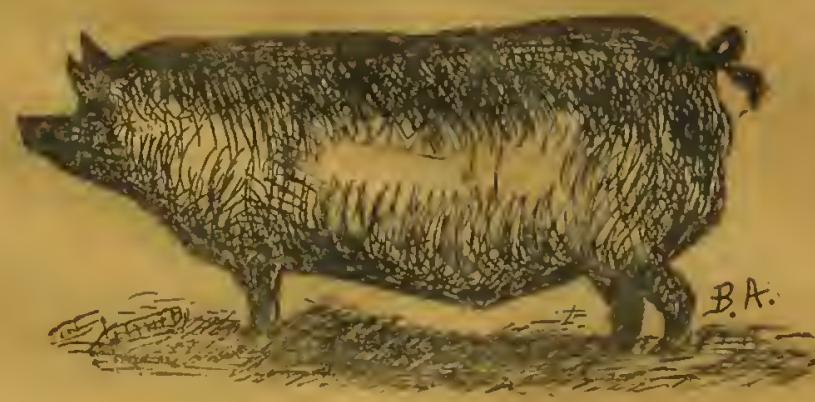

ESSEX DOAR.

The Essex originated in the south of England and are cntirely black. Thcy are small to medium in size, and arc exteusivcly used in Lngland as crosses on the large coarse swine, with a vicw to improving their fattening qualities. The best specimens may be known by being black in color; face short and dishing; ears small and soft, standing erect whilc young, coming Cown somewhat with age; carcass long, broad, straight and deep; hams heavy, and well lct down; boue finc, and carcass when fattened, muinly composed of lard; hair generally rather this; fattening qualities supcrior. The black color of the Essex, as is the case with all the imfrroved black swine, is nnly confined to the epidcrmis or scarf skin; when dresged the skin is beautifully white and clean. The cut we have given of the Esscx boar, will very well represent the Nerpolitun with the exception that the Lssex is a comparatively woll hairod breeu.

\section{प. The Yorkshire Hog}

The Yorkshires aro among the best of the pure bred swine of England, and have stamped thcir impress upon neariy all the modern white breeds. Their good qualities are: They are of a size, shape and flesh that aro desirable for the family or the packer's use. They are hardy and vigorous in constitution, have a good cuat of hair, protecting the skin so well eithes in extreme cold or heat that it rarely chills or blisters. They are very prolific and good mothers; the young do not vary in color, ind so little in shape that their form when natured may bc determined is advance by an inspection of the sire and dam.

The Yorkshire, medium or middle breed, says Mr. Syduey, is a moder 
invention of Yorkshire pig breeders, and perhaps the most useful and popular of the white breeds, as it unites, in a striking degree, the good qualities of the large and small. It has been produced by a eross of the large and the small York and Cumberland, which is larger than the small York. Like the large whites, they often have a few pale blue spots on the skin, the hair on these spots being white. All white breeds have these spots more or less, and they often inerease in number as the auimal grows older.

It was not until 1851 that the merits of this breed were fully recogn.zed, when at a meeting of the Keighley Agrieultural Society, the judges having called the attention of the stewards to the fact that several superior sows, which were evidently closely allied to the sinall breed, had been exhibited in the large breed elass, the aspiring intruders wero, by oficial authority, withdrawn.

The middle Yorkshire breed are about the same size as the Berkshirn breed, but have smaller heads, and are much lighter in the bone. They are better feeders than the sinall whites, but not so good as the largn whites; in fact, they occupy a position in every respect between thess two brceds.

The Cumberland, a middle loreed Yorkshire, are not distributed throughout the West, but when thoroughlbred specimens have been introduced they are held in great esteem, as well for an animal for exhibition purposes as for fanily use. They are especial favorites with packers who buy their stock on foot for the reason that they yicld larger proportionate net weights than any other hogs which grow large enough for their use. They are small in bone but large in flesh, of the very best quality; eveuly and proportionately distributed over the whole frame.

\section{The guffolks.}

The Suffolks otre nearly all their good qualities probably to the infus eion of Yorkshire blood.

Mr. Sidney says that Yorkshire stands in the first rank as a pig feeding county, possessing the largest white breeds in England, as well as excel. lent inedium and small breeds, all white, the latter of which, transplanted into the south has figured and won prizes under tho name of divers noblemen and gentlemen, and under the name of more than ono county. The Yorkshires are closely allied to the Cumberland breeds, and have been so much intermixed, that, with the exception of the very largest breeds it is difficult to determine precisely where the Cumberland begins and tho Yorkshire ends. The Manehester boar, the improred Suffolk, the improved Middlesex, tho Calesn:Il and the Prince Alberts or Windsors wark. 
all formed on Yorkshire-Cumberland stock, and some of them are nearly pure Yorkshires, transplanted and re-christened. Speaking of the pigs kept in the dairy district of Cheshire, he says that white pigs have not found favor with the dairymen of Cheshire, and the white ones most used are the Manchester boars, another name for the Yorkshire-Cumberland brecd. All the writers who have followed him down to the latest work published on the subject, occupy space in describing various county pigs/ which have long ceased to possess, if they ever did possess any merit sworthy of the attention of the breeder. Thus the Norfolk, the Suffolk, the Bedford and the Cheshire have exch separate notice, of which the Suffolk alone is worthy of eultivation, and the Suffolk is only another naine for a small Yorkshire pig.

We submit also a brief description of the Suffolk's "points:" Head small, very short; checks prominent and full; face dished; snout small and very short; jowl fine ; ears small, thin, upright, soft and silky ; neck very short and thick, the head appearing almost as if set on front of shoulders; no arching of erest; crest wide and deep; elbows standing out; brisket wide, but not deep; shoulders and crip-shoulders thick, rathcr upright, rounding outward from top to elbows; crops wide and full. Sides and flanks - ribs well arched out from back, good length between shoulder and ham ; flank well filled out and eoming well down at ham. Back broad, level and straight from crest to tail, not falling off or down at tail; hams wide and full, well rounded out; twist very wide and full all the way down. Legs and feet-legs small and very short, standing wide apart, in sows just keeping the belly from the ground; bone fine; fect small, hoofs rather spreading; tail small, long and tapering. Skin, hair and color - skin thin, of a pinkish shade, free from wolor; hair fine and silky, not too thick; color of hair pale yellowish white, pcrfectly free from any spots or other color. Size small to medium.

\section{Lancashire Hogs.}

Thcre are three breeds in Lancashire, England, that have attained celebrity, namely, the short-face, the middle breed, and the large Lancashiro white. On next page we give an illustration of the short-faced breed.

This breed of swine may be known by the following characteristics: The shortness of the face from the eyes to the end of the snout; prict ears; small bones; a good coat of white hair ; oubie in form, with hroad back and broad hams, well let down. The skin, as well as the hair, in white, although an occasional one may be found with a few dark bluo epots in the skin. but never dark or black hairs: The small bread hog 
must have small bones; a short fuce; sllky hair ; fine, small, upright ears; a comparatively square form; must hare good square hams, the most valualle part of the hog; nust cury the meat neur the ground; llat on Ėe back, straiglit and culic in form.

VIII. Irarcashiro IIiciàlo Breod.

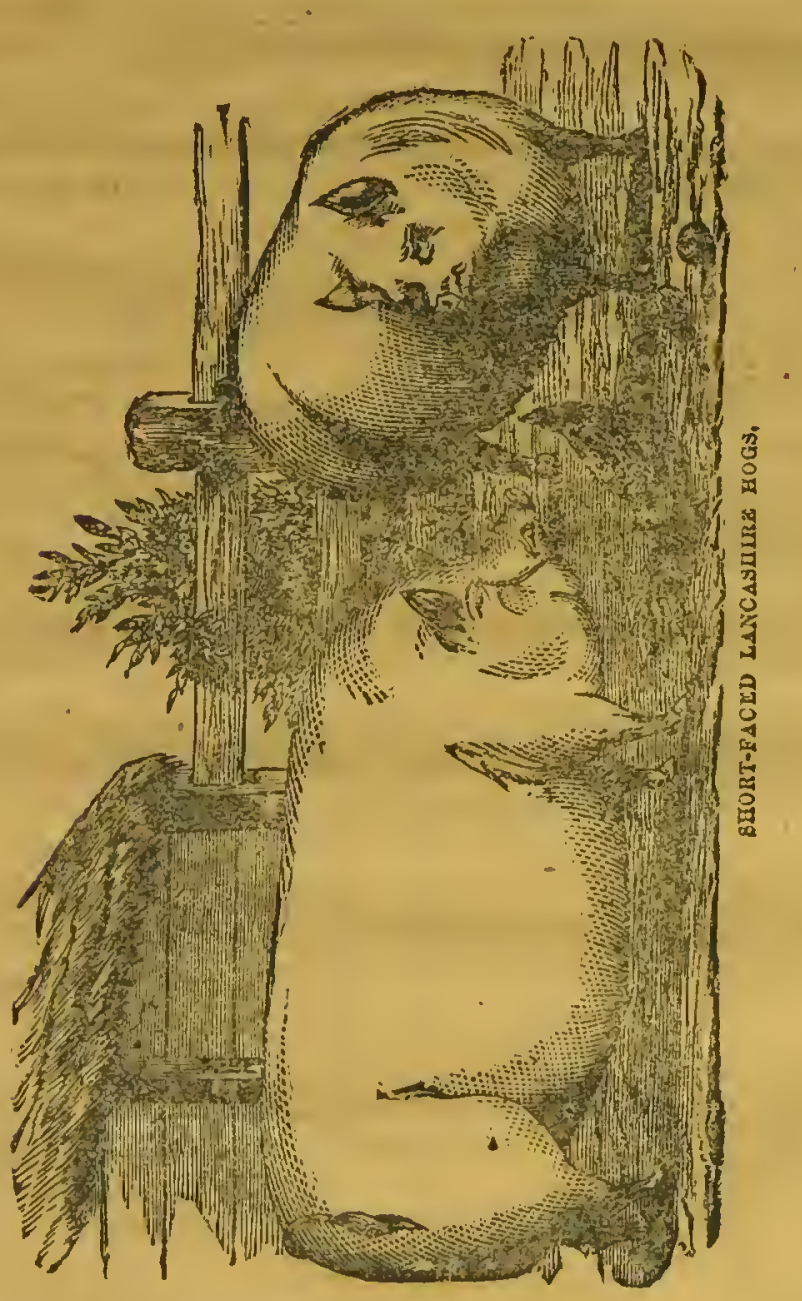

This breed is one which partakes of the quality of the small breed and the sizo of the large lreed. Mirldle bred hogs are got by crossing larego bred sows with small bred boars, but all attempts to attain the same results by reversing the operation, and putting lirge bred boars to smali bred cows, have proved failures. The largest of the middle bred sows aro used 
to improve the large breed. A middle bred hog must have a short face, and all other good qualities of the small breed, except that they may be longer in proportion to their width; must have thicker legs and longer bones to earry the greater size; should be well haired (fattening to full form often causes the hair to fall off, which must be allowed for.) As good a short rule as ean be adopted to judge them by is as follows: The best middle bred hog should have the greatest possible share of all the qualities of the small breed, with the leugth, and, in a measure, the larger. bones of the large breed.

\section{Large Lancashire.}

This variety of swine have large bones, of great height and length, and are the largest breed of swine knowu. They are a true brced, their qualities have descended from generation to geueration - the quality being improved by judicious selection. They must be of large size; great length ; flat baek, with large square hams, and when fattened, must carry their width of baek along over the hams; must have deep and tolerably straight sides ; large feet and leg bones; lair short; may have a long face, but it had better be short, as they fatten better; may have a large, drooping car, but other quality and size bcing equal, an upright, smuller ear is preferred. They usually have a long, thick, strong tail. They must bo of great weight when fattencd.

\section{American Breeds.}

Sagaeious breeders in the United States nearly fifty years ago, saw the necessity of establishing breeds of swine that should be eminently adapted to the especial requirements where Indian com and grass must necessirily form the principal food of the swine from weaning time until slaughtered. Then and until the list twenty years, mere fat was the important product in swine, as it was in a degrce in eattle. Since that time the universal introduction of petroleum has reduced the value of lard and tallow to a minimum. Improvements in the art of preserving food fresh has mado barreled pork, a lcss nccessary product cven for long voyages, and the attention of the breeders was again turned to the production of as much lean incat in their logs as possible. This naturally led to a reduction in the weight of the hog, or at least, if the animal should be eapable of reaeling a heavy weight at maturity, it must also possess the important quality of fattening at any age. This has now been fairly met in the best English and Ameriean breeds. If we were asked to ehoose the breeds from each which would produce the most lean ment for the carcass, we should say the Berkshire of English breeds, and the Poland of American breeds

$12 \mathrm{M}$ 
X. Poland China.

Orer the history and characteristics of this breed there has been much

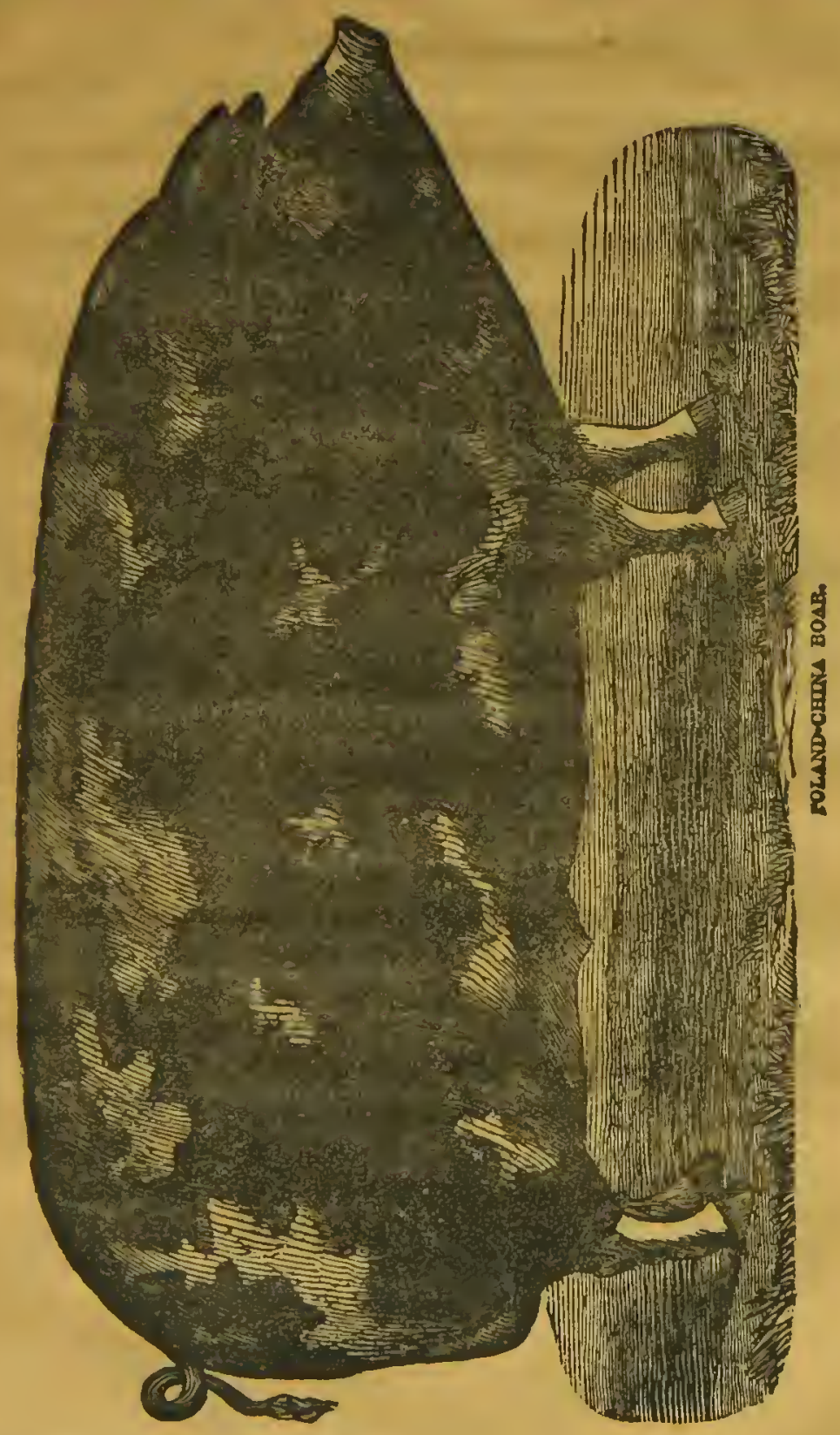

controversy. Individual breeders have sought to take undue credit to themselves in the establishment of the breod, and have sought undw 
prominenee by attaehing their own names to the swine of their breeding. The faets are, the name Poland-China is a misnomer so far as Poland is concerncd, for there is not a particle of evidence that a distinetly Polish breed of hogs ever gave an infusion of blood. The nearest evideneeand this traditionary - to this effeet, is, that long ago a sow was bought of a Polander, which, proving an excellent brccler, it went by the namo of the Polander sow. The breed is now largely indebted to the Chinas) and Berkshires for their good qualities. Although they certainly have an infusion of so-called Irish grazier in them. Why this broed should have becn called grazicr, one cau only surmise. They certainly were anything but grass caters, but the name made them popular for a time in the then far West where grain at that time was scarce. The facts are, the Chinesc hogs, imported into Olio in 1816, and bred upon the best native stock of the country are the basis of the brecd. In 1835 the Bcrkshire was introduced, and in 1839 or 1840 the Irish grazier. These were extensively used by the best breeders, on the bost descendants of the China crosses. Since 1842 , there is good evidenee to show that new blood has not becn introdnced, but by careful selection, and judicious breeding, in Ohio and the West, or, by occasional judicious infusion of Berkshire blood, they now leave little to be desired, as a heavy, well meated breed, that will fatten kindly at any age.

\section{Characteristice of Poland-China.}

The best specimens lave good length, short legs, broad, straight backs, deep sides, flanking well down on the leg, very broad, full, square hams and shoulder's, drooping ears, short heads, wide between the eyes, of spotted or dark eolor; are hardy, vigorous and prolific, and when fat are models, eombining the cxcellencess of both large and small breeds.

\section{Chester Whites.}

The Chester Whites originated in Chester eounty, Pcnnsylrania, about 1818, through the importation of a pair of fine pigs from Bedfordshire, England, by Captain James Jeffries. These were inter-bred with the vest stock then existing in that county, and by careful selections a permanent strain of large, casily futtened, quiet hogs were produced, whieh continued to breed with great uniformity. Something like thirty years ago some attempts wero made to eross the Suffolk and Berishire upor them, but it was discontinued as not being eonsidered an improvement, and the best speeimens to-day should be pure white, witin no blaek about them whatever. 
In the West this breed became very popular some years ago, and stil] is in many parts of the Northwest. Farther south, however, in the truo corn zone, pure white hogs of any breed are not favored. Thoy are thought not to stand out-door usage so well as black or nearly black wine. Where great weights are required the Chesters will always bo biter.

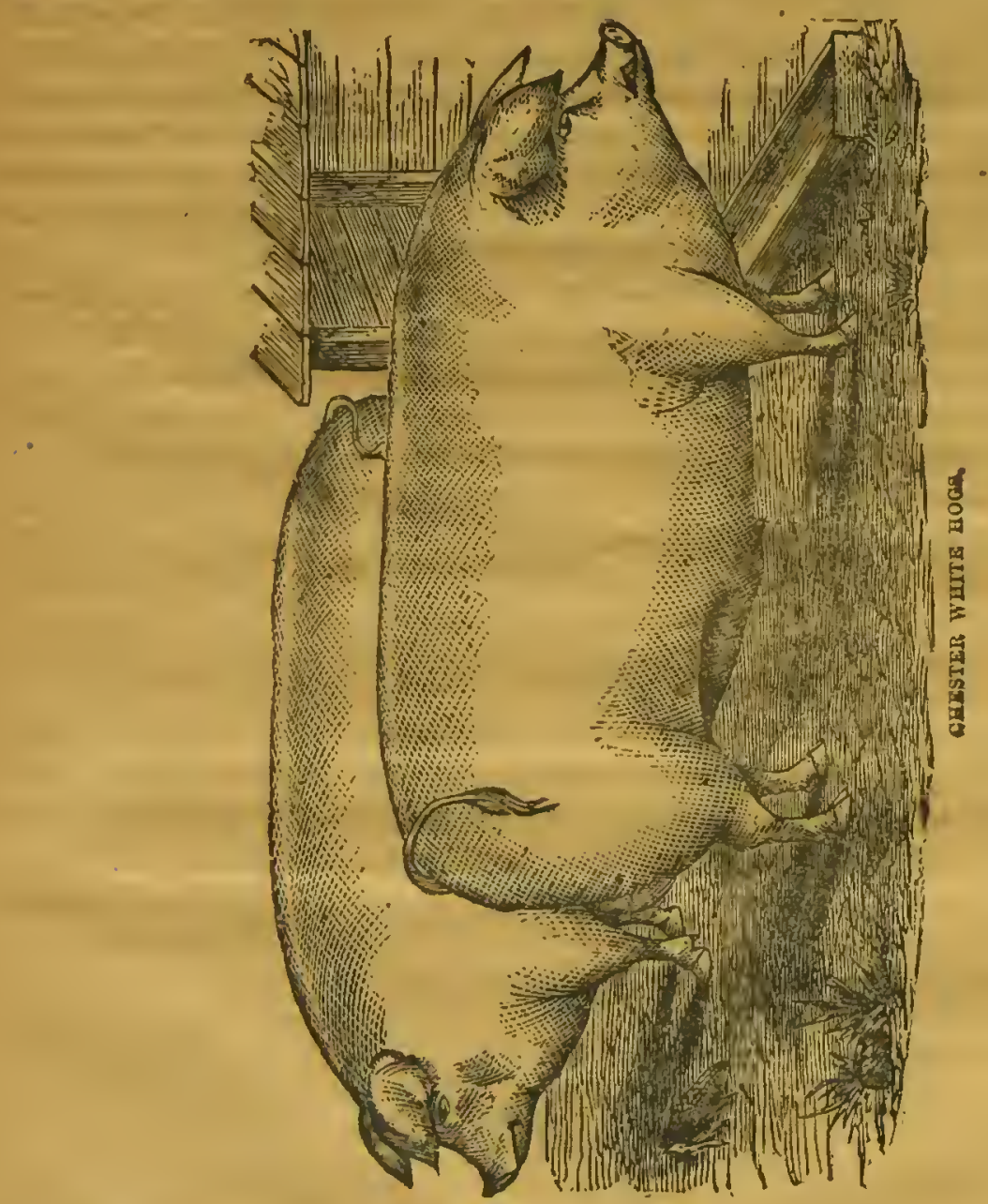

The following may be given as the charactcristics of theso hogs: Head bort and broad between the eyes; ears thin, projecting forward and lopping at the point; neck short and thick; jowl large; body lengthy and deep; back broad; hams full and dcep; legs short and well set under the body; coat thin, white and straight; (if a littlo wavy it is no ebjection). The tail should be small and with no bristles. 


\section{Jersey Reds.}

This large and rather coarse breed of hogs have been somewhat disseminated in the West. They are certainly a hardy breed, and well edapted to ncw eountries where there is good range alid mast. Their history seems to be as follows:

The positive origin of this family of swine is unknown. Thcy have scen bred in portions of the State of New Jersey for upwards of tifty years, and with many farmers are considered to be a most valuable family. They are of large size and eapable of making heary growth, 500 and 600 pounds' weight being common. They are now extensively bred in the middle and southern portions of New Jersey. In some neighborhoods they are bred quite uniform, being of dark red eolor; while in other sections they are more sandy and often patehed with white. They are probably dcsccnded from the old importations of Berkshires, as there is no record of tho Tamwortl, the red hog of England, ever' having been brought into this eountry, nor is this likely, as the 'Tamworth was not considered a valuable breed, and was confined to a limited area. The Reds resemble the old Berkshires in many respects, but are now wuch coarser than the improved swine of this breed.

A good spccimen of Jersey Rcd should bo red in color, with a snout of moderate length, large top cars, small head in proportion to the size and length of the body, standing high and rangy on their legs; bone coarsc, having tail and brush and hair eoarse, inclining to bristles on the back.

\section{Cheshires.}

This is a comparativcly modern breed, if indeed it is yot fully cnough established to bc eallcd a breed. It has been somewhat disseminated in various parts of the Unitcd States, and for villagers and small furmers, possesses about all the good qualities of the Suffolk, without some of their disabilities. They are said to havo originatcd in Jcffcrson county, New York, from a pair of pigs scnt from Albally under the name of Cheshire. It was probably a pet name for an cxceptionally good pair of pigs. Since then they have been erosscd with Yorkshires and other pure white breeds, until of late years by selcction they have become uniform in their make up.

The so-ealled Cheshires are pure white in color, with little hair. They are not uniform in this respect, as pigs in the same litter differ widely in the amount of hair. The snout is often long, but very slendcr and fine. The jowls are plump, and the ear ercet, fine and thin. The shoulders are wide and the hams full. The flesh of these hogs is fine-grained, and 
they aro commended on account of the extra amount of mess pork in proportion to the amount of offal. The tails of the pigs frequently dron oif when young.

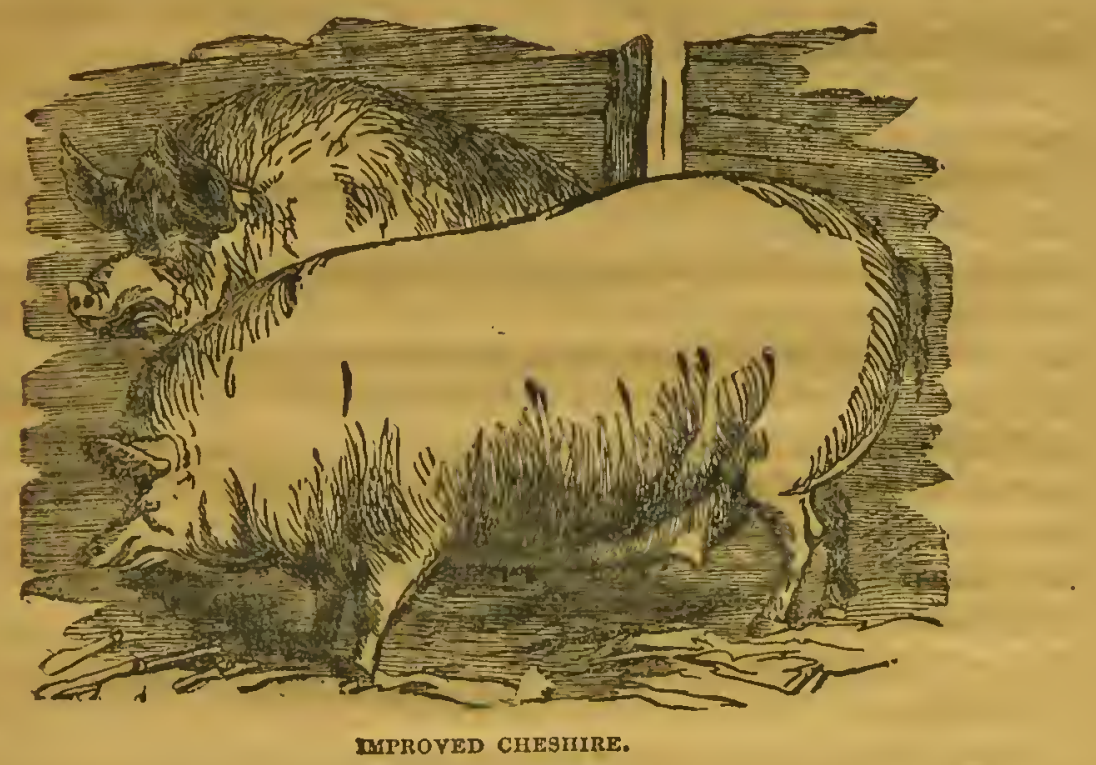

Recapitulation of Breeds.

The principal English brecds arc as they wore known twenty years ago, the Berkshire, the Essex and tho Yorkshire. The Berkshire is a mediun breed weighing at full maturity up to 500 pounds. There are large and amall Bcrkshire, but the nedium finmily is the most valuable. They are now bred cntircly black except a dash of white in the faco and white feet.

The Esscx is all black, or rather a blue black, and will weigh up to 450 pourds at maturity. They are one of the most stylish of tho small English brecds, as they are the largest of the small brecds, and to our mind tho best of the small breeds for tho West-quite good fecders, handsome and making gocd pork.

The Yorkshires aro divided into threc elasses, small Yorkshires, medium Yorkshires, and largc Yorkshircs. The so called Prince Albert Suffolks are small Yorkshires, and the best of the small white breeds. All the Yorkshires have occasional dark spots on the skin. The hair, howcver, is white, and these dark spots are not indications of impurity of blood but rather the reverse.

The Amcrican brecds, in the best repute, are first, the Poland-China, 
sometimes called, in Uhio, Magie. Twenty years ago they were coarse blaek and white hogs, with oeeasional sandy markings. Of late years they have been, through earefui breeding and seleetion, refined, and aro now bred in the West, nearly black, the white, in the most approved strains, being distributed pretty equally over the head and body in fleeks and irregular patehes. They are tho most widely distributed of any Amerienn breed in the West, and fully deserve all that is elaimed for them, as large, quiot, early matured, and lindly feeding hogs.

The Jefferson eounty, Niew York, so ealled Cheshires, are, as before stated, but modified Yorkshires, but in every respeet stylish hogs, feeding well and making good pork, and are well adapted for small farms and for feeding in pens. The so ealled Hospital breed, or Morgan county hog of Illinois, whieh some years ago gained consideruble repute, are uncoubtedily, modified Yorksbires, and in no respeet superior to that well known breed. They were produeed by erossing the Suffolk on the best white hogs of that eounty. Within the last five years they have ceased to attract attention.

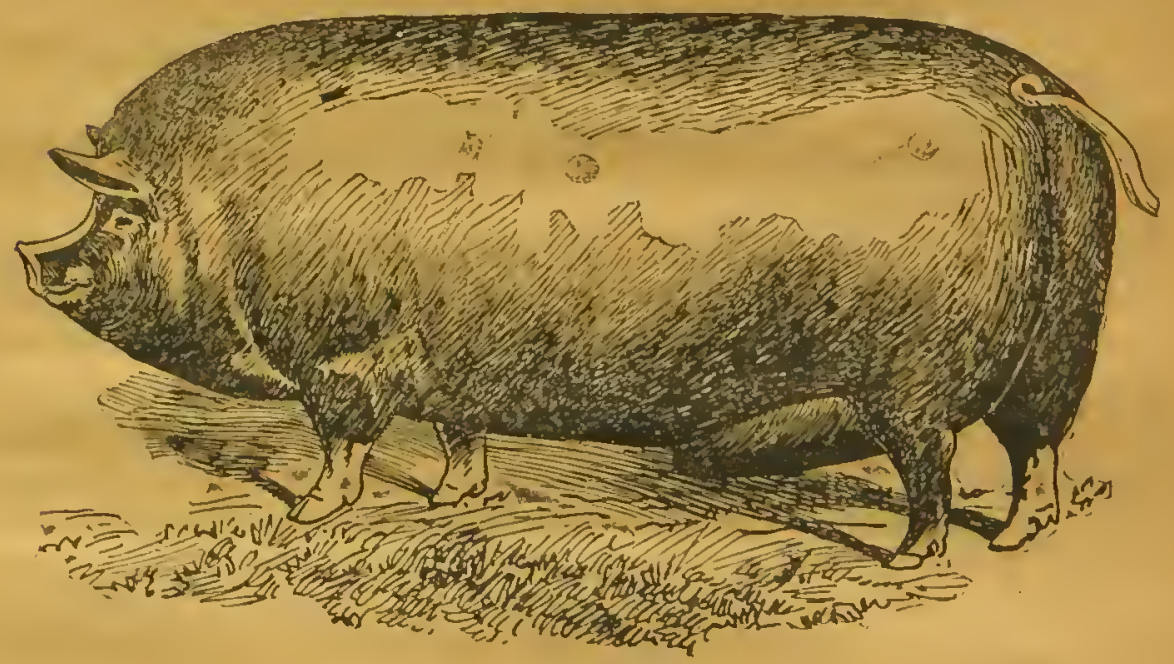

BERKsmirn BOAR DURe III. by King Longfellow $\mathbf{X}$. Pinnock's Pride. Bred and owned by Mr. C. I. Hood, of Lowell, Mass. Duke III. is head of the Hood frim berd; never benten; exhibited at Nerr England Fair, 1896 and 1898, aud

- Varions others. Weight 1,000 pounds. 


\section{CHAPTER $\Pi$.}

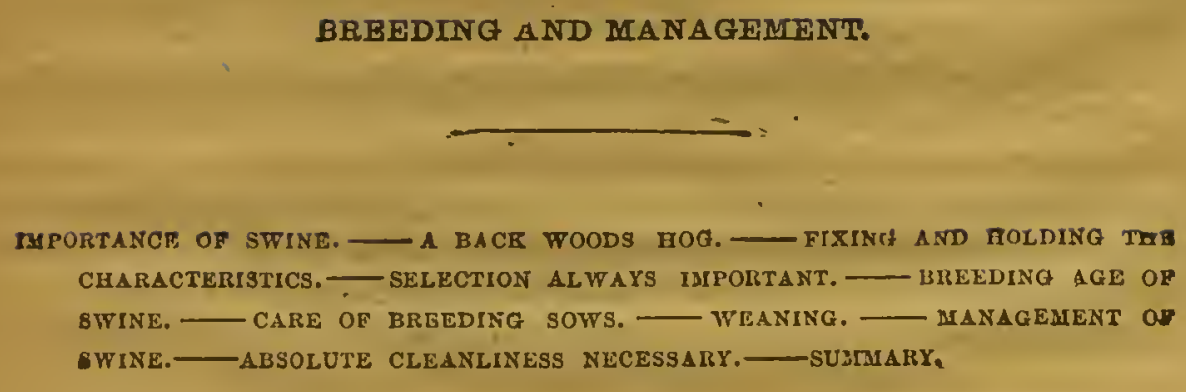

Importance of Swine.

The breeding and management of swine constitutes one of the most inportant agricultural intercsts in the West, and should do so in the South. To be successful none but the best breeds should be allowed on the farm. The feeundity of swinc leares no excuse for holding on to land pikes and the descendants of selli-wild breeds that must be run dowa by dog and rifle, in ordor, when they are lilled to get a sinall quantity of inferior meat. $A$ boar of any of the improved breeds will be sufficient for six or eight sows, and the inerease is so astonishing when therc is no epidemic disease, that it would from a single pair take but three years to stock the largest farm. It should be unnecessary to pursue this matter further. There is no class of farm stoek that pays better, as between indifferent and good breeds, than hogs, and the wonder is that in some sections of the country farmers still cling to a breed of grunters that will always greet you with a snort and a boh-0-o, and which no fceding can fill-in fact animals like those shown on the following pagefully a match for the average dog, always hungry, ready to eat anything that falls in their way, even to half grown children. occasionally, but which when wanted for meat are nowhere within shooting distauco.

362 
The vcry first requisite, however, in keeping any improved breeds, or In fact any breed from which money is to be made, is the best of feeding, and shat daily, from the time they are born until they are slaughtered.

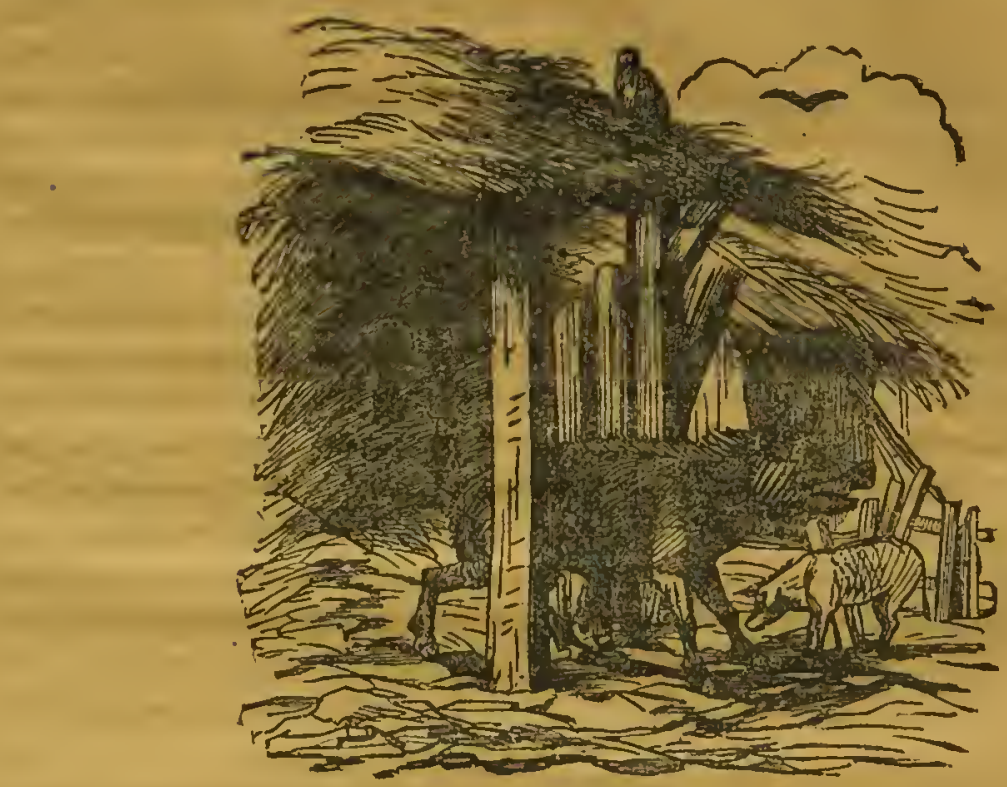

\ BACE WOODS HOG.

The hog is simply a machine for making what is to be converted into lard, bacon, salt pork and hams. The average daily gain is a gradually lecreasing quantity from month to month, until after a ccrtain time nothing more can be gained in weight. This ouglit to be sufficient to be said upon this point. You can neither breed, nor keep a breed profitably by starving or allowing them to shift for themsclvcs. As elsewhere, so in stockraising, it holds true that what costs little to acquire, brings little at sale. Caro and labor to secure the best will always pay the most.

\section{Fixing and Holding the Characteristics.}

In breeding swine, howevcr good or perfect the brecd, they will surely, 'degenerate unless the greatcst care in selection is pursucd. Muny persons wonder why it is that from the prolific nature. of swinc, the country is not soon stocked with none but the most supcrior animals. The simple reason is, the want of accurate judgment and care in selcction; the error will be plainly seen by noting what we say farther on. Indeed, what has been said in previous pages on this general topic will apply equally well at this point. Care in selection and breeding is fundamental to success. 


\section{Selection Always Important.}

in animals usually haring but one young at a time, the progeny pretty uniformly partake of the nature of both parents, and are bred with toicrably uniform results. In animals producing a number of young at a time, the progeny will be found to vary very consilerably in the same litter.' Thus the selection of those specimens that partake of uniform and characteristic excellence becomes of the first importance, since unwise selections will result in carrying the brecder farther and farther from the excellent points to be perpetuated. Agrin, herodity, that is throwing back to an original type, or rather in the scnse in which wc use it, inlıeriting eertain fixables, as constitutional vigor, iuclination to fat, ctc., is shown far more clearly in animals having many young at a time, than those having only one young. The progeny will not only vary morc in particular animals, but ccrtain characteristics will reappear by rcversion after a grcater number of gcnerations, in animals having many young at a time, and to a greater dcgree than in those usually having but onc. Ar least such is our cxperiencc. Hence, as we have stated, absolutc necessity of the strictest care, is not only ncccssary in brceding, but in the sclection of animals for futurc brecding.

In domestie animals it is a mattcr of common obscrvation that the temper and other pcculiaritics of individuais arc detcrmined by inheritance. Thus, virtually, quictness of disposition, or mildness, tractability or viciousness, courage or timidity, are coustantly shown. Now from the general law that like produces like, and the well determined law that variation is a constant integer in all cross bred animals, and from our own observation that it is often intensified in animals having many young at a litter, the full force, as regards judgment in selection will bc apparent; and the fact that the country is not soon filled up with superior brecds of hogs is due mainly to the want of proper care in the selcction of the breeding animals, and also from a lack of accurate knowledge and ability to niccly discriminatc by the breeder, in regard to form, constitutional vigor, and excellent points in the young animals selected as breeders. Absolute accuracy in this respect is in fact possessed by but few individ. uals in a gencration. There must first be a natural tact inherently possessed and digested and maturcd by years of study aud observation.

\section{Breeding $\Delta g \theta$ of Swine.}

The sow is eapable of breeding at about scven months of ago, and the boar is fit for service at the age of one year. As a rule, howover, the sew should not be allowed to farrow under the age of fiftecn months, and the boar is not fit for continued service until bo is eighteen months old. 
The sow may, under exeeptional eircumstanees, be made to breed threo times in a year, but two litters are all that should be allowed. Many of our best breeders do not allow but one litter a year, whero tho produce is simply required for making pork, and under eertain circunstances this is not ineompatible with eeonomieal management.

\section{A Warm Farrowing Place Necessary.}

The young pig is even more tender than the new-born lamb. If they get ehilled before they suck it is diffieult to save them. Where there are good eolveniences for warming the farrowing pell, sows may have their first litter in March, and if put with the boar the fourth day after farrowing they will generally receive him. This will bring the next litter in tho Summor, a very good timo for pigs to be wintered. If the sow do not catch the first time sho will not come in heat until the pigs aro weaned. Yet this will not throw the next litter later than September. If good facilities are not had for keeping the early litters warm, the farrowing had better be deferred until May, or at the time of grass, according to the latitude.

\section{Gestation.}

Gestation continues about four months. Three months, three reeks and three days is considered the averago time, and it is not far out of the way. A variation will sometimes be found of thirty days. Young animals, and those of feeble constitutions earry their young for a shorter time than mature and strong animals, and sows usually remain prolifie for five or six years, and unless they get overloaded with fat, old sows aro more eoustant and eareful mothers thin young ones.

\section{Caro of Breeding Sows.}

The sows that naturilly have a strong tendeney to fatten may bo bred at nine months old, and should be kept breeding pretty steadily, and be fed only sufficient to keep them strong and in fair flesh. During gestation the sows should be kept in good heart but not fat. When potatoes aro plenty they ean bo substituted boiled, and in eomcetion with milk will be most excellent feed. In any event thcy must have plenty of sueeulent food-clover, pig-weed, or other green food in Summer, and roots of some kind in Winter. Wo have alway's kept a pateh of artichokes for Fall and Winter, when the ground was not frozen for them to root and amuso themselves in. The practice of ringing breeding sows to keep 
them from rooting is vicious in the cxtreme. We havc nevcr practiccd is at all with any hogs. To remain healthy they must root some. It in their natural instinct. If the pasture be clover, and in the rotation to be followed with other crops, the damage by rooting will be light in comparison with the health of the swine. Loss at one point will be fully compenated at the other.

When the sow is near her time her food should be of such a nature as to keep up her strength and give due sustenance to the young but not. stinulating. When the pigs are thrce or five days old, and danger of inflammation is past, fecd liberally, and with rich sloppy food to induce a good flow of milk. But under no circumstances feed $s 0$ as to make the young pigs unduly fat. Skimmed milk and the mill refuse of wheat, what is known as mill feed, is best, but in the absence of this potatoes, pumpkins and other roots in the Fall, or boiled beets in the Spring, with corn meal enough to kcop the sow in good heart, makes admirable food. When there is grass to be had, the sow should be allowed all she will eat. Thus you may get the very best results both in the health and continued usefulness of the sow, and the constitutionul growth and vigor of the young pigs.

\section{Weaning.}

The young pig as we have shown is born ready for work. That is, it has teeth that in a short time arc competent to grind and prepare food for the stomach. We should wean at six weeks old, allow all the skim. med milk and butter-milk possible to the growing pigs, and with it aftc the pig is two months old, a fair proportion of ground wheat skimmings, or light rye, barley, etc., ground and made into mush, to bc mixed with the milk as a tolerably thin slop. Tcach the pig early to eat grass, and at three months old he will takc care of himself on good pasture with all the corn he will eat at night. By this means the older stock are early freed from care of the young and become ready for other uses.

At the age of two or three weeks the pigs should be gelded, so they may be well ovcr the difficulty before weaning time. Keep rings out of the noses of young pigs. They have been the means of spreading contagious diseases. We prefer slitting the cartilagc of the nose, or cutting notch in it at the time of gelding, if it is absolutely necessary that they do not root. At all events it is time enough to do the ringing the second year, if to be kept over. But by proper care if the litters of rigs come early, any of the bctter breeds may be turned off the next Christmas, and from this time until the first of Fibruary, beconfofo and of as heavy veight as is profitable in the markats. 
Mtanagement of Swine.

Hogs are not succeptible to cold when fat. Nature in denying them much bair, has provided them with a thick layer of fat under the skin that acts in the same manner to the skin outside as a covering of hair in a er animals. It has also given them the instinct of providing themeal yea

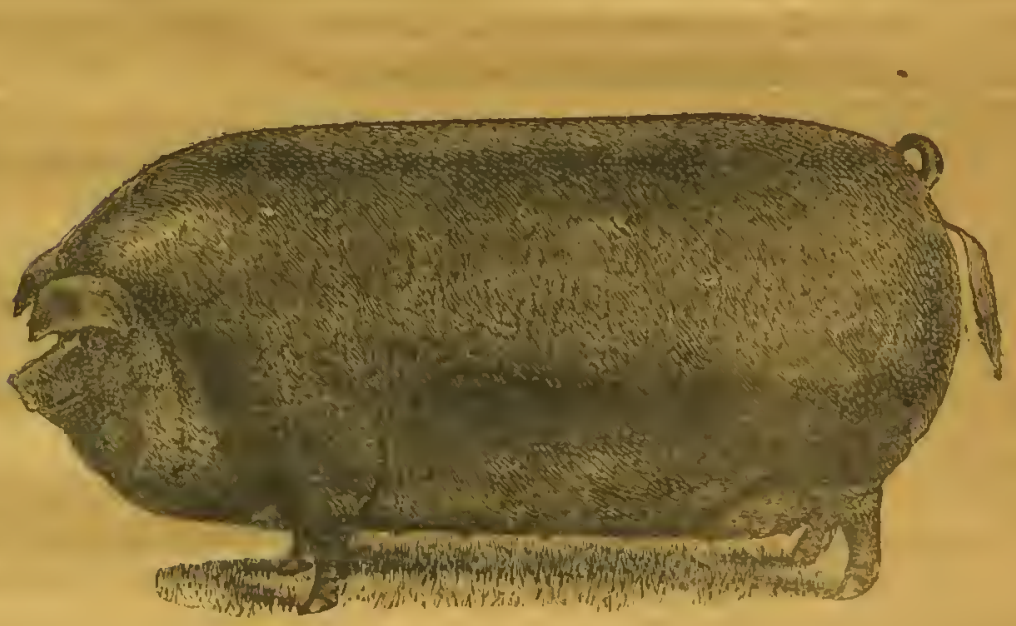

Deroc Jersey Sow. (Rro Jlugro.)

Properts of C. Il Holmes Leatrice, Nch.

warm bods in sheltered situations in which to lie, and, in addition, given trom the inclination to lie together in considerable numbers; and lsept together, with insufficient shelter, they will pile together in such numbers wo over lie each other, by which the wcaker ones are often smothered. We have known those who considered themselves sensible men, to get up in cold winter nights and go to the hog yard and separate the drove 
when so piled. It is about on a par with the whipping and dogging of cattie about a yard at night to get up warmth. A more sensiblo and cheaper plan would be to provide comfortable quarter's, where thoy might lie warm, and separate them into gangs, according to age and strength. Thus with plenty of fat next the skin, and good liberal feeding, rcry little difficulty will be experienced, in keeping them growing stearily, rutil of a sufficient age for the slaughtcr pen.

\section{Absolute Cleanliness INeoessars.}

Of all farm animals hogs especially must have plenty of water. It ohould also be pure. Swine breeders can not too soon disabuse themsclves of the idea that swine are dirty, or filthy feeders, or that they naturally incline to wallow in the mud. There are no farm animals ricer in the food thoy cat than swine if allowed to bc. It is true, they are

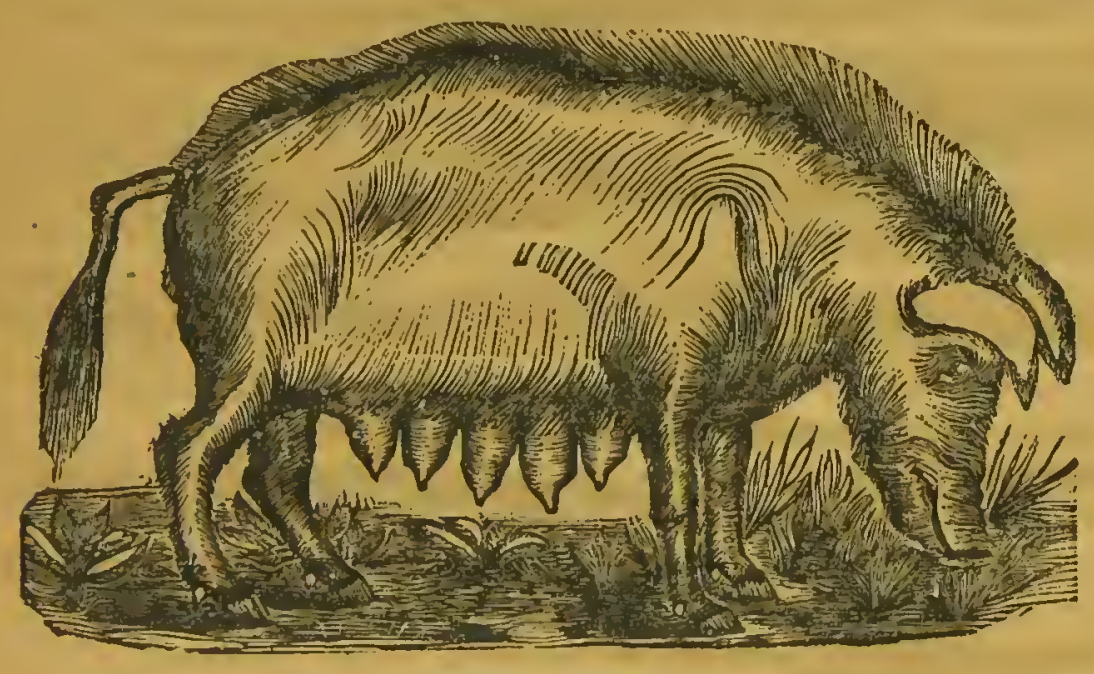

HAZEL-SDEITTER.

omnivorous feeders. So is man. Like man, although they eat fish, flesh, fowl, vegetables, roots, and grain, they like it fresh. If forccd by hunger they will eat disgusting substances, so again will man. The elephant, the rhinocclos, hippopotamus, and tapir, scek the water to clean and cool themselves in Summer, like all pachydermatous animals. Tho wild men like swine will cover themsclves with mud to ward off the attacks of biting and stinging insects. In their wild state the nearest tree furnishes to swine tho means of rubbing it off when dry, and tho rubbing post furnishes them the mcans of eleaning thcir skins in a state of domesticity. 
If kept from the attacks of flies, they will not wallow in the mud but in the cleanest water they can find, and stagnant water they will not drink at all, unless forced to do so, by dire necessity.

The sagacious breeder and feeder will understands this; they also understand the danger of malignant diseases attacking their swine when forced to wallow and drink impure water. Hence they strive by every means in their power that swine are kept away from these eauses of disease and death, and thus such would be almost entirely exempt, except that there are always men enough of the shiftless typo in a neighborhood whose stock take and spread contagion to their neighbors. Wo do not know how we can illustrate more foreibly the two types of breeders than by the eut given of a sow of an improved breed properly kept, and of a sow of the "hazel splitting" variety, improperly kept. The one in a dry, firm pasture, with plenty of pure water, the other on a half marsh, and apparently made to succumb from miasmatic influcnces.

\section{Summary:}

Hogs, and especially pigs in eonfinement often suffer for want of water. No matter how sloppy the food they should always have pure water within reach. If thcy can have a bathing place in Summer it will add much to their health, and assist much in fattening. Swine, in confinement, should always have eharcoal, bitumiucus coal, salt and rood ashes within reach. They often suffer from acidity of the stomach and the remedy being ncar the swine will always use it.

Oil cake mixed with the feed of swine when suckling pigs, a gill a day, assists the milk secretion. It should not be given to pigs. As they begin to eat they should have a trough where they can go and feed but which the sow cannot get at.

Bran is not valuable for swinc. Where highly eoncentrated food is given it is well to bave a little dry bran in a scparate trough, so the hogg can take it when they want it.

If ordinary diarrhœa attacks pigs give a porridge of sweet skimmed milk and flour. For constipation give two or three drachms of soap dissoived in an ordinary sized tumbler of water, and repeat if necessary in eight hours, or give as an injection. It is also a good diuretic and for acid stomach.

Provide a strong scratching post. Bore inch and a half holes at intervals to accommodate hogs of different sizes, and drive in pins letting them project an inch and a half.

Castrate pigs before they are weaned, say not later than two woeks before weaning time. 


\section{CHAPTER III.}

\section{FEEDING AND SEDELTEHR.}

OOOD VS. BAD FOOD. - SUMHER FEEDING. 一OTEER SEMMRE FOODS. - ROOT THE GRAINS. - FEEDING SOUTH. — MAST. - FEEDING IN CONFINEMENT. - HOG BARYS. - $\triangle$ CROBS BARN. - $\triangle$ SIAIPLE PEN. - SUMMARY. LIJGT VB. HEAVY HOGS.

\section{Good va. Bad Food}

Vegetables and grain are the basie of success in the making of pork whatever the breed may be. Hogs kept about large stables or distillery yards, where they get only offal, or fed in butcher's yards, on the refuse offal of the slaughter house, are unfit for human food. They are liablo to become infested with trichina, and, thcrefore, no breeder and especially no feeder should buy animals from such localities. In fact there is only one redeeming feature among the disgusting filth and nastiness in which they are fed-they are generally provided with pure watcr, and warm shelter.

\section{Bummer Feeding.}

Pasturage is of the first importance. This should be ample. In pas: curing swine, but few varieties of grass are required. Clover, both whito, and red, will be the main rcliance. In all that region where red and white clover are not natural to the soil, and where alfalfa (lucerne) and other membcrs of the pulse family do well, these may be substituted. Swine take kindly to blue grass, when it is young, and to orchard grass. They do not refuse timothy, but timothy has a bulbous root just at the curface of the earth. This swine eat, and thus destroy the grass. Ryo 
and oat mako good pasturage for hogs. Rye grass and foul meadow grass are ulso well relished. In this respect the feeder should experiment with grasses, to be cut and given in the pen, and then feed to such varioties as do best, and are most oagerly eaten. Of weeds, purslain, (portuZaca oleracea), lambs quarter, also called pigweed, (chenapodium album) and the green amaranth, also called pigweed, (amarantus hybridus) aro the most common of our native and introduced weeds that are valuable as grcen food for swine. There is also a native woed growing in Illinois and along the alluvial banks of the Mississippi and northward; the winged pigweed, (cycloma platyphyllium) that is much liked by swine. Yet the list of plants eaten by them is not large, about eighty species comprising the whole.

\section{Other Summer Fooda.}

Besides clover, the grasses, and weeds, there are other plants that may come in during tho Summer, and be used with profit. Oats and peas may be suwn together, two bushels of 'oats and one of peas, together, per acre, as early in the Spring as the ground is in fair condition for working. The swine raby bo turned into the field when the crop is ripe, being confued to given space, by a hurdle fence, which is to be removed us thcy eat clean. A better way, however, is to harvest and thresh, and feed either snaked or dry. Later, Summer squashes and pumpkins will come in, to be followed by artichokes in the Autumn. Wo do not advise any of these foods except grass on the score of economy. Corn and grass are the cheapest food in all the West, so far as mero cost of production is concerned. But unless the health of swine is retained, there is no profit. Hence the aecessity of these additional foods.

\section{Roots.}

Rutahagas make an excellent Winter food for swine in connection with corn; they are casily 'and cheaply raised, as we have already stated. Parsnips are also generally liked, either raw or cooked. Bects are also a good Winter foed boiled with meal. The tops are also occasionally rel. ished. Cabbnge is a cheap and wholesome food; they are not, however, cheaply kept over Winter. They may be used with profit up to the firet of January.

The Grains.

These, after all, must be the main dependence, both in raising and fattoning swine. The kind of grain fed will, of course, depond upon the 
climate and region where raised. Where corn is a sure crop, is must bo relied ou almost entirely. The asssertions of theorists, that it is unfit for feeding, except during the short fattening season, although the merest twaddle, in the sense they intended it, will, from another point of view, be correct. The fattening season of swine should be from the time they are weaned until they are slaughtered. Swine for pork should never lose in condition from the time they were born until turned off for the butcher. The feeding of all the corn they will eat in connection with grass and other food, to kecp them hcalthy, and which will apply with equal force, whatever the grain fed, will bo found not only the most

- economical throughout the West and Southwest, but in all that region of country where corn is natural to the soil and climate, or where it may be cheaply bought

\section{Fording South.}

In nearly all the country South, corn may be cheaply raised as a part of the rotation. Here corn must be the main stay, supplemented by such grasses and plants as are natural to the region. The artichoke will do well much further south than is generally supposed, and some of the tuberous varieties may undoubtedly be found well down to the tropics. When it can be profitably cultivated, the Jerusalem artichoke should be used. The name Jerusalem is a corruption of the Italian nane Girasole, meaning sunflower, the botanical name being Helianthus tuberosus, or tho tuberous rooted sunflower.

Chafas, a tuberous rooted grass, (Cyperus), has become widely naturalized in the South, and is highly spoken of for feeding swine, since like artichokes, the hogs are left to gather them for themselves, and unlike the artichokes, they are most nutritious and fattening. They aro exceedingly easy to cultivate, but are sometimes said to be difficult to extirpate South. This, however, is probably incorrect, since from their very nature, a thorough Summer fallow will kill. North of thirty-nine degrees they do not survive the Winter. In fact, if frozen anvwhere, they are killed.

\section{Mast.}

In all the great timbared region South, "trec seeds, acorns, beechnuts, chestnuts, the softer shelled hickorynuts, and hazelnuts, form a most valuable food for swine. They should bo utilized to their fullest extent. So papaws, persimmons, and the other wild fruits of the forests South, may be made available in tho making of pork. Where bogs can have 
plenty of range, they will do very well with a little feeding, are generally entirely healthy, and upon being put up to fatten, a very little grain suffices, if only attention has been paid to get the proper breed. For the South, we believe the Berkshire, or crosses of the Berkshire on the best native sows to be one of the inostp profitable breeds. The Polaud-China of American breeds will be found most valuable for breeders and raisers at the South.

\section{Feeding in Confinemont.}

In all the great mine growing regions, where from twenty-five to five hundred hogs are amnually fattened and sold from single farms, the life of tho animals must necessarily be passed out-of-doors. So far as the breeding stock, and the first few months of the life of the pigs are coneerned this is always best, both from an economical and sanitary point of view. Thero are, however, inany small farmers, who annually fatten, from what they require for family usc, up to fifteen or twenty head a year, who find it most convenient and cconomical to feed and fatten both in Summer and Winter in pens. All this large class must depend, first, on tho skim milk, buttermilk and whey, and upon the slop of the kitchen for eceding; sceond, upon clover, cut and fed, weeds and other refuse material about the farin, and lastly and prineipally on corn either ground or raw. It is better for all this elass that the aens when built be planner Eo as to combine ease of handling with security aud comfort of the animals.

\section{IIog Barns.}

The hog house need not be an expensive building. For a few hogs 1 s may bo in the form of a parallelogram, with a passage way in the middle five feet wide, with pens opening into roomy yards outside. Each pen should be provided with a swing door, linged at the top, so the hogis in passing out and in may raise and lower it themselves. This they soon leurn to do: The pens may be about eight feet by ten feet, which, if kept elean, will accommodate three or four hogs each. Thus, a range of pens on each side ten feet decp and a five feet passage way between will, require a burilding twenty-five feet wide. A scuare building of this size will feed twenty-four hogs. If a less number is required to be fed the building may be twenty-five feet one way, and, say sixteen feet the other way, allowing for pens. If fifty hogs are to be kept it will require six pens on a side, and the building, to secure proper accommodation, must bo twenty-five by forty-eight feet, 


\section{A Crose Barn.}

If a large number of hogs are to be kept it is better that there be a central building twenty-five feet square, sixtcen feet of which is to be used as a room for the boiler and for storing and preparing the food. Extensions from this on every side are to be built twenty-five feet wide, and as long as necessiriy to aecominodate any required number of hogs. A tiglit box on four snall iron wheels arranged so it will turn short corners will carry the food to every pen, which should of course be pro. vided with a good trough, into which the feed may be easily pourcd. This with extensions, each forty feet long and twenty-five feet wide, will give you a cross barn, good for from 150 to 160 full grown hogs; and these extensions nay be cilried out to aecommodate 500 , if neccssary, but if more than 100 hogs are to he kept the central building should be forty feet square, three stories high, the upper stories uscd as a granary with corn eribs next the outside. Twenty feet square should be given up for the storage and stove room below, and the breeding pens placed next on account of the greater waimth. In a building of this description near Chicago, wo for years kept and fed, in connection with a largo market gardeu, from 400 to 500 annually, the principal food used being the daily waste from large hotel kitchens, which we daily supplied with vegetables, the garden furnishing economically the necessary grcen vegetable food. We had no sickncss or difficulty worth mentioning. The water supply was ample and pure; the pens were daily eleaned and washed in warm weather; the drainage was carefully attended to; salt and bituminous coal was supplied, so the hogs could take either at will, and we always had fat hogs to supply eity butchers, and the pigs wcre turncd off at about eight or nine months old, wcigling from 250 to 300 pounds each. This was about fiftcen years ago, and the breeds then kcpt were Chester county sows, crossed with Yorkshire or Suffolk boars.

\section{A Simple Pen.}

When swine are only to be kept in pens during the period of final fatu tening, and are allowed to run at large in the fields in the Summer, a pen fourteen feet wide, and of sufficient length to accommodate the number of hogs kept, will sufficc. It should be floored tight, and one-half of the width allowed for sleeping. These must be closed in and roofed, the feeding pen bcing open to the weather, the whole being divided into compartments or spaces, eight feet one way, or wide enough for four hogs to feed abreast. This also is a good form when not more than a dozen bogg are to be kept. 
Still another plan is to select a yard, in a dry, well drained place, allowing twenty feet square for each ton hogs; thus a lot forty feet square would accomodate twenty hogs. Along the middle of the pen, 2

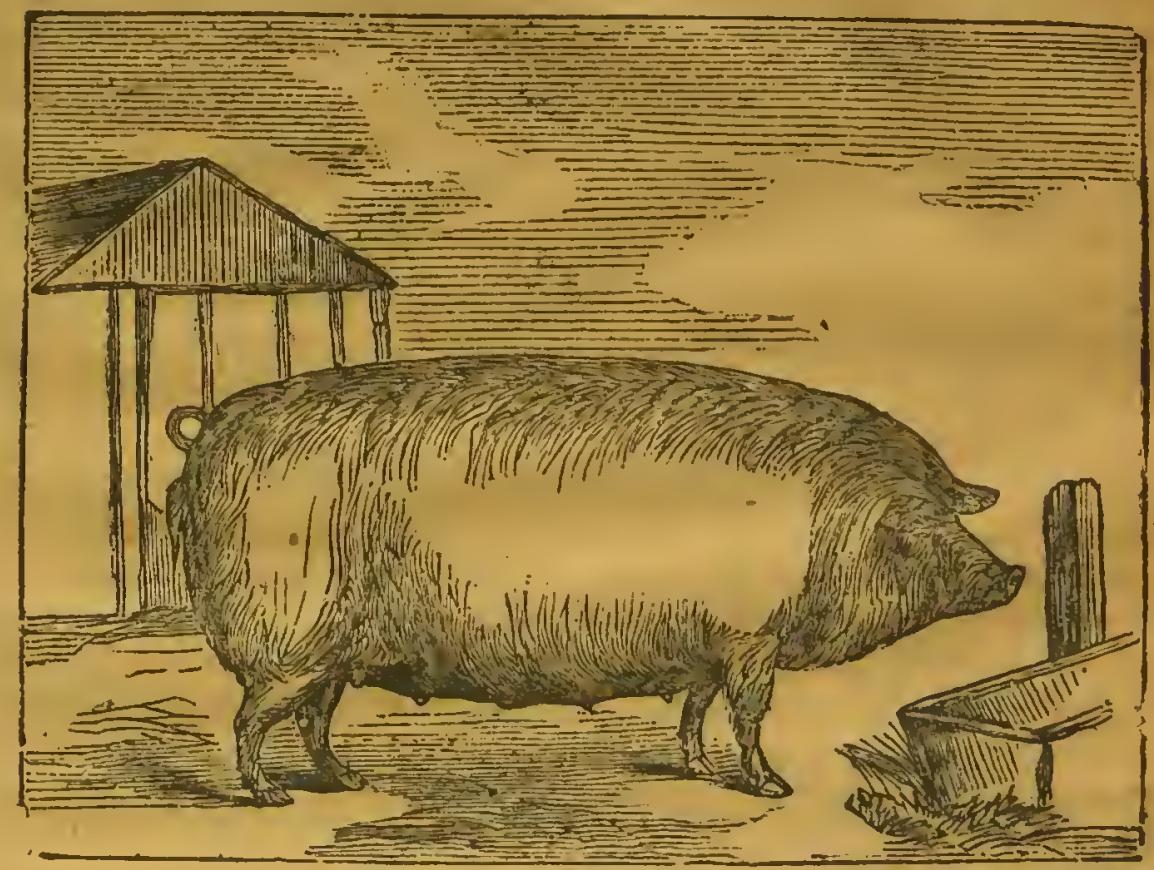

BREEDER IN GOOD FLEST.

wodding plaee is built, sixteen feet wide, with a partition in the middle, and divided the other way every twenty feet by partitions. The feeding place should be floored, eight feet wide, and have a low trough two feet wide, along the side for holding ear corn. Unless the season is very wet and muddy, hogs do very well thus kept. 'If wet, they must be kept out of the mud by means of hay and litter thrown into the yards from time to time, and the sleeping places must be kept well bedded. Kept in either of the ways we have designated, your hogs will go to the buteher fat, and showing a profit on the right side of the ledger, and your breeding sows will look like the illustration of a well-bred animal, which we give in ordinarily good breeding flesh, on this page. If on the other hand, you let your hogs shift for themselves, running wild over the prairie, or running about in the woods, they will, as the illustration on next page shows, come out pretty mueh like "Arkansas tooth-picks." Stock of this kind may be able to care for itself, but it will yield only a paltry retura in the market. 


\section{Summary.}

In what we have said in relation to foeding in close pens, we are not to be understood as advising the practice on the farm. There should bo plenty of pasture in Summer, and plenty of pure water always. Without this no one can succecd. There must be protection from insects and heat in Summer. The first may be perfectly secured by providing a dark place to which the hogs can retire at will. In Winter thcre must bo warm, dry and othcrwise comfortable sheltcr provided, and there must also be plenty of good food, at all tines. Of all animals the hog, at least, must not be allowed to lose flesh from the time it is born until it is killed. When fat, kill at once, unless the market happens so that it will pay to hold for a short timo for a turn. As a hog becomes fat, it eata

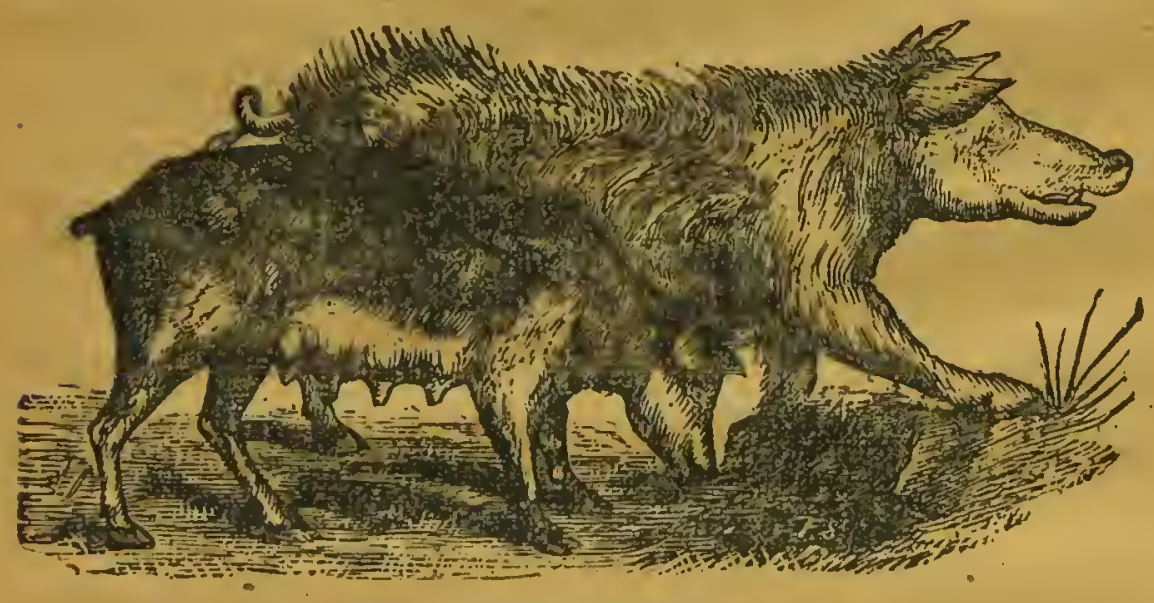

"ARKANSAS TOOTH-PICK8."

less and less, and it also fattens more and more slowly. Nevertheless, the same daily animal waste goes on. Many good feeders are so particular that they weigh their hogs every two weeks, and note tho gain. Then they are able to determine just how much thoir stock is improving, and also as to the proper time for turning them off. If not ready, or tho season and prices are not right, they increase the condition of tho food given, so that the small quantity taken shall make up in richness what it lacks in quantity. This class scldom sell stock over twelve months old, and many of our best feedcrs sell their hogs at ten months old, which will turn the scales at from three hundred to four hundred pounds each. Such feedcrs never keep hogs two Summers and ono Winter, in order to get au average of two hundred pounds each. 


\section{Light vs. Heavy Hoge.}

Years ago, when lard and side pork were the prineipal hog products looked for, the heavier the hog, the better the price. We oneo sold a hog weighing 650 pounds for fifteen eents a pound. That was in wartimes, and it brought one cent per pound over the priee paid for light and well fattened hogs. The same animal to-day, would not bring within a cent a pound, of what nice young nine and ten months, well fattened pigs would, in any of our prineipal markets. To get the weight named, tho hog was fed two years and a half. Take three pigs against this' one. The differenee in the first eost of the three sucklings as against the one, would not exceed three dollars. The three pigs will be fed nine months, and weigh 600 pounds, - (we have made pigs farrowed in Mareh and killed the next January, weigh dressed, up to 380 pounds, and have more than onee turned off sueh pigs at ten months old weighing alive over 300 pounds average) the other must be fed almost three years, and you must be a good focder if you make him weigh 600 pounds. In the first cuse, you have fed nine months each, or twenty-seven months on the three pigs for 600 pounds, and in tho other case, you have fed thirty-six months for the same weigh $t$. The one big hog has eaten more eorn than the three pigs, and yet the three pigs weighing the same as the one will bring about six dollars more, giving you three dollars on the original purehase, as between the three and ore, end a very considerable amount of corn on the credit side of your aecuunt büir. 'You don't believe it? Examine tho tabies we huve given on feeding and turning off eattle young, as against feeding until they were mature. We could show many instances fully as convineing as this, in the ense of hogs; but why pile up testimony after the argument is conclusively established beyond controversy. 


\section{Diseases OF S'WINE.}

\section{CAUSES, SIMPTOMS AND CURE.}




\section{CHAPTER I.}

\section{DISEASES OF SWINE:}

BAPLANATION OF CUT. - DIFFICULTY IN ADMINISTERING MEDICHNE. - GOOD NERSING THE ESSEITIAL. MALIGNANT AND CONTAGTOUS DISEANW.- HALIGNANT EPIZOOTIC CATARRT.-HOW TO KNOW IT. - WUAT TO DO. INTESTINAL "HOG CHOLERA."— HOW TO KNOW IT.—CAUSES. - - TREAT. MENT. - PREVENTION. — CONTAGIOUS PNEUMO-ENTERITIS. — ITS ORIGIN. -TUE FRYSIPELATOUS FORM.—THE FORM MALIGNANT SORE THROAT. WHAT TO DO.-MALIGNANT ANTIMAX, SPLENIC FEVER.-TRUE CIIAREON. CONTAGIOTS PXEUMO-ENTEITIS. — INFLABIMATORY DISEA8ES. — QUIN. gET, OR STRANGLES.- - RISTIG OF TIV LIGHTS.—-PNECMONIA.—CATARRH IN THE HEAD, TDISEASE ON TEE SKIN.—-MEASLES.— HOW TO FNOW IT. -THE LARD WORB._-WHAT TO DO.——TRICLINA SFIRALIS.——EOW TO CURE. - LICE.—DIARRHEA.——SUMMARY.

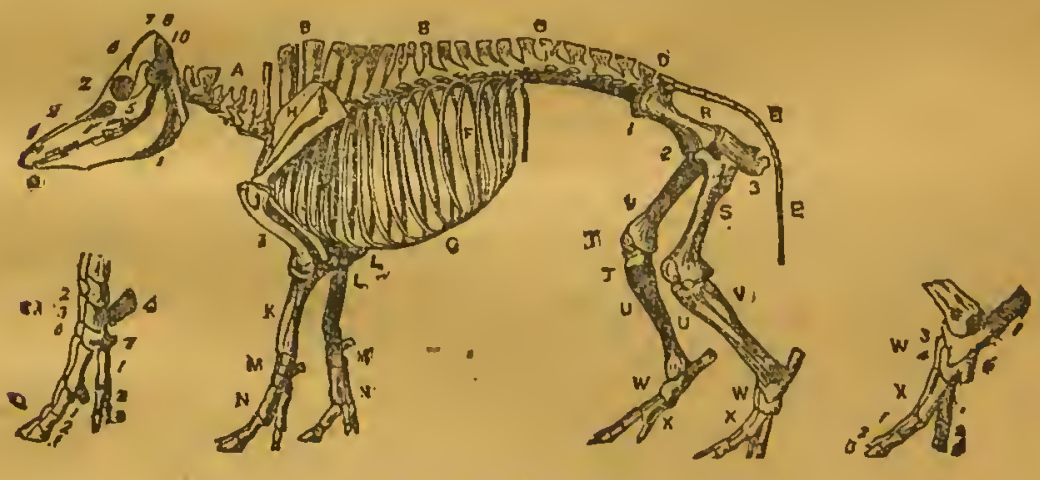

SKELETON OF THE HOG.

Explanation-A-Cervical vertebræ. $B, B$-Dorsal vertebræ. $C$-Lumbar vertebræ. D-Sacrum. $E, E$-Coccygeal bones. F, $F$-Ribs. G-Costal cartilsges. $H$-Scapula. $I$-Humcrus. $K, K$-Radius. $L$-Ulna. $M$-Carpus, or knee. 1. Scaphoid. 2. Semilunar. 3. Cuneiform. 4. Trapezium. 6. Trapezoid, 6. Os magnum. 7. Unciform, 8. Pisiform. $N, N$-Large meta 
carpal, or eannon. $O$-Small metacarpal. $P, P$-Sesamoid bones. $Q, Q-$ Phalanges. 1. Os suffraginis, or pastern bone. 2. Os coronal. 3. Os pedis. $R$-Pelvis. (Fore-leg of pig. Phalanges 1, 2,3). 1. Ileum. 2. Pubis. 3. Ischium. S-Femur. T-Patella. U-Tibia. V-Fibula. W-Hock. 1. Os calcis. 2. Astragalus. 3. Cunelform magnum. 4. Cuneiform medium. 5. Cuneiform parvura. 6. Cuboid. 3, 6. Cubo cuneiform. $X$-Large metatarsal (Hind-leg of pig. Phalanges 1, 2, 3). $Y$-Small metatarsal. $Z$-Head. 1. Inferior maxills. 2. Superior maxilla. 3. Anterior maxllla. 4. Nasal bone. 6. Molar. 6. Frontal. 7. Parietal. 8. Occipital. 9. Lachrymal. 10. Squas mous-tempoid. 11. Petrous-tempoid.

\section{Difflculty in $\Delta$ dmintstering Medicine.}

No elass of farm animals are so diffieult to treat in siekness as swine. The horse, the eow, and tho sheep, may have medieino administered to them by an intelligent opcrator with comparatively little difficulty. Not so swine. They resist every effort with their utmost strength, and med. ieine can only be forced down by main strength, the resistanee itself, being, in nine eases out of tcn more injurious, than the good the medieine may do. When it must be administered by the mouth, the best means we have ever found, is to plaee the hog in a narrow pen in which he ean not turn round, put a slip noose around the upper jaw, turn the medicino -in thc ease of a drench-down from a horn, or when it may be admissible give it in the form of an injeetion. In the ease of boluses they may he laid on the baek of the tongue, next the palate, and the animal thus co æde to swallow.

\section{Good Nursing the Essential.}

For the reason that medicine is so difficult to administer, it is always best, when the hog will eat or drink to disguise the dose in some food or drink it likes. In fact our praetiee has always been, if medicine eould not be so administered, to let good nursing and care be the chief dependenee in bringing the animal safely through.

In the ease of thosc malignant forms of epidemic and eontagious diseases which, under the eommon name of hog cholera, have so frequently scourged the West within the last few years, unless the affeeted animals arc treated during the first or symptomatic stage, the only course to purBue is to isolate every diseased animal from the herd as soon as found, and remove the well animals to a separate plaee where they are not in danger, and above all where they eannot eome in eontact with other hogs; then with sueh medieine as they will eat in food or drink trust to nature and good eare to bring them safely through. 
So far there has been but little success attending the treatment of these diseases, probably from the fact that the incubative stage of the disease was passed and the animals bcyond the reach of remeaial mcans before the owners were aware that the animals were attacked. In the treatment of the diseases of swine, we shall first describc fully the three principal forms of those malignant discases termed hog cholerd, and for which there are so many specifics advertised-some of them by men so ignorant as to call all distempers hog cholera, and prescribe identical treatment, for diseases that require entirely different remedies.

\section{Malignant and Contagious Diseases.}

There are three principal forms of malignant discascs, called hog cholera. The first is malignant epizootic catarrh, which in 1875 and 1876 swept over Illinois, Missouri, and neighboring States, destroying vast numbers of swinc; next the disease noticed by Professor Kiline, of England, and described as contagious pucuno-entcritis ; the third, anthrax and splenic fever and $a$ form of intestinal fever closely allied to the list if not identical, and which Dr. Law designates as intestinal fever or hog cholera.

\section{Malignant Epizootic Catarrb.}

This disease, if it does not originate in filthy yards and putrid pons, is amazingly developed there. The poison germs find a congenial home in the mucous membrane of such hogs, and in those whose skins are so dirty that the natural perspiratory acts cannot take place, so if perspiration be checked during the prevalence of this epidemic, or the swine be exposed to sudden changes or the chilly night air, it will surely predispose them to attacks.

\section{How to Know It.}

There is a short, hoarse cough, difficulty of breathing, with panting of the flanks. The head is held in a stretched and drooping position; there is fever, a stiff, tottering gait, sometimes running at the nose, often efforts to vomit, generally constipation, but at times diarrboa. In this form the disease is shown is the dead animal by inflamination of the lining membrane of the nose and upper part of the throat, thence to the windpipe and lungs, which are more or less solidificd.

A second form of this disease has a short cough, not so pronounced as in the first form, and there is less oppression in breathing; but there is more decided paralysis in the hind quarters and the gait is more tottering. There is at first constipation, followed by a profuse and fetid diarrhea 
The disease is spending itself in the stomach and bowels. The animal arching its back and especially the loins from the intensity of the pain. The brain is often affected so there is partial or total blindness and aimless movements. So also the glands will be enlarged and sometime serofulous ulcers will show in different parts of the body. The dead animal shows the lining membrane of the intestines inflamed and degenerated. The spleen enlarged, dark, and soft; the liver diseased, and often water exudations in the chest and bellv. The duration in either form is from five to fifteen days.

\section{What to Do.}

If the disease has progressed so as to show the latter symptoms we have described, kill, and bury the animal at once, and deoply. In any event separate the animals showing the slightest symptoms from the rest of the herd, and remove the well ones to comfortable and dry and well ventilated quarters, and give pure water and good, easily digested food. As soon as the first symptoms aro discovered give an cmetic as follows:

No. 1.

15 to 20 Grains powlered white bellebore, \% Pint milk.

Mix for a full-grown hog, and let it drink ; if it will not, turn it down with a horn as previously described. This having vomited the log, in a couple of hours after give two.or three grains of tartar emetic, if the trouble is in the lungs; if in the bowcls, two or three grains of calomel; either medicine to be given in the half of a roasted potato or apple if the animal will eat, or to be cnveloped in tallow or lard and laid on the root of the tongue and the animal made to sivallow. Repeat the dose twice a day until relief is obtained. According as the lungs or bowels are affected apply to the sore place the following blistcring ointment, heating over a modcrate fire, for half an hour and stirring to mix: No. 2.
$\begin{aligned} & 4 \mathrm{Oz} \text {. powdered cantharides, } \\ & 4 \mathrm{Oz} \text { olive oll. }\end{aligned}$

Rub in well and repeat the application if no blister is drawn. If tho animal improves, givo every day for a few days the following:

No. 3. 20 Grains sulphato of iron,

30 Grsins carbonate of potagh.

Thls, when the lungs have been the seat of disease; if in the bowels, omit the carbonate of potash. Professor Townsend thinks that in many cases the liver is torpid, and thus blood poisoning takes placo. When 
the attack commences with copious and dark discharges from the bowels, he recommends to give at once:

- No. 20 Grains podophylitin.

2 Drachms bicarbonate of sods.

Or, if constipation be present:

No. 6.

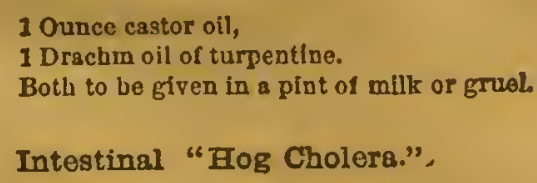

In relation to this disease, undoubtedly analogous to the one last described, Dr. James Law thinks it is a specific contagious fever of swine, attended by congestion, exudation, blood extravasation, and ulceration of the membrane of the stomach and bowels. That is, fetid diarrhœa, general heat and redness of the surface, and on tho skin and mucous membrane spots and patches of a scarlet, purple or black color. It is fatal in from one to six days, or ends in a tedious, uncertain recovery.

\section{How to Know It.}

Incubation ranges from a week to a fortnight in cold weather, to threo days in warm. It is followed by shivering, dullness, prostration, hiding under the litter, unwillingness to rise, hot, dry snout, sunken eyes, unsteady gait behind, impaired or lost appetite, ardent thirst, increased temperature (103 degrees to 105 degrees $\mathrm{F}$.), and pulse. With the occurrence of heat and soreness of the skin, it is suffused with red patches and black spots, the former disappenring on pressure, the latter not. The tongue is thickly furred, the pulse small, weak and rapid, the breathing accelcrated and a hard, dry cough is frequent. 'Sickness and vomiting may be present, the animal grunts or screams if the belly is handled, the bowels may be costive throughout, but more eommonly they become relaxed about the third day and an exhaustirg foetid diarrhwea ensues. Lymph and blood may pass with the dung. Before death the patient losos control of the hind limbs, and is often sunk in complete stupor, with muscular trembling, jerking, and copious and involuntary motions of the bowels.

\section{Causes.}

It is mannly propagated by eontagion, though faults in diet and management serve to develop it. The infection is virulent, and may, if 
is supposed, be communicated by the wind, and is with difficulty dostroved in log-pens, fodder, bedding and other articles of contuct.

What to Do.

Treatmont should not bo permissible, unless in a constantly disinfectcd atmosphere. Feed barley or rye, or in case these raise the fever, coin starch made with boiling water; give to drink ficsh cool watcr, slightly acidulated with sulphuric acid. For the early constipation give a nild laxative (castor oil, rhubarb), and injections of warm water, to bc followed up with nitrate of potassa and bisulphate of soda, of cach 20 grains at a dose. If the patient survives the first few days and shows signs of ulceration of the bowels, by bloody dung, or tenderness of the belly, give oil of turpentine fifteen to twenty drops night and morning. Follow up with tonics and careful, soft feeding.

\section{Prevention.}

Kill and bury the diseased; thoroughly disinfect all they have come in contact with ; watch the survivors for the first sign of illncss, test all suspicious subjects by means of a clinical thermometcr introduced in the rectum, and separate from the herd if it shows 103 or more degrees Faranheit. And as soon as distinct signs of the disease are shown kill and bury deep. Feed vegetable or animal charcoal, bisulphate of soda, carbolio acid or sulphate of iron to the healthy swine, and avoid all suspccted food or places, or cven water which has run near a diseased herd. All newly purchased pigs should bo placed at a safe distance in quarantine, under separate attendants, until their health has been surely ostablished as sound.

\section{Contagious Pneumo-enteritis.}

This disease known commonly also as "hog cholera," "purple," "bíuo disease," etc., is a contagious inflammation of the lungs and bowels, accompanicd with red and purple blotches of the slcin, the last described being one of rolative forms of this discase.

\section{Its Origin.}

It is supposed to be caused by extremes of temperature and wet seasons, feeding on. low or swampy soils, impure watcr, filthy feeding pens. Whether thcsc causes originate the disease or not they incline the system to infections from the subtle poison which Dr. Klein, an eminent English 
veterinarian, has proved to be duo to a minuto vegetable organism, (bacillus) found in the serous fluids, and tissues of animals infected. M. Roche Lubin, a French veterinary authority says the disease fill disappear if proper sanitary means are used, protection from tho sun and rain, well ventilated quarters, and clean bedding, often renewed, with pure water and wholesone food. We have been thus particulur in quoting, to intonsify what we have repeatedly said, cleanliness and care.

\section{How to Enow It.}

There are two principal symptomatic forms which are important to bo ooticed, as follows:

The Erysipelatous Form.

The animal at first is dull, loses his appetite, lies down and movos unvillingly. If hangs his head, and sometiunes makes efforts to vomit. The bowels at this time aro generally coustipated, the excrement being hard and dark colored; cough and difficult urination.

The sext day or in in few hours, even, the characteristic symptom of the disease shows itself. This consists in the appearunce of dark red or purple blotehes, pussing into a bluish-black color. Once seen, they canmot be mistaken. Their most frequent seats are the ears, throat, neck, breast and inside the fore legs. If he is a white hog the discolorations are very visible. With these there is often a discharge from the nose of a dark purple fluid. Soon his breathing becomes panting and labored; he is palsied in his hind quarters, and if he is driven up runs reeling with his hind legs and his head dropped to the ground. At this stage a fetid diarrhœu sometimes sets in. The fatal termination is reached in one or three days.

\section{The Form with Mralignant Sore Throat.}

The gener.l symptoms at the commencement are the same; and the appearance of the throat has that same deep red, passing into dark puiple hue, which we have just noticed in the erysipclatous variety. But the obstructions to the functions of breathing and swallowing naturally prom duce a train of characteristic symptoms not seen in the former case. There are attempts to vomit, difficulty in swallowing, and labored breathing from the first, the sensation of choking being so distressing that the animal will sit on its haunches, like a dog, gasping for breath, opening its mouth wide, and protruding a livid and swollen tongne. Sometime the swelling about the laryax is so sudden and cousiderable that the an 
mal is choked to death in less than an hour, and before hajdly any urher symptom has had time to manifest itself (œdema of the larynx).

\section{What to Do.}

The chenpest remedy with animals distinctly attreliod, is to kill a. onee, and bury deeply out of sight, to prevent eontagion. If the animals are valuable, isolate them from all danger of spreading the contagion; giro two to three ounces of eastor oil, and as soon as it operilces, give twenty grains of nitrate of potash, and twenty grains nitrate of sodil, mixed for a dose-two or three times a day. Give also powdered charcoal in the drink, and if the borrels are swollen and tender give twenty drops of turpentine in a little gruel, as may be needed. 'The preseription of M. Lubin, and one of the must valuable known is :

$$
\text { No. } 6 .
$$

10 Grains poridcred camplar,

1 Drachin nitrate of potash, 5 Grains culomel.

Mix and give in a little gruel three times a day, omitting the ealomel after the third dose.

The loeal trentment should be attended to. Foment tho smollen part with hot water saturated with eopperas (sulphate of iron). If there is gangrene, saturate the surrounding tissues with turpentine and street oil, and attend strietly to the general sanitary conditions of the hosihitil or flace where the animals, both siek and well we kept. Professor Williams advises the use of ehlorate of potash as superior to all othen medisines. His preseription is :

No.7. 2 Draclums chlorate of potash, \% Piut wator.

Professor Turner, the well known Illinois scientist and extcnsive farmer, advises the following ns having becn suceessful witin him as a pretentive, and if talien in the early stages of the diarthan, as a curo:

Ne. 8

$$
\begin{aligned}
& 2 \text { Ibs. flowers of sulphur, } \\
& 2 \text { Lbs. sulphate of iron, } \\
& 2 \text { Lbs. madter, } \\
& \text { 1/: Lb. black antlmony, } \\
& \text { 3/2 Lb. nitrato of potasl, } \\
& 2 \text { Oz. arsenlc. }
\end{aligned}
$$

Mix with twelve gallons of slop, and give a pint to each hog; this quantity being for 100 hogs.

Our best word of adviee is, if the affected hogs eannot bo mad.e to talie the remedies in their food or drink, since it is a question of profit and 
1068 simply, then kill, bury at onee, and disinfect promptly. For the means of disinfecting, see chapters on eontagious diseases in cattle. If we had simply stid kill and bury, our readers would not have been satisfied. Thus we have given much point to remedies; yet it will again bear repcating: In all contagious diseases of animals, of a malignant type, it is eheapest and most humane to KILL AND BURY QUICKLY AND DEEPLY. We have never found any remedy effective once it assumes a malignant form. Unfortunately, there are too many careless or pennywise persons who will not kill, and who constantly spread contagious diseases.

\section{Charbon, Mralignant Anthrax. In Swine, Splenic Fever.}

It has been denied that this disease attacks swine. Since it is a blood poison known to attack various animals, and which may be communicated to man, there seems to be no good foundation for the assertion. In this country there has not been sufficient systematic investigation to separate the names of the true Anthrax from what is popularly linown as hog cholera. The distinetion betwecn Anthrax (Churbon) and contagious pneumo-enteritis is stated explicitly by Dr. Klein as follows:

TRUE CHARBON.

Period of incubation, or latency, from a few hours to three days.

Easily transmissible to other species of animals.

Spleen always enlarged, and often broken down.

Blood after death dark and fluid.

Bacillis anthracis in the blood.

Lungs and bowels frequently not implicated. Cough may be present.

The discoloration local, and of a true carbuncular appearance.
CONTAGIOUS PNEUMO-ENTERITIS.

Period of incubation from two to five days and morc.

Rarely and with difficulty transmitted to other specics.

Spleen rarely enlarged or otherwise changed.

Blood after death of ordinary appcarance.

No bacillus anthracis in the blood, but numberless bacilly in the serum of the throax and abdomeu.

Lungs and borrels always both inflamed. Cough always present. The red or purple color diffused over the surface, and of an crysipelatous appearance.

The most common form of anthrax in pigs is popularly called "whito bristle." There is a carbunculirr swelling, usually on the throat, presenting the features of color alrendy described. The bristles on the spot turn white and brittle, whence the name just given. The swelling extends 
inward, involving the windpipe and gullet, enusing difficulty of breathing and swallowing, and at length death in convulsions through suffocation. Ocensionally the true apoplectic or splenie form of charbon appears, and also the varicty which attacks the tongue and moutb, both aente 'and quickly fatal, tho apoplectic form often killing almost instantly. The nesh of all animals dying of any form of this disease, as previously stated, is pcisonous, and tho blood and discharges capable not only of epreading the disease anong others of the same species, but also, if in oculated into the human system, of bringing on that mortal malady, "malignant pustuie." The treatment, if trentment for so fearful and fatal in cliseaso may be allowed, should be essentially the same as that preseribed in eontagious pneumo-enteritis. As a preventive the recipe of Prof. Turner may be used. We advise to give medicine if only enrly Eymptoms be observed, but if animals be distinetly attaeked to kill immediately, bury out of sight, and DISINFECT THORODGLLY.

\section{Inflammatory Diseares.}

Srine are from their nature, and the usual manner in which they aro kept, quite subject to coughs, colds, quinsy, and inflammatory disenses. especinlly of the lungs.

\section{Quinsy, or Strangles.}

This is a disense quite common and fatal. It is an imflammation of tho glands of the throat, (tonsils) and often kills quickly through suffoeation, If in feeding them there be found diffeulty in swallowing, or protrusion of the tongue, and slavering from tho mouth, and if thero be a swelling under the neek and lower jaw, lose no time, cast the pig so he may be leld firmly, and with a laneet or sharp knife, scarifying the slin of the throat deep enough to draw blnod frecly. Fonent the parts witl cloths wet with hot water and partially wrung out, repeatchly appliced to induce bleeding, and reduce the inflammation, while an assistunt prepares tho following injection:

No. 9.

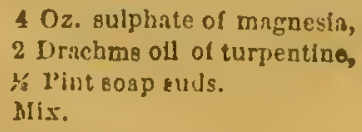

Tith a forther fastened to a sinall rod, the hog's mouth being held oper, swah the tonsils and inside of the thiout as far as ean bo reached, with equal parts of lard oil :nnd turpentine, or if the bog will eat, give doses of two tea-spoonfuls each in a pint of Eruel. 


\section{Rising of the Lights.}

This is the namc applied to an ordinary cold. To cure this, keep tho animal warm, feed well, and rub inustard, moistcned with vinegar, on the throat and chest. If it does not yield, give an ounce of tar daily, by putting a slip noose over the snout, opening the mouth, and placing tho tar well back on the tonguc with a narrow wooden paddle.

\section{Pneumonia.}

The symptoms of inflammation of the lungs arc, quick and laborious breathing, loss of appetite, slivering of body and limbs, more or less severe cough; and the animal will not eat. The rcmedy is to keep tha animal thoroughly warm and quiet. Rub the preparation of mustard and vinegar cu the chest, aud give internally,

No. 10.

2 Draelums nitrate of potash, 2 Draclms bisulpuate of soda, hol'ts.

Mix in a pint of grucl if the animal will eat. If not turn down from a

\section{Catarrh in tho Fead,}

Commonly called snuflles. Give the animal a elcan, dry, warm pen, and feed and wator well; soft food boing prefernble.

\section{Disease of the Skin.}

Swine are esscntially liable to discases of the skin, when kept in confincmont, unless pains be taken to do for them what they cannot do for themselves, exeept where they have their libcrty.

\section{Measles.:}

Measles in swinc hare nothing in common with the disease of the samo name in the human subject. The name is given to a parasitic affection, oce cusioned by the hog taking the eggs of the tapeworm, either in grazing, where they have becu dropped with the excrement of the dogr, or from

- fecling on pastures manured with human exerement. These eggs latel and work their way into the tissues and become eneysted, and if the pork of such animals is caten, insuffieiently cooked to destroy them, by man, they transfer the tapeworm. In fact, it is not eertain that ordinary cookhg does destroy all, therefore it is nerer safe to eat measly pork. Tho appearnnce of the pork is owing to the presence of minute cysts, the sizo of grains of barley, distributed through the muscular and other tissues. 


\section{How to Know It.}

There may or may not be, but generally is, a discharge from the noso, running of the eyes, weakness of the hind parts, and general ill health. By cxamining the skin, small watery pimples will be found of a pink or red color. The remedy is undoubtedly beyond the reach of medicine, though a so-ealled specitic is small doses of sulphux and saltpetre, given daily for weeks. The prevention is, to put no human exerement on grazing fields, to kecp dogs clear of tapeworm by an oceasional vermifuge, to bury all exerement of dogs found in the pastures, and to kill all stray and worthless curs.

\section{The Lard Korm.}

There is another parasite of the hog, the lard worm (Stephanams Dentatus), from one to one and three-quarters of an inch long, which is oceasionally found in all parts of the body ; of swine is frequent in the liver, kidneys and fat around the ribs, and in various organs of the body, including the heart. When present in large numbers, especially in the kidneys, its eggs may sometimes be diseovered in the urine, by means of the microscope. Another worm, Eustrongylus Gigas, also inhabits the lidneys; both may produce weakness of the back, but it would not be safe to treat for these parasites, unless this was surely determined by the microseope.

\section{What to Do.}

Do nothing. Various remedies have been preseribed, such as small doses of sulphur and salt, given daily for several weeks, or small doses of salt and turpentiue. Neither have eertainly been known to do any good. Minute doscs of arsenic, cne-eighth of a grain, given daily for two or three wecks, so it may be taken up by the system, would be tho proper course indieated. The better way is to prevent their getting measly, by keeping the diseased ones entirely from the well ones, and the young away from the old.

\section{Trichina 3piralis.}

This minute parasitc is capable of infesting all domestic animals, including man. The mature and fertile worm lives in the intestines of the animals, and the immature worm in cysts in the musele. The eating of rats, and other vermin, and slaughter house offal is the prolific souree from whenee they come. The prevention is obvious. They are rarely found in western farm-laised, colm-fed hogs. There is no danger from eating pork infocted with trichina, if it be thoroughly cooked. There is 
no means of discovering then in flesh, except by the microscope. Eat none but corm-fed pork, and that cooked done. Rare conkcd pork in any form whatever, is an ahomination, and pork fed in slaughter house yards cud distilleries should wan'ment their owners beirg seat to the penitentiary. 4.s., , . Miange, or Scab.

This is caused by the presenee of a minute insect, sarcoples suis, tranes missible to man, and should not be allowed in any herd of swine.

\section{What to Do.}

As soon as discovered, rub the infested animals thoroughly with soft soap, let it remuin an hour, and wash off with warm water using a good orrsh, lot the animals dry, and apply the following ointment:

No 11.

1 Pint train oil,

a Drachms oil of tar,

1 Urachan netroleum.

Mix with sufficient flower of sulphur to make a thiek paste. Thin dhould be well rubled in, and remain on threo days. Then wash thor. sugb y with strong soap suds, clry, and change to cuirters perfectly clean; burn.tl beddirg, and cleanso the quarters thorouglly with carbolic acid and rater. The carbolic liquor of gus works is good, of which there shova always be a larrel on the furm. It is cheap. Thin down slaked lime with it, and thoroughly paint all infected places.

\section{Liee.}

If lice are found on swine, it is a sign that something is wrong. To Bave never seen then on well conditioned swine. When they vecur from ony cunse, sponge tho animal freely with crude petroleum, or kerosene, sud gire a little sulphate of iron. (copperas) one quarter drachm a day, in the feed. Ist thr fond also be ample and rourishing. Another efficient and safe remedy for killing lice is Scotch snuff, iubbod up with lard, und aplicd where tho lice are found.

\section{Diarrhe».}

Diarrheal affections often attack young pigs during their sucking sen eon, generally in the first week of their life - and often caluses their denth. Usmally the eause is due to disersed nilk of tho eow, eitber from bald food, or other eauses. If so, change the food. In any case, the remedial means must be used with the sow. Place charcoal and salt where now and pigs may get it, and prepure tho fullowing powder 


\author{
No. 12 \\ 2 Founds fcnugreek, powdered, \\ 2 Pounds anise secd, porvdered, \\ 1 Pound gentian, powdercd, \\ 2 Ounces carbonate of soda, \\ 2 Pounds chnlk, powdered. \\ Give a table-spoonful of this in the food, every time the sow is fot.
}

\title{
Summary.
}

- From what mo hare said the reader will easily perceive that we huvo not much faith in remedial means in contagious diseases of swine. 'Tho came hoids good with any animal when once the discase is pronounecd, and of a malignant type-unless the animal be so valuable that it will pay to call a veterinary surgeon. Even then in the malignant forms o: the discuses described, and which are known under the popular misnomer of "Ing Cholera," lilling and burying is the cheapest and altogether the most humane. Tho dangुer of epreading; the difficulty of isolation; and the next to impossibility of treating a hog too sick to eat, lout never too sick to be contrary, or resist to the full extent of their power, and the ordinarily small cost $\mathrm{c} f$ swine per head should be well considered in the treatment of swine. Use proper discretion in treuting tlom, but do not hesitato a monent in killing, when the discase is malignant, and in olclinary cases remember that if the $\log$ will not take his physic kindly in his gruel, better let nature and good nursing perfect the cure tian to violently force medicine down. Please remember the value of good nursing in human paticnts. To reinforce this we may state tho sact thas in France, long continued experiments in hospitals, with nuany paticnts, treated under the rarious systems of medicine, a greater proportion recovered witl no medicine and good care and nursing, than did under JEDICATION WITH ORDINARY IOSPITAL CARE AND NURSING. This may not have been complimentary to tho hospital management, yet in no country in the world are they better or more conscientiously managed.

The necessity cis good nursing in the case of swine is no less inperativo than in that of humac leings, ujd its good results are as raanifeat. 


\section{POULTRY.}

HISTORY, BREEDS, CHARACTERISTICS

AND MANAGEMENT. 
4

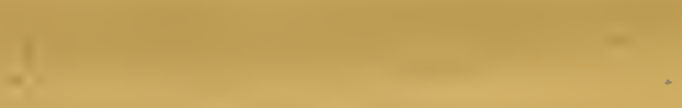

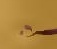

$-$ 


\section{POULTRY.}

\section{CHAPTER I.}

HISTORY AND WILD TTPES.

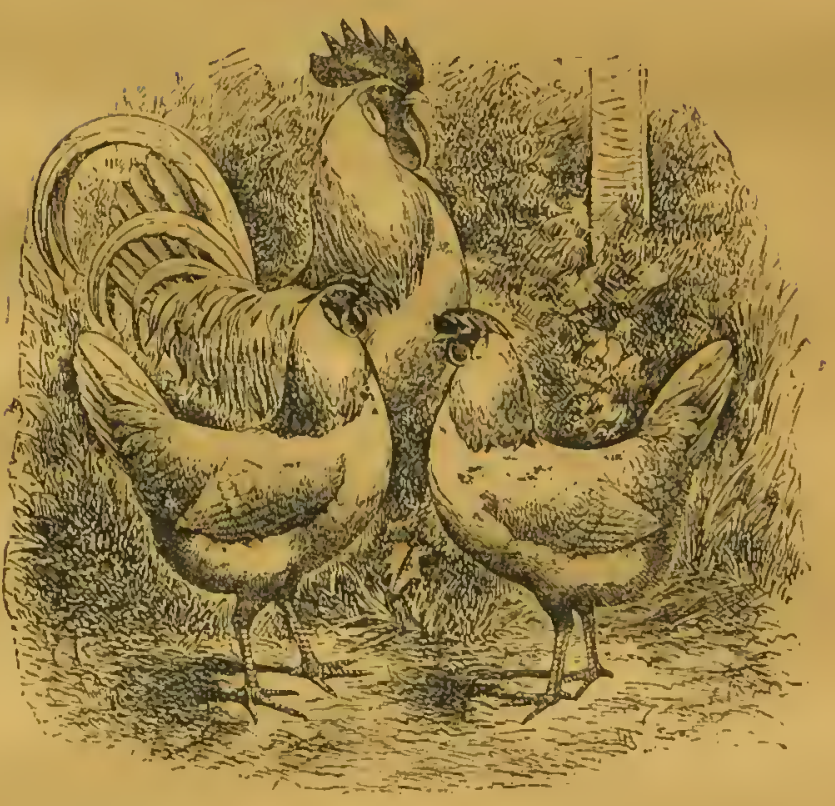

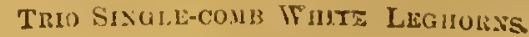

Origin of Domestic Fowls.

The first domestication of the farm yard fowl is lost in the obseurity of the past. We bave not even tradition to guide us. There is a legrand 67 


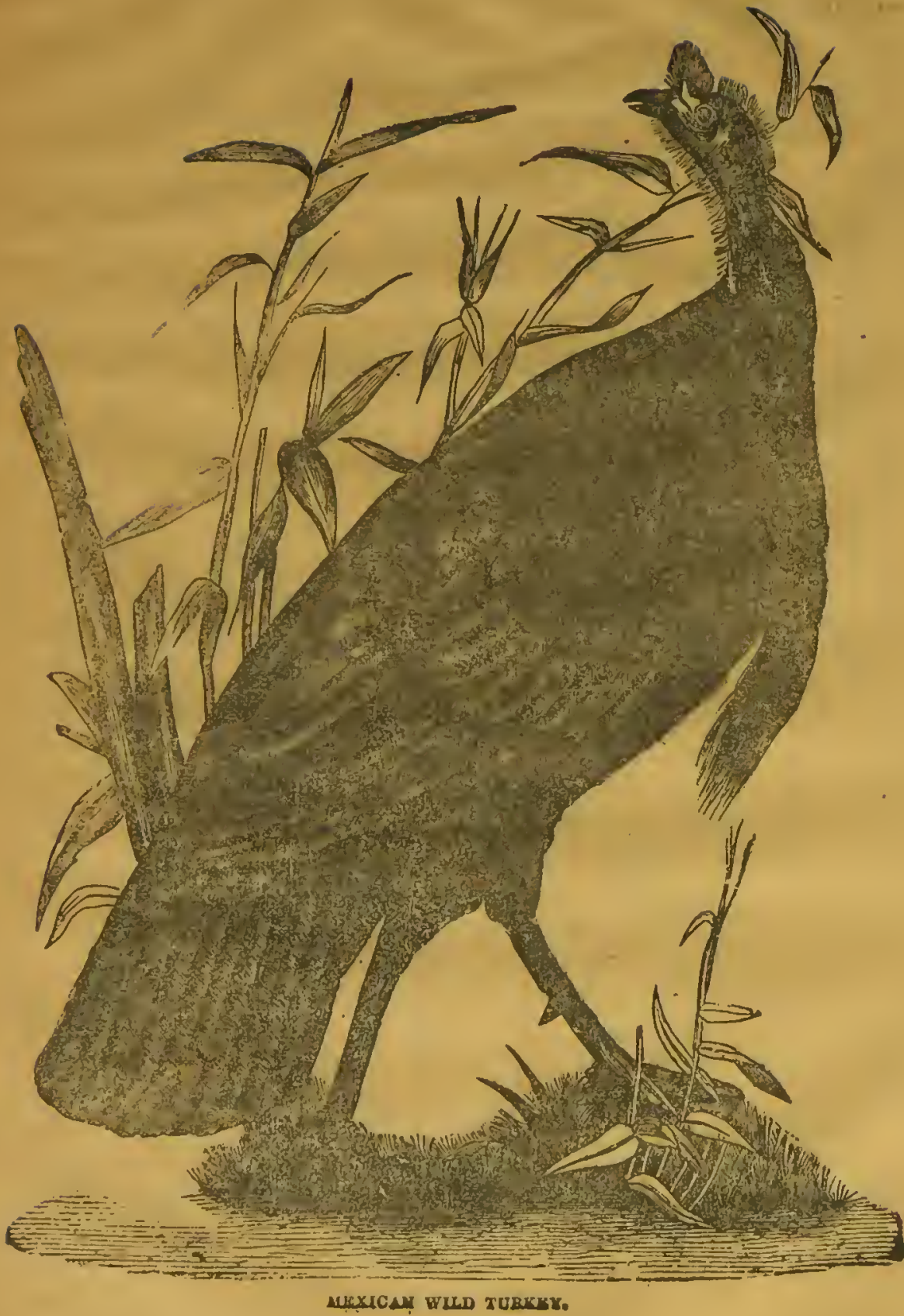


that Gomer, the son of Japhet, took his name from the cock, and hence it has been inferred that he was the first to domesticate the species. As well might some future historian attribute the domestication of various

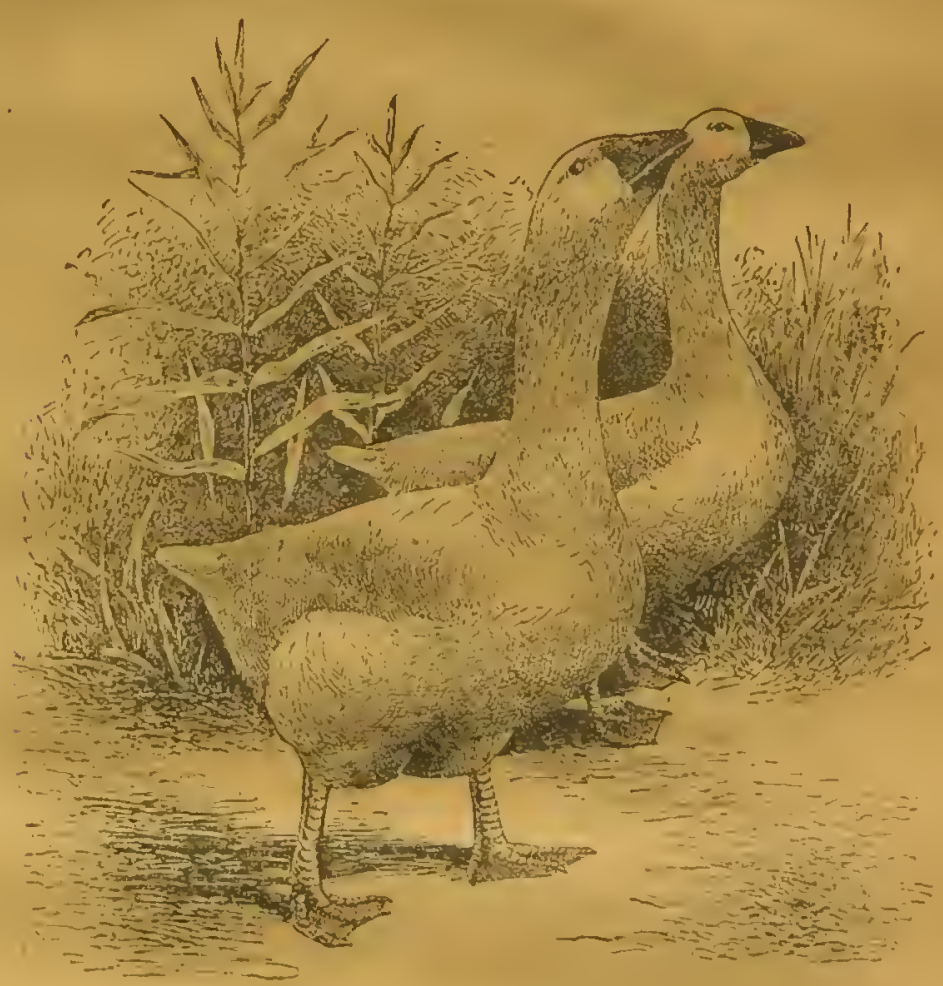

P.IM EMU⿴囗十⿱ GE GE,

wild and domestic animals of our time to the savage Indian, obose faney leuds him to accept the name of various wild beasts and birds os hith ore 
The fact is, the domestication of wild forls is exeeedingly easy, as has heen proved within the last three hundred years by the domestication of the wild turkey of Ameriea, (meleagris) of which there are but two specles known, M. Oceellata, a native of Mexieo and Honduras, and M. Gallopavo, from which our common domestic varieties have descended. Later the American wild goose, (anser canadensis), a distinct species from the gray legged goose of the North of Europe, and the supposed ancestor of the common white or gray goose, and the Embden or Bremen goose.

Besides Europe and America, Asia and Africa havo furnished us with four sub-varieties of geese, three of which are ealled China gcese, the fourth being the Afriean or Hong Kong variety.

Afriea has also furnished us with the Guinea fowl,(Numidia meleagris) called Pintado by the Spanish. It is a native of Northern Africa, where it is still found wild in large numbers, in some parts. The Pea fowl, (Pavo cristatus) has also been known from the remotest antiquity and is often used by ancient writers as an emblem of pride and arroganee, and it may be added, what is also true of the arrogant and strutting turkey, it is as cowardly as it is arrogant and cruel.

The pheasant may here be notieed as a breed long half domestieated, end yet never brought perfeetly under the domestieation of man. The probable reason for this is that like the Peacock, they have always been considered more ornamental than uscful. There are four or five distinet and beautiful species, that as ornamental breeds in parks stiould be more extensively bred thali they are.

The Swan is nnother breed long known in history and yet which camnot be eonsidered of special value, exeept as ornaments in artifieial lakes in the parks and grounds of the wealthy. Their dying song is often quoted from elassic literature; so far no one has yet been charmed with its song in modern times, which may prove one of two conelusions, either the ancients were satisfied with a very low order of voeality, or else the modern taste for musical sounds has become too refined to appreciate the notes of the swan either in liealth or siekness.

The duck seems to have been one of the most easily domesticated of fowls, and if the rarieties are not exeessively multiplied, it is because they are not eonsidered a delicacy, and eomparatively little used as food. Nevertbeless, we think them underestimated. Somo varieties are very beautiful in plumage; they are handsome in the water, and their flesh is by no means to be despised. Among the most valuable varicties are tho Aylesbury ducks, a prominent English breed, au illustration of which ao give. 
Of the progenitors of barn-yard forvls (Gallus), there are several wild species. Anjoing these may be mentioned the Sonnerat fowl, discovered by the nilturalist of that name in the Ghautes, which separates Malabar from Corarnandel, a thoroughly wild species never yet tarned. Sonnerat was probably mistaken in supposing they were the orimitive type of our

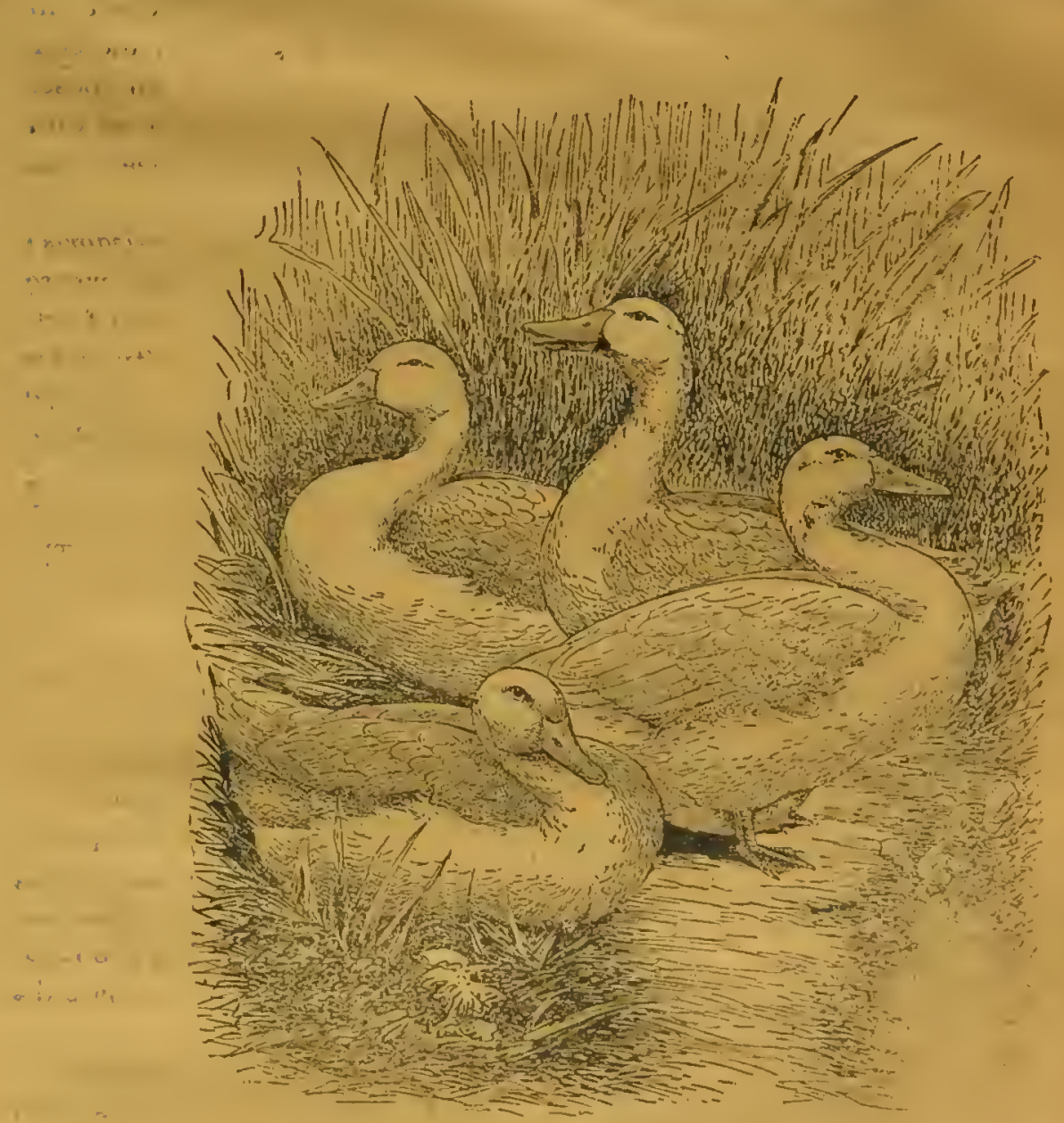

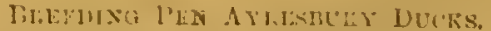

from the English st:mind of watertons:

domestic tribe. Damphier had previously found rrilt coclss in the islancte of the Indian Archipelago, that are now known to nearly approximate ours. The Bonbiva species in Java, and tho Liulm or gigantic cock at 
Sumatra and Southern Asia-the jungle fowl of the continent of India, may also lay elaim to being tho progenitors of our domestic fowls, as woll as tho speeies named after tho egotistio Somnerat. In India our farm fowls aro believed to havo sprung from tho junglo coek and wild specios of Malay and Chittagouey.

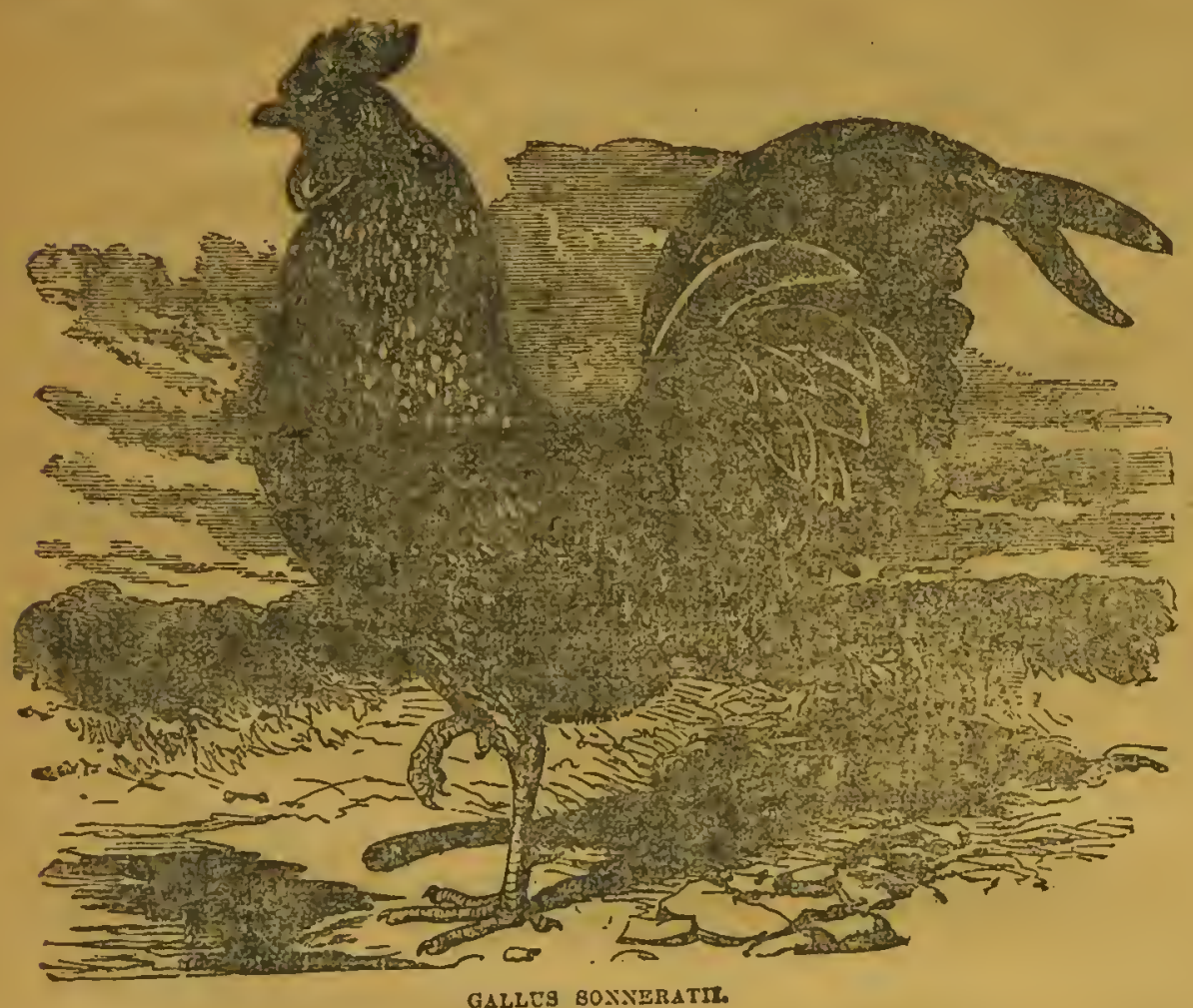

Our Bantams are undoubtedly sprung from the Bankiva junglo fow?. Our large Asiatie from the great Malay and Chittagong raees through long generations of breeding and seleetion in China. Whaterer the races from whence they sprung, the wild types are now very searce and diffcult to find, while domestic fowls, in their almost infinite varieties, are found not only in every farm-yapd and village lot, but are bred extensively and suceessfully in our largest cities.

But wild fowls, of the genus Gallus, are also natives of tho Brazillian forests of America. Oliver de Serres writes of them as follows:

"In traveling over the gloomy and inextricable forests of Guiana, when the dawn of day began to appear, amidst the immense forests of lofty trees whieh fall under the stroke of time only, I often heard a crowing 
imilar to that of our cocks, but only weaker. The considerable distance which separated mo from every inhabited place, could llot allow ono to think this crowing produced by domesticated birds; and tho natives of those parts, who were ln company with me, assured me it was the noiso of wild coclss. Every one of the colony of Cayenue, who has gone very fal up the country, gives the samo account of theso wild fowl. I havo seen ono myself. They have the same forms, tho fleshy comb on the bead, the gait of our fowls, only that they are smaller, being hardly lurger than the common pigcon; their plumago is broma or rufous.

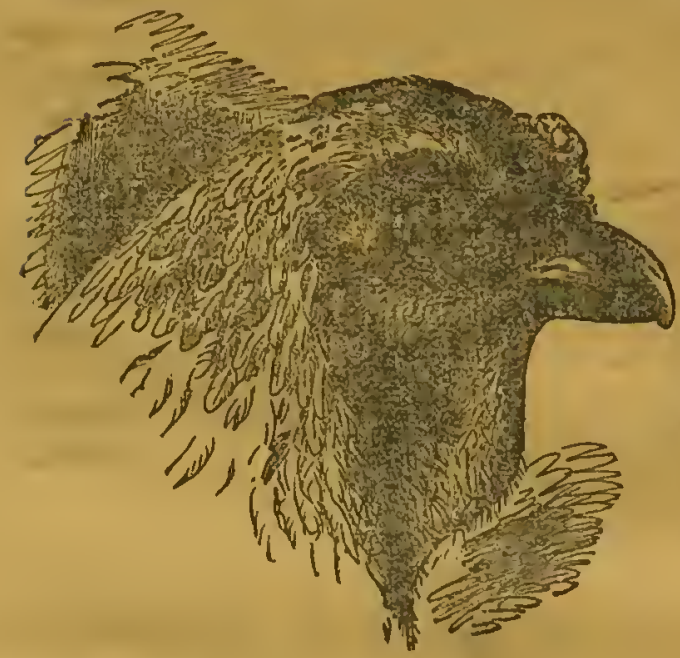

IRAD OF GIXGLE-WATTLED BRAMMA FOFL,

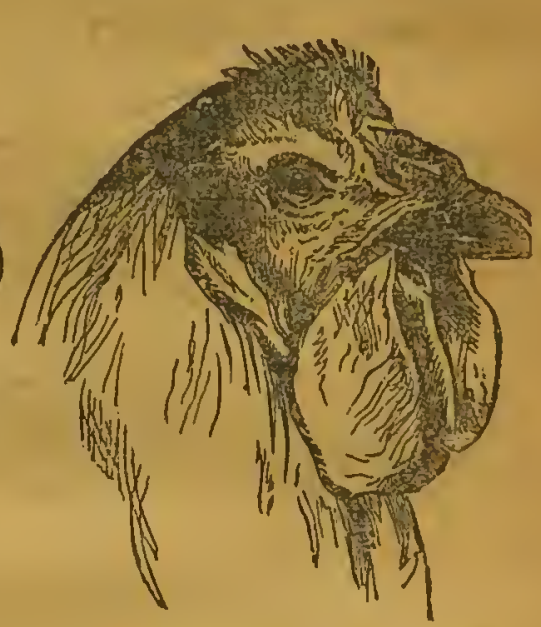

IEAD OF BREDA, OR GCEIDRE.

Before this the wild fowls of America had been mentioned. Tho Spaniard, Acosta, provincial of the Jesuits of Peru, has positively said that fowls existed there before the arrival of his countrymen, and that they were called in tho languago of the eountry, talpa, and their cgrga ponto. Wo aro not urraro that this species has ever been brought into a state of domesticity, or that the wild species has ever been taken and reared. The wilds of the great South American forests are yet as a coled book, in many respects, to the naturalist. Under the regime oz tho present practical and scholarly Emperor, this, in Brazil, is being changed, and gradually this immense territory will bo made to yield not only increased stores to our ornithological knowledge, but also in othe: departments of practical art and science.

Our domestic poultry may be divided into four groups, each of which will be separately considered. 
1. Our Common Barn-yard fowls.

2. Asiatic fowls.

3. Games, includiug Game Bantams.

4. Pet Rantams.

In the flrst group we shall notico English, American and continental families. In the second group all Asiatic hreeds. In the third group all. the more important Games, and in the fourth group all the bettel known small varieties of Bantams, except Ganes, both smooth and feathered leggred.

Un the preceding page we give illustrations of two curious varicties in domestic fowls, one in a sub-family of Brahmas, the nthor is a family of fowls of Dutch origin. 


\section{CEAPTBR II.}

\section{TARIETIES OF BARNT-YARI OWLR}

8

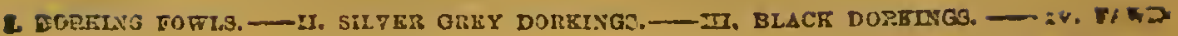

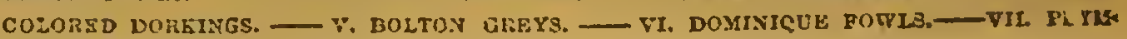

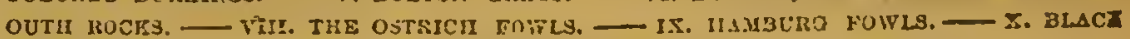

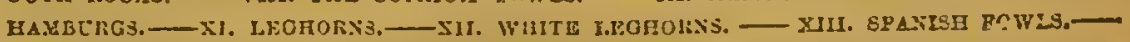

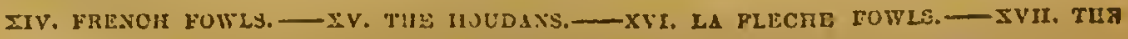

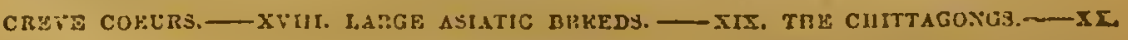

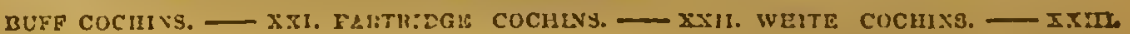

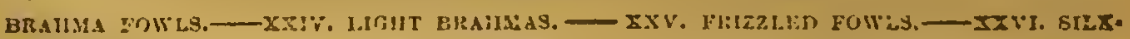

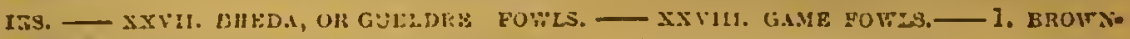

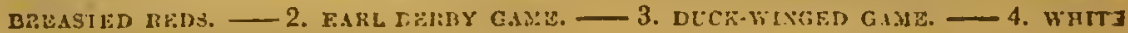

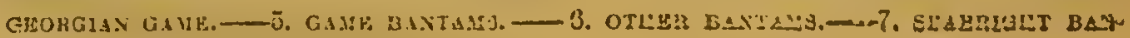

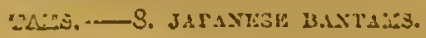

\section{Dorking Fomiz.}

Of distinct English breads the Dorkings have becoms tho most colon brated. Of these the White Dorking of Surrey is the typicul forvl. It is, as comprared with the so-ca!led dun:-hill fowls, lingo, cften weighing, the inature cocks fully ten pounds, the be:s eight to ine pounds, and at a year oid from six to eight pounds. They are of good size, plump, compact, with strong heads, full nattled, and with single serrated comb, ehort necks, short white lems, with fire toes, and full plump breast, the plumage pure white and without spot. They are tolembly hariy, good layers and most excellent mothers. The illustration on following page is a regresentative of this broos. 


\section{Silver Gray Dorking.}

This variety is considered to be a sport of the White Dorking perpetaated by careful breeding and selection. With stock from families that have been carefully bred by careful selection they may be kept to the standard. But they vary much in color, the dark varietics often producing tilver gray chieks.

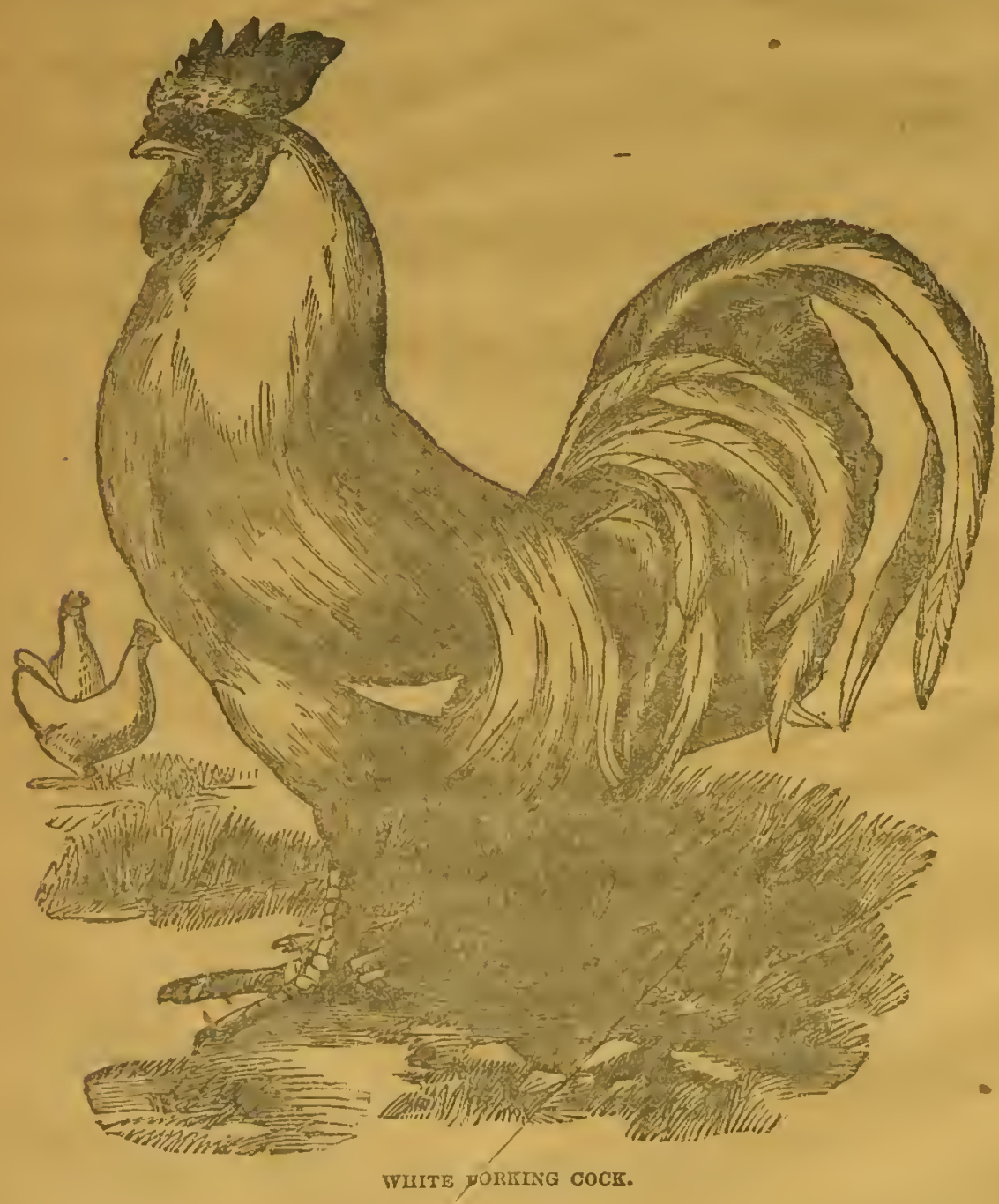

1.jo Gray Dorkings are rapid growers, and if well supplied wth food wre in condition for the table at any age, often before they fairly get their feathers. The distinguishing colors are : breast, tail and lurger tail feathers perfectly black; tho head, neck, hackle, back, saddle, and wing 
bow a clear, pure, silvery white, und across the wings a well defined black bar, in striking contrist with the white outside web of the quill feathers and the white hacisle of the neck and sadale. The rec: of tho bey in

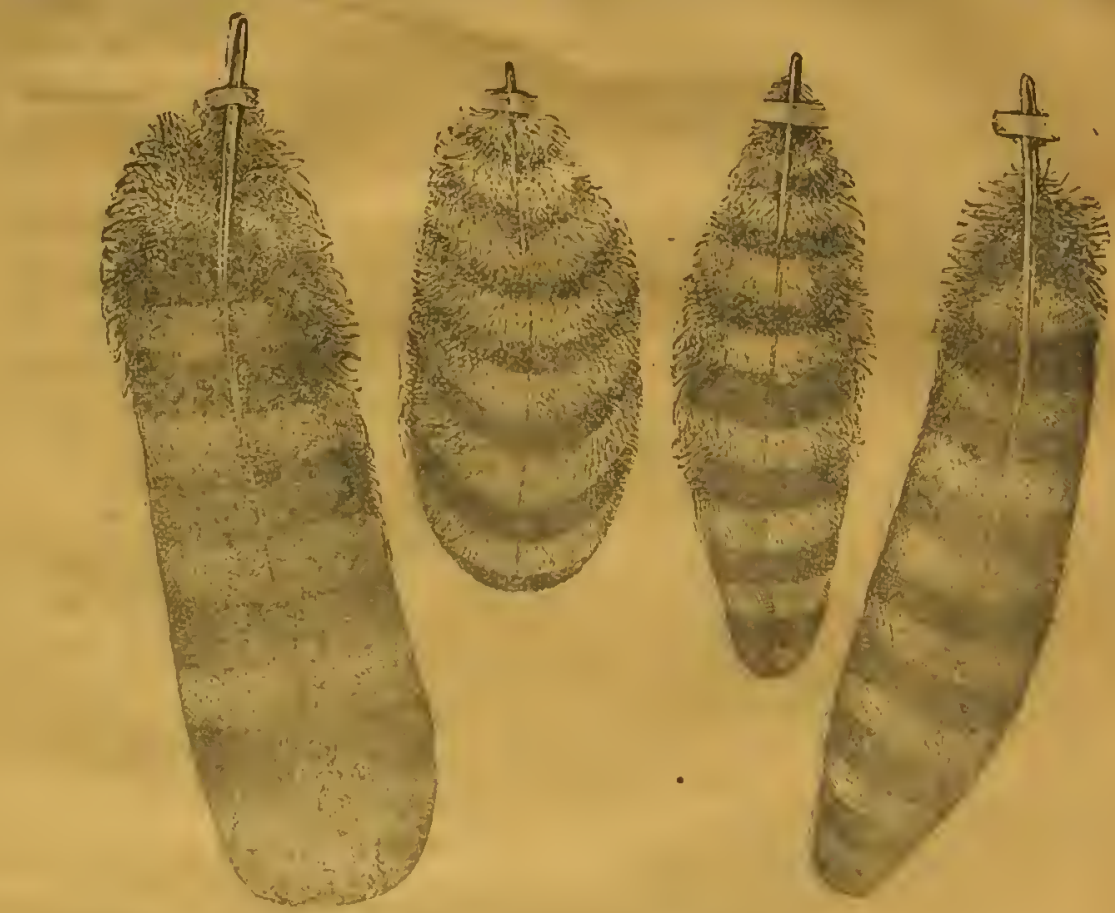

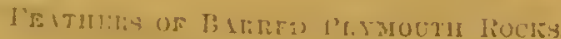

oilvery white, the breast salmon-red, changung to gray near the thighs the wings silvery or slate gray, and without any tinge of red whatever. The tail should be dark gray, the inside nearly black.

\section{Black Dorlsings.}

This sub-family are jet black in color, the neck feathers of some of the cocks tinged with gold, and of the hens tinged silvery. The comb may be either rose or single but usually double, short and sometimes cupped; wattles quite small and very' red near the head. The tail feathers shorter and broader than those of the white variety; the legs black, short, and with the two under toes quite distinct and separate, sometimes showing a rudimentary toe. They are hardy, the hens are good layers, good setters and careful nurses, and the eggs are of a large sizo.

\section{Fewn-colored Dorkings.}

These are handsome birds of high carriage, said to havo been produced by a cross between the White Dorking and fawn-colored Turkish fowl. 
Their tails are shorter than any other variety of Dorkings and the legs blact. The cocks will weigh from eight to nine pounds and the hens from six to seven. They have remarkably fine flesh and lay large eggs. In relation to the Dorkings as a class, we have found them not well sdapted to stand wet, cold weather. Yct with proper care they are the best of the distinct English breeds.

\section{v. Bolton Gray.}

This breed, sometimes called Creolc, used to be in good repute in England, and were bred with such nicety that individuals eould scarcely be distinguished apart. They are great layers, but poor setters, and when carefully bred are one of the best breeds for the farm yard. They are $\approx$ medium sizcd, plunip, short-legged fowl; neck and body puro white thickly spottcd with black, black burs at the extremity of the tail,

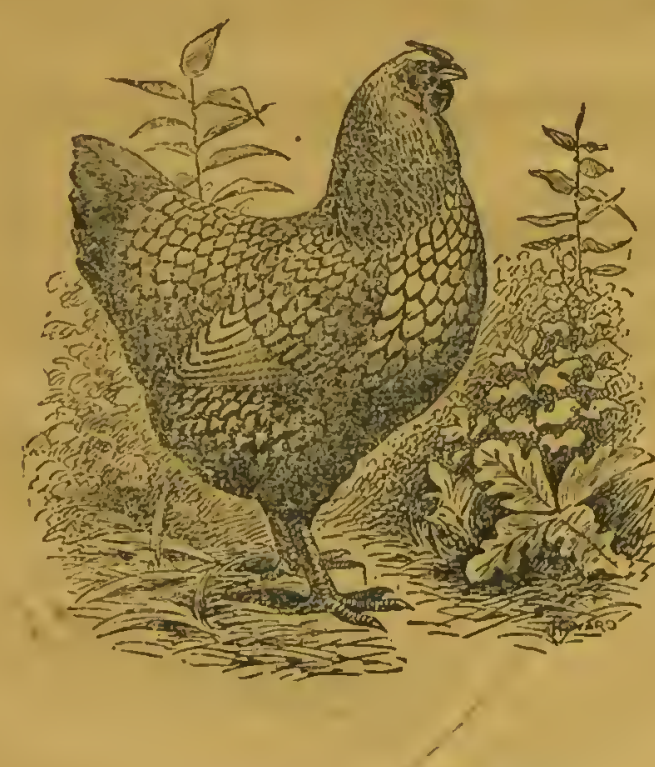

SIIVER-IACLD W YASDUT:H PUIIAT.

Tha hens are constant layers, but the eggs, although of food curitity. 2:0 rather small, reighing about one and a half ounces earh. They ars comparatively rare in the United States.

\section{Dominique Fowls.}

The Dominique, a distinctly American breecl, and for the ordinary sarmer, where hardiness, fecundity, good laying propensity, and excel. 
lence of fies is concerned, is one of the very best in existence. They breed constant in color, marlsings, constitution and vigor, and aro always well able to take care of themselves.

"The true color of the Dominique is a light ground undulated and penciled in the softest manner with slaty bluc-almost black-forming bands all over the body. The hens and cocks are shaded alike ex. cept that the plumnge of the cerk is more distinct, often with golden hackles, and bronzed wings. The comb of the cock may be either, single or double, but, we prefer the single comb, as most indicativo of the truc type. The iris of the cye is a bright orange, and the bill and legs a bright ycllow or buff color. They are square built, broad breasted, ratlier short legged fowls, with little offil, and with high tlavored and profitable flesh; elegant in plumigc, and a bardy, bealthy, profitable and prolific race of birds.

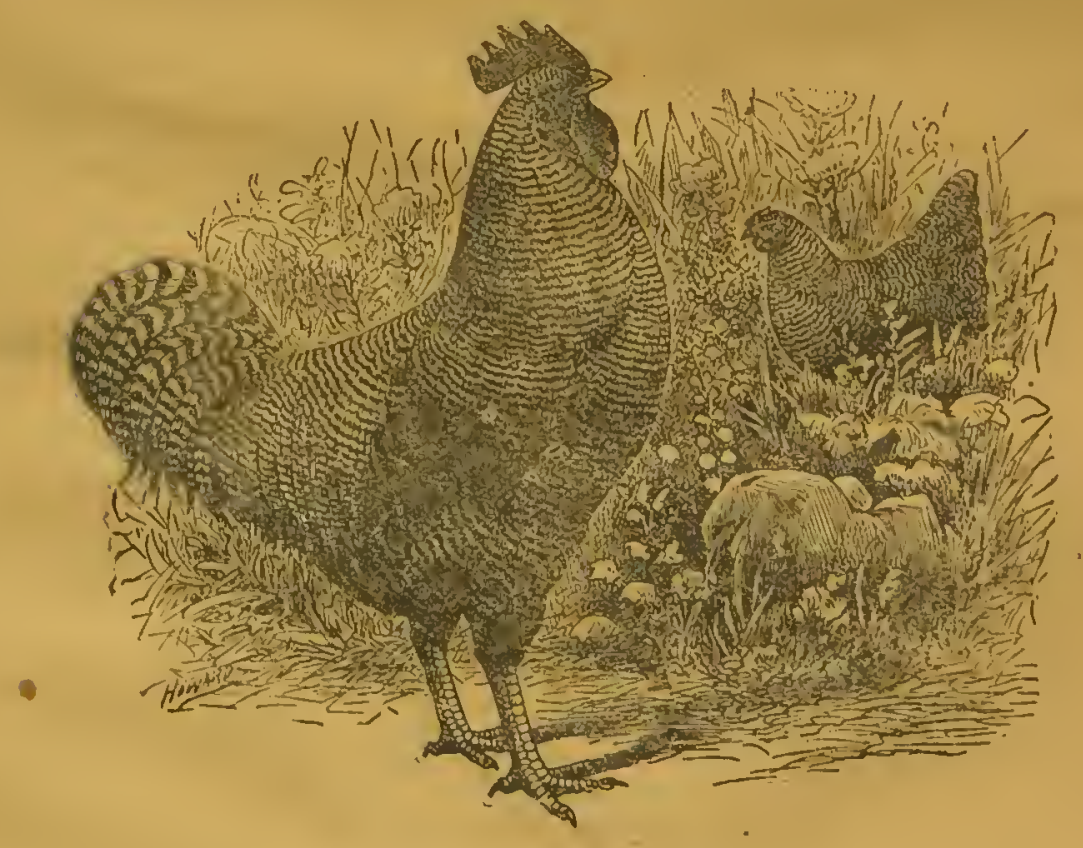

Barrim Plymoutu ,Rocks,

VIr. Plymouth Rocks.

This is a modern American breed originated by Dr. Y. C. Bernett, and Irst shown at Boston in 1840. Sirid to have been produced by a cross of - Cochin-Chia cock. with a beu, berself a cross between tho fawu-colored 
Dorking, the large Malay, and the Wild Indian forrl. Fanciers becoming intorcsted in this brecd, it was vory considerably disseminated, but failed to give satisfaction on account of the want of uniformity in the chickens cither in marking or form. Much bitter controversy has ensued, which shows that there were scvoral different origins, in which the Java, Cochin, Gray Chattagongs, Dominique, Gray Doring, and even the common dunghill fowl figurcd. Of late ycars fowls have been produced under the name of Improved Plymouth Rocks, the modern style showing excellent and uniform breeding. A fowl that grows rapidly, fledgos early, making flosh fust, and which in the hands of cxpcrt funcicrs, combines many of the most excellont qualitics to be desircd, eithor as layers or as table birds.

\section{The Ostrich Fotrls.}

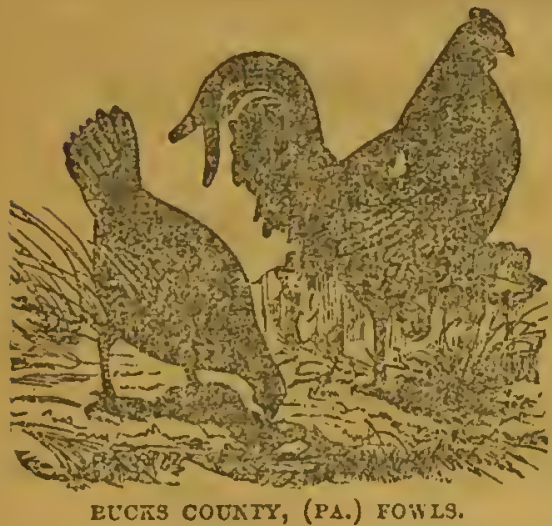

This excellont breed originated in Bucks county, Pa., and woro callod Bucks county fowls. Tho cocks of this varicty will avorage ninc pounds. They are good laycrs, sometimes producing forty or fifty oggs before becoming lroody. The eggs are large and of good flavor; the flesl white, firm, and of excellent quality. The color of the cock is a dark blucblack; the cuds of the foathers tipped. with white; wings a yellow or goldon tinge; hackle dark, glossy bluc. A doublo rose comb sumounts the head with large wittlos beneath. The carriago is bold and alert. The hen is similarly colored, but nore sober in shade, with a plump, thick body, a high serrate single comb, wattles large, and legs short and of a dark color.

\section{Famburg Fowls.}

The Hamburg fowls all have these charactcristics: Thoy have bright double combs, firmly fixod, and ending in a long point turned up behind. They are of modium size, of sprightly carriago; tails large and held upright with long plume feathers; of robust oonstitutions, great layors, seldom broody; in fact, almost never, when kept in confinoment. The oggs are small but of excellent fluvor.

\section{Black Hamburgs.}

This is probably the best variety of the family for farmers, and in fact one of the very best of the black fowls. Possessing tho two-fold valne 
of being alert, noble looking, handsome fowls, color deep black with 8 metalic luster; hardy, robust, and the bens constant layers.

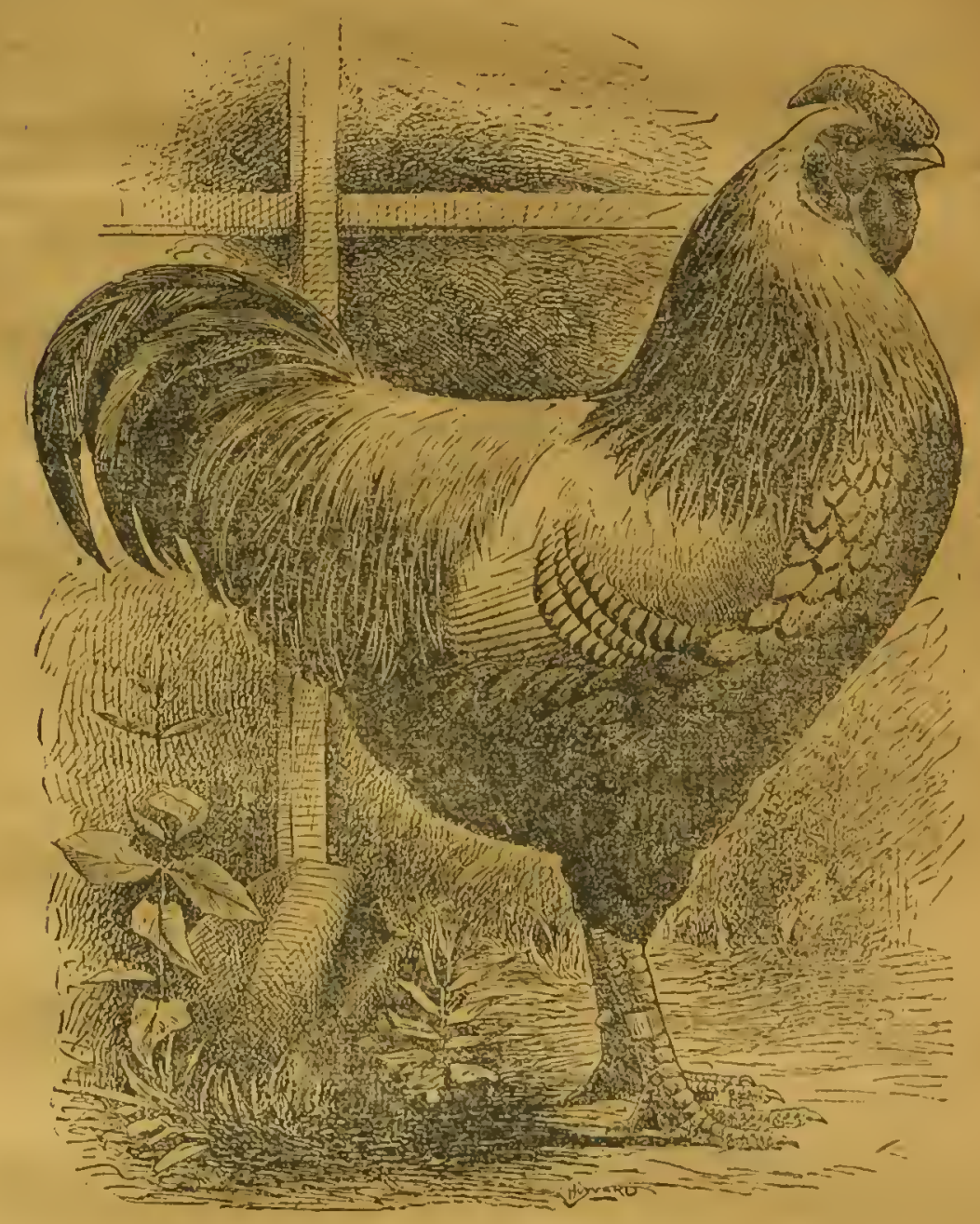

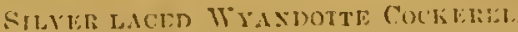

$A$ winer of seseral promiums in the West.

\section{Poneiled Hamburgs.}

These are of two varieties, the Silver and Goldcn. Ir the Silverai sub-family, the ground color is silver-white, sometimes with a slight yel. low tinge, but every feather margined with the most glossy black. Tho 
eocts of oither varicty exhibit the percilings, as do the bens, bin are white or brown in the Silvered or Cioiden breods respectively.

Thero are fer, if ain, more striking fowls than these in the had ${ }^{2}$ of expert and careful breeders, with their symmetrical, gay and upright carriage, their vill-defincel deaf cars, elegant combs and wattles, tleir Qupir, well-fwathered twils, und fine-boned, taper, blun legs.

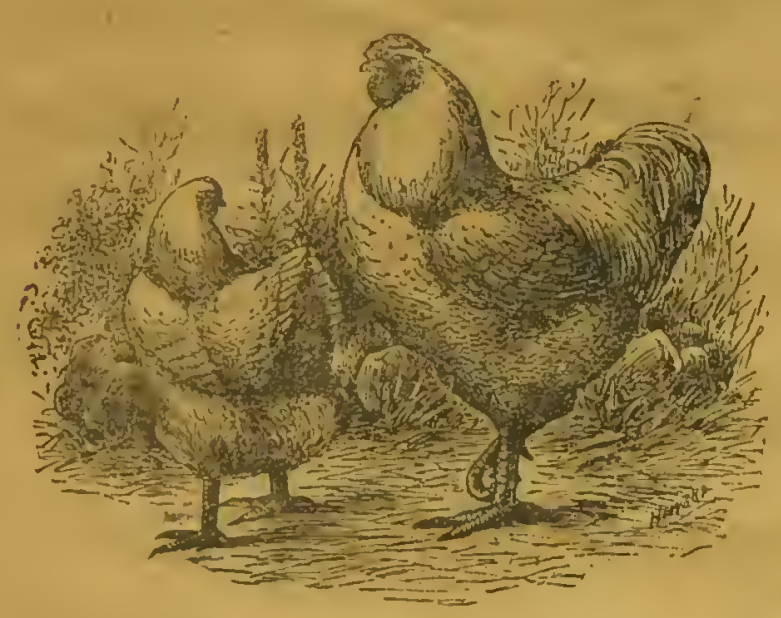

PAIR WHITE WYYNDOTTES.

The hens of both varieties must have the body elearly and definitely penciled, and the hackles of both eocks and hens must ie entirely freo from dark marks. The engraving which we give fully illuetrates the characteristics of the "several varietics. $\Lambda$ s fancicr fowls they are superb: as farm fowls delicate.

\section{Leghorns}

This admirable breed of European fowls las become widely dissemInated in the United States, being valued for their many good qualities, anoris which are beauty and constant laying propensities. They aro bred by fanciers of all colors from white to black.

\section{XeI. White Leghorns.}

Whito Leghorns are, we think, the most valuablo to the farmer as they 
are the bandsomest. The description of this varicty will suffice for all, excepting color.

The Whites are in size about that of the Spanish, and like the Sparish ine combs of the best hens lop over on one side. 'The plumage is white with hackle feathers sliglatly gec!den tinged, the rest of the feathers paro white. They are compuratively a hardy brced, standiug extremes of,

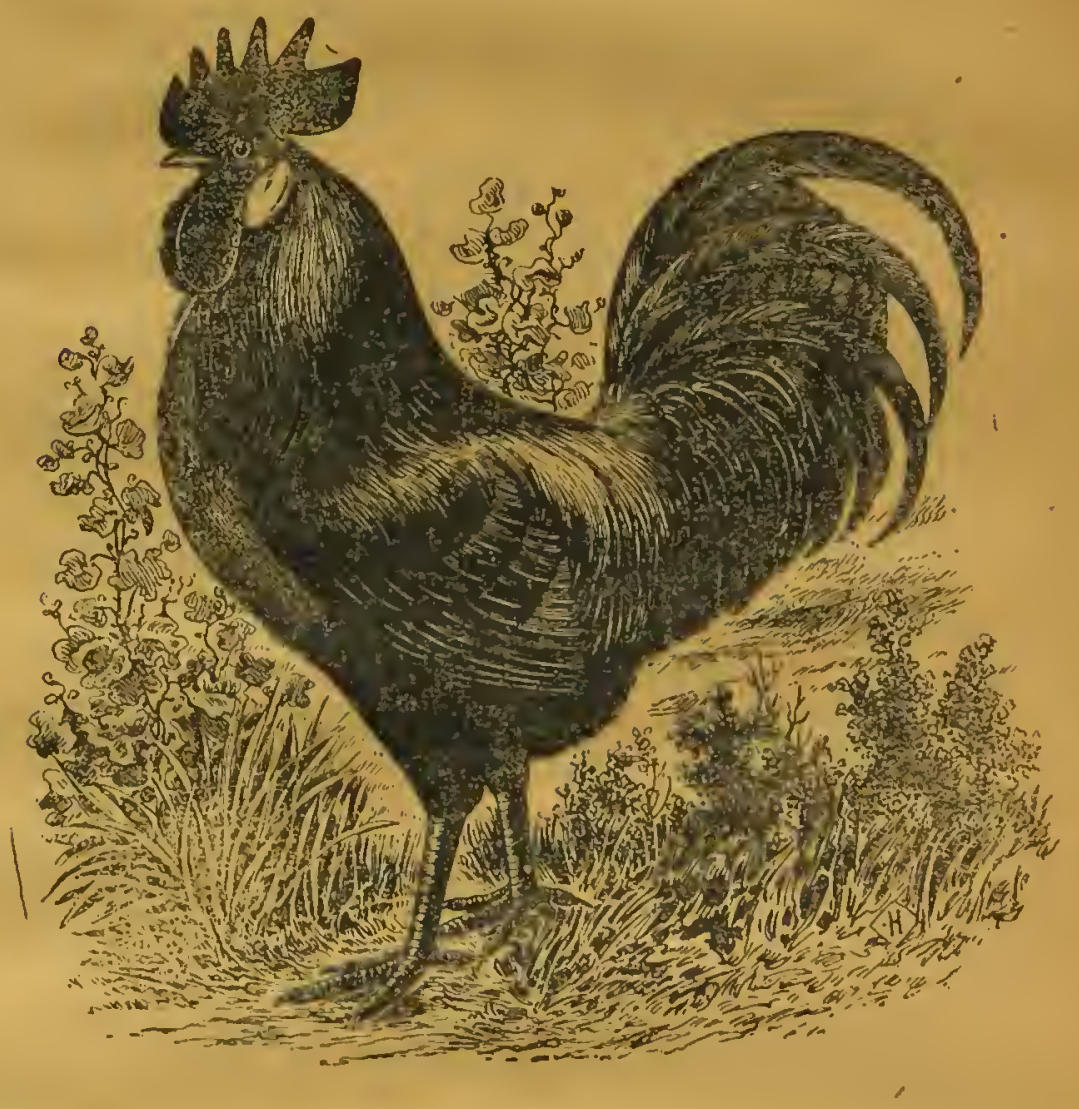

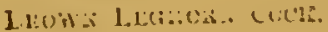

cold and sudden ehanges fairly, except that their imme:sso sirgie coatcs are liable to freczo in ifinter. The hens are persistent layers, and especially grood Winter layers, when they are licpt comfortahly boused, and scldom inclinc to sct. The legs and slin aro yellow. The cocks have larro singic perfectly croci sarrato combs, tha livikiors being i 
fact spiked. The wattles are full and large, wh wite or eream colored car lobes, extending sometimes up on the fuce. The chicks are hardy, good foragers, feather early, and at the age of six to cight weeks are miniature fowls, showing much of the stature and graee of the maine lowl.

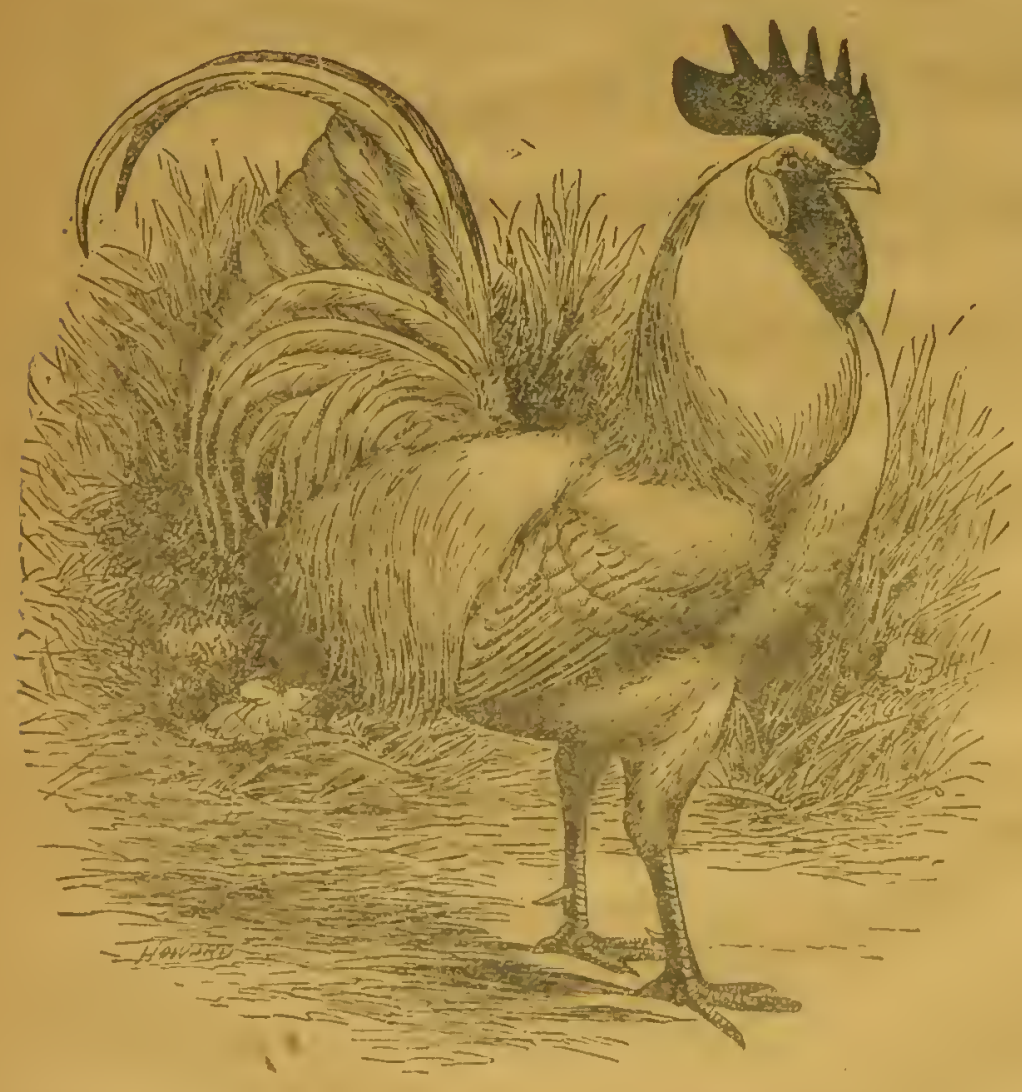

WHite luEurnory COCK.

A typical specimen of this varicty of fowls.

The cut will show what woulú be considered prize Iowls in any show ring

XIII. Spanish Fowls.

The Spanish fowls in their several varinties have long been known and justly esteemed in the United States for their grent laying and non-setting properaities. The whole race, however, aro rather tender as fur as cold 
vet weather is concerned. But for the amateur who will give good care and attention, they will amply repay their cost in the production of plenty of large, meaty eggs. In the South they are an admirable breed. In any locality they must be allowed plenty of liberty sineo they soon suffer from elose confinement. There are many varieties described besides the pure white and the pure black, as the red-faced black, or Minorea, the Aneona, Gray, or mottled breed, and the Bluc or Andalusian. The cut which wo give on the next page, of the Black Spanish and description of same, will suffice for all.

The cock should carry himself ercet and stately, the breast projecting and the taii creet, and with sickle feathors fully developed. The plumage should be jet black, and witlout the lcast approach to white $01^{\circ}$ any other colored spots, but with glossy refleetions in the sunlight. The fowl

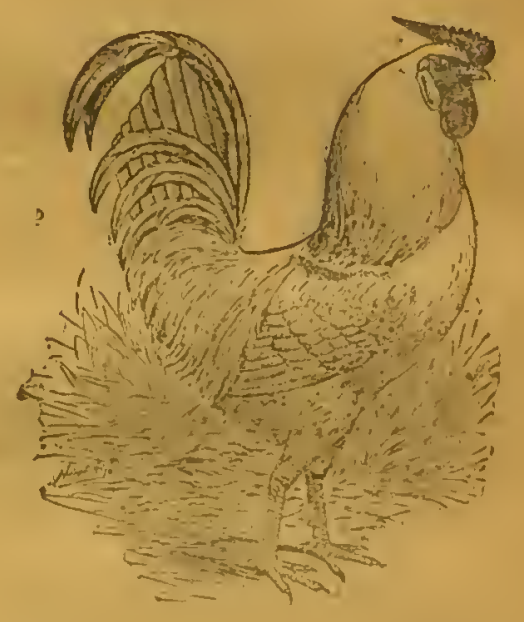
plump and compact; the legs blue or dark lead color; the comb large in both scxes, bright vermilion in eolor, decply scrrate or ratho notched like a saw; that of the cock entircly upright and without twist whatever, and cxtending well back of the head. The comb of the lien should fall completely over on one side; the face must be quite white and without red specks, wide and deep and extending high over tho eyc, arehod in shape, approaching the bottom of the comb, extending sideways to tho ear lobes, meeting under the throat, and in texture entirely fine and imooth. The ears must be large and pendulous, and as white as tho face.

XIV. French Fowls.

There alo three prineipal breeds of French forls inat have withir tho last ten years acquired an excellent reputation wherever known. They are the Houdan, Crove-Cour-both of whieh are quite well disseminated -and the La Flcehe. The first two breeds take their namas irom vil. lages of these names, and the latter from the arroudissement of $L a$ 
Fleehe, in France, where they are most eommoniy raised. Besides these thore are several other varieties of useful and ornamental breeds known in Franee as, first, the de Breda, de Breese, Court Paltas, and ciu Mans, and among the oruamental varieties the Chamois, Hollandais, Horwices and Pastous. The Bredas have already been described.

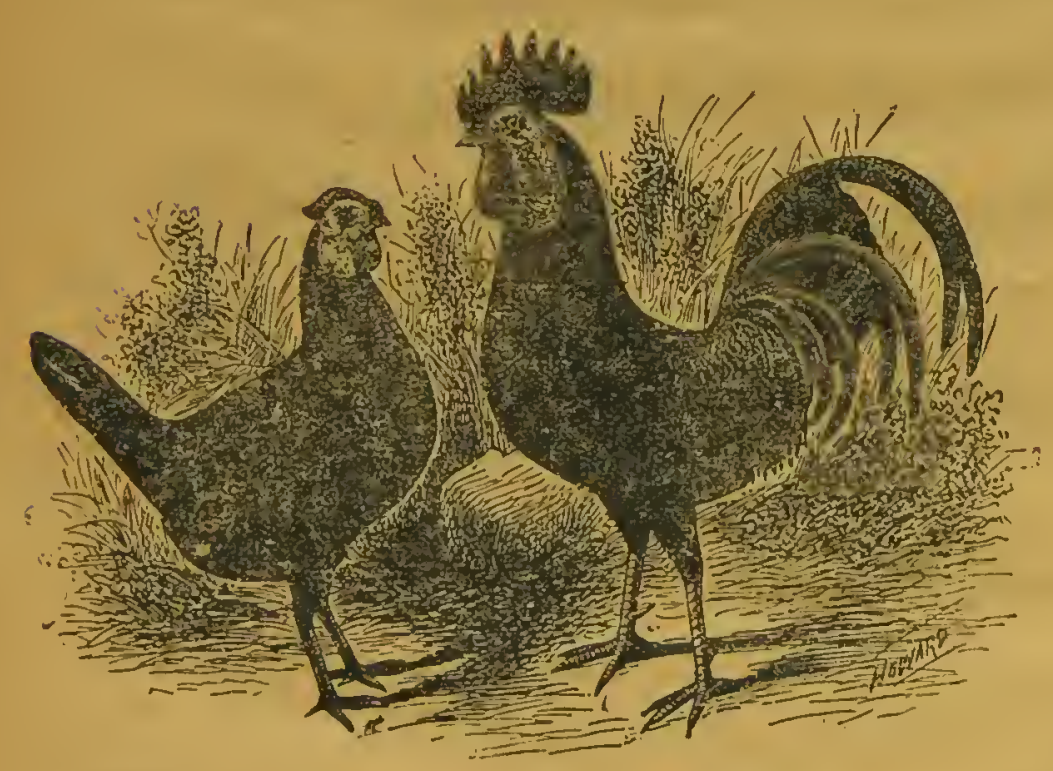

Patr linak Sifasisir

XV. The Houdans.

Those fowls are held in France in fully as high estımation as aro tero Dorisings in Englund. They are hardy, easily raised, fatten kindly, lqy good sized ergs, and are of a most exeellent quality ${ }^{\circ} f$ flesh. They are B five-toed race, and are reported to have originated between a cross of 
tise Dotking and the ailver Juhn. They should ho of a white end slack color, crenly distrihuted, miking them distinctly speckled. Fied

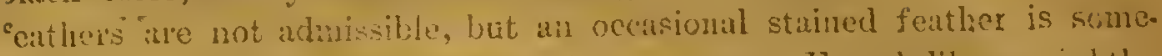
cunes secu in the bost fowla. They aie very Flench-like, sprightiy, visacious, loring to wancher, lint brang confunenent well. The comb is couble leafed, and they hare whisks sind heard growing woll up on their Eace, ribh, with the erest er top-knot, gives them a curious urd yet etriking appearance. The crest of the lien mpecially being thick and full. In shape they resemble the Dorking, bat are less in size. In every rospect they are bri!liat abl striking in ajpurance.

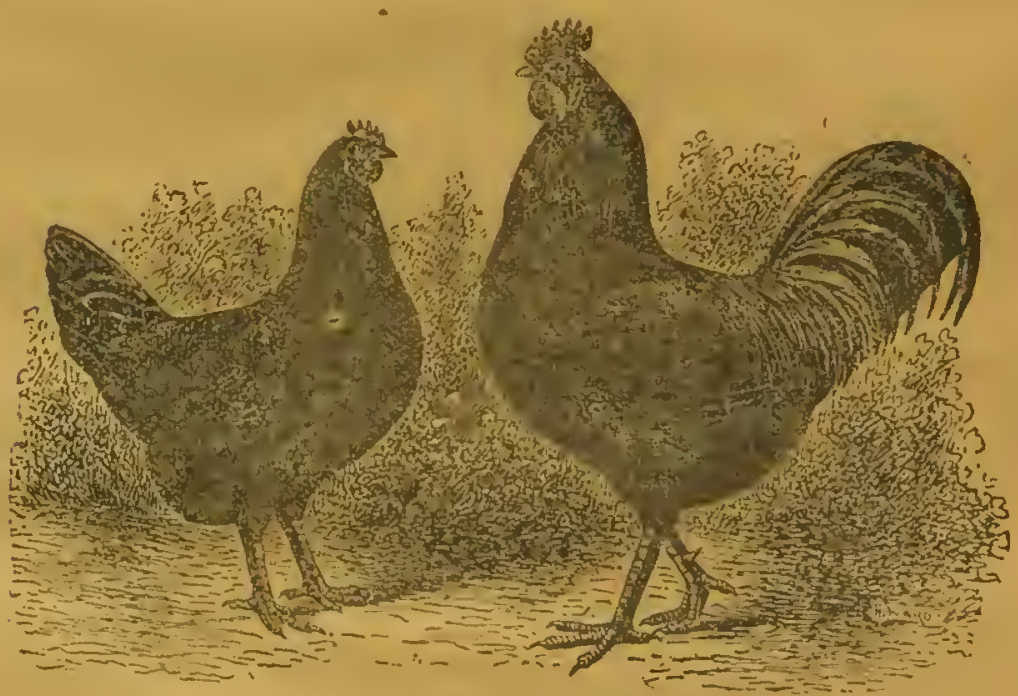

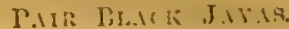

XVI. La Flecho Fowis.

These bancisome fowls are rery tall but compact; in size equaling the Dorking; yetblack, firmly knit, with strong, long limbs; the body ruther angular, the plumage firm and dense. The head is handsome, witb epikes of feathers behind the comb, looking like a double horn. They have smal! protuberances between the nostrils, which latter are full and cxpanded. They bave large, olnuge car iobes, crusat like, very losy 
pendant watties, it moderatcly curved beak, neek hrekies long and ano, reflecting riolet and green-blick color's, as do the breast, wings and urper tail feathers. The legs are long, slate-blue in young fowls, and a leadgray when old. The hen is enlored iike the eock. The eocks arrive at their fill growth at cighteen months old; the hen at twelve. The flesh is considered the finest and the most valuable for table uses of any French breed. Thosa familiar with them are pleased with no other.

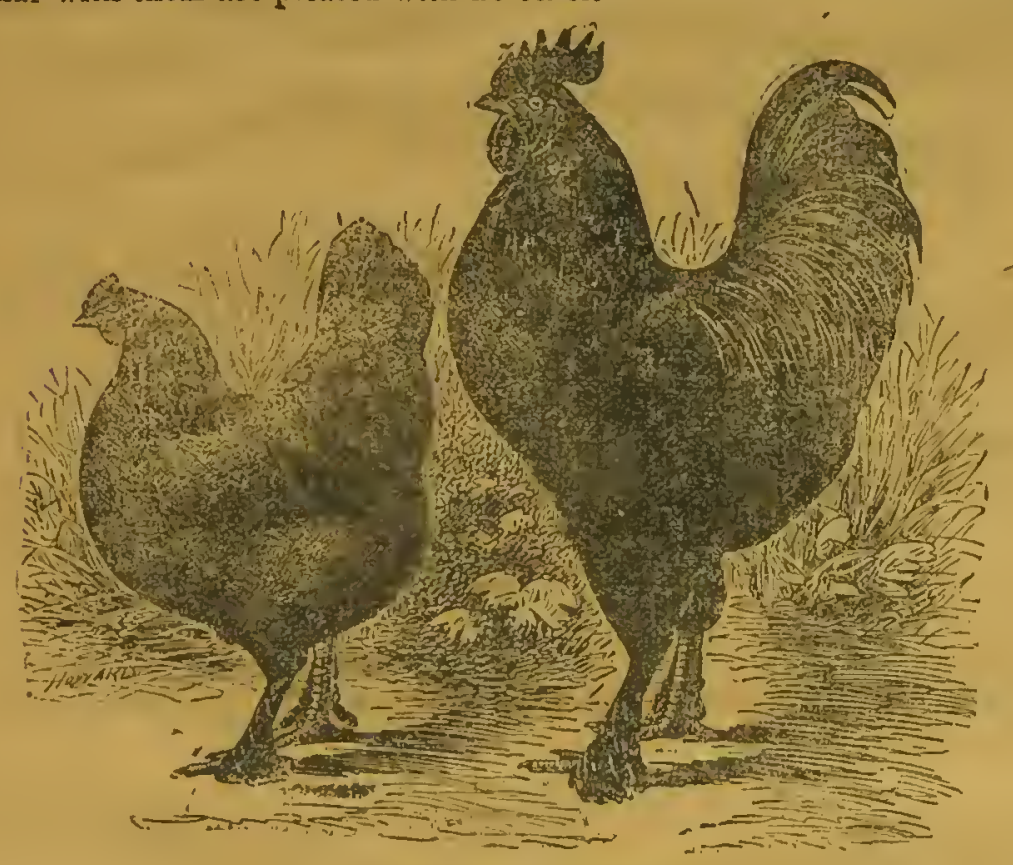

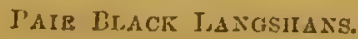

ZVII. Fho Creve Cocurs.

This is tho most striking of the Freneh breeds, their black crested lheads being euriously relieved mith deep erimson, forked or antlered-like comb. Their aspect is bold and stately, the plumage black, shaded with green, thick and shining. The eomb must be conspicuous and full, wattles long and deep, breast large, full and deep, the back straight not: drooping. The legs should be strong, firm, leaden blue, in eolor, and short, with strong elaw's. The hen should have a soft, thick, round crest, and very little eomb and wattles. The eolor must be entirely blaek, no other eolor being admissible in pure bred fowls. Old birds, however, will sometimes show an occasional white feather in the erest: a sort of turning prraj. 
XVIII. Large Asiatic Breeda.

Of the numerous breeds and sub-divisions of these gigantio forlo, the Cochin-China and the Brahmas stand confessedly at the head. The Bhanghæs, and the Chittagongs have, of late, fallen into disrejute, and

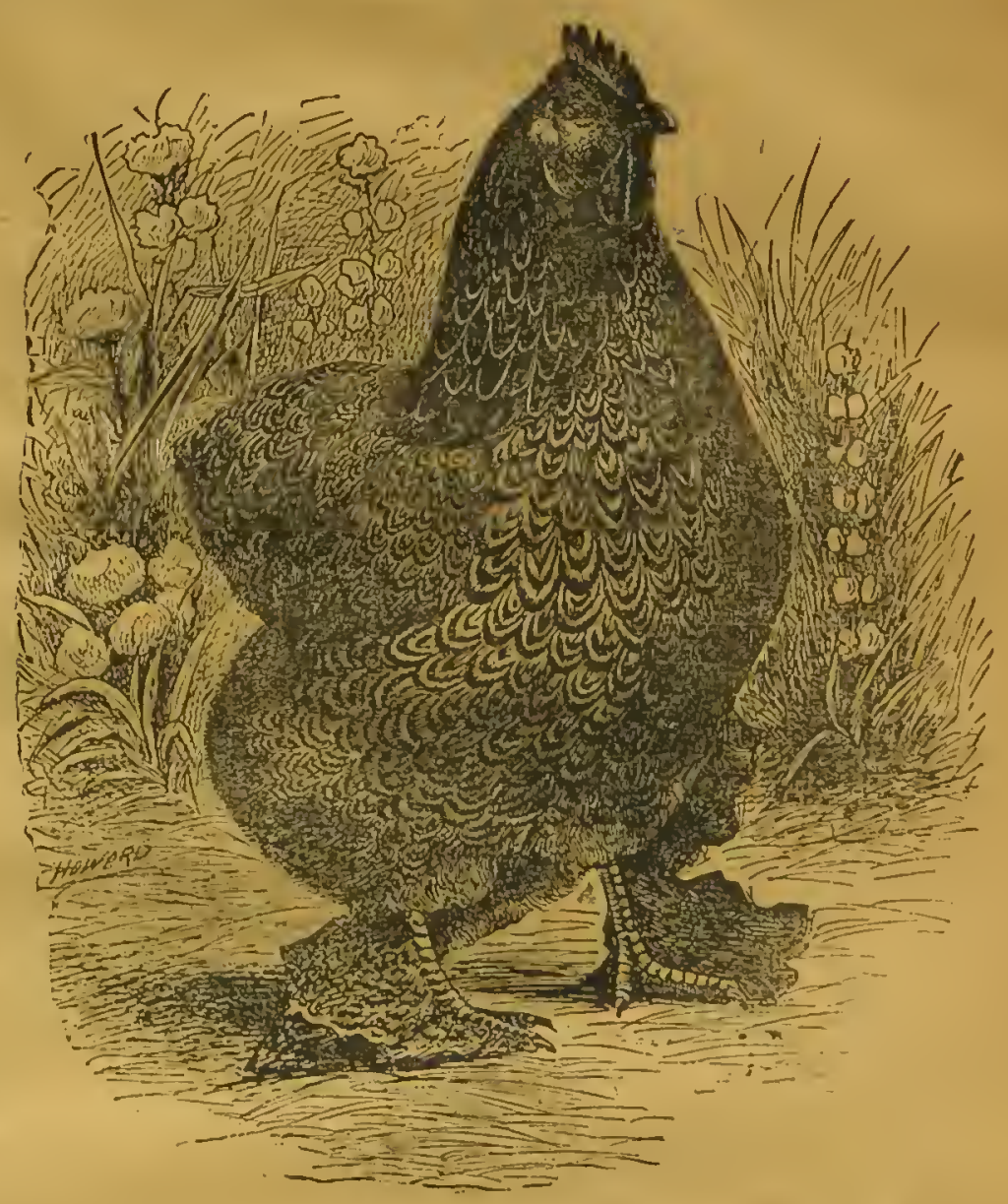

PArtrinat Cochis Hris.

A splen 3 icl sumpimen anel winner of severa! prizes

confessedly so, from the superiority of the Cochins and the Brahmas In the Shanghwe family there are various colors. Gray, buff, cinzamon, partridge-colored and black. Twenty-five years argo they were regurded with enpecial favor, from the fact that they were of the then largest ale mown. It must bo confeaged that when bred pure they are quiet, goed 
citters and nurses, little inclined to ramble, and among the bost fortes wothers to other chickens that can bo found.

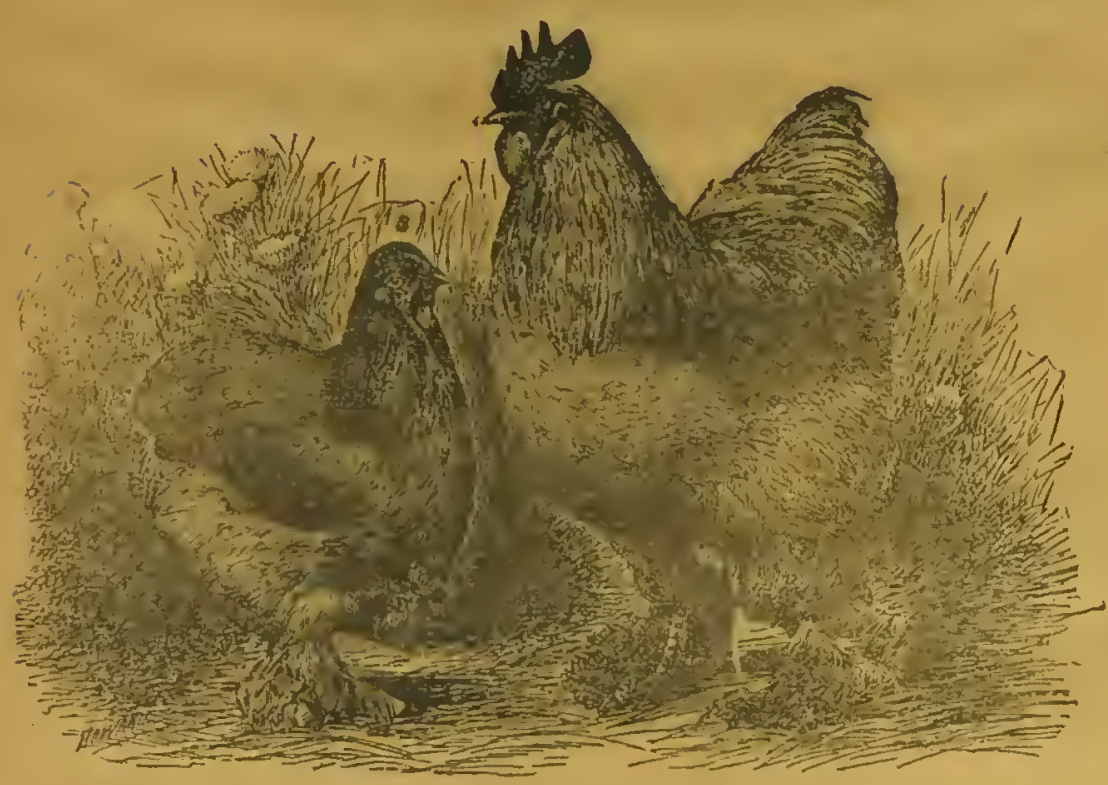

PAIR BUFF Cochins.

Drawn from prize winuers.

\section{XLX. The Chittagong.}

This is a giant among fowls, the cock often standing twenty-six inchea in height, and notwithstanding their long legs and necks, they aro majestio looking. There are two principal breeds, tho gray being the larger breed. In the dark red variety the breast and thighs are black. The bens yellow ef brown; legs in both sexes being yellow, heavily covered with black 
feathers, and the earriage in all the varieties graeeful, majestic, prompt and easy.

\section{₹X. Buff Cochins.}

There are 6everal varieties, in eolor buff, lemon, and cinnamon, the ro sult of peeuliar crosses and breeding. The buff is the true type of the colored sorts, and for utility wo think the best. The eock should be upright and strong in his carriage; breast broad, not full, but forming nearly straight line between the erol and thighs; back short and wide; tail only slightly raised; legs strong and with great thighs and saddlos.

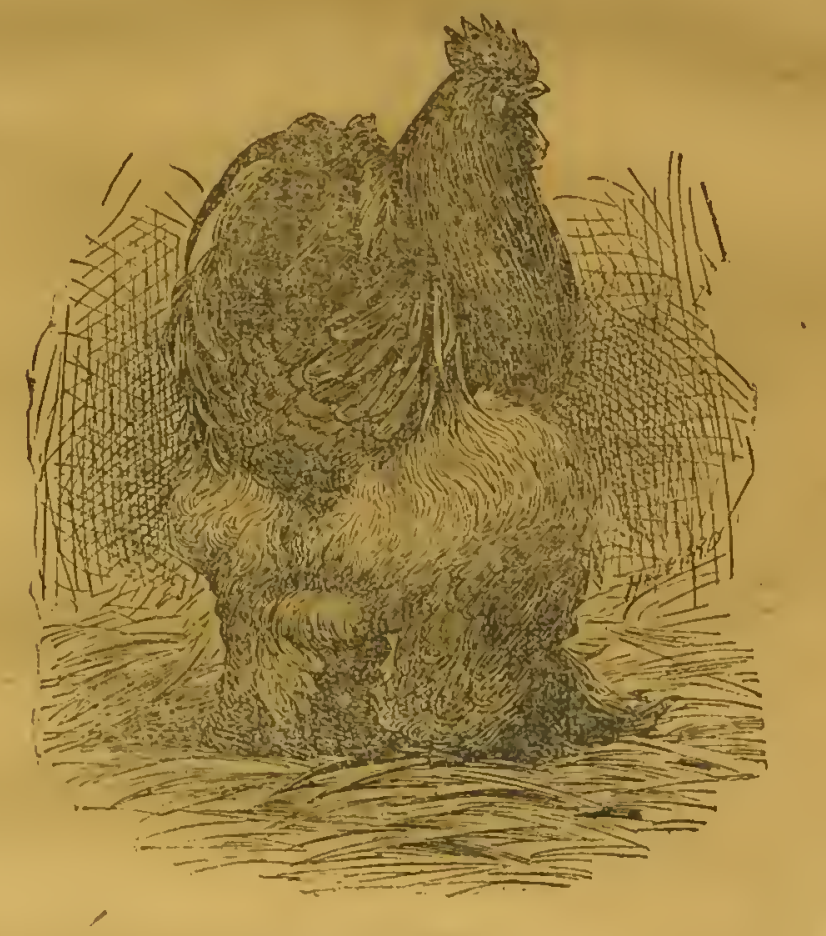

BUFF COCMIN COCK.

A portrait of a famous winner.

The head is small, for so long a burd; tho beak yellow, stout, short, curved, and strong at the base; comb single, not large, and with rather small wattles, florid, thin and fine; the ear lobes well developed, long, thin, fine, and entirely without white. The eye of the eock should be of an ochre-yellow eolor, and in the hen a darker huo. The hackle of the cock should bo full, spreading over the thighs, and of a light bay color, 
and free from markings of any kind. The lixckle of the hen is a clean, distinct buff. A slight penciling is admirable, a dark colored one not. The saddle of both cock and hen should bo free from markings. $\Lambda$ black tail in the cock is admirable, and if the principal feathers are bronzed, so much the bettcr. The breast of both cock and hen slould be clear buff,

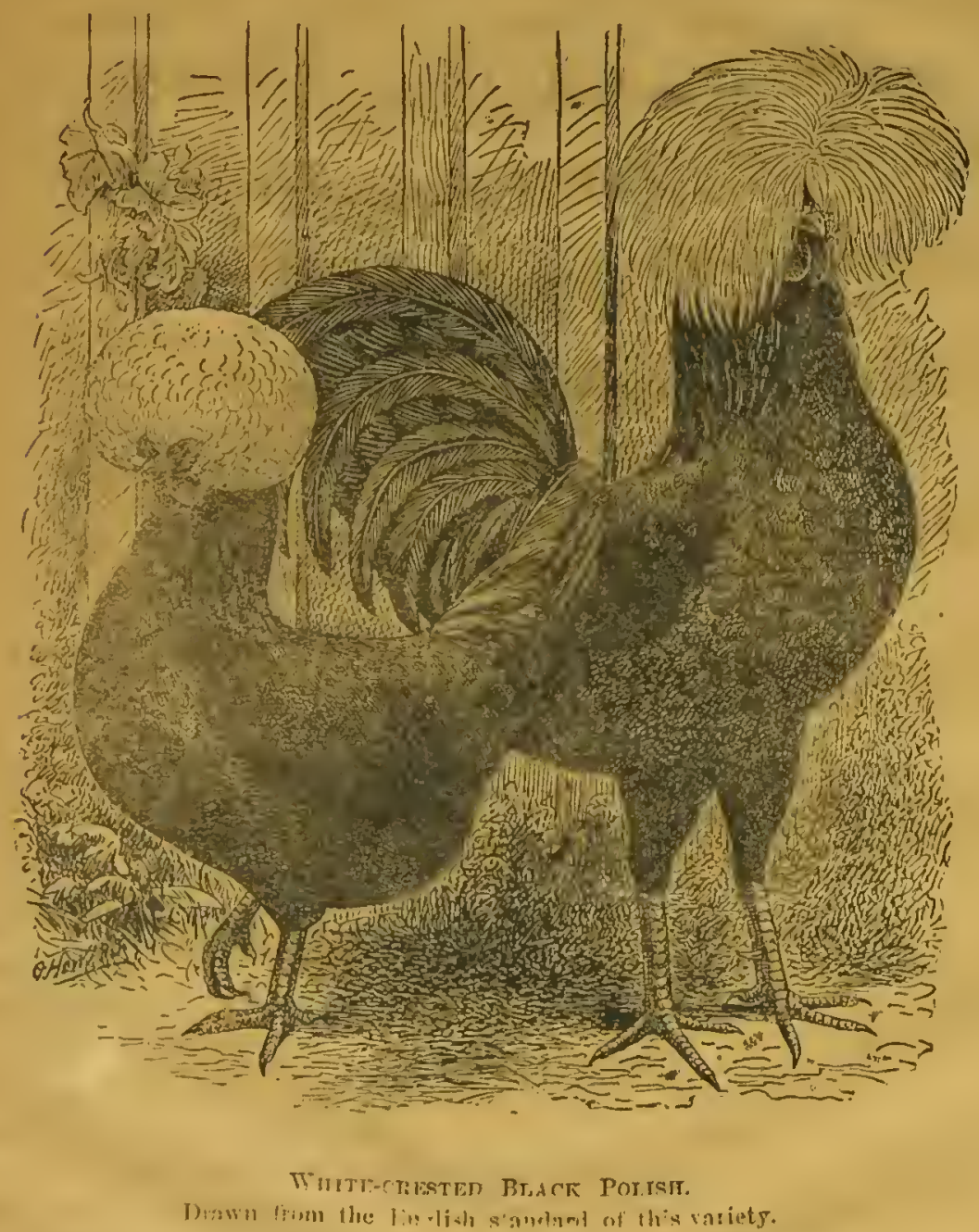

bocoming lighter toward the tip, with a wavy appearance m vie sun, and both primary and secondary quill feathel's should be buff, withoul other color. The legs should bo heavily fcathercd, covering the outside toe, and partly the one behind. Vulture bocks, as shown in tho Blark Breds 
variety is not admissible, as they not only show mixed blood, but aro unsightly.

\section{Partridge Cochins.}

These are admirable fowls. Among the heaviest of the Asiatic breeds, attract attention wherever showı, from thcir round, full, plump forms, elegant feathering and majestic carriagc. Merely as specimon birds they aro objects , $\hat{i}$ beanty.

The head of the Partridge Cochin is a rich orange red. The hackle and saddle feathers the samc, but each distinctly marked down the middle with a black stripe. The back, shoulder-coverts and wing are sclf colored, red and darker than tho hacklc; the lower wing-coverts black, with grecnish or blue reflections forming a "bar" across the wing; the primary wing feathers black, edged brown or bay on the lower cdges; secondaries bay on the outcr edges and black on the inner, each feather black on the (...., forming a black edge on upper side of the butts of the wings; the breast, thighs, tail and leg feathers black and without other color; the leg dusky yellow. The hen should have her hackle golden yellow, each feather striped black along the center, the rest of the plumago light brown, pencilcd with dark brown, the pencilings over tho body should be densc, and the purer the brown the better. On the breast the pencilings should be crescent shaped. Lergs dusky yellow, peuciled brown as in the body.

\section{XZI. Whito Cochins.}

White Cochins should be whitc, purc white all over. This purity in color is essential, since a yellow or other tinge detracts from the beaty of the bird. The cock should have a medium sized, straight, smooth, freely serrate comb, large, rcd, deaf ears, large wattles, red eyc, strong, yellow beak and legs, and with plenty of fcathers on the feet. This foathering should be characteristic of all Cochins, avoiding as far as possiblo any tendency to vulture hocks. Breed also to large stock, of good carriage, and you will havo in the progeny as pretty a sight for fowls as conld well appcar, cither in the farm-yard or on the grass. Yon will also have ral value, for such fowls as these will always command a market. Their eggs are large and of good quality, and their flesh is sweet.

The hon should be largo; the head, bcilk, cyc, denf ears and wattles colored as in the cock. Avoid especially a grayish eye. It is supposed to show a tendency to blindncss and a generally weak constitution. Tho body must be broad, the tail small, almost covercd with the soft feathere about it, and with well feuthored rumps and plonty of fuff. 
XXIII. Erahma Fowls.

These majestio fowls, said to have been originally brought from the banks of the Brahma-pootra river, which watcrs the fertile territory of

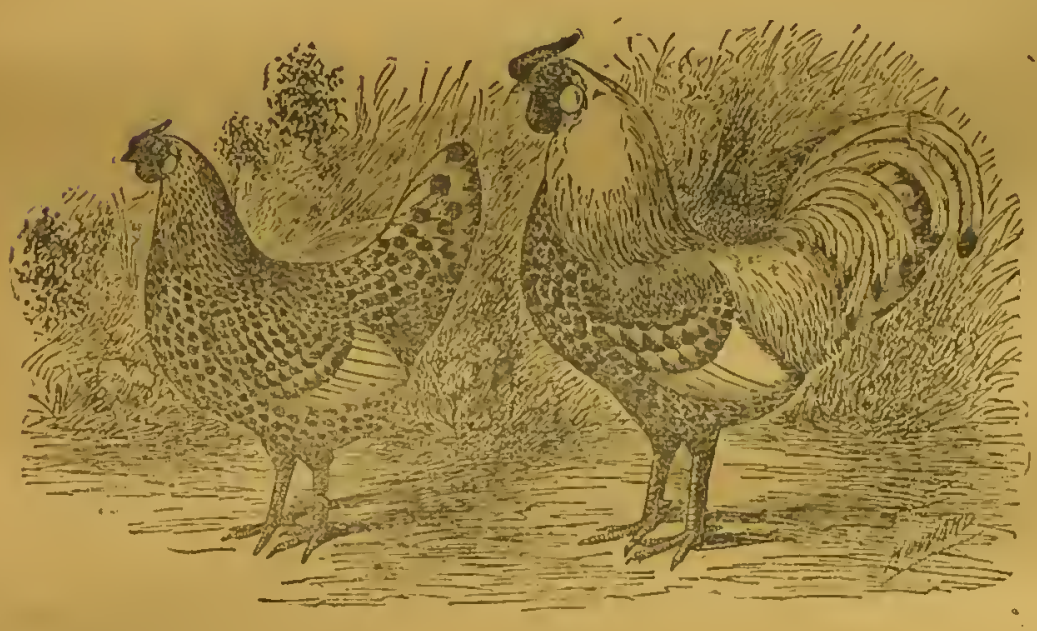

Pair Sucver Spanaten Hamiung.

Assam, are divided into two classes, the light and dark, each having their special admirers, and either good enough for any farni yard. As a rulo howcver, the dark are more highly esteemed, and the fowls sell for bigber prices than the light.

The head of the dark Brahma cock should have a pea comb, that is, thrce combs running parallel to each other, and with the length of the head, the middle one the highest; the beak strong and curved, car lobes red, and falling below the wattles, which should be full, and like the ear lobes, deep red; the ncck short, woll curved, with the hackle ful?: silver white, striped with black, and flowing over the back, and sides of the breast; the back strong, very short, wide, flat, the feathers almost white, the saddle feathers long and white, striped with black; the tail small, onft, upright, the feathers on the rise from the aaddle to the tail, and the 
side feathers of the thil a pure lustrous black; the breast full, broad, rathe- prominent, the feathers pure black tipped with white, and the featherg at the head white; the saddlo feathers and thigh tluffs ample; the wings small, with a good black bar across them; the wings well cucko 1 inder the saddle feathers and thigh fluffs: the fluff on the hinder

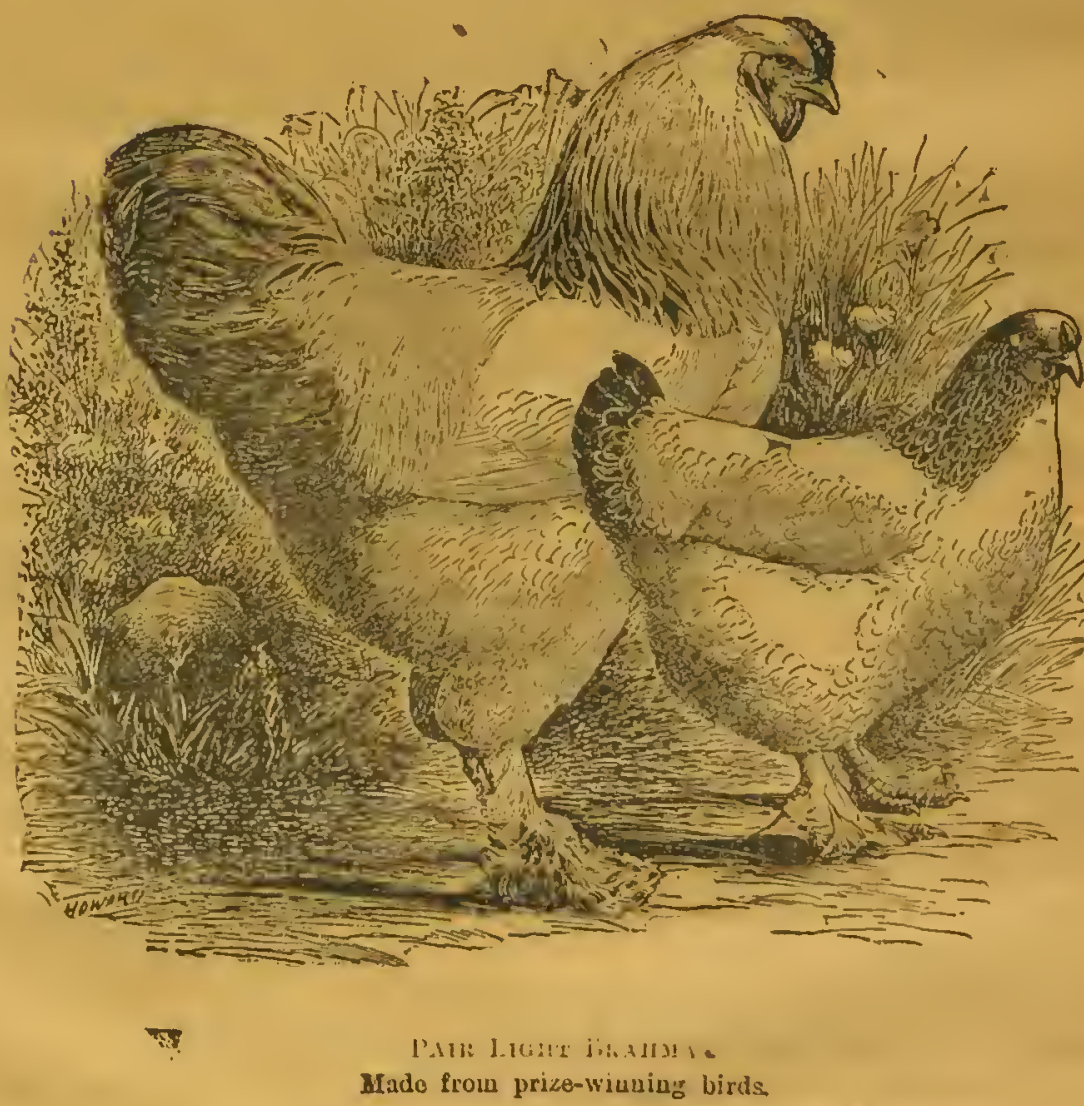

part of the thighs black or dark grily, the feathers on the lower part co the thighs soft and nearly bluck; legs short, yellow and profusely corored with feathers on the outside.

The marking of the hen is almost identical with that of the cock. axcept that it is more uniform all over except tho head and tail, aach 
feather closely penciled, with dark steel gray on a dingy white ground, and cxtending nearly up to the throat, on the breast. In carriage, the hen is not so upright in carriage as the cock, and the legs are very considerably shorter.

\section{Light Brahmag.}

Pure brcd fowls are mostly white in color, on the outside, but if the Seathers are parted, the under plumage is bluish-gray. This distinction is strongly marked as between the Light Brahmas and Whito Cochins, which latter are white to the roots. The head is of the same general shape as in the dark variety, and with pea combs; the car lobes and wattles are pure red; the neck hacklcs are distinctly marked with a black stripe down to tho centcr of each feather, on a white ground; the quill feathers of the wings are black, but when folded the wings should show only white; the tail should be black, tolerably upright, but opening out like a fan, and the within tail coverts reflecting a peculiar green hue in the sunlight; the legs are ycllow and well covercd with white feathers, somotimes slightly mottled with black. The hen is colored like the cock, except that the plume may be somewhat darker, and the general appearance more sobcr in color. 'The tail should be black and smaller than that of the cock.

\section{Frizzled Forwls.}

One of the most curious of the Oriental breeds, and occasionally seen in the yards of amatcurs and fanciers, are the frizzled fowls originally brought from Java. Linnzus named them Gallus pennis revolutis, or fowls with feathers rollcd back. The color should be white, though they aro also bred black and brown. They are ccrtninly curious and intercsting as showing freaks in breeding. So far ss value, in comparison with other breeds is concerncd, it is nil.

\section{Silkies.}

Far more ornamental in appearance, and really of some value, are what are known as Silkics. The bcst specimens are puro white, and have this peculiarity, the webs of the feathcrs lack cohesion and are filamentous, hence giving the silky appearance to the plumage.'

They are sometimes called negro fowls, from the fuct that the skin is of a dark violet color, almost black, and the comb and wattles often dark purple, low and flat and covered with small warts. The bones are also covered with a dark usembrane, which altogether makes this breed the most singular and interesting of the gallinaceous tribe. 


\section{Breds or Guelder Fowls.}

The Breda or Guelder fowl is peeuliar in some repects, and shows that there is an infusion of Asiatie blood, although they are Polish in ahape and closely related to this breed. They are of various colors, but

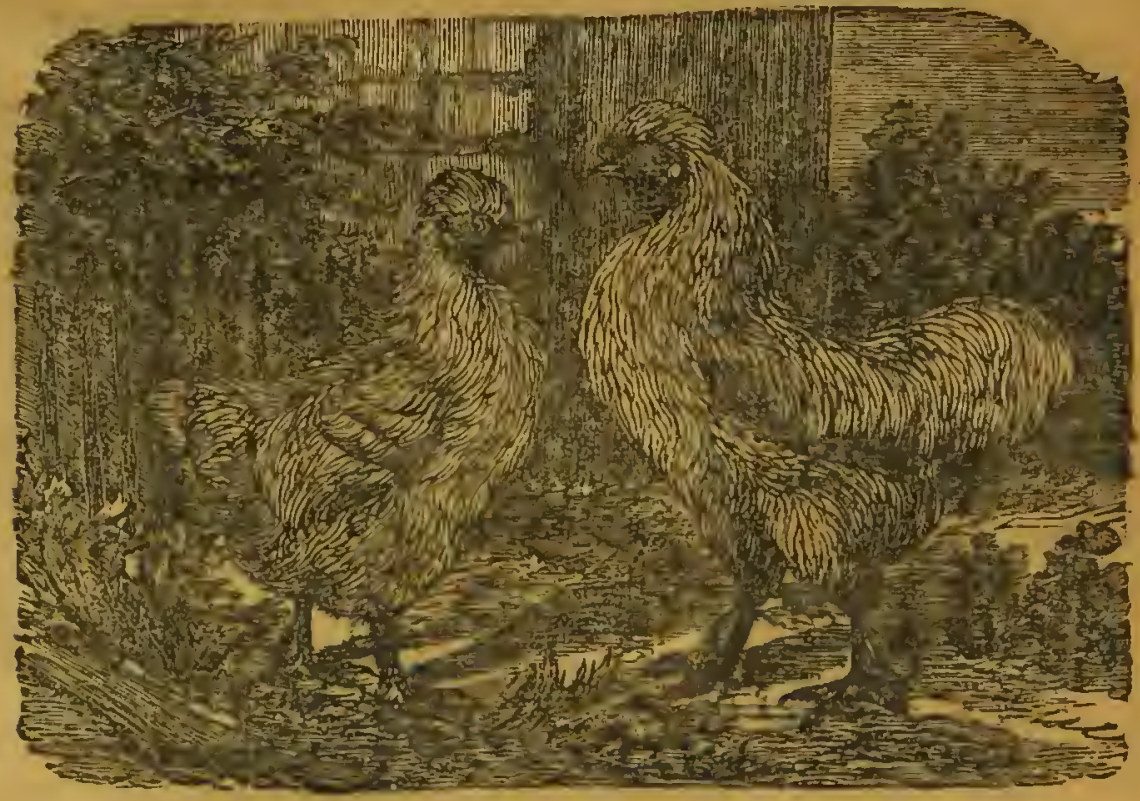

PAIR OF BILKX FOWLS.

the only true families that are bred in the United States are the Cuekoo or Dominique marked, ealled Guelders, and those pure black, denominated-Breda, though we believe the true Breda is applied to all the Guelders, not Cuekoo marked. They have a erest, only just 'pereeptible, and of the same eolor as the body.

Whatever the eolor, they are lightly feathered on the legs, which are slaty-blue, and the thighs are vulture hoeked. They have no eomb, but a depression where the comb should be; the nostrils are eavernous, and particularly conspieuous. The eut given will show their general appearanee, and the likeness of a Breda head given on a previous page will show the ehief peeuliarity of the head. In size they are mediun chieks, ear lobes and wattles red and peeuliur in shape, being extremely pendulous in the eoek. The plumage is elose and eompaet like that of gamo fowls, with large and flowing tails. The eggs are large, smooth and of good flavor, and the chickens are hardy and feather quickly. 


\section{Gamo Fowls.}

The several varieties of game fowls are the most elegant and noble of the gallinaceous tribe. The cocks are watchful, courageous, always ready to attack an enemy whatever it may be, and fighting to the death. And of most elegant carriage and coloring. Tho bens are good mothers, lay

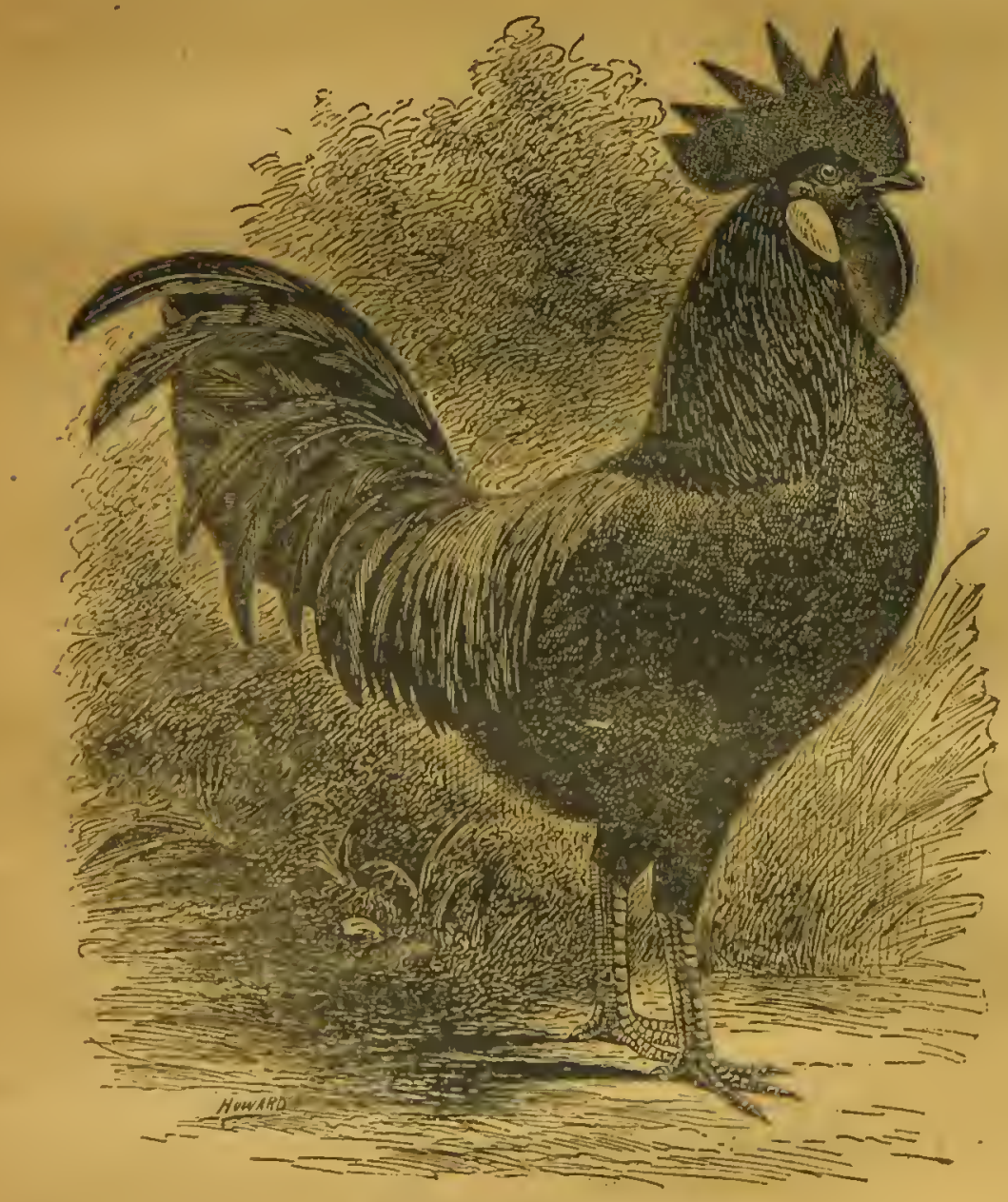

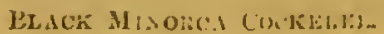

the finest meated eggs of any breed, are hardy, and excellent foragers. There is burdly a breed of "dung-hill" fowls, but what owe their good qualities to the infusion of this prepotent blood. This general description will suffice for all the varieties, which aro innumerablo, and belong 
to overy country, England, Ireland, Spain, Cuba, Mexioo, Malay and China being the most celebrated for their strains of blood. In all these rarieties of games the cocks are noted for the brilliancy of their marking and the hens for their soberuess of color.

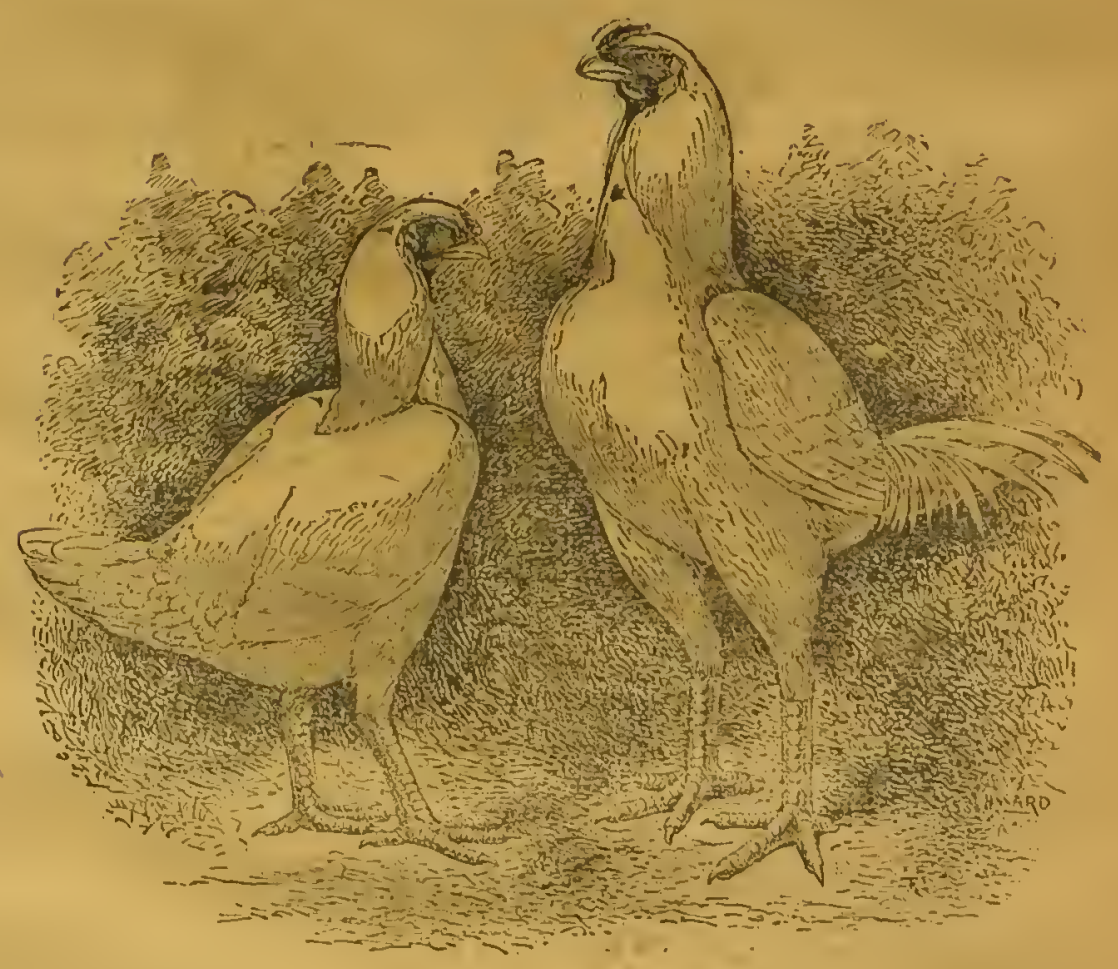

WHTE INDIAN GaMES.

The Brown-bresated Reds.

This variety is considered as one of the best of the games, an illustration of a group of which we give. In this breed tiro bicusi of the coots 
should be red-brown, shoulder sometimes orange-red. The comb and face must be dark purple, the beak dark; wing butts dark red or brown, with dark talons; hackle with dark stripes; thighs like the breast; tail a dark greenish black; the wing crossed with a glossy, green-huod bar. The plumage of the hen should be very dark brown penciled with light brown; neck hackle dark, golden, copper-red, thickly striped with dark feathers; comb and face much darker than that of the cock. When the tall feathers are spurred and show a slight curve, it is considered indicer tive of strong blood.

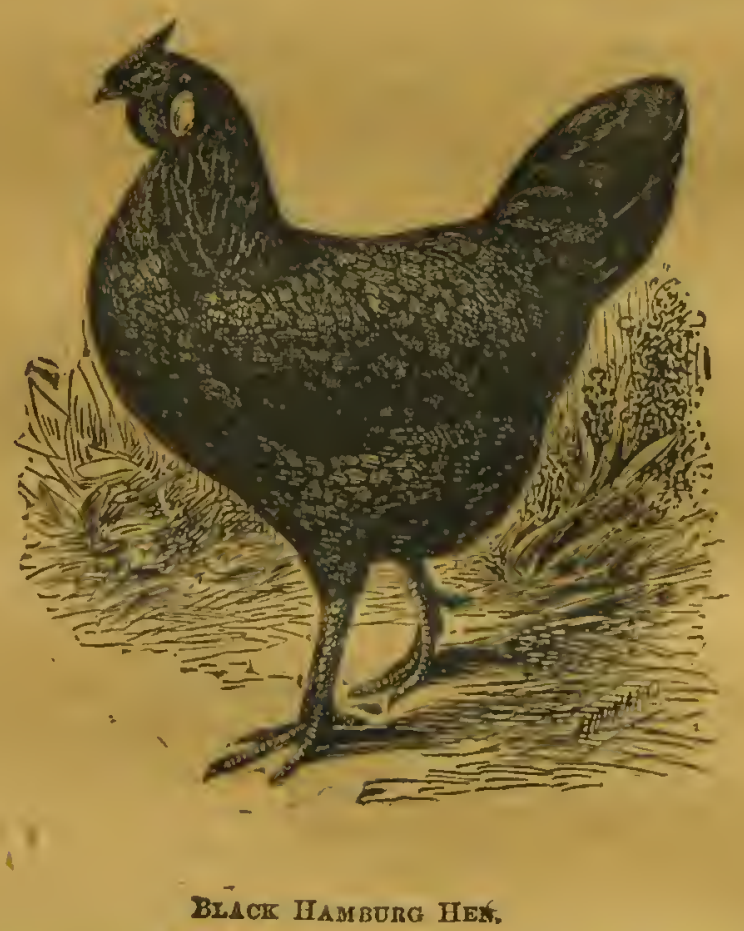

This magnificent strain which has been bred in great purity in England tor over a century, are Daw-eyed, that is the eye is gray like that of the Jackdaw. They have a round, well knit body, on long, strong legs, with white feet and claws; the head is long, the bill lance-shaped and elegants the face bright red, with small comb and wattles red; back intense brown-red; lesser wing coverts maroon colored; groator wing coverto marked at the extremity with steel-blue forming a bar across the wings : primary wing feathers bay ; tail irridescent black; haokle well feathered, touching the shoulders; wings large and well quilled; back short : breast round and black; tail long and sickled. being well tufted at tho root- 
thick, short and stiff. The hen is thus succinctly and perfectly described by Beeton in his English work on poultry: "Head tine and taperiug; face, wattles and comb bright red; extremitics of upper mandibic and the greater nortion of the lowcr one white, but dusky at its base and eround its nostrils; chcstrut-brown around the cycs, continued beneath the throat; shaft of neck liackles light buff; web pale brown edged with black; breast shaded with roan and fawn color; belly and vent of an ash tint; primary wing feathers and tuil black, the lattcl carricd verticully and widely cxpanded; legs, fcet and nails perfectly white." The carriage of both cock and hen of this breed is upright and dignified.

The pugnacious disposition of the cock equals that of any other gamo bird; and its cndurance cannot be surpasscd. Years ago they wero numbercd among the best brecd of birds for the cock-pit; and for the table they are not surpassed by the swcet and nutritious flesh of the Dorking fowl.

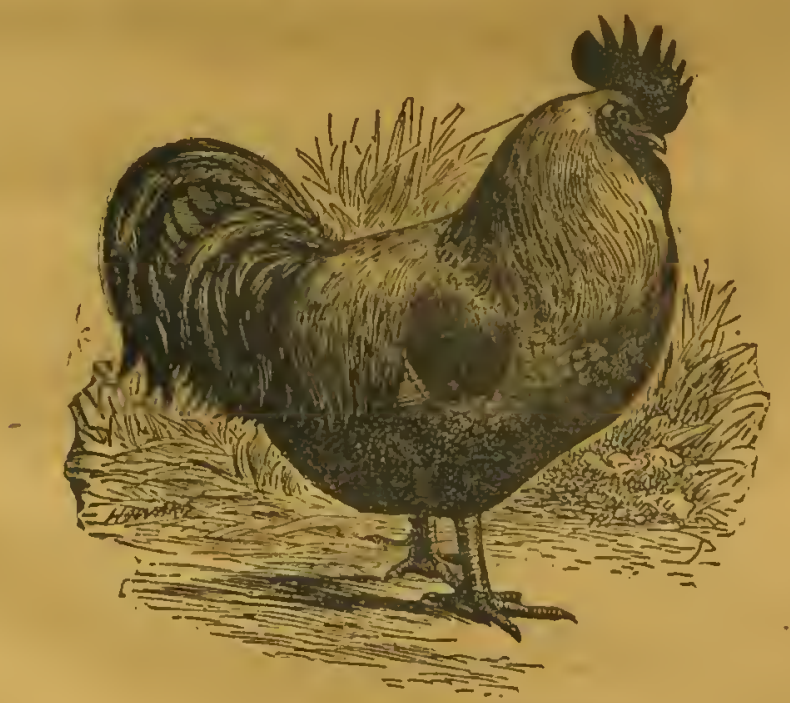

Silfer-gliay Donkisa Cork.

There are several varieties, including the Duck-winged game bantams. To our mind the best are the silver-grily, a purc-blooded, hardy and high couraged bird. The cock must be silver-gray in color : the head, comb, face, wattles and bill of the true game typc; the first four of them bright red, the bill light colored; cyes red, skin whitc, and the logs white: the hackle is striped black underneath, but clean above; tho breast a cleau, nearly silver-gray; the back a bright silver-gray; tho 
lower part of the wings creamy white, crossed above with a bar stecl-blue in color.

In the hen, the plumage should be a silvery bluish-gray, frosted with hito: neck hackle silvery-white, striped with black, aud the breasc $\cdots$

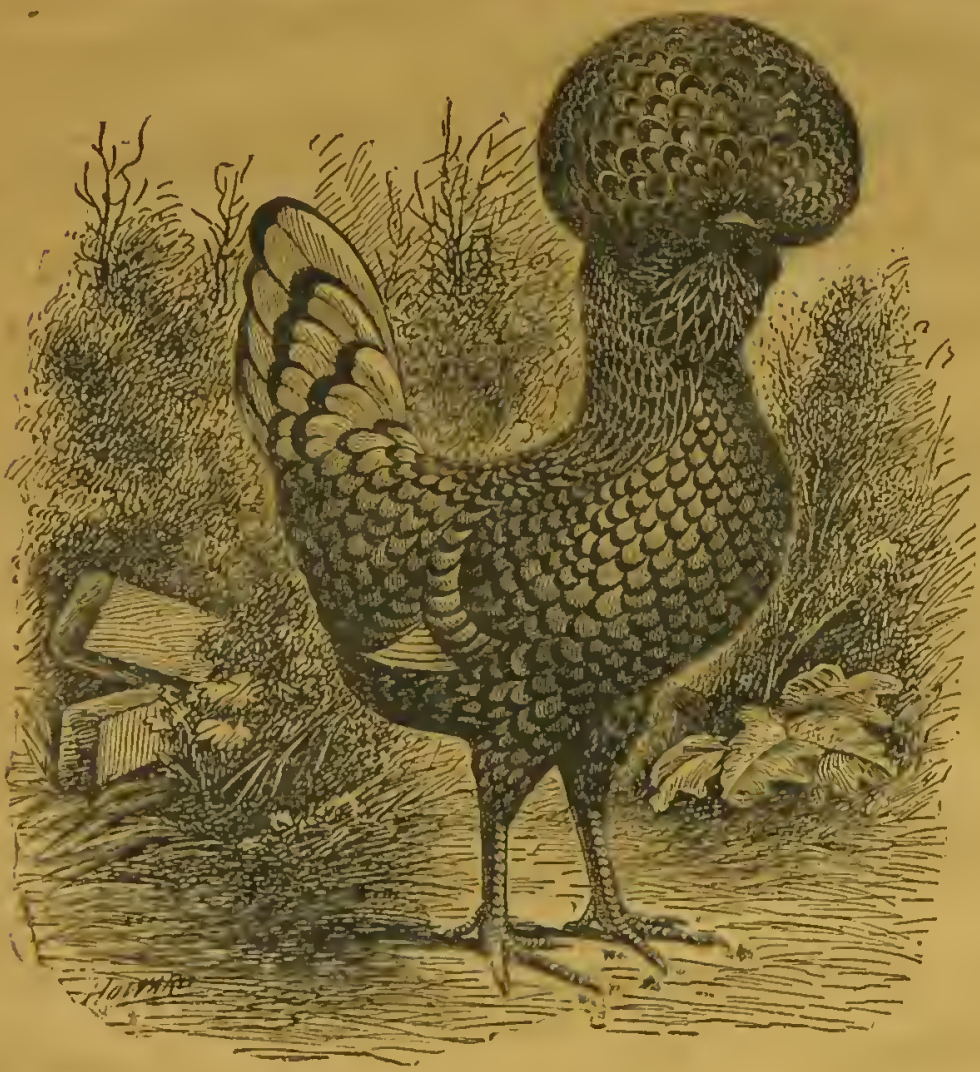

Sirver Poima HeN.

After an Euglish dratring of these beantiful fowls.

nale fawn color, more subdued tran in the cock. The other character totics, as to tiace eyes and feet, etc.. should bo identical with that of tho male bird. 


\section{White Georgia Gamo.}

This variety, originally bred in Europe, but brought into Georgis many years ago, and since carefully bred in various parts of the South, aro game in the pit, and most excellent farm fowls, being hardy, courageous, and the flesh most excellent in quality. For beauty of plumage, elegant shape and lofty carriage, they have few if any superiors.

In the color they should be pure white all ovcr, with no shade whatever on neck, brcast, hock or tail. The legs may be white or yellow. We prefer the yellow, since it is an indication of a stronger constitution. The bcak should hirmonize with the legs, and the comb, ear lobes and wattles must be of the deepest vermilion color. Such a breed on the lawn makes one of the prettiest sights we have ever seen, and in quality of the flesh they have no superiors.

\section{Gamo Bantams.}

These are small varieties of the more common large breeds. Alert, courageous little fellows, some of them not larger than good sized pigeons, but fully eapable of driving any ordinary barn-yard fowl, however large it may be. The more prominent of thcse are the Black Breasted red game bantams. As pets they arc most attractive and may be kept with any of the large breeds without danger of intermixing as to the hell bantams.

\section{Other Bantams.}

The most highly prized of the faney bantams are the golden and silver spangled Sebright bantams. There are also bantams of the white and black races of smooth-legged forwls, as there also aro of the Asiatics.

\section{Sobright Bantams.}

There are two varieties of these, the golden penciled and the silver penciled, idcutical in shape and markings exeept the color. Both varietics are remarkably beautiful ; pert, lively, vigorous, and when small and well bred, among the nicest pets of the farm-yard. The plumage of the Silver bantam is of a silver-white color with a jet black margin. The Golden varicty is identical except that the ground color of the plumage is golden. The legs are smooth, the heads are clean, the comb double and pointed at the back, and the tail straight and without the long sickle feathers. Whether they be golden or silver spangled, the value of the

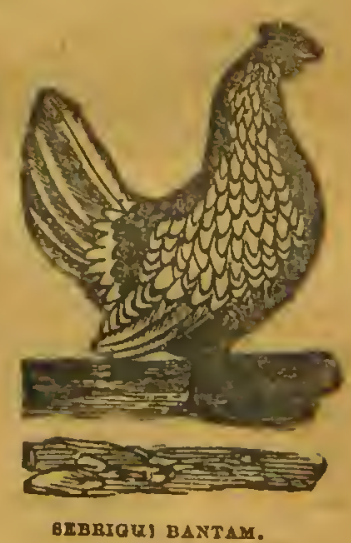
birds consists in the delicacy and pencilings of the markings. The cocto 
should not weigh over twenty ounces at most; the ben not more than airteen. Hens have been shown weighing not more than twelve ouncès.

A peculiarity of this variety is, that occasionally an old or a barrea

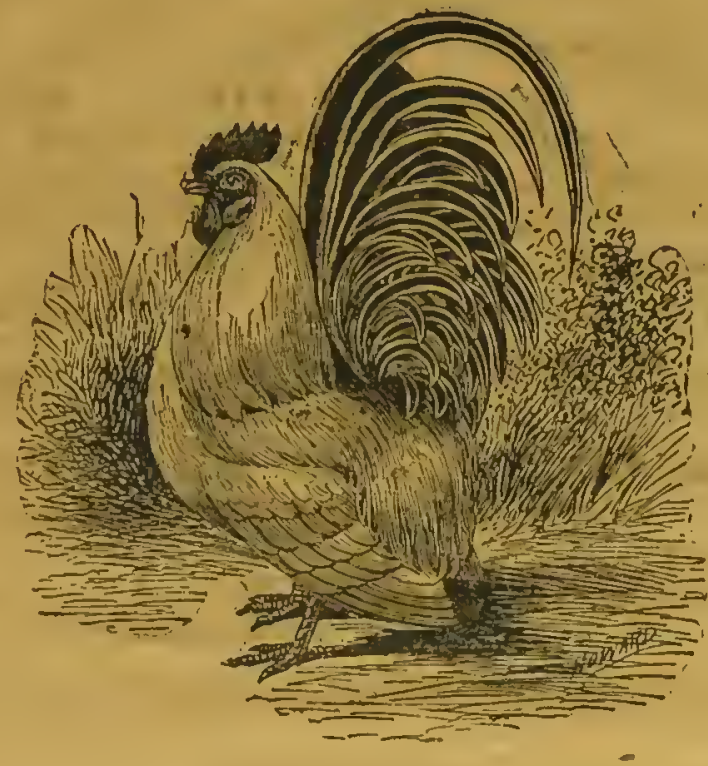

BLACK-TAILED JAPANE.E BANTAM COCK.

remalo will assume the plumage of the cock. "When we remember that the males of this breed are what are called hen-tailed, the remarkable reversion, as shown in the cut, of a hen, will be interesting to the scientiat and curious to all.

\section{Japanose Bantams.}

Among the most curious of the bantam tripe are the Japanese bantame. In this rare breed, the body must be as pure white as possible, the tail black, the sickles very long, upright, little curved, but carried over the back as shown in the cut. The shafts of the sickle feathers white; tho comb large, upright, not too strongly serrated; wattles long and red; legs very short and yellow. The body of the wings should be white, with black flight feathers. The hen should be fan tailed, and the comb crinkled. They are quiet, easily domesticated. Tho hens are good layers and good nurses. The chickens are tender, and for this reason should not be hatched before the weather is warm. In fact as small size in bap: 
Cams is an essential point, the best chickens are fall-hatched and kept through the Winter with oniy feed sufficient to continue ther growing cairly and to keep them in good bealth.

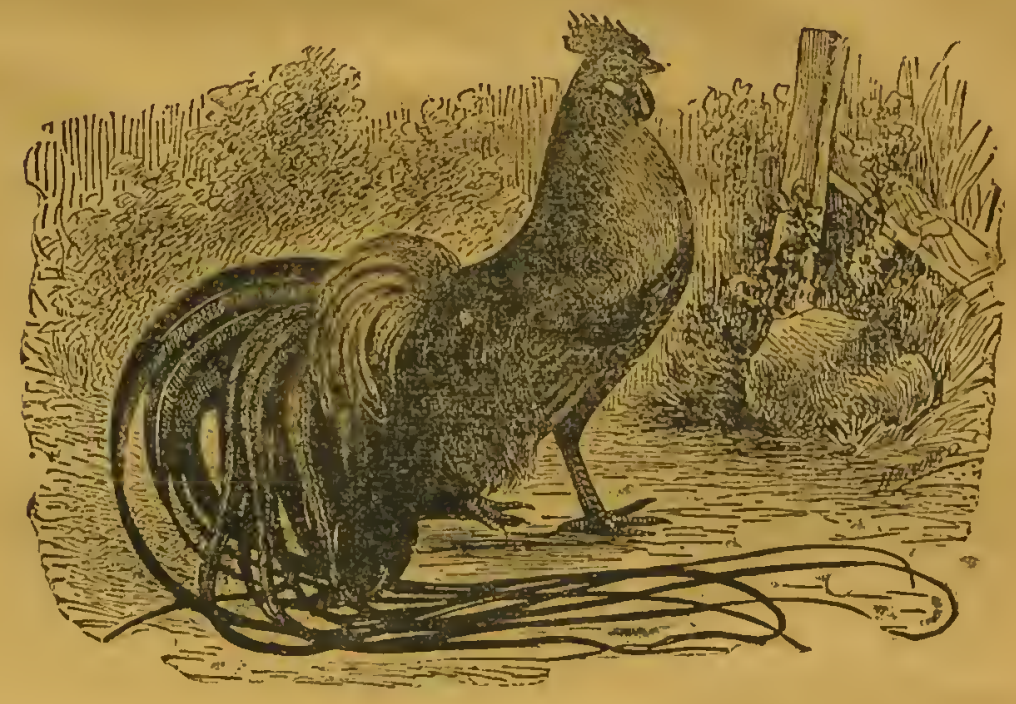

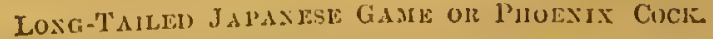



tan

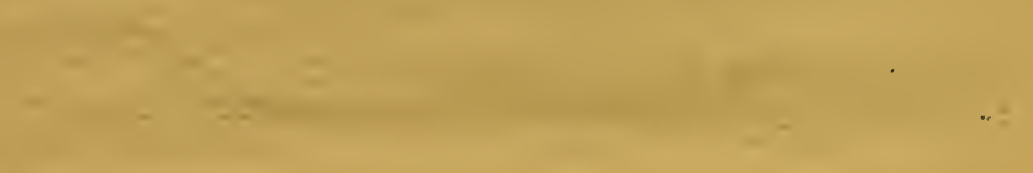

$$
4
$$

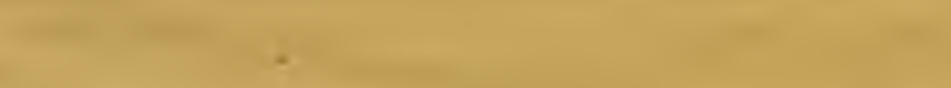

$a^{x}$

$$
\text { . }
$$




\section{CBAPTER ITL}

\section{BREEDIKG.}

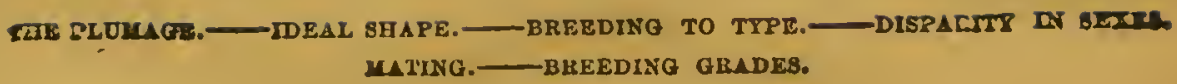

In the breeding of poultry it is absolutely necessary that the breeder have a good and elear idea of the points of fowls. For this reason wo give a series of illustrations showing the entire fowl, and also others accurately figured and explained, so no readcr can err. It is absolutely necessary to a correct understanding of any business or profession that a correct knowledge of the technicalitics connected thercwith be had. The poultry breeder nust not cmly understand how to feed and rear chickens but he must have a nice discrimination as to plumagc, the chief characteristics of the scveral breeds of fowls, and their peculiaritics of constitutional vigor, style, carriage, etc., but he must also understand comething of the anatomy of the fowl, their points, and also those relating, to outward parts, and the technical terms used in describing the several parts. In addition to what follows we have prepared a pretty completo glossary which will be found at the end of the chapters, so that any person may ensily inform himself as to the sevcral terms used by the fanciers and breeders. The technical terms used by poultry fanciers, in describing the points of a fowl, are not always understood by the uninitiated. 
Eor the benefit of such we give an illustration, with lettered referencs, thich vill supply the necessary information on the subject

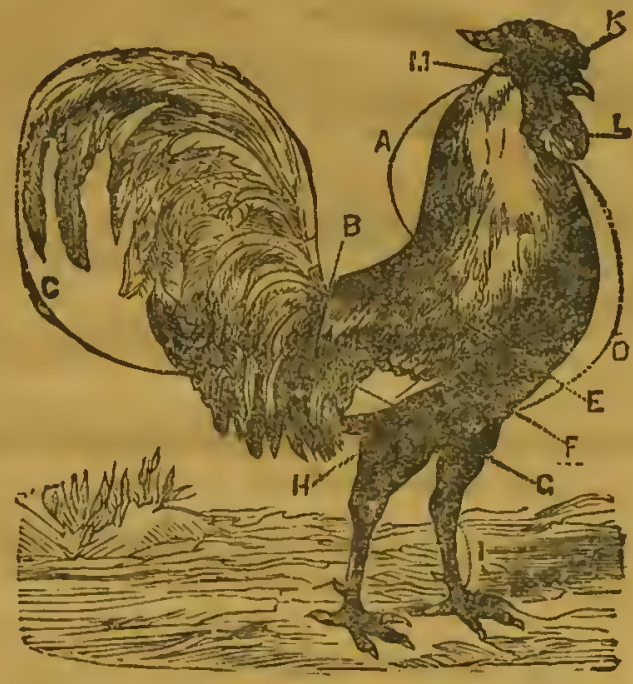

POINTS OF POULTRT.

Explanation-A-Neci backle. $B$-Saddle backlo. C-Tail. D-Breactos E-Upper Wing coverts. F-Lower Wing coverts. Q-Primary quills. aThigbs. I-Legs. ' $K$-Comb. L-Wattles. IL-Ear lobe.

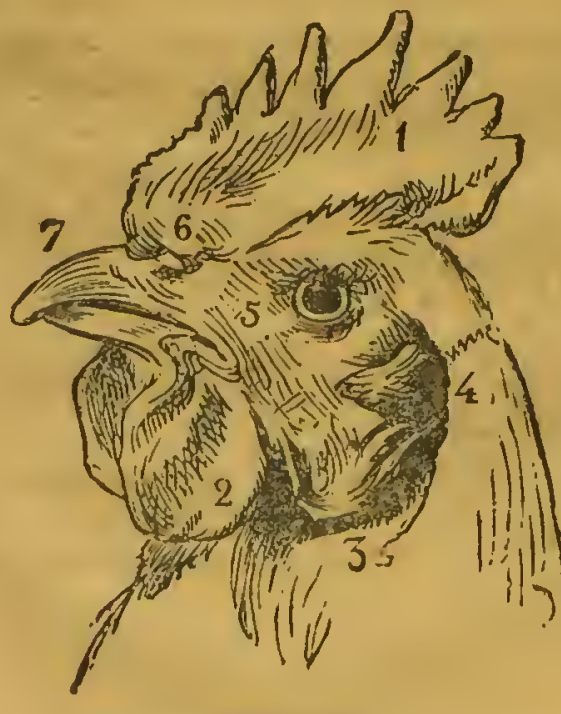

POITTO OF TIE HEAD OF COCJ.

Explanation.-1-The comb, which surmounts the olkull. 2-The wattles, riduch bang underneath and on each side of the beals. B-Tho ear watulen 
which hang ander the cheek. \&-The tufts of little feathers, which cover and protect the auditory organ. 5-The cheeks, which commence at the beginning near the nostrils, cover all the face and re-unite behind the head by a continus. tion of the flesh of the same nature, but covered with feathers. 6-The nostrils, which are at the beginning if the beak. 7-The beak, of which the two parts, the upper and lower mandible, are horny.

The head of the cock, as of the hen, is composed of two principal parts: 1st, the skull is a firm union of bones, which include tho upper part, or mandible, of the bcak; 2 nd, the lower part or mandible of tho beak, being the lower jaw-bone, formed by a single picce. In the skull are the sockets or cavities which contain the cye; the nostrils are in front of the cye; the auditory organ, or ear, is bebind the eye. The hcad, cxcepting the beak, is entirely covered by a fleshy covering, round which may be seen several appendages or caruncles, which are the crest, the two ear-lobes, and the two ear-wattles. This covering forms the cheeks, the color, the size; the form of each of these parts is varied according to the variety, and often scrves to characterize each. A tuft of short feathers called "the tuft" covers the auditory organ.
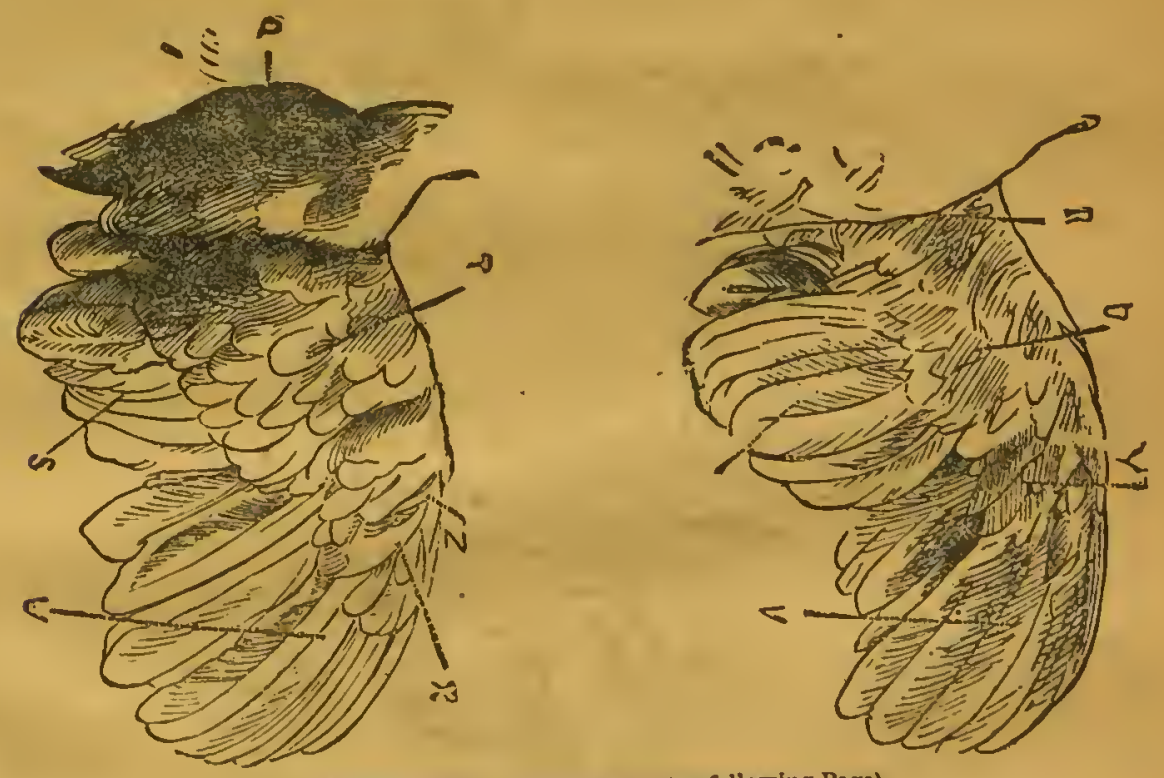

aXstrsts of miNo pLtwage (see following Page).

The comb is straight or drooping; it is single when it is composed of only one piece, double when there are two alike united or near tomether, it is triple when it is rormed or two alike and one in the midd!c; it is frizaled when full of granulations more or less decp, and crect excrescences, it is a crown when it is circular, bollow, and indented; it is goblet shapees 
when hollow, fisoular, and not indented. There are other forms but they are composed of parts or unions of those particularized.

\section{The Plumage.}

With the hen there nay be three kinds of feathers distinguished: 1. The large feathers on the wings for flying, and on the rump to form the wil ; 2. the middle-sized feathers which cover the large feathers, and are

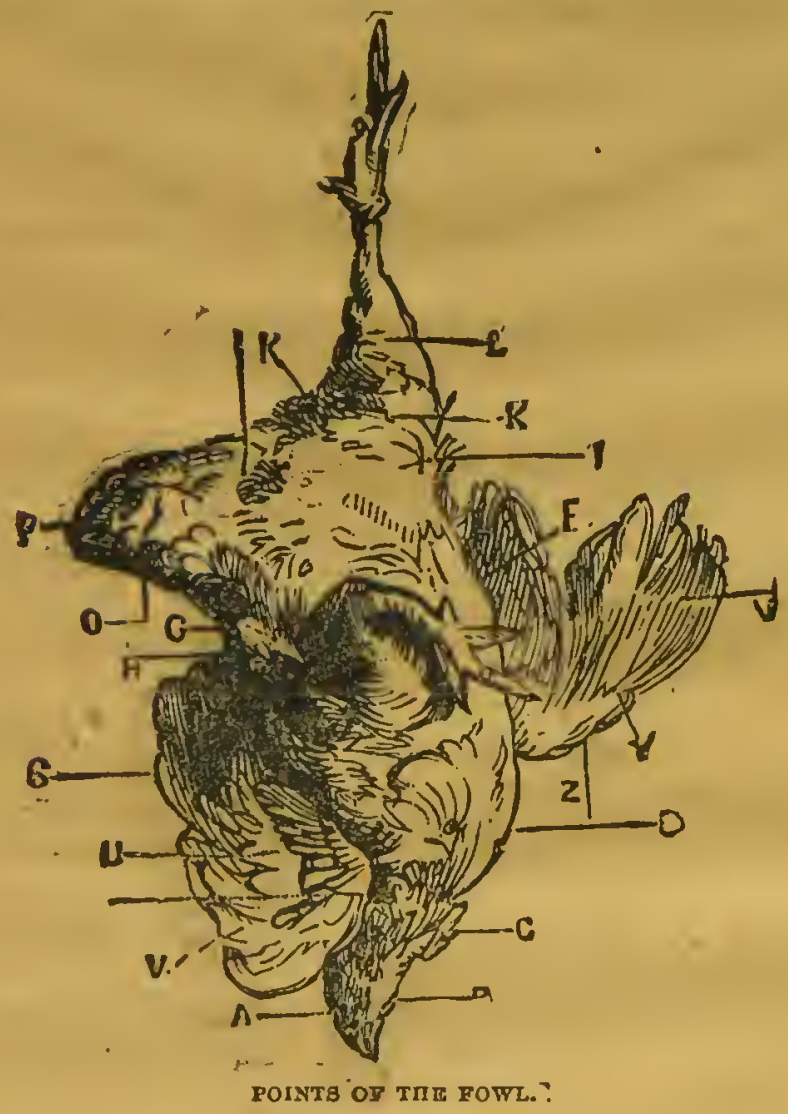

'also found on the wing and rump; 3. the neck, the back, the wilem, the throat, the shoulders, and a part of the wings. They aro always in layers compactly covering those beneath them like tilos. We shall designato them by the namo of the places they occuly, and refer to the engravings (4) render them easy to recognize :

Explangtion-A-The upper feathers of the head ure very emall in thoso fowls not turted. 'They surroued the skull. 
$B$-The underneath festhers of the head are nimast like bristles. They corer the cheeb. In the space which separates on tho wattles.

a-The upper feathers of those at the back of the neck are short, and lengthening lower down, forming what is callcd the hackle. They becomo longer hetween the shoulder. when they cuver the beginning of those on the back and the commencement of the wings

$D$-The feathers of the back, forming a laycr about 10 . Theso teachers are of the same aature as those of the neck, hut a little larger, and form the saddle.

$F$-Tise feathers of the breast cover thic entirc length of the two breast muscles, extendhe beyond the breast-bone at each side and uniting at its cnd. The whole forme what is termad the breut. I'heso teathers, with thu fcathers of the lusns, overlag those of tho aides.

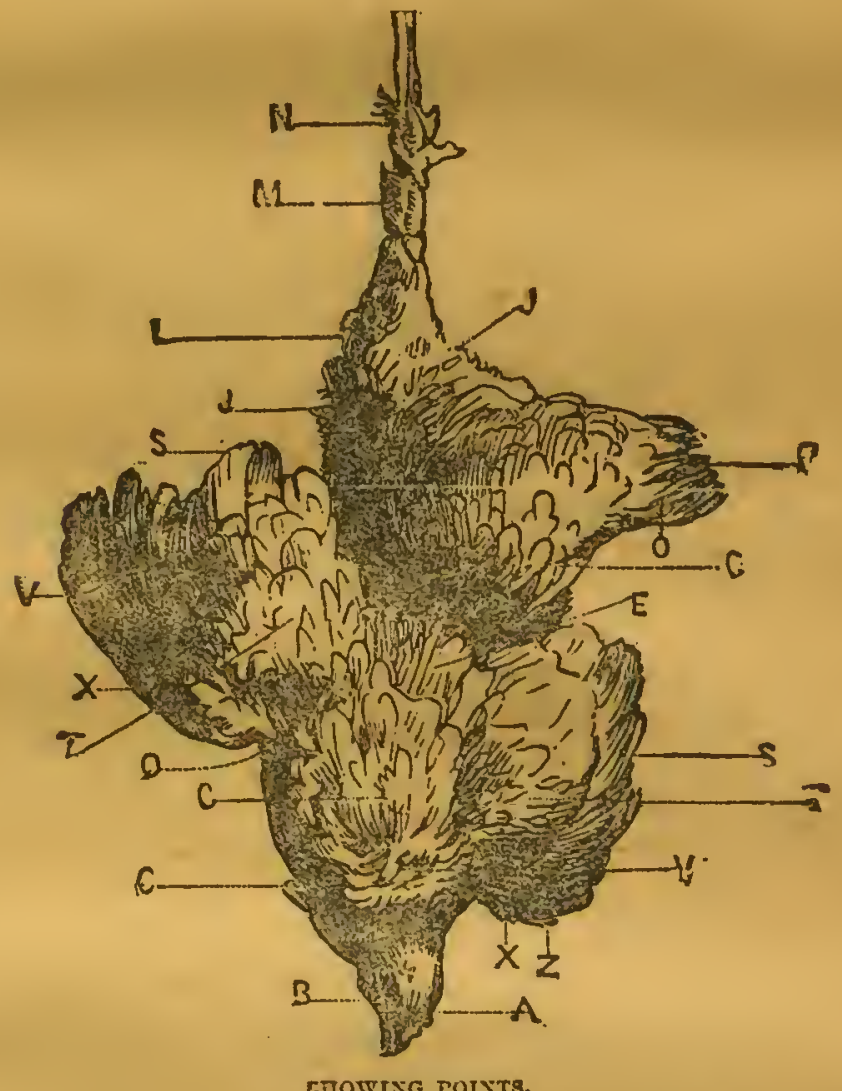

a-The feathers $c_{n}$ the sides cover the loins, taking in the back as far as the rrmma which they go beyoul anl cuver the lower part ot the feathers of the tall. "They also cover the commencetnent of the feitherz of tlic nanks, thighs and ahdomen.

$H$-The feathers of the finks are llerht nul nudy. 'Thcy cover the upper part of the thigh feathers and sllp under those of the breist.

I-The fenticrs of the nbdimen corer und enrelope all this nart from the end of the breast to tho rump. These feuthcrs ure gencrally flufy, of 1 silky nature and epread out In a tuit.

-The outsije fenthers of the thioh cover those of the abdomen and ieg. 
$\boldsymbol{L}$-The outgide and Inside feathers of the leg stop at the heel, or in some varleties they proceed lower and form what are called rufles or vuitured hocks.

$M$-The feathers of the feet or sole are long, short, or entlrely absent, in the different varletles. These feathers are along the sluank In either one or several row8. They aro al wass on the outslde part.

$N$-''he feathers of the toes appcar on the outsldes.

0 -The middle tail feathers envelope the rump and cover the bases of the large feathers of the tail.

$P$-The larger tail feathers are in a regular line of seven on each side of the rump, and form the tail.

Q-The outside feathers of the shoulders eover a part of the other feathers of the wing. They form the shoulder.

$R$-The inside feathers of the shoulders are small, thin, and slender.

$S$-The larger feathers of the pinion forn, where the wiug Is opened, a large, arehed surface, and are of different sizes. 'These feullers grow out of the under side of the pinlon.

$T$-'The small outside feathers of the pinion are of different sisies. They come on all the outside surfaces from the shoulder to the pinion. They begiu quite suall on the outsido. edge, and finish a medium size on the Inside edge.

$U$-The inside feathers of the pilulon are close, middle-slzed, and small, eovering the bases of the large feathers of the pinion.

$V$-The large flight feathers, or feathers of the hand, are large and strong, and are of most use to the bird in loconotion. They begin at the under edge of that whlch ls callerd the top of the wing.

$X$-The outside llight-fcathers cover the large ones; they are stlff and well fattened on the others.

$Y$-The Inside flight-feathers are, some small and others medium-sized; eover the bases of the flight-feathers.

Z-An appendix called the pommel of tl:e wing, which represents the fingered part. It is at the joint of the pinlon and lias some middle-sized feathers of the same deseription as the large pinion feathers, and have some small ones to cover them. 'These feathers assist in the flight.

When the whole wing is folded, almost all the feathers are lidden by the larger feathers of the pinion and middle external feathers. Classification of the feathers of the cock are the sume as those of the hell, but the forms of some of them are different.

\section{Ideal Shapo.}

The cut on next page will serve to show the contour of the fowl, the Dorking being the one selccted on account of its compact body ; and the nearer the fowl comes to the ideal the inorc profitable it will bc. Nevcrtheless it must be remeinbercd that cach brecd has its peculiar characteristica, and that some one point must often be sacrificed in favor of another.

\section{Brpeding to Type.}

In the breeding of poultry, as well as farm animals, there should be no violent crosses made. In fact, nono but the thoroughly scientifio. breeder, who has given his life study to the task. should undertake 
crossing with a view to forming a new wrced. It will not pay. The general breeder should get the best represcritutives of the breed he pro-

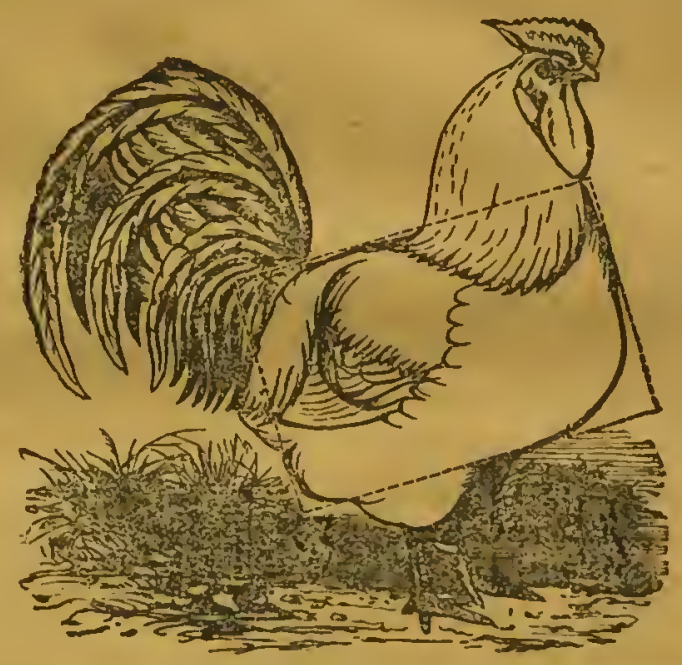

BRERDING TO TYPE.

poses to use and confine himsclf to it. No more than one breed should be allowed on the farm. If so it will cnd in intermixing and confusion. No more should be attempted than by careful brcediug and selection to perpetuate the strain in its purity, and if possible to improve it. A careful study of the forcgning will render this possible, and thus any farmer may breed a given strain equal to the best.

The cock should be lajge, broad brcasted, strong winged, muscular, easy on his legs, and of strong points in his plumage; tho hen from good laying stock or a good mother as the rase may be.

\section{Disparify in Sexes.}

As to the number of hens to the cock it will vary with the breeds. With Gancs, Dorkings, Houdans and Creve Cours they may be cight or tea to one; Spanish, Cochins and Brahmas, ten or twelve to one; Hamburgs twelve or fourtcen to one. If the flock is large enough so two or more cocks are kept all but one had better be eonfined, giving them in succession to the flock, and it is better in large flocks to have a reserve to use when necessary. By this plan much fighting over and unnecessary worry of the hens will be saved. If too many males are nllowed to run there will be a loss in eggs, and if too few they will be deficient in fertility, this being one of the greatest drawbacks to this system. So, as betwcen tho two, always buy eggs for setting from brecders who give their flocks 
a good range, and aro cureful that the heus have neither too few nor wo mally wale:

\section{Mating.}

Always mate a short, compact, deep-bodied male, with long-backed hens, but not the reverse, and as a rule, for the best results tho hen should be over one yen old when she sets. From that to four years sho will do the best. Do not be afraid of breeding in-and-in. Unless carried ton far it will result in better success than out crosses. So in breeding to color let all self colors be as solid as possible, and in parti-colored breeds study their charieteristics, and brecd as weir to a feather as possible. Avoid vulture hocks in all poultry, and especially so in the Asiatic breeds. In breeding Brahmas and colored Cochins have plenty of color in the males, as the tendeney is to get lighter. Yet in this discrimination inust be used. If the saddle is very heavily striped, or tho neck liackle very dark, tho chicks will be apt to run to spots. Yet as a rulo heavily-penciled males must bo used to get heavily-penciled cock chickens. So very dark hackled coeks and hens with the hackles lightly penciled will produce chiekens with delicutely peneiled hackles.

\section{Breeding Grades.}

If you cannot get fowls purn get a woll bred coek and keep with a few of your seleet hens. Breed him again to his chicks, so long as he lasts; thus by the exercise of judgment you may have very superior poultry in a short time. A better way, however, is to get a setting of pure eggs and commecee right at once. They cost comparativaly little, are easil sent hy express, and will soon rejay their cost. 


\section{CHAPTER IV.}

\section{MANAGEMENT OF FOWLS}

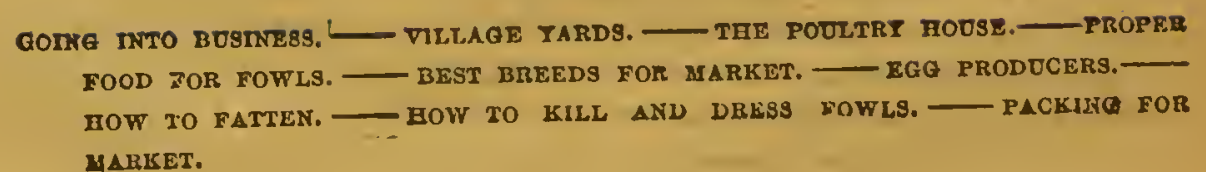

YARISET.

\section{Going Into Bueincss:}

Before going into the business of raising poultry be sure and hate comfortable quarters for the fowls. These necd not be expensive stroctures, poles and hay will nake a warm, comfortable roosting and nesting places until something better can be provided. Be sure that plenty of dry dust for bathing is supplied at all times. It is the great remedy against lice. to which fowls aro especially liable. This with plenty of sun, plenty of puro water, and liberal fecding, will insuro success both in eggs and chickens. Do not over crowd the houso. Sec that everything is liept corupulously neat and clean. If you build a permanent house, know that there is to bo plenty of ventilation; all birds require a largo anount of fresh air. Plenty of heat, plenty of food and water, and plenty of fresh air are what givo plenty of fresh eggs in Winter, wher- they are scarce and high. In the Summer let tho fowls range over the farm as much as they will, they will thus be paying for their kecp in destroying insects, and kecping themselves healthy; wo aro writing for farmers, and not fanciers. In villages the case will be different; thele, fowls inust bo kept shut up a great part of the time.

\section{5}


Here, some tact must be used. If the fowls must be kept up during the day, let them out for a run, an hour before sundown, in the street or alley; they will eome baek all right at feeding time. What you laek in range, you must make up in eare and attention to the wants of the fowls, and in the eeonomy of the hen house, and the little range of griss whieh they may have. Green food of some kind wust be givell. Cabbage, lettuee or onion tops, ehopped, are all good. Animal food must also bo provided; any lough meat will do if chopped. Ono of the mistakes often made is feeding too much at a time. Give them their food so they may take it at will, if it ean be kept clean, or throw down food to them liberally, so long as they eat eagerly, and, make them eat pretty elean.

\section{The Poultry House.}

The poultry house should face the Souch on ono of its broad sides, and the more glass you have in this, the better. One portion should be half zark for the nests, and, for setting hens, this should be large enough so a dust bath may be supplied slso. The roosting place may be in one end, and should pot be more than two feet from the floor, especially if the breed bo heary. The perches should be all on a level, and pretty large. A two by four scantling nieely rounded and sct on edge, is not too large for the heavy birds. Keep everything about the house scrupulously elean. Whitewash at least once a month with lime and if lice make their appearance, fumigate the house, and sprinkle Scotch snuff among the feathers of the fowls. Follow this up until the lieo aro exterminated.

\section{Proper Food for Fowls.}

Never give forls sloppy food. When mixed fecd is given, it should be made as stiff as possible. Never feed in a trough, it cannot be kept clean. Have the dough so stiff that, as it falls from the hand it will break, and so, feed on elean ground. Indian meal and small potatoes cooked together and fed pretty hot in Winter, with a little ehopped onion intermixed, makes a good food. Have broken bones, lime rubbish and gravel always where forls ean get it, and in Winter a sheep's pluck hung where the hens ean just reach it, by jumping up to piek it piecemeal, will keep the fowls in mod laying trim. Chandler's eake is good, if other meat cannot be had. This may be broken fine and mixed with one of their daily feeds. Be eareful, however, that you do not overfecd with meat. If so, it will show in loss of feathers and general ill health.

\section{Best Breeds for Market.}

We do not believe there are any better market fowls, an things eon. sidered, than the Brahmas and Coehins. The Dorkings are undoubtedly the most superior table fowls; they are also teuder and harder to rear. 
I.s a cress for carly plump table breeds, a Dorking cock crossed on Brahma or Cochin hens will give fast growiug, plump chickens of carly maturity. In this, horever, fancy li:s much to do.

The Asiatics are not great layers, but by using judgment, fully as many egrs can be got from cither Biuhnis or Cochins in Winter as from any other breed, and Winter eggs are what bring moncy. Give them warm and roomy quarters, with plenty of range for exercise, with liberal fecding, including green vegetables, and they will bring jou monoy in eggs.

\section{Egg Producers.}

The Pnland, the Leghiorn and the Houdan are inveterate layers, and their eggs are guod. The Hamburgs are good layers, but like the black Spanish, tender, and inore fit for the amateur thun the practical man. For eggs, there is little doubt that the Polands should carry the palm. For young chickens for rrarket, Brahmas and Cochins, and for home wable use, the Dorkings are best. Why then, asks the reader, have you Nescribed so many fowis? The answer is, so that the table being well flled, you may take your choico of breeds.

\section{How to Fatten.}

When ready to fatten, poultry should be always ecifined in a small space; the smaller the better. Two weeks should make them fat. If kept after they are fat, or when they cense to increase, they again inmediately lose flesh. The best food in the West is corn-meal, boiled into a very thick mush, and then made as thick as possible, waile scalding hot, by mixing in all the meal that can be worked. The forwls may be kept in well-ventilated coops, feeding them thrce times a day with the feed warm, and allowing them plenty of water and gravel all the time, except for the last week, when the grivel may be onitted. The eoops must of course be kept clean, and should be small enough so the fowls cannot turn around; should be littered with clean straw, and never allowed to get foul. If, instead of water, their drink is skimmed mils, they will vecome extra fat.

\section{How to Fill and Dress Fowls.}

Never kill your forwls until they have fasted twenty-four hours. No man ever made any money by selling his fowls with their crops stuffed to make them weigh. The petty fraud is too apparent. To kill and dress, tie their legs together, hang the fowl up, open the beak and pass a shary pointed, narrow bladed knife into the mouth and up into the roof, dividing the membrane. Death will he instant. Inmedintely cut the throat by dividing the arteries of the neck and tho bird will bleed thoroughly. 
We never seald; the nicest way is to pick the fowl diry and while yet warm. A little eare will prevent tearing tho flesh, and the bird will bring enough extra in the market to make it pay. Mest persens, hon:ever, will prefer to scald, and for home eonsumption, or the village market this will do.

Have the water just scalding hot-not boiling-190 degrecs is just right. Immerse the fowl, holding it by the legs, taking it out and in, until the feathers slip easily. Persons become very expert at this, the feathers eoming array by brushing them with the band, apparently. At. all events, they must be pieked elean. Hang turkeys and ehiekens by the feot, and dueks and geese by the head, to cool. It should bo unnecessary to say that under no eircumstanees whatever, should ducks and geese be sealded; they must invariably be pieked dry. Take off the beads of ehiekens as soon as pieked, tio the slin neatly orer the stump, draw out the insides carcfully, and hang up to eool. Never sell fowls undrawn. 'Thoy will bring enough more drawn and nicely packed, with the heart, gizzard and liver placed insido each fowi, to pay for the trouble. Let them get thoroughly cool-as cold as possible-but never, under any circumstanees, frozen. There is always money in properly prepared poultry; the money is lost in half fitting them for market, tho fowls often being forwarded in a most disgusting stato. There is moncy in the production of eggs; there is money in raising poultry for the market. The money is lost in improper paeking and in a foolish attempt oecasionally made to makc the buyer pay for a crop full of musty corn, at the price of first-elass meat. It is that elass of men, however, who are too smart ever to make money at anything.

Packing for Market.

The poultry, having been killed as directed, carofully pieked, tho heads eut off, and the skin drawn over the stump and neatly tied-or if : preferred, leave the head on, the fowl will not bring less for it-and the birds ehilled down to as near the freezing point as possible, provido elean: boxes and place a layer of elean hay or straw quite free from dust, in tho bettom. Piek up a fowl, bend the head under and to one side of tho: breast hone, and lay it down flat, on its breast, back up, tho legs extending straight out behind. The first fowl to be laid in the left hand corner. So placed, lay a row aeross the box to the right, and pack elese row by row, until only one row is left, then reverse the heads, laying them next the other end of the box, the fect under the previous row of heads. If thero is a space left between the two last rows, put in what birds will fit sideways. If not, pack in clean long straw, and also pack in straw at tho cides and betweon the birds, so they cannot move. Pack straw enough 
over one layer of fowls, so that the others cannot touch, and so proceed until the box is full. Fill the box full. There must never be any shaking, or else the birds will become bruiscd, and loss will cusue. Many packers of cxtra poultry place paper over and under each layer before filling in the straw. There is no doubt but that it pays. Nail the box tiglit; mark the initials of the packer, the number of fowls and variety, and mark plainly the full name of the person or firm to whom it is consigned, with street and number on the box. Thus the rcceiver will know at a gance what the box contains, and does not have to unpack to find out. These dircetions, if carefully carried out, might save a person many times the cost of this book, every year.

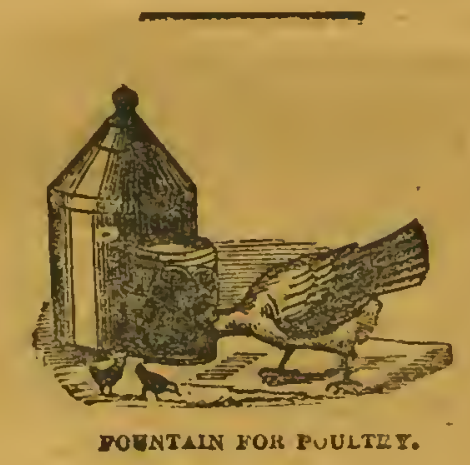




\section{Turkeys, Dther Fowls, Breeds and Managemeat.}

\section{. CHAPTER V.}

\section{THE HOME OF THE TURKEY.}

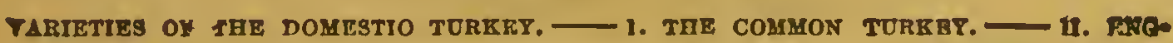
LISH TURXEY. - III. THE HONDURAS TERKEY. - IV. BRONZED-BLACE TUE KEY. - V. GUINEA FOWL.-VI, THE PEACOCB.

Although it is only about three hundred years since the turkey-from any well authenticated accounts - was brought under domsstication, we already see them broken up into screral distinct breeds, although there are but two wild varieties, the brown turkey of North America, and the Honduras turkey of Central America; a cut of the latter beiug shown on following page, and of the former the introduction to poultry in generul, illustrate these varieties.

There is, however, one fact peculiar to the turkey as with pheasants. It still retains and persistently holds many of its wild traits. It is shy, intractable, does not care for home, and like the pea fowl and guinea fowl, is much inclined to wander. When full grown, and indeed aftcr becoming full fledged, they are the hardiest of domcstic fowls; in fact, as hardy as any of our Winter species of wild brecds; yet when young, they are the most dclicate, tender and easily chilled. For this reason they should nover be hatched until the weather, both nights and days, is warm; and for the reason that tho hen turkev is so careless of hes 450 
young, and so poor a provider, we have always raised them under careful hens, giving a large hen seven eggs and aiming to have two broods come off at once, giving both broods to one nurse.

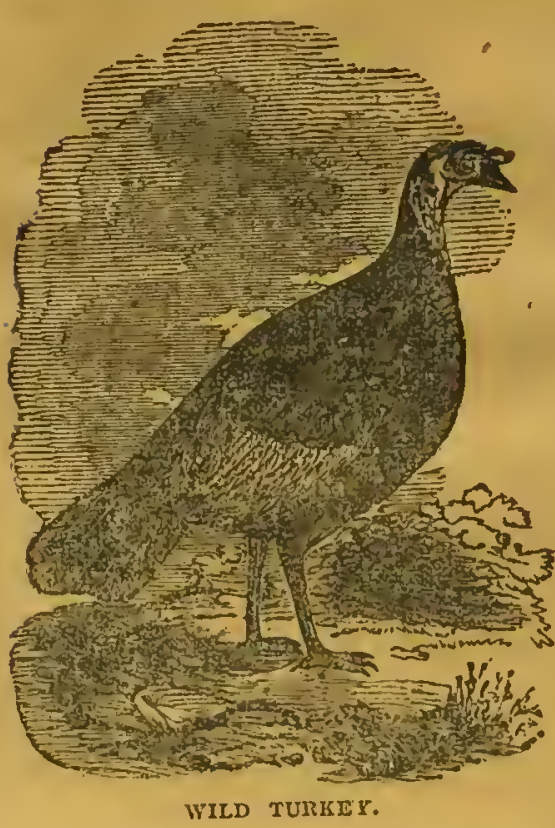

The eggs require from thirty to thirty-two days to hatch, and for the first four weeks tho young chicks should be carefully watched. They will neither stand the hot sun, heavy rains, nor much dew, and they must be liept warm. Hard boiled eggs rubbed up with oatmeal or cornmeal is a good food for the first two weeks. After which, light wheat and cracked corn may form the staple. About the time they aequire the red head, which is at about six weeks of age, which next to the third day is the most critical period of their life, they should have nutritious food, and, if a little bruised hemp seed is added, so much the better. In feeding give but a little at a time and often, and that out of the reach of the hen or other

forrls. Young onion tops, chopped very fine and well mixed with the food is excellent. Curds of sour milk are eagerly eaten, but should not be given as a constant food. Pure cold water must always be at hand as a drink, but occasionally, say once a day, skim milk may be given. Where cornmeal is the basis of the food, it should always be cooked into a hard mush before being fed.

\section{Varieties of the Domostic Turkey.}

These are the bronze, the English (so-called) turkey, the white, the buff, and the erested turkey. The latter is extremely rare, having been eupposed to have originated in Europe, in the early part of the last eeutury, then entirely lost, and again said to have bcen recovered, curiously enough, from Africa.

Temminck, in a wcrk relating to pigeons and fowls, printed in Amsterdam in 1813, mentions them as follows: The erested turkey is only a variety or sport of nature in this speeies, differing only in the possession of a feathered erest, which is sometimes white, sometimes black. These crested turkeys are very rare. Mademoiselle Backer, in her magnificent menagerie near the Hague, had a breed of erested turkeys of a beautiful Isabelle yellow, inelining to ehestnut; all had full crests of pure white. 
Lieutenant Byam described crested wild turkeys as having been seen by him in Mexico, but it is supposed he must have mistaken eurassows for wild turkeys, since no others have been able to find them, and the curassow is thoroughly domestieated there. The white and buff turkeys are simply varieties in eolor from the common forms, which have in some instances been porpetuated by careful breeding and selection. So also there aro copper-colored, faimu-colored, party-colored, and also gray tarkeys. These ean hardly be considered worthy of breeding except in an amateur way for amusement.

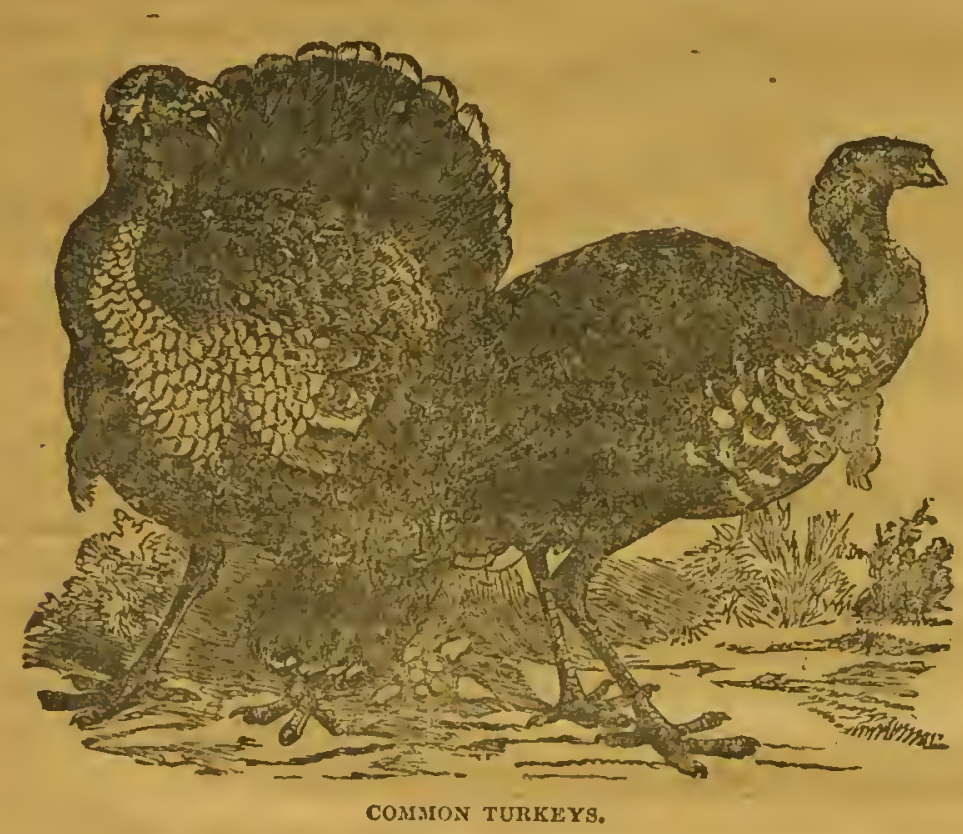

I. The Common Turkey.

These are pure white and blaek mixed, with the peculiar wattle and head of the wild turkey. They are of medium size, less given to wandering than some of the breeds, and will weigh dressed, if fat, at seven or eight months old, from ten to twelve pounds, sad at full maturity nixteen pounds.

\section{English Turkey.}

This is simply a modifieation of our common turkey, which by careful breeding has been made uniform and of an increased size. Of these the Norfolk turkey is black, with a few white spots on the wings. The breed most valued in Cambridgeshire is a bronze-gray, and longer legged that the Norfolk variety. 
III. The Honduras Turkey.

The Honduras or Ocellated turkey is onc of the most elegant of tribe, and is found all ovcr Central America. It breeds frcely with our domestic variety and the progeny is quite fertile. The ground color of tbo plumage is a beutiful bronzed-green, banded with gold-bronze and chiny black, and lower down the back with decp blue and red. Upon

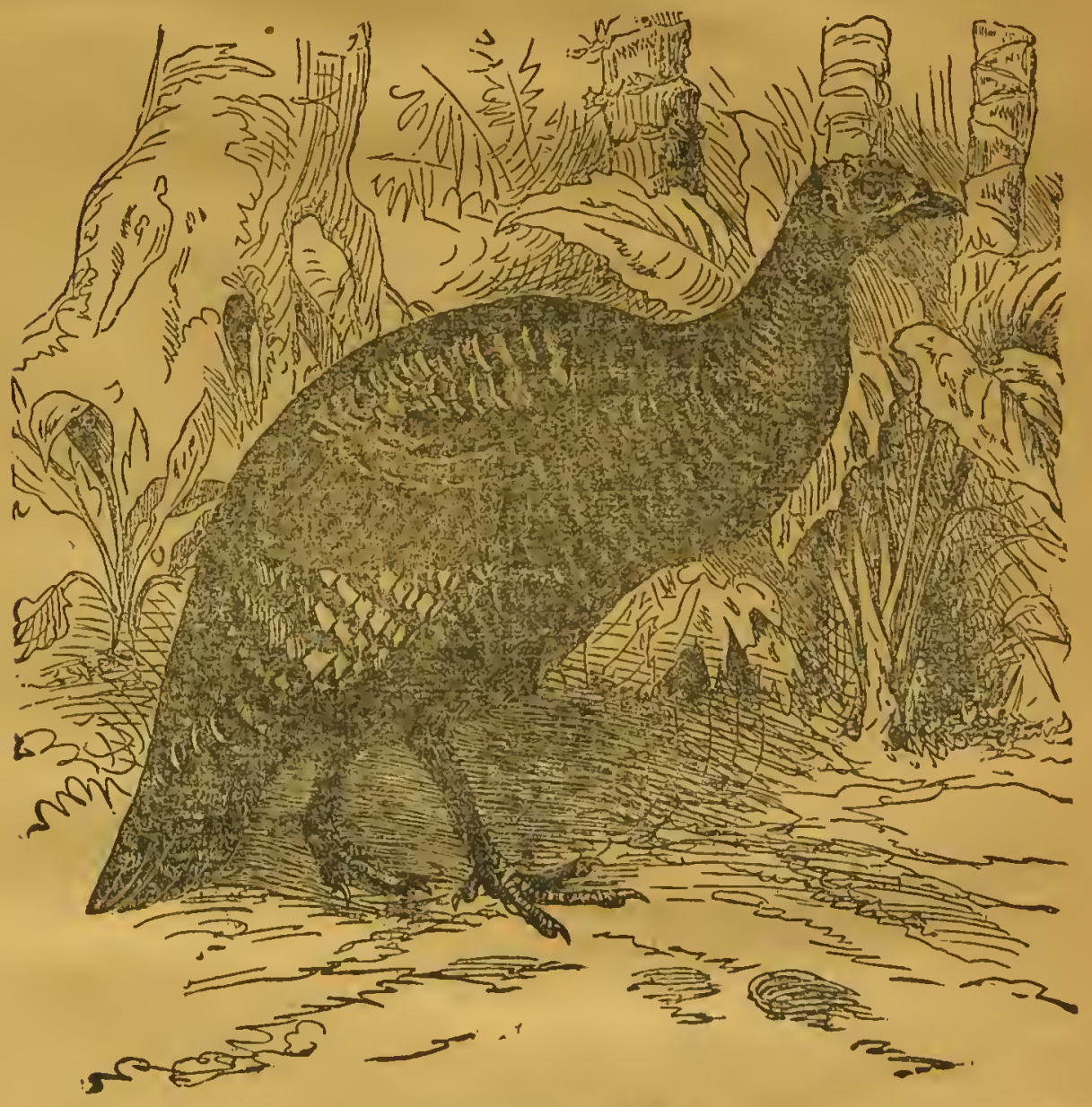

OCXLATED TURKEY HEN.

the tail these bands aro so wcll defined and sharp, that they become ocellated or eyed, and hence the namc. Unfortunately their southern origin makes them too tender for the North, but in the South there ahould bie little difficulty in ireeding them. The Mexican turkcy differs 
bat little from the foregoing. Thero is more white in the tail feathers and tail coverts, and like the Honduras turkey, it bleeds freely with our wild or domestic turkey.

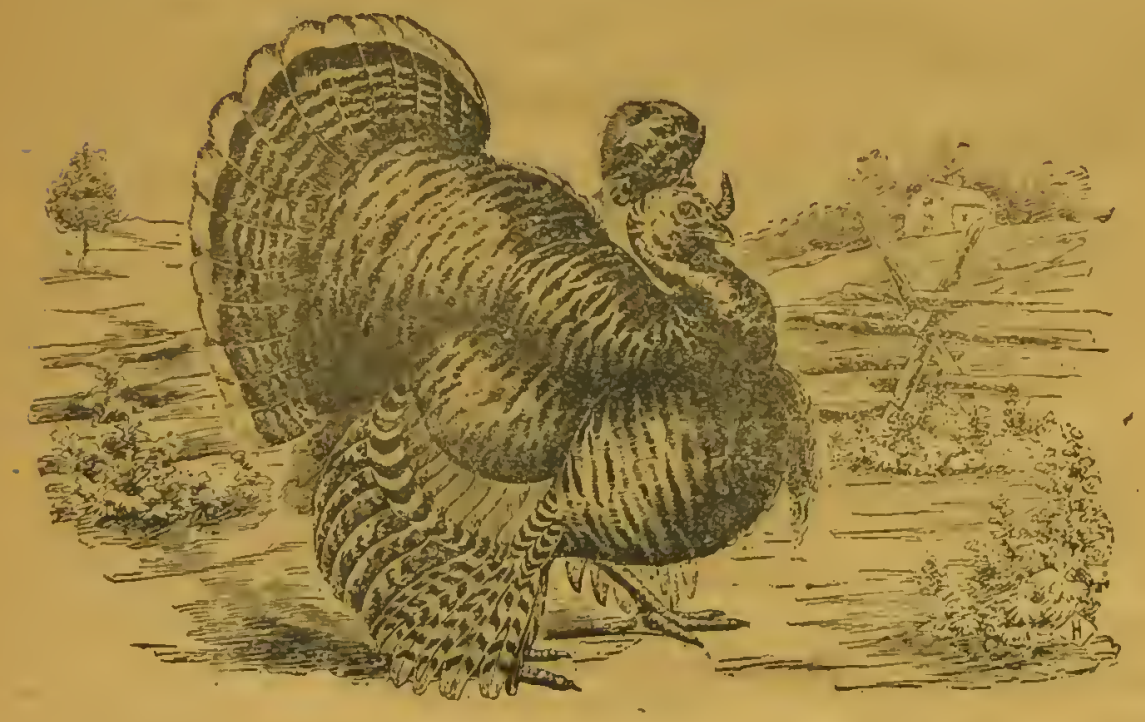

CRESTED TURKEx.

IV. Bronzed-black Turkey.

This is the largest as it is the best of the domestic turkeys, and was. undoubtedly produeed by a eross of the wild male upon our common turkey, impressed and fixed by careful breeding and selection, until they will weigh with the best speeimens of the wild breed, sometimes attaining a weight of over forty pounds each. The general average, however, is about thirty pounds for mature, well fattened birds, while hens will go 
from twenty to twenty-five pounds cach. It is the largest as it is tho most magnificent in plumagc of the domesticated rarieties, and as hardy as it is beautiful.

In the cock the face, ear-lobes, wattles and jaws are dccp rich red, the wattles warted and sometimes edged white, the bill curved, strong, of a light horn color at the tip and dark at the base. The neck, breast and back black, shaded with bronzc, which in the sunlight glistcns golden, each feather cnding in a narrow glossy black band extcnding clear across. The under part of the hody is similarly marked, but more subdued. The wing-bow is black, showing a brilliant grecnish or brown lustre, tho flight-feathers black, barred across with white or gray, even and regular; the wing-coverts rich bronze, the end of each feathcr terminating in a wide black band, giving the wings when folded a broad bronze band across each; tail black, each feather irregularly penciled with a narrow brown band, and ending in a grayish-bronze band. Fluff abundant and soft ; legs long, strong, dark or nearly black, The hen is similarly colored, but more subducd.

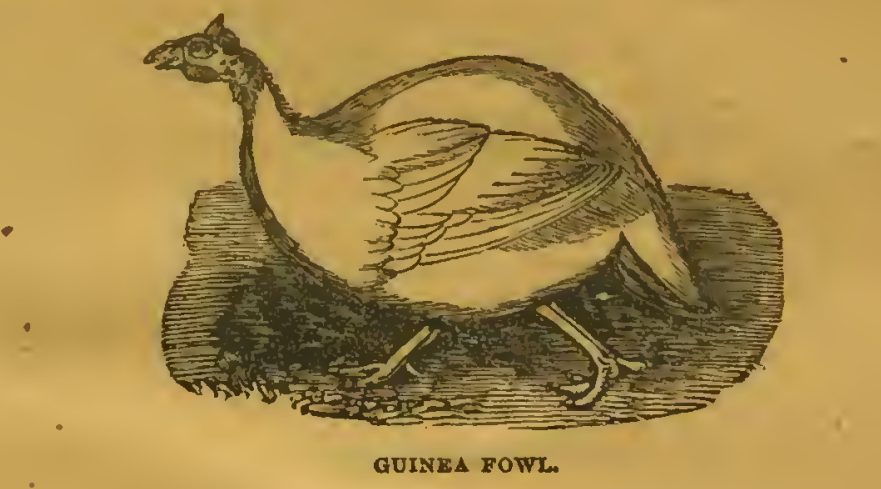

\section{v. Guines Fowl.}

The Guinea fowl is quite widely disseminated, being found in its domesticated or rather half-domesticated state all over Europe and America; yet ean hardly be called common. The reason is thcy aro ohy and ratber inelined to pair as in the case of other wild birds. In domestication one male may be allowed to about six females. They are grouped by some naturalists into a considerable number of varicties, but Bince the so-called spccies are all quite fcrtile together, the distinction is probably merely fanciful. They are found wild in the Cape Verd Islands and in Jamaica, having undoubtedly been carricd thence.

The hen will lay about sixty or seventy cggs in a year, though they cometimes reach one hundred. The Pearl guinea fowl is the variety 
most usually met with in domestication, the spots heing small and whito on a purplish-gray ground. Rarely these eolors are found reversed. So blue and dun colored birds with but ferw and even no spots are sometimes seen. There is also a pure white varjety, excecdingly rare. The sexcs are difficult to distinguish, the eolors being so nearly alike. The cock has more wattle, is often more mincing in his gait, as though walking on his tocs, and more pugnacious. In faet, their quarrelsome nature and Phabit of straying has perhaps as much as anything else, prevented their becoming more common.

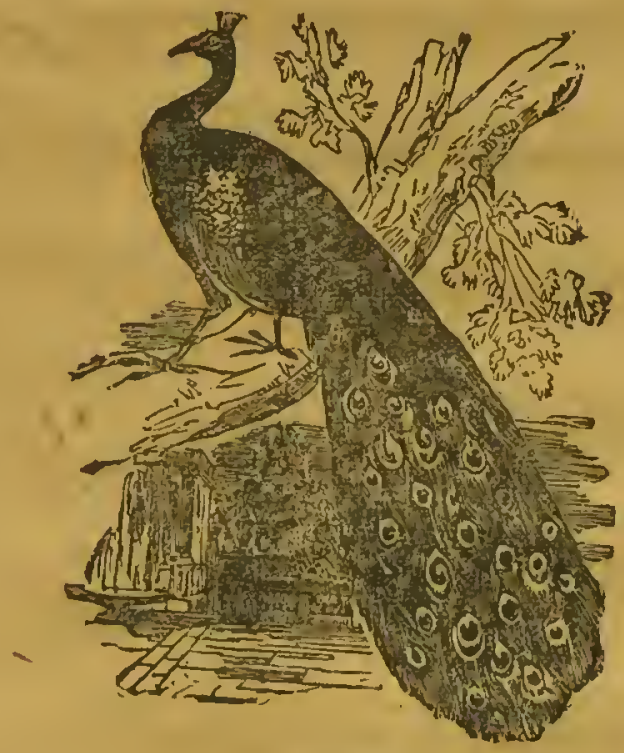

PEACOCK.

vI. The Peacock.

This magnificent bird, as useless as it is beautiful for its tail feathers, and a rarity in the barn-yard, is as hardy as a turkey at maturity, and the young arc not difficult to rear. The hen is very secret in stealing her nest in some out-of-the-way place where the male bird may not find it, since, if so, he is pretty sure to destroy the eggs. They do not commence laying until pretty late in the scason, and keep their brood out of view until cold weather drives them home for food. The male is much given to wandering, often roaming for miles about the country, his strong pinions and immense tail enabling him to fly long distances. 


\section{Water Fowl.}

\section{CIAPTER VI.}

DUCKS.

2. TOTEN PUCRS. - N. AYTESBTRY DUCKS

III. CALT DTCKs.

Tr. CATOGA

BLACK DUCKJ.- V. GLAY DUCKS.

VI. BLACK EAST INDIA DUCKS.

SUMMART

Ducks and geese are becoming more and more fancied from year to Jear on the farm, as they should properly be. The reason why they have not been more extensively mised than they bave, is from the erroneous opinion that a pond or lake is essential to them. They should have a pool of water to wash in; this pronuced, it is all that is necessary so far as water is concerned; in fact, without water they are morodomesticated and less inclined to lamble. All the principal fain breeds of ducks arc probably descended from the Anas boscleces, or wild Mallard. Like the wild goose, it is not difficult to domesticate wild ducks. All that is neeessary is to get the cgggs and rear them under a hen, the eggs hatching in twenty-eight days. There is no farm bird that is a more - inveterato insect hunter or more agile than a young duck, one specimen taking fully doublo per day what chickens will. Hence their value to the farmer, and especially the gardener, is very considerable 'in addition to their egg and flosh producirg qualitios. They should be raised more extensively than they are, aud on cvery farm.

\section{IRouen Ducks.}

Whatever may have been the origin of the name, Rouen, from a town fn France, celchrated for its duclis, n' renn. from its color, this varicty os suply a wild Mallard, improved and enlurged by selection and care in 
breeding. The markings as found in the wild variety will very perfectly describo the tame. Good specinens will dress six pounds each, and over ocrasionally specimens will weigh nearly eleven pounds, alive. Thei:

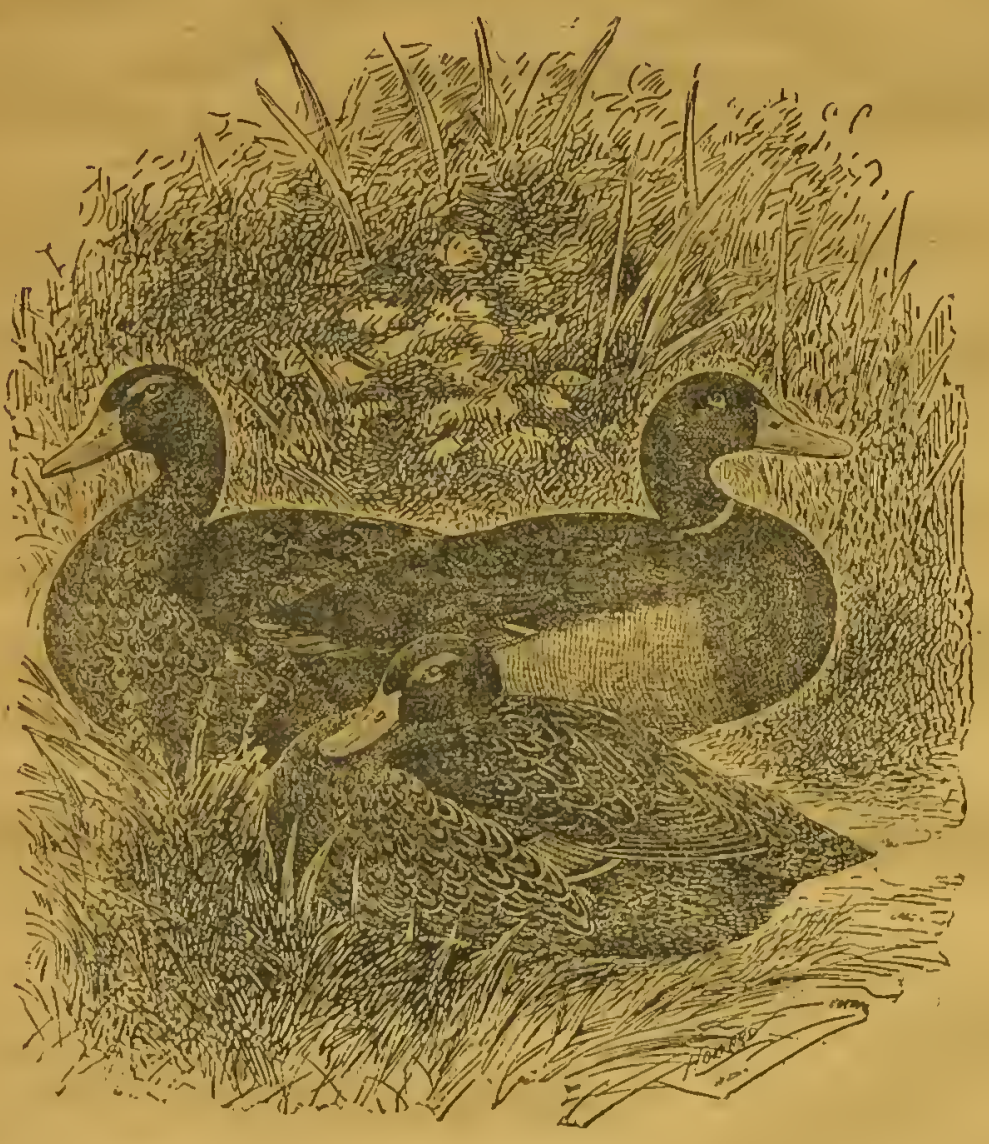

Trio Roules Ducrs.

Aesh is abundant and of the very best flavor. They searceiy wander a all. In fact, they are so lazy and disinclined to exercise, that if abund 
antly fed they soon become so fat that their abdomens truil on the ground. From their inactivity they are the most easily stolen of any variety. The eggs are laid in great numbers, of a blue-green color, with thick shells, and should average in weight about thrce and a half ounces.

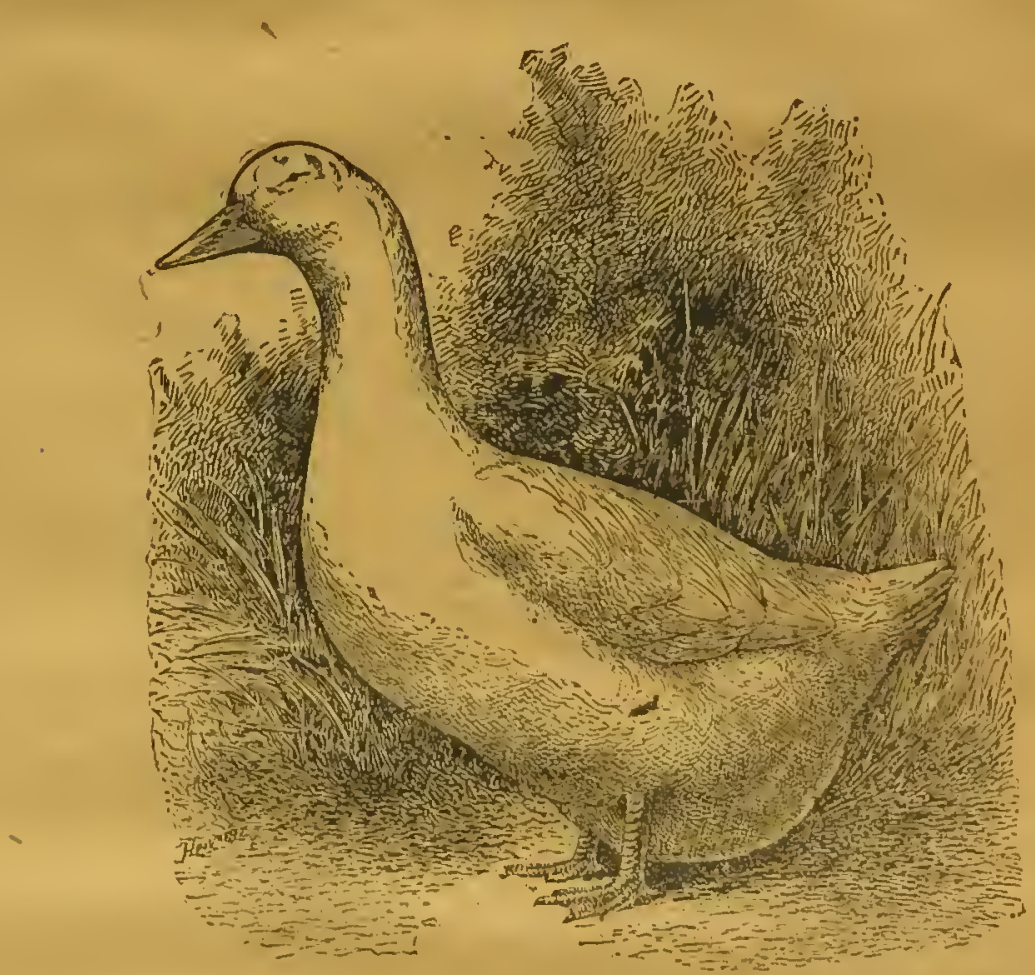

THE PEIKIN DUCK.

The most practical and profitable dnck for market purposes.

II. Aylesbury Ducks.

The Aylesbury duck is without doubt the most valuable of the English breeds, and fully as well appreciated in this country as in England. They hardly reach so great weight as the last mentioned variety, eightoen 
pounds the pair being about the outside figure. They are prolific layers, the eggrs of a pure white color, thimer in the shell than those of the Rouen. The ducks are excellent mothers because less unwieldy than the Rouens.

In buying ducks for breeding purposes, and especially the Aylesbury avoid those that are down behind, from undue stretehing of the abdominal muscles; such birds are always stcrile, both as to the ducks and drakes.

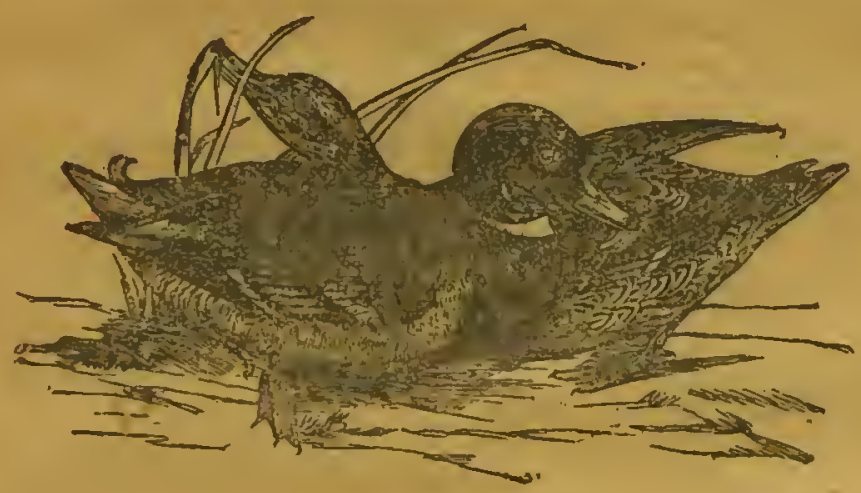

GRAY CALL DUCKg,

III. Csll Ducks.

There are two varieties of small ducks that have the same relation to the large varicty, as Bantams have to Barn-yard fowls. One is the Gray Call, the other the White Call duck. The first is an exact counterpart of the Rouen in every respect, even to the legs, feet and bill; the other being in color like the Aylesbury, but diffcring in the bill, which is a clear yellow, while the Aylesbury is fleshcolored. As fanciful things on a piece of water, they are very pretty, as to either varicty. The colored variety

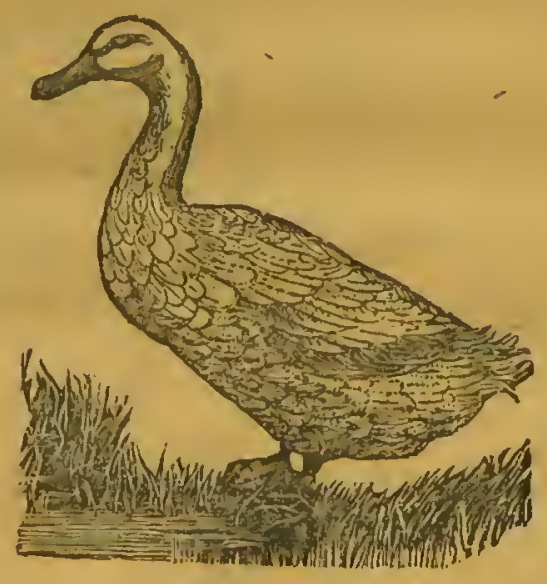

WHITE DUCK. is much used as decoy ducks for the wild species, being remarkable for thcir loud, shrill and continuous quacking note. Hence thcir name, as they call the game from grcat distances and lure them within the range of the eportsman's rifle. 
IV. Cayuga Black Ducks.

These are the finest of the American breeds, as they are the largest, most valuable and handsomest of the duck tribe. The plumage is a rich metallic black, with lustrous reflections on the head, neck and wirgss. The bill is blue-black, with a jet black splash in the middle of it

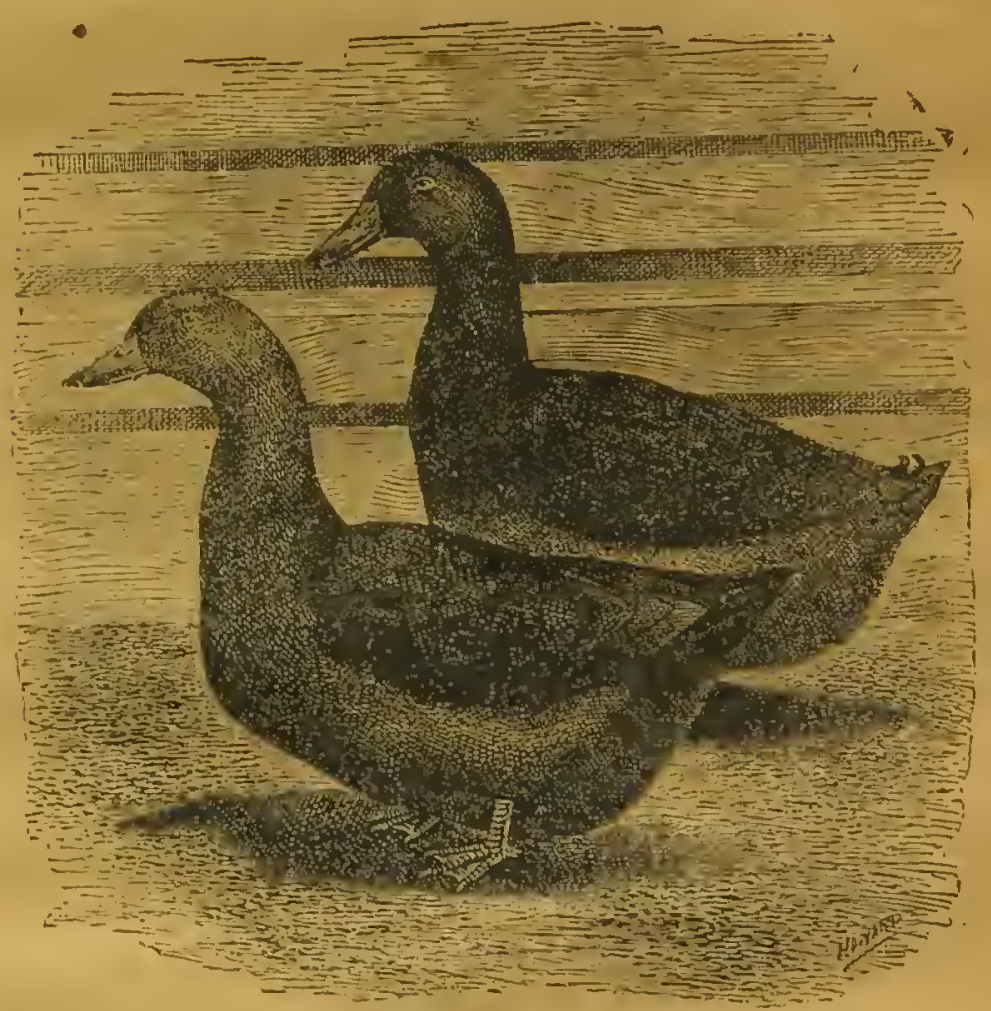

Pair Bu.lck Ciyuna Ducko.

They have long, straight necks, long, straight head and beak, and in eize they are fully equal to the Roucn, often weighing ten pounds each. The flesh is gamy in flavor, and to our taste fully equal to any of the wild species, except the Canvas-back, Widgeon and Teal. They are prolific in eggs, are quict, mature at an early age, and excepting possibly the Bouen, are the most valuable of all domesticated ducks. 
V. Fancy Ducks.

Among the most ornamental of the duck tribes are the Mandarin and the Carolina ducks, both unsurpassed for brillinnce of plumage and variety of coloring. The Mandarins are a Chinesc variety, and tho Caroliuas the wild wood duck of the United States, domesticated aud improved by carcful brecding.

The Muscovy duck is a large breed, and thought to be valuable on thi account by some. They are only mentioned here on this account, since their strong flavor of musk should kccp them from the tables of all who appreciate fine flavor.

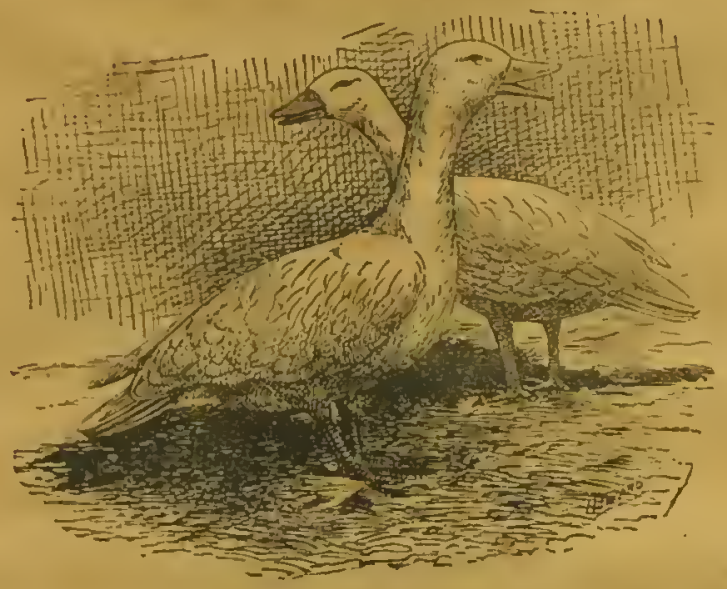

Paik White Call Ducks.

VI. Black East India Duck.

The Black East India duck which has appeared from time to time under various foreign names, as Labrador, Buenos Ayrean, and later as Black Brazilians, have little if anything to rccommend them in comparison with better and larger breeds. They are undoubtedly a sport of the Mallard, and certainly are among the most beautiful of the small breeds, and ars so hardy, and give so little trouble that it accounts probably for thoir many admirers.

\section{Bummary.}

Ducks are valuable both for their feathers and flesh, for their aptitude in foraging for themselvcs, and especially for the great insect eating propensities of the young, they should be raised on every farm. Wild ducto 
are so numerous in the West that this is probably a reason why they wro not more extensively bred there. - But wild ducks are in the market for caly a comparatively sbort time in the Spring and Fall, and at all other

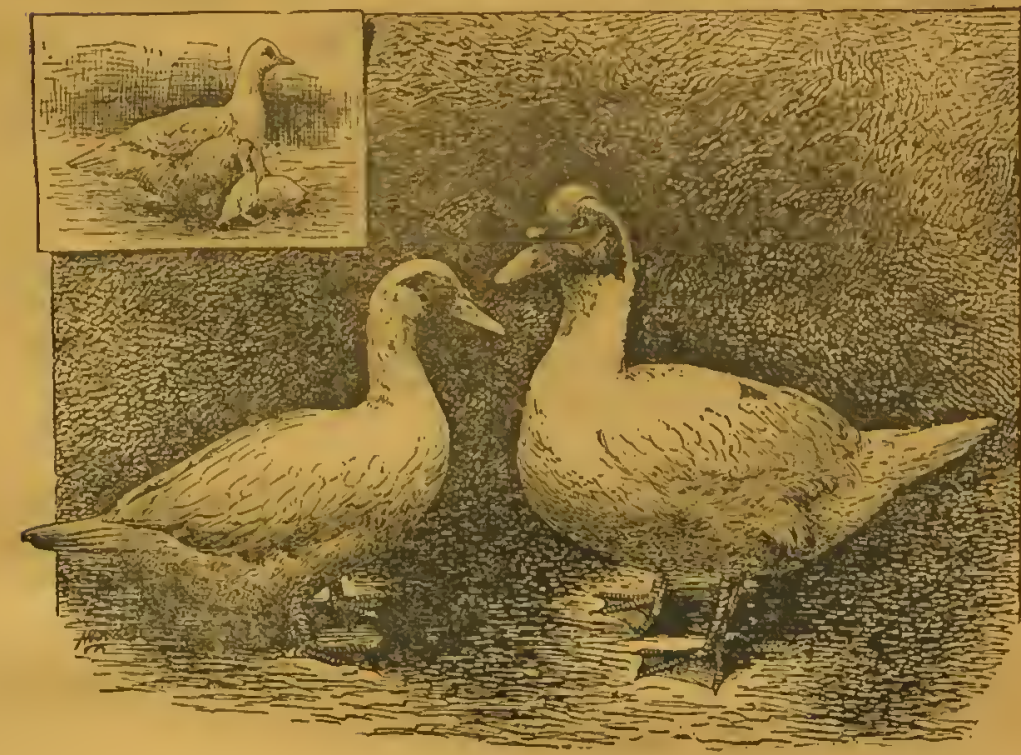

Pata Muscovy DưcKs.

cool seasons ducks may be sold, and are not to be despised on the tables of the farmers.

When flesh is the principal object, and handsome ornamental qualities desired, the Rouen and especially tho Black Cayuga will give satisfaction. If white feathers are desired the Aylesbury will be the best variety. As 
to the rearing it is extremely simple, they are little liable to diseast, and woll able to take care of themselves; they must, however, have plenty of water to drink, and a pool to wash and swim in. These being furnisioo. if hatched under hens, they will give little trouble and fully repay tho labor bestowed on them. Their period of incubation is thirty days.

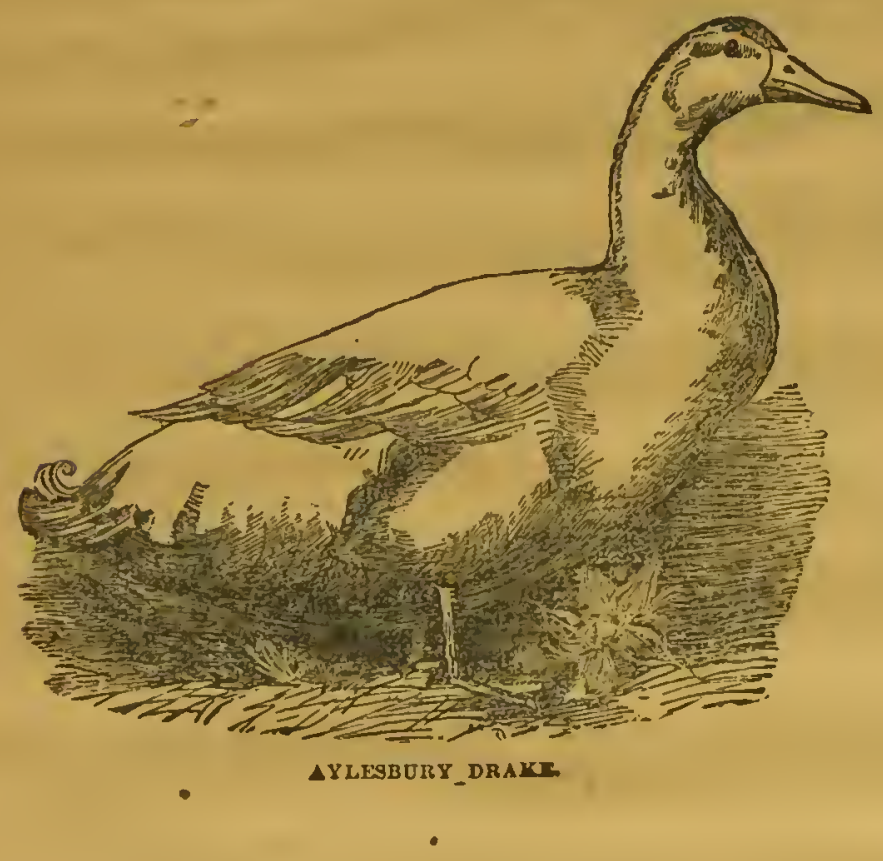




\section{Water Fow}

\section{CHAPTER VI.}

GEESE.

- TMDEN OR BREMEN GEESE.

II. TOULousE GEESX III. HONG RONO GREรE. -

IV. WHITE CHINESE GEESE. Y. THE AFIRICAN GEESE. VI. CANADA WILD GEESE. - MANAGEKENT OF GEESR.

Geese, like the guinea fowl are noisy ereatures, and these two birds aro nine times out of ten better "wateh dogs" than the average eur. The former on the ground, and the latter perched high in a tree, see the smallest obieet and hear the slightest sound, and giving the alarm tho noble watch dog wakes up, barks and gets the eredit. There are only a. fow varieties which we shall notice, but these constitute about all that aro valuable of those for. is that "saved Rome."

\section{Embden, or Bremen Geese.}

These, the most valuable to our mind of the whole tribe, taken for large size, pure white feathers, and aptitude to fatten, are worthy a place on any farm. They are spotless white in eolor throughout both male and female, full, and ereet in carriage, the legs deep orange in color and the bill dark flesh eolor, the eyes bright blue. The eggs are white, large, and with rough thiek shells. This breed attains enormous weights, often goIng over thirty pounds, when mature, and the goose ove. thirty-tive pounds. For breeding purposes twenty pounds will be a tull weight for the ganders. 


\section{Toulouse Geese.}

' Next in order of practical merit, to our mind, is the Toulouse; theso are called after the city of that name in France. They are most compact in body, not so tall as the Bremen, but will often outweigh them. Io

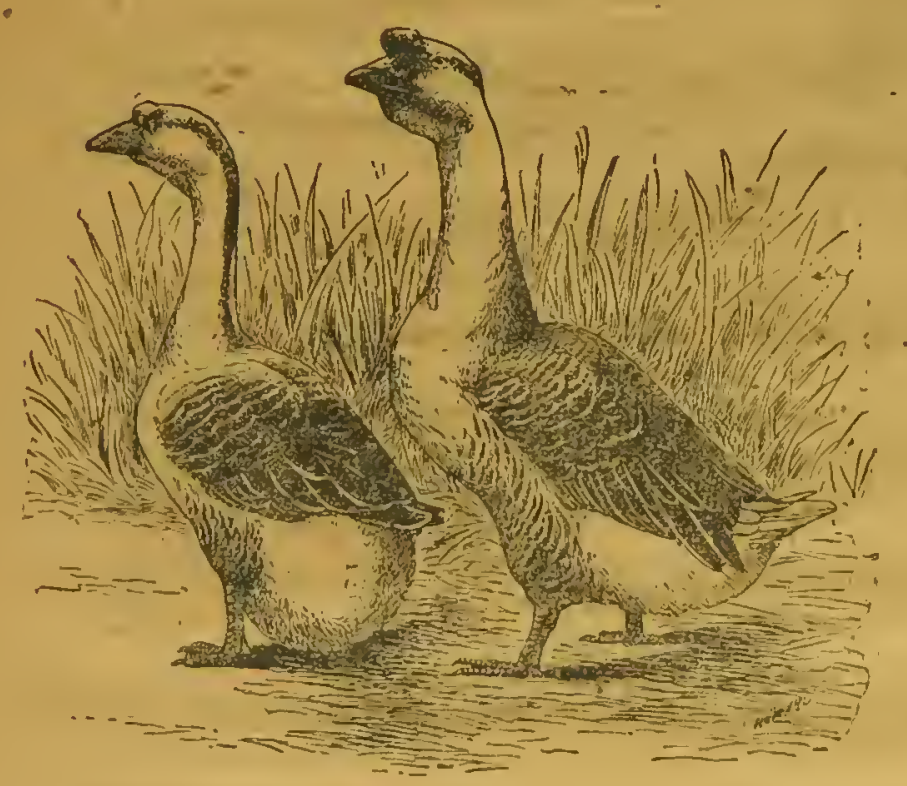

PAIR GRAy AFrican Gerse.

color thcy are light gray as to their bodies and breasts, the neck dark gray, getting gradually dirker until it approaches the back, the wings are of the color of the neck, shaded off lighter as it approaches the belly and at length becoming white; the legs and feet are a deep reddish orango, 
the bill the same, toncd somewhat with brown. Both the Embden and Toulouse may ke casily raised under hens, by regularly sprinkling the

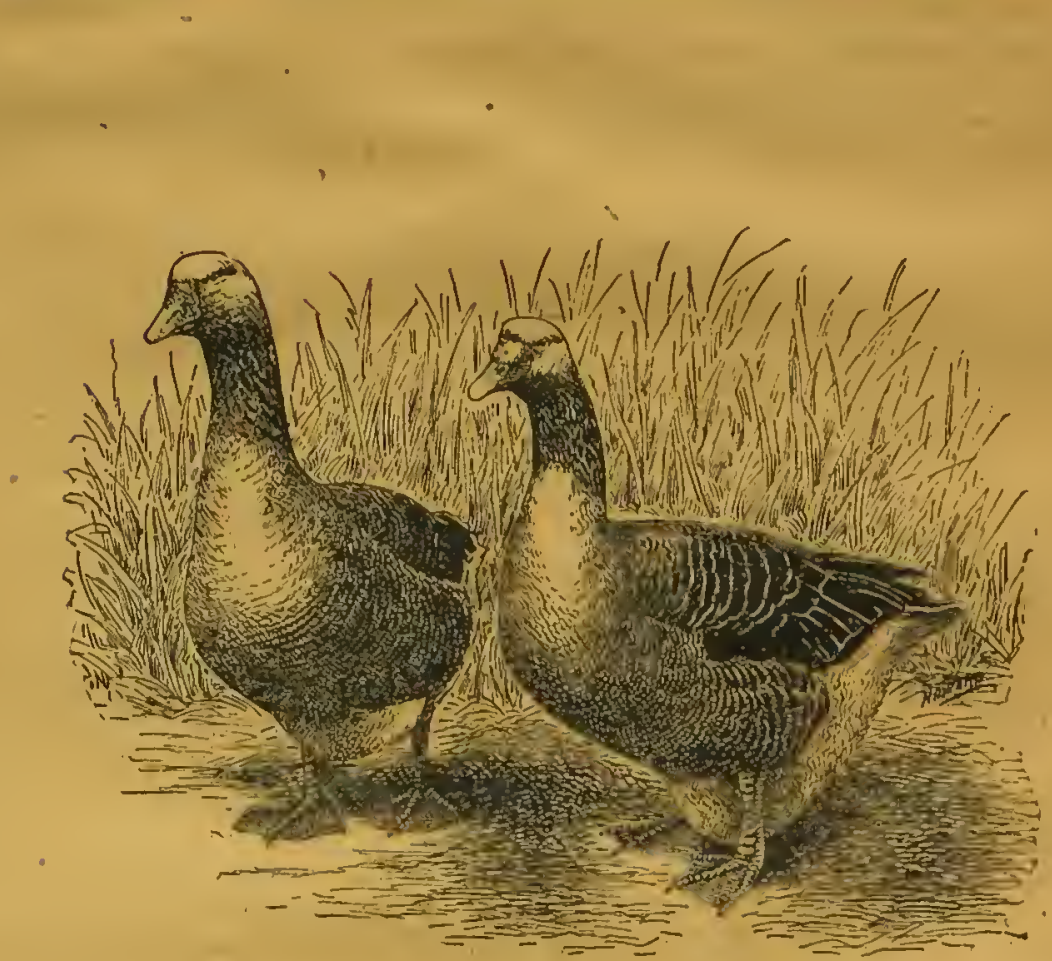

Pair Toutorst Gerge.

eggs with blood-warm watcr, to keep the shells from becoming hard and thus imprisoning the young. This, with even a lub of water set in tho ground, and good fecding, will insure suecess in gecse raising.

\section{Hong Kong Goese.}

The China Hong Kong, or Tinosbed goose, so named from the protaberances at the base of the bill, really possesses some of the characteristics of the swan as it docs of geese. It is also in size, betwcen a medium sized guose anc swan, is highly ornamental in the water, hardy, the most prolific of any in eggs, and the quality of the flesh is superior. It has a barsh, discordant cry, and if allowed full liberty will stcal away at night, if water for swimming in be near, or it can find it. This nocturnal habit, bowever, can be prevented by shutting up at night in a place safe frove 
fores or owls, which should be practiced with all geese and ducks. Hong Kong geese vary much in color; they all have the same characteristic protuberances at the bill, and also a distinct stripe down the back of the neck. They should have a dewlap, or feathered wattle under the throat, the bills and legs should be of an orange color, and the protuberances at

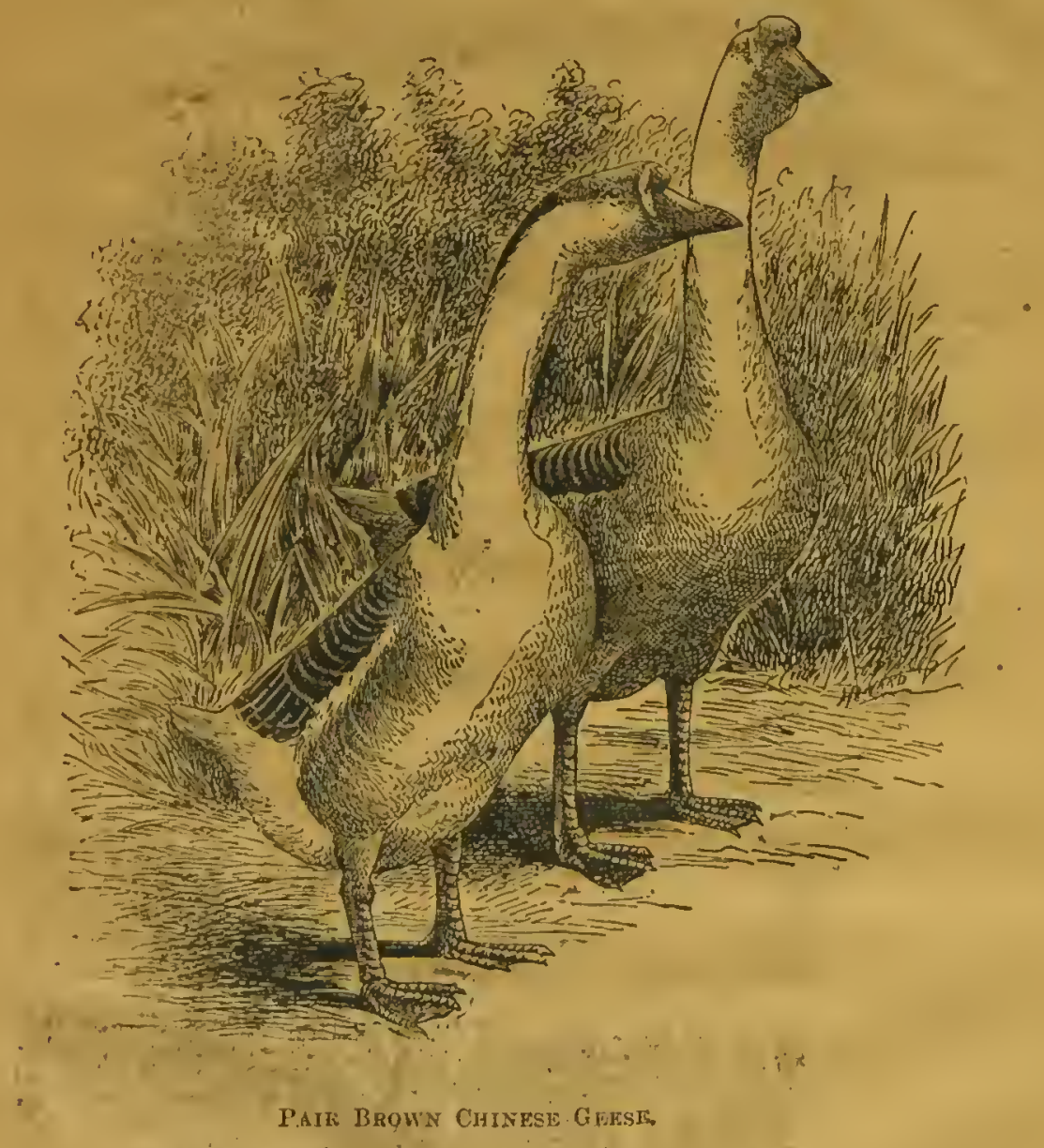

the nase of the upper bill, dark, in fact almost black, the most usual colcr is grayish brown on the back and upper parts, changing to white ar whitish gray under the abdomen, the neck and breast ycllowish gray, with a distinguishing stripe of dark brown running down the entire back of the nock, from the head to the body. 


\section{White Chincso Geese.}

The $W$ hite Chinese geese are of immense size, pure spotless whito throughout; the legs bright orange colored, bill the same color and with a iarge orange colored knob at its base. It is more swau-like than the

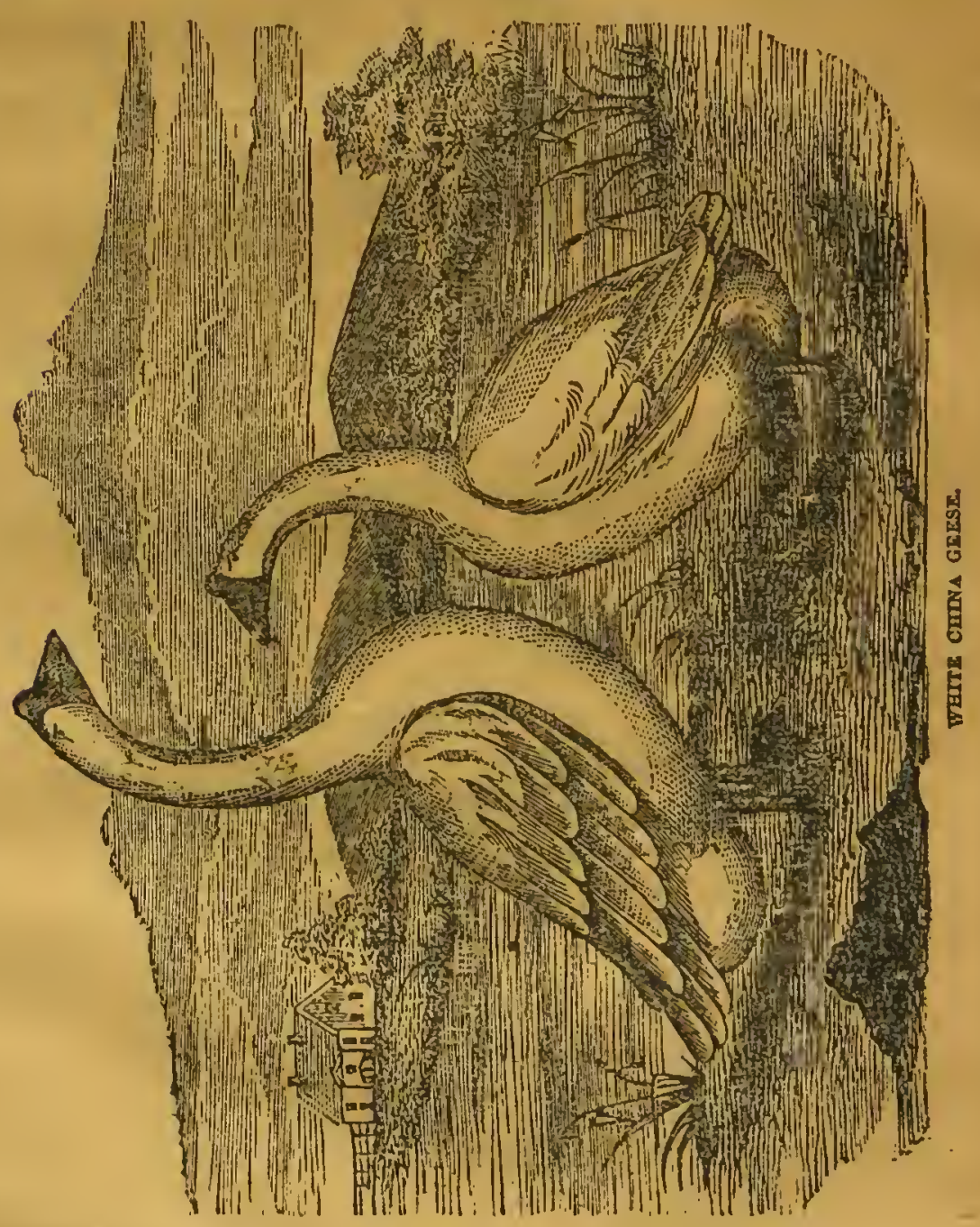

Hong Kong, of which it is perhaps a variety, and either in or out of tho water is a most pleasing object. When swimming, its long, slend-r neck is gracefully arched, ard whether for ornament or use, it is certainly a valuable breed. It is certainly as prolific as its colored relation, laying a larga number of rather swall eggs in a scason, biceding threo or four times, 
the period of incubation being five weeks. The goslings are easily raised, and are of fine eating quality. A peculiarity of the lureed is the disparity in the relative size of the sexes, the males being often one-third hesvier than the females.

\section{Tho African Goose.}

This immense goose, among the largest of the tribc, is of fine earriage and bulk, carrying its neck upright, and head high, when walking. The head and top of the neek aro brown, deep on the upper side and somewhat lighter on the under side; the bill is armed with small indentations

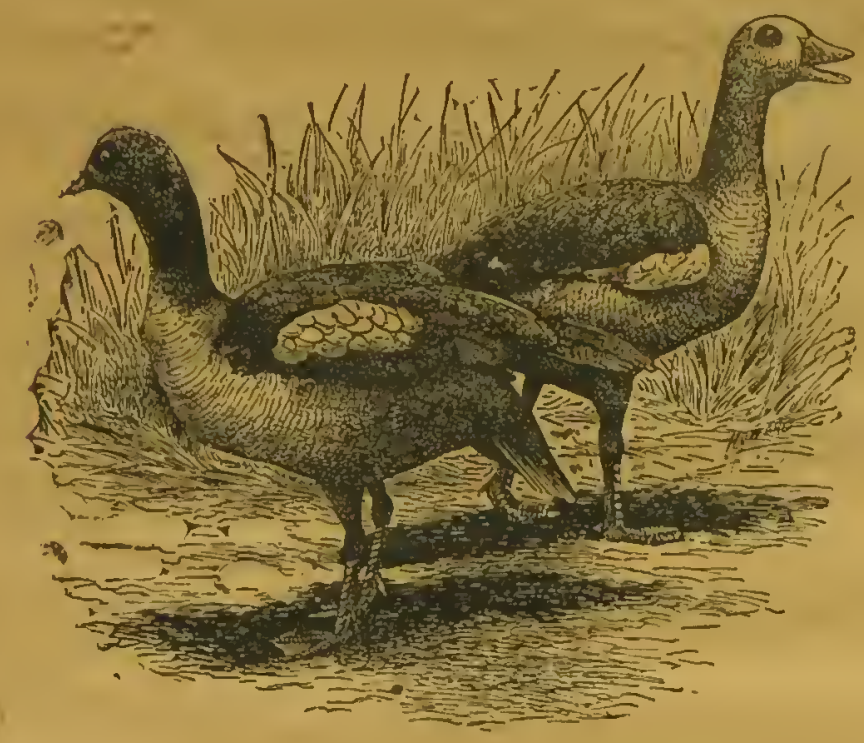

PAIR ERYPTIAN GEESE--PUIELY UKAAMUSTAL.

along the sides, and at the tiase, on top rises a lound, fleshy tubercle, of - bright vermilion color, and under the throat is a hard, firm, fleshy membrane. These birds have also been called Siberian geese, but the name African is undoubtedly the proper one.

\section{Cenada Wild Goese.}

This excellent goose may be easily hatched from wild egge, and which apon being domesticated, take kindly to the farm. It is too well known 
to need deseription; when farm-bred it retains much of the game naturo of the flesh of the wild bird. Their sagneity is superior to that of any other goose. It has a wide runge of flight in its wild state, being found at proper seasons from the Aretic eirele to the Torrid zone, and in Europo as well as in Ameriea; specimens haviug been shot in England. It is certainly one of the most beautiful of water fowls. It breeds kindly with any of the common varieties, and is reputed in Irance to have interbred with swans.

\section{茫anagement.}

There is but little care neeessary in breeding geese. They require a dry place for passing the night; are subject to but few diseases, and these only when young. For diarrhca, give a drop or two of laudanum in a sittle water, to be repeated if the first dose does not eure. For giddiness, bleed them in the prominent vein which separates the elaw. In. bects cometimes annoy them by getting into the nostrils and ears. It may be known by their hanging wings, and the shaking of their heads. Feed them eorn.at the bottom of a vessel of water. For fattening, there is nothing better than eorn-meal, steaned potatoes and skimmed milk, alternated with ground buckwheat, oat-neal or barley-meal. During tho fattening process they should be kept elosely confined. When fattening, the Freneh pluek the feathers from the belly. They should be fed threo times a day, and supplied with plenty of pure water, and when fat, whieh should be in two or three weeks from the eommeneement of feeding, they ahould be scld immediately, since they at once begin to lose tlesb agrin. 


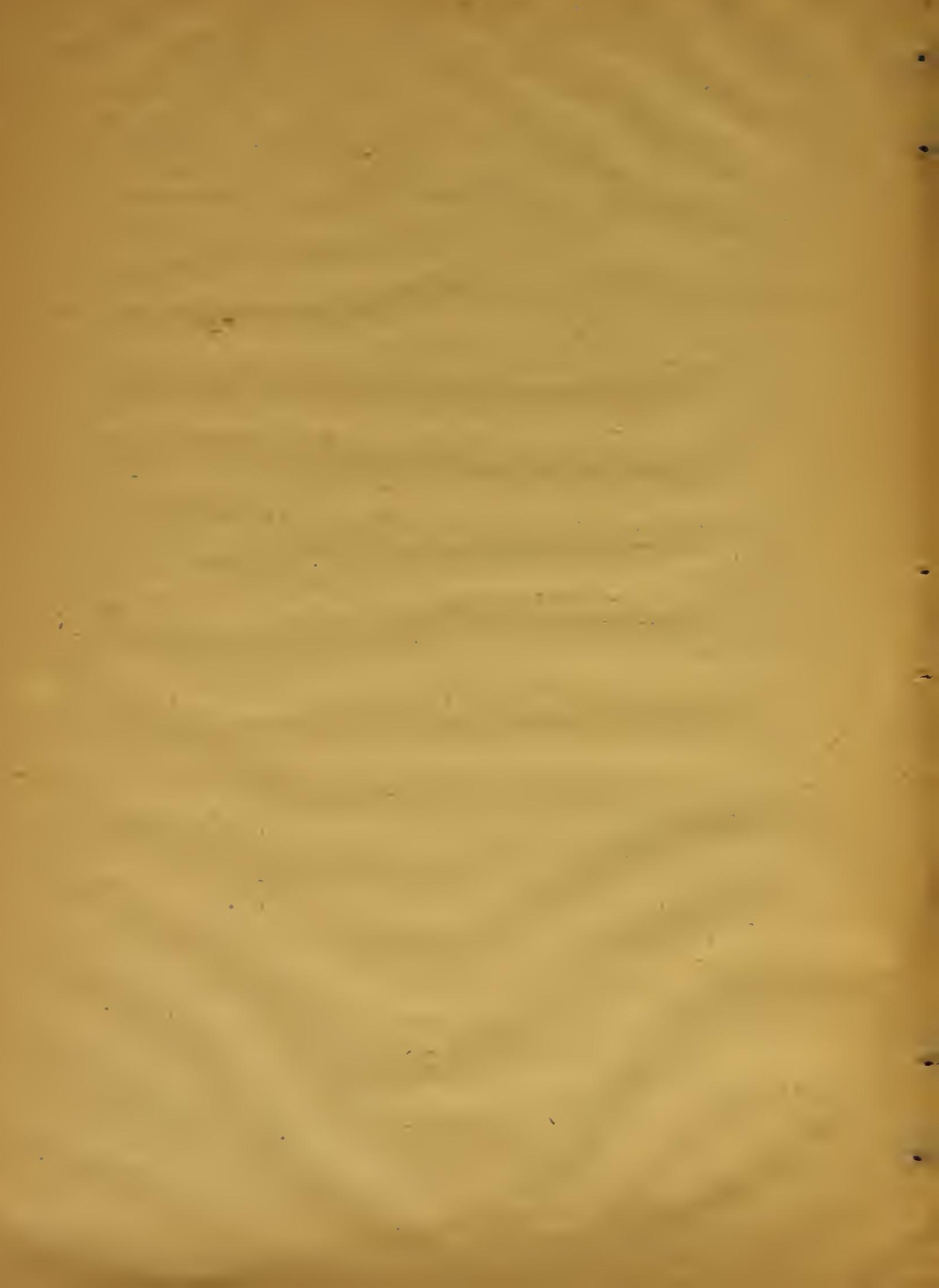




\section{Diseases of Poultry,}

AND THEIR $\{$ REMEDIES. 


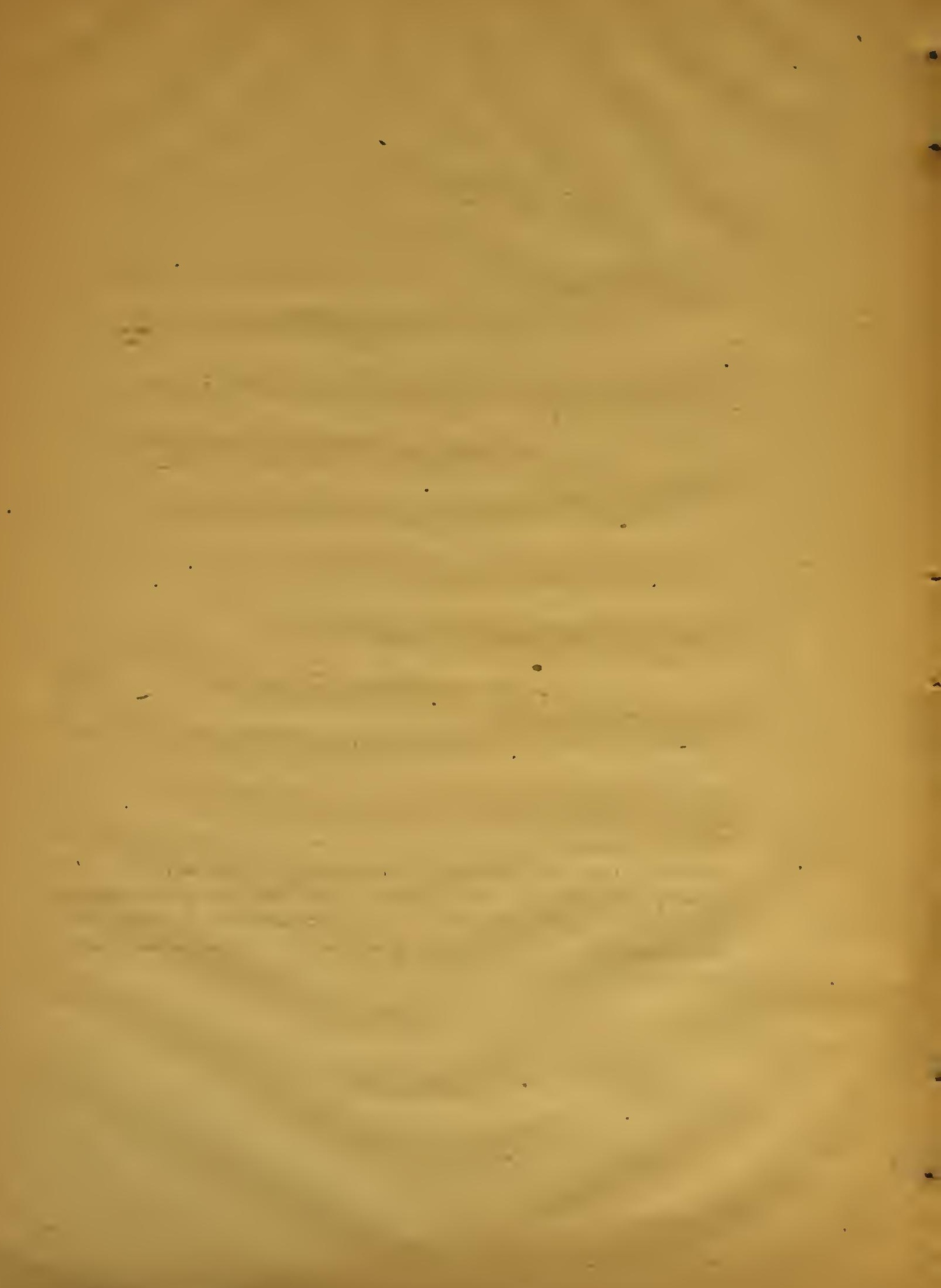




\section{CHAPTER I.}

\section{DISEASES ATD REMEDIES}

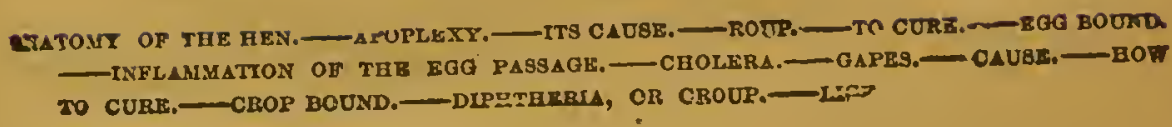

Diseases of Fowlis.

There are but few diseases to which fowls are subject. Some of these, as apoplexy, are so sudden and fatal that there is searcely time for lemedics. Others, as so called chicken cholera, are maligrant and infectious, and thus require watching. Others agair, inflammatory in their nature, are difficult to understand and hence difficult to treat. The general run of diseases, hnwever, to which the fowls of the farmer and suburban fancier are liable to in his flock are, as a rule, simple in their nature and - of easy treatment. We shall, therefore, divide diseases into but two divisions-dangerous and simple ailments. In the first elass will be considered thoso more fatal, and in the second class mere ailnents, as leg weakness, bumble foot, eatarrh, diarrhea, pip, lice, and other parasites. For a better understanding of the subjects, we introduce figures showing the skeleton of a fowl, their true positions and proper nanes. It will make a good study in counectiou with those cu plumage, etc. 


\section{Anatomy of the Hen}

Explanation. $-A-T$ The head, length $23-4$ inches. $B-$ The neck, length $51-2$ Inches. $C-$ The back or spine. $D$-The hips or hip bones, (the back and hips

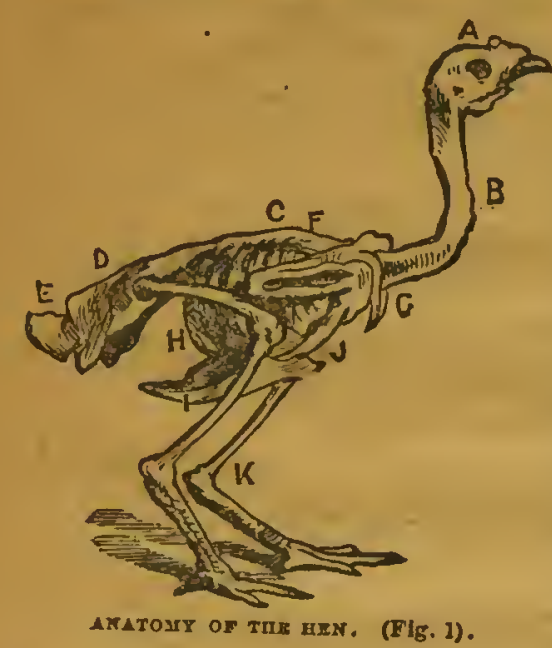
comprise from the shoulder to the tail, ) length 5910 inclies. $E-$ Rump or coceygis, length 1 1-2 inches. F-Shoul. der-blade or shoulder. G-Collar bone or merry thought. $\quad B$-Cuest or thcras, composed of the sides and breast bone (bone of the throat), it contains the heart, liver, etc. $I-$ The breast bone, iength a little over $31-2$ inehes. J-The wing bones, as will be seen, are composed of the humerus or shoulder-bone of the wing, length 3 1-7 inches; also the radius and the cubitus, the forearm or pinion, length 28.4 inches; the tip of the wing, or that which takes the place of the hand and fingers, length 2 1-3 inches. $K$ The leg, composed of $d-$ (Fig. 2.) the

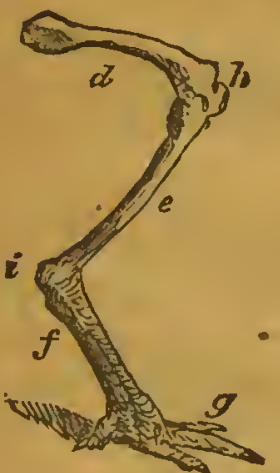
thigh bone, 3 1-7, inches; $e$ - the shin bone, length $41-3$, inches; $f$-the bone of the foot, the tarsus, length 3 1-7 inches; $g$-the claws, that of the middle, length $21-3$ inclies: the two to the right and left, length $16-10$ inches; that of the back, leugth $8-10$ inches; $h$-the patella or knee; $i$-the os ealcis or heel.

The engraving (Fig.1.) represents the skeleton of - an ordinary hen of an average size, and in the pro-. portions to be grenerally met with. The only important museles are those which compose the flesh, fiom (Fig. 2.) -which aro formed the breast, the thigh, tho leg and a little for table uso. the wings. All the others are slender and only furnish

People often confound the thigh, the leg, the foot and toes of the hen, and so it is with nearly all animals. Ope expects to see her walk on the foot, though she walks like them on the toes. It is evident that the tarsus of the hen is the foot she would use on the ground if she walked like man; the end opposite the toes is the heel. Some fowls have five or six toes but they do not all rest on the ground always.

\section{Apoplexy-Its Cause.}

Over-feeding and over-stımulating of fowls-seldom occurring on the farm-and generally known by finding the subject dead, often in the 
nest. Prevention is the proper means to use. Givo plenty of exercise and good wholesome food, but not that of an over-stimulating nature. The cure is by opcning a blood vessel and blecding freely, selceting the largest of the veins on the underside of the wing. Hold the vein between the opening and the body, and release it when blood enough is takcu. Keep the bird quiet and on light dict until recovered.

\section{Roup.}

The symptoms are at first those of severe catarrh. The dischargo loses its thin, watery, transparent character, gets opaquc, with a peculiar and offensive smell. The inner corner of the eye contains froth, the lids swell, stick together and at last closc. The nostrils elose from the same aecumulation; the sides of the face swell and the bird dies. It is B disease of the lining membrane of the nasal cavitics.

To Cure.

Provide warm, dry, wcll-vcutilated quartcrs, stimulating and nutritious food. Give internally a tea or a table-spoonful of eastor oil, aceording to the size of the fowl, syringe the nostrils with ehloride of soda, two parts water to one part of chloride. Inject by inserting the syringe in the slit at the roof of the mouth. Thrce or four hours after the oil give the following:

No. 1.

3. Oance balsam copaiba, $*$ Ounce liquorice porrder, \% Drachm plperinc.

Divide into thirty doses, enclose each in a little gelatine, and give a dose twicc a day. Isolate the sick fowls from all others, and kill promptly if they do not yield to treatment.

\section{Egg Bound.'}

In this disability the eggs cannot pass down the passage. Strip a tail feather to within an inch of the cud; saturate it thoroughly in lard oil or swect oil, and pass it carefully up the passage to the egr, lubricating the wholc. If rolief is not given, repeat the process.

\section{Inflammation of the Egg Passage.}

Symptoms.-Therc will be gcneral fcrerishness, dullness, and tho feathers, cspecially those over the back, will be raised and ruffled. Givo the following:

$$
\begin{array}{ll}
\text { No. } 2 \text { 1 Grain calomel, } \\
1-12 \text { Grain tartar emetle. }
\end{array}
$$

Mix; envelop in gelatine and place well back on the ront of the tongue entil swallowed. If relicf do not ensue in two days, give another dose. 


\section{Ctolera.}

Symptoms. - There is sudden and great thirst with diarrhcea; the evao. astions are greenish, but soon change to a whitish character; eramp ensues and the bird totters, falls, and often dies suddenly. Administer every three hours, until rclief is obtained, the following:

No. 8.

5 Grains rhubarb, 2 Grains eagenue pcpper, 10 drops laudanum.

Give this at a dose for large fowls, and half this quantity to chickens two monthsold. Between eaeh dose kecp up the strength by giving a tea-spoonful of brandy and water, lialf and half. This is also good for common diarrhoea, omitting the brandy.

\section{Gapes.}

Parasitic worms (sclerostoma syngamus) in the windnipe, occurring in chickens up to two or three montlis of age.

\section{How to Cure.}

Separate the chickens affeeted; strip a small quill feather to within half an ineh of the end. Dip in spirits of turpentine; pass it down the small opening of the windpipe, at the base of the tongue; turn it once or twice around and draw it out. If it does not relieve operate again next day. Give a warm, dry place, plenty of good food, and for drink, milk well sprinkled with black pepper. It is supposed that the gape worm is produced by a small parasite insect rcsembling a tick found on the heads of young ehickens. Examine the heads with a pocket lens and if found use the following, lightly rubbed ou.

No. 4

$$
\begin{aligned}
& 1 \text { Ounce mercurial ointment, } \\
& 1 \text { Onnce lard oll, } \\
& \text { 1/2 Ounce florvers of sulphur, } \\
& 1 / 2 \text { Ounce crude petrolcum. }
\end{aligned}
$$

Mix, and apply just warm enough to be melted. It is said that a case of gapes has never been found in which the young chickeus were not first infected with the tick parasite.

\section{Bläck Rot.}

Swelling of the legs and feet, the comb black, resembling mortification. Give a tea-spoonful of castor oil, and then daily, until relieved, half 
con-spoonful of flowcrs of sulphur. This is also good in scaly leg, and cruptions of various binds, using also, after washing clean, the following:

No. 5.

1 Onnces lard oll,

1 Ounce turmeric powder.

Anoint the affected parts.

Catarh-Symptoms like the first in Roup. Cleanlinsss is the besi prevcntion. To cure, feed black pepper in mashed potatoes. If thin iuils, take:

No. 6

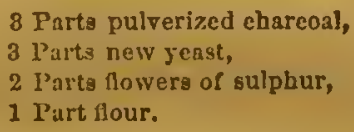

Mix into pills the size of a hazclnut and give one, three times a day; bathe the nostrils and eyes frequently with tepid milk and water, and kecp the fowls otherwise clean.

\section{Crop Bound.}

The food sometimes becomes bound and impacted in the crop. The remedy is to make an incision into the erop sufficiently largo so the contents may be carefully extracted with a blunt instrument. Close with a stitch, and feed with soft food for two or three days, in which a littio gentian and cayenne pepper is mixed.

\section{Diphtheria, or Croup.}

It may be known by the cough, raising of the head to breathe, and the offensive smcll.

What to do-Strip a feather to within half an inch of the end; wet it and dip in powdered borax, and swab the throat well. Nitrate of silver would be more effective. Give to drink, chloride of potassium one-fourth of an ounce dissolved in a half gallon of water.

Preventive-Cleanliness, good ventilation and care. The rule will apply to roup, catarrh, gapes, pip, and other acute and chronic diseases.

Pip-This is a result of other diseases rather than a disease of itself. Remove the crust at the tip of the tongue and wash with chloride of soda. examine the nostrils for any stoppage, and give a tea-spoonful of castor oil if the fowl be very sick.

Rheumatism-Cause-Exposure to damp, and cold winds, and bad roosting places; remove the fowls to comfortable quarters, and feed warm, rather soft, stimulating food.

Laying soft eggs-Give plenty of lime rubbish, burned and broken oyster shells, or bone meal. 
Lico.

There should be no excuse for infestment by these parasites. They will sometimes make their uppearanee on new fowls, and setting hens will sometimes eontraet them. They are of two kinds: tho eommon hen louse, and minute "hen spider," so-ealled. The latter ve!y minuto and infesting every part of the house, and often the horse stables, if the hens are allowed to run there. To rid the bouse, take out every movable arto iele and wash thoroughly with earbolie aeid and water, or with the ammoniacal water of gas faetories, which is eheap. Wash also crery portion of the bouse with the same. Or, fumigate by elosing every ereviee, and burning in an iron pot eontaining a burning hot stone, half the size of a man's head, a pound of roll brimstone, keeping the house elosed two or three hours. Then wash every part of the house with lime-wash in which a pound of potash has been dissolved to eáeh quart of water used in thinning tho wash. Wash also the furniture, nests, perehes and all else with the potash solution, one pound to a quart of water. Put back the furniwure, place fresh hay in the boxes, plenty of dust baths near, and the liee will leave the fowls and die. In ease the stable becomes infested, or other places that may not be fumigated, wash with the potash solution, or the lime-wash, containing one part in twenty of earbolie aeid. 


\section{BEES.}

THEIR HISTORY, CHARACTERISTICS

AND MANAGEMENT. 



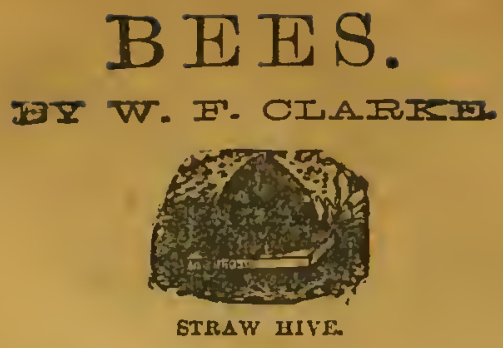

Bees belong to that elass in the animai kingdom known by naturalists as insecta. The division in which they range is ealled Hymenoptera, from tw 3 Greek words denoting membrane and wings. Wasps, ants, iehneumon flies, and saw flies, are members of the same family. The natural history of bee is a large study in itself, and can only be dealt with in these pages, in so far a it bears on the management of an apiary. There are several varieties of beek. That vglieh has been domesticated by man is known as Apis Mellifica, or the honey-bee. The earliest historieal referenees to this insect are found in tho Bible. Samson ate honey that had been stored in the careass of a lion previously slain by him. Honey is mentioned several times in the Old Testament. It is spoken of as dripping from the flinty rock, an allusion which shows that in ancient times, as now, the bees of Palestine took possessioa of rocky eavities as hives and stored honey in them. Wild honey formed part of the diet of John the Baptist. Honey, and the honeyeomb, are familiar Seripture emblems. Coming now to profane history, we find Aristotle writing of bees upwards of three hundred years B. C. Virgil immortalized them in his fourth Georgie, some three lundred years later. Colunclia and Pliny the elder wrote about bees during the first eentury, after whieh nothing worthy of note is on record coneeruing them, until two centuries after the revival of learning in Europe. Swammerdam, a Dutel entomologist, published about the middle of the seventeenth eentury, "The Natural History of Bees." A century later, Linnæus, the great Swedish naturalist, threw a flood of light on the whole subjeet of inseet habits, those of bees ineluded. Reaumer of Franee, Bormet of Switzerland, Fabrieius of Denmark, Kirby and Spence of England, Huber of Gernany, Packard and others of Amcrica, also, later on, Dzierzon, the Baron of Berlepseh, Langstroth, Quinby, Cook, and a host of others have writtell treatises on the honey-boen w that the literature of this supject forms a large library in itself. 


\section{QUEen, Drones, AND WORKERS.}

There are three kinds of bees in every stock or colony, a queeu, a nuin. ases of drones, and a far greater number of workers. The accompanying cuts will give some idea of their differenees in size, shape, and general appearance:

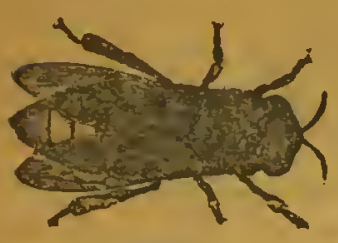

DRONE.

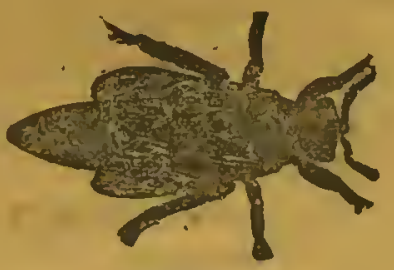

QUEEN.

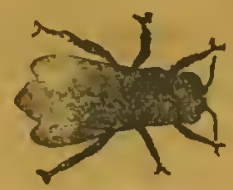

WORKER

The queen is the most important nember of the eolony, being the mother bee, and laying all the eggs from which an inerease of population is derived. Her wings are short, her body long and tapering, and her movements peeuliar. The drones are portly-loolring, aldermanic inseets, each with a jolly corporation of his own. They are "the lazy fathers of the industrious hive." They perform no work, but live a life of luxurious idleness. The worker aro undeveloped females; on them all the labors of the hive depend.

THE STAGES OF BEE-LIFE.

As in the case of other insects, there are four separate stages in the development of bees, the egg state, the larva, the pupa and the imago. Three of these terms need explaining. Larva means grub or maggot. The pupa is Bonetimes called a elırysalis. At this stage of its life, the inscet is like a babe wrapped in swaddling clothes, a thin membrane being bound around its body. The term imago, or image, refers to the faet that the form of the inseet is now somplete, real and apparent. Two kinds of cgrgs are laid by the queen-bee,

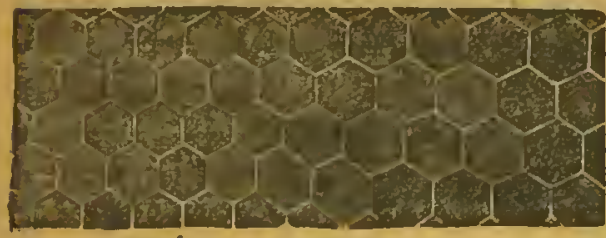

COMB FOUNDATION, SHOWING DRONE AND WOKKER CELLS. drones and workers. There are two sizes of eells in every hive, the larger called drone-eomb, to eontain drone oggs; and the smaller called workereomb, to receive worker eggs. The' instinet of the queen guides her in making the eggs eorrespond with the eells in whieh they are laid. When it is necessary to rear a queen, one of the worker eells, containing a newly laid egg, is enlarged until it resemble - pea-nut in shape and size. The following out will make all this plainer 


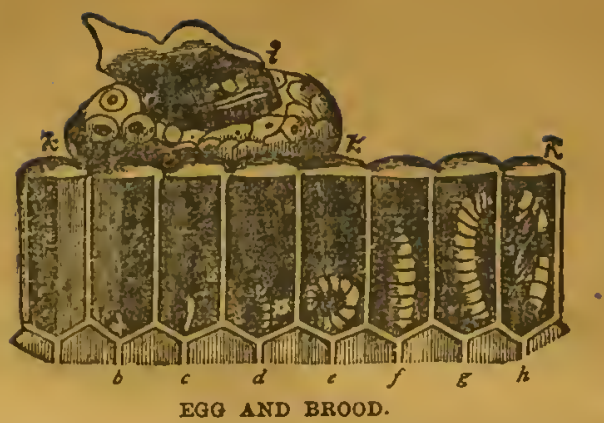

$b$, and $c$, eggs. $i$, pups of queen in queen eell. $d, e, f, g$, various sizes of larve. $k, k, k$, eaps. $h$, pupa.

The worker egg when first laid is a mere speek. In three days it hatehes into a small white grub or worm. It is fed by the worker bees and grows rapidly; in six days the eell which contains it is capped over by the worker bees; then the larva spins a thin silken eocoon, and in three days assumes the pupa state. Then eomes a long period of repose. In twenty-one days, the fullyformed worker bee energes from the eell. $\Lambda$ queen is more quiekly developed than a common or worker bee. She eomes forth, a perfect insect, on the sixteenth day from the laying of the egg. The drone takes longer to mature, and requires twenty-four days for its growth from the egg to the perfeet condition.

\section{DEVELOPMENT AND FUNCTIONS OF THE QUEEN.}

After hatehing out, a queen requires inpregnation to fit her for her maternal duties. This takes place during flight. Five or six days after issuing from the ecll, or perhaps earlier, if tlie weather be pleasant, the young queen goes forth on her bridal tour, meets a drone on the wing, and returns to the hive impregnated for life. Slie never leaves the live again, exeept when she does so with a swarm. As only a single drone, and one sexual act is needed to render a queen fertile for life, wonder has been expressed that there should be so many drones. It is doubtless a provision of nature to prevent the extinetion of bees when in single colonies in the woods. Bee-keepers who understand their business, knowing that only a few drones are needed in an apiary, will reduee their number by eutting out drone eomb when it is superabundant. About two days after she is impregnated, the queen usually begins to lay worker eggs. It is a curious faet in bee-life that a queen can lay fertile drone eggs, without impregnation, another wise provision of nature for the preservation of the speeics. Before laying an egg the queen generally looks into a eell, to see if it be empty. Finding all right, she turus about, inserts her abdomen in the eell, and drops the tiny egg, which by virtue of a aticly fluid which encuses it, is immediately glued to the bottom of the cell 
The one duty of the queen is to lay eggrs, and the number she will produce. if a good layer, is truly astonishing. Two or three thousand cggs per day will be laid by such a queen, and an extra fertile one will lay threc thousand or more in a single day. Henee a hive will inerease in population very rapidly during the working season. At such a time many bees are lost while out forming, moreover they are short-lived inseets, so that the hive nceds constant and quick replenishment. A worker usually lives but a few weeks or at most months, whilc the average life-time of a queen is about three years. Drones are nsually found in the hive from May to November, though it is the eustom of the rorkers to lill them off early in the summer.

\section{PRODUCTS OF BEES.}

Bees gatlier honey, an article too well known to require deseription. They also manufacture wax out of whiel the cells are made, and which forms the becs-wax of commeree. They collect pollen or bee-bread, which forms the staple food of young becs. A substance called propolis or bee-glue is gathered by the bees. It is the produet of various resinous buds; is soft and plastic when warn, but hard and very adhesive when cold. It is used by the bees to fasten the combs to their supports, to fill up all erevices and rough places inside the hive, or to eover foreign substanees which cannot be removed.

The above is only a mearre skctch of the natural history, characteristics, and functions of bees, but it must suffice by way of introduction to sonie bricf remarks and directions about

\section{BEE MANAGFMENT.}

Bee-keeping takes rank among the lesser eeonomies of the farm. In Great Britain a farm would not be thought properly stocked unless it had a few hives of bees upon it. This is doubtless the correct view; but keeping bees : is engaged in by many persons as an independent pursuit. Skillfully managed, it is found to be a fairly remunerative business, and, with special talent and application, may properly be regarded as a money-making affair! There are men on the continent of America who liave amassed respectable fortunes out of it. Bees may be kept on a small seale by others besides farmers. On a small town or village lot, a few lives well-cared for, may be made a sourec of mueh pleasure and profit. A vast amount of national wealth is being lost tlirough neglcet of bee-keeping. It is a suitable avocation for women, many of whom are now engaged in it, and some of them rank among the best apiarians of the age.

\section{OLD AND NEW STYLE BEE-KEEPIYG.}

Until of late years, bee-keeping was a very crude affair. It was nsually carried on with straw or box hives, to the interior of which the bee-keeper 
had no aceess, consequently the bees were left almost wholly to their own devices during the working saason, at the elose of which they were brimstoned, and robbed of their stores. It was a great step of progress when movable frame hives were invented. By the use of these, artifioial swarning takes the place of natural swarming, and instead of the bee-master liaving to await the convenienee and eaprice of the bees, with the risk of losing swarms if watch of the apiary be intermitted, he consults his own convenienee, divides overpopulated eolonies, and avoids loss of swarms. Moreover, when stoeks become queenless and are in danger of extinetion, a new queen, or brood from which to reur one, ean readily be supplied; moths can be exterminated; comb, bees and honey can be given to weak eolonies, and surplus honey realily taken. The bees, instead of nanaging themselves under the guidance of mere instinet, are managed by the superior intelligenee of their human lords.

\section{THE HONEY EXTRACTOR.}

It was a still furtler step in improved apiaculture, when the honey extrzetor was devised. This maehine, by the simple application of eentrifugal foree, empties the well-filled eombs almost to the lust drop of honey, and on theis

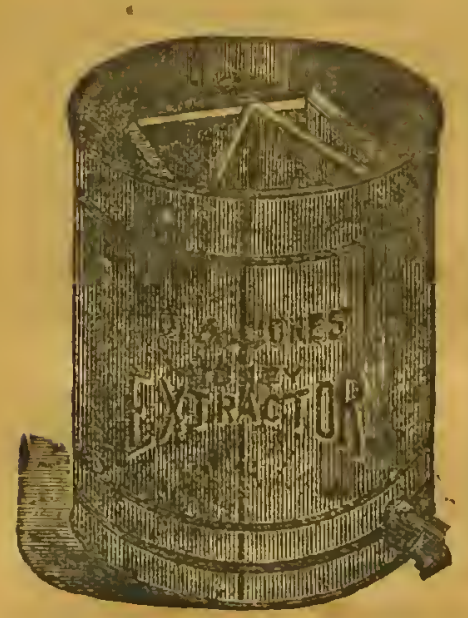

HONEY EXTRACTOR.

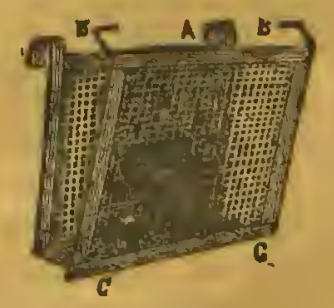

COMB BASEET FOR IXTRAACTING HONLY FROM BROKEN COMB.

being replaced in the hive, the bees at onee proeeed to refill them. By tho use of this machine, the yield of honey is doubled, trebled, and even quadrupled, in good seasons.

THE WAX EXTRACTOR.

Wax, to be put in shape as the bees-wax of commerce, requires to be melted and strained, so as to secure perfect purity. This is best done in a double 
L vessel, laving as the inner receptacle, a strainer. The accompanyirs

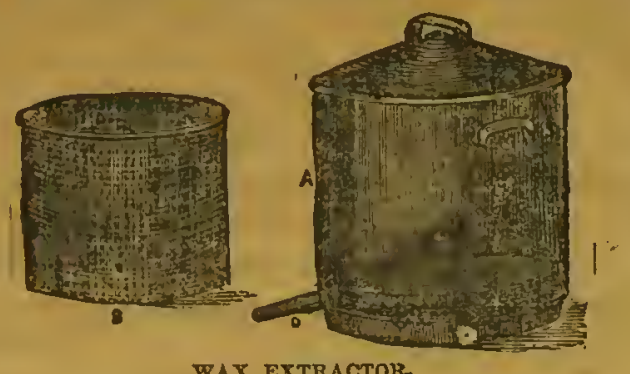

cat represents the kind of vessel now in use by the best apiarians for this purpose.

\section{NEW RACES OF BEES.}

The importation and breeding of Italian and other foreign bees is another: progressive idea of great valuc. Bees, like larger stock, deteriorate by in-1 snd-in breeding, and there are common and superior tribes of bees, as there are of cattle, horses, sheep, swine and poultry. The Italians have proved a great advance on the ordinary black bees. They are hardier, nore busy: than "the little busy bee" with which all are fawiliar, more prolific, mor

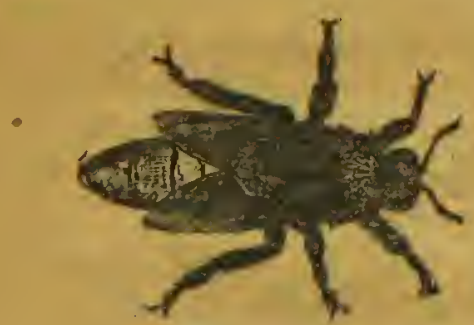

JAVA QUEEN.

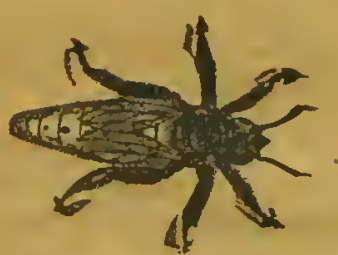

CYPRIAN QUEET.
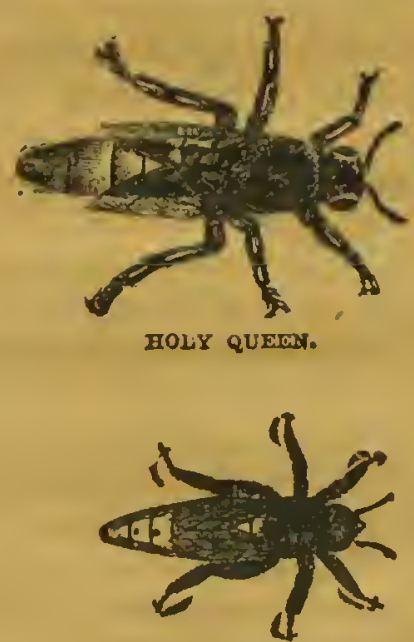

ITALIAN QUEEN.

besutiful in appearance, and, last but not least, more pacifio-not so easil provoked, and consequently less inclined to sting when meddled with by man. There are other races of bees from which much is expected; notably those of the island of Cyprus, and the land of Palestine. So far as tried, these are bolieved to be superior to the Italians, A buge bee found on the islana of. 
Java, apis dorsata, is about to be imported. The bee of the future is yet to be developed by careful breeding, and it is especially desired to secure a greater length of tongue, so as to penetrate flowers whose honey cells are too deep to be reached by any known race of bees. The red olover yiclds a vast anount of honey, but it reinains mngathered for want of bees able to harvest the crop.

\section{PROSPECTS OF BEE-CULTURE.}

Apiarians are sanguine in the belicf that bee-keeping is but in its infancy as yet. Grent improvements have been made in the art, of late years, and there can be little donbt that further advances in it will be witnessed ere long. The march of progress has not reached its limit; scieuce and skill are busily engaged in experimenting, and it is reasonable to expect that, in a few years, apiaculture will take a much higher place tran it now does among rural. industries.

\section{STARTILA AN APIARY.}

Bec-leeping is an art requiring both study and practice. No one should attempt it who is not resolved, in the first place, to master the prineiples on which it is based. To do this, a good manual on the subject shonld be obtained, and thoroughly studied. Next, it will be well to visit some skilled apiarist, and watel his methods. Indecr, a short apprenticeship wonld be a wise course on the part of any and all who think of going iuto bees extensively. Those who only meditate leeping bees on a small seale, maý venture, after studying a manual, and visiting a good bec-keeper, to start with a hive or tivo. More are not desirable, at the outset, us in case of failure and nishap, the loss might be serious. In buying stocks, care shonld be taken to have them strong, and from tlie start, the motto will be fouud to be a wise one, "lieepl all colouies strong."

\section{IITYES.}

It is to be presumed that no intelligent person will go into bee-lreeping now-a-days with any intention of using the old-fashioned box-hive, still less the time-honored and picturesque-looking straw "slepp." The movable frame principle is essential to any success worthy the name. A great many styles of hive have been put on the market, many of them too compliented and costly for pretetieal bec-kecping. $\Lambda$ simple, clieap hive is as good as the best; in faot, is the best. MIr. D. A. Jones, of Beeton, Ontario, the most renowned and suceessfnl bee-keeper in the world, at the present time, after a trial of all the hives of any note in America, and an inspection of the leading apiaries of Europe, lias settled down ou a live, which is the simplest, cheipest, and nost easily managed of any hive now in use; while it is as nflective as any. It is made in two styles, single-boarded and double-boardep. Tho accompanying engraving will give an idea of the double-bourded hive: 
Mr. Jones has furnished the following description of his hives: "My single-boarded hive costs onc dollar, and contains twelve frames about $10 \frac{3}{4}$ by 13 inches. Thic frames are of the most approved shape, so constructed tilat the projection at the bottom prevents the killing or injuring of any bees,

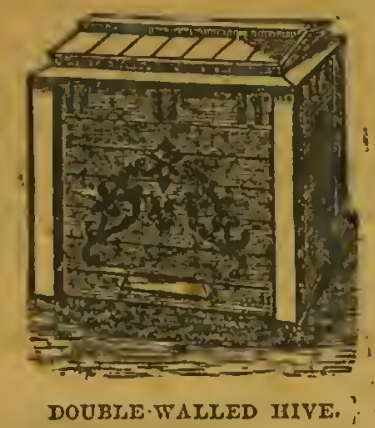

while lifting ont the combs, or manipulating them. It also contains a movablc division-board, which is indispensable to success, it being adjusted to suit the size of the colony of bees. No hive is complete without onc. The inside dimensions of my hive arc $12 \frac{1}{8}$ by 18 by 15 inches. My double walled hive is the sane size interiorly, taking the same frame as the singlcwalled hive. It is very neat in appear -

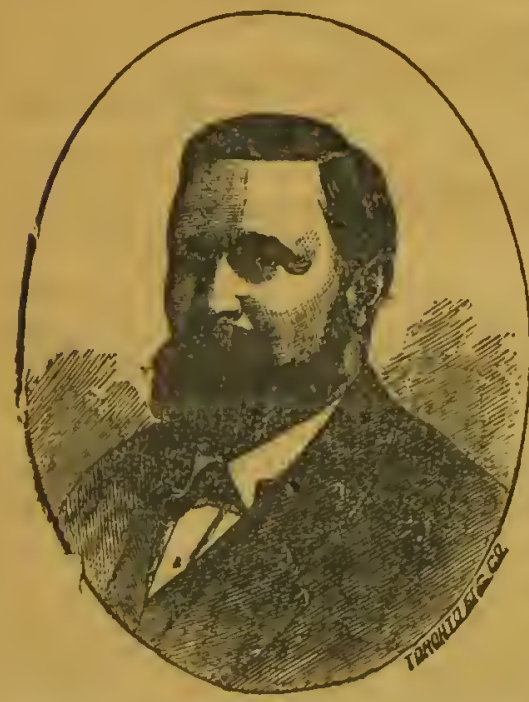

2A. D. $\triangle$. JONES, THE CETFBRATED BEEKING OF BEETON, ONTARIO. ance, and looks well on a lawn. It is equally wcll alapted for both cxtracisd and comb honey. From its peculiar construction, it requires no extra protection cither summer or winter. In it, colonies may be safcly wintered on their summer stands. The boards used are thin, yet the. hive is strongly eonstructed. It has a hollow four-inch wall on all sides of it, and a double bottom, also enclosing a four-inch space. The four-inch spaces thus made are closely packed with straws cut fine in a cutting-box, which forms an exccllent non-conductor. A chaff cushion, eight or ten inclies thick, is laid on top of the frames, on the approach of cold weather. Thus the bees are kept at once warm and dry."

TRANSFERRING BEES.

The beginner in apiaculture will very likcly have to buy bees housod in boxe 
hives, which will render it necessary to transfer them into movable fram lives. A brief explanation of the transferring process is therefore desirablc. The best timc to transfer is early in the season, when there is but little honcy or brood in the hive. It may, however, be donc at any time, with proper care. 'The weather must be warm, and the bees busily at work. Blow a little smokc in at the entrance to the hive; pausc for two or three minutes to give the smoke time to producc its effect; then carry the hive a few foct away, and turn it bottom side up. Place a box ovcr the hivc, and with a stiek rap on the live for about tirenty minutcs. The bees will fill themselves witto loncy, and go witlı the queen up into the box, forming a cluster therc. A few . young boes will remain in the old hive, but this is of no eonsequenec. 'Take the box to the old stand, leaving the front odge raised, so that the bees out foraging can join their companions, and all get fresh air. If other bees give no trouble, the rest of the opcration can bo perfurmed out-of-doors, but if there is any annoyance of this kind, remove the old hive into a room, shed, or barn, pry it apart carcfully; cut thc combs from the sides, and get them loose with as little damage as possible. There should be a barrel set on end, and a board of convenicnt size placed on top of it. Lay several thicknesses of cloth on the board, as a soft bed for the conlb. Now take a sheet of comb, lay it flat on the cloth, place a frame on the comb, and earefully cut out the eomb, the exact size of the frame inside. Press the frame over the eomb, being particular to have it "right side up" as it was in the old hive, then fasten the comb in the frame by winding around it either twine or fine wirc. To raise the frame perpendicular before fistoning the comb, tilt the board beneath it. Sct the frame, fixed as described in the new hivc, and proceed with the rest in

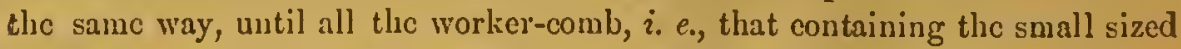
sells, is secured. It is a good opportunity to get rid of drone-comb. The pieces of worker conib left at thic end of the process may be fitted into a Irame, and scoured there by thin flat strips of wood, tied at the end with iwinc, or tacked with very small tacks. Having fastened all the workercomb practicable into the frames, all the remaining bits hotls of worker and dronc-comb should be saved as starters for boxes and sections. Now place the hive on tho old stand and shake all the bees out of the box in front of the hive. If the alighting-board is properly arranged, so that the bees can readily find their way in at the entrance, they will not be long in taking possession of their new homc. They will go to work at once and put things to rights. In two or threc days they will have all loose eombs fastened, so that the strips, wires and strings may be removed.

THE BEE-SMOKER.

In the operation just deseribed, and many others, a littlo machine ealled the bee-smoker will be found very useful. Blowing a little smokc into a hive 
of hees has a quieting effect upon them, so that they can be easily handled The smoker is merely a small pair of bellows attached to a pipe, into whieh some cumbustible material is put; the gmoke from this is driven by the

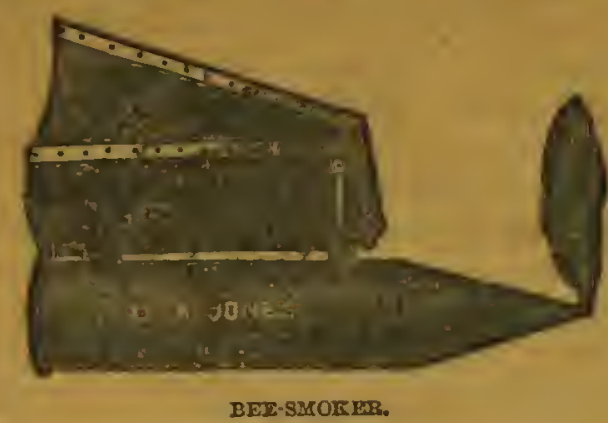

Wellows ont of the pipe, and can be directed to any plaee desired. The smoker can be worked with one hand, leaving the other free to do whatever the $h: \Omega-1$ :e:per may wish.

\section{LOCATION OF TIIF APIARY.}

the apiary should be near at hand, where it ean be closely watehed with but little trouble. An easterly aspect is preforred by most bec-keepers, in order that the early morning sun may strike the hives, and aronse the inmates to rork betimes. Slade during the hottest part of the day is desirable. A grove, if somewhat open, is a niee plaee for hives of bees. In many cases they can be set to good advantage in an orchard. A lawn and shrubbery often afford eligible places for bee-hives, under the partial shelter of a shade-tree, an

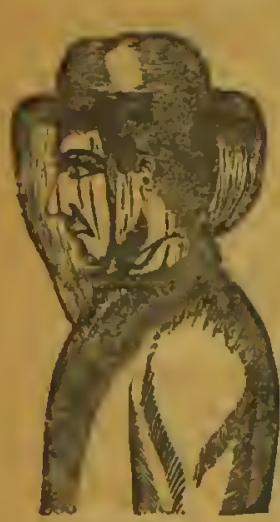

DEE VEIL. evergreen, or a grape-vino. Bee-honses arc generally dis= carded by the best bec-keepers. It is better to have eaeh hive by itself. In cxposcd situations, wind-sercens are necessary. A close buard fonee is, in many cases, very suitable. The use of a double-walled hive renders several of the preeautions just mentioned unneeessary.

\section{BEE VEILS.}

Beginners in bee-keeping and those who are oljeets of dislike to bees, as some people are, find it necessary to wear a veil. A simple pieee of blaek net fastened around the hat with an elastic string, and long enough to tuek undcr the collar of the eoat, will answer the purpose. The annexed engraving will show a bec-keeper thus attired, ready

for huciness.

Simnc also wear gloves, but these are very awkward in handling becs. The tuot tor the purpose are the sheep-skin gauntlcts linown as "thistle-mits." 
AN FXAMPLE OF EIGHLY SUCCESSFUL BEE-REEPINO.

Mr. D. A. Jones, of Beeton, Ontario, heads the list of sucecssful apiarians and ranks as the champion bec-kecper of the world. He has kept becs from boyhood, beginning with the old-fashioned method, but, at length getting hold of the best modern books on bee-lkeeping, rapidly made his way to the front, and became wiser than his teachers. He attained his highest suecess in 1879, when from three hundred colonies of bees he obtained the marvellous averagc of two hundred and fifty pounds of honey per hive. The next year being unfavorable, the honey yicld was less, but he largely increased his colonics in number, so that his profits from stoeks and honey were in the ncighborhood of six thousand dollars. He has now one thousand colonics, which, at the low averagc, for him, of ten dollars profit per hive, will yicld next scason ten thousand dollars. The likelihood is that le will double that amount of gain. Mr. Jones lias visited various parts of Europe, including the island of Cyprus, aud lias also been to the Holy, Land in search of the best raees of bees for loncy storing. He has an agent, who is a slitlful apiarian, travelling through Asia on the samc crrand, and specially charged to obtain the best specimens of a large bee called apis dorsata. The races of bees thus eollcctcd are being bred with great care on isolated islands in the Gcorgian Bay, varions crosses made, and points of. excellence noted with seientific accuracy. Grcat advanees liavc alrcady been made in bee-breeding, and it is belicred that a race of becs will yet be developed, that will bc, likc the shorthorn among cattlc, far in advance of the common and native brecd. Mr. Joncs considers that bec-keeping only, requires to be better understood to become a vast source of individnal and national wcalth. As he has no seerets to hide, and is only anxions to see apiaculture undertaken more extcinsivcly, he is ready at all times to impart what he knows for the bencfit of others, and las firnished for this work the following aeeount of the way he handles his becs witl a vicw to sccuring the largest amount of profit attainable from them:

\section{MR. JONES'S WAY OF BEE-KEEPING.}

"My method varies somewhat with seasons and circumstanees. I will state it as applicable to ordinary seasons, and shaped so as to secure a modcrato inerease of stoeks, along with the largest practieablc yield of surplus honey..,

\section{SETTING OUT THE HIVES IN SPRING.}

"Supposing the bees to have been wintered in a cellar or frost-proof honse, the first care of the beo-keeper in early spring will bc to set them on tho stands they are to occupy during the summer. No precisc date can be given for doing this. I usually set out my bees on the first appearance of black 
alder bloom, which oceurs the first really warm spell of weather. They will take \& purifying flight, and then the bce-keeper nust seize the earliest opportnnity of examining each stock to see that all have queens. Any quecnless ones may be doubled up, with weak stocks that have queens. All wcak stoeks must be doubled up, whether quecnless or not, clse they will dwindle away to nothing. Great eare must be taken so that they may have plenty of food, as there will be a quiek consumption of it when breeding begins. I crowd the bees up into a very limited eompass by means of division boards, and fill the spaces between the division-boards and the walls of the hive witl ehaff or cut-straw. Feeding the bees daily stimulates the queen to lay, and as the combs become filled with brood, more should be given. By this means a large quantity of young bees will be hatohed out ready for honey-gathering, and by the time white elover blooms there will be plenty of active workers in the field to gather its yieid of honey. Care must be taken not to give extra combs too fast, lest the young brood should get chilled. No more combs should be in the hive at any time than the bces can cover. The whole season's profit depends on the observance of these rules. In addition to these inside regulations, attention must be paid to the outside of the hive. When the weather is cold, and every night through early spring, the entranee must 'be elosed so as only to idmit one bee at a time. When the weather is warm, and every morning as the sun begins to mount up in the heavens, the entranee must be made larger. A little observation and practice will enable the beelieeper to keep the inside temperature of the hive in that state of uniform warmth which is most conducive to the raising of brood.

QUEEN REARING, AÑD ARTIFICIAL SWARMING.

"Get the stock from which you wish to raise queens as strong as possible, tho that it wlll proceed to build queen cells. Now, from each one that is vtrong enough to spare it, take one comb wltl plenty of brood in it and make is nueleus, by using the division-board as above direeted, and after from twenty-four to forty-eight hours, give them a queen or a cell from those which have been started by the extra strong colony already spoken of. In a few days the young queen will begin to lay, and brood should be taken from the parent stock suffieient to keep it just below the swarming-point. The most honey and the best results are obtained by keeping the bees just below the swarmingpoint, which is done by the judicious removal of brood with which to build up the young swarm. In this way, both will be boiling over with bees when the honey season is at its lieight. If they cannot otherwise be kept baek from swarming, draw a comb from each of six or more hives, putting them with their bees all in one hive, which makes a strong stock by giving them a queen. In every apiary, there should be surplus queens on hand throughout 
the working season, ready for sueh emergeneies. Queen rearing can be carried on without building up, and onc frame of eomb answers for the queen to lay iu, until it is eonvenient to add more.

\section{INTRODUCING QUEENS.}

"There are varions methods of introdueing queens. Whatever method is adopted, four things must be carefully attended to: 1 . The hive must contain no queen or queen-cells. 2. The bees must be made to fill themselves with honey. Sinoke will usually do this, but some bee-keepers also sprinkle tlicm with liquid honey or syrup. 3. The queen must be pervaded by the same odor as the bees to which she is introdnced. Some add to the syrup or honey sprinkled on tlrem an essenee, sueh as peppernint or the like. Others do-

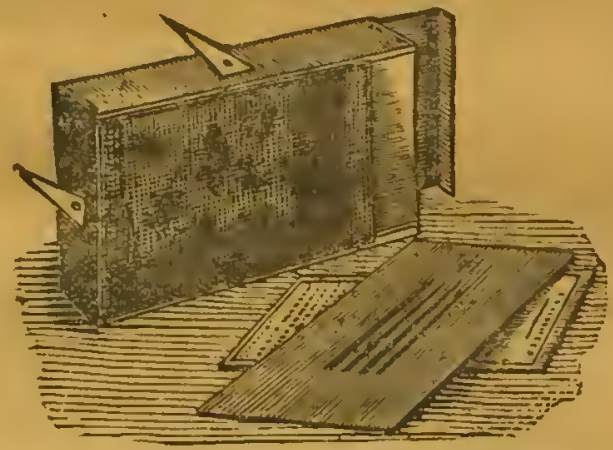

CAGE FOR SHIPPING OR INTRODUCING QUEENR.

pend on smoke, using tobaceo whieh must not be strong enough to stupefy them. 4. The queen must not be introduecd hastily, or she will be treated as an intruder, and specdily killed. Covering the qucen with honey or syrup when she is put among the bees is usually sufficient. By the time they bave licked her clean, which they will at once proeeed to do, they will be willing to accept lier. Many use a cage for introdueing queens. She is confined in this for a time, inside the hive, until the bees beeomc used to her. Sueh a cage in also used for shipping queens to a distance.

\section{EXTRACTING COMB IIONEY.}

"Assoon as the brood chamber begins to get crowded with honey, which seldom oeeurs before white clover blooms, the cxtractor must be used. Quiet the bees with smoke, draw out the combs, shake and brush off the bees, carry the combs to the extracting-room (which may be a novable-box or tent), with honey-linife slave off the capping of the cells, extract the honey, return the combs to their plaees, close up the hive, and proeed in the same way with 
the next. In my aptary, I usually have a man or boy taking out frames, and brushing off the bees; one or two boys carrying them to the extracting-room; one

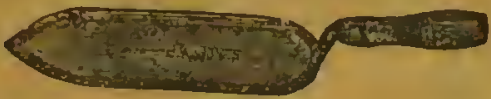

RONEY-IKNTFE. uncapping, another extracting, and one putting back the frames as fast as thicy are emptied. In this way all keeps moving along, and we can take thus from 1,000 to 2,000 pounds of honey per day in the height of the season.

\section{TREATMENT OF EXTRACTED HONEY.}

"The honey is put into large tin tanlss and open barrels, left to ripen from six to twelve days. It is then drawn off into tin cans holding $2 \frac{1}{2}, 5$ and 10 pounds. The cans should be made with a balc and screw top, so as to be ready either for shipment or for salc in the original packages. I sometimes ship in barrels. These should only hold 100 pounds, and must be coated inside with wax.

\section{COMB HONEY.}

"I take all my comb honey in sections. During the past season I have greatly increased the yield of comb honey by the usc of a perforated zino plate as a divider. The holes will admit the passagc of worker bees, but not the quecn, who can thus be confined within a limited space, her laying restricted to that space, and the whole worker force of the hive employed in filling the sections with comb honey. Shonld this plan continuc to work wcll, it will add largely to the yield of comb honey. Section honey can be taken above the frames, and at the back part of the hive. Extracted honcy ean be fed back to the bees, and stored in sections. By the proper usc of the extractor along with sections, more lioney can be got, and stocks kept equally strong as on the old system.

\section{PREPARATION FOR WINTERING.}

"When the honey harvest is over, scc that all stocks have young or still vigorous queens. Remove all failing queens, and replace with young and vigorous oncs. Remove all surplus comb, and store it up for use anotlier year. Crowd the bees into a compact form. If short of honey, feed thicm with pure granulated sugar syrup ( 2 pounds of sugar to 18 ounces watcr). As soon as the honey liarvest shows signs of failure, feed the bees a little to keep up breeding, and, as soon as the first frost kills the flowcrs, feed liberally, until there is a sufficient store for winter; then fced lightly to keep up breeling as late in the season as possiblc. Plenty of young bces are the best security for wintering well. If the becs are all old in the fall, they will die off befor young ones are hatched out to take their places in the spring. 


\section{WINTERIN}

With good queens, plenty of young bees, ant abundanos of stores, bees are ready to go into winter quarters whenever cold weather sets in. About thirty pounds of honey or sugar syrup will be required for out-door wintering, and about twenty for in-door wintering. If wintered out-of-doors, crowd the bees on to four or six framcs, pack around them with chaff or saw-dust, and lay a good chaff cushion on top of thic fr:.: 1 , leaving the entrance open. To winter in-doors, on a sunny day late in tice fall, the of covers and cushions, remove all propolis-coated clothi, let the sun dry off the bees thoroughly, lay on clean cloths, cover with cushions, and carry into a beehouse or dry ccllar. The bee-house should be built with bollow walls, having not less than twenty-one inches of space filled in with chalf; tan-bark, or alv-dust. When thus housed in a cellar or bee-house, keep in utter darkness and quiet, maintain a temperature from forty-two to forty-five degrees, and give your bees a good letting-alone until spring returns again. Thesso who winter out-of-doors in my double-hive, will not require to do any chaffpacking. All that is necessary is to crowd the bees up into small compass with the division board, and lay a thick chnff cushion on top af tho framos" 

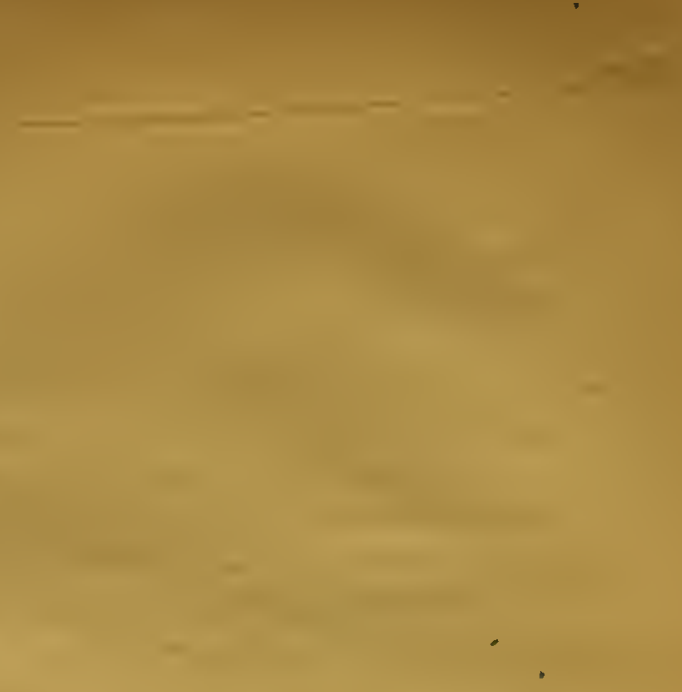

!

.4

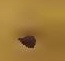

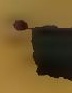




\section{THE DOG.}

\section{HISTORY, BREEDS AND}

CHARACTERISTICS: 


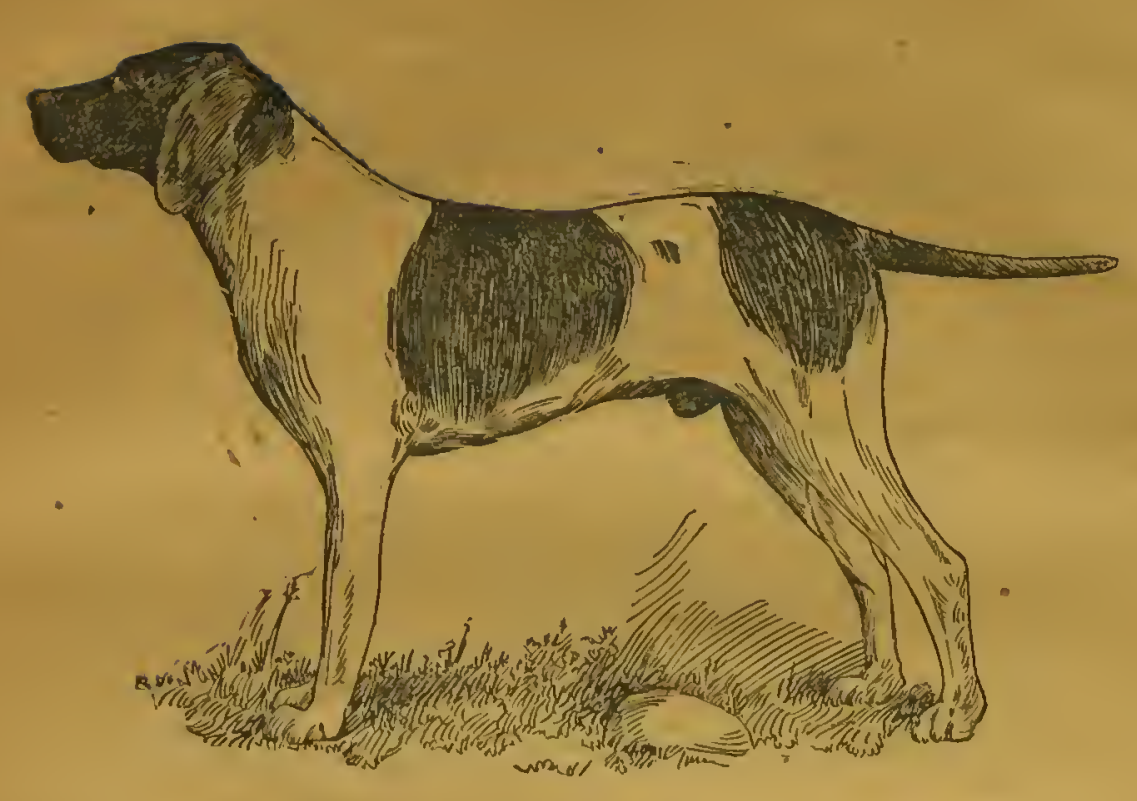

Purstek, "EaltiL Jrico." No. 46,6i8. Jrize winner at Westminster K. C. Show, New
York, 1899 . Property of Mr. E. M. Jeale, Lewislurg, Pa

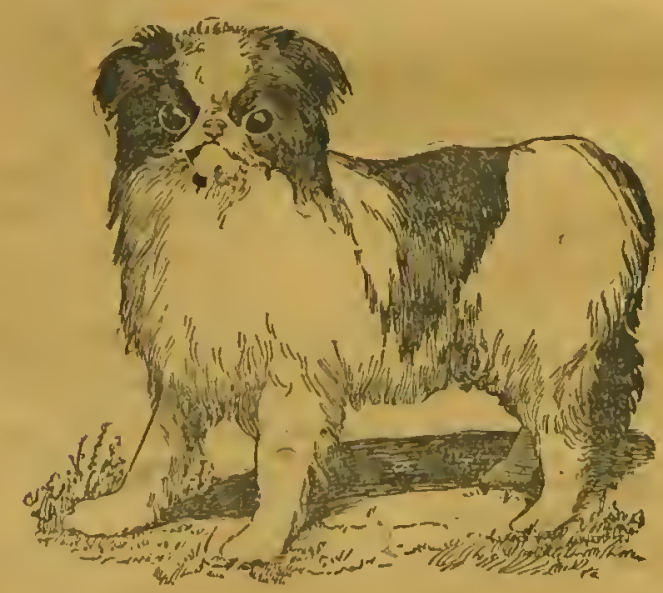

JAPANESE SPANIEs, "Kito ITo." Prize winner at Westminster K. C. Show, New York, 1899. Property of Mrs. F. Senn, New York. 


\section{THE DOG.}

\section{IISTORY OF BREEDS AND CHARACTERISTICS.}

\section{CHAPTER I.}

Urigin of the dog--Usefulness of the dog to man-The English Setter-The Irish Seiter -Tho Gordon Setter-The Native Setter-The Dropper-The Pointer-Tho Spaniel-The Newe foundland dog-The Mastiff-The Eull dog-The Ilood hound-The Fox hound-The Feaglo -The Slieep dog-The Greyhound-The Dalmatian or Coach dog-T'he Scotch Terricr--Tho English Terrier-The Skye Terrier-The Poodle.

\section{MISTORY AND BREEDS.}

Is both the Old and New Testaments the dog is spolien of almost rith alhorrnce; everywhere it is designated unelean and an abomination, and yet man has no sures or more tried friend, ever on the guard to protect the property and person of his master. It appears to lave been the great object of the Israclites to engender this hatred, in order to prevent the idolizing and worshipping of the dog as was praetised by their neighbors and early masters, the Eryptians.

Consichable dispute exists with regard to the arigin of the dog. Many naturalists traee him to the wolf, others to the jackal, and some to the Dingo and Pariah; but no satisfactory conclusion has been arrived at. There is, however, but little doulst that the wolf and dog are varietics of the sarra family, as they ean be erossed, and their offspring continuing the cross thus made will produce a race entirely different from the original. A circumstance in favor of the common origin of the two quadrupeds is the existence in our own country of the prairic wolf, who whines and barks in a nanner so similar to small dogs, that it is alnost impossible to distinguish his voice from that of the terrier.

Judging from the fact that almost every eountry has its wild $\log$ or wolf, it may not be amiss to eonclude that the many varieties of $\log$ now existing have their common origin in either the one or the other, and whieh by adaptation to surrounding cireumstanees, and eare in breeding, have attaincl their present high standard of execllence.

In Northern India the wild dogs of Nepal hunt in paeks; have an exquisito sense of smell ; give tongue after the manner of the hound, and show wonderful intelligenee in the ebase, and can be domesticated when eaurht at an carly agc. 
In Southern India therc exists a wild dog readily tamed, and many are to be seen in the possession of the natives of Dakhund. $\Lambda$ wild breed termed the Pariah inhabit the lower ranges of the Himalaya Mountains. They likewise hunt in packs and seldom miss their prey. When trained by the inhabitants of this country they make useful companions of the chase, bringing the wild boar to bay, or indicating which eourse he has taken when disturbed.

In Australia the settlers are mucli troubled by the Dingo or wild dog of the country. Many sheep are yearly worried to death, and the Dingo proving untamable is the greatest pest wherewith the herder has to deal.

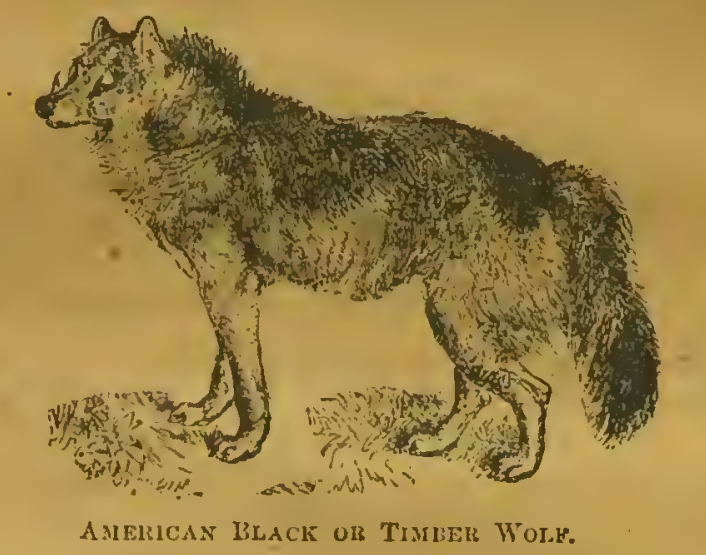

All wild dogs possess the ereet pointed ear of the wolf he so much resemble in nature, the cye lilicwise is oblique or angular as in the fox and the wolf. Prof. Beel gives a very ingenious reason for the pupil of the eye of the dog being circular and not oblique. He attributes the forward direetion of the dog's cye to the constant habit for many generations of looking towards his master and obcying lis voice.

\section{USEFULNESS OF THE DOG TO MAN,}

While almost every other quadruped fears man as his formidable enemy, there is one who regards lin as a companion, and follows him as a friend; he does it from clioice, seems to be ereated for the very purpose, and is not happy unless in his serviee, asking but a trifle in return, and a kind word is all that he requires. His swiftness of foot, great strength, courage, intelligenee, and highly developed power of smelling, have made him a powerful ally of man against the other animals, and he is the only one that has followed the human being all over the earth a willing slave. To tle husbandman he is invaluable as a protector and aid in lierding sheep, a useful companion of the cliase, an exterminator of vermin, and guard to the house.

It is not, our purpose, in these chapters, to dwell upon those breeds that are 
not readily procured and ordinarily possessed by the farmer, or to relate of other thau the leading varieties. We begin therefore, with

\section{THE ENGLISH SETTER.}

Authors disagree on the subject of the origin of the setter dog, but it is now very generally conceded he is either deseended from the spaniel, or that both sprung from the same stock. Before the invention of gunpowder, at least prior to its use in fowling and shooting on the wing, the spaniel was taught to stop or set with his nose pointing in the direction of the bird, his acute sense of smell indicating the presence of the partridge. His attitude was one lying flat on his belly that he might not impede the drawing or throwing of a net over the covey or flock before him by the fowler. This act of setting has given the name to the dog supposed to be the improved spaniel. Since the improvement of firearms, and sinec shooting on the wing is followed by sportsmen, setters almost universally stand ereel in their points at game which aclmits of their close proximity as it lies endeavoring to avoid danger. The most fumous strain of English setters is the Lavarack, which takes its name from its celebrated brecder, MIr. E. Lavarack, of Shropshire, England. The pedigree of this family of setters dates back to 1825 , when Mr. Lavarack purchased old Ponto and Moll fiom the Rev. A. Harrison, of Carlisle, England, who had kept the strain pure for twenty-five years. From the fact that all Mr. Lavarack's 'dogs descended from Ponto and Moll, it would strike the reader that unless fresh blood was sought, his animals would be so inbred as to be worthless. But such is not the easc. Mr. Lavarack declares all his rlogs came dircetly from Ponto and Moll without an outsidę cross, and so famous have they become that even at the present day they are eagerly sought for, and fabulous prices are paid for them by breeders who are anxious to improve their own stock. Their sense of smell is wonderful, their speed in the field tremendous, and their natural desire for the chase so rcmarkable, that an introduction of this blood in other families is at once noticeable in the offspring. The Lavarack setter in color may be black, white and tan; white mottled or flecked with black so as to produce a blue-gray appearance (from whence the term blue belton), orange and white, lemon and whitc, or orange or lemon ticked, termed orange or lemon belton. Mr. Lavarack's system of breeding has decreased the size of his dogs, and when purely bred are most difficnlt to raise. In the north of Eugland there are very many straius of setters claiming to be fully as finc as the Lavaraek; this we donbt, but that of Mr. Purecll Llewellyn we must mention in particular as being quite as noted, if not superior in some respects to the Shropshire strain. Mr. Llewellyn having conceived the idea that Mr. Lavarack was breeding in and in to an excessive degree, crossed his noted Dan with a pure Lavarack bitch, and a sister to Dan with a pure Lavarack dog, and produced sctters which have become famous in England and thi 
country, at first termed the field trial breed, but now taking the name of the Ilewollyn setter. The setters known as the Graham and Corbet breeds; those of the Earl of Tankville, Messrs. Waterpark, Bishop, Bayley, Lort, Jopes

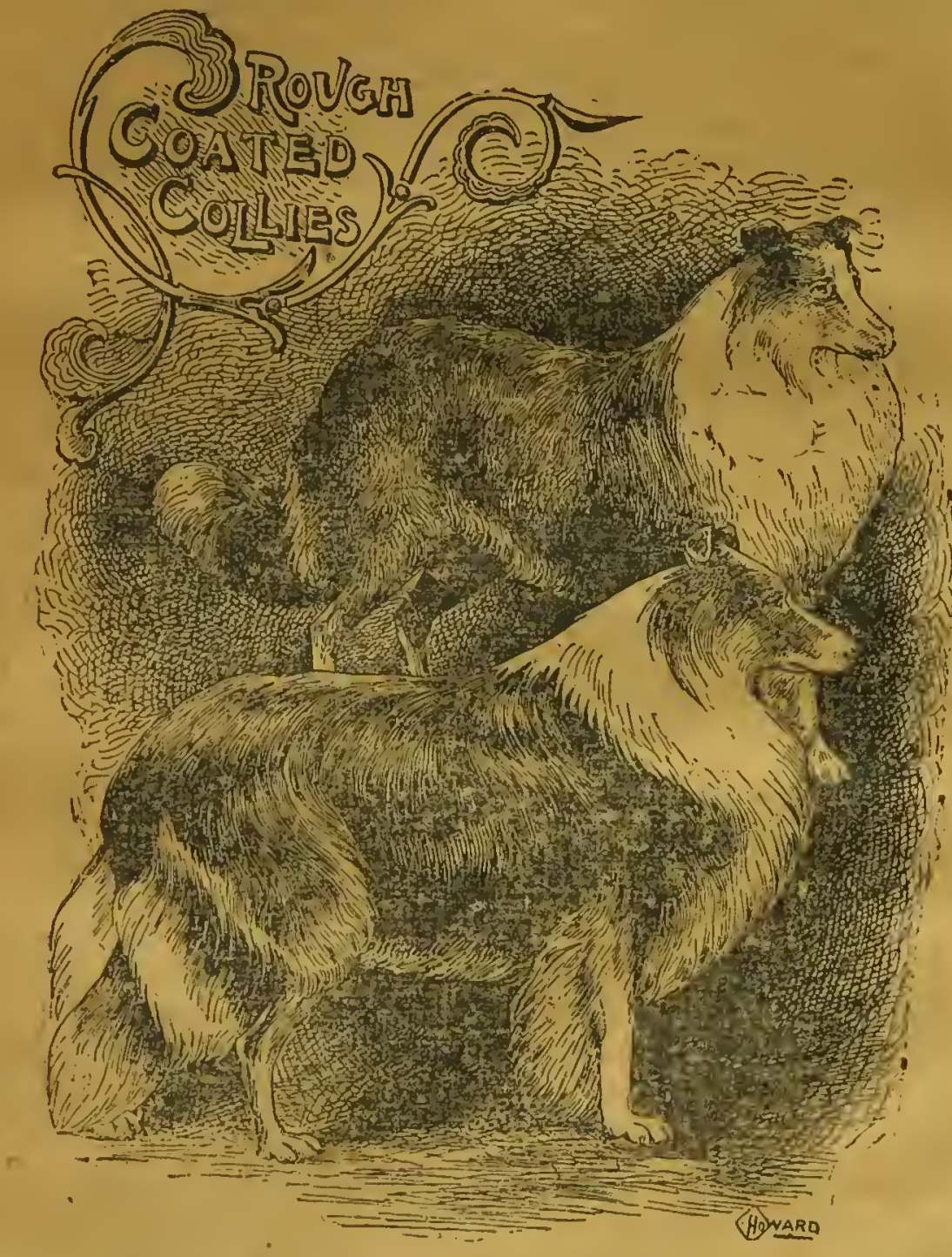

Farkett and Macdona, are noted in England for their superiority, many of these gentlemen using the Lavarack blood in order to obtain that which they desired in a good field-dog. The English setter may be thus described ? 
1. The skull differs from that of the pointer in not having the squareness of the latter named, does not possess the occipital boue to so large au extent, is narrower between the eyes and lias a smaller brow.

2. The nose is long and broad, and has au average measurement of fonr inches from the inner corner of the eye to the end. Midway between the end and the root of nose there should be a dip or depression; a straight one is admissible, but there nust be no' hump or rise.' The nostrils should be well open, and in health moist, the color black or livel-colored, but there exists many a pink or flesh-colored nose, carried by a setter of fuc scenting powers ; using a well-kuown saying in this connection, "a good horse may be of any color," the most preferable shades, however, are the first mentioned.

3. The ears are shorter than those of the pointer, well set back and droopiug towards the neck, and of finer texture, or "leather," as it is called; the eyes full and rounded, and the best color brown or dark hazel.

4. The neck of the setter is more slender than the pointer's, aud set into the head without any prominenee at the base of the skull.

5. The shoulders sloping and elbows well down; chest deep and roomy.

6. Back-quarters and stifles. A curved loin is desirable; but not to snch a degrec as to present a sway back appearance, stifles bent well so that the after legs may be thrown well forward in running.

7. Legs and elbows should be straight, with no inclination to turn in. The arins well boned and nuscled with strong broad knees and short pasterns.

8. The feet weil clothed with hair between the toes, yet not too long so as to accumulate inatter in wet and snowy weather.

9. The tail should be slightly curved from root to tip, tapering to a fine point at the eud and furnished with long silky hair, without a vestige of curl.

10. The quality or texture of coat in the English setter is soft, silky and shiniug, without auy teudency to curl, fringed ou the hind legs as well as the fore.

11. The English setter may be of any color. The following shades are in order the most fashionable:

White with black mottles so as to appear-blue; first with tan marking on the eliecks and.over the eyes, and second withont it; black, white and tan, black and white, orange and white, lemon and white. orange and lemon mottled, and lastly liver aud white, and liver flecked.

\section{TIIE IRISH SETTER.}

This breed of setter is one of the oldest in Great Britain, deriving its name from the island where it originated. - Yet it is now extensively bred in Fngland, and has many admirers on recount of its bold, dashing and untiring disposition in the field. It is rather more diffieult to breals than the English 
setter, and requires constant use to keep in hunting trins. It differs from tha English dog as follows:

1. The head is longer and more narrow, and the oceipital bono almost as prominent as that of the pointer.

2. The uose is longer and square at the end, of a decp mahogany or flesh color.

3. Eyes and ears. The eyes should be dark brown; ears long enough to almost reach the end of the nose, and morc tapering than the English dog's, yet never pointed, and well set back.

5, 6. The Irish setter stands higher than the English; his clbows, notwithstanding, wel' let down; his shoulders long, brisket deep and narrow, and his ribs not so long as those of his cousin. Loin slightly eurved, strongly fastened to his hips, but not wide, sloping quarters, and tail set on low but straight, finely tapered and carried with boldness.

7. Legs straight as an arrow; hoeks good; bent stifles, and strong but not too heavy haunches.

8. Feet harelike, not as hairy as the English setter between the toes.

9. The tail oruamented with a long comb of hair, not bushy or heavy; no curl.

The coat of the Irish setter is coarser than that of the English dog, wavy, but not curly, and by no means long; hind legs and fore legs well fringed, but not heavily, the ears covered with feather, with a tendeney to wave but not eurl.

12. The color is a rich, dark red, without the least trace or tinge of black either on the head or back. A speck of white on the neck, breast or toes is admissible; not too mucb, however, is seen in good strains.

In the field the Irish setter is most encrgetic, never tiring. His nose by some is considered not quite so delicate as the English dog's. $\mathrm{He}$ is fast and stylish in his movements, and has many admirers who prefer hin for single work. The In Touche, Hutchinson's, and the Knight of Kerry's strains aro most noted in England.

Plunket, a celebrated Irish setter dog, combining the La Touche, Hutchin. con and Hon. D. Plunket's breeds, is now owned in this country.

THE IMACK-TAN OR GORDON SETTER.

The black-tan or Gordon setter derives its name from the faet that the Dukes of Gordon, in Seotland, bred and for a long time owned setters of this color. The breed has ncver attained great notoricty in the field, being withoul doubt deficient in nose when compared with the English and Irish setters, and not having the intelligenee of either. 'The Gordon is apt to be gun-shy, stub. born or mulish. Many writers suspeet a dash of the eolly or sheep dog bloorl present in the breed, and clarge his color to this eause. Others dcclare it to 
have been brought about by a eross of the hound at some remote period. Cers tain it is, the Gordon setter is fond of hunting the rabbit; in fact, always shows a liking for hair. With all his beauty he is not a favorite with the experienced sportsman in England or the United States.

The points of the Gordon setter are very nearly the same as those of tho English dog, execpting the following numbers:

1. The head is lieavier.

2. The nose is wider.

9. The "flag" is sliorter.

11. The eoat is liarsher than eitler the English or Irish setter, and soma tines eurled.

12. The color is insportant; the blaek should be deep with a plum shade in some lighlsts and witlout tan hairs; the tan of a red shade, and not fawn-like in color. Gordon setters were originally very often blaek, tah and white, but of late years only a little white is allowed, and this must be on the neek, chest, or on the toes, in this elass at dng shows. The tan should show on the lips, cheeks, throat, over the eyes, on the fore legs to the clbows, on the hind legs to the stifles, and under the tail, stopping short when eoming to the blaek, the line of eolor being well defined.

The most noted strains of Gordon setters are those bred by Messrs. Coathy and Barelay Field in England.

TIIE NATIVE SETTER.

Very little need be said of the native setter, as he is a direct deseendant of bath the English and Irish dog, or in other words a cross or admixture of many fumilies of both. So great has been this admixture and we are sorry to say pointer blood is many times a part, that our own dog, speaking in general terms, has few elaracteristics to partieularize him. No system has been followed until late years in the breeding of the setter in America, but lovers of this dog are now endeavoring to reaeh the English standard of excellenee in using the blood of the Lavarak, Llewellyn and Maedona, for this purpose. It is astonishing when we observe the carclessness with which breeders of the United States have niade their choiee of sire and dan, that we are able to find so miny gool field-dogs of American breeding. In Delaware, Maryland and Virgini:, setters of good quality and fine ficld performauce are often come across, but in eomparison with the English dog, they are coarse and lunbersume. No desipiption is needed for the native setter; that of the first described will auswer every purpose.

THE DROPPER.

The dropper is a cross between the setter and the pointer, sometimes pos. 
sessing the long siiky hair aud feather of the former, and not unifequently the sliort satin-like coat of the latter, but often times having a texture between the two. It is an error to suppose by breeding the setter and pointer together one can obtain the good qualities of either or both. By unions of this nature it is seldom a good animal is obtrincd, yet it is true the offspriug may sonetimes turu out fair field-clogs, but their dispositions are never such as are desired, they are cross and sullen, and if good workers on game, headstrong, self-willed and unable to transmit such goud traits as they may possibly have to their progeny, whether bred to either a pure setter or pointer. The majority of native setters owe their poor quality to introduction of pointer blood; but of late years we are glad to be able to say our sportsmen aud breeders are opposed to the eross, and the dropper is not looked upon with favor. We eannot see why it is when such fine specimens of eaeh race can be so readily obtained in all purity, that the abominable admixture is ever indulged iu. A description of the dropper is not needed.

\section{TIE POINTER,}

The modern pointer is deseended from the Spanisl dog of this name, introduced into England nearly three centuries ago, and is so improved by judieious crosses, that the heavy, slow and awkward appearance of the latter is now entirely lost, and we have instead a quick, aetive and invaluable dog for field work. The pointer fiuds and points lis game similar to the setter, ereet and rigid, his short hair enabling him to huut on the prairies where water is searee and to eontinue without this neeessity for a mueh louger time. In New Jersey, Delaware and Mraryiand, and in eountries where the quail invariably takes to briery thiekets when flushed, the pointer is at a disadvantage, and in eold aud rainy weather he suffers greatly on aeeount of his short cant. Nevertheless we have seen them so highly strung and ambitious as to worle wherever desired at a risk of injury to thenselves. The modern pointer lias been brought to its present state of perfection by crosses of the fox hound to give him additional speed and nose. He differs greatly from the setter in being furnished with a close, eompaet, short and fine eoat of hair lying elose to his skin; the better lie is bred the more satin-like it beeomes.

The pointer also differs from the setter as follows:

Head noderately large; wide in proportion to its length, witl high forebead. Eye of nedium size, muzzle broad with square outline not reeding as in the hound; "flews" not very pendent; ears not set baek so far as the setter's, also more rounded and less drooping.

The head should be set well on the ncek with that peeuliar rise at the baso where it is joined, only seen in the pointer. The neck should not be too wrinkled or have too mueh loose skin visible under it, whieh gives the dog a "thronty" apyearauce as it is called. "Ihe body of good lengtl, strong loins, 
THE DOT.
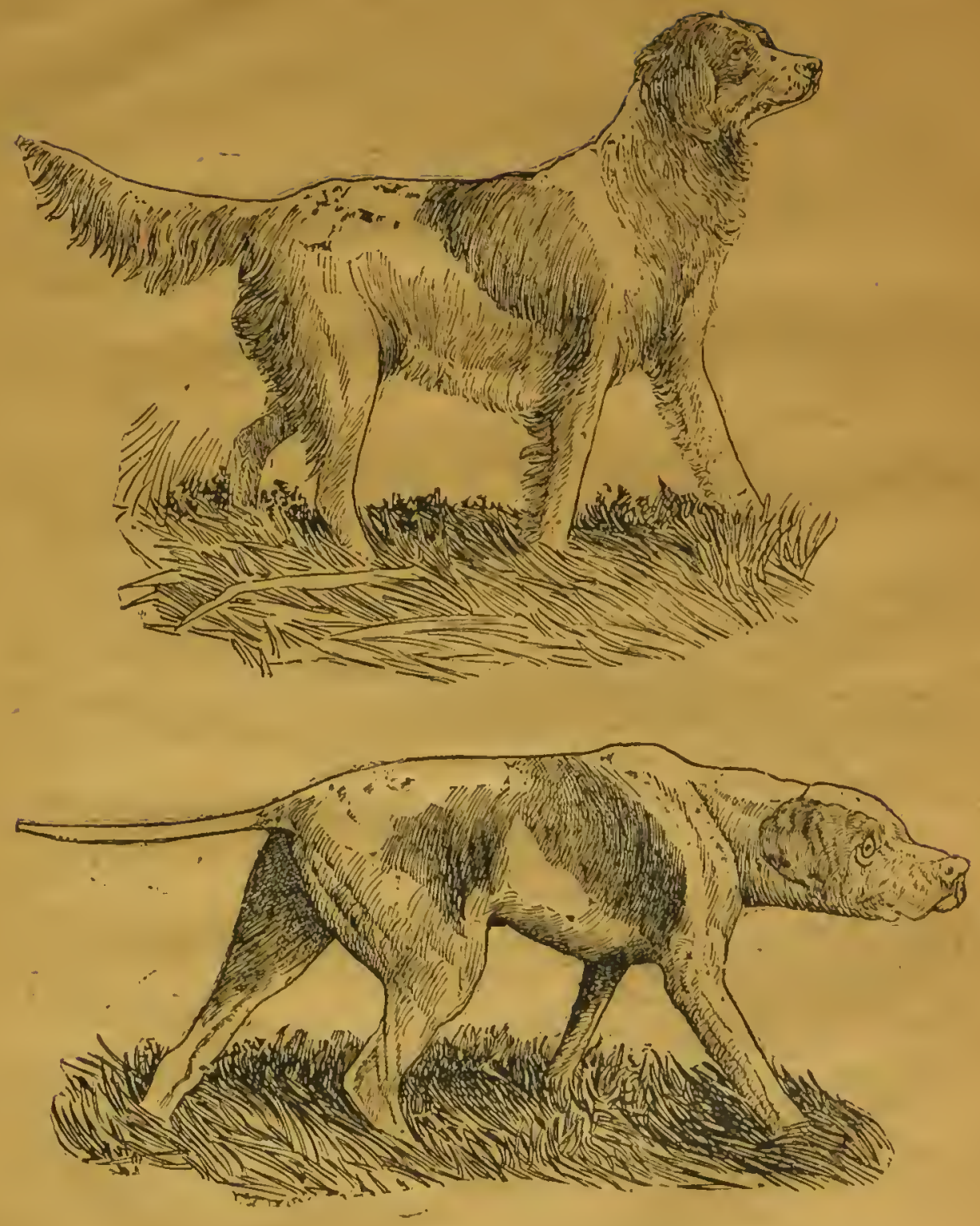

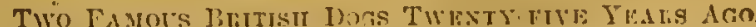

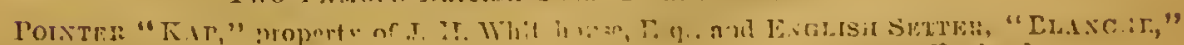

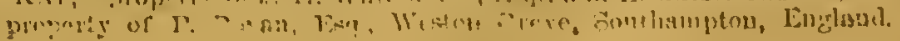


and hips, and arehed ribs, eliest low and not sharp as in the greyhound; the tail is strong at the root and quielily diminishing becomes fine, and then tapers to a sharp point at the end; a thick and chubby tail shows want of loreeding. The shoulders are points of importanec, and must be nuscular and united to a large upper arm. The clbow sliould be well let down, and the fore arm short. The leg of the pointer must have good bone musele and tendon, a strong lince, a round foot well proteeted with a thick sole. Stifles well bent large hocks, and the hincl feet of the same charucter as the fore feet. The color always mainly white, the more the better if liver or lemon markings are present. White with black, liver, yellow, or lemon-colored heads ne most prized, althouglı solid shades are quite common, especially the liver. Some pointer's have tan markings on the eheek and over the eye, but this is considered as indicating too mich fox hound bloor.

The pointers of Germany and France are inferior, being coarser than the modern English setter; a few reach this country.

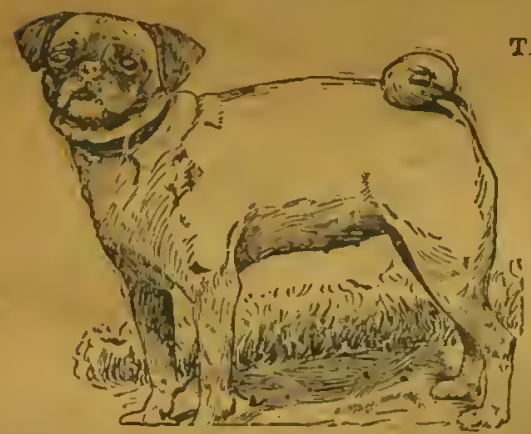

TIIE SPANIELS.

Under this heading we slall only place and deseribe the Clumber, Sussex, Cocker and water spanicls as counterdistinguished from the toy spaniels. The Clumber and Sussex are seldom met with in this country; the former is even rare in his own. The cocker being of so many varieties, anl differing so in appearance, it will be diffienlt FUC, "HA UaPTY MingE." (Imported.) to give a minute deseription of him. II: Property of Mr. E. C. Nims, Palnsvilie, Obla is the most common of the four, however, in the United States, and tlie best known.

- He is used to find and flush his gane to the gun, never pointing at, but indicating its near presence by low whimpering at first and by short quiek barks when it is on the wing; for this reason it is trained to work within twenty-five yards of the shooter that the bird may not be put up out of gun-
shot.

In general he is a light, active dog, of 14 to 20 pounids, of a very lively and spirited nature. He hunts rapidly and carries his tail klown, working it vigorously all the time. The eye is medium in size, boly fairly long, and his shape much resembling the setter. He is clothed with a soft, wavy coat of hair, not curly, as it would then indicate water spanicl blood; the coeker is well fenthered. The colors are solid liver, black, black and tan, white and blaek, white and liver, white and red, white and lemon. He is higher on the leg than the Clumber or Sussex in proportion to his size, and very much nore act $^{2}$. It has been the custom for a long time to cut off nearly one-half of 
the tail of the cocker spaniel that it might not be worn sore by eonstant motion in the thickets while hunting.

\section{THE CLUMBER SPANIEL}

Is a long, low, and heavy dog for his sizc, wcighing 30 to 40 pounds. The head is heavy, much rescmbling the sctter, but more angular. Body very long and strong, clothed with wavy hair not too thick. Tail bushy, but not woolly. Shoulders wide apart, arms short but strong, clbows not well let down, plenty of bone. Colors always ycllow and white, or lemon and white. In motion the Clumber spanicl is slow and deliberate; he has the most exquisite scenting powers, trailing and flushing his game with unerring certainty, working wute, and gives no notice that the bird is on the wing.

\section{TIIE SUSSEX SPANIEI}

Differs from the Clumber in shape and color. In height and weight they are much alike, and also in general character of head. In length, however, he is not as remarkable, yct he may lie called a long dog also. He stands higher in the legs than the Clumber, but not so high as the cocker.

The coat is nearly the same in 'exturc, being soft aud silky and frce from curl. The head is not quite so bieavy. The color liver. Legs and fect strong and wcll feathered. Tail cropped as with the Clumber and cocker. The Sussex spaniel indicates ty voice the rise of the game he lias beeu trailing.

\section{TIIE WATER SPANIEL.}

Head.long and narrow, eyes small, cars of medium length covcred with crimpy, curly hair. Body stout, loins strong, and round clicst, broad across the shoulders. Fect large and spreading. His body is clothed with very curly hair. Tail curved. The water spaniel, as his name would indicate, is much used as a retriever for duck-shooting, espeeially that of marsh, upland, or fresh water fowl. He is often crossed with the larger variety of cocker,

TIE NEWFOUNDLAND DOQ.

There are two varieties of the Newfoundland dog met with in this country. 1st, 'The large long-haired varicty, called the large Labrador. 2d, The small compact, comparatively short-liaired dog known as the St. John. Both were originally natives of Newfoundland, and are alike good water dogs, and can remain immersed a long time; but the large variety possessing a inore woolly coat is hardicr. The characteristic points of the large Newfoundland are great size, say from 25 to 30 inches high, form strong and stout. The head not large in comparison to its size; wide across thic eycs. Muzzle. of moderate length, wide, aud without "Đlews," as in the hound. Eye and ear small, neck 
short, clothed with a ruff of hair; tail curled. Coat long, st aggy, and shining, without very much admixture of wool. The color should be black, though sumetimes it is black and whitc, or white with a little blacl: or liver colcr or reddish dun.

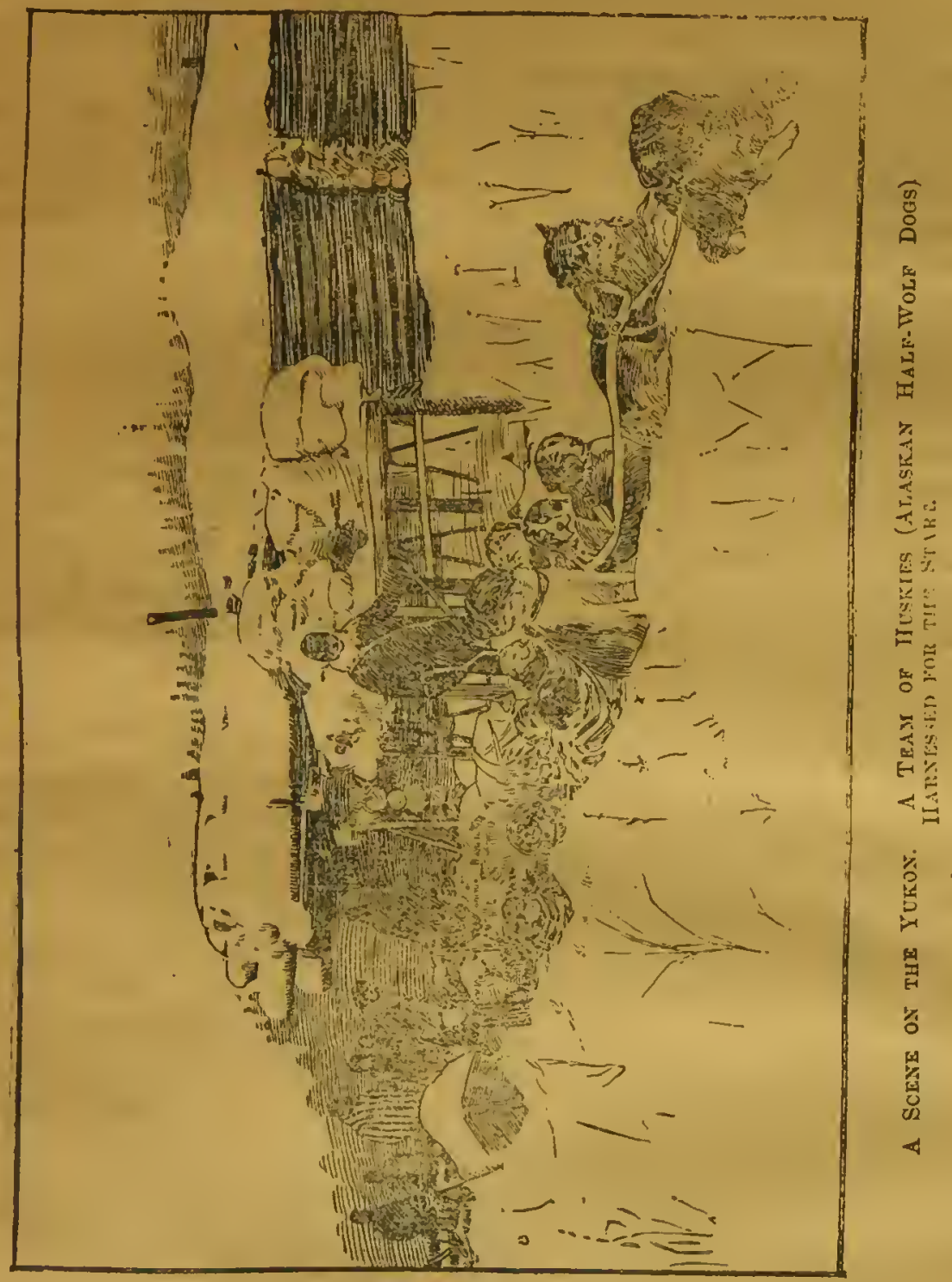

The St. Johns, or smaller Nicwfoundland, is seldom more than 25 inchea kigh. 'The head is larger in proportion to his sizc, and the cur fuller, neck bsoger, borly far more compact and clothed with shorter hair. In color he 
always jet blaek. As a watch dog the Newfoundland is valuable, becoming much altached to his owner and home, but as frequent bathing is indispensable to his health he is not a desirable animal for the farmer uuless a goud strean or pond is in elose proxinity.

\section{TIE MASTIFГ.}

The mastiff is a commanding and powerful animal in every respect, and although possessed of hight courage, his temper can be more relied upon than any of the large dogs. He makes an admirable yard dog, and will proteet his master's property with zealous vigilanee. In England he has been known for many years, and old works give cuts of this breed scarcely changed in characteristies from the modern animal. $\mathrm{He}$ is doubtless indigenous to Great Britain. The Cuban mastiff is much like the English dog, but shows that he has been erossed

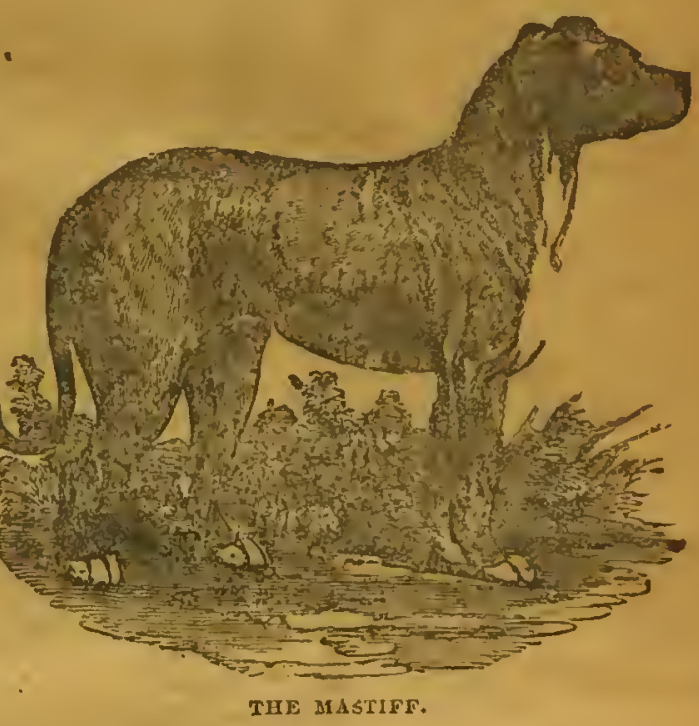
with the bloodhound. The points of the nastiff are: $\Lambda$ large head, partaking of the shape of the bloodhound and bull-dog, with great nuscle, and having, to a great cxtent, the hanging upper lips of the hound; ear small, drooping somewhat; eye small. In shape lie resembles the hound; but is much more compact and with moro bone. Loin well knit and strong, limus powcrful, tail rough and carried over the back. Tone of voice loud and decp, coat smooth, color red or fawn, with dark, or what is preferred black, muzzle, or brindled or black, or black, red, or fawn and white; height, 30 to 34 inches.

The Mount St. Bernard dog is closcly allied to the mastiff, but has the appearance of having Newfoundland blood in his veins, with the nature and desire to fetch and carry of the latter. This dog is used by the monks on the Alps to rescuc snow-bound travelers.

TIE BULL DOG.

The bull dog is one of the oldest known breeds native to Great Britain, and has always bcen deseribed as idiotic in his ferocity. This is a mistaken idca 


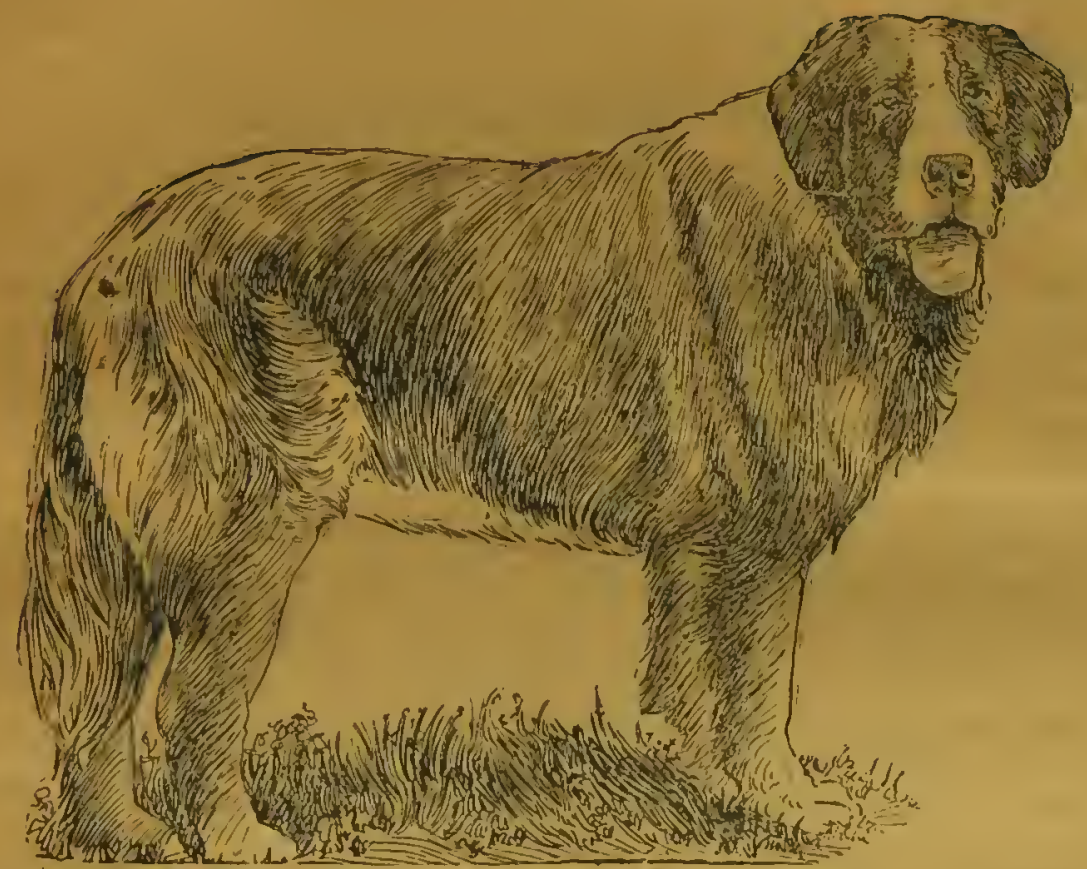

St. Bersati Champos, "Sir FTHedwoon."

Property of Mr. Jins. J. Shenlunoks, lialtimore, Md.

Dr he is not at all quarreisome when pureyy bred. The bull mastiff, however, $n$ cross of this dog, and also the bull terrier, are pugnacious in the extreme, and excel in this respect owing to their training. The bull dog undoubtedly

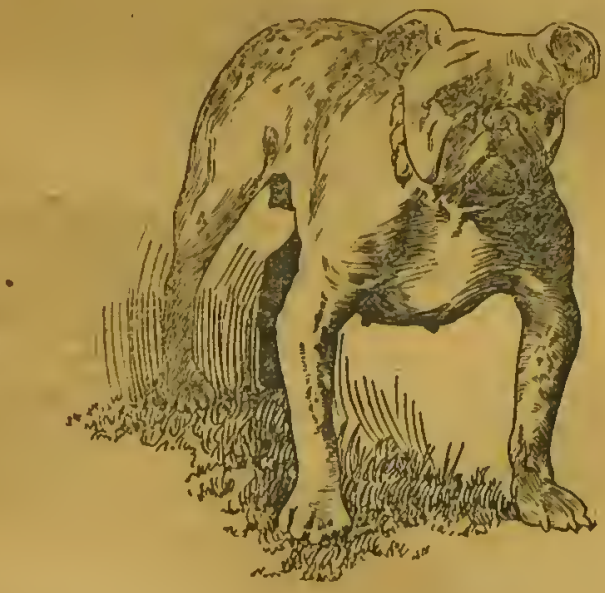

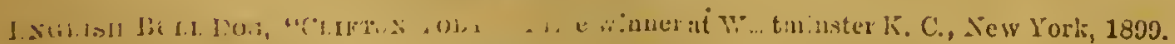
l'sopriy of Mr. lobent s. Mecruery, of New lork. 
has been used as a cross merely to obtain his very museular and compact frame, and not for a disposition to combat. The points of a well-bred bull dog are as follows: Hcad round, skull high, eyc of moderate size and forehead deeply sunk between them, ears partly erect and diminutive, growing from the top of the head and close together; pose short, and having good cliops ; back short, somewhat arclied towards the tail, which in well-bred specimens is fine and of medium length. The coat is always fine, the cliest deep and broad, legs nuscular with good boine, and the foot hare like. The bull terrier, as his name would indicate, is a cross of the English terrier and bull dog, and has the muscular frame of the last combined with the activity of the former. Having been almost exelusively used and trained for fighting purposes, this breed of dog by such cultivation has become irascible to a high degree, and is now most noted for his muguacity.

\section{TIIE BLOODHOUND}

Derives his name from the power he possesses of following the scent of wounded animals, and to single out from a number of deer onc that has been crippled and hurt, and to stick to his trail until run down. The true bloodhound, as he was bred years ago, does not now exist in Great Britain. The treed is doubtless extinct; but in Cuba and in the Southern States a dog less pure is used for lunting the deer and following runaway negroes, much resembling the old English bloodhound, and is still plentiful.

The following are the points of this dog. Height 24 to 26 inches, long and narrow head, ears 7 to 10 inches, lips low hanging, throat pendulous with plenty of skin. Deep brisket, body round, broad loins, stout lcgs, straight feet and powerful thiglss, tail fine and tapering.

Color black and tan, red or fawn. No white slould be seen exeept on the tip of the tail.

The texture of the bloodhound's coat should be coarser than that of the pointer's, yet smooth and glossy. His voice low aud deep, with much meludy. Disposition very courageons, yet kind and gentle.

\section{THE FOX IIOUND}

Differs from the bloodhound in being not quite so tall. Height should be 20 to 24 inches. Hcad smaller and fuller in comparison, lips low, hanging, but. with not quite so much "flew," lcss loose skin about the neck, or less "throaty" an appearance. Legs nore eurved, and shoulders more oblique and better formed for speed. The ears of the fox liound in England are always cropped or rounded off at the ends; if allowed to grow, as they are in this country, they would be low and hanging. The fox hound, otherwise than the above differences, resembles the bloodhound. Those unet with in the United States seem to huve becn crossed with the blopdhoupd of tho Southern States, and show 
1:1 yy of his characteristics. In fact, so diverse are the different strains in Air.rica that the dog might be called another breed than the English. The curt of the fox hound is close, and likewise not so short as that of the pointer's ;

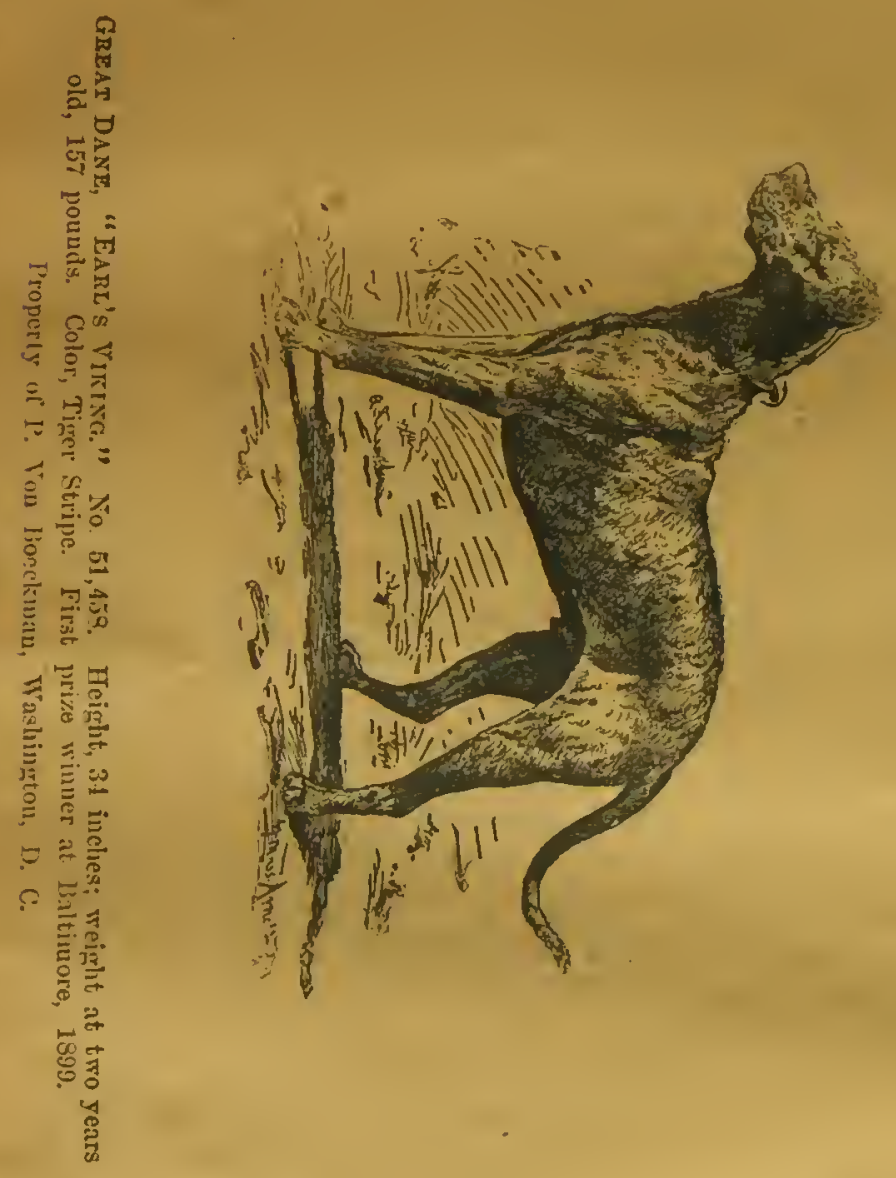

he ourries his tail high as he runs, and it is oftener fringed with longer hairs approaching a featlecr. Colors: 1st. Blaek, white and tan; 2d. Pied, as red 
pie, bluc pe or yellow pie, gray pie, lemon pie; $3 \mathrm{~d}$. Black; 4 th. White; 5 th. Red; 6tl. Bluc.

He trails quickly, and is speedy and of great bottom, and in this country frequently used for rabbit hunting.

\section{TIIF BEAGLE.}

The beagle hound of a century back has been almost entirely displaced by the dwarf fox hound, or a cross of the sinall bengle with the fox hound and harricr. In this country they are found of many sizes, and may be styled the aivarf medium, and the large beagle. He can be appropriately termed a pocket edition of the fox hound, and resembles him very much in appcarance.

He is used almost exclusively for rabbit hunting, trailing at a noderate pace with a true nose and musical voice. The dwarf beagle is now scarce even in England, and should mensure not higher than 9 to 16 inches. The mediun , beagle measures 12 to 20 inclies high, and the deseription given can be taken as a type of all. Head wide and round, short nose, drooping and full ears, body that of a diminutive fox homd, and eolor of the same shades.

\section{TIE SHEEP DOG.}

The English sheep dog is found of many varieties, and so different are they, that we can only dwell upon the main cliaracteristics of the leading one. He has a sharp nose, medium size liead, small cyes, and well-shaped body covered with thick and almost woolly hair, growing full and strong about the neck and breast. Tail long and bushy; legss strong, and feet protected with hair for work on stony roads and hills. Shecp dogs are always found with dewclaws. Color grey, or black, or brown, with more or less whitc. Weight about 50 to 60 pounds.

The colly, or Scotch.sliecp dog, has a broader head, which gives his mozzle a sharper appearance than the English doer. His cye is lilicwise small, but his ear is slightly more pricked as a rule. His tail is long and bushy, and his form a little stouter than the Euglish shepherd dog's. Color always black and tan with little white.

\section{'THE GREYHOUND.}

This dog has also been known in Great Britain for many generations, and has always been used for coursing the hare, or in other words to run down his game by sight. His head is very long and narrow, neck slender and duelilike, as it is called, back strong, tail long and ratlike, gradually turning upward as it begins to taper, hind quarter's greatly curved, and shoulders oblique, showing great fleetness. A good measurement for the greyhound would be as follows: circumference of head between the eycs 14 to 15 inclics, length of nesk 10 inches, circumference of chest 28 to 30 inches, length of arm 9 iuches, 
length of knee to the ground $4 \frac{1}{2}$ inches, eireunference of loin 18 to 19 inches, length of 11 pper thigh 101 inclies, lower thigh 11 inches, leg from hock ta ground $5 \frac{1}{2}$ to 6 inches. Color black, blue, red, fawn, briudled and white. Coat short, fine and glossy.

The Albanian greyhound resembles the English in form, and like him in every particular cxeepting that he has long and silky hair.

The Persian greylound is coated like the setter, and the rough Seotel greyhound, or deer hound, is also in every way forned like his English brother, but elothed with rough shaggy hair, and uses his nose to trail his game, while almost all the other greyhounds hunt entirely by sight.

\section{TIIE DALMATIAN OR COACH DOG}

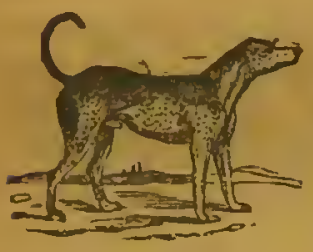

DALSIATIAN DOG.

Stands about 24 to 25 iuches, and very much resem. bles the pointer in form and texture of cout, but is cifferent in color, being beautifully marked with numerous small black spots on a white ground. He is foud of horses, makes his home in tho stable, and is never tired of following the carriage.

\section{THE ENGLISII TERRIER}

Is a smoothly-coated animal weighing 6 to 10 pounds. We are now speaking of the usetul dog of this breed, and not the dininutive toys that weigh as little as 3 to 4 pounds. His nose is long and tapering, cye bright and liquid, ears well set on, and when not trimmed are slightly raised, turning over at the tips. High forchead, flat skull, and strong jaw; neek strong; body well shaped, loins powerful for his size, chest deep and not too wide; shoulders freo and very powerful to enable him to dig well; fore legs strong and straight, bone light; tail fine and tapering; color black and tan.

\section{THE SCOTCII TERRIER}

Closely resembles the English in all but his coat, which is rough and wirelike. His habits are the same, being a great vermin rog. He is found in color black and tan and sometimes gray. The skye terrier in some respects is like the Scotch, but differs from him in having a long, weasel-like body, short legs, long wide head, long neek, bandy forelegs, and long straight hair parted down the baek and falling over his sides, coarse in texture, but on the legs silky.

There are two varicties of the skye terrier, one smaller than the other, with the coat entircly soft, and the one we have first deseribed. A very farorite cross is made between the large skye terrier and the Dandie Dinmont, which partakes of the nature and form of both. 
The Dandie Dinmont terrier is supposed to be a eross between the Scotch terrier and the otter hound. He has two shades of hair, one brow'il called mustard, the other blue-gray called pepper. He has silky hair ou the liead, legs short, body long, low slıoulders, paws long, and muzzle tapered, ears largo and hanging, tail curved up. hound-like, and weighs 18 to 24 pounds.

\section{THE POODLE}

Has been known in France, Germany, and England for many years. Ite is notably intelligent and most easily taught, and is fond of the water. In England he was formerly used for retrieving in duels-slooting. He has a large wide head, small eyes, square muzzle, pointer-like body, and eovered with very eurly elose hair, hanging down at some parts in ringlets. His height is 16 to 20 inches. The Barbet, a variety of small poodle, is a native of Frauce seldom seen here

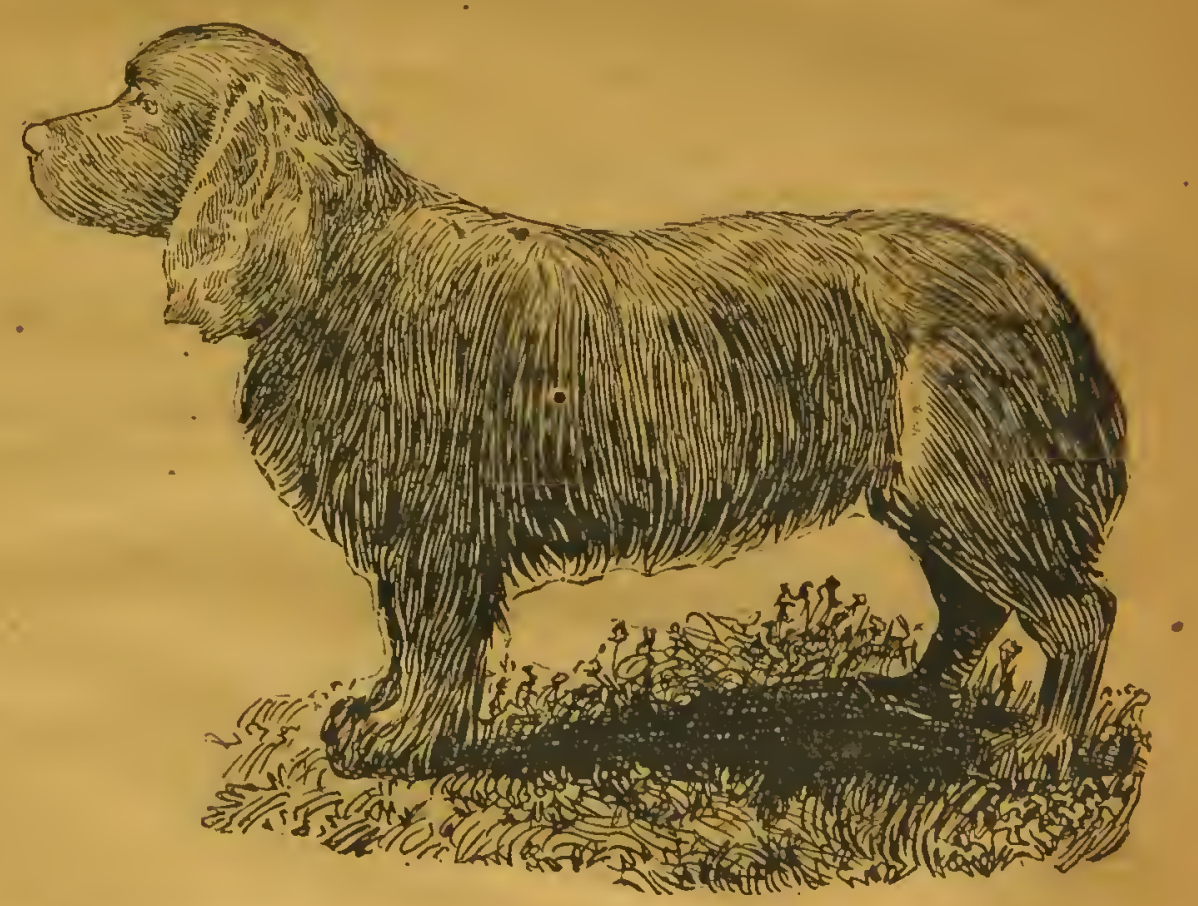

Cocker Spanitl, "Surprise:" No 49,928. 'Chmmpion puppy, 1892 Iroperty of Mr. Chas. S. Mison, of New lork. 


\section{CHAPTER II.}

Choice of Sire and Dax in Breeding-Age to Breed-Time of Fear to Breed-Management of Bitch in Season-Duration of Heat-Management of Bitch in Whelp-Whelping-Care of Whel ps-Weaning-Feeding-Training of Pointers and Setters-Training of Spaniels-Train. ing of Ifounds-Training of Vermin Dogs-To Prevent and to Break from Ciun ShynessHunting a Bitch while in Whelp.

\section{CHOICE OF RIRE AND DAK}

IT is of great importanee that the breeder should choose good speeimens of both sire and dam of the breed he intends giving lis attention to. If settes or pointer, selecting a dog that possesses the qualities or traits that are wanting in the bitch, and which he desires to intensify in the offspring. For instanee, if the dam is of a timid nature, but otherwise having no great funlts, she should be served by a bold, courageous sire; or, if the dog is not as speedy as is wanted, the dam nust be the opposite. Seleet always sueh animals whose breeding is assured, and have proven pedigrees if possible. Ereeding in and in is generally very beneficial, and tends to stamp any partieular family trait more indelibiy in the offspring, but it ean be carried to an injurions extent, and a point will be reaelied when fresh blood must be songht, which being obtained we may go baek to original strain again. It is held by some that the first impregnation has an effect upon subsequent litters by different sires. It is neeessary, therefore, to be eareful in the seleetion of the eross that it will not neutralize the original impregnation or in like manner be neutralized by it. Like produees like in breeding, so in proportion to the purity of the breed will be the qualities transwitted to the whelps.

\section{AGE TO BREED.}

Most bitches are of an age to breed before they are a year old; but it is advisable to wait until the appearanee of the seeond heat, and allow the first to pass without giving her the dog. At one year old small dogs ean be permitted to breed, for at that age they will have reaeled the period of the seeond heat. Setters and pointers at 15 to 18 months are perfeetly matıred and in proper development, but the mastiff and other large dogs, not attaining their full growth until they are two years old, must not be bred until that age.

TIME OF YEAR TO BREED.

Spring and fall, if not too early in the first and too late in the last season, 520 
are the best times of the year to allow dogs to breed. If puppies are whelped in the spring they have ample time to grow and be able to stand extreme lot weather, and if in the fall they will have attained a size which will enable them to better endure the winter's cold. The majurity of bitches come in season soine time in the spring or summer; by allowing a summer "period" to pass without serving, the next will very probably come around during the spring following, when the dog can be allowed. The bitch after this serving will bo likely to be regular in the leats.

\section{MANAGLMENT OF TLE BITCH IN SEASON.}

- Bitches, when in season, should be confined so that no dog but the one cliosen may come to her. This frequently causes ill-health, and will have an effect upon the whel ps unless regular exercise is given (on the chaiu if necessary), until the period has passed.

\section{DURATION OF MEAT.}

A bitch is in heat about three weeks; the first week she scareely ever willingly accepts the dog, and at this time bleeds from the vulva. Not until this bleeding has subsided should she be lined, and then no time should be lost as desire now soon begins to pass away, and continues gradually to do so for the balance of the trueuty-one days. It is a mistaken idea that the sex of the whelps can be regulated, by the time of the heat the dog is allowed to go to the bitch. There is no surc rule to follow.

\section{MANAGEMENT OF BITCH IN WHELP.}

A bitch from the time she conceives will run from sixty-three to sixty-five days before she gives birth to her litter. As soon as it is discovered that she is in whelp the exercisc begun as directed should be kept up and rather increased daily. Her food now should be soft, yet nutritious, and easily digested, such as thickened soups, oatmeal and boiled nilk; oatmeal with lean meat, miuced finely, mixed with it. Care being obscrved that her bowels be liept open. If costiveness shows itself a dose of castor oil or salts may be given.

\section{WIELPING.}

As soon as the day for whelping arrives, a quiet, clean and comfortable place should be provided for the bitch, and she should be left entircly alone, nature being her best assistant, unless something wrong takes place or nalformation shows itself. While in labor and betweeu the throes (it may be she will be the whole day in whelping) no food is required. She must be kept as quiet as passible. Some nervous bitches are apt to devour their puppies if 3 isturbed at this time. After all is completed a luke-warm gruel of half milk and half 
water may be given the mother. Nothing cold should be placed before her. After the first thirty-six hours the bitch will of herself leave the whelps to empty herself; from this time stronger and more nutritious food can be given,

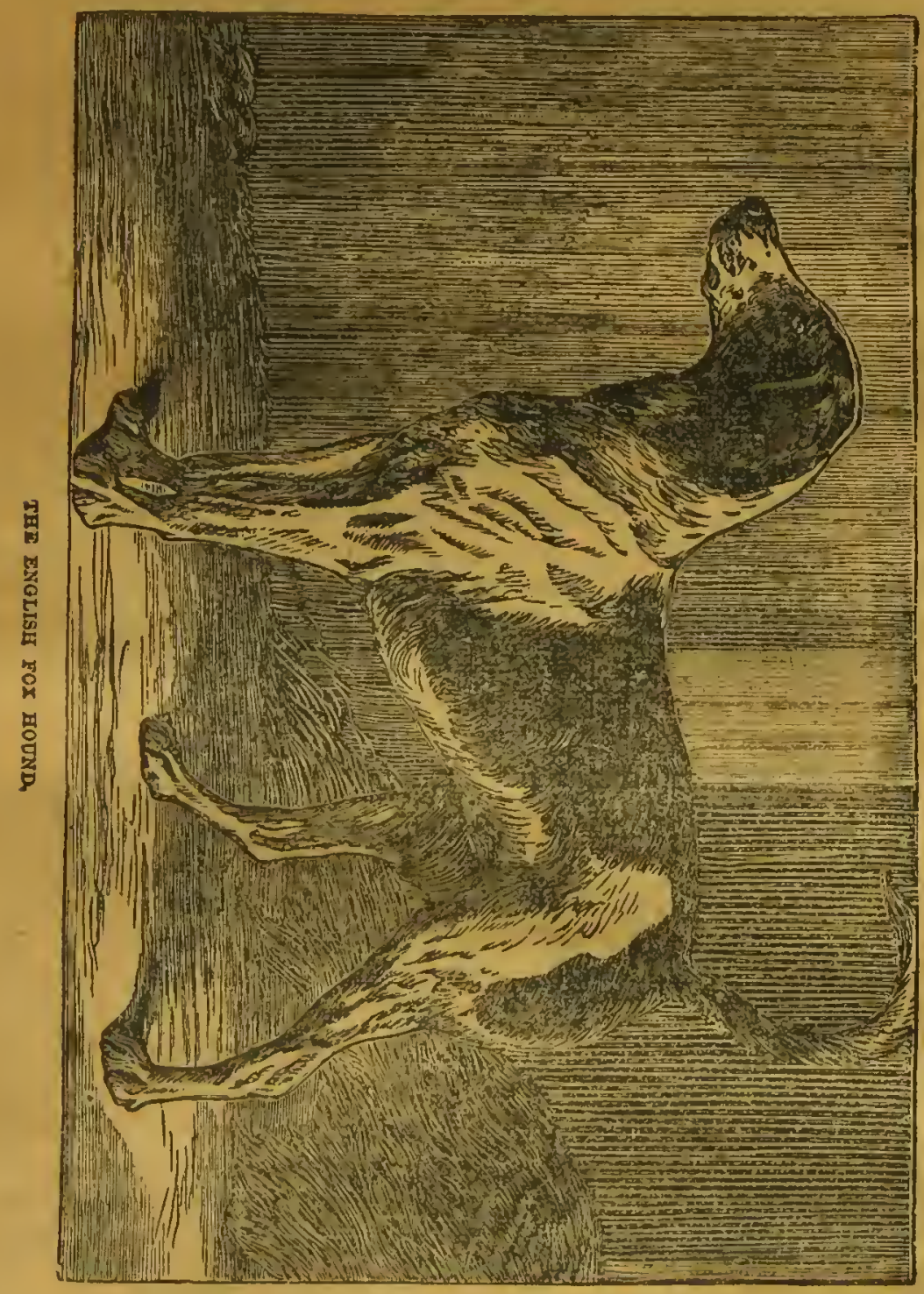

abundant milk allowed, and the most nutritious diet provided to aid her rain: ing her ravenous family.

Exerrise must be now continued, which the mother will be glad to accept 
In about two weeks after the birth of her puppies, that she may have an hour or two of rest daily froin their growing demands and sprouting tectl. She may be allowed to go free.

\section{CARE OF WHELPS.}

The puppies should be carcfully examined for lice and other parasites as won as the bitch will allow you to handle them. If any are discovered the whelps should be washed with a lukewarm decoction of Quassia chips or Persian insect powder carefully rubbed iuto their coat. The bed or nest must. now be changed, new liay or straw being furnished and sprinkled with the insect powder. Nothing troubles and takes away from the growth of puppies more than lice and fleas. Their quarters must be roomy that they may be able to run about and romp with one another, and thus develop healthy bone and musele. At about three to four weeks they may be taught to lap onethird water and two-thirds cow's silk preparatory to weaning.

\section{WEANING AND FFEDING.}

At five or six weeks the puppies niay be safely weaned. They have already learned to lap. Stronger food can now be furnished, the milk given pure, mixed with erumbled bread, or well-boiled oatmeal. Feeding time should be regular and at stated hours tluree times a day, and the dish, trough or vessel containing the food taken away as soon as the youngsters have filled themoelves. After a time food twice a day will be sufficient; say morning and night. As the puppies become larger a bone containing some meat may be given them; too nuch flesh is injurions. A sheep's head thoroughly boiled is capital now and then for then to pick at. It is of the greatest importance that the whole litter should be allowed abundance of exereise, and liberty be given them at stated times during the day. - Pups deprived of exereise are apt to have the riekets or enlarged joints, or be out at the elbows.

\section{TRAINING OF POINTERS AND SETTERS.}

In choosing a puppy from a litter of well-bred setters or pointers it becomes a diffieult task which to determine upou. If possible wait until they have attained the age of four or five months, by which time they have become comewhat developed. Sit down where you cals see them all together, and notiee which is the most active aud intelligent. The overgrown mother's pet, generally the strongest of all, is frequently lazy, and sleepy, and slows but half the spryness of his sualler brother or sister. Select a puppy with a good brain development, such a elaracteristic lolds good with the canine as well as the liuman race. We have never seeu a bad dog with a good head and face. 
Having decided apon a joung setter take him to yourself, and when he is

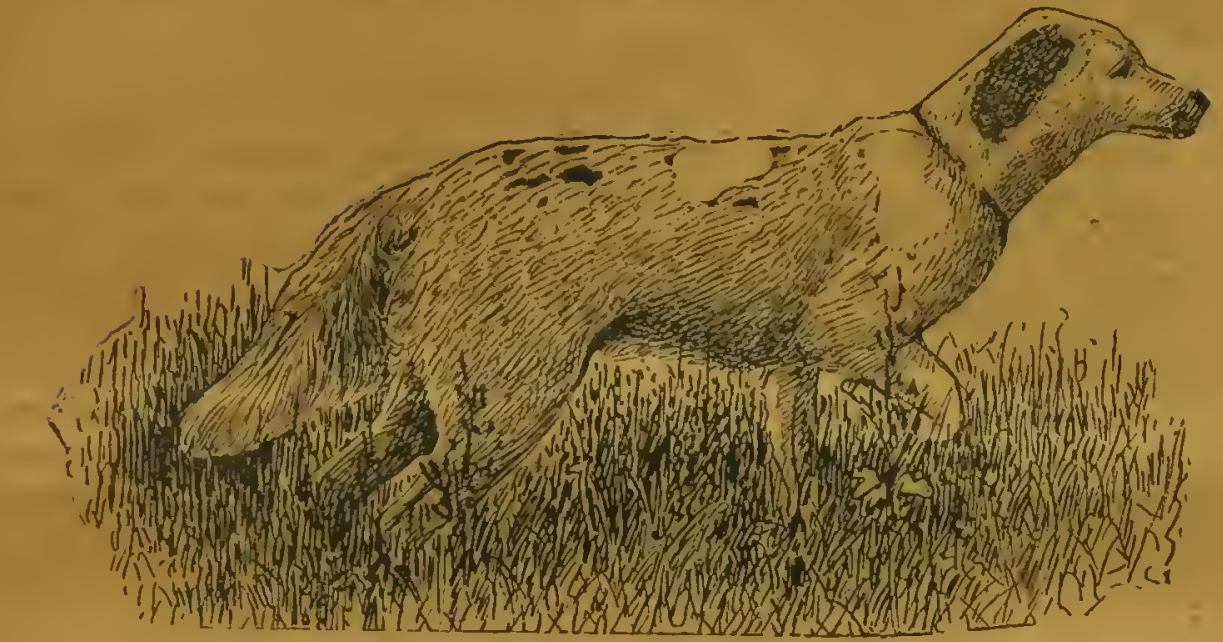

Exalisir Setrer, "Flora Blanneva." No. 61,797. Member of a famous hanting family. Color, xshite, black about the ears.

Picture from photograph while standing fast on a covey of prairie chickens. l'roperty of Mir. Cassian Andrews, of Lirwin, S. D.

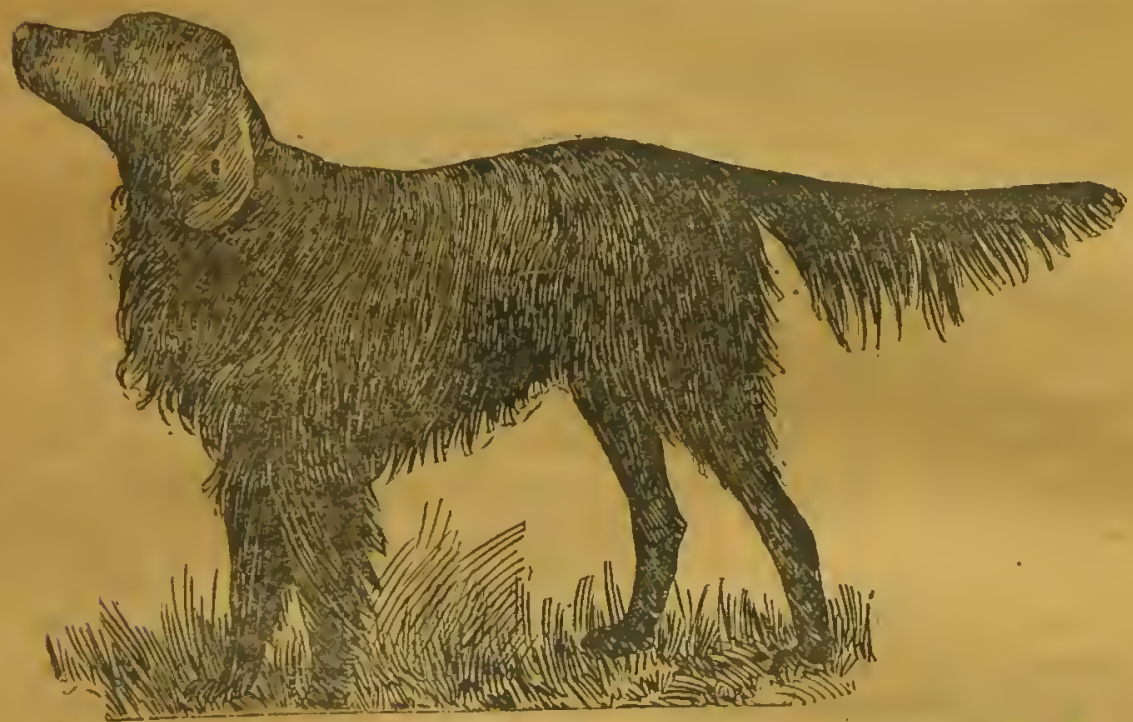

Irign Setrer. "Shamrock O'Mone." I'rize winner at Westminster K. C. Show, Now lork, 1 moy.

l'operty of Miss G. Shippin, New York City.

air or seven wonth eld, eight will do, begin bis primary tuition. Allow no 
one to feed him, attend to this yourself, accustom him to your voice and manuer, let him follow yon on all your walks, and it will soon be noticcable low devoted he will become to you. The dog has a mission to fulfil on earth, that of serving his master, and as soon as he fully understands what is wanted of him it becomes his happiness to serve his owner; therefore study lis disposition and assist him in learning his duty. Never flng cruelly and only when you are positive your dog has committed a wilful fault; then be merciful, for many are ruined in spirit by harsh treatment.

Most well-bred puppies will point from natural instinet and take to luuting without tuition, but it is absolntely necessary to impress on your young dog, before taking him into the field, the necessity of pronipt and strict obedience, and for this reason begin at lome with the check cord at an carly age. Provide yourself with some morsels of food, and take your seholar into a room or yard where there will be no one to interfere with the lessons. Fasten a cord four or five yards in lengtl to his collar, and throw a piece of food where he ean see it fall; he will naturally rush for it; allow him to do so, but as he nears it, jerk the cord ant hold him, saying, "Ho," or "Tolı" in a commanding tone. Practise lim in this inanner for an hour cach day until he will stop over the morsel at the coinmand "Toho," without the jerking of the cord. All this will be found a little diffeult, but by patience it can bo accomplished. Never let your temper get the better of you, but he cool, determined and persistent. Care sliould be taken not to alarin your scholar in these lessons, especially if he be of a timid nature; an intelligent log though will learn very soon, and retain all you impart as he understands what is required of him. He should be taught that an uplifted hand is equivalent to an order to drop or charge. After thoronghly scliooling your young dog indoors or in a yard, and when you are satisfied he is well practised in his lessons, take him into a ficld witl a long cord attached to his collar, say fifteen or eighteen yards, and have onc end of it fastened to a stake, which drive firmly into the ground. Begiu again as you did indoors, making him hunt out the morsel of food and checking him with the cord and "Tolıo." You can now begin with suapping a cap on your gun at the monent you jerk him, theu nsing a little powder and incredsing the charge until he finally accepts the report as a command to drop. While he is down walk away from him, make him stay there uutil allowed to rise, then run from him; he may start after you, but the stake will stop him when he comes to the end of the cord, at which time cry "Toho," the moment he is checked. Now walk around him, now from him, again insisting on his being obedient. All this will tend to make your dog steady at the "charge." To teach your dog to return is not an easy task. This idea of fetching should be imparted when the puppy is quite young, giving him a taste for it by tlırowing an old glove from you and having him run after it, until as we have said before he brings it back for 
annther play. From the start in these lessons always repeat the word "feteh," which although not understood at first is eventually assoeiated with the aet and its meaniug remembered. We will now supposc your dog is perfeetly under command, and that by patienee, perseveranee and kindness you liave yard-broken liva.

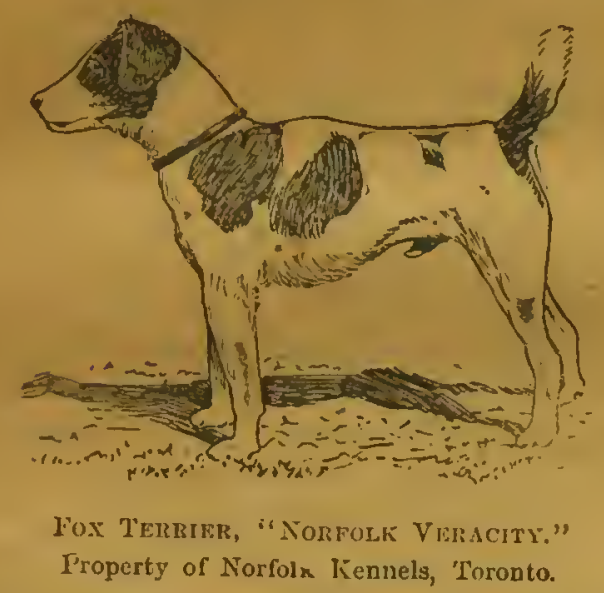

It may be three or four months before you have broken your young dog perfcetly indoors, and practised him likewise in some open field. It is now time to prepare him for real work. If it eau be done, select a country where game is plentiful, and have a friend aceompany yon with an old triegd pointer or setter. When you have reached your shooting grounds, attael a strong cord to your dog's eollar, sueh as is ealled a loom cord well twisted about the diameter of a pencil, and fifteen or sixteen yards long; allow him to range with it trailing after him; the eord will not tangle.or foul as would be supposed. Naturally the old dog will find the first covey of quail, and your pupil will notice the ploint, and if he is well bred will baek; if he does not and is anxious to move forward to the old dog, step on the end of the cold and hold him, saying "Tolıo" or "Ho," which he should be familiar with by this time. Your eompanion must now start the eovey and kill a bird, and his dog should clarge or drop at onee, while you must check your own dog to drop also. Allow the old dog to retrieve, and let the young dog see lim bring it, which when lie has several times observed he may be allowed to do also, having been taught indoors to feteh as deseribed. Continuc thus througliout the day for several days. Too mueh hunting cannot be given your youngster the first season. It would be a good plan to take your puppy out alone during your trip and urge him to find birds on his own account, for fear he may be satisfied to play seeond fiddle; very frequently young dogs whien worked too much with more experieneed animals, learn to be satisfied to baek the other pointer only.

Do not remove the check cord until he thoronghly knows his business and is entirely under your control. The oord is far better than the whip.

TRAINING OF BPANIELS.

Spaniels do not point their game; all that is required of them in trai- 
mg is steadiness, obedience, to drop or down eharge, to work elose to this shooter, aud to retrieve. Therefore, in breaking, the same rules may be observed as those in the education of the pointer and setter, excepting that portion which relates to pointing. Spaniels learn retrieving very readily, more so than any dog, save the poodle. Their training may be begun at an carlicr arre than that of the pointer or setter.

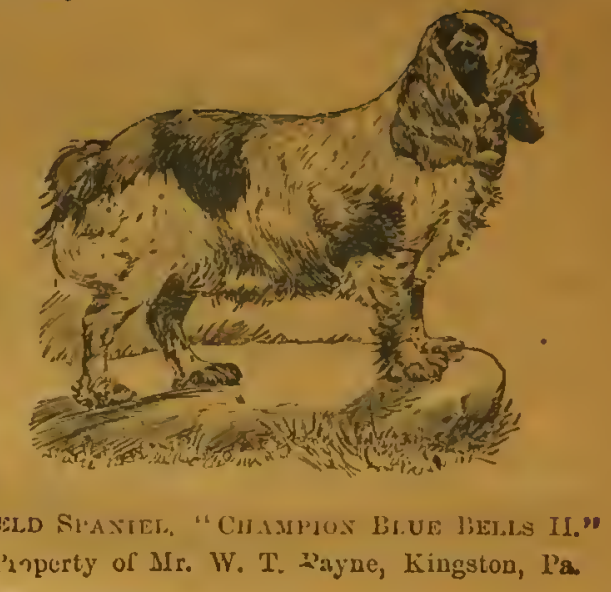

TRAINING OF HOUNDS.

All tliat is necessary in trainiug hounds is to accustom them to the sound of the horn, to break up any riot in behavior, and to have then obey their master. Young hounds will take to trailing naturally when iu company with older dogs. Experience is their best teacher. Beagles are taught that the report of the gun is a call for them to come in.

\section{TRAINING OF VERMIN DOGS.}

Care should be observed not to allow terriers to attack vermin when they are very young, which they will do if allowed, unless they are protected from injury. A good plan to follow is to remove the teeth of a rat and allow the puppy to worry it, or, what is better, give him a mouse 'for his first vietim to kill. A full-grown rat will sometimes so punish a puppy as to render him fearful ever afterwards. Terriers hunt vermin at an carly age, and no training is needed. When wanted for rabbit-hunting, and they are useful for this sport, they soon lcarn from the beagle, with whieh they may be allowed to run.

\section{TO PREVENT AND TO BREAK FROM GUN-SHYNESS.}

It is diseouraging to the sportsman to find his dog, notwithstanding he may be purcly bred, to be gun-shy, or afraid of the report of firearms. To avoid all such dauger, especially if the animal shows himself to be of a nervous nature, he should never be fed unless a pistol was first fired off, beginning with. light eharges and increasing the loads when he began to associate the report? with the pleasure of satisfying his hunger. Then when we are ready to begin to train, the sight of a gun, and the noise made thereby, can be borne.

A grown dog ean be in the same manner corrected of shyness by keeping him with a kem appetite for his meals, and striving to show him that the gun will not injure him, and to associate its report with a pleasure at feeding time. He should be so fed as to be ravenous wheu the hour for his meals approaches 


\section{IUNTING A BITCH WHILE IN WIIELP.}

There is certainly a sympatlyy between the nother and the unborn foetus, and puppies that are born shortly after a bitch has been shot over several times are much easier to break than if she was not worked. They take to liunting and pointing as naturally as a duckling goes to water when hatelied. For two wecks prior to pupping make it a duty, therefore, to run your bitch where there is game and have her point as much as possible; it will amply repay the breeder. In like manner allow hounds to run, and terriers to liill vermin, the more the better, so that your dog does not so, injure herself as to bring on premature labor.

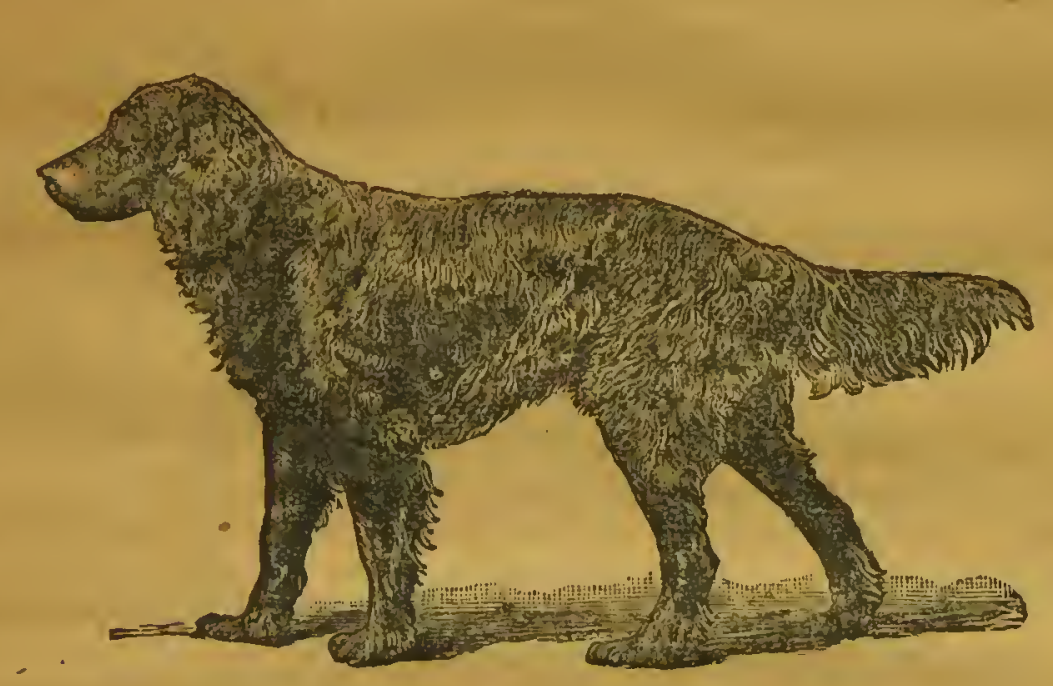

LADY FILOT; A FIXE. GORDOY SETTER.

Born July 4th, 1880. Nraed by Samuel G. Dixon, of Philadelphis 


\section{CHAPTER III.}

\section{DISEASES OF DOGS AND THEIR TREATMENT.}

Trentment of Asthma-13ronchitis-Common Cold-Influenza-Pleurisy-Pneumohin-Con. -inisuion-Rhenmatic Ferer-Distemper-Inflammation of the Stomach-Inflammation of the Suser-Iuflammation of the Bowels-Mange-Canker of the Lar-Fleas and Lice-Chores or Wrks-Fits-Worms-Rickets or Iarge Joints-Tumor and Cancer-Puerperal Fits-Pro- tructed Libor-Spraius-To I1arden Tender Feet-Rabies or Hydrophobia.

\section{'TREATMENT OF ASTIMA.}

Astuma in dogs is ofttimes hereditary, especially in house and pet dogs, and niay be bronght about by indigestion or irritation of the stomach. A sudder: elange of wcather will bring it on. Fat dogs are especially prone to it; tho) symptons are: thick, heary breathing, a loollow, lusky bark, much panting, aud great constipation. Begin with low dict and administer

\section{Charcoal, 1 scruple; \\ Iron, 10 grains,}

in a pill three times a week. Excreise and kecp bowels moved with castor-oil twice a week until relieved.

\section{BRONCHITIS}

Is caused by neglected colds, eold, damp kennels, want of care after returna ing from wet hunting-grounds, etc., and may be known by a continuous whec\%ing dry eough, which at times causes an effort to and brings on vomiting, the expectoration being frothy and mixed with blood, the eyc inflamed, and the nose dry; the tongue parelied, with the pulse quick. In the beginning of the attack give the $\operatorname{dog}$ a warm kennel where there are no draughts, and doso with

1 to 3 grains tartar emctic, according to size of animal.

If this docs not eheek give spirits of eamphor $\frac{1}{2}$ oz., spirits of æether nit. 1 ounce, cxt. liquorice $4 \mathrm{oz.}$; a teaspoonful for small dog three tiries a day, and

- three times the amount for large dog three times daily. Feed with warm broths and bread and milk.

\section{COMMON COLD}

Is known by sudden chillness with heated surface of the body, quiek pulse and hurried breathing. The appetite fails, bowels are costive, and urine high 
colored. Very often there is a slight congh, and a runoing from the eyes and nose, which is hot and dry. Cause, cxposure or sudden cliecking of the temperature of the body. For treatinent give a dose once a day of

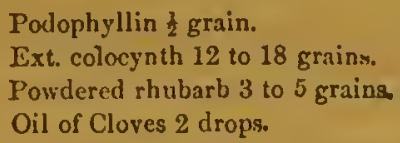

INFI,UENZA

Is difficult to distinguish from common coln; the rumning of nose and eycs is more copious and continued, cough screrer and fever lighler. Administer dose as for comnon cold, and if not relieved give bolus of

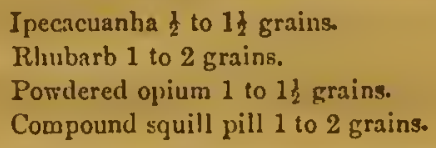

Give night and morning. Ireen in dry comfortable kennel indoors, and feed on light diet.

\section{PLEURISY}

Is an inflammation of the membranc of the lungs caused by debility, cold of inflammation of the neigliboring textures, and some times by wounds, or a severe beating of the body. It is ushered in by shivering and quick breathing, inspiration especially short, caused by the pain occasioned by the movement of the ribs. A dry cough is present, fever, nose lot, tongue slimy, cyes watery, pulse liard. The log sits on his hind quarters, with his forc legs stretched apart, as if to elose them caused pressure and pain. Administer

Spts. wether. nit. 2 ounces.

Liq. ammonia acetat. 4 ounces.

A teaspoonful erery four lours, nixed with double the amount of linseed tea for a small dog 1 trice the quantity of each for large dog.

Apply counter irritants of mustard plaster to chest.

\section{PNEUMONIA}

Is brought about by cxposure likewise, and oftentimes by the animal not being thorouglly dried and protected from the cold after washing in warm water. The dog is seen to shiver greatly; this shiveriug is followed by high fever, pulse rapid, breathing quickened, accompanicd with a short congh, eyes bloodshot. Treat the same as in plenrisy, especially the counter irritants.

\section{CONSUMPTION}

Is hareditary in the dog as in man. Close confinepment will bring it on, 
wll bad food, and excessive in and in breeding; it sometimes follows dia temper. All that can be done is to keep up the strength of the dog, with codliver oil and iron and good diet, avoiding a damp or cold kennel.

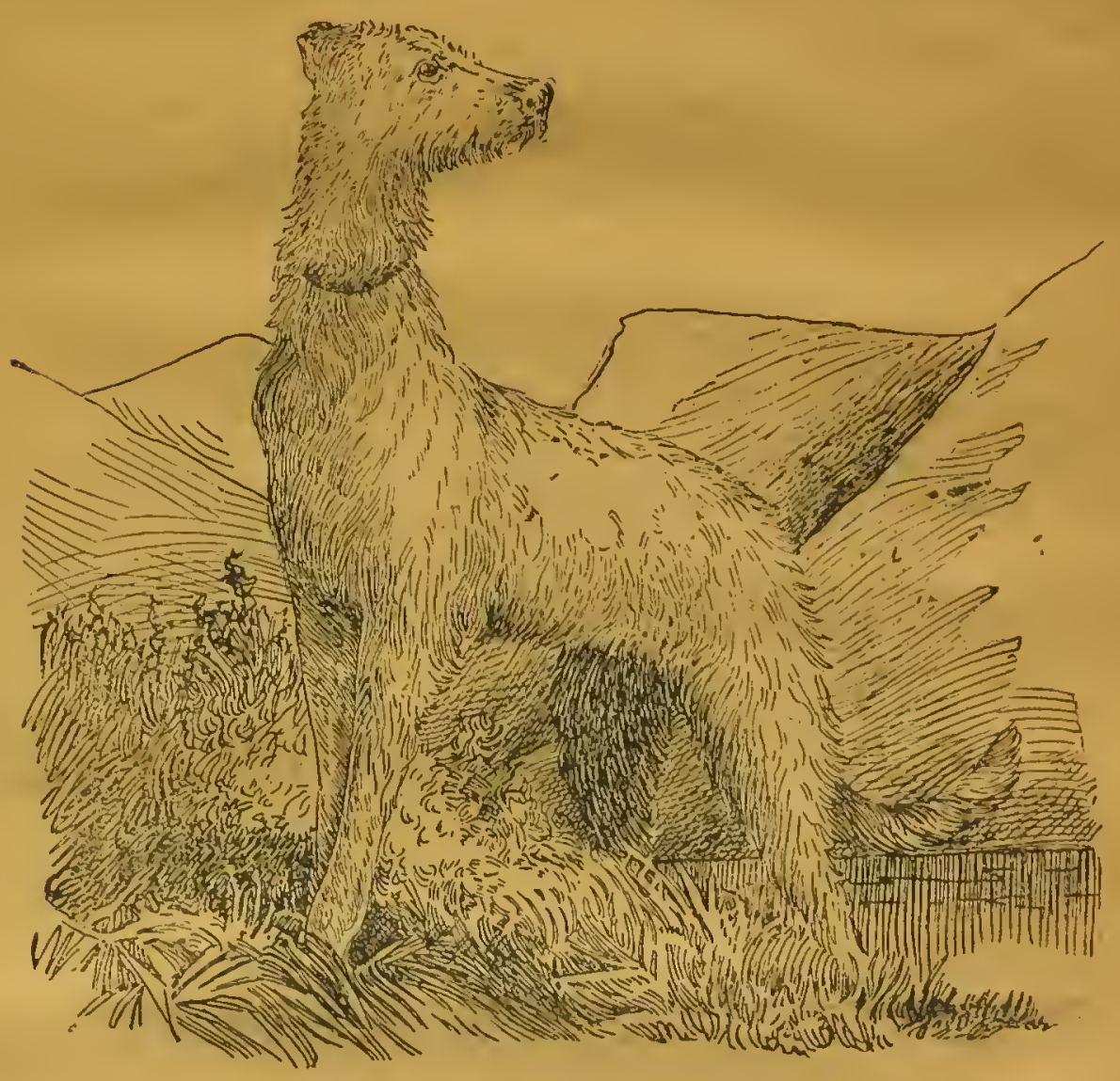

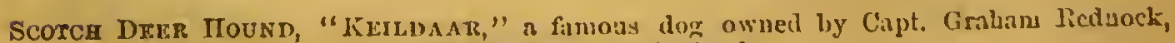
Gloucestershire, Jinglaud.

Dons frequently have rhenmatisn, especially hunting dogs, and it is always cocompanied with more or less fever; damp kennels often cause it. Its signo 
are as follows: there is considerable fever, but of not very hicrll eharacter: the pulse is quick with shivering exeept when touched, when the sliehtest appruach will eause a sliriek apparently from pain. A good treatureut to Hrat a doste of physic of

\section{Calomel 3 to 5 grains.}

Jalap 10 to 20 rrins.

Mixed with syrup and made into a bolus

And follow, after it has operated, with

Calomel 1 grain.

Powdered opium 1 grain.

Powdered colclicum 2 to 3 graina.

And syrup enough to make one pill

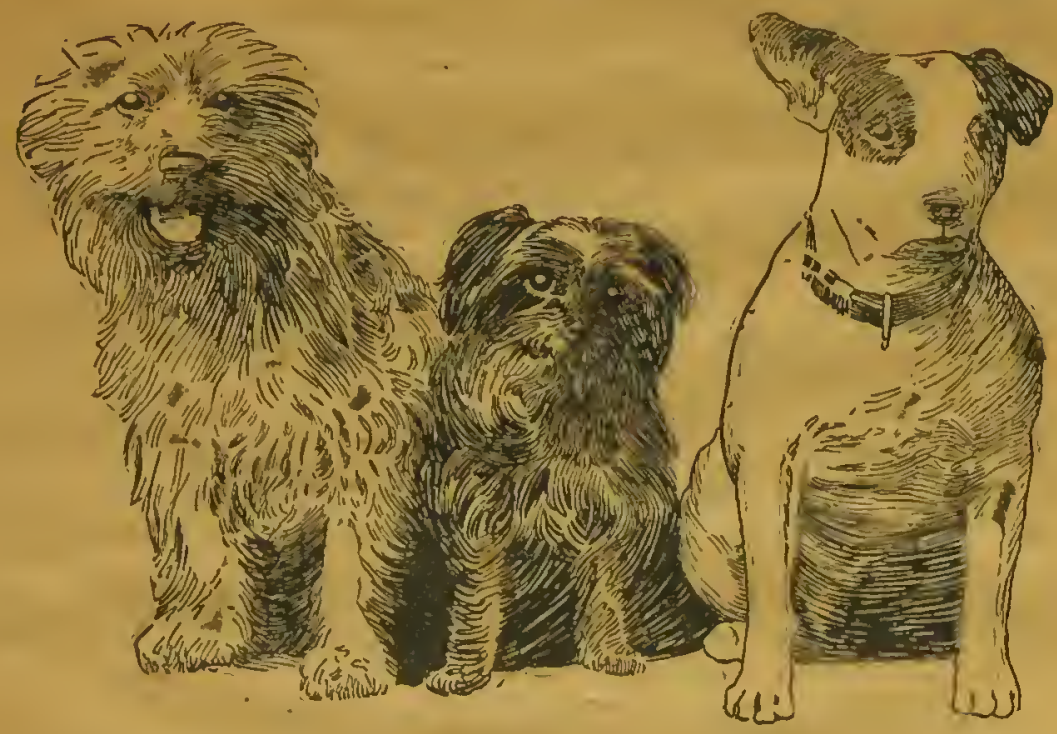

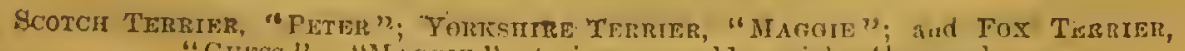

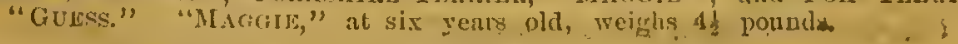
I'roperty of Mr. Honson Iloward, of New York.

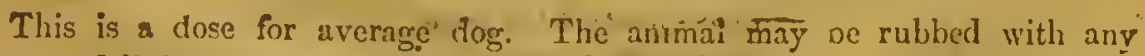
approved liniment where the pain seems to be present, and his diet be mado a low one.

\section{DISTEMPER.}

The great majority of dogs are attacked with distemper about the time they are casting their milk teeth, or a short time after they have gained their seeond; but few animals escape it. $\Lambda \mathrm{n}$ ordinary course of an attack of distemper is as 
rollows: great dullness with loss of appetite, followed in a day or two by a husky cough, especially showing itself after exereise; a sneczing is now noticed, 6trength and flesh rapidly diminish, the stools are inky and offensive, the urine becomes very high eolored, and the membranes of the eyes and sometimes the whites are greatly inflamed. Some cases of distemper seem to be eonfined principally to the head, another to the eliest, and the third the bowels. When the brain is attacked the eyes are more injectel than when the bowels or the lings are affected. The uose and eyes show inereased mueous discharge as the disease progresses. These are the general symptoms which intensify to the third, fourth or fifth week, when the dog dics from disease of the brain, lungs, bowels or exhaustion. When the head is attacked there may or not be a running from the nose. $A$ fit is most always the surest sign of brain trouble, and when this takes place more than twiee, the distemper generally proves fatal, or the animal is ever afterwards affected with ehorea, or the jerks. If the lungs be involved there is rapid breatling, eongh, and profuse rumning from the eyes and nose. If this runs into inflammation of the lungs the danger is as great as if the head was affected. The bowels are sometimes seized and show by Llack purgings that these organs are involved, very often in this stage discharges of blood quickly carry a dog off. The best general treatiueut for disiemper is as follows. $\Lambda$ the commeneement of the attack.

Syrup of bucktliorn 2 ounecs.

Syrup of poppy 1 ounce.

A tablespoonful once or twice at intervals of two days. A seton placed in the back of the neek, covering the tape with blistering ointment, will relievo the head if it appears to be affected. And a fever mixture as follows:

Nitre 1 drachim.

Spts. of nitre 3 drachms.

Midererus spirit 1 ounce.

Camphor ruixture $6 \frac{1}{2}$ ounees.

Two tablespoonfuls every six hours.

If the lungs are severely attacked, a powder must be put upon the dog's tongue every night and morning of

Nitre in powder 3 to 5 grains.

Turtar emetic $\$$ grain.

And a cough bolus of

Ipecacuanha in powder $\frac{1}{2}$ to $1 \frac{1}{2}$ grains

Powdered rhubarb 1 to 2 grains.

Purified opium $\frac{1}{2}$ to $1 \frac{1}{2}$ grains.

Compound squill pill 1 to 2 grain 


\section{Administezed every night and morning. If diarrhœa shows itself chock 2 with}

Prepared chalk 2 to 3 drachms.

Aromatic confection 1 drachm.

Laudanum 3 to 8 drachms.

Powdered gum arabic 2 drachms,

Water 7 ounce.

Two tablespoonfuls every time bovels are reisxed.

For a dict, bcef tea thickcned with rice can be given, and for a time when the dog shows great exhaustion, a mixture of tincture of bark 2 ounces, decoction of yellow bark 14 ounces, a tablespoonful 3 times a day to a large dog, should be administered; especially at the time of exhanstion should good strong beef tea with the white of an egg broken iuto it while it is lukewarm, be given by spoon every two or three hours. And if the animal will not swallow it, his head slould bc held up and he should be foreed to. If this troublesome plan of feeding is attended to, many a valuable dog can be saved to his owner. As strengtl gradually returns the diet can be made stronger, with care followed to allow no exercise until a gain is wcll cstablished, and strength greatly restorch for fear of a rclipse. The liennel during distemper should be dry and moderately warm, and in a position where the dog will not be exposed to draughts of air. Finely bred, animals suffer the grcatcst, especially those that are much in and in bred, when thic malady many times attacks the brain, which is the most dangerous seat of the disease. Fit after fit talies place and the dog is carriced off by them. Some seasons distemper appears to bo epidemic and is norc severe and fatal in its cffects, and scarcely a dog in certain sections eseapc. Dogshows arc a great means for sprcading the disense, and it is advisable not to cnter an aninıal until he has had tlic discase. Distemper can bc had twice, but it is scldom a dog is attacked more than once.

TREATMENT OF INFLAMMATION OF THE STOMACH.

Inflammation of the stomach or gastritis is brought about by improper food; foreign substancc in the stomacl or poison. When a dog is suffcring from this complaint he makes frequent and violent efforts to vomit, and has great thirst, dry and lot nose and quiek respiration, and will ofttimes lie on the floor, or pavement, or ground with his belly in contact with it as if to allay the pain. Give

Calomel 1 grain.

Opium 1 grain.

In pill every three hours.

And feed if he will take it with light soup and gruel. Gastritis and dyspepsia are much alike and may be treated the same. Continue easily digestcd food in dyspepsia; the pceuliar posture deseribed is not noticed in the latter complaint. 
TREATMENT OF INELAMMATION OF THE LIVER.

Sporting dogs frequently have this affliction, espeeially when they have been exposed to cold and wet. Animals having little exercise oftimes are attaeked owing to torpidity of the liver, which many tines runs into this eomplaint. The whites of the eyes in this disease are yellow. Shivering, hot nose, rapid breathing, eostiveness, wcak pulse and seanty clay-colored stools are also aceompanying symptoms. The dog should be moderutely bled, and then given a pill of

Podophyllin $\frac{1}{2}$ grain.

Ext. of colocynth 12 to 18 grains.

Powdered rlubarb 3 to 5 grains.

Oil of cloves 2 drops.

The greater proportion for large dog and less for small dog.

As soon as this has operated rub the right side with an embrocation of

Strong mustard 3 to 5 ounces.

Liquid ammonia 1 ounce.

Spts. turpentine 1 ounce.

At same time give a pill,

Opium 1 grain.

Calomel 1 grain,

And keep bowels open with castor oil.

TREATMENT OF INFLAMMATION OF THE BOWFLS

Is generally cansed by eonstipation or a great anount of indigestible fuod, and may be known by great thirst and loss of appetite, and the peeuliar attitude the animal takes; his baek beeomes arelied and his legs drawn together. It may be relieved by bleeding, and calomel and opium in doses of 1 grain eaeh every 3 or 4 hours. If severe, bathe the dog in warm water, and after he is well dried, rub his belly with a liniment of $\frac{1}{2}$ ounce each of spirits of turpentine, liquor ammonia and laudaunm. Feed with very light and easily digested fuod.

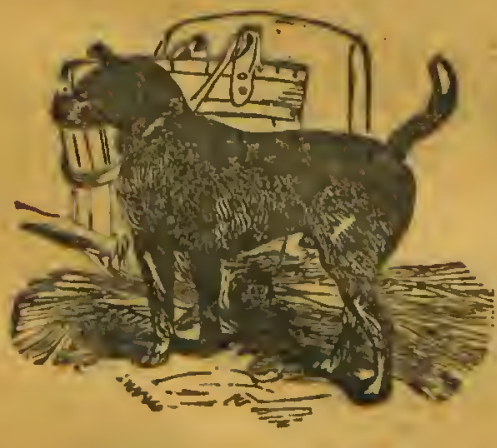

CI UOLISU TERRIFR

\section{MAITEE.}

Mange is a skin disease in dogs arising from filth, damp kenuels, housing in ccllars, and parasites; the disease is of different varieties. First the bloteh, which appears in scaly lumps of hair ehiefly on the back, sides, head and quarters, and in a few days the scab drops off, leaving a moist red spoto Give

Calomel 3 to 5 graing. Jalap 10 to 20 grains 
Krep on low diet and give exercise. Secondly the foul mange, which is brought about by impure blood, and cannot be cured until it is changed. It is considered hereditary though not contagious. In foul mange the skin becomes thick and discharges an offensive matter, and finally runs into ulcers, with great itching all the time, the hair bocomes dead and falls out, and the animal is nervous and irritable. To cure requires patience and oftimes long treatnent. Change the diet at once, give 110 meat, starve the dog nntil lie will accept oatmeal mush with boiled vegetables freely mixed with it, then administer liquor arsenicales with the food, one drop to each four pounds in wcight of the dog thrce times daily, dividing the food into three portions for monning, noon and night. This must be kept up until itching ceases, and very often continued for montls. Cosmolipe may then be rubbed on the mangy skin thrice daily.

Red mange is a disease of the hair, and may be known by the red appearance alwayss at the roots in spots, at the elbows under the arms and inside of them, also inside the thighs. An ointment for red nuange, of the following, well rubbed into the spots, is good:

Green iodide of mercury $1 \frac{1}{2}$ draclims.

Spts. of turpentine 2 draclims.

Lard 11 ounces.

$\Lambda$ wash of earbolic acid 1 part to water 30 parts, and pluin cosmoline is efficacious also.

\section{CANKER OF THE EAT.}

Whenever a dog is seen to shake.his head eontinually, and frequently Ecratcl his ear, endeavoring to relieve an appurent inward itching of that organ, it is gencrally safe to conclude lie has the cankcr. Sometimes the tipg or edges are first affected, and the inflammation will, if not then arrested, gradually extend to the interior, which when attacked discharges offensive matter. Hunting dogs, especially water dogs, are subject to canker. To cure, place on low diet, and syringe the ear, first having washed it out with lukewarm water, with a weak solution of

Nitrate of silver 2 to 6 grains.

Water 1 ounce.

According to size of dog,

the frst day; and on the seeond drop into the ear

1 Green iodide of mercury 1 drachm. Melted lard 8 drachms.

Alternate these until relief is had. If there are any sores on the edges ot the ear, touch them with blue stone. 
FLEAS AND IICE.

Make a stiff lather that will stand alone of strong rosin soap ; rub it thas. oughly into thc hair and all over the body, being careful of the eyes, and let it dry on the dog, and remain an hour. Then wash off, and the water will carry the dead fleas and lice with it. This is safe and most cortain.

Persian inseet powder is best for young puppies.

\section{CHOREA OR JERKS.}

This disease, often also called St. Vitus' dance, cannot be mistaken in a dog when he is affictcd. He will have cither a eontinual jerking movement of the paws, head, shoulders or foreleg, intensificd when asleep. It often follows distemper and eaunot be cured. The auimal's general health does not seem to be affected by it, but it renders him unfit for very hard work. It evidently affects his powcr of seenting to a degrce. Keep from exposure to wet and cold, and give a touic when very nervous of

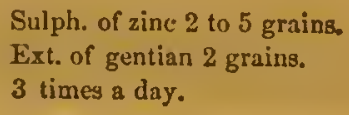

FITS

are of three kinds. 1st. Those arising from irritation (frequently worms), and the majority of times in puppies. 2d. Those caused by brain troubles. $3 \mathrm{~d}_{\text {. }}$ Epilepsy. Fits resulting from irritation come on at the age when puppies begin to cut their teeth. A hot bath will elheck them. Apoplectic fits are gencrally fatal. The dog does not foam at the mouth in these, but lies quite still on his side and breathes hearily.

Epileptic fits arc known by the frothing at the month and a champing of the jaws. These ean be cut short by an injection of five drops ather to an ounce of warm water. Give also two grains bromide of potassiuns twice a day for chree or four weeks.

\section{WORMS.}

There are three kinds of worms that infest the stomaeh of a dog." 1st. The maw worm, of a white eolor, about an inch long. $2 \mathrm{~d}$. The round worn, 4 to 7 inclies long, pointed at both ends. 3d. The tape-worn, often growing a number of feet in length, and eorriposed of niany small links or joints. Whan a dog is troubled with worns his cont bccomes harsh and dead in appearance. He is costive and loose at times, and his stool is gencrally mixed with a white gliny mucus. His appetite is ravenons, yet sometimes poor. He seems to derive no benefit from his food, and may be seen to swallow small pieces of dirt, ashes, rags or stieks, in order, as it were, to force the worms from the atomach, 
An infallible cure for the maw and round worm is a dosc cach day of Fahnetock's vermifugc on an empty stomach, followed in two hours with castor oil. This vcrmifugc is composed of male fern and santoniue. Another good remedy is powdered areca nut-half of an avcrage-sized nut made finc to a dog 30 pounds in weight, given each day, as much as cau be held on a 25 -cent piece, on an empty stomach, followed in two hours by castor oil.

A good expellant for tape worm is 3 to 10 drops of turpentinc, according to the size of the dog, in a teaspoonful of oil, having well fusted the auimal.

Powdered glass, madc impalpably finc, combined with lard and ginger, in a bolus, is another cxpellant much used. Usc as much powdered glass as cau be heaped on a nickel piece, and follow with dose of oil.

\section{RICKETS OR LARGE JOINTS}

are caused by defective bonc substancc. Cod liver oil and phospinate of lime (the combination can be rcadily purchascd) will remedy. Dose, dessert

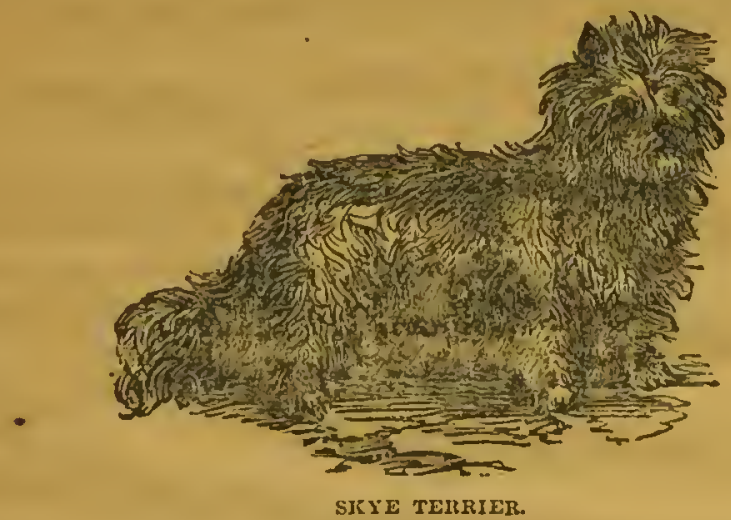

spoonful three times daily for large dog, a teaspoonful three times a dav for small dog. A young dog with rickets should have amplc cxercise. A want of it aids in bringing on the diseasc.

\section{TUMORS AND CANCERS.}

A dog suffering with tumor or cancer should only be treated by a skillful veterinary surgeon, when the kinife is al ways resorted to.

\section{PUERPERAL FITS.}

Sometimes after a mother has given birth to a litter of puppies, and about the time she begins to sucklc them, sle is taken with spasms or puerperal fits. Wheil this occurs, place her at once in a hot bath, and immerse all except the bead. This is, in the majority of times, unfailing in its effect. 


\section{PROTRACTED LABOR.}

A healthy bich very seldom has trouble in giving birth to a litter. The time nay be prolonged in some and short in others, but, as a rule, it is best to allow nature to have its conrse. If, however, assistance is absolutely needed, a gentle manipulation may be made, and a few drops of ergot administered.

Rub the injured part with

SPRAINS.

Malt vinegar 1 ounce.

Spirits vini et camp 2 ounecs.

Aqua 7 ounces.

TO HARDEN TENDER FEET.

Bathe the feet daily in solution white oak bark and alum. Every other ngo rub into the soles cosmoline.

\section{RABIES OR MYDLOPIOBIA.}

The term rabies significs inadness, and liydrophobia fear of water. The fitst is the appropriate name for this dread discase in dogs; the latter conrcys the wrong idea, as a rabid animal does not in any manner fear water, nor does the sight of it bring on spasms. The inability to swallow water and the agony experienced in attempting it, results entircly on aceount of the inflamed condition of the throat and the closing of its passage. The cause of rabies is not known. Some writers eliarge it to the absence or deprivation of natural Eexual interconrse on the part of the dog. It is notable that the number of males outnumbers that of females in very great proportion, and in rural districts bitch puppies are invariably destroyed owing to the fact of their tronble when in season, and the donble tax impused on their owners in the countics where they are kept, so that the argument is a rensonalile one to say the least. $\Lambda$ gain, wild animals of the eanine species, the wolf, fox, ete., ard never known to be affected with it unless innoculated. It may occur in a dor: in cold as well as a hot climate, but hot weather seems to generate brain troubles. Symptoms: The dog becomes sullen, hias a desire to be alone, hides hinself, and when ealled sneaks off to his retreat again. As the clisease ad vanees he begins to gnaw and pull at the woodwork of his kennel or sleepingplace. His eyes have a vacant expression, and will seen at times to be looking into the distance at some imaginary olject. Snall insects will be attentively observed by the sufferer, and will be intently followed in their movements; as they near hin he will suddenly jump forward, and make an angry mnap at the supposed offender, and then sneak off as if astramed of himself. Thick saliva will now come from his lips, and he will champ his jaws. As the 
disease intensifies the saliva becomes more copious, and he will attempt to paw it from his mouth. His voice becomes a hoarse howl. The poor animal will at this period start on his tramps to attain as it were relief from agony lie in in. His gait is now neither a walk nor a trot, but an indescribable jog, once seen never to be forgotten. Anything crossing his path appears to irritate him, and he will savagely snap at it; very often he will go ont of the apparent straight course he has taken, wander into the fields and attack cattle, shcep and swine. We can say nothing in reference to the cure of a rabid dog: the best remcdy is the shot gun; but as prevention is better than eure, a remedy is given for warding off hydrophobia when a subject has been bitten by a rabid nuimal. All $\log$-bites should be treated as if they were inflicted by a rabid dog, by immediate suetio 1, followed by cauterizing or by application of nitrie acicl. If rabies is known to be present, suction should be followed by complete excision of the wound. The following communication in regard to what is known as the Goodman cure, was written by a leading and highly respeeted citizen of Philadelphia, a prominent wholcsale druggrist of long standing, and who is well prepared to judge whereof he writes. It is proper to state that having, purely from a desire to save others from the terrible sufferings of hydrophobia, consented without the slightest compensation to our use of this valnable discovery in this volume, lie has preferred to withhold his name lest he might seem desirous of bringing himself rather than the remedy into publieity. He has, however, given his consent for the publishers of this volume to refer any honest inquirer, after full assurauce of the iuestimable value of this first discovered

\section{PREVENTIVE OF HYDROPIOBLA,}

directly to him, but at the same time hopes that as the remedy is simple and the material abundant and cheap (obtainable for a mere trille of any druggist), no one will negrlect to use it should occasion arise. The Gooduan cure lias been tested numerous times sinee the instances referred to aud fuutd invariably effieaeious.

\section{THE GOODMAN CURE.}

"My attention was drawn to Eleccmpane many yenrs siunce as a preventive of hydrophobia. The active nedical principle of this plant is found in the root, aud is called inuline. From my experience, I be!leve this inuline nentralizes the virus or poison of hydrophobia. Allow me to give a few instances where this simple remedy has been used. "Ify oun nẹphew, then a small boy, was bitten barlly in the face by a $\log$ unmistakably mad. This oecurred within a few miles of this city. The father of the lad came immediately to town to obtain medical advice. We called on an eminent plysician (now decensed) who at once prescribed the plant named. The root was. obtained and adruinistered as 
hereinafter directed. No symptom of hydrophobia appeared, and the lad, now a hale, liearty farmer in Montgomery county, lives to show the sear of the wound in the face.

"The physician above referred to relater to me a number of instances in which the remedy hacl been used, and always with suecess. Hc in fact renırkerl, 'I never knew it to fail when properly administered.' I will give ut two cases. .

\section{A STRIKING proor.}

"First: Two tnen living near this city were bitten in the hand by the samo dogr, and within fifteen mimutes of each other. The dog, a stranger to them, was securerl and imprisoned to avait an owner. The next day he showed unmistakablc signs of malness, and finally died with hydrophobia. Alarmed for their safety, both men canc to the city and waited on the physician quoted above. Hc prescribel Elecampane Root. One of the men remarked, 'that is an old womau's remedy,' and refused to take it. This man, returning to his home, placel himself under the care of his own doctor, who cauterized the wound, and arlministererl medicine to salivate him. On the ninth day he was seized with spasms and dicd in agony. The other and more fortunate man took the Elccampanc as prescribed, and never suffered in the least degree from the dreaded disease.

"Second: A number of cows feeding in a pasture were all bitten by a mad dog. The cireumstances coming to the knowledge of those who liad licard of this Elccampane remedy, thought it a good opportunity to give it a trial. The cows were accordingly separated - to onc-lialf the number, thic root was siministercel (in form of deenction), and not onc of the corrs suffered from bydrophebia; whilst all of those not so treatcel took the malady and elied from its effeels or were shot. In quite a number of cases coming under my own obscrvation of persons bitten by dogs supposed to be mad, I have recommended the usc of the Elecimpane, and have yet to learn of the first case of 'hydrophobia resulting from such bite where the root was used. I think, therefore, I have good reason to have confidence in the remedy as a preventive.

"Whetlicr, after" a manifestation of the clisense, it would have a good effect or any cffect at all, I am unable to say. I donbt whicther it would. But tho antidote is so simple, and so readily obtained, that it would be almost criminal not to cmploy it. Having said this much, allow me to give the

MODE OF USING THE REMEDY.

"To one and a half ounces of good, sound Elecampane Root, bruised in a mortar, add one pint of new milk, boil to half pint, strain off, and when cold, take at a dose in the morning, fasting. No food should be taken for from threc to five hours afterwards. Repeat the dose on the third moruing, allowing ono 
morning to intervene, and again on the fifth morning. The above quantity is for an adult; for ehildren given in proportionate doses, say to one of twelve years, half the quantity."

\section{FACTS MORE POTENT THAN THEORIES.}

"A correspondent, impelled by the narration of the death from hydroplıobia of John Knippel, writes that for thirty years past a farmer named Fry, residing near Allentown, Pennsylvania, has treated hydroplobia witl unvarying success by the following simple method:

"The patient is to be kept free from exeitement of every sort, espeeially from that caused by the visits of sympathizing friends. The medicine is to be prepared by taking one ounce of Elecampane Root, powdered; one tablespoonful of madder and one quart of new milk, and boiling them all together slowly (in a water bath if possible), until reduced to a pint. 'The dose is one wineglassful onee a day for three days, then internit three days, then repeat and intermit again, and again repeat. That is, nive wineglassfuls are taken in all, and there are three iutermissions.

"In support of the efficacy of this treatment it is stated that thirty years ago Mr. Reed and Daniel Merslon were bitien at Germantown by a rabid dog, that Mr. Reed was treated by au eminent physician, and died of hydrophobia, while Mershon, under Fry's trentment, never suffered at all. A young man named Jaeoby and \& daugliter-in-law of John Boyer, at the corner of Mill street and Chelten avenue, under similar treatment, reevered from the dreadful disease about twenty years since, and in 1858 a policeman so far gone with hydrophobia as to have to be held in the carriage in which he was driven through Germantown to Mr. Fry's residenee, was also treated with entire success. A number of additional cases are quoted, in all of whieh the remedy deseribed is elaimed to have effected eomplete cures."

The writer of this article believes that the Elecampane will cure the diseaso after violent symptoms have been manifested. I would say that I have never known a case where it was used after a full manifestation of the disease, but should most certainly strongly urge its use, particularly so, as no physician has any knowledge of a eure for the awful malady. When the person is bitten by a dog, mad or otlerwise, great care should be taken to avoid talking about it, or doing anything calculated to exeite the imagination.

The Madder added in the second recipe is of no use whatever, and was, $\mathbf{I}$ imagine, put in simply to disguise the medicine, at a time when "Fry". charged an exorbitant price for his secret remedy. 


\title{
PIGEONS, BIRDS, AND PET STOCK.
}

\author{
GENERAL MANAGEMENT.
}




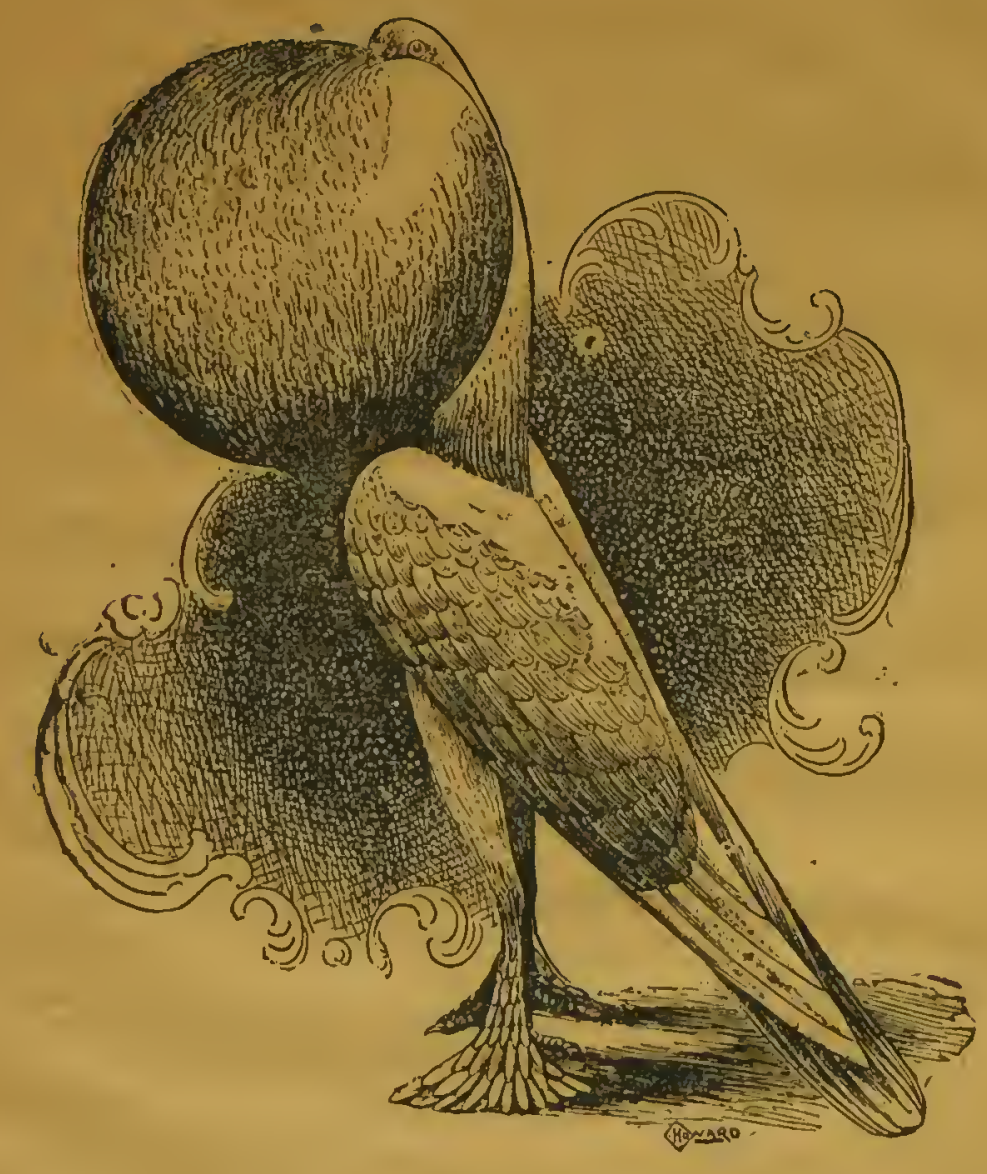

- ideal WiIte PoUter. 


\title{
PIGEONS, BIRDS, AND PET STOCK.
}

\author{
PART XIII. \\ GENERAL MANAGEMENT-STANDARD VARIETIES OF PIGEONS. \\ POPULAR VARIETIES OF CAGE BIRDS-RABBITS, GUINEA \\ PIGS, AND CATS.
}

COMPILED AND WRITTEN BY GEORGE E. IIOWARD.

CIIAPTER I.

\section{PIGEONS.}

\section{BREEDING AND MANAGEMENT.}

BUILDIXG THE LOFT.-PERCHES FOR PIGEONS.-FOOD FOR PIGEONS.-POITLAR VARIETILS OF PIGEONS.-DISEASES OF PIGEONS.

The Romans kept domestic pigeons very much as we do now; they were reared for fancy purposes and as an article of food. According to Pliny, the Campanian pigeons were of the largest size. In speaking of the fancy he says: "Many are mad with the love of these birds; they build towers for them on their roofs, and will relate the high breeding and ancestry of each after the ancient fashion." Pigeons becante the trusty letter-carriers of those remote times, and it is likely that this feature had more than anything else to do with their popularity. It is evident that the pigeon has been a profitable pet down through the ages, claiming amongst its admirers the most learned men of the world.

There are every shape and color in pigeons, and the delicate tints: of the feathers seen hardly possible to be a part of a living thing, which bespeaks well the patience and skill of the men who bred them. It would be a difficult matter to find the high standard of excellence here portrayed in any otherr thán feathered beauty.

The business of pigeon raising would be a good field for the Aneri-

- can farmer to cultivate-one in which there is both pleasure and profit. On many farms are seen empty lofts of barns and outhouses that are of no use whatever, which could be utilized with profit for a pigeon loft. This is a growing industry, and one that is likely to reach large proportions in the near future. Pigeons are liept as an article of food 
and for fancy purposes. As an article of food nothing is more delicate or commands a ligher price than-a squab, while breeders of highclass pigeons realize enormous sums from the sale of a single bird, according to their standard of breeding.

\section{Building the Loft.}

The housing of pigeons plays no mean part in the success of a pigeon fancier. Talke any exhibitor of note, whether of horses, cattle, or dogs, and he will tell you that good housing is an essential point. While good houses are a necessity for the successful rearing of pigeons, elaborate houses are not to be desired. For preference, and if to be permanent, brick buildings are best. But these are far too expensive,

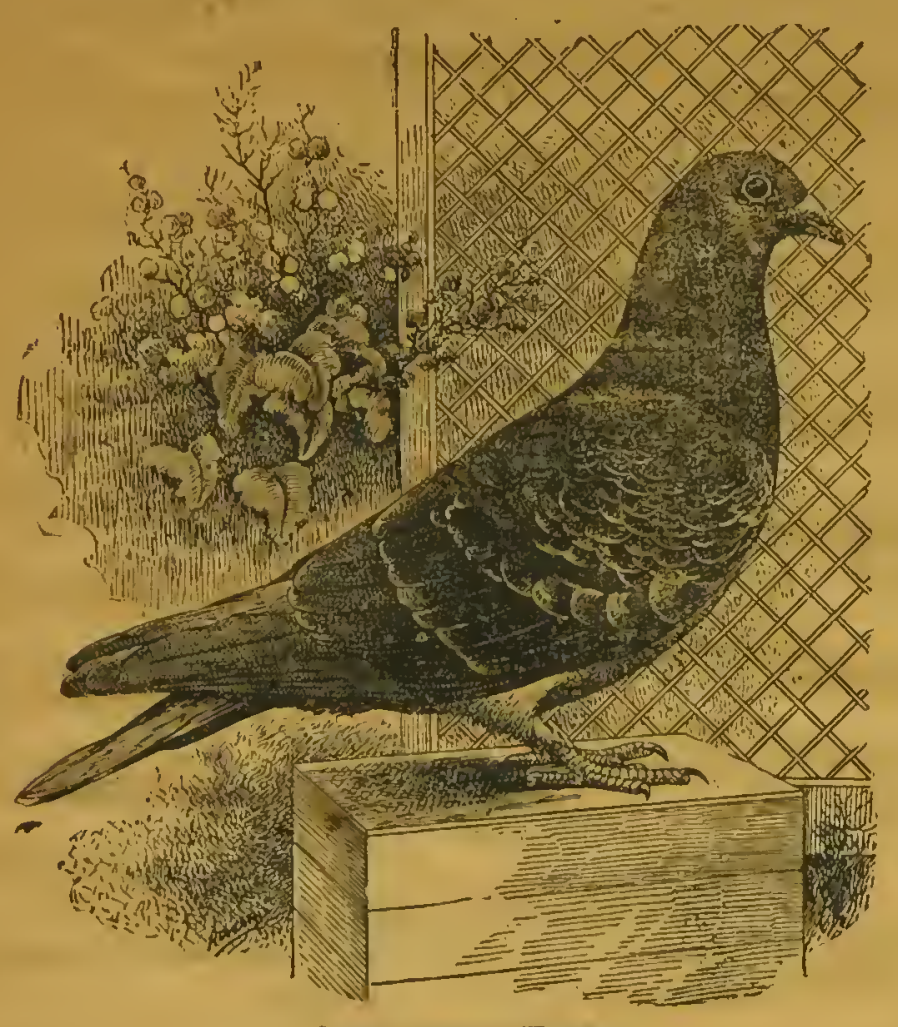

DUUU CHECK HOMER.

except in the case of a man with an unlimited purse. Brick under. pinnings to a hight of I 8 inches and the rest boarded is a good plan, but this is expensive also. The best buildings, therefore, to suit ordinary fanciers, are those made of boards nailed to posts driven into the ground. Eaih bird should have at least 12 feet of cubic space, besides the cubic spice in the flight, and the breeding places more. This 
seems a great deal, but when conpared to the regulation of 300 cubic feet of space for each person deminded by the factory laws, the proportion will not ba far wroag. Plenty of air for each bird should ba a strong point.

In providing a habitation for pigeons, ventilation should be a primary consideration, and this with a loft is sometimes a very diffcult matter, on account of adjoining buildings. When both ends are built against there is nothing else for it but a window back and front,

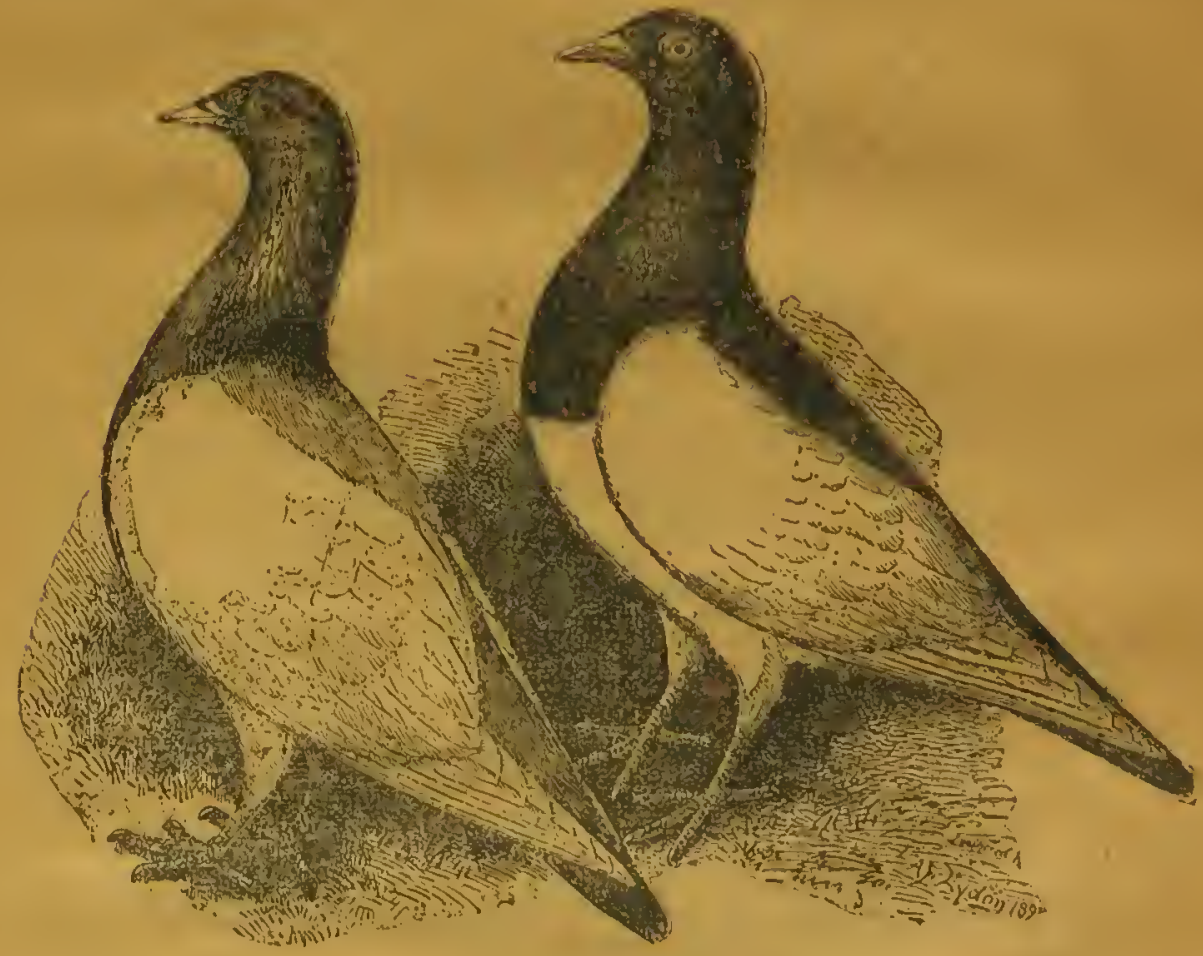

SILVEI: MARTL HEN.

BIALK MAOPIT: COCK.

or a revolving roof ventilator; but where one end is free the airlet sliould be as high $\|_{i j}$ on this as possible, and a commmon sheet-iron ventilator on the roof at the other end would suffice. Where it is possible the best plan for ventilation is to make a series of holes in the boarding uncler the roof insets, so that a slide can regulate the ventilation according to the weather. The great point is to provide as much air as possible without creating a draft.

In a good loft the roof is made of nne-inch weather-boarding, well tarred and sanded. Iron roofs are not desirable, as they are hot in Summer and cold in Winter, and sweat. They may be used, however, with advantage for roofing flights, and when they are used large mesh-

$18 \mathrm{M}$ 
wire netting should be nailed across under the roofing. The main posts are $2 x^{2} 2^{1} 2$ inches, with smaller posts at intervals, $2 \times 1 / 2$ incles. These sloould be rell tarred, and driven into the ground 18 inches. The sides and frunt are of $x$-inch weather-boarding. Sinall windows, each pane 9.1 mch and of 15-ounce glass, are placed for light, and are

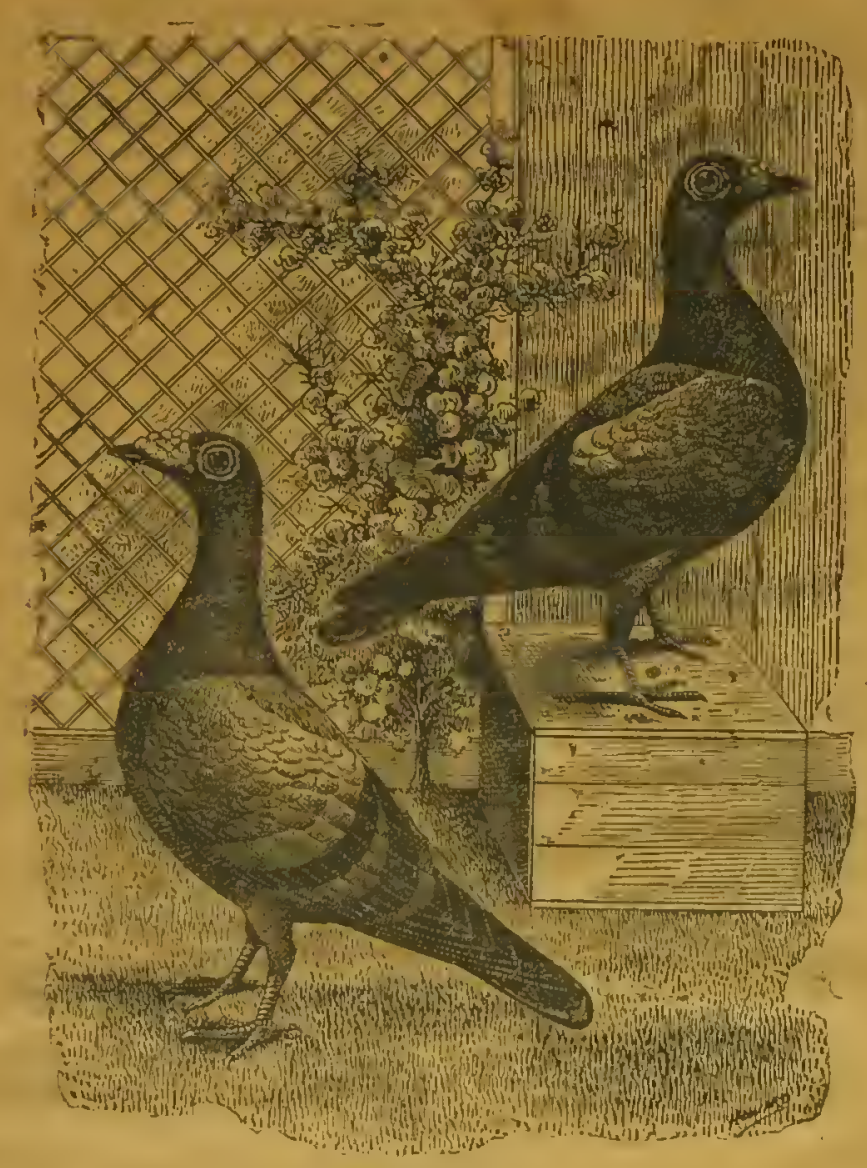

DRAGONNS.

riatic to open. Ini the -ighthand place, where the only door is at one extrente end, there aie ioir openings. These are usually talien by the four "soclis of the walk," thus leaving the doorway free for the admissi:n and exit of the smaller fry. The doors are made of I-inch groovedand-tonriced red boarding, size 2.5, feet, and at least one foot from the ground level. This prevents the entrance of vermin, and also of wet.

The floors of the inner places are of concrete two inches thick, placed on six inches of rubble, in the proportion of one of cement to four of sand; six inches under the cement, in inner places, half-inch mesh- 
wire netting is stretched. This is carricd 11 , the sides to the hight of one foot all around, and well nailed to the boards. The rubble is then placed on this, and the cement on top again. Tris proves perfectly effective against raids of nots. Where there is not much likelihood of veruin it is sufficient concrete the floors as above, and nail

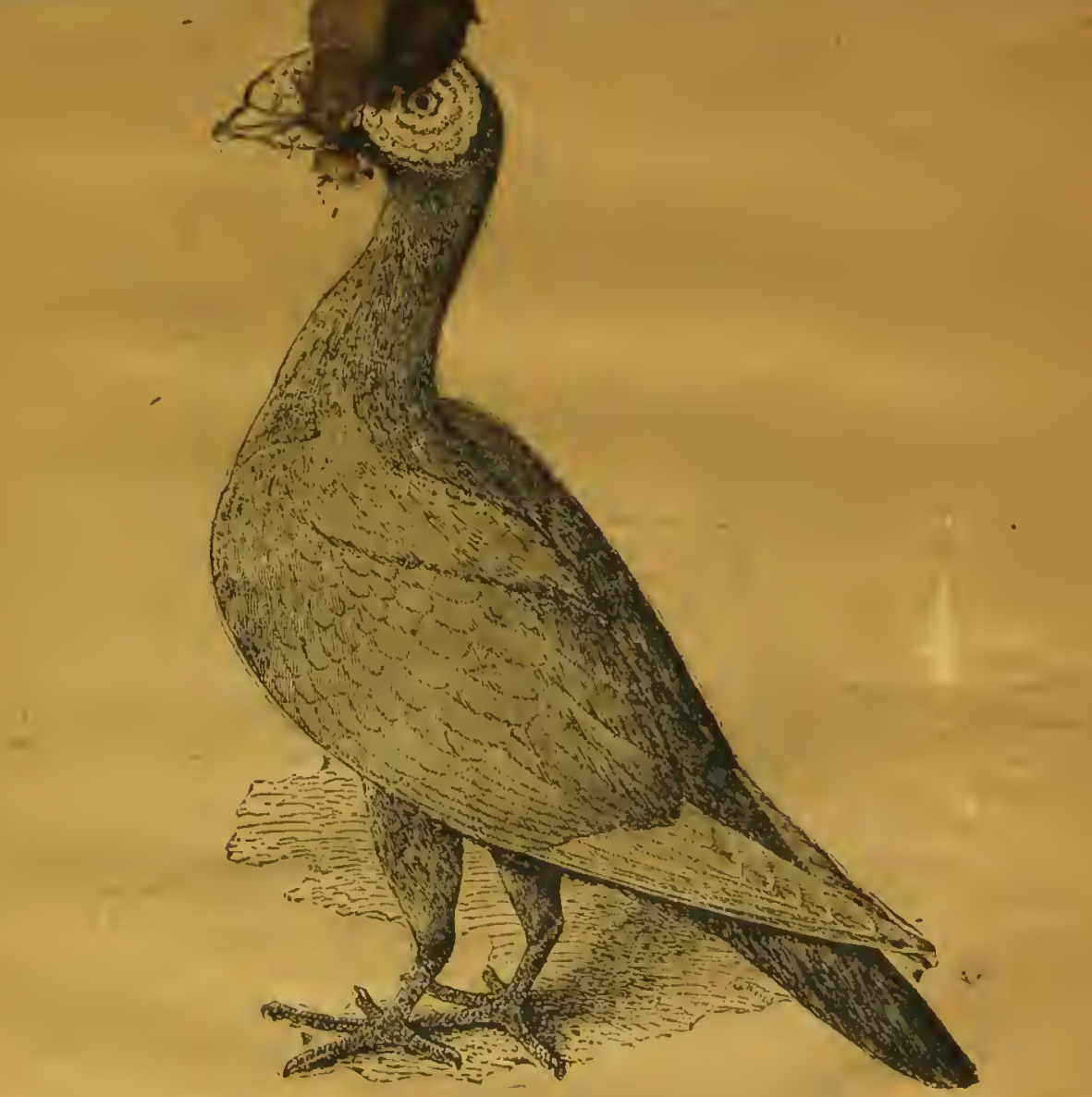

I UN CARRILR COCK.

strips of zinc three inches al ove ground and six inches bencath, around the cutire building of the inner places.

The flight is made of a framework of $2.5 \mathrm{I} / 2$ incls spars, with posts $2 \times 2$ inches, and wire netting $\mathrm{I}^{\mathrm{1}} / 2$ of inch mesh. It is, undoubledly, a great saving of food to have the mesl of sparrow-proof size, but this is nore expensive. The height of the flight is seven feet six inches, which enables you to walk upright in it, but not so high as to nalie the catching of the birds laborious. There are thrce doors, 3.56 feet, to the dights, one communicating to the other flight. They are also fitted 
with a slar for perches. These fights may be roofed in or not, according to opinion, though covered flights are generally considered better. If covered, they should be slightly raised at the end near the louse, and should be provided with a 3 -inch half-round gutter. The perches are circular, $3^{\frac{1}{1}} 2$ inches in dianctemand? should be at least ${ }_{5}$ inches from center to center. Undernes they should be provided with a slanting board, so that the droppingsyay not fall on the birds below:

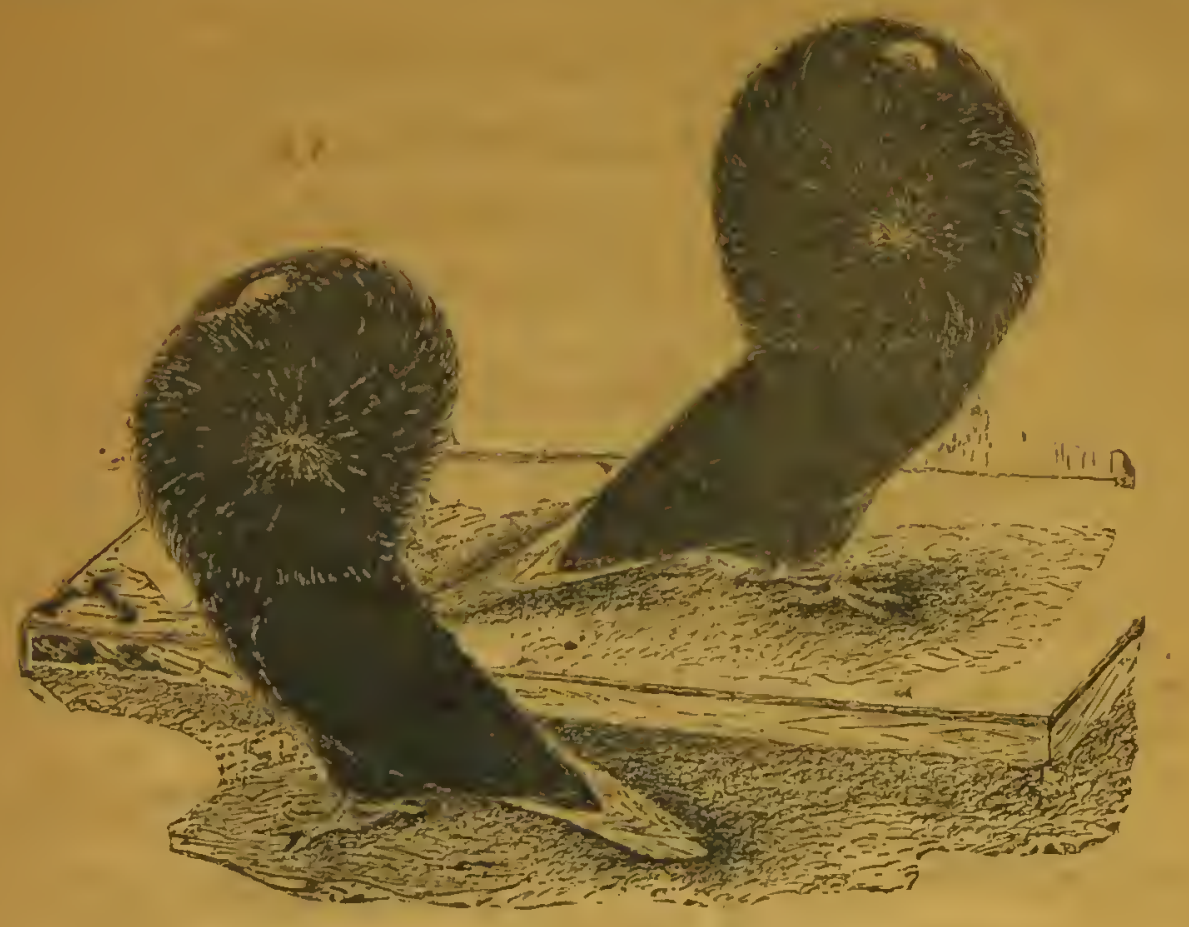

BLACK JACORIN COCKS.

The nest-boxes are movable, to take out in Winter. They are $3 \times \mathrm{XI}^{\mathrm{T}} / 4$ feet, and are divided in the center by a board five inches high. In front is a ledge four inches high, which can be renoved to facilitate cleaning. A second nest-pan can, therefore, be placed in the vacant half as soon as the squabs are old enough. These boses are in tiers of three, so as to give cach pair a choice of the odd boxes.

\section{Perches for Pigeons.}

Perches should be arranged for the convenience of the especial kind of pigeon kept. All pigeons are not constituted alike, and the perch that will be just the thing for one class is entirely unsuited for another. It would be absurd to suppose that a Fantail could grace 
with comfort the perch in the top of the loft that is intended for the Homer, and the Homer would be out of place on the low platform roost of the Fantail. Everything is to be gained by having the perch suited to the bird with regard to its individual characteristics.

A good arrangement of nerches for the average loft suitable for all classes except the Carrier, Pouter and Fantail is shown in Fig. I.

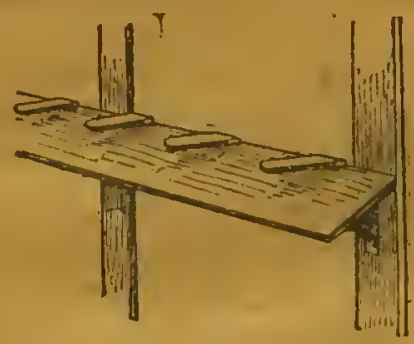

FIG. 1.

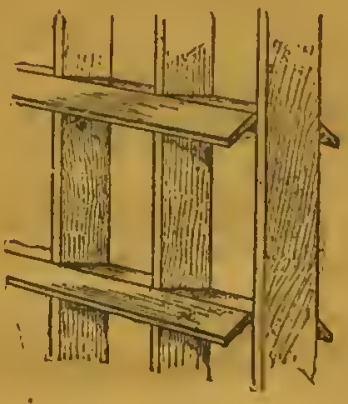

FIG. 3.

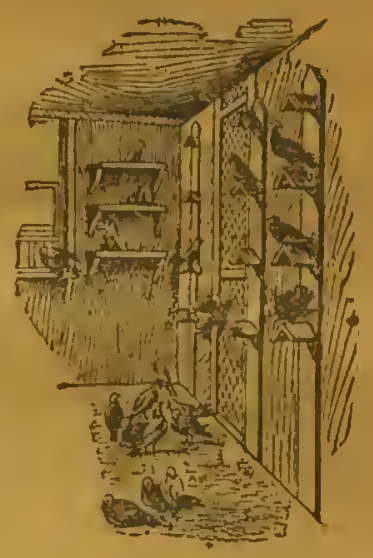

FIG, :2.

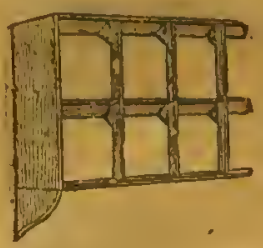

FIG. 4.

These are made by nailing boards Io inches wide, planed smooth on the upper side, on triangular brackets fastened to the wall, or to perpendicular uprights fixed to it, so as to secure them in a slanting position. as shown in cut. On the top edges of these boards are nailed or screwed in a horizontal position slips of wood about $4^{1} / 2$ inches long by $2^{1 / 2}$ inches wide, with the corners rounded off to prevent injury while flying. These slips or perches must not be less than ro inches apart, so that one bird can not possibly peck at another while on the perch. The boards catch the droppings, and prevent any bird soiling the plumage of the one underneath it or on the floor, while the slant prevents the boards being perched or walked upon.

Another plan for general purposes is shown in Fig. 2. These perches are known as the V-perch, and are adapted to the clean-legged varieties. They are placed in tiers, one above another, as shown in the cut, and should be a foot apart, so as to make them casy of access. The 
perches may be made on strips or nailed to the sides of the loft, to suit the pleasurc of the keeper.

Fig. 3 shows a perch that is especially designed for Carriers. To raise Carriers successfully they should have somewhat different accommodations frem other pigcons. 'They should be kept apart, and their frerches should be built in compartments, as shown in the drawing. These perches are buitt in the form of a frame made of boards five inches wide and dividing the whole into two spaces, each measuring nime inches wide and 12 inches high. Along each range is fixed, on both sides, ships or narrow boards inclined at a kevel. Each of these spaces or compartments forms the perch for a single bird. Figs. 4 and

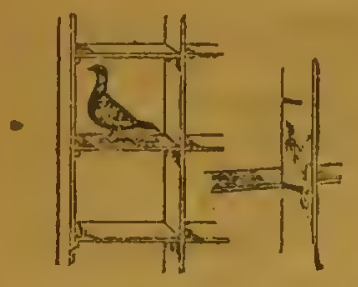

IIf. 5 .

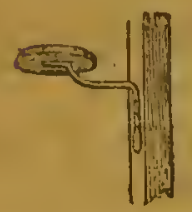

Fic. 7 .

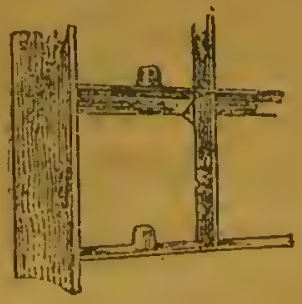

FIG. 6.

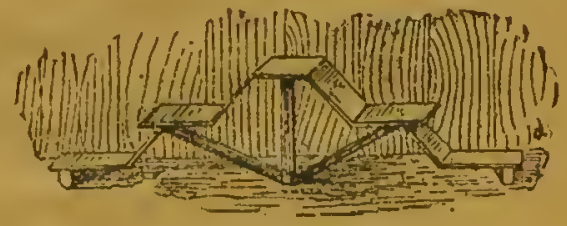

IIIG. 8.

5 show excellent plans for single-comprartment perches, and will do well for all varicties except the Poutcr and Fantail. The great advantage of these perches is that only one bird can occupy cach compartnicnt, and there is consequent freedom from fighting. The dimensions may be varied a little to suit the different varietics, but a good general size for each division is 14 inches high by II inches wide. Perches of the kind shown in Fig. 4 should not be more than three inches deep, made of half-inch pine, and fitted with slanting boards at the back about five inches wide, to carry off the droppings. The perches should be placed about 12 inches from the wall. Fig. 5 is what nay be termed a plain box stall, and is a cheaper perch (though not so good) than the one shown in Fig. 4. The construction of this perch (Fig. 5) is shown plainly in cut, and is made by fitting the boards together in grooves to fit the thickness of material used in making them.

Pouters need more room than any other pigcon. A good plan for perches for Pouters is shown in Fig. 6. The mcasurements of each division should not be less than 20 inches high by 14 inches wide. 
The pedestals should be about $2^{1} / 2$ inches high and $3^{1 / 2}$ inches in diameter at the top. The pedestals should be screwed to the platform, so that they may be easily removed for cleaning. The bracket perch shown in Fig. 7 is another excellent plan for perch for Pouters and the muffed varieties. The drawing so well shows the construction of the perch that description is unnecessary. Do not place these perches one above another, unless a surall board is used underneath to catch the droppings.

The Fantail needs no perch. A novel idea for perches for the Fantail is shown in Fig. 8. This perch or platform being a movablo

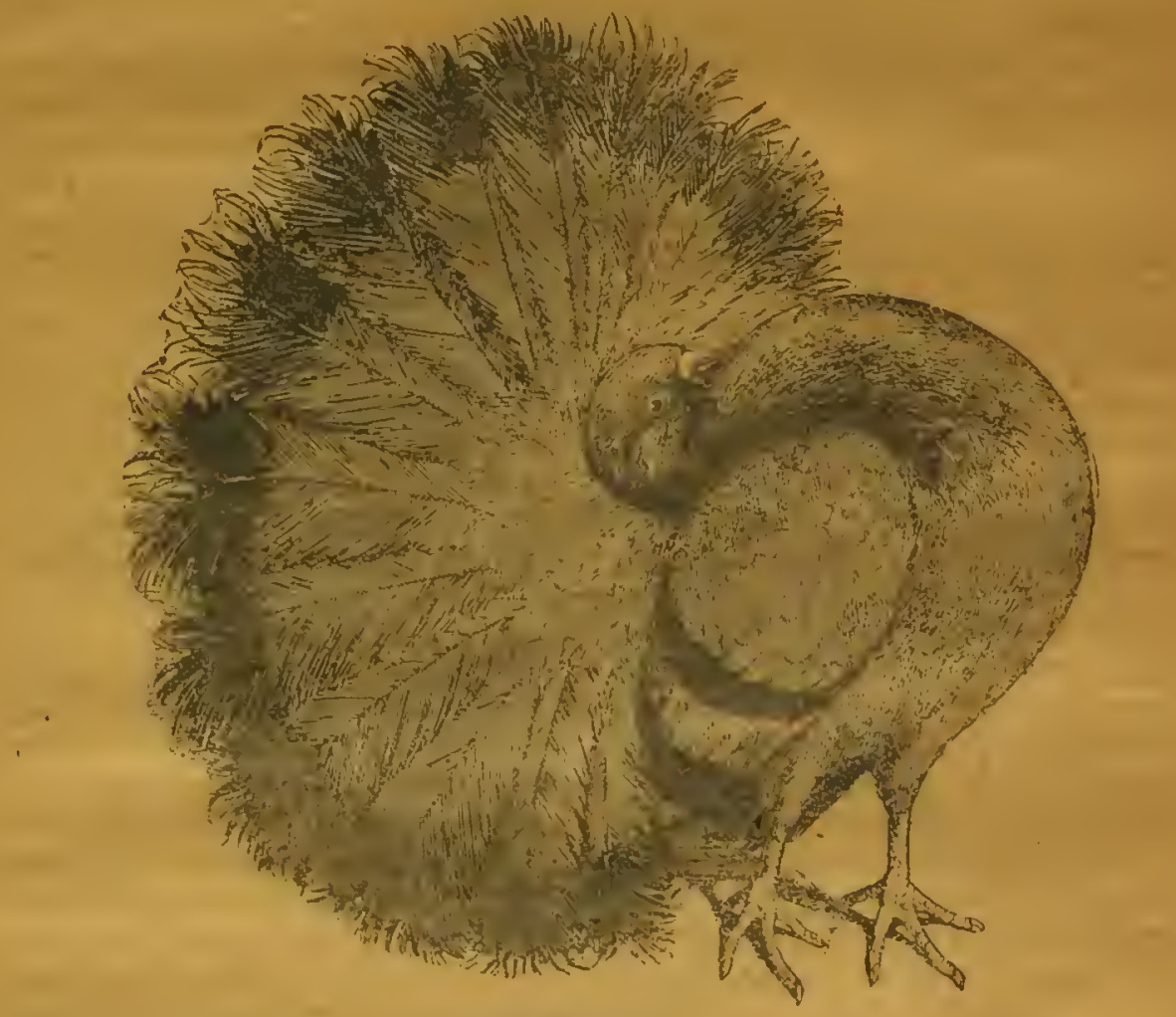

Bueg Fantarl.

one can readily be arranged to suit the exigencies of almost any style of pigeon house. The light from the floor to the topmost platform should be two feet, each platform being nine inches square; the lower platfonn is six inches from the floor, the others being nine inches apart. This kind of perch may be used for Trumpeters. A long, narrow rail about three inches wide is the most surtable perch for the aviary, and may be attached to the sides by brackets. Do not place crossed perches in the aviary, but only have them around the sides. 
Food for Pigeons.

The question as to the proper kinds of food that pigeons slould be furnished is one of great importance to the breeder of fancy pigeons who wants to lieep lis birds in the best condition and yet do it econonically. To the thinlsing man it is evident that the lowest-priced food is not always the most economical, because it is generally composed of grain that has been dannaged either by water or smolie, or of wheat that is slirunken or brolien and mixed with chess, cockle, and grass seed, and linown as screenings.

Grain that has been wet and dried again is apt to be musty, and musty food can in no sense be regarded as healthy. Pigeons may live. and, for a time, apparently do well on it, but it is dangerous food to give them, and its dangerous effects will sooner or later make themselves felt. Grain that has been sinolked is not acceptable to inost pigeons, and a great deal is generally thrown out and wasted, in the attempt of the bird to find something palatable. Good sound red wheat, cracked corn, Canada peas, with dry, stale or toasted bread broken in small pieces, make excellint food. Vary this with an occasional treat of millet, canary seed, buckwheat, or hemp seed, and pigeons will need nothing nore to insure good health and condition.

There are a $n$ umber of varieties of grain foreign to this country that are lighly esteemed by fanciers abroad, but owing to their cost being inuch in excess of the grains and seeds mentioned, they are too expensive for the average breeder here. Such are tares, dari, tick beans, etc. Some of the wealthier fanciers use them and estecm them very highly, but it is not noticeable that their stock looks any better or does any better than that of the man who has to depend upon good American grain. Barley is recommended by some authorities, but pigeons will not usually eat it unless forced to by hunger. Set barley and good sound wheat before them, and the wheat will rapidly disappear, while the barley will remain undisturbed. Set the barley down alone, and after a time the most of it will be thrown out on the floor by the birds scratching for inore accentable grain.

While Indian corn constitutes the chief grain supply of the average pigeon fancier, because of its cheapness and the case with which it is fed, and while thousands of pigeons are raised with little change from a corn diet, it cannot be recommended to the breeder of high-class stock as the feed par excellence, particularly during the breeding season. it being too heating, and, consequently, liable to produce canker and other scrofulous affections arising from an overheated condition of the blood. For Winter use, especially in the colder parts of our country, it is a valuable food, as it serves to generate the warmth so necessary to keep the birds in a robust condition; but the large-grained corn should never be fel whole, as it is not only difficult for them to swallow, but is liable to choke all but the largest birds, and even they sometimes have a hard time to dispose of it. espezially if very hungry and consequently greedy. 
There is a variety of corn now grown with a small, round kernel, about the size of a medium pea. known as Kaffir corn; this, on account of its size, is far preferable to the ordinary corn sold for food, as it is casi y swallowed by the smallest pigcon and has all the fattening and heating qualities of the larger variety. It is of comparatively recent introduction, and is probably not yet known in some sections of the country; but when it does become generally known it will, without doubt, supplant all other varictics of corn as a food for pigeons.

All grain fed to pigeons should be thoroughly dried and seasoned. New grain is sure to cause indigestion with its attending derangcment of the bowels, such as diarrhea and dysentery, and consequently is to be avoided as a dangerous foe. especially to high-class pigeons. Pigeons flying at liberty, such as the common birds seen about the farm and country villages, fly to the recently-harvested fields and secn to eat the new grain with impunity. But this must be because of thcir hardihood arising from their free and natural manner of life. The fancy pigeon, living as it does in confinement and under artificial conditions, does not seem to have the digestive power necessary to assimilate and dispose of the crude, unripened grain, and, therefore, needs to be protected, and fed only such material as it can properly dispose of, and such as will guard against the weakening diseases mentioned.

Hemp and canary seed are included in the list of grains and seeds recommended, but it is not advisable to feed these in the liberal manner that wheat, peas, or corn can be fecl, but more as a dainty and occasional treat. An occasional handful given through the weck will be very nuch enjoyed, and, if properly distributed, will be found very influential in removing timidity and causing your visits to the loft to be welcomed and appreciated.

While not regarded as a food, a supply of grit and oyster shells is almost as much of a necessity to pigeons in confinement as grain, and so every well-ordered loft has its boxes of grit and shell. The frequency with which they are cmptied shows that they are a necessity.

Salt and salt-cat are also necessary adjuncts to the food supply, and to be without either is to deprive the pigeons of a luxury, and to invite disease; for these articles, placed where they can be partalicn of at will, will do much to keep the birds in good health and to ward off many of the diseases liab'e to attack pigeons kept in confinement. Supplied with these condiments and such food as has been mentioned. and a constant supply of fresh water, there is no reason why pigeons should not breed well, keep in good health, and multiply.

\section{Popular Varieties of Pigeons.}

The most popular varieties of pigeons are the Fantails, Jacobins, Pouters, Archangels, Turbits, Antwerps, Carriers, Trumpeters, Mlagpies, and Tumblers.

In the Fantail we recognize a most beauliful creature, and one that is a general favorite. The Fantail, as its name implies, is so 
nanied on account of the resemblance of its tail to a fan. There are from 20 to 36 feathers in a tail; the more feathers a bird has the greater is its value. The shapely body and tapering neck give it a swan-like appearance. The chest is brought forward; the carriage is erect, with head thrown well back and resting on tlie cushion. The tail is circular, slightly concave, and should be carried well up evenly, not drooping over the head or hanging loosely to the right or left. The Fantail in appearance has a graceful movement, and appcars as if standing on tiptoe, walking in a jaunty manner, with a series of conrulsive jerkings or twitchings of the neck. The head is small; eye, dark hazel; beal, thin and about one-half incli in length; beak, wattle and eje-cere are small and fine in texture, and legs short. Fantails arc bred in all colors, but the pure white are the most popular.

The Jacobin is a beautiful as well as an interesting bird. The characteristic points of feather in the Jacobin are the hood, chain, rose and nuane. In size they are small and rather slenderly built, with an erect carriage of the head and neck to display the hood advantageously. This variety is bred in all colors.

The Turbit holds an exalted place in the ranles of pigeondom. Their wonderful beauty and dainty little forms claim for them the admiration of all. The Turbit is a small bird, with a plunı, broad chest; short on the legs and in the neck. Their bold and upright carriage and jaunty manners makce a pleasing picture to the eye. They are bred in all colors.

The Antwerp pigeon, better known as the Ilomer, is perhaps the best-known of all the varieties of pigeons; they are among the foremost in popularity as an interesting bird. Their utility for the purpose of messengers has established then as a profitable as well as an ornamental bird. It is not only as messengers that Homers are profitable. for this is the breed of pigeons used for squab breeding, which has become one of the most important branclies of pigeon raising. A nice young squab makes a delicious dish, and the number lilled and used for the purpose extends into the tens of thousands annually. An immense number of squabs are used in place of wild birds in the leading hotels and restaurants, and the number bred and consumed by lovers of high living is beyond estimate. In fact, the business of squab breeding is a growing and profitable one to engage in as a 3pecial business, or in connection wlth other branches of stock raising. This is a branch of stock breeding that can be conducted profitabiy by. nearly all fowl keepers or farmers.

The Honner is used for breeding sq!1ab; in preference to all other varieties of pigeons, o: account of its large size and prolific and fertile breeding; they are splendid breeders, the squabs are always in nice, fat condition for selling for broilers, or they can be raised to full growth and sold at a profitable price. They can be bred in confinement or at liberty, and raise from $I 2$ to 16 young in a year, or a pair every six weelss from January to November, or molting time. They lay but 
two eggs, sit about eighteen days in hatching, and then they feed their young while they are preparing for another nesting, which they usually have before the squabs can feed themselves. Homers are not subject to a number of diseases, and if kept clean and free from insect pests will keep in good health, will make a nice lot of pets, and return a larger profit than any variety of pigeons in existence.

The Trumpeter is a variety that will attract attention wherever seen, and is con"inonly spolien of as a "bunch of feathers." Among

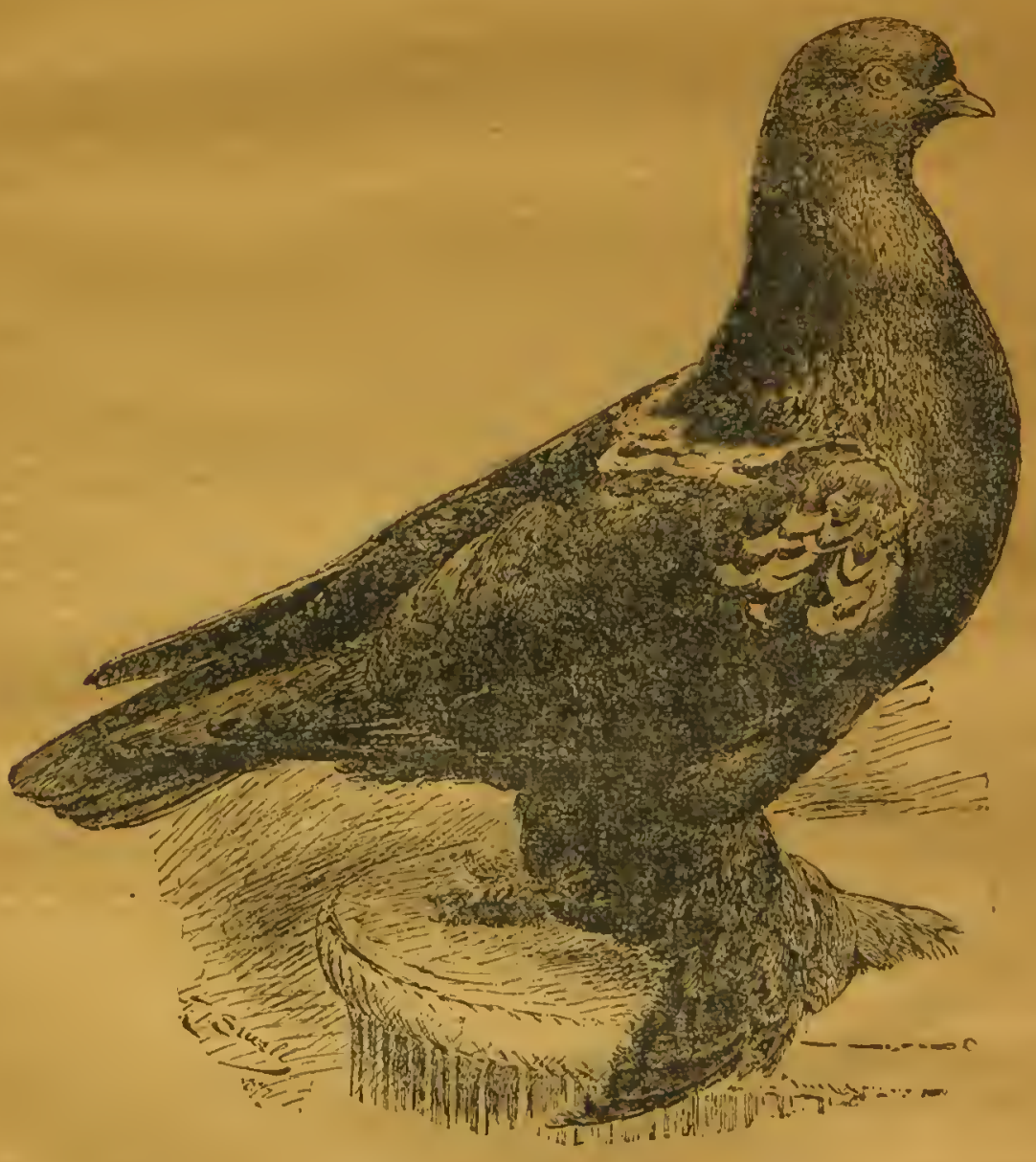

E) ACK MUFIED ROSEWING TUMBLER.

the toy pigeons the l'rumpeter is an established favorite. Their long, thin bodies, full chests, and snake-like appearance give them a distinction that is peculiar to themselves. 
The Magnie, without doubt, is the most pleasing ard the most widely-cultivated of any of the numerous varieties of pigeons. A cursory glance might lead one to suppose that this pigeon could be readily produced in plenty of passable quality, but this is not the experience of all who.breed this variety. However, it can not be denied that much progress lias been made in perfecting this breed. The Magpie, though now regarded as a distinct bird, is doubtless of Tumbler origin, in common perhaps with other of the toy varieties.

'Tumbler pigeons are fast gaining favor ainong fanciers. Among the varieties of Tumblers are the following: Long-faced Tunblers, Outside or Flying Tumblers, and Inside or Parlor Tumblers. Under the Long-faced Tumblers are included the several beautiful exhibition varieties, as disting uished from the Flying Tumblers proper; not but that some of the show birds would doubtless render a good account of themselves in the air, if put to the test.

The Long-faced Tumbler has been commended to the first consideration of the amateur in pigeon culture, as being easy to manage, hardy, prolific and-at any rate in the case of the self-colored birdseasy to breed of fairly good quality. A start in the fancy can thus be made at a trifling 'cost, and much experience gained of the requirements of pigeons generally, that will enable the novice to later launch out into choicer breeds with an assurance that he knows something of the mysteries of the fancy. In the time when pigeon shows were not so numerous as they are at the present time, and, consequently, there were not the same inducements to breed the higher-class varieties, the Flying or Performing Tumbler was extensively bred, more so, perhaps, than any other variety. It is most interesting to watch the many gyrations of Flying Tumblers, as they inove upward and downward. now turning backward once, twice, or thrice, then revolving to the right or left, and so on. These birds are chiefly bred for their flying qualities, little regard being paid to their color and markings, and a good lsit of trained Performing Tumblers is of great value.

The Pouter is the fancier's ideal of gentleness and grace, and the beau ideal of the loft. The Pouter is a large bird, with a long, slender body; the legs are long and straight, and are in well-proportioned birds about seven inches long. The carriage is perpendicular, so that a line would run from the eye to the feet. The head is rather long and oval, with a sufficient length to accord with a neat wattle; the eye is small in proportion to the size of the bird. The crop is the chief point of interest in this variety. This feature is the one which severs all similarity to the other species. The crop should be large and round when inflated, and possess an amount of elasticity that will prevent its hanging loose and flabby when the bird is at rest.

The color and markings of the Archangel place it foremost in the favor of lovers of a lustrous plumage. The wings, back, and rump are dark, as well as the flight feathers, the latter, however, being difficult to get. The tail is also dark in color, though it is generally a blue-black, except a bar of black at the end. The head, neck, breast, 
and under-parts, including the thiglis, are a rich coppery-bronze color covered throughout with a bright metallic luster that must be seen to be appreciated.

Diseases of Pigeons.

Among the discases most frequently known to pigeons are the following:

Canker.-Canker is an evil that the squab raiser las sometmes to contend with. The cause of it is often ascribed to impure air and water, but as it makes its appearance in flocks that have the best of care, this evidently is not the true cause. It is diphtheritie in its nature, and the symptoms are high fever, congestion, and swelling of the blood-vessels of the throat, accomyanied by little white ulcers, which, if neglected, spread very rapidly over the interior of the mouth and throat. Lilie roup, it generally malies its appearance in cold, damp weather. When a squab once becomes affec.ed old and young should be at once talien from the breeling room, and the apartment they occupied disinfected. The old birds should be examined, and if found with canlier in the r mouths it shonld be renoved and the canlier spots painted with a solution of lemon juice and sugar. Powdered burnt alum is also good to pply. The young birds can be treated in the same way, but if the canker has spread much about the mouth it liardly pay's to spend much time over them. The old birds need to be thoroughly cured before turning back into the breeding room. A small piece of alum in the drinking water of the old birds will aid in the cure, and if the whole flo:k is threatened a piece in the different drinking
vessels for a while will act as a preventive.

Cholera.-Cholera usually attacks pigeons in hot weather, and can generally be altributed to improper food, new wheat, nusty corn, foul screenings, or impure water. It is accompanied by a watery diarnea of a greenish color. The phmage is dull, and the bird mopes and soon loses its strength. Change its food and place a little prepared chall in the water. A lump of quiclilime about the size of a walnut placed in a two-gallon vessel of water has been found to check the discharges.

Egg Bound.-Hens, especially young ones. often have trouble in voiding or passing their eggs. Frequently the first egg will be voided all right, and the hen on the following day gives evidence of distress, sometimes entirely losing the use of her legs and unable to stand. By taking her in the hands, and feeling of the abdomen, the egg can generally be located, and when convinced that this is the cause of the trouble nature needs to be assisted. One way to do this is, after rubbing the passage with vaseline or sweet oil, introducing the finger as far as possible, at the same t ine being careful not to break the egg; liolding her abdomen over steam, not so hot as to scald, but so as to thoroughly warm and relax the parts as much as possible. After a few minutes of such treatment as this, put her in a quiet pen, and unless a stubborn case she will soon pass the egg. Somc, at the same time as treating with steam, give the hen a small quantity of molasses internally. 
En'eritis.-Inflammation of the bowels, or enteritis as it is called, is the result of a chill, and the syniptonss are a "puffed-up" condition of the feathers, moping, and a bloody discharge of nucus. Place the bird in a wam p'ace and give a few drops of paregoric two or three times a clav.

Going Light.-- "Going light," the term used among pigeon fanciers for atrophy or wasting, is a condition in which the bird gradually grows thinner and thiuner, and is a form of consumption. While not thouglit to be contagious, it is best to remove the sufferer from the rest, for no bird with any form of disease should be allowed to remain in the breeding roou. It is usually accompanied by diarrhea, the discharges clinging to the vent, fouling the plumage, and presenting a disgusting appearance. If you see a bird with its plumage discolored, its motions uncertain, its eye dull, catch it, and you can soon delermine by feeling of it whether it is "going liglit" or not; for its breast-bone will be proninent and its natural plumpuess gone if affected with this disease. If taken in the early stages a certain remedy has been found to be plucleing ont its entire tail. Then, by using one or two cod liver oil capsules and a grain of quinine daily, and feeding a little hemp seed with its other food, it will, by the time its tail has grown again, be entirely recovered. But it will be a long time, if a hen, before it will be in laying condition, and the question naturally arises, is it profitable to wait for recovery and also give the tine necessary to attend to it while sick?

Roup.-Roup is a disease of a catarrhal nature, affecting the mucous nembranes of the nostrils, head, and throat, and is usually accompanied by a profuse discharge of a sticky mucous matter from the nostrils, which, if the disease is neglected, becomes very offensive. It is very contagious, and should be checked as soon as it makes its appearance by removing the sufferers to a distance, as if left to fly around they will soon containinate the inost of the flock. It seems to be miasinatic in its nature, as it malies its appearance suddenly, sometimes affecting a number at once, and when they have been in no way exposed to its influence. Sudden changes of tenuperature, with damp and chilly conditions, are particularly favorable to its appearance. On the first indication of difficult breathing give a pill, about the size of a medium-sized pea, of butter and black pepper, equal parts, and swab the throat with a solution of chlorate of potash. Should there be a discharge of mucus, wash the nostrils and inside of the mouth with a solution of peroxide of hydrogen. This is said to be a sovereign remedy for roup. Dry quarters, protection from draughts, and the occasional use of a disinfectant ivill help to keep this scourge at bay.

Smallpox.-A disease that sometimes makes its appearance in large flocks of pigeons, and quite contagious, is known as smallpox. It comes in the form of small sores about the head, and if left to take its course spreads over the head and neck, forming one large niass of scabby sores. On its first appearance isolate the afflicted ones, and touch the sores with a solution of blue vitriol. A few applications will generally check its tendency to spread. 
Sudden Colds.-In cases of sudden eold, or where a tonie seems to be necessary, a one-grain pill of quinine and a capsule of eod liver oil, given twice a day, will be found to have good results. Especially is this the case during the molting season where a bird does not seem to shed well and is drooping. It is a trying time for all pigeons, and unless in robust health the process will be slow. As they do not usually breed while molting, it is an advantage to have it over as soon as possible, and consequently pigeons should be lrept in good, healthy condition and encouraged to shed as rapidly as is consistent with good health. A little stimulating food, such as hemp and canary seed, is go od at such times.

Wing Disease.-Wing disease is a stiffening of the joints of the wings, caused by the formation of a tumor at this point, and, no doubt, arises from a strain or injury by a blow. It first appears as a small, inflaned spot, and, if neglected, grows larger and larger, until finally it hardens, fills with a yellow, cheesy matter, which after a time breaks the slin and protrudes, increasing in size daily, until it evidently wealiens the bird so much that it dies. If you notice one of your birds chat secuns to lave a difficulty in flying, and drags one wing on the ground, examine it and you will, no doubt, find the wing-joint- inflamed. Place it in the hospial that should be attached to every breeding house, rub it well with strong spirits of camphor twice daily, or paint with iodine, and you will, if you have discovered it in time, no cloubt effect a cure. Sometimes, even though you may ralieve the inflammation and apparently cure the clisease, the wing will renain stiff. This, while it renders the bird in a nleasure helpless and unsightly, does not injure it as a breeder, for it will still continue to lay, sit, and feed; but on aecount of its being unable to fly it must, of necessity, malke its nest on tlie floor.

Worms. - Worms sonetimes prove troublesome to pigeons. The pigeon has a varying appetite, and while it may seem to eat and drink, does not appear to be doing well. If watched earefully the wornis will appear in their dung, and when it is deternined that this is the eause, give a piece of garlic about the size of a medium white bean every morning, and watch the results; or a small pill of powdered areca nut and butter, for two or three days, followed by a capsule of castor oil. 'This has been found to be an effective eure. A snrall piece of guin aloes, about the size of a Canada pea, will also be found effective; all to be given before the bird is fed in the morning.

Douglass Minture.-What is linown as the Donglass Mixture added to the drinking water, in proportion of a tablespoonful to a pint of water, is a good tonic for all times. The mixture is made by dissolving one-half pound of green eopperas in two gallons of water, adding to it one ounce of sulphurie acid. This, if placed in the drinking vessels occasionally during the molting season, will be found to assist molting, and keep the strength of the bird from diminishing. 


\section{CAGE BIRDS.}

BRFIDTAG CANARIES.-THE MOCKING BIRD.-TIF IULI,FINCH-THE CARDINAL GROSBEAK, OR RLD BIRD.-THE LINNET.-THS HLUE LIRD.-THE NIGHT. WAALE.-TIE STARLING.-THE TIRUSH.-THE BLACK MIRD.-RING DOVES. 'ARROTS.

The Canary.

Sometime about the fourteenth century, a merchant ship, sailing from the Canary Islands, in the Atlantic Ocean, was wrecked on the coast of Italy. It had on board a few song birds, natives of the islands, which soon made new honies for themselves on the wooded shores. Thcir sweet songs attracted the natives, who soon captured them all. From Italy these birds, called canaries, from the islands whence they came, were transported to France and Germany.. The Germans soon proied thenuselves especially expert in breeding them, and to-day they are sent from Germany over the entire globe. It is estimated that about one hindred thousand canaries are annually imported into America, and probably no other bird has brought so much pleasure into the homes of both rich and poor. There are about fifty varieties of this little songster, each of which will preserve its characteristics if vroperly paired.

\section{Breeding Canarios.}

Cage birds are like cliildren in many respects. 'The more common sense exercised in the matter of food, clothing, and general family regulation the better health, temper and mental vigor will the children enjoy. So, too, with the pet canary. He will respond just as quiclily and appreciably to good or to indifferent care as any child. His wants are simple, but atl the more necessary because of their simplicity. Ile needs bright, heavy, nutritious seed. free from dust, and judiciously mixed, pure water and regular temperature, with his cage hung in the sunlight, kept clean and sweet, and clear of all draughts. These are the necessaries of his happy, musical life, and too much stress can not be laid upon them. Every lover of canary melody should, first of all, secure a well-recommended bird from sonie established, reliable dealer, and then proceed upon the pious principle that "an ounce of prevention is worth all the nostrums on earth" in relation to the health of his checry little songster.

The staple food of the domestic canary is the best quality of Sicily canary and German Summer rape seeds in about equal parts, with a third part made up of fine millet and maw seeds in the proportion of two to one. To this may be added a moderate allowance of fresh 
lettuce or groundsel in season, and an occasional tid-bit in she form of egg food. An excellent recipe for egg food is to mix a hard-boiled egg. grated finc, with half the amount of fresh pulverized cra:ker, and a surinkling of Cayenne pepper. The English breeders sift in a little powdered sugar also.

It is an excellent principle to trust to the sagacity of the reputable bird dealer, and shum the drug store and grocery when purchasing seed. Ground clay is freelv mixed with bird seed to malic it profitable

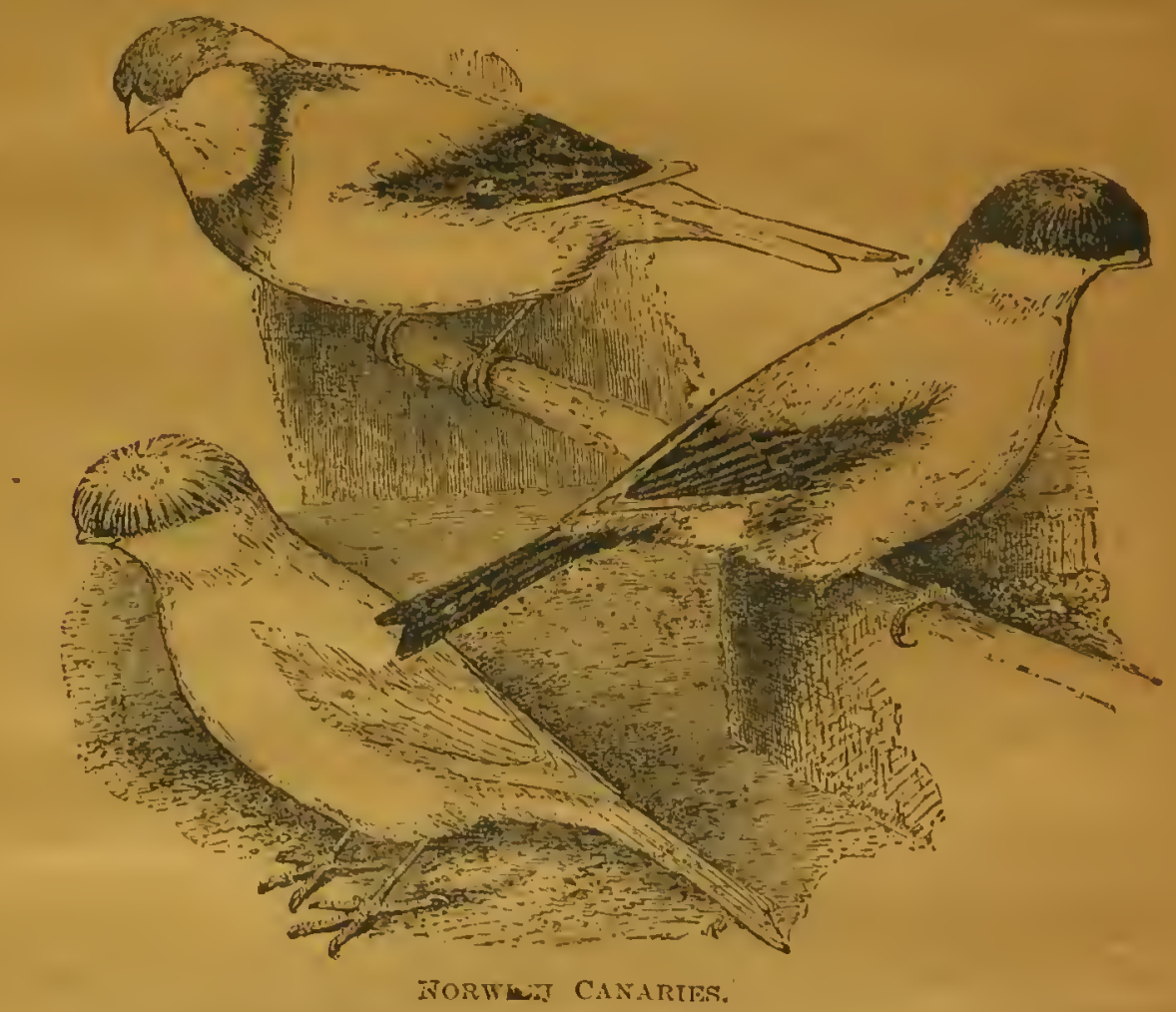

in the scales, and the bird dealer is the only man engaged in handling seed who can not makr: this deadly adulteration pay. He is forced in self protection to keep pure, clean seed, or suffer a ruinously high death rate in his cages. Then, every singer should be supplied witl a cuttlcbone on which to whet his bill, and the bottom of his cage should be liberally strewn with silver sand or fine gravel, changed every day, or at least once in two days. Pure drinking water is essential to heilth and song, and the requirements of cleanliness also demand the introduction of a shallow bathing dish into the cage several times a week. according to the partiality of the individual singer to a morning dip.

There is no such thing as lump sugar, cake, and the liundred and one harmful luxuries with which ladies insist in murdering their pets, 
to be found in the well-regulated bird houschold. The canary is a frugal, old-fashioned little soul. He asks for but few treats, and these should always talie the form of bird manna, or some other standard preparation put up by experienced hands. In the nolting season bird manna. or sone good equivalent, is very helpful. The changing of plumage is a weakening process, and unless some extra stimulant is provided, no sensible canary will exert himself to remain in sung, and has all he can attend to in kecping his health. A few drops of a wholesome tonic containing iron and an extra allowance of

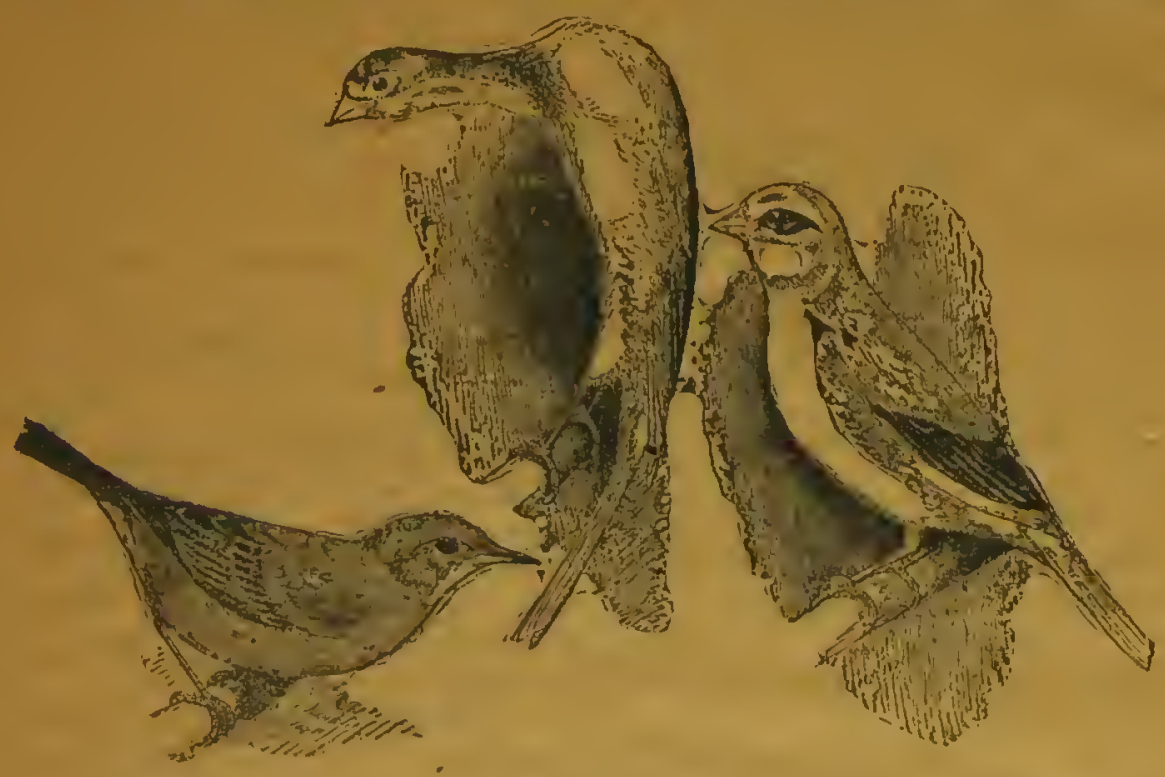

SUGAR BIRD HEN. BUFF PIEN SCOTCII

FOUT-POINTED YETLOT BORDER FANCX CANARY.

egg or nesting food will pull the little patient through the annual crisis bravely, and bring him out in lis Winter overcoat in bright, smooth, glosst plumage and full song.

Sunlight is a powerful agent in the production of fine feathers, and a little sweet wine splashed into the bathing water occasionally will be attended with good results. The ailments with which canaries are afflicted are generally traceable to neglect or inattention of some sort. Old, dusty, rancid, or withered seeds, neglected water cups, draughts or irregular temperature will produce asthma, sneczing, consumption and a dozen other maladies. Prevention in any case is easy-cure is next to impossible. The true friend of the feathered pet will see to it, then, that his little charges suffer through no carclessness or faulty treatment.

Timely care males discase a stranger in the aviary: In the event, however, of an ailment it is well to be provided with the few 
simple remedies prescrited and put nip by tlicse lorg skillod in atterdance upon the bird rccm. Such nenceles are a vays to be bad in convenicnt form, with plain directions for their use. and any fet-steck dealer of cstablished reputation can ke relicd cn to stipply thine. It is a good general rule to remove a sick bird to a wamer place. sheltercd from all currents of air, as sonn as he is observed to be under the wcather. Warmth, aided by a dose or two of the excellent tonics to be had in the bird stores, will work wonders in the first stages of nearly every ordinary malady to which canaries are subject. Neglected cases, of coursc, call for heroic remedies, but this is 110 part of the ordinary care of tl:e houschold pet. It is sufficient for those who content themselves with one or two singers, to licep a bottle of standard tonic ahways at hand for use in case of emergency, relying chicfly on good, wholesome sced, pure water, and eleanliness to insure health and melody in the cages.

Canaries are wonderfully hardy. If they were not, half of them would speedily drop ont of existence, for the average singer has more indigestible victuals to dispose of than even the rictim of cheap boarding-house rations. He is satisfied with a moderate-sized cage, which should be square-oblong in shape, as dizziness is often fomented by round cages. The perches should.be as thick as a schoolboy's periholder, to spare the pet the torture of cramping his f cet to chutch a small roost. It is a good plan to scrape the perches with a dull knife, and scour them in dry sand, in place of washing them. Wet perches are apt to encourage colds and rhculvatisil.

If a bird is tormented with insects he will betray the fact by his uneasiness. A picce of white cotton flannel thrown over the cage at night, if exannined in the morning, will be found full of little red mites. To destroy these miscrable pests it is best to procure a pacliage of the German powder prepared for the purpose, and follow the directions which accompany it to the letter.

Canaries will thrive in any tcmperature between forty and cighty degrees, provided it is kept regular and miform and free from draushts. No singer should be hung in the noxious gases that rise to the ceiling of a sitting room when the lamps are lit, nor should he breathe cighty degrees of heat in the daytime and frost-laden air at night. The thin and almost imperceptible draught that sncalis in at a window casement is a fruitful cause of cold and death. It is downight cructy to hang a bird so that he has no escape from it.

In selecting a songster it is very poor economy to pull the pursestrings too tight. Choose a thoroughly recommended bird of whatever breed is preferred, pay a fair living price to the chealer, and you will stand a far better chance of getting satisfaction than you would had you wasted your money on one of the cheaper birds so industriousty hawked about the country by wandering faliirs. A good St. Andreasberg canary, well cared for, will add fully: as much confort to a home as any article of equal cost that can be chosen to adom it.

The nale bird is the soingster. The female rarely sings, and 
when she does her notes are weak. The beak of the male is short and stout, and his head is llat. The eromn of the head of the female is rounder than that of the male. The song of the canary is familiar to all. It sings in all seasons an? in the dullest weather. It becones very lame, and may be taugint a nunber of amusing triclis.

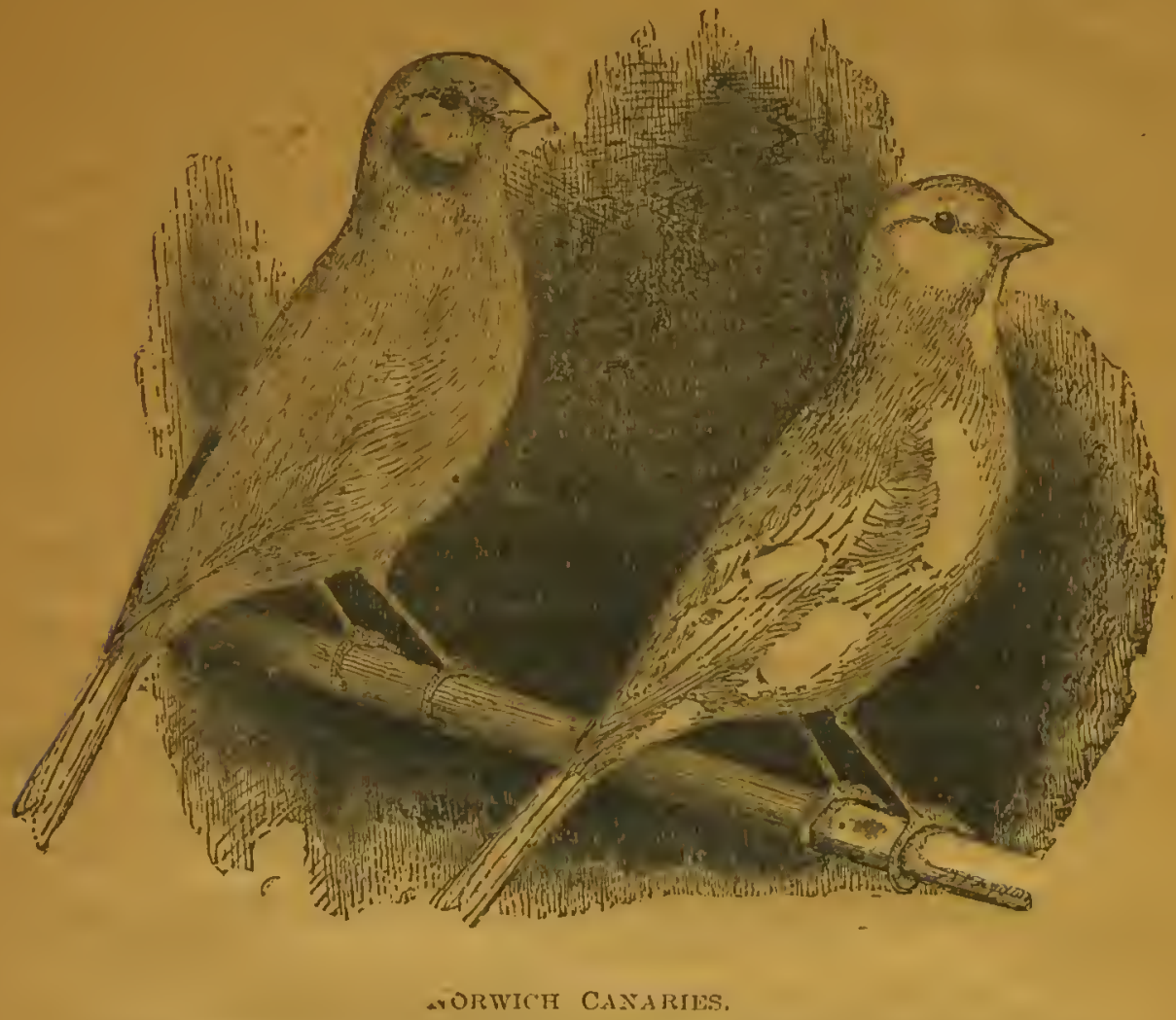

The German Canary:-In many parts of Germany the breeding of canaries for the markets of the world is the principal occupation of the people. The best singing canaries known are bred in the little hanilet of St. Indreasberg, in the Jartz Mountains. These birds are called St. Andreasberg Rollers. Only the best grade of singers are bred, from three to six months of constant training being given to bring them to the desired degree of perfection. They are put under the instruction of the European Larks and Nightingales, and mecranical devices are also employed to teach them long trills and flute notes and other oddities. Their extraordinary vocal powers make then most desirable pets.

The Belgian Canary.-Bird breeding has long been a hobby with all classes in Belgium. In breeding canaries they have given the 
'preference to shape rather than to voicc. The Belgian canery is a jlong, slender bird, when at rest resembling a right angle in shape, his head and neck horizontal, his body and legs vertical. He is very Igawky in appearance, and extremely awkward in all his movcnicnts, but to the traincd eye marks of high breeding are every where apjarent. His color is usually yellow, and he is of an exceedingly nerrous tcniperament. The full-bred bird is scldom found in this country, but half or threc-quarters bred birds are highly prizcd, for while not so high bred as to shape, they are inuch better songsters.

The English Canary:-The English in breeding canarics give more attention to color and size than to voice or shape; and the English birds are becoming justly popular. Their voices are good, their phunage bright and raried. Antong the English raricties may be mentioned the Manchesters-long and large; the Norwich-a decp gold; the Crimson, or Cayenne-fed, a dcep orange or nearly crimson; and the Gold or Silver Spangled Lizard canaries-the most magnificent in plumlage of all.

The Crimson canary is not really crimson, but a very decporance with a tendency to shade to crimson. Sone have dark-green crests and wings. The color of these b rds is produced by selecting young birds of a decp ycllow, or a dcep yellow and green, and feeding them all they will eat of a mixture of cgg food and a heaping teaspoonful of the brightest colored Cayenne pepper. This should be fed before each moulting, otherwise the bright color will be lost.

Gold Spangled canarics have bright gold capped heads and lines of bright gold spangles with olive-green centers from the neck down the back. The Silver Spangled are niarked like the Gold, but hare silver spangles in place of the gold.

The French Canary. - The French canary somewhat rescmbles the Belgian, although snaller. While a better singer than the Belgian, he can not be especially recommended for his musical qualities. The breast feathers are ruffled, giving the bird an odd appearance. These birds are bred in all the canary colors, and plain-headed or with crest.

The Scotch Canary.-This is a remarkable variety originating in Scotland. The outline of the shape closely approximates a perfect half-circle. They are about of the size of the Belgian, and their voice , is about on a par with that of the French. They are bred in all the ,colors, the decp yellow being the most attractive.

\section{The Mocking Bird.}

The mocking bird belongs to the great family of thrushes, and is distinctively an Anierican bird. Apart from being a most beautiful songster he surpasses all other birds in his wonderful power of nimicry. To produce any and every familiar noise of city or country seems to be a delight to this master-minic.

The home of the mocking bird is in the Southern and Gulf States, whence many thousands are annually sent to the Northern markets. 
His is migratory as far north as Pennsylyania and Oho, but is rarely fnund north of the Ohio River.

The male and female mocking birds are very similar in both size and plumage, and as the fcmale occasionally possesces a rather gord voice, it takes an expert to distinguish the sex. This is generally deternined by the markings on the wing feathers.

The plumage of the mocking bird is very modest in color. The head, neck, and back are dark brownish-ash; the throat, breast, and under-parts a clouded white; the wings and tail almost black; the priniaries are white, the first and second rows of corerts tipped with white; the two outer feathers of the tail are also white. In the male, the white on the wings extends over the nine primaries; in the fenale, only over seven or eisint.

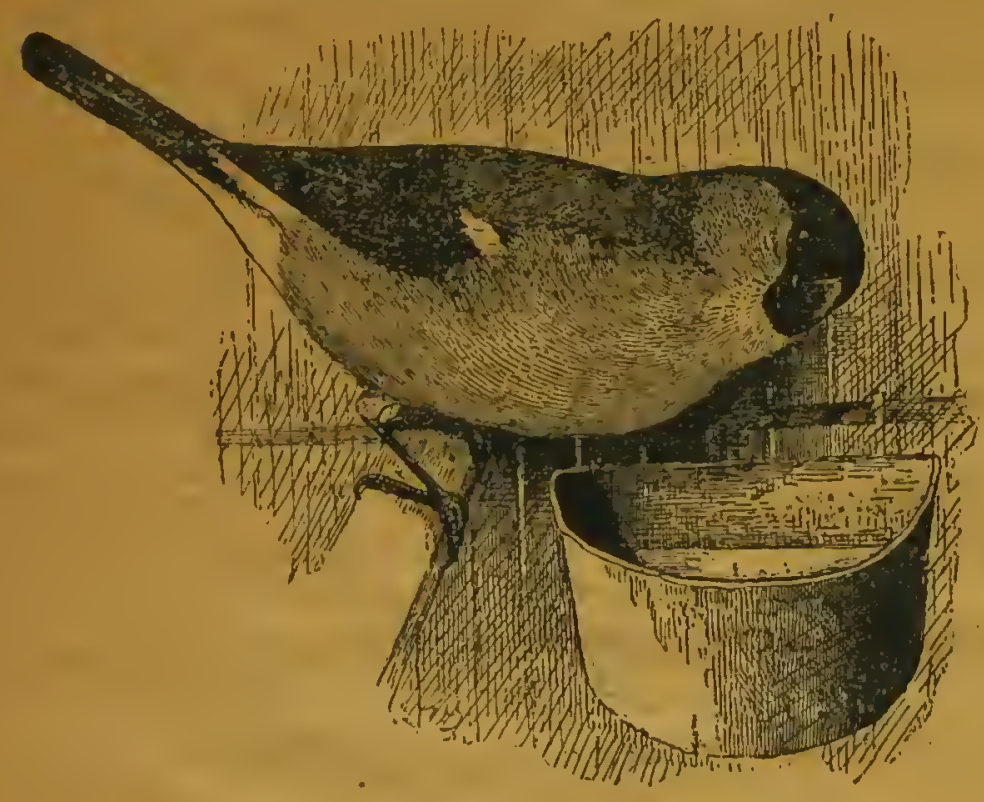

RUSSIAN BULLFINCII.

The cage for the mocking bird should belarge, and lept scrupuously clean, with plenty of clean gravel on the bottom. The bird should not be exposed to inclement weather, and when hung out for the fresh air a cover should be thrown over the top of the cage to protect him from the burning rays of the sun.

The food for the mocking bird is usually some prepared food sold by all bird stores, mixed with one-quarter grated carrot for a steady diet. This may be varied with berries (especially elder berries), insects, fruit, or a little of the hard-boiled yoll of an egg.

, Mocking birds should have a daily bath. and the bath-tub removed 
as soon as the bird has bathed. With regular care and proper food a mocking bird should remain in health and song many years.

\section{The Bullfinoh.}

The bullfinch is a great favorite among bird lovers; for while his natural song is hardly worth mentioning, his power of imitation is so great as to make him a most interesting companion. He is about the size of a sparrow; his plunage is dark; the breast of the female is gray. brown; of the male, red; the beak, blacli and well rounded.

In Gernany nany bullfinches are trained by tailors, weavers, and other peasants of sedentary occupations, who are thus enabled tc give a great deal of time to the work. The training is begun when the bird is very young, and they are always fed and cared for by one person, the one who is to train them. The bird is put in rather a dark place, and the tume he is to learn is whistled to him over and over, a few bars at a time, always in the same key, no other tune being whistled in the bird's hearing until he has inastered the one in liand. His lesson is given to him as early as possible, and on an empty stomach, his food having been removed from his cage the day before. When the lesson is over, the shutters are flung wide open, his cup is piled with seed, and as a special reward he is given two or three hemp seeds. After a couple of hours his food is all removed, and he is not allowed to have it again until after his next morning's lesson. In this way he looks forward to his lessons, and proves a good scholar. Those birds to be sent to England are taught "God Save the Qucen," "Pretty Polly Perkins," and other English airs; while those intended for the Ancrican Mankets learn "Yankee Doodle," "Hail Columbia," and "Star Spangled

\section{The Cardinal Grosbeak, or Red Bird.}

This is one of the most attractive of our native birds, and is deserving of more attention than has been bestowed upon him, as much on account of his brilliant plumage as for his melodious whistling.

He is known by several aliases, among others the Virginia nightingale, fron his liabit of singing in the night, and the red bird, from the color of his pluniage. Ile is about seven inches in length. His pluniage is of a rich vermillion red over the entire body, with a darker shade of the same color over wings and tail; the face, cheelis, throat, feet; and legs are blacli; the bill, red. The head is surnounted with a tuft of brilliant red feathers, which the bird is capable of erecting at will.

The female is a rich brown, with some red on breasi and wings; and, though not as striking in appearance as her husband, is equallyas beautiful, and is often as good a whistler.

The cardinal grosbeak is naturally a very active bird, and his c age should be a good-sized one, as large as for a mocking bird; otherwis: he will damage his feathers. He should be linng up quite high, so that he may not needlessly be disturbed. The floor of the cage sliould be 
strewn with red gravel or silver sand. He will thrive well on canary seed, with unhulled rice and craclied corn and occasionally a little hemp seed. His drink should be of soft water; hard or lime water having a tendency to malie hin costive, which, if not cured, will soon carry him off. He should not be liept too warm, as he is very hardy, enduring the inclemencies of severe Winters with great indifference.

\section{The Linnet.}

The linnet is one of the nicest of the finch family. He is nuore grateful for kindness, more solicitous of pleasing, than almost any other cage bird. During the first year of his life the linnet is called the gray linnet, from the color of his plumage. After the second molt, the red of the breast blending with the amber edges of the feathers produces a golden hue, and the bird is then known as the yellow linnet. At the end of the third molt the breast becomes bright carmine and the flanks the color of iron rust, and it is known as the rose linnet.

Gray, yellow, or red, his nusic will be the same; even sickness does not end his exquisite piping, and the older he grows the better he sings. IIe sings both Winter and Sunmer, except during the tine of molting. "The song of the linnet consists of a number of sentences or "jerlss," as they are called, and each distinct from the other, while the wonderful variety of notes is astounding.

A male linnet will mate with a female canary, and the offspring will resemble in color a gray canary; but the song of the "mules" will be very fine, and they are highly prized on that account. Linnets should be kept in a square cage, as in it they are less subject to giddiness than in round cages. They require the same food and manage ment as canaries.

The Blue Bird.

Everyone lnows the plumage and song of the blue bird, so that a detailed description is hardly necessary. In Europe the blue bird is liept as a cage bird, and he is much admired for both his song and plumage, where is he usually called the blue robin.

\section{The Nightingale.}

The nightingale is usually conceded to be the king of songsters. At night, when other birds are silent. this sweet musician reigns supreme. His plumage is very modest, and he is about the size of a blue bird. He should be given a large cage, which should be hung in a subdued light. He is an enormous eater, and requires a large quantity of food. The utmost cleanliness and daily supplies of gravel and water are absolutely necessary to secure a healthy bird. Although inclined to be delicate when first caught, the nightingale. after becoming accustomed to cage life, if given proper care, becomes one of the longestlived of cage birds.

\section{The Starling.}

The starling is about the size of a sniall black bird. He is one of the most gifted of birds. being ahle to sing. whistle tunes, and can even 
be taught to repeat sliort sentences. Iis plumage is lark, of the varying shades of green and purple, the ends of the feathers being marlied by pale yellow spots. Starlings reguire a large cage, the size of that used for the mocking bird, and should be fed the same food as the mocking bird, and a generous supply of insects when yossible. They are very hardy birds, sometimes attaining the age of fifteen years.

\section{The Thrush.}

The song-thrush is a melodious singer, and is gifted with an unusually powerful voice. In a wild state he sings only during the Spring. but when caged will sing eight or nine months of the year. He is of a glossy brown color, with a speckled breast. The purchaser of a thrush shovild make sure of the sex by hearing the song, as the male and fenale are much alike; the female being slightly smaller, and not quite so glossy. 'The thrush should have a large cage. plenty of sand or gravel. and water for drinling and bathing; but his bath should be removed at once when used, as he is liable to cramp. His diet slould be the same as that given the mocling bird

\section{The black Bird.}

The black bird is a jolly songster whose mellow notes, while not so varied as those of the thrush, have a much sweeter tone. He is about the size of a robin, and his color is a velvety black. A great mimic, he soon learns any tune whistled to him, and once learned it is never forgotten. Black birds are very hardy, and will live in captivity twelve or sixteen years. They soon become tame, and when cagcd sing throughout the year except during the molting season. They are very fond of bathing and bath water should be supplied daily, but the cage should not be left wet, as they are subject to cramp. "Their food and treatment should be the same as for the mocling bird.

\section{Ring Dores.}

Ring doves, or mourning dores, as they are someines i alled, from the peculiar sound they malse, are very preity birds. The:r plumage is very sleek, of a yellowish-dun color, with a black ring sound the neck. 'They become very tame, and can be readily handled. They breed even unore prolifically than pigeons, laying two white eggs, and the male bird taking care of the nestlings while the female builds another nest and lays again. They require a large-sized breeding cage, and should be fed on cracked corn and wheat. They will also eat canary seed.

\section{Parrots.}

Parrots possess the power of imitating the human voice in a very marlied degree, and this characteristic has made them a favorite hunsehold pet. They are natives of the tropies. and are usually brought to our markets when a few months old. When taken young. pariots subnit readily to confinement and are more easily instructed. 'They 
are very long-lived birds, sometinues living for fifty, seventy-five, or even a hundred years. The inales and females are very nuch alike, being the same in size and color, and equally capable of being taught. Parrots will seldom breed in confinement.

A few birds are taught to talk before being sent to this country, but such birds are not always to be had, and very high prices are asked for them. It is more satisfactory to buy a young bird and teach it yourself. As a rule, parrots will learn quicker from women than nien. and quickest from children. After purchasing a parrot, let it remain for about two wceks unnoticed, except to give it the necessary care. Then try to win its affection with gentle words, and gradually accustom it to being handled. . After being placed under instruction it is usually from four to twelve months before the bird will try to talk, but when once it does so, it adds to its vocabulary daily The plan of splitting a parrot's tongue is not only exceedingly cruel, but it is useless, and will simply prevent it from ever articulating distinctly.

A parrot should be chained or caged, as, if allowed its liberty, it will be apt to find unwholesome food. The usual cage is about two feet in leight, and fifteen inches in diameter. It must be lept scrupulously clean, and a plentiful supply of clean sand or gravel should be furnished for both eating and bathing, as parrots do not bathe in water, but cleause themselves with sand. However, it is best to once a week sprinkle your bird with slightly-warm water.

In one cup of the parrot's cage should be kept a mixture of canary seed, and large Russian sunflower seed, hemp or unhulled rice may be added occasionally. In the other cup keep boiled corn, a slice of stale bread, or a cracker soaked in coffee; at noon, remove this and refill the cup with water. Occasionally they may be given nuts, boiled corn, or ripe fruit. Never give meat or greasy food of any kind.

Among the varieties of parrots the following are the most prominent: The gray parrot, the Mexican, the Australian paroquet, the Arrazon, the Cuban. Other varicties are the cockateel, the cocliatoo, the cut-throat cockatoo, and the rose-breasted cockatoo. 


\section{RAJBITS AND PET STOCK.}

\section{CARE AND MANAGEMENT.}

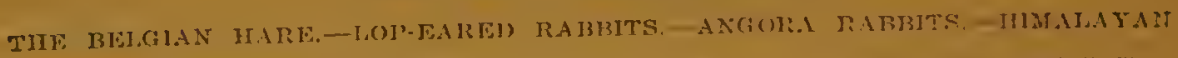

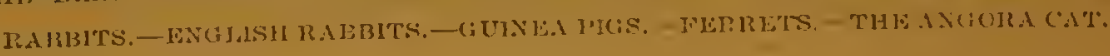

Tho Belgian Haxe.

The Belgian hare is pre-eninently the best doncs icated rabbit for market purposes. They are of a rich hare colc: wc.gh from eight to nine pounds each at maturity, are very prolific, producing from five to eight young every cight or ten weeks, and the flesh has a fine gancy flavor, dressing clean and attractive. They are extremely harly and exempt from disease and vermin, and stand confmement unusially well if cleanliness is observer

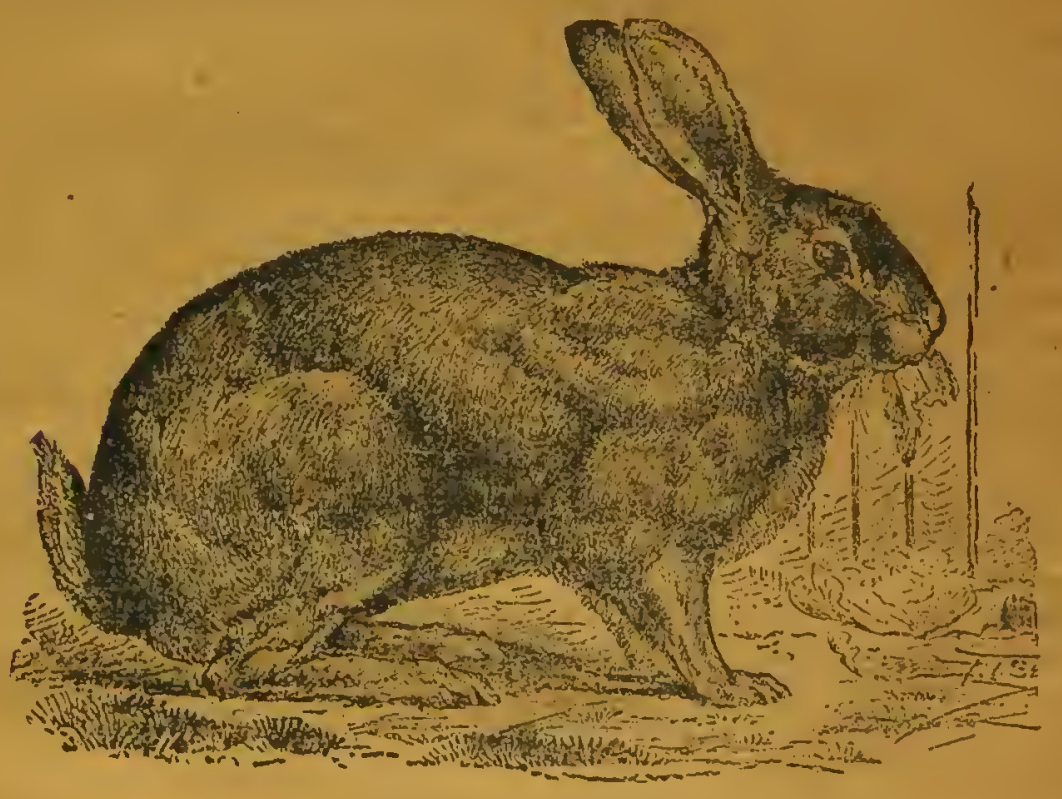

BPLGIA.Y FARE.

A hare at five months of age will wcigh from four and one-lialf to five pounds, and will cost less than twenty-five cents to piochuce, which fact alone commends them for home consumption or to the marlict man. 
With their bright, contented appearance, their quiet and cleanly habits, together with their good qualities in general, they appeal alike to the fancier and the lover of pets. Belgians, though not so showy as some of the smaller breeds by reason of their self-color, are noble-looking. animals, and for domestic use are of greater value than any of their companions. They are hardy, and few are born that will not with! ordinary care and attention be reared to maturity. 'They are very! docile, much niore so than the smaller varieties, and do not consume as much food as would be expected for their size.

Of all domestic breeds the flesh of the Belgian tastes the most like that of the hare, and has not the rank fla vor so common in the ordinary rabbit. They will live and thrive in the woods or warrens, when turned down for brecding at six or cight months old, if some protection be given then from the inclemencies of our seasons; thus in two or three generations they become acclimated and require no further attention.

\section{Lop-Eared Rabbits.}

Of the different varieties of fancy rabbits none has attained so great a degree of prominence and favor as the lop-eared. That they are justly entitled to their great popularity no one will deny, for the grand thoroughbred lop undoubtedly stands at the head of the list.! In fact, there are many fanciers who consider the lop-eared as the only variety worthy of notice. Their long, drooping ears are their most peculiar and estecined feature, and in good specimens they will measure from fifteen to twenty inches. What is neant by lengtl of ears is not the length of cach individual ear, as miglit be supposed, but is the distance obtained by resting a rule across the top of the head and measuring from the tip of one ear to the tip of the other." They are of all colors common to the rabbit tribe, and weigh from I8 to 25 pounds per, pair.

\section{Angora Rabbits}

Angora rabbits will give general satisfaction and genuine pleasure in breeding them. The pure white ones with pink eyes are the inost in demand. The fur is long. soft and silky. after the style of the Angora sheep and goats. In the good specimens the fur measures from three - to five inches in length. The Angora is hardy and prolific, generally having from five to nine young to a litter.

\section{Himalayan Rabbits.}

This varicty of rabbits bids strong for popular favor on account of its beautiful markings. The body is white, and the fur short and fiñe, while the ears, nose, fect, and tail are dark brown, alınost black; lie eves are red, the ears very short and firm. They weigh from five to seven pounds and are extremely hardy and prolific.

English Rabbits.

English rabbits are not only desirable as pets, but are valuable for their excellent tabie qualities. The flesh of the wild rabbit bears, 
no comparison with it, for while the wild meat is dark, dry, and has more or less of a strong taste, the meat of a tame rabbit is white, tender, and juicy, lilie the breast of a chicken.

Rabbits breed when from four to six months old, producine from six to eight litters a tear. Fine hay should be given the due for her nest, the inside of which she lines with fur talien from her budy. The young number from five to nine to a litter, are born blind and helpless, and covered with a short, velvety down. It the age of six clays they open their eyes, and when one minnth old they are quite lively and do not need their mother's care. The period of gestation of the doe is thirty or thirty-one days. The life of the rabbit is frm six to eight years. Rabbits will eat almost anvthing of a recelable nature, such as oats, turnips, Leets, clover, carrots, apples, and cabliage In fceding clover do not give it to them wet and heavy. let it be cut the day before and get wited. In feeding for the table avoid giviner cabbage. Keep water by them in warm weather. The eround is the best place for then to rum on, but they will not do well confuncd in boses. Rabbits will burrow and breed in the ground.

\section{Guinea Pigs.}

Everyone linows what a common Guinea pig is like, hence a long description is unnecessary. As a pet for clitdren he is one of the best, being perfectly harmless, and the young follis secm especially to like him. He is smaller than a rabbit, and bears some resemblance to one in form, except that his legs are shorter and his head is placed so near his shoulders that it seems to have no neck, and his ears are short like those of a rat. They have prominent black eyes and no tail. They breed when two months old, having a litter every two months of from two to five. The young run about and eat the same kind of fond as the old ones, as soon as they are born. There is a variety of Guinea pigs called Abyssinian Guinea pigs, which are pure white with pink eyes. Their hair stands up in irregular ridges, giving then a very odd and grotesque appearance.

\section{Ferrets.}

The ferret is a native of Africa. They have been domesticated, and breed well in confmement, being of great use to man not only in driving out squirrels from their burrows or holes, but in killing or driving away rats, which are often of great annoyance. In stables, grain stores, or grist mills, a ferret is a sure cure for rat troubles. 'They will also drive out prairie dogs and gophers; gray squirrels may also be driven out of ledges or hollow trees by the use of a ferret. In all cases when the ferret is at worls perfect quiet should be kept.

There are two kinds of f(rrets-the English, which are buff or white, with pink eyes; the other, called the fitch, which are of a dark silver-gray color. As to the hunting qualities of either breed or sex, there is no difference. Males can be used at all times, but it would not always be prudent to h:ant the females. To handle a ferret, take him 
by the neck slowly and quietly; nercr catch the ne quickly, unless jou are faniliar with them. If one talies hold with his teeth, don't pull away, but hold still or push toward him, when he will relcase you. If you are afraid of them put on leather gloves and handle them quietly. They will soon learn that you mean them no lfam, and you can then handle them as you please without gloves and they will not bite. A ferret that bites should be fed before handling lim, as some would bite much quiclier if hungry. Feed them morning and evening with cracker and milk, giving them what they will cat at times of feeding. Fresh meat of any kind is good for then-birds, squirrels, rabbit heads, beef or fowl. If they get too fat, dilnte their nills with water, give them quantity but not quality, and feed less meat. Keep water by them in warm weather, and a cool, dry place is best for their comfort. They zan be liept in bnxes, cages, or have a sinall room to run in, and they should have sand or sawdust to run on, if liept on a floor. Ferrets live fronl four to six years.

\section{The Angora Cat.}

The Angora cat has attained a very high position among the very best families, and as yet is a rare species of our animal kingdom. We treasure them more highly for their scarcity, for one feels in buying one that they have something everyone does not have. Society demands thoroughbred animals. 'The Angora' is so different from the ordinary house-cat that but slight complarison can be made. This country has been a little backward in introducing the Angora, and until recently they have not been within reach of the public. The cost and expense of importing was not only high, but the risk in bringing the animals to this climate was great. But now they have become rery hardy raised here, their hair grows longer, is much brighter; and in every way improved is the American Angora cat.

Angoras are of large size, have extra long, soft, sillsy hair, with large, bushy tail and big, bright eyes. The hair is very even, being prettily curled upon the body, and about the neck is a lovely ruffle like a collar, which adds inuch to the attractiveness of the animal. They are very plarful and can be taught many tricks, as they are very intelligent. Angoras are excellent mouscrs if not overfed, and may be easily taught by a few scoldings what they may not catch. They are 1ısually allowed their full liberty, but if not, they should have a bountiful supply of catnip. Cats may be fed on anything that is good. Coolied meat may be fed in small quantities, but it is best not to encourage that much, as it is rather heating and causes the skin to get hard and the hair to lose its lovely luster. As Angoras are good mousers, they get about all the meat they need in that manner. Angoras are bred in a variety of colors: black, white, yellow, gray, black-and-white, yellow-and-whte, gray-and-white, etc. The wixixed ones are usually very beautifully marlied, but the solid white ones with pinls eyes are generally preferred. 
.

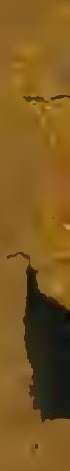



